\title{
An Overview Study of LNG Release Prevention and Control Systems
}
P. J. Pelto
E. G. Baker
G. M. Holter
T. B. Powers

March 1982

Prepared for the U.S. Department of Energy under Contract DE-AC06-76RLP 1830

Pacific Northwest Laboratory Operated for the U.S. Department of Energy by Battelle Memorial Institute 


\title{
DISCLAIMER
}

This report was prepared as an account of work sponsored by an agency of the United States Government. Neither the United States Government nor any agency thereof, nor any of their employees, makes any warranty, express or implied, or assumes any legal liability or responsibility for the accuracy, completeness, or usefulness of any information, apparatus, product, or process disclosed, or represents that its use would not infringe privately owned rights. Reference herein to any specific commercial product, process, or service by trade name, trademark, manufacturer, or otherwise, does not necessarily constitute or imply its endorsement, recommendation, or favoring by the United States Government or any agency thereof. The views and opinions of authors expressed herein do not necessarily state or reflect those of the United States Government or any agency thereof.

\author{
PACIFIC NORTHWEST LABORATORY \\ operated by \\ BATTELLE \\ for the \\ UNITED STATES DEPARTMENT OF ENERGY \\ under Contract DE-AC06-76RLO 1830
}

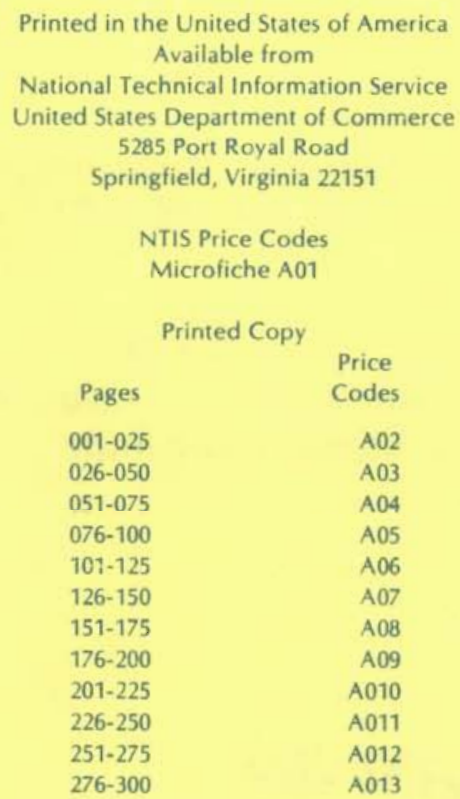


AN OVERVIEW STUDY OF

LNG RELEASE PREVENTION

AND CONTROL SYSTEMS

P. J. Pelto

E. G. Baker

G. M. Holter

T. B. Powers

March 1982

Prepared for

the U.S. Department of Energy Office of

Environmental Protection, Safety and Emergency Preparedness

Under Contract DE-AC06-76RL0 1830

Pacific Northwest Laboratory

Richland, Washington 99352 

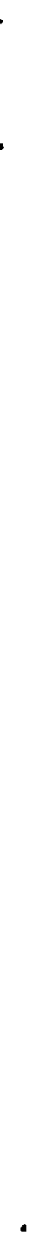
FOREWORD

This report is one of a series prepared by Pacific Northwest Laboratory (PNL) to communicate results of the Liquefied Gaseous Fuels (LGF) Safety Studies Project, being performed for the U.S. Department of Energy, Office of Environmental Protection, Safety and Emergency Preparedness (DOE/EP). The DOE/EP Office of Operational Safety, Environmental and Safety Engineering Division (ESED), is conducting the DOE Liquefied Gaseous Fuels and Safety and Environmental Control Assessment Program. The LGF Safety Studies project contributes research, technical surveillance and program development information in support of the ESED Assessment Program. This overview study of LNG release prevention and control systems benefited from the technical direction and guidance provided by Dr. Henry F. Walter and Dr. John M. Cece of the ESED.

Completed effort in another task of this project is documented in a PNL report entitled Assessment of Research and Development (R\&D) Needs in Ammonia Safety and Environmental Control (PNL-4006). An assessment of research and development (R\&D) needs in LPG safety and environmental control is also nearing completion. Other work in progress includes more detailed studies of topics identified in this LNG assessment as being worthy of further investigation. Reports of this series are in preparation on the following subjects:

- Import Terminal Release Prevention Analysis

- Peakshaving Plant Release Prevention Analys is

- Storage Tank Analysis

- Fire Prevention and Control Assessment

- Human Factors in LNG Operations. 


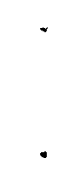


Many members of the PNL project team contributed to the preparation and publication of this report. The following list acknowledges the individual contributions of the principal authors and others who assisted this effort.

\section{LGF Safety Studies Project Manager}

J. G. Desteese

LNG Release Prevention and Control Study Task Leader and Coordinator

P. J. Pelto

Analysis Approach

P. J. Pelto

Assessment of LNG Export Terminal

E. G. Baker

S. L. Weber

J. D. Eklund

Assessment of LNG Marine Vessel

E. G. Baker

S. L. Weber

D. E. Blahnik

Assessment of LNG Import Terminal

E. G. Baker

S. L. Weber

Assessment of LNG Peakshaving Facility

G. M. Holter

A. M. Schreiber

P. J. Pelto

S. E. Lyke

Assessment of LNG Satellite Facility

T. B. Powers

C. A. Geffen 
Descriptions of Reference LNG Facilities

E. G. Baker

S. L. Weber

Technical and Editorial Review

J. G. DeSteese

N. M. Burleigh

C. A. Counts

P. M. Dating

Word Processing and Report Preparation

N. M. Burleigh

M. M. Hale

K. E. Rodriguez

M. D. Linse 


\section{CONTENTS}

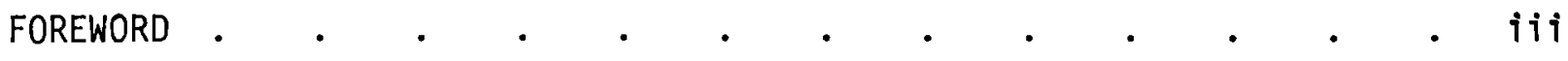

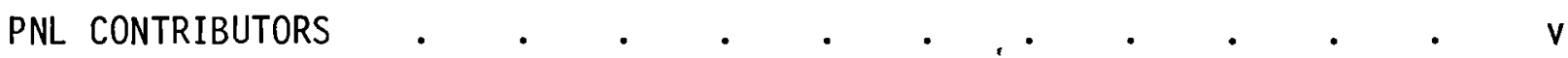

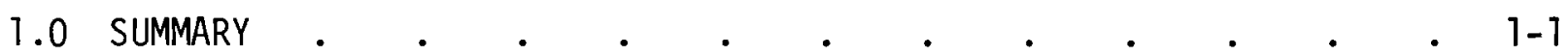

1.1 STUDY APPROACH . . . . . . . . . . . $1-1$

1.2 STUDY RESULTS . . . . . . . . . . . . . . $1-2$

1.2.1 Export TerminaT . . . . . . . . . 1-2

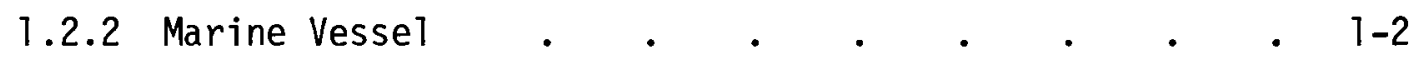

1.2 .3 Import Terminat . . . . . . . . . . 1-3

1.2.4 Peakshaving Facility . . . . . . . . 1-3

1.2 .5 Truck Tanker . $\quad . \quad$. $\quad . \quad$. $\quad . \quad$. $\quad . \quad$ 1-3

1.2 .6 Satellite Facility . . . . . . . . 1-3

1.2.7 Information Needs . . . . . . . . . . 1-3

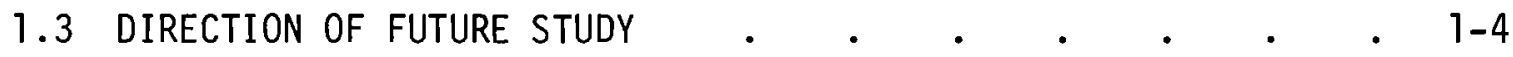

2.0 INTRODUCTION AND ANALYTICAL APPROACH . . . . . . . . 2-1

2.1 STUDY PURPOSE AND ANALYTICAL APPROACH . . . . . . 2-1

2.1.1 Reference Facility Descriptions . . . . . 2-3

2.1 .2 Overview Study . . . . . . . . . . . $\quad$. $2-3$

2.1.3 Detailed Assessment . . . . . . . . 2-3

2.1.4 Fire and Vapor Control Assessment . . . . . 2-5

2.1 .5 Supporting Research . . . . . . . . $\quad$. 2-5

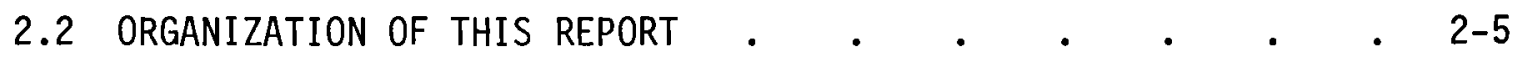

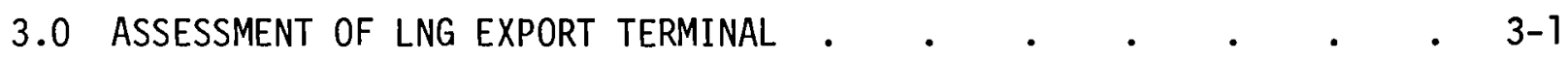

3.1 SUMMARY SYSTEM DESCRIPTION . . . . . . . . . . $3-1$

3.1.1 Gas Treatment . . . . . . . . . 3-1

3.1 .2 Liquefaction . $\quad . \quad$. $\quad . \quad . \quad . \quad . \quad$. $3-1$ 
3.1 .3 Storage . . . . . . . . . . $3-2$

3.1 .4 Loading. . . . . . . . . . . . $3-2$

3.1 .5 Safety Systems . . . . . . . . . $3-3$

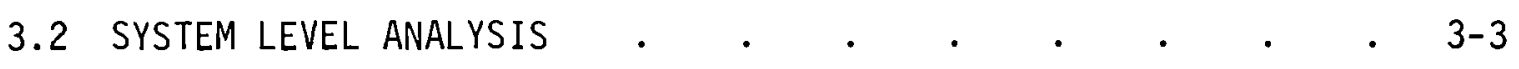

3.2.1 Gas Treatment and Liquefaction . . . . . 3-4

3.2 .2 Storage. . . . . . . . . . . 3-5

3.2 .3 Loading . . . . . . . . . . . . . . $3-6$

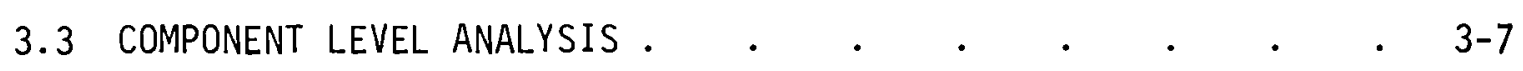

3.3.1 Gas Treatment and Liquefaction . . . . . 3-7

3.3 .2 Storage . . . . . . . . . . $3-13$

3.3 .3 Loading . . . . . . . . . . . $3-17$

3.3 .4 Operator Interface . . . . . . . 3-20

3.4 REPRESENTATIVE RELEASE EVENTS AND INFORMATION NEEDS • • 3-21

4.0 ASSESSMENT OF LNG MARINE VESSEL . . . . . . . . . . . . . 4

4.1 SUMMARY SYSTEM DESCRIPTION . . . . . . . . . .

4.1.1 Basic Ship and Propulsion System . . . . . 4-1

4.1 .2 Cargo Storage Tanks . . . . . . . 4-2

4.1.3 Cargo Handling System . . . . . . . . 4-2

4.2 SYSTEM LEVEL ANALYSIS . . . . . . . . . . 4-3

4.2.1 Cargo Handling System--Category I Spills . • . 4-4

4.2.2 Cargo Storage Tanks--Category II Spills . • . 4-5

4.2.3 Basic Ship and Propulsion System . . . . . 4-5

4.3 COMPONENT LEVEL ANALYSIS • • • • • • • • . . . . 4-6

4.3.1 Cargo Handling System . . . . . . . 4-6

4.3.2 Cargo Storage Tanks . . . . . . . . . . 4-9 


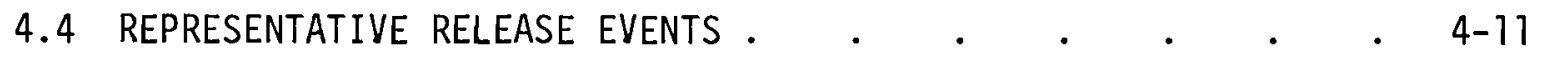

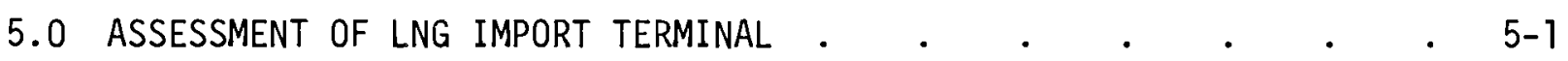

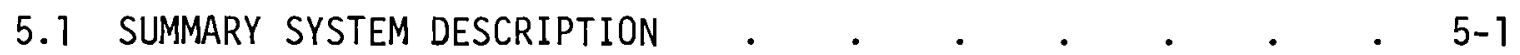

5.1.1 Marine Terminal and Unloading System . . . . . 5-1

5.1 .2 Storage System $\quad . \quad \ldots \quad . \quad \ldots \quad$. $\quad . \quad$. $5-1$

5.1.3 Compressors and Sendout Pumps . . . . . $\quad$. 5-3

5.1 .4 Vaporization System . . . . . . . 5-3

5.1 .5 Safety Systemis . . . . . . . . . . . $5-4$

5.2 SYSTEM LEVEL ANALYSIS . . . . . . . . . . . 5-5

5.2.1 Marine Terminal and Unloading System . . . . 5-5

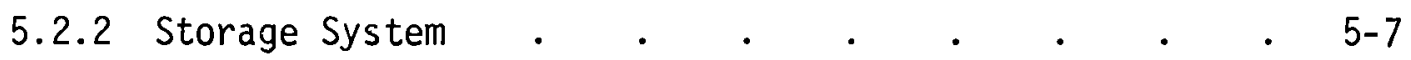

5.2.3 Compressors and Sendout Pumps . . . . . 5-7

5.2 .4 Vaporization System . . . . . . . . . 5-8

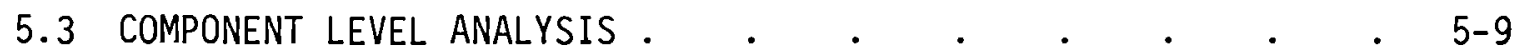

5.3.1 Marine Terminal and Unloading System . . . . 5-9

5.3.2 Storage System . . . . . . . . 5-12

5.3.3 Compressors and Secondary Pumps . . . . . . 5-16

5.3.4 Vaporization System . . . . . . . . 5-16

5.3 .5 Operator Interface . . . . . . . 5-23

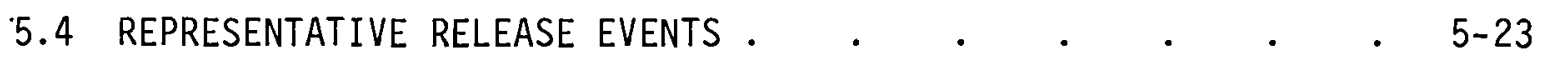

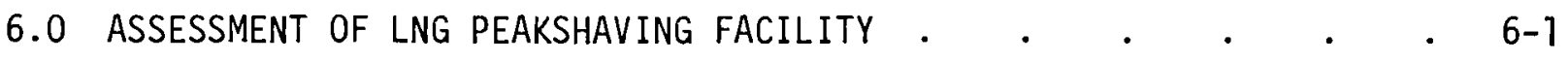

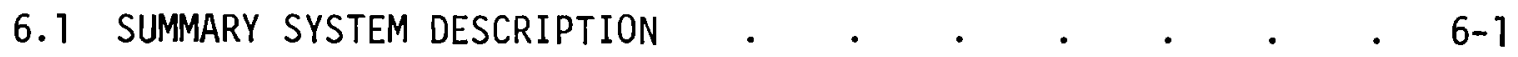

6.1.1 Gas Treatment System . . . . . . . 6-1

6.1 .2 Liquefaction System . . . . . . . . 6-1

6.1 .3 Storage System . . . . . . . . . 6-2 
6.1 .4 Vaporization System . . . . . . . 6-3

6.1.5 Transportation and Transfer System . . . . 6-3

6.1 .6 Safety Systems . . . . . . . . . . 6-4

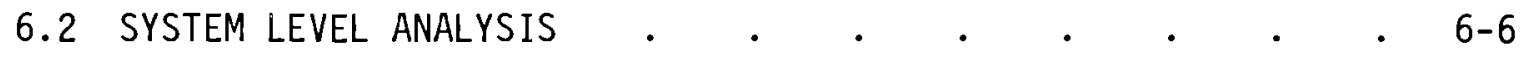

6.2.1 Gas Treatment System . . . . . . . 6-6

6.2.2 Liquefaction System . . . . . . . . 6-7

6.2 .3 Storage System . . . . . . . . . 6-7

6.2.4 Vaporization System . . . . . . . 6-8

6.2.5 Transportation and Transfer System . . . . 6-9

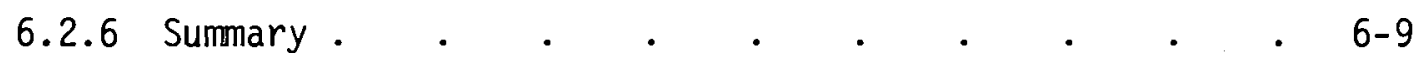

6.3 COMPONENT LEVEL ANALYSIS • . . . . . . . . . . . 6-9

6.3.1 Gas Treatment System . . . . . . . 6-10

6.3.2 Liquefaction System . . . . . . . 6-13

6.3.3 Storage System . . . . . . . . 6-16

6.3.4 Vaporization System . . . . . . . . 6-20

6.3.5 Transportation and Transfer System . . . . 6-23

6.3.6 Operator Interface . . . . . . . . 6-23

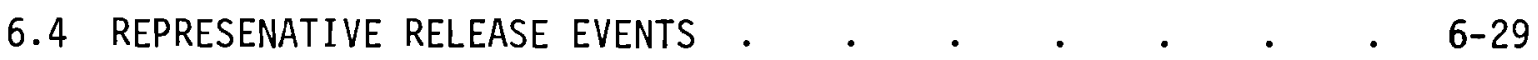

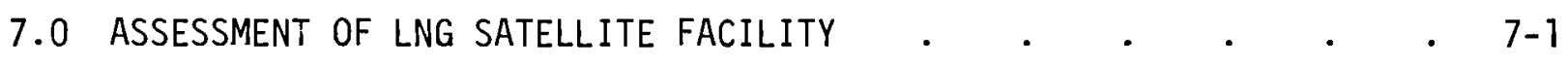

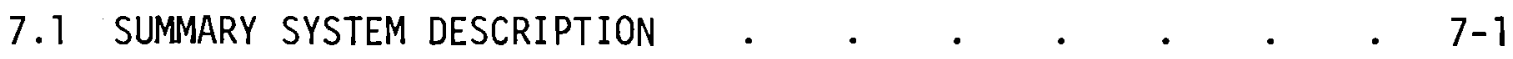

7.1.1 Transportation and Transfer System . . . . . 7-1

7.1 .2 Storage System . . . . . . . . . 7-2

7.1.3 Vaporization and Sendout System . . . . . 7-3

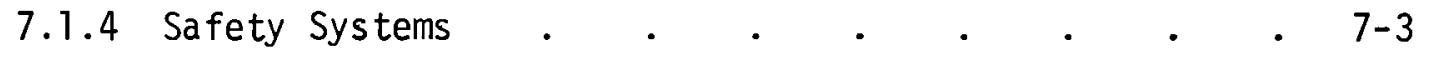

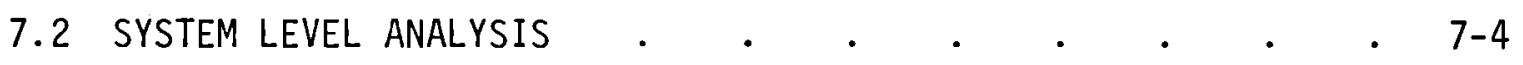


7.2.1 Transportation and Transfer System . . . 7-5

7.2.2 Storage System . . . . . . . . . .

7.2.3 Vaporization and Sendout System . . . . . 7-6

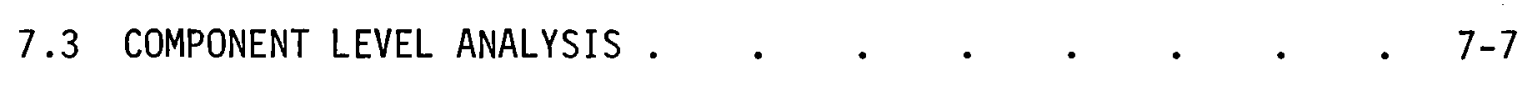

7.3.1 Transportation and Transfer System . . . . 7-7

7.3.2 Storage System . . . . . . . . 7-8

7.3.3 Vaporization and Sendout System . . . . . 7-13

7.4 REPRESENTATIVE RELEASE EVENTS . . • • • • • . 7-16

8.0 CONCLUSIONS AND RECOMMENDATIONS • • • • • • • • •

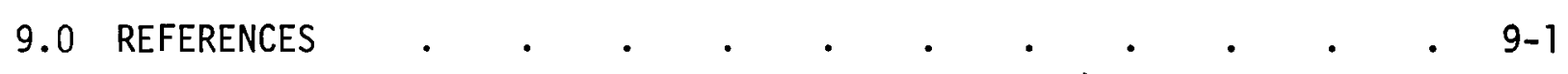

APPENDIX A - LNG INDUSTRY OVERVIEW . . . . . . . . . . . A-1

APPENDIX B - FACILITY DESCRIPTION OF REFERENCE LNG EXPORT TERMINAL • B-1

APPENDIX C - FACILITY DESCRIPTION OF REFERENCE LNG MARINE VESSEL . . C-1

APPENDIX D - FACILITY DESCRIPTION OF REFERENCE LNG IMPORT TERMINAL . D-1

APPENDIX E - FACILITY DESCRIPTION OF REFERENCE LNG PEAKSHAVING PLANT - E-1

APPENDIX F - FACILITY DESCRIPTION OF REFERENCE LNG SATELLITE PLANT • F-1

APPENDIX G - ANALYSES OF REPRESENTATIVE RELEASE EVENTS • • • • • $\quad$ G-1

APPENDIX H - PROCESS FLOW DIAGRAM SYMBOLS • • • • • • . $\mathrm{H}-1$ 


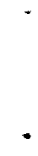




\section{FIGURES}

2.1 Analytical Approach for LNG Release Prevention and Control Study . 2-2

2.2 LNG Facility Operations . . . . . . . . . . . . 2-4

A. 1 Principal Operations Performed at Various LNG Facilities . . A-3

B.1 Block Flow Diagram for LNG Export Terminal . . . . . . B-3

B.2 Plot Plan for LNG Export Terminal . . . . . . . B-5

B.3 Gas Treatment Section - Process Flow Diagram . . . . . . B-7

B.4 Propane Precooled Multirefrigerant Cycle - Process Flow Diagram . B-13

B.5 Propane Refrigerant Heat Exchanger . . . . . . . . B-17

B.6 Main Cryogenic Coil-Wound Heat Exchanger . . . . . . . B-18

B.7 Flow Diagram for Marine Terminal and Storage Facilities . . B-21

B.8 LNG Storage Tank . . . . . . . . . . . . . . B-24

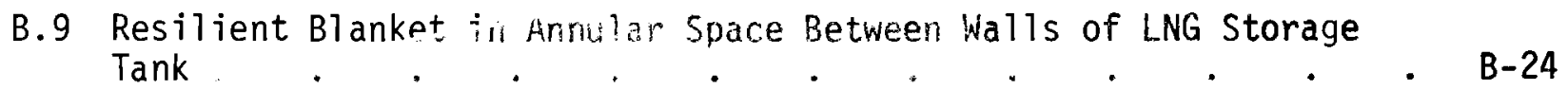

B.10 Load-Bearing Insulation and Anchor Bolts . . . . . . . B-25

B.11 Storage Tank Foundation Details . . . . . . . . . . . B-25

B. 12 Suspended Insulation Deck . . . . . . . . . . B-26

B.13 Bolloff Facilities. . . . . . . . . . B-29

B. 14 flow Diagram for Loading System . . . . . . . . B-33

B.15 Export Terminal Loading platform and Trestie. . . . . . B-34

B.16 Major Equipment on Unloading Deck . . . . . . . . . . . B-35

C.1 125,000 $\pi^{3}$ LNG Transfer iessel . . . . . . . . C-6

C.2 Navigational Equiphent for LNG Transfer Vessel . . . . . C-8

C.3 LNG Cargo Handing Systens . . . . . . . . . . . . C-11

C.4 Purging and Drying of Storage Tanks with Inert Gas . . . c c-17 
C.5 Spray Cooling of Cargo Tanks with LNG . . . . . . . . C-19

C.6 LNG Loading Operations . . . . . . . . . . . . C-21

C.7 LNG Unloading Operations . . . . . . . . . . . . . C C-27

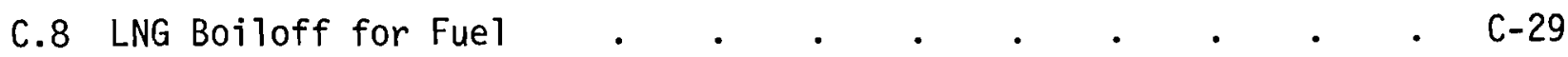

C.9 Kvaerner-Moss Spherical Tank Assembly . . . . . . . . . C-31

C.10 Kvaerner-Moss Spherical Tank-Equator Ring Forging . . . . . C-32

C.11 Insulated Skirting . . . . . . . . . . . . . . C-33

C.12 Insulation for Kvaerner-Moss Spherical Tank . . . . . . . C-33

C.13 Cargo Tank Safety Instruments . . . . . . . . . . . C-34

C.14 Collision Resistance of LNG Vessel . . . . . . . . . . . C-48

D.1. LNG Import Terminal - Block Flow Diagram • • • • • • D-3

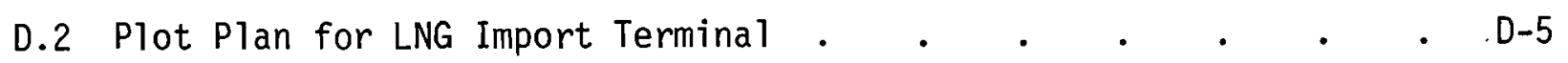

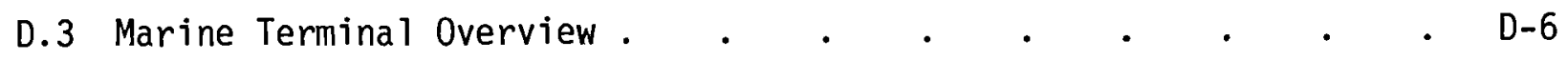

D.4 Marine Terminal Elevation . . . . . . . . . . D-6

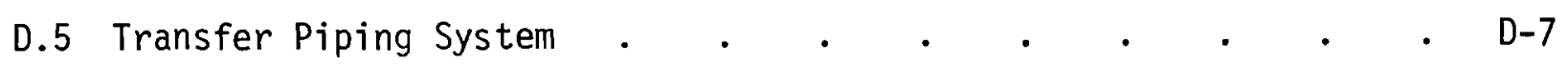

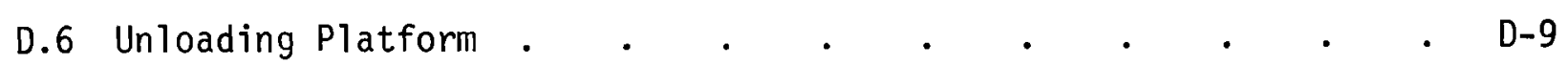

D.7 Piping and Instrumentation for LNG Transfer and Storage • • D-14

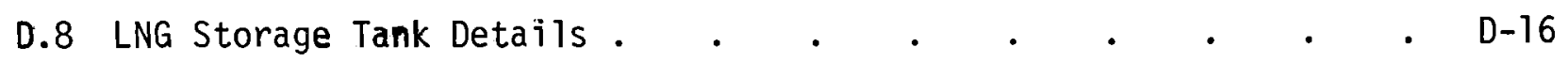

D.9 Resilient Blanket in Annular Space Between Walls of LNG Storage
Tank.
.

D.10 Storage Tank Foundation Details . . . . . . . . . . D-17

D.11 Compressors and Secondary Pumps . . . . . . . . . . D-19

D.12 Flow Diagram of Vaporization System . . . . . . . . . D-28

D.13 Falling Film Open-Rack Seawater Vaporizers . • • • • • • D-29

E.1 LNG Peakshaving Plant - Block Flow Diagram . . . . . . . E-5 
E.2 LNG Peakshaving Plant - Plot Plan . . . . . . . E-8

E.3 Gas Treatment Section - Process Flow Diagram . . . . . . E-11

E.4 Liquefaction Section - Process Flow Diagram . . . . . E-15

E.5 Spiral-Wound Heat Exchanger . . . . . . . . E-18

E.6 Storage Section - Process Flow Diagram . . . . . . E-23

E.7 LNG Storage Tank Details . . . . . . • . . E-26

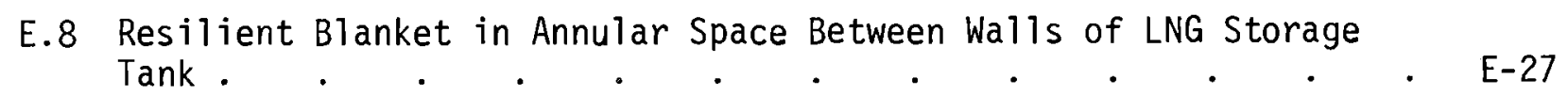

E.9 LNG Storage Tank Suspended Insulation Deck • • • • . E-27

E.10 Load Bearing Insulation and Anchor Bolts . . . . . E-27

E.11 Storage Tank Foundation Details . . . . . . . . E-28

E.12 Vaporization Section - Process Flow Diagram . . . . . E-35

E.13 Cutaway View of Submerged Combustion Vaporizer • • . . E-37

E.14 Components of Submerged Combustion Vaporizers . . . . E-38

E.15 Cross Section of LNG Trailer . . . . . • . . E-42

E.16 Flow Diagram for Trailer Loading and Unloading . • . . E-44

F.1 LNG Satellite Plant - Block Flow Diagram . . . . . F-3

F.2 Plot Plan for LNG Satellite Facility . • • • • • F-5

F.3 Process Flow Diagram for LNG Storage . . . . . . . F-7

F.4 LNG Storage Tank . . . . . . . . . . . . F-8

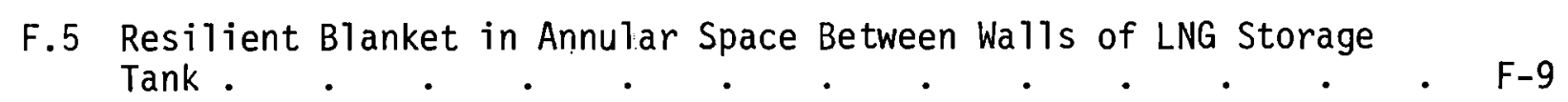

F.6 Suspended Insulation Deck . . . . . • . . F-10

F.7 Foundation for LNG Storage Tank • • • • • • • F-11

F.8 Process Flow Diagram for LNG Vaporization and Sendout • • . F-17

F.9 Cutaway View of Submerged Combustion Vaporizer . • . . F-78

F.10 Components of Submerged Combustion Vaporizers . . . . F-19 


\section{TABLES}

3.1 Liquefaction Section - Inventories and Flow Rates . . . . 3-5

3.2 Storage Section - Inventories and Flow Rates . . . . . 3-6

3.3 Loading Section - Inventories and Flow Rates . . . . . 3-7

3.4 Preliminary Hazards Analys is for the Gas Treatment and Liquefaction

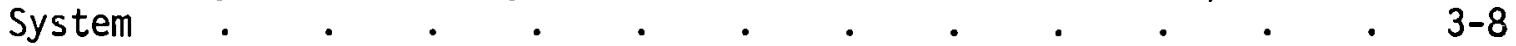

3.5 Preliminary Hazards Analysis for the LNG Storage Tanks and Boiloff Systems . . . . . . . . . . . . 3-14

3.6 Prel iminary Hazards Analys is for the Loading System . . . 3-18

3.7 Representative Release Events for an LNG Export Terminal . . 3-21

4.1 Selected Operating Parameters for the LNG Marine Vessel . . 4-4

4.2 Prel iminary Hazards Analys is of Cargo Handling System . . . 4-7

4.3 Prel iminary Hazards Analys is of Cargo Storage Tanks . . . 4-10

4.4 Represenative Release Events for an LNG Marine Vessel . . . 4-12

5.1 System Capacities and Flow Rates . . . . . . . 5-6

5.2 Preliminary Hazards Analysis for the Marine Terminal and

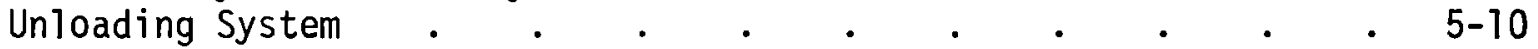

5.3 Preliminary Hazards Analys is for the Storage System . . . 5-13

5.4 Preliminary Hazards Analys is for the Compressors and Secondary
Pumps . . . . . . . . . . . . .

5.5 Preliminary Hazards Analysis for the Vaporization System . . . 5-21

5.6 Representative Release Events for an LNG Import Terminal . . 5-24

6.1 System Process Operation Conditions . . . . . . . 6-6

6.2 Postulated Releases from Pipe Breaks in a Peakshaving Facility . 6-10

6.3 Preliminary Hazards Analysis for the Gas Treatment System . . 6-11

6.4 Preliminary Hazards Analysis for the Liquefaction System . . 6-14

6.5 Prel iminary Hazards Analys is for the Storage System . . . 6-17 
6.6 Preliminary Hazards Analysis for the Vaporization System . . 6-21

6.7 Preliminary Hazards Analys is for the Transportation and Transfer System . . . . . . . . . . 6-24

6.8 Representative Release Events for an LNG Peakshaving Facility . 6-30

6.9 Representative Release Events for LNG Transportation and Transfer Operations . . . . . . . . . . . 6-30

7.1 System Process Operating Conditions . . . . . . 7-5

7.2 Preliminary Hazards Analysis for the Storage System . . . 7-9

7.3 Preliminary Hazards Analys is for the Vaporization and Sendout System . . . . . . . . . . . 7-14

7.4 Representative Release Events for an LNG Satellite Facility • • 7-16

8.1 Summary of LNG Facility Scoping Assessment . . . . . . 8-5

B.1 International Baseload LNG Liquefaction Facilities . . • B-2

B.2 Gas Treatment Section . . . . . . . . . . B-9

B.3 Liquefaction Section . . . . . . . . . . B-12

B.4 Storage and Loading Sections . . . . . . . . . B-23

B.5 Functions of the Pressure Control System . . . . . B-28

C.1 LNG Tankers in U.S. Trades . . . . . . . . C-4

C.2 Principal Characteristics of $125,000 \mathrm{~m}^{3}$ LNG Carrier . . . C

C.3 LNG Cargo Handling Systems . . . . . . . . . C-10

D. 1 U.S. and Canadian LNG Import Terminals . . . . . . D-2

D.2 LNG Transfer and Storage Systems . . . . . . . D-15

D. 3 Compressors and Secondary Pumps . . . . . . . . D-20

D.4 Pressure Control Settings . . . . . . . . . D-21

D.5 Vaporization System . • • • . . . . . . . . D-29

E.1 U.S. LNG Peakshaving Plants . . . . . . . . E-4

E.2 Gas Treatment Section . . . . . . . . . E-13 
E.3 Liquefaction Section

E.4 Storage Section

E.5 Storage Tank Connections and Fittings

E.6 Vaporization Section

F.1 Storage System .

F.2 Vaporization and Sendout System

G.1 Representative Release Events for an LNG Export Terminal

G.2 Representative Release Events for an LNG Marine Vessel.

G.3 Representative Release Events for an LNG Import Terminal

G.4 Representative Release Events for an LNG Peakshaving Facility

G.5 Representative Release Events for Transportation and Transfer Operations

- $\mathrm{E}-14$

- $\mathrm{E}-25$

- $E-29$

- $\mathrm{E}-37$

- $\mathrm{F}-6$

- $F-16$

- $\mathrm{G}-2$

. $\mathrm{G}-19$

- $\mathrm{G}-26$

- $\mathrm{G}-44$

G.6 Representative Release Events for an LNG Satellite Facility . . G-70

$x i x$ 


\subsection{SUMMARY}

The liquefied natural gas (LNG) industry employs a variety of release preyention and control techniques to reduce the likelihood and the consequences If accidental LNG releases. A study of the effectiveness of these release urevention and control systems is being performed by Pacific Northwest Laboratory (PNL) as part of the Liquefied Gaseous Fuels Safety and Environmental jontrol Assessment Program conducted by the U.S. Department of Energy, Office If the Assistant Secretary for Environmental Protection, Safety and Emergency Jreparedness (DOE/EP). The overal1 objectives of this PNL research project ire to develop an adequate understanding of release prevention and control systems and to identify factors which may alter or nullify their usefulness.

\subsection{STUDY APPROACH}

A phased approach was selected to accomplish the study objectives. First, reference descriptions for the basic types of LNG facilities were developed. In overview study was performed in the next phase of the study to identify .reas that merit subsequent and more detailed analyses. The final phase of she study is to conduct these more detailed analyses.

This report summarizes the results of the first two steps in the above approach. The specific objectives of this effort were to: 1) characterize she LNG facilities of interest and their release prevention and control systems; ?) identify possible weak links and research needs; and 3) provide an analytical framework for subsequent detailed analyses. The information presented in this meport has provided a necessary basis for the final (ongoing) phase of the PNL ; tudy and also background information to assist the overall planning of techlical effort in the DOE/EP Program.

The LNG facilities analyzed include a reference export terminal, marine 'essel, import terminal, peakshaving facility, truck tanker, and satellite facility. This report includes a reference description for these facilities, $\therefore$ preliminary hazards analysis (PHA), and a list of representative release scenarios. While the emphasis of this overview study is on release prevention, 
release control is implicit in many release prevention approaches. The reference facility descriptions outline basic process flows, plant layouts, and safety features. The PHA identifies the important release prevention operations. Representative release scenarios provide a format for discussing potential initiating events, effects of the release prevention and control systems, information needs, and potential design changes. These scenarios range from relatively frequent but low consequence releases to unlikely but large releases and are the principal basis for the next stage of analysis.

\subsection{STUDY RESULTS}

This overview study has identified some important release prevention features that merit more detailed consideration in the next phase of the stud: These are summarized below for each of the LNG facilities analyzed.

\subsection{P Export Terminal}

The storage and loading sections of the export terminal have the potentii for the largest LNG releases. Key storage section components include the inner and outer tank structure, the pressure control systems, the internal shutoff valves, and the liquid-level indicators and alarms. Important loadin! section components include the transfer line, the loading arms and coupling mechanism, and the loading emergency shutdown systems. In addition, the operator interface can have a significant effect on release prevention for al systems in the facility.

\subsubsection{Marine Vessel}

The largest potential spills of LNG from the marine vessel occur when one or more of the cargo tanks rupture. Failure or faulty operation of the cargo handling system generally results in smaller spills. Important cargo handling system components include the primary tank structure, the outer and inner hulls, the cargo tank level indicators, and safety valves. Important cargo handling system components include the liquid header, crossover line, valves, and the emergency shutdown system. The human element is also a factol during tanker loading and unloading. Crewman and operator training and good communications between ship and terminal personnel are particularly important 


\subsubsection{Import Terminal}

The storage section and the unloading sections of the import terminal have the potential for the largest LNG releases. The key storage and unloading components are the same as those of the export terminal.

\subsubsection{Peakshaving Facility}

The storage system and the vaporization system have the potential for the largest LNG releases from a peakshaving facility. Key storage section release prevention components include the inner and outer tank structure, the pressure control system, the tank discharge line, and the storage tank pump vessel. Important vaporization system release prevention components include the vaporizer heat exchanger tubes and water bath tank, the vaporizer discharge line, and the temperature controller on the discharge line. In addition, the operator interface can have a significant effect on release prevention for all systems in the facility.

\subsubsection{Truck Tanker}

The LNG truck tanker is analyzed as part of the peakshaving facility scoping assessment. Important transportation and transfer system release prevention components include the double-shell truck tank, the operator interface, and the pressure relief devices.

\subsubsection{Satellite Facility}

The storage system of the satellite facility has the potential for the largest LNG releases. Key storage section components include the inner and outer tank structure, the pressure control system, the tank discharge line, the LNG recirculation 1 ine, the storage tank pump vessel, and the boiloff heaters.

\subsubsection{Information Needs}

In performing this overview study, additional information needs were identified. Some of these needs were specific to the facility being analyzed and are discussed in the respective sections of this report. More general information gaps and needs were identified in such areas as the structural 
integrity of storage tanks when subject to hazardous conditions, the operator interface and its effect on release prevention and control, LNG equipment failure rate data, and the effect of thermal cycling on LNG equipment performance.

\subsection{DIRECTION OF CONTINUING STUDY}

The results of this study show that the marine vessel, import terminal, and peakshaving facility contain the basic release prevention and control elements utilized in the LNG industry. Building upon these results, PNL has initiated more detailed assessments of LNG import terminal and peakshaving facility release prevention and control systems. Marine vessel release prevention and control was considered in a separate portion of the DOE/EP Assessment Program (Arthur D. Little, Inc. 1980). The objective of the detailed import terminal and peakshaving facility assessments is to estimate release frequencies and volumes for the representative release sequences identified in this overview study. The effect of alternative release prevention and controi systems and procedures will be examined and compared on a quantitative basis. Studies are also being conducted by PNL on LNG fire and vapor control systems, LNG storage tank operations, and human factors in LNG release prevention and control. 


\subsection{INTRODUCTION AND ANALYTICAL APPROACH}

Liquefied Natural Gas (LNG) plays an important role in meeting the energy needs of the U.S. and other countries. Since one unit volume of LNG is equivalent to 600 unit volumes of natural gas, large volumes of gas can be economically stored and transported in the liquefied form. In the United States, LNG has a twenty-year record of safe handling and use. However, as is true for all large-scale energy related industries, LNG operations have some potential for accidents that present risks to property and life. Expected changes in industry size and characteristics and the scarcity of detailed knowledge about safety related issues have generated the need for an integrated safety and environmental control assessment of LNG operations. The Energy Research and Development Administration (ERDA) initiated a research program in 1977 to meet this need. This program has evolved into the Liquefied Gaseous Fuels (LGF) Safety and Environmental Control Assessment Program conducted by the U.S. Department of Energy, Office of Environmental Protection, Safety and Emergency Preparedness (DOE/EP). The plan for this DOE Program is presented in the first LGF Program Status Report. (U.S. Department of Energy 1979).

The LNG industry employs a variety of release prevention and control techniques to reduce the $1 \mathrm{ikelihood}$ and the consequences of accidental LNG releases. These release prevention and control systems are being studied by Pacific Northwest Laboratory (PNL) as part of the DOE/EP Assessment Program. The overal1 objectives of the PNL study are to develop an adequate understanding of release prevention and control systems utilized in the LNG industry and identify factors which may alter or nullify their effectiveness. This report contains the results of the first two phases of this effort which together provide an overview of release prevention and control in LNG processing, transportation and storage.

\subsection{STUDY PURPOSE AND ANALYTICAL APPROACH}

The purpose of this study was to provide information to assist the planning of the DOE/EP Assessment Program and to supply a basis for decision-making by the various parties involved with LNG safety and environmental control. To fulfill these goals the specific objectives of the PNL study are to: 
- Identify important features and possible weak links of LNG release prevention and control systems

- Identify data needs and information gaps

- Recommend approaches for obtaining this necessary additional information

- Identify potential areas where release prevention and control systems can be effectively improved

A phased analytical approach was adopted to accomplish the above objectivt The elements of this approach are indicated in Figure 2.1 and described below.

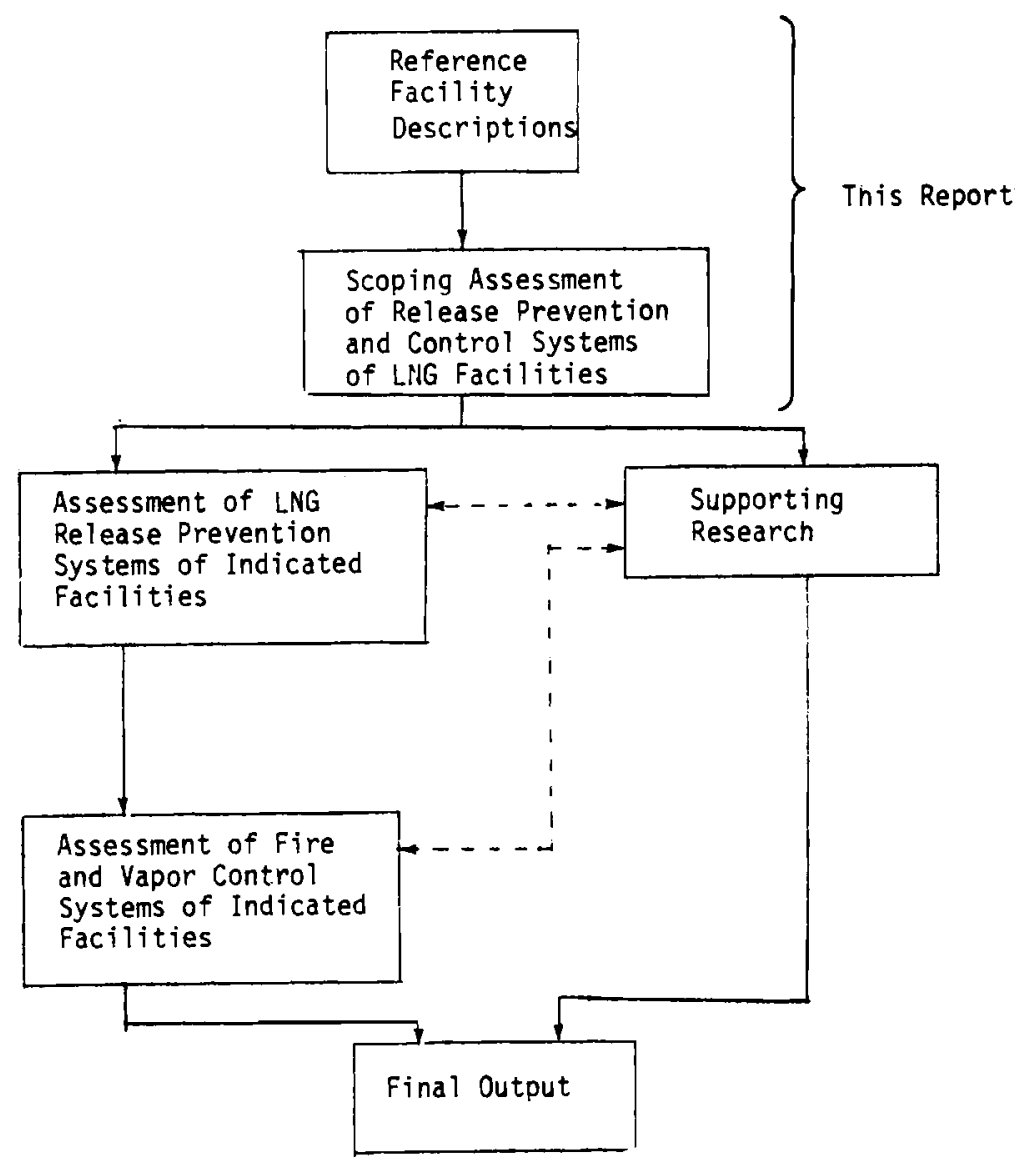

FIGURE 2.1. Analytical Approach for LNG Release Prevention and Control Study 


\subsubsection{Reference Facility Descriptions}

The basic facilities for LNG processing, transportation and storage are illustrated in Figure 2.2 and include the export terminal, marine vessel, import terminal, peakshaving facilities, truck tanker and satellite facility.

The first study phase focused on developing reference descriptions for each of these LNG facilities. It was recognized that there are many design alternatives and that there are no "standard" designs for these facilities. The reference designs developed and used in this study were based primarily on recently constructed or proposed LNG facilities. The reference facility descriptions provide a common basis for evaluating representative release prevention and control systems.

\subsubsection{Overview Study}

The reference descriptions were used in the second study phase to perform an overview, or first level analysis, to identify information needs and release prevention and control areas which may merit more detailed study. A preliminary hazards analysis (PHA) was performed in which potential hazard conditions were outlined for each major subsystem or component. The effect of hazardous conditions and existing prevention and control measures are described. Using the results of the PHA, a 1 ist of representative release events were developed for each facility. These events range from relatively frequent but low consequence releases to unlikely but large releases that are typical of the range of hazards involved in LNG operations. Possible initiating events, the influence of the release prevention and control systems, additional information required for further analysis, and potential design and operational changes were assessed on a preliminary basis. The representative release events form the basis for the quantitative evaluation of the release prevention and control systems in the next phase of analysis.

\subsubsection{Detailed Assessment}

The third phase of the study (to be presented in later reports of this series) consists of more detailed analyses recommended by the overview assessment. Because many LNG processing and storage operations are similar at different LNG facilities, the more detailed release prevention and control 


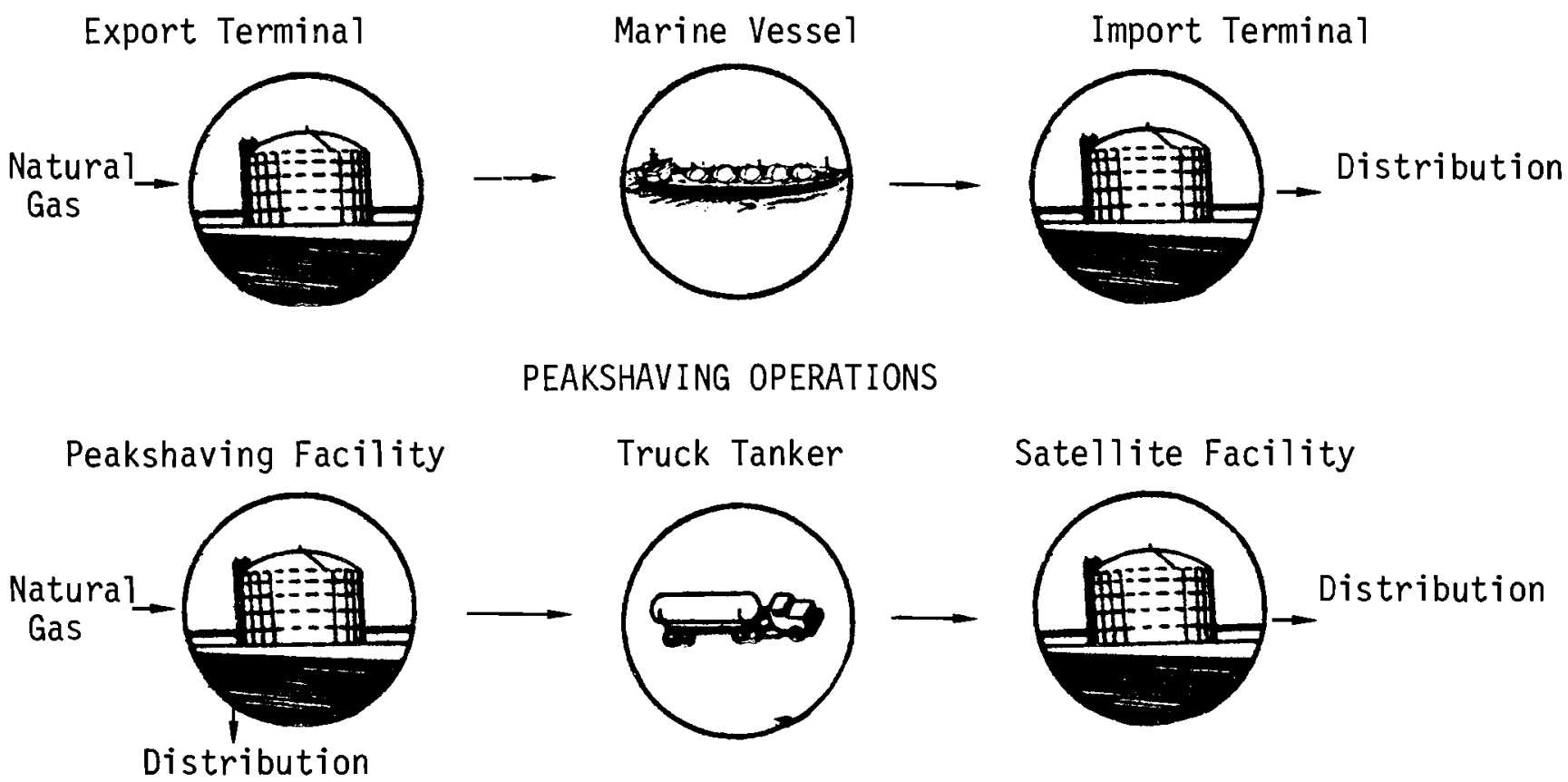

Export Terminal - a large capacity facility which receives natural gas, liquefies it after cleaning and stores the LNG until it is loaded on marine vessels for shipment to an import terminal.

Marine Vessel - ocean-going ship utilizing either self-supporting or membrane LNG storage tanks.

Import Terminal - a large capacity facility which receives LNG from oceangoing tankers, stores it and regasifies it to supply base-load demands.

Peakshaving Facility - a relatively small capacity gas treatment, liquefaction and storage unit with a high capacity vaporizer to supply peakshaving needs when the pipeline capacity cannot meet peak demand.

Truck Tanker - an over-the-road cryogenic trailer (with tractor) constructed with double walls and insulation in the annular space.

Satellite Facility - a small facility similar to a peakshaving facility but without a liquefaction unit. LNG is supplied normally by tank truck from a peakshaving facility.

\section{FIGURE 2.2. LNG Facility Operations}


assessments concentrate on a smaller number of facilities and unit operations. For the facilities of interest, representative release scenarios developed in the overview study are being quantified in terms of frequency of release and release quantity. Fault tree and event tree methods are being used where appropriate, and design alternatives quantitatively compared on the basis of changes they effect in the frequency or quantity of LNG releases.

\subsubsection{Fire and Vapor Control Assessment}

Fire and vapor control aspects are being considered in another phase of this study. The frequencies and consequences of the representative release scenarios are to be reevaluated in terms of vapor generation and fire potential. Finally, simple event trees are to be prepared and used to compare fire and vapor control systems design alternatives.

\subsubsection{Supporting Research}

The overview study identified and supplied general information required in subsequent detailed release prevention and control assessments. The results of the overview phase also suggest the need for more detailed study of LNG storage tank operations and human factor effects in LNG release prevention and contral.

\subsection{ORGANIZATION OF THIS REPORT}

The balance of this report provides an overview of release prevention and control systems for each of the representative LNG facility types considered in this study. Sections 3 through 7 , respectively, provide summary assessments of the export terminal, marine vessel, import terminal, peakshaving plant and satellite facility. The truck tanker assessment is included with the assessment of the peakshaving facility. Each of these sections provides an independent summary overview of a particular facility, including 1) a characterization of the basic facility and its release prevention and control systems, 2) the identification of knowledge gaps and research needs, and 3) an analytical framework for further detailed analyses. 
General conclusions and recommendations resulting from this study are presented in Section 8. Appendixes A through $G$ contain an overview of the LNG industry, detailed facility descriptions and data sources, and analyses of representative release events. Finally, Appendix $H$ summarizes the process flow diagram symbols used in this report. 


\subsection{ASSESSMENT OF LNG EXPORT TERMINAL}

This section presents the overview study of the reference LNG export terminal.

\subsection{SUMMARY SYSTEM DESCRIPTION}

The reference facility used for the export terminal overview study is designed to deliver 400 MMscfd of natural gas from Alaska to the lower fortyeight states. The plant consists of two 200-MMscfd liquefaction trains; two 550,000-bbl storage tanks; a 2,200-ft pier and trestle; and a loading platform to accommodate a $130,000-\mathrm{m}^{3}(820,000-\mathrm{bb} 1)$ LNG marine vesse1. The major operations performed at the plant and the plant safety systems are briefly described in the following paragraphs. A detailed description is presented in Appendix B.

\subsubsection{Gas Treatment}

The natural gas feed to the plant contains small quantities of $\mathrm{CO}_{2}$ and water which are solids at the final liquefaction temperature of $-260^{\circ} \mathrm{F}$. To prevent plugging in the liquefaction heat exchangers, each train has an amine scrubber to remove "acid gases" $\left(\mathrm{CO}_{2}\right.$ and $\left.\mathrm{H}_{2} \mathrm{~S}\right)$ and a molecular sieve adsorber to separate water. After treatment, the gas is routed to the liquefaction equipment.

\subsubsection{Liquefaction}

Refrigeration for the facility is provided by a propane precooled, mixed refrigerant cycle. The feed gas is first cooled to $-30^{\circ}$ by evaporating propane, and is then 1 iquefied and cooled to $-260^{\circ} \mathrm{F}$ by heat exchange with a multicomponent mixed refrigerant. The propane cycle also chills the mixed refrigerant. In each train, there are three levels of propane cooling and one main cryogenic jeat exchanger where heat exchange with the mixed refrigerant takes place. Three gas-turbine-driven compressors provide the work for each train's refrigeration cycle. Each train also has a feed gas booster compressor. 


\section{1 .3 Storage}

Liquefied natural gas leaves the main cryogenic heat exchanger at $-260^{\circ} \mathrm{F}$ and $560 \mathrm{psig}$ and, on entering one of the storage tanks, is let down to $0.9 \mathrm{ps}$ Storage at the facility consists of two 550,000-bbl, flat-bottomed, double-wa aboveground LNG storage tanks. The inner tank is constructed of $9 \%$ nickel steel and the outer shell of A131 carbon steel. The annular space between the walls is insulated with expanded perlite.

The outer tank has a lap-welded, dome-shaped steel roof. Suspended from the roof of the outer tank is a lap-welded metal deck that serves as a ceilin for the inner tank. The inner and outer tank floors are separated by a layer of foamglass, a nonflammable, load-bearing insulation. The outer tank floor rests on a ringwall foundation at the perimeter and compacted sand in the center. The sand layer contains electric heating elements to prevent "frost heave." The outside diameter of each tank is $225 \mathrm{ft}$, and the overall height is $146 \mathrm{ft}$.

To maintain the tank at $-260^{\circ} \mathrm{F}$ and $0.9 \mathrm{psig}$, boil-off vapor resulting fr heat leakage into the tank is removed and compressed for use as plant fuel. Pressure and vacuum relief valves are provided to protect the storage tanks from pressure variations.

\section{1 .4 Loading}

There are five LNG transfer pumps per tank, each with a capacity of $15,000 \mathrm{gpm}$. At the normal loading rate of $55,000 \mathrm{gpm}, 10-11 \mathrm{hrs}$ are required to load a $130,000-m^{3}$ ship.

The LNG is pumped via an insulated, 36-in. transfer line to the loading platform located at the end of a 2,200-ft-long pier. The loading platform supports four 16-in. LNG loading arms, one 16-in. vapor return arm, two vapor return compressors, and a 48-ft-high control tower.

During loading, vapor displaced from the ship's tanks is returned to shore via the 16-in. vapor return arm, the vapor return compressors, and the 24-in. vapor return line. When a ship is not being loaded, LNG is circulated through the 36-in. transfer line and back to the storage tanks through a 4-in recirculation 1 ine. 


\subsubsection{Safety Systems}

Combustible gas detectors, flame detectors, and temperature sensors are located throughout the plant area. These sensors activate alarms that indicate the exact location of a spill or fire on a graphic panel in the contol room.

Various pieces of equipment in the plant are connected to the Emergency Shutdown (ESD) system. The ESD has two major circuits: the Master Emergency Shutdown (MES) which shuts down the whole facility and the Loading Emergency Shutdown (LES) which shuts down just the loading system. The ESD is activated by certain of the sensors described above, by limits on certain process control variables, or by the plant operators.

Spill containment at the plant is provided by dikes in various areas. Each storage tank is encircled by a concrete dike $55 \mathrm{ft}$ high and $285 \mathrm{ft}$ in diameter. Each liquefaction train is surrounded by a low-level dike, and a common impoundment area serves the three refrigerant storage tanks.

Pressure relief valves are used to protect various processing equipment, tanks, and piping in the facility. Gas discharges from these valves, except those from the storage tanks, enter the flare header system and are directed to the flare stack for incineration. The storage tank relief valves vent to the atmosphere. Liquid discharges are collected and returned to the storage tank. A portion of the flash gas generated from cargo filling is vented to the atmosphere through the vapor return vent.

The fire control system consists of a fire water loop with hydrants and monitor nozzles and a dry chemical system which includes fixed systems with permanent nozzles, fixed systems with hoselines, and portable extinguishers. High-expansion foam systems are not used because of the cold weather at the terminal.

\subsection{SYSTEM LEVEL ANALYSIS}

The purpose of the system level analysis is to identify those sections of the export terminal that are most critical with respect to release prevention and control. The evaluation of each system is based largely on two factors: 
1) the quantity of a potential release of hazardous material due to either the inventory or the flow rate and 2) an estimate of the relative probability of a release (low, medium, high).

\subsubsection{Gas Treatment and Liquefaction}

Operation of the liquefaction train (and associated gas treatment system) involves the use of four hazardous materials:

1. natural gas/LNG $\left(98 \% \mathrm{CH}_{4}, 1 \% \mathrm{C}_{2} \mathrm{H}_{6}, 1 \% \mathrm{~N}_{2}\right)$

2. propane (gas and liquid)

3. mixed refrigerant consisting of nitrogen, methane, ethylene, and propane (gas and liquid)

4. monoethanolamine (MEA) scrubbing solution.

The major hazards associated with the first three are the flammability of the gas and the cold temperature of the liquid. The fourth, MEA, is both toxic and combustible.

Table 3.1 gives the flow rate, process operating conditions, and an estimate of the inventory of each of the four materials. This data is for each of the two liquefaction trains.

There are two general modes for releases from the 1iquefaction system:

- leak or rupture in pipes, vessels, valves, pumps, etc.

- discharge from the process relief valves (either to the flare stack or back to the storage tank).

Generally, one containment barrier is provided (i.e., a single leak or rupture will result in a release). In some cases, two failures are required for a release (e.g., failure of tubing in heat exchanger shells would not result in a release). All liquid releases from the liquefaction system are confined to the liquefaction area by low-level dikes. No relief valves in the liquefaction section exhaust directly to the atmosphere.

In an emergency, the MES blocks the natural gas feed line and isolates the 1 iquefaction system from the rest of the facility. This system is activated by 
TABLE 3.1. Liquefaction Section - Inventories and Flow Rates

\begin{tabular}{|c|c|c|c|c|}
\hline & & & Operating & Conditions \\
\hline Material & $\begin{array}{c}\text { Inventory } \\
\text { (gallons [scf]) }\end{array}$ & $\begin{array}{l}\text { Flow Rate } \\
\text { (gpm [scfd]) }\end{array}$ & $\begin{array}{c}\text { Pressure } \\
\text { (psig) }\end{array}$ & $\begin{array}{l}\text { Temperature } \\
\left({ }^{\circ} \mathrm{F}\right)\end{array}$ \\
\hline LNG/Natural Gas & $1.2 \times 10^{3}\left[1.0 \times 10^{5}\right]$ & $1.7 \times 10^{3}\left[2.0 \times 10^{8}\right]$ & 500 to 600 & 80 to -260 \\
\hline Propane & $1.0 \times 10^{4}\left[3.1 \times 10^{5}\right]$ & $1.4 \times 10^{4}\left[6.0 \times 10^{8}\right]^{(a)}$ & 1 to 240 & 129 to -35 \\
\hline Mixed Refrigerant & $3.6 \times 10^{3}\left[1.7 \times 10^{4}\right]$ & $5.8 \times 10^{3}\left[4.0 \times 10^{8}\right]^{(a)}$ & 167 to 650 & 250 to -30 \\
\hline MEA Solution & $1.0 \times 10^{2}$ & $1.0 \times 10^{2}$ & 480 to 520 & -- \\
\hline
\end{tabular}

(a) Because both refrigeration cycles and the MEA system are closed loops, the actual flow into the system is zero, so the flow rates given are the normal circulation rates.

fire detectors throughout the plant, by the gas detectors in the compressor building, or manually from several locations throughout the plant. The largest potential release of natural gas from the system is about $1.4 \times 10^{6} \mathrm{scf}$, assuming the system can be isolated in 10 minutes. The probability of this release is estimated to be low.

\subsubsection{Storage}

The storage section includes the two main LNG storage tanks as well as three small refrigerant storage tanks. The hazardous materials stored at the facility are LNG, propane, and ethylene. All three are hazardous because of their flammability, and LNG and ethylene are also hazardous because of the cold temperatures at which they are stored. Ethylene is moderately hazardous if inhaled. Table 3.2 gives the sizes of the storage tanks and the storage conditions for each material, and also includes the normal flow rates into and out of the tanks.

The main LNG storage tanks and the ethylene storage tank are low-pressure, double-walled, cylindrical storage tanks. Only the inner tank is constructed of materials suitable for cryogenic temperatures, so failure of the inner tank would probably lead to failure of the outer tank. The two propane tanks are fully pressurized, single-walled, spherical storage tanks.

Besides gross failure of the storage tanks, there are two other general release modes in the storage section:

- leak or rupture in inlet and outlet piping and fittings

- discharge to the atmosphere from the storage tank relief valves. 
TABLE 3.2. Storage Section - Inventories and Flow Rates

\begin{tabular}{|c|c|c|c|c|c|}
\hline $\begin{array}{l}\text { Storage } \\
\text { Tank } \\
\end{array}$ & $\begin{array}{l}\text { No. of } \\
\text { Tanks }\end{array}$ & $\begin{array}{l}\text { Volume } \\
\text { Per Tank } \\
\text { (gallons) } \\
\end{array}$ & $\begin{array}{c}\text { Flow Rates } \\
\text { In/Out } \\
\text { (gpm [scfd]) }\end{array}$ & $\begin{array}{l}\text { Operating } \\
\text { Pressure } \\
\text { (psig) }\end{array}$ & $\begin{array}{l}\text { Conditions } \\
\text { Temperature } \\
\left({ }^{\circ} \mathrm{F}\right) \\
\end{array}$ \\
\hline LNG & 2 & $2.3 \times 10^{7}$ & $3.3 \times 10^{3}\left[4,0 \times 10^{8}\right]$ & 0.9 & -260 \\
\hline Propane & 2 & $1.7 \times 10^{5}$ & - & 200 & 60 \\
\hline Ethylene & 1 & $1.0 \times 10^{5}$ & -- & 0.5 & -155 \\
\hline
\end{tabular}

The MES isolates the LNG storage tanks from the rest of the plant in the event of an emergency. The MES can be activated by a high level or high or low pressure in the LNG storage tanks. The largest possible spill in the storage area is $4.6 \times 10^{7}$ gallons, resulting from failure of both LNG storage tanks. The probability of this release is estimated to be low.

\subsubsection{Loading}

LNG is the only hazardous material handled in the loading section of the plant. The loading section has two general modes by which LNG can be released from the system:

- leak or rupture in pipes, fittings, loading arms, connections, etc.

- discharge from the thermal relief valves in the transfer line (routed back to the storage tank).

The main LNG transfer line connecting the storage tank facilities with the loading platform is an insulated, low-pressure pipeline made of stainless steel. Because of the length $(2,200 \mathrm{ft}$.$) and diameter (36 in.) of the line, a$ single leak or break can result in a large spill. The LES is designed to reduce the amount of LNG released in the event of a leak or break. The inventory and flow rates in the main transfer line, as well as the vapor return line and liquid recirculation line, are shown in Table 3.3. The maximum spill in the loading system is approximately $1.7 \times 10^{5}$ gallons if the LES works properly. If the LES fails, the spill could be considerably larger - up to $7.0 \times 10^{5}$ gallons or more. The probability of this release is estimated to be low. 
TABLE 3.3. Loading Section - Inventories and Flow Rates

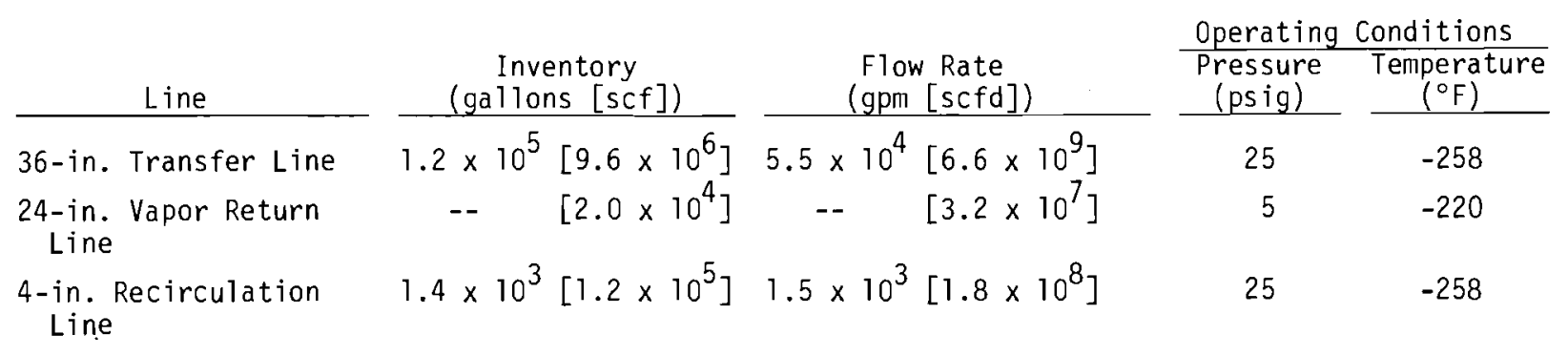

\subsection{COMPONENT LEVEL ANALYSIS}

The system level analysis indicates that the largest inventories and flow rates of hazardous materials occur in the storage section and the loading section. The maximum size of a spill or release from these sections is orders of magnitude larger than the largest spill or release possible in the liquefaction section (including gas treatment). However, the majority of the processing equipment and plant piping is in the liquefaction section, so there appears to be a greater likelihood of a spill or release in this section. As a result, a component level analys is is presented for all three sections.

This component level analysis consists of a preliminary hazards analys is (PHA). The PHA's for the export terminal operations are given in tabular form in the following sections. The potential hazards, effects, and existing preventive and control measures are outlined.

For active components (e.g., pumps, controllers, compressors, electrical components), two or more separate failures are required in most cases for a significant release. For passive components (e.g., piping, process vesse1s), a single failure can result in a release, but in many cases the emergency shutdown systems are designed to 1 imit the release.

\subsubsection{Gas Treatment and Liquefaction}

The results of the preliminary hazards and analys is for the liquefaction section are shown in Table 3.4. (Component numbers given in the table refer to designations used in Appendix B.) Because of the complexity of the liquefaction unit, the list is quite long. Many of the postulated initiating events are leaks 
TABLE 3.4. Preliminary Hazards Analysis for the Gas Treatment and Liquefaction System

\section{Potential}

Hazard

Component

1. Gas pipelines in amine system

2. Amine contactor, $v-3$

3. Amine stripper, V-4

4. Piping, pumps, valves, etc in amine system

5. Gas pipelines in mole sieve section

6. Water separator, V-6 and mole sieve units, $v-7$

7. Regeneration system

8. Feed gas piping and valves up to propane exchangers, E-123, 122,121

9. Feed gas piping and valves from propane exchangers to main cryogenic heat exchanger, E-102

10. reed gas tubing in propane exchangers E-123, 122, 121

11. Feed gas tubing in main cryogenic heat exchanger, E-102

12. Mole sieve driers, $V-7$; filter, $V-101$; air cooler, E-101 and scrub column,
Rupture or leak

a) Failure to scrub out $\mathrm{CO}_{2}$

b) Rupture or leak

a) Failure to scrub out $\mathrm{CO}_{2}$

b) Rupture or leak

Rupture or leak

Rupture or leak

a) Failure to remove water

b) Rupture or leak

a) Failure to regenerate mole sieves

b) Rupture or leak

Rupture or leak

Rupture or leak

Rupture or leak

Rupture or leak

Rupture or leak
Preventive \& Control Measures

Release of natural gas

a) Potential plugging in cryogenic heat exchangers

b) Release of natural gas and amine liquid

a) Potential plugging in cryogenic heat exchangers

b) Release of amine liquid

Release of amine liquid

Release of natural gas

a) Potential plugging in cryogenic heat exchangers

b) Release of natural gas

a) Water carryover in feed gas - potential plugging b) Release of natural gas

Release of natural gas

Release of natural gas plus some liquefied heavy hydrocarbons

Natural gas leaks into propane refrigerant

Natural gas leaks into mixed refrigerant

Release of natural gas 
TABLE 3.4. (contd)

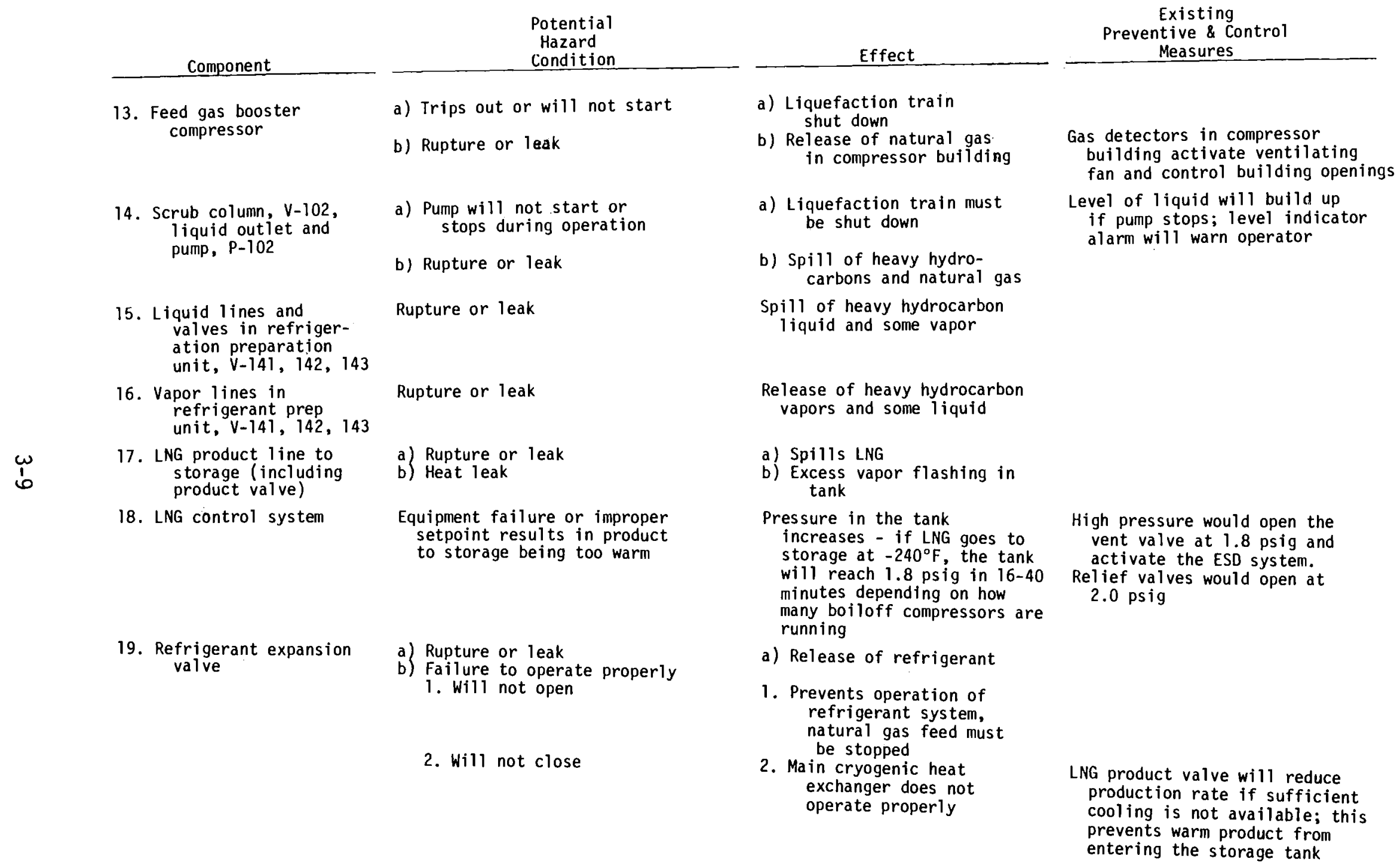


TABLE 3.4. (contd)

\begin{tabular}{l} 
Component \\
\hline 20. Refrigerant liquid \\
line from separator \\
V- 112 , to ma in cryo- \\
genic heat exchanger, \\
E-102 \\
21. Refrigerant liquid/ \\
vapor tubing in E-102 \\
22. Refrigerant vapor 1 ine \\
from separator, $V-112$ \\
to E-102 \\
23. Main cryogenic heat \\
exchanger, E-102
\end{tabular}

$\frac{\omega}{0}$

Potential
Hazard
Condition

Rupture or leak

Rupture or leak

Rupture or leak

a) Rupture or leak in exchanger shell

b) Large heat leak resulting from from inșulation failure, etc 24. Refrigerant 1 ine from
E-102 to compressor C- 111

25. First stage refrigerant compressor, $\mathrm{C}-111$

26. Second stage refrigerant compressor, $\mathrm{C}-112$

27. Piping and valves from 2nd stage compressor, C-112 to propane exchangers, E-123 (including air cooler c-112)
Rupture or leak

a) Rupture or leak

b) Trips out or will not start

Same as lst stage

Rupture or leak
Existing

Preventive \& Control

Measures
Refrigerant 1 iquid/vapor leaks into refrigerant vapor,

process upset

Releases refrigerant vapor

Release of refrigerant vapor

b) Reduction in LNG produced or pressure buildup in LNG tubing and possible pressure buildup in ma in heat exchanger shell

Release of refrigerant vapor

a) Release of refrigerant vapor

b) Refrigerant flow stops and LNG production stops, 2nd stage compressor may overheat if not shut down quickly

Same as lst stage except that 1st stage may overheat if not shut down quickly

Release of refrigerant vapor 


\section{TABLE 3.4. (contd)}

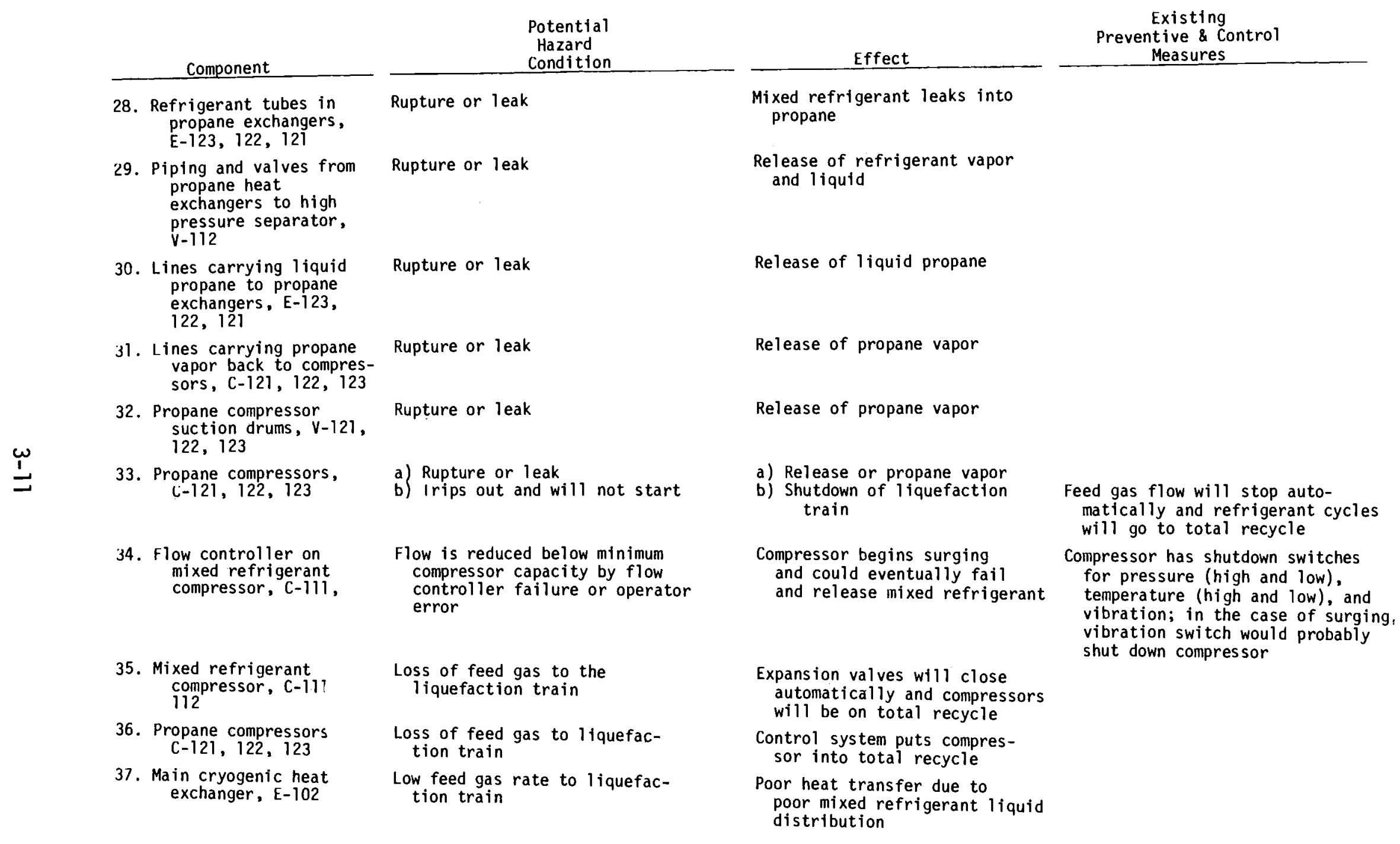


TABLE 3.4. (contd)

Potential

Hazard

Condition

38. Propane compressor $c-121,122,123$ Improper control settings or
controller failure

39. Mixed refrigerant compressor, $\mathrm{C}-121$, 122,123

40. Liquefaction train

41. Level controller in propane flash drums

42. Compressor shutdown
switches
a) Mixed refrigerant compressors
b) Propane compressor
c) Feed gas compressor

Trips out and will not start

Loss of air coolers in refrigerant systems, E-111, 112, 124,125

a) Controller fails and flash drums fills with liquid

b) Controller fails and flash drum loses liquid level

Fail to operate properly

Effect

Compressor surges and could eventually fail

Loss of cooling to main heat exchanger

Refrigerant systems and feed gas will begin to heat up

a) Liquid propane could reach compressor suction, possible failure of propane compressors, $C-121,122,123$

b) Insufficient cooling of the Same as 40 (above) feed gas and mixed refrig-

Compressors are not shut down in the event of high vibraation, over temperature, etc This could lead to failure of the compressor
Existing

Preventive \& Control

Measures

Compressor shutdown, either manually or from high vibration switches

LNG flow controller would close due to high outlet temperature; propane compressor would go into total recycle automatically

Product temperature controller will stop feed gas flow and refrigerant systems will go to total recycle; if not shut down, the system pressure will rise quickly and activate the relief valves

Compressors can be shut down manually 
or ruptures in pipes, valves, vessel and similar components. Key components in the liquefaction unit, as indicated by the PHA, are listed below:

- Process Control System. Control of the liquefaction train is quite complicated. Often two or three process variables are multiplied together to get a signal for a control valve. Improper control point settings or failure of the control loop can result in insufficient cooling of the feed gas and excess vapor in the storage tank, surging of the refrigeration compressors (and possible failure of the compressor or the inlet and outlet piping), liquid carryover to the compressor suction, and numerous other potentially hazardous conditions. The probability of these types of failures is estimated to be medium.

- Refrigerant Compressors. These large, gas-turbine-driven, centrifugal compressors can fail from changes in the operating conditions of the refrigerant cycle. Low flow rates can cause surging, and changes in the suction conditions (temperature and pressure) can cause liquid to condense in the compressor. Proper operation of the shutdown switches for high pressure, temperature, vibration, etc., is necessary to prevent failure of these compressors. The ability of the control system to prevent upsets and to put the refrigerant cycles into total recycle in emergency situations is critical to safe operation of the compressors. The probability of a compressor failure is estimated to be medium.

\subsubsection{Storage}

The preliminary hazards analysis for the storage section is presented in Table 3.5. Important components in the LNG storage section, as identified by the PHA, are listed below.

- Pressure Control System. This includes the boiloff compressors, the pressure indicators and controllers, and the tank relief valves. The probability of failure for these types of components is estimated to be medium. 
TABLE 3.5. Preliminary Hazards Analysis for the LNG Storage Tanks and Boiloff Systems

\begin{tabular}{|c|c|c|}
\hline Component & $\begin{array}{l}\text { Potential } \\
\text { Hazard } \\
\text { Condition }\end{array}$ & Effect \\
\hline
\end{tabular}

1. Storage tank, T-201, 202 a) Leak or rupture in inner cryogenic barrier

b) Leak or rupture of outer tank from

1. Overpressure

2. Underpressure

3. Other causes

2. Vapor lines into and out Leak or rupture of tank

3. Boil off compressor and a) Leak or rupture

controller, C-221, 222 b) Fails to operate properly 1. Will not run

2. Runs at full speed only

4. Pressure relief valve(s) Fails to operate properly a) Opens below set pressure

b) Fails to open on demand or opens above set pressure

5. Vacuum relief valve(s)

Fails to operate properly

a) Opens above set pressure

b) Fails to open on demand or opens below set point a) Spills LNG into space between tanks, could cause failure of outer tank and collapse of tank

1. Will likely fail at roofshell joint and depressure the tank

2. Collapse of outer tank could cause failure of inner tank

3. Same as b2 above

Depressures the tank

a) Depressures the tank

1. Pressure in tank rises

2. Pressure in tank falls

a) Tank depressures until valve closes

b) Pressure in the tank continues to rise and tank could fail from over pressure

a. Tank depressures to a tmospheric pressure

b) Pressure in tank continues to fall and tank could fail from underpressure
Existing

Preventive \& Control

Measures

Inner tank constructed of $9 \% \mathrm{Ni}$ steel which has good cryogenic properties

Protection against overpressure is provided by a vent valve which opens $01.8 \mathrm{psig}$ and 12 relief valves which open o 2.0

psig.

Low pressure would activate

emergency gas supply to tank a 0.2 psig; vacuum relief valves would open 0.03 psig

Same as b2 above

Same as b2 above

High pressure would activate alarm and would open control valve to vent 01.8 psig;

pressure relief valves would

relieve 02.0 psig.

Same as b2 above

Maintenance and inspection of relief valves

\section{Same as 4 above}


TABLE 3.5. (contd)

Potential

Hazard

Component

6. LNG fill lines and other Leak or rupture

liquid lines entering the top of the tank

7. LNG withdrawal 1 ines from the bottom of the tank

8. Insulation between inner and outer tank walls

$\frac{\omega}{G}$

9. Storage tank

10. Storage tank

Rollover

Leak or rupture before first block valve

\section{Ineffective}

Overfill

11. Foundation heater

Fails to operate
Existing

Preventive \& Control

Measures

Low temperature detection in

tank dike would activate MES

Same as above NG spills into diked are or on to tank

b) If the lines are not in

operation and the break

occurs before the first

blocked valve, the tanks

will be depressured

See loading system PHA

Heat leak results in increased boil off and potential overpressure of the tank; could also result in cold spot on outer tank wall and potential

failure of outer tank

Spills LNG into annular space between tanks; could cause failure of outer tank

At $95 \%$ of full capacity, alarm is activated; at $98 \%$ of full capacity, 2nd alarm is sounded and all liquid inlet and outlet lines are closed automatically

Excessive vapor produced; could Tank has top and bottom fill nozcause pressure increase in tank zles to mix different densities of LNG; tank has thermocouples which can indicate stratification and potential rollover; tank can be recirculated from top to bottom and vice versa

If rollover does occur and pressure in tank rises, same as 3 above
If pressure in tank rises, same as 3 above
Ground under foundation freezes and the resulting frost heave could cause storage tank to fail 
TABLE 3.5. (contd)

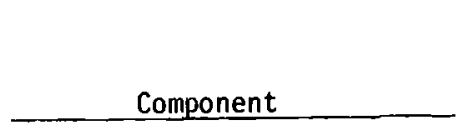

12. Propane storage tanks

13. Ethylene storage tank

14. Master Emergency Shutdown (MES)

a) detectors

c) controllers

d) isolation values

e) shutoff switches
Potential

Hazard

Conditit

Failure of tank shell or inlet and outlet nozzles and fittings

a) Failure of outer tank shel1

bailure of inner tank shell

c) Failure of liquid outlet nozzles before the first block valve
Fails to operate properly
Existing

Preventive \& Control

Measures

a) If break is above liquid level, propane vapor is released

b) If break is below liquid level, propane liquid is released

a) Release of ethylene vapor
b) Liquid ethlene spills is outer tank and outer tank could fail, releasing ethylene

c) Entire contents of the tank would be released

Terminal systems are not shut down and isolated automatically in an emergency

All functions of the MES can be performed manually 
- Internal Shutoff Valves. If the liquid outlet lines from the tank rupture before the first block valve, these internal shutoff valves can be closed to prevent the entire tank contents from spilling. The probability of an internal shutoff valve failure is estimated to be medium.

- Storage Tank Level Indicators and Alarms. These alarm in the control room and activate the MES to prevent overfilling the inner storage tank. The failure of level indicators and alarms is estimated to have a medium probability.

- Storage Tank Insulation. Improper installation of insulation or subsequent loss of effectiveness can cause cold spots on the carbon steel outer shell and possible failure of entire tank. The loss of insulation effectiveness is estimated to have a low probability.

- Outer Tank. This protects the insulation from exposure to the elements and protects the inner tank from external events such as fires and explosions in the plant, sabotage, and severe storms. The probability of a failure of the outer tank is estimated to be low.

- Inner Tank. Built of $9 \%$ nickel steel, this she11 is exposed to temperatures ranging from $-260^{\circ} \mathrm{F}$ to ambient (when out of service). A leak or crack in this shell could eventually lead to failure of the entire tank. The probability of such a failure is estimated to be low.

While not nearly as large as the LNG storage tanks, the refrigerant storage tanks also pose a potential hazard. Several failures of this size and type of tank have been reported, and the proximity of these tanks to the LNG storage tanks makes them even more important.

\subsubsection{Loading}

Operation of the loading section is not complicated. However, for release prevention and control purposes, the loading section may be the most critical portion of the export terminal because of the high flow rates, the long length of the transfer lines, and the large diameter valves and fittings. The preliminary hazards analys is for the loading section is shown in Table 3.6. The PHA shows the following components to be most important with respect to release prevention and control. 
TABLE 3.6. Preliminary Hazards Analysis for the Loading System

\begin{tabular}{|c|c|c|c|}
\hline Component & $\begin{array}{c}\text { Potential } \\
\text { Hazard } \\
\text { Condition } \\
\end{array}$ & Effect & $\begin{array}{l}\text { Existing } \\
\text { Preventive \& Control } \\
\text { Measures }\end{array}$ \\
\hline $\begin{array}{l}\text { 1. } 36 " \text { transfer line on } \\
\text { loading dock }\end{array}$ & Rupture or leak & $\begin{array}{l}\text { Spills LNG into basin under } \\
\text { dock }\end{array}$ & $\begin{array}{l}\text { Low temperature detector in. spill } \\
\text { basin, gas detector on dock, or } \\
\text { low pressure in transfer line will } \\
\text { will activate LES }\end{array}$ \\
\hline $\begin{array}{l}\text { 2. } 36 \text { " transfer line } \\
\text { and } 4 \text { " recirculation } \\
\text { line between dock and } \\
\text { the shore }\end{array}$ & $\begin{array}{l}\text { a) Rupture or leak } \\
\text { b) Large heat leak (insulation fail- } \\
\text { ure, etc.) }\end{array}$ & $\begin{array}{l}\text { a) Spills LNG on trestle and in } \\
\text { water } \\
\text { b) Possible overpressure of } \\
\text { line }\end{array}$ & $\begin{array}{l}\text { Low pressure will automatically } \\
\text { activate LES } \\
\text { High pressure will automatically } \\
\text { activate LES; lines are equipped } \\
\text { with thermal relief valves }\end{array}$ \\
\hline $\begin{array}{l}\text { 3. Valves in transfer lines } \\
\text { from loading pumps, } \\
\text { P-201, 202, to ship } \\
\text { coupling }\end{array}$ & $\begin{array}{l}\text { a) Rupture } \\
\text { b) Failure to operate properly } \\
\text { 1. Will not open } \\
\text { 2. Will not close }\end{array}$ & $\begin{array}{l}\text { Spill LNG } \\
\text { 1. Can not load ship or } \\
\text { recirculate } \\
\text { 2. No major effect on loading } \\
\text { may not be able to recir- } \\
\text { culate }\end{array}$ & $\begin{array}{l}\text { If on dock, same as } 1 \text { above } \\
\text { If on trestle, same as } 2 \text { above }\end{array}$ \\
\hline & 3. Close too fast & $\begin{array}{l}\text { 3. Fluid hammer and possible } \\
\text { pipe rupture and spill of } \\
\text { LNG }\end{array}$ & $\begin{array}{l}\text { LES is programmed so that block } \\
\text { valve closing rates will not } \\
\text { cause fluid hamer }\end{array}$ \\
\hline $\begin{array}{l}\text { 4. Valves in dock drain } \\
\text { lines }\end{array}$ & $\begin{array}{l}\text { a) Rupture or leak } \\
\text { b) Failure to operate properly } \\
\text { 1. Will not open } \\
\text { 2. Will not close }\end{array}$ & $\begin{array}{l}\text { a) Spills LNG into basin under } \\
\text { dock } \\
\text { 1. Can not drain loading arms } \\
\text { 2. Spills LNG into dock drain }\end{array}$ & $\begin{array}{l}\text { Same as } 1 \text { above } \\
\text { Same as } 1 \text { above }\end{array}$ \\
\hline 5. Loading arm & $\begin{array}{l}\text { a) Rupture } \\
\text { b) Bad connection with ship's flange } \\
\text { c) Excessive ship movement }\end{array}$ & $\begin{array}{l}\text { a) Spills LNG into basin under } \\
\text { dock or into water } \\
\text { b) Spills LNG into water } \\
\text { c) Ruptures loading arm and } \\
\text { spills LNG }\end{array}$ & $\begin{array}{l}\text { Same as } 1 \text { above } \\
\text { Each loading arm has motion sen- } \\
\text { sors which automatically acti- } \\
\text { vate the LES; if the LNG } \\
\text { spilled, it would drain into } \\
\text { spill basin; low temperature } \\
\text { detector would activate LES } \\
\text { if it had not already been } \\
\text { activated }\end{array}$ \\
\hline
\end{tabular}


TABLE 3.6. (Contd)

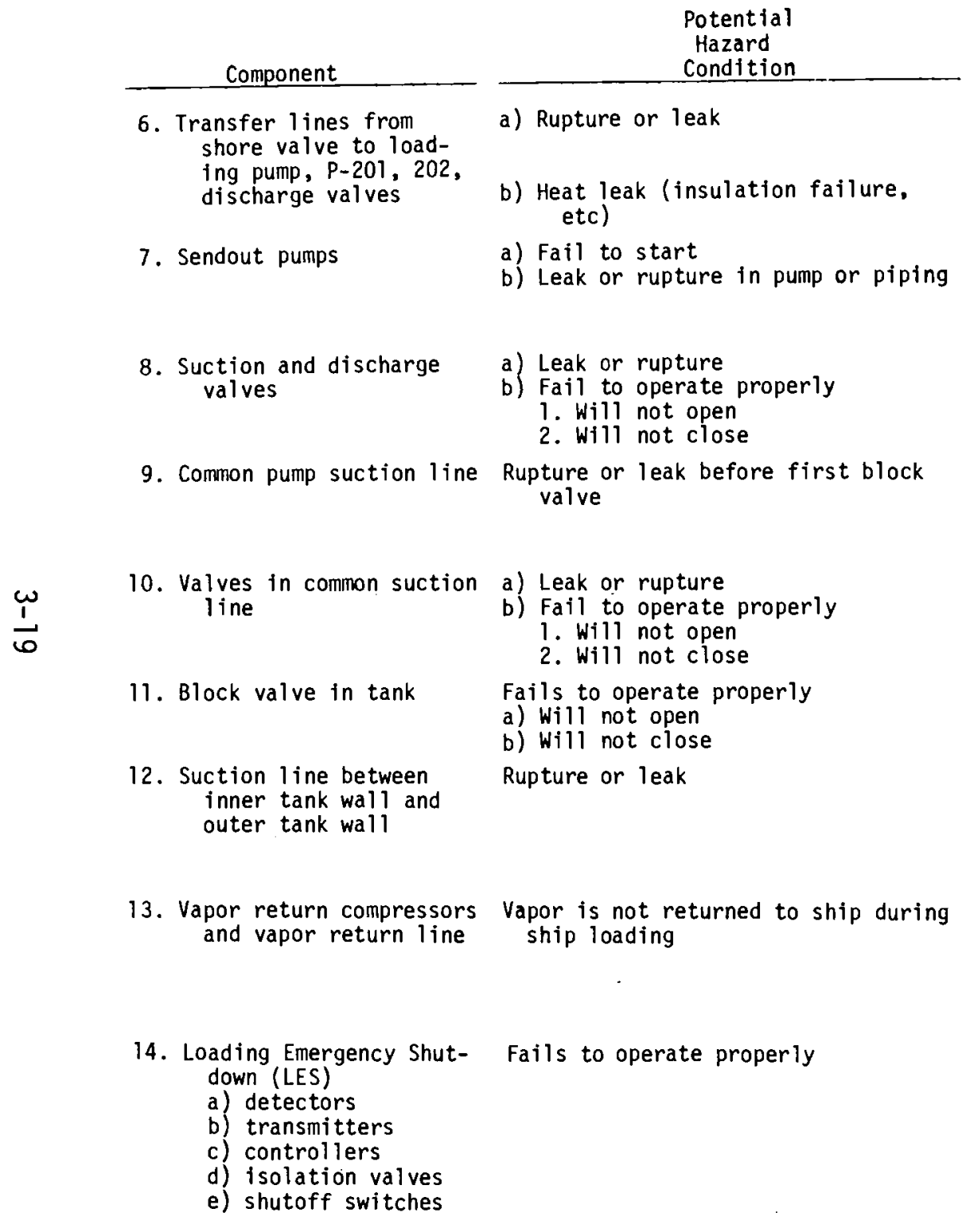

Effect

a) Spill LNG into diked area

b) Possible overpressure of of line

a) Reduces loading rate

b) Spills LNG into diked area

a) Spills LNG into diked area

1. Reduces loading rate

2. No effect

Spills LNG into diked area

a) Spills LNG into diked area

1. Can not load ship

2. No effect

a) Can not load ship

b) See 9 above

Spill of LNG between tanks, could cause failure of outer tank and possibly inner tank

Pressure in the tank decreases - tank will reach 0.2 psig in 10-15 minutes at normal loading rates

The loading system is not shut down and isolated automatically in an emergency
Existing

Preventive \& Control

Measures

Gas or low temperature detector at pump building would activate MES

Gas or low temperature detector at pump bullding would activate the MES

Same as 1 above

Same as 1 above

Block valve in tank makes it possible to stop flow out of tank

Low temperature detector in insulation would activate MES Block valve in tank makes it possible to stop flow out of tank

Low pressure would activate emergency gas supply 0.2 psig and shutdown loading system. Relief valves woula open 0.03 psig

A11 functions of the LES can be performed manually 
- 36-in. Transfer Line. This includes the 36-in. valves, expansion joints, and other fittings. The line is approximately $2,200 \mathrm{ft}$ long, and a leak or rupture in any section could result in a large spill. The probability of a transfer line rupture is estimated to be low.

- Loading Arms and Ship Coupling Mechanism. These components must be able to handle the cold temperature of the LNG and the movement of the ship. Proper operation of the swivel joints is particularly important. The probability of a loading arm failure is estimated to be low.

- Loading Emergency Shutdown System. If this system operates as intended, it will prevent or limit the size of many spills in the loading section. of primary importance is the proper operation of detectors and sensors that activate the system, the ability of the $36-i n$. valves to function satisfactorily in the event of an emergency shutdown, and the performance of the ship coupling mechanism in an emergency.

\subsubsection{Operator Interface}

Although the plant operators are not traditionally viewed as plant components, they are essential to the proper operation of the plant. The interface between operator actions and plant operations is therefore a critical factor relating to release prevention and control.

Operators perform a number of diverse tasks at the export terminal, most of which relate to release prevention and control either directly or indirectly. During normal plant operations, the operators run the plant within set limits and standards to prevent conditions that may lead to releases. During offstandard conditions, the operators must respond appropriately to alarms, indicators, and other signals to prevent releases from occurring or to limit releases in progress. Plant inspection and maintenance is also important to identify and remedy conditions that may lead to subsequent releases.

Because of the number of operator tasks performed at the facility, the probability of operator error is judged to be medium to high. The probability of LNG or natural gas releases resulting from operator errors varies from a high probability of a small release to a low probability of a maximum release. 


\subsection{REPRESENTATIVE RELEASE EVENTS AND INFORMATION NEEDS}

Using the results of the system level and the component level analyses, a 1 ist of potential release events considered to be representative of the export terminal was developed. The representative release events are listed in Table 3.7. Preliminary analyses for these events are presented in Section G.1 of Appendix $G$. The representative release events range from relatively frequent but low consequence releases to unlikely but large releases. They form the basis for the quantitative evaluation of the release prevention and control systems in the next phase of analysis.

\section{TABLE 3.7. Representative Release Events for an LNG Export Terminal}

1. Rupture of the 36-in. main transfer line between the loading pumps and the dock.

2. Rupture of the 24-in. liquid outlet line between the storage tank and the first block valve.

3. Rupture of a 16-in. loading arm.

4. Storage tank pressure relief valves open.

5. Storage tank vacuum relief valves open.

6. Inner tank is overfilled with LNG.

7. Complete failure of storage tank.

8. Rupture of 18-in. feed gas 1 ine in 1iquefaction train.

9. Rupture of 20-in. mixed refrigerant 1iquid piping between high pressure separator and main cryogenic heat exchanger.

10. Rupture of 10-in. nozzle to propane/mixed refrigerant exchanger.

11. Failure of a refrigerant compressor (propane or mixed refrigerant).

12. Rupture of 12-in. transfer line from 1iquefaction area to the storage tanks.

13. Rupture of outlet nozzle or piping on refrigerant storage tanks (propane, ethylene).

In performing the overview study, several areas requiring additional information were identified. Some of these are outlined below.

- Emergency Shutdown (ESD) System. Of particular interest are the location and number of detectors that activate the ESD, how quickly the shutdown occurs, exactly what equipment is shut down and what valves are closed, and details on the inspection, testing, and maintenance of the system. 
- Plant Piping Network. Details, such as diameter, length, wall thickness, and materials of construction are needed for the piping, vessels, valves, loading arms, expansion joints, etc., that make up the plant piping.

- Structural Mechanics of Storage Tanks. A key factor in this area is the effect of various hazard conditions on the structural integrity of the tank. Such conditions include overpressure, overfilling the inner tank, and a fire or explosion in another area of the plant. The effect of heatup and cooldown on the tank, the potential problems encountered during these transitions, and the correct heatup and cooldown procedures are necessary for more detailed analysis.

- Liquefaction Plant Process Control. Important factors include the details of the control scheme, potential hazard conditions that can result from improper control, and startup and shutdown procedures.

- Failure Rate Data. The overview study of the export terminal considered the potential release frequency in a qualitative manner. A more detailed study of the export terminal release prevention, detection, and control systems must carefully consider the likelihood of the release initiating event and the reliability of the release detectors and control systems. Due to the lack of operating experience of LNG facilities, little data is available for LNG equipment failure rates.

- Operator Interface. Reliability information on operator tasks performed at the facility is needed. 


\subsection{ASSESSMENT OF LNG MARINE VESSEL}

The overview study of the reference LNG marine vessel is presented in this section.

\subsection{SUMMARY SYSTEM DESCRIPTION}

The tanker used as a basis for the LNG marine vessel scoping assessment

is a $125,000-\mathrm{m}^{3}$ vessel with five Kvaerner Moss-type spherical tanks. The tanker is designed to operate 345 days per year, with 20 days allowed for miscellaneous delays and repairs. The approximate cargo deliverability of the vessel is $90 \%$ of cargo capacity on a typical voyage, with boiloff vapors from the storage tanks used as fuel. The ship has a design speed of 20 knots, and takes 10-15 hours to load or unload under normal conditions. The basic ship and its propulsion system, the cargo storage tanks, and the cargo handling system are briefly described in the following paragraphs. A detailed description is presented in Appendix C.

\subsubsection{Basic Ship and Propulsion System}

The vessel is designed to meet rigid requirements for both impact and damaged stability. Wing side ballast tanks and a double hull throughout the vessel reduce the possibility of damage to the cargo tanks in the event of collision or grounding. Each spherical cargo tank is supported by a vertical cylinder. The top of the cylinder is welded to the equator of the cargo tank, and the bottom is welded to the ship's hull structure. Only over a small portion of the hold length and depth do the spherical storage tanks come close to the hu11. At locations other than midtank, the ship can withstand greater penetration and greater impact velocity.

The ship, which is $926 \mathrm{ft}$ long and has a deadweight of 63,600 long tons, is powered by a heavy-duty marine steam turbine rated at 43,000 shp. Steam for the turbine is generated in two high-pressure boilers by burning boiloff gas and bunker fuel. In addition to standard navigational equipment, the vessel has several safety features to improve manueverability and prevent collisions; these include: 
- bow thrusters for improved maneuverability

- loran precision position-fixing equipment

- bridge control of main engine

- collision avoidance system.

\subsubsection{Cargo Storage Tanks}

Each cargo storage tank is $120 \mathrm{ft}$ in diameter and is constructed of 5083-0 aluminum alloy. The tanks are insulated with polyurethane foam applie to the outer surface of the sheres. Normal boiloff from the tanks is $0.15 \% \mathrm{t}$ $0.25 \%$ of full tank volume per day. The tanks are hydropneumatically tested $t$ 31 psig and equipped with relief valves to protect the tanks from overpressur

The cargo tanks are designed on a "leak-before-failure" basis, and no secondary barrier or emergency containment system is provided. A leak detection system consisting of a drip pan with a liquid-tight cover is provided beneath each tank.

\subsubsection{Cargo Handling System}

The ship's cargo handling system consists of the liquid cargo handling system, the vapor handling system, and the recirculation and purging systems.

The liquid cargo handling system includes the main liquid header, the crossover line and valves for loading and unloading from either side of the vessel, the isolation line connecting the header and crossover, loading and unloading lines at each tank, and the unloading pumps in each tank.

The main vapor header, a vapor line to each tank, the crossover line and valves for accepting or returning vapor from both sides of the ship, boiloff compressors and heaters, and the gas supply to the boilers make up the vapor handling system.

The recirculation system consists of a spray header, a small spray pump in each tank, and a spray nozzle in each tank. This system is used to cool down the tanks and to keep the tanks cold on ballast voyages. The purging system includes a small liquid nitrogen storage tank, an inert gas generator, a warmup heater, and an LNG vaporizer. 
The emergency shutdown (ESD) system is incorportated in the cargo handling system so that any cargo !andling operation can be stopped quickly. Activation of the ESD causes the collowing actions:

1. Valves in these lines are closed: liquid crossover; vapor crossover; liquid/vapor header isolation lines; the unloading, loading, and vapor lines of each tank; and the boiler feed gas line.

2. The following equipment is shut down: the submerged cargo pumps, the boiloff compressor, and the boiler feedgas heater.

In most instances, the ESD is activated manually in response to an emergency condition. The ESD is automatically activated by the high-high level indicators in the cargo storage tanks and by excessive ship movement during loading. It is also activated in the event of a fire by several thermal fuses located throughout the ship.

The ship personnel also have the capability to activate the terminal ESD system. Terminal operators can close the ships loading/unloading valves as part of the terminal shutdown procedure.

\subsection{SYSTEM LEVEL ANALYSIS}

The purpose of the system level analysis is to identify those sections of the marine vessel that are most critical with respect to release prevention and control. The evaluation of each system is based largely on two factors:

1) the quantity of a potential release of hazardous material due to either the inventory or the flow rate and 2 ) an estimate of the relative probability of a release (low, medium, high).

Spills from LNG tankers can be divided into two broad classes: spills resulting from equipment failures or misuse of equipment during normal operation (Category I) and spills resulting from external forces (Category II).

Category I spills are most likely while the vessel is loading or unloading. The cargo handling system of the ship is most important with respect to Category I spills. Collisions, groundings, and severe storms are examples of external forces which could cause Category II spills. The cargo storage tanks 
are the portion of the ship most likely affected by external forces. Category II spills are most likely while the ship is in transit.

Table 4.1 shows the inventories, flow rates, and operating conditions for the various parts of the vessel.

TABLE 4.1. Selected Operating Parameters for the LNG Marine Vessel

\begin{tabular}{|c|c|c|c|c|c|}
\hline Component & Material & Inventory & $\begin{array}{c}\text { Typical } \\
\text { Flow Rate }\end{array}$ & $\begin{array}{r}\text { No } \\
\text { Operating } \\
\text { Pressure(psig) }\end{array}$ & $\begin{array}{l}\text { nal } \\
\text { Conditions } \\
\text { Temperture }\left({ }^{\circ} \mathrm{F}\right)\end{array}$ \\
\hline $\begin{array}{l}\text { Cargo Storage } \\
\text { Tanks (5) }\end{array}$ & LNG & $6.6 \times 10^{6} \mathrm{gal} \mathrm{ea}$ & $10,000 \mathrm{gpm}$ & 1 to 2 & -260 \\
\hline $\begin{array}{l}\text { Liquid Header } \\
\text { and Crossover }\end{array}$ & LNG & $1.7 \times 10^{4}$ ga 1 & $50,000 \mathrm{gpm}$ & 1 to 100 & -260 \\
\hline $\begin{array}{l}\text { Vapor Header } \\
\text { and Crossover }\end{array}$ & Natural Gas & $2.3 \times 10^{3} \mathrm{scf}$ & $\begin{array}{l}7.0 \text { to } 22.0 \\
\text { MMscfd }\end{array}$ & 1 to 2 & -250 \\
\hline $\begin{array}{l}\text { Gas Supply Line } \\
\text { to Boilers }\end{array}$ & Natural Gas & $7.0 \times 10^{2}$ scf & $7.0 \mathrm{MMscfd}$ & 50 & 100 \\
\hline Spray Header & LNG & $2.0 \times 10^{2} \mathrm{gal}$ & $200 \mathrm{gpm}$ & 10 & -260 \\
\hline $\begin{array}{l}\text { Liquid Nitrogen } \\
\text { Storage Tank }\end{array}$ & $\mathrm{N}_{2}$ & $6.6 \times 10^{3} \mathrm{gal}$ & -- & -- & --- \\
\hline
\end{tabular}

\subsubsection{Cargo Handling System--Category I Spills}

A spill or release of LNG or natural gas from the cargo handling system is hazardous because: 1) the vapor is flammable and a serious fire and/or explosion is possible, and 2) the cold liquid could cause serious structural damage to the ship.

There are three general modes by which LNG or natural gas can be released from the cargo handling system:

- leak or rupture in pipes, fittings, valves, etc.

- discharge of relief valves to the atmosphere

- misoperation of valves in the system.

The largest possible spill from the cargo handling system is on the order of 67,000 gallons (a rupture of the liquid header during loading or unloading) assuming the emergency situation is recognized, the emergency shutdown (ESD) system operates as designed, and the spill causes no serious structural damage 
to the ship. The ESD shuts down aıd isolates the loading/unloading system within about 1 minute after it is activated. It is activated automatically in the event of a fire, excessive ship movement at the dock, or overfilling of a cargo tank. The system can be activated manually at the bridge, the cargo control room, and the deck. A failure of the ESD would result in a significantly larger spil1, up to about 520,000 gallons, because of the high flow rates. The probability of this release is estimated to be low.

\subsubsection{Cargo Storage Tanks--Category II Spi11s}

Grouping spills from cargo storage tanks and Category II spills together does not imply that spills from the cargo storage tanks cannot result from failure or misoperation of ship equipment. However, it is assumed that external causes pose the most significant hazard to the ship's cargo tanks.

The most likely cause of a release from the cargo storage tanks is penetration of the tanks by another ship during a collision. If the entire contents of one tank are spilled, the release would be $6.6 \times 10^{6}$ gallons $\left(25,000 \mathrm{~m}^{3}\right)$, as shown in Table 4.1 . The maximum spill (if all five tanks are lost) is $3.3 \times 10^{7}$ gallons $\left(125,000 \mathrm{~m}^{3}\right)$. These are very large releases, but it should be noted that the probability of these releases being instantaneous is low. The release would most likely spread out over hours or even days.

The ship has a double hull thoroughout that protects the storage tanks in a collision or grounding. The ship also has various navigational equipment to help prevent collisions and groundings.

\subsubsection{Basic Ship and Propulsion System}

Failures or misoperation in the rest of the ship can indirectly result in a release of LNG or natural gas. Events of this nature can generally be grouped into three broad classes:

1. defects and failures in the ship's structure that affect the cargo tanks or cargo handling system

2. failure of navigation equipment or navigational error that results in a ramming or grounding 
3. failure of the propulsion system, in which case the boiloff gas must be yented.

Maximum size of the release is $6.6 \times 10^{6}$ gallons $\left(25,000 \mathrm{~m}^{3}\right)$ if one

tank ruptures and $3.3 \times 10^{7}$ gallons $\left(125,000 \mathrm{~m}^{3}\right)$ if all tanks are lost. The probability of this release is estimated to be low.

\subsection{COMPONENT LEVEL ANALYSIS}

The system level analysis indicates that the largest potential spills of LNG occur when one or more of the cargo tanks rupture. Failures or misoperation of the cargo handling system generally result in smaller spills. However, because there is more equipment involved and because the human element plays a large role, spills are much more probable in the cargo handling system. Failure in other portions of the ship can indirectly result in a spill or release from the cargo handling system or the cargo tanks, and arè included in those sections for this analysis.

For passive components (e.g., piping and cargo tanks), generally only one failure (e.g., a pipe break) is required for a release. The emergency shutdown system is designed to limit the size of these releases. For active components (e.g., motors, compressors, valves, controllers), usually two failures are required to initiate a release. In many cases, one of the failures is failure on the part of the crewmen to recognize and respond correctly to situation. The emergency shutdown system is, in some cases, automatically activated when a component fails.

\subsubsection{Cargo Handling System}

The results of a preliminary hazards analys is (PHA) for the cargo handling system are shown in Table 4.2. Based on this analysis, the following components are identified as being the most critical with respect to release prevention and control:

Liquid header, crossover line, and valves. Because of the high flow rates, a leak or rupture can result in a large spill. It is also possible for crewmen to nisvaive the system and cause a large spill. Maximum spill 


\section{TABLE 4.2. Preliminary Hazards Analysis of Cargo Handling System}

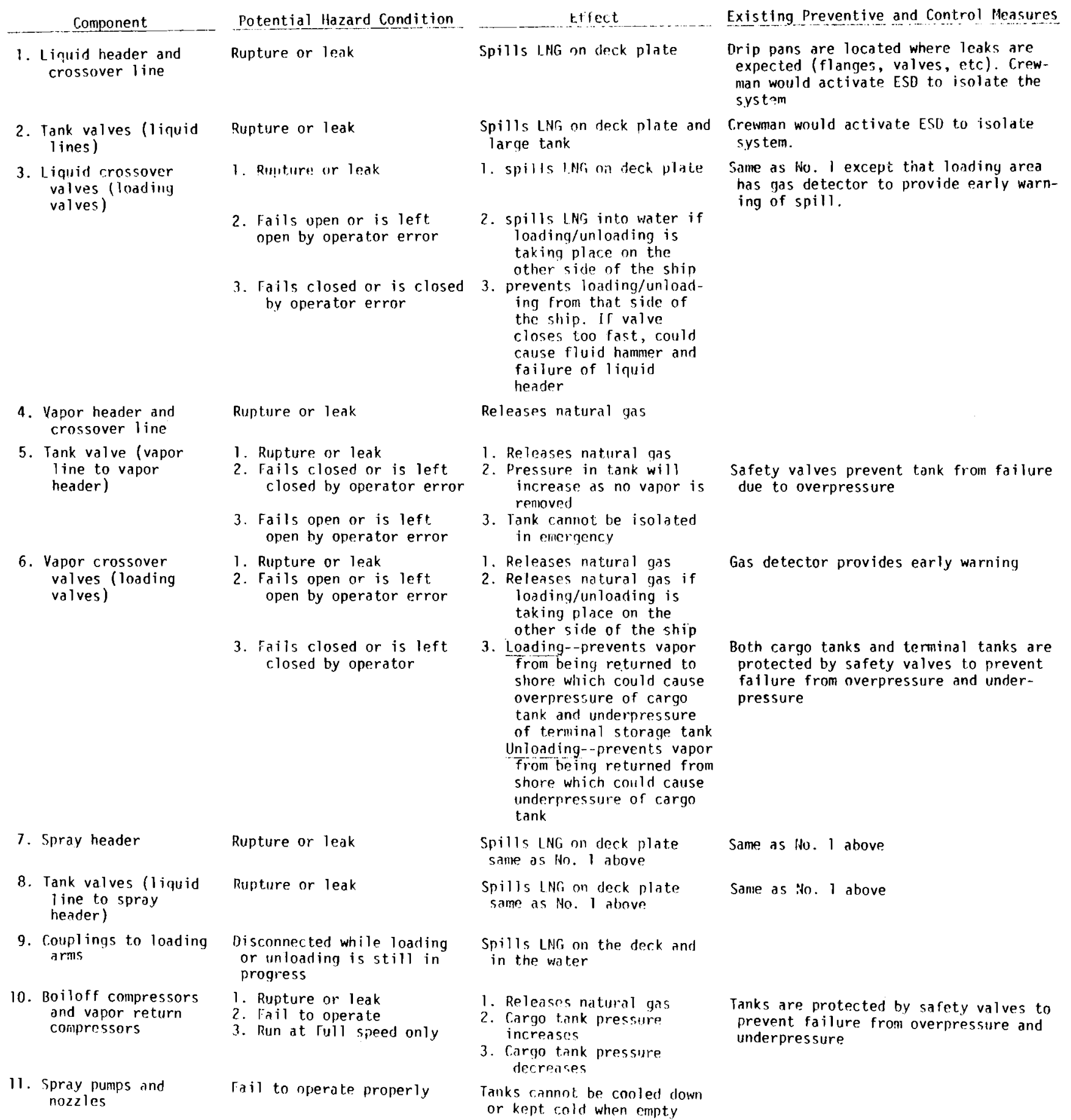


TABLE 4.2. (contd)

Component

Gas supply line to boilers

13. Boiloff heaters

14. Emergency Shutdown System

a. detectors and process instruments

b. transmitters

c. controllers

d. valves and switches

Rupture or leak

Effect

Release of natural gas

Fail to operate

Fail to operate properly

Cold gas would enter gas supply line to bollers. This could cause failure of carbon steel piping or equipment.

Cargo handling system is not isolated and shut down in an emergency situation

Rupture or leak
15. Liquid $N_{\text {g }}$ storage tank and associated piping up to inert gas generator

16. Relief valves on vapor header (gas ma in)

17. Valve to forward vent riser

Fatl to open on demand

Fails open or is let open by operator

Fatl to operate

Spills $\mathrm{N}$ on deck. Could

cause deck plates to crack. All purging on the ship would be stopped

Pressure in vapor header continues to rise and vapor header or other equipment connected to it could fail.

18. Propulsion plant or boilers released out the riser

Ship cannot move under its has to be vented.
Natural gas or LNG is own power. All boiloff gas

\section{Existing Preventive and Control Measures}

Gas supply line to the propulsion equipment is a double pipe with the gas being carried in the inner pipe. The annular space is purged with $\mathrm{N}_{2}$ and the gas analyzed for $\mathrm{CH}_{4}$.

Redundant heaters

System can be activated manually if detectors or transmitters fall.

Valves can be closed and equipment shutdown manually if controllers, valves. or switches fall.
Valves are inspected and tested periodically 
size would be around 67,000 gallons if the ESD works properly. The probability of failure for these types of components is estimated to be low.

Emergency Shutdown (ESD) system. If this system fails to operate in an emergency, a very large spill could result. In the case of a rupture of the liquid header, the spill could be as large as 520,000 gallons. Proper interconnection of the terminal and ship ESD systems is important to ensure a fast, complete, and safe shutdown in emergencies.

Tanker loading and unloading, including operation of the cargo handling system and the terminal equipment, is the segment of LNG baseload operations in which the human element plays its biggest role with respect to release prevention and control. "Human considerations" particularly important in preventing spills during tanker loading and unloading are:

- crewman and operator training--particularly for emergency situations

- good communications between ship and terminal personnel.

\subsubsection{Cargo Storage Tanks}

Table 4.3 presents the prel iminary hazards analys is (PHA) of the LNG storage portion of the vessel. Components that are most important with respect to release prevention and control are:

Primary barrier. A rupture or leak in the spherical aluminum tanks can result in a large spill (up to $6.6 \times 10^{6}$ gallons). The probability of tank failure is estimated to be low.

Outer and inner hulls. These protect the primary barrier from a collision. They also contain ballast water that, if it leaks out, could ruin tank insulation and freeze on the cargo tanks. The probability of such a failure is estimated to be low.

Cargo tank liquid-level indicators. If these fail, the tank can be overfilled. Liquid will overflow out the vapor lines and could cause significant damage in other portions of the ship. The probability of a level indicator failure is estimated to be medium. 


\section{TABLE 4.3. Preliminary Hazards Analys is of Cargo Storage Tanks}

Component

1. Cargo tank

Potential Hazard Condition

Rupture or leak

Rollover

2. Equatorial ring and and support

3. Cargo tank liquid level indicators

4. Safety valves on cargo tank (pressure relief)

Do not open on demand

Give incorrect readings or fdil to activate ESD system

Fails to support the tank

Open at lower pressure than design

5. Safety valves on carg, tanks (vacuum relief)

6. Cargo tank insulation

Do not open on denand

Open at higher pressure than design

Ineffective

7. Cargo tank pressure indicator/controller

Gives incorrect readings or fails to operate

8. Outer and inner hull Outer and inner hull are penetrated in a collision or grounding
Increase in bojloff which may have to be vented. Could cause increase in tank pressure.

Increase or decrease in tank pressure

Cargo tariks inay be ruptured. Ballast water is released and may ruin the insulation and freeze on the tank.
Pressure in tank increases

Tank would fall into nold area and could fail and spill entire contents.

Cargo tank is overfilled and liquid flows out the vapor line and into the vapor header. From there it can go to the compressors, the compressor lines, or the vent lines, or the vent riser.

Pressure in tank continues to rise and tank could overpressure

Existing Prevencive and Control Measures

The cargo tanks are designed to "leak" before they "fail". A drip pan is located beneath the tank to catch sillall leaks. A gas detector in this area provides early warnings in case of leaks.

Tanks have safety valves set at 3.5 psig to protect against failure froll overpressure

Each tank has two independent liquid level indicators

Safety valves open at 3.5 psig and tank can withstand at least 31 psig in vapor space. Each tank has two safety valves. Valves are inspected and tested periodically.

Releases natural gas to vapor header unnecessarily

Pressure in the tank continues to fall.

Valves are inspected and tested periodically

Valves are inspected and tested periodically

Valves are inspected and tested periodically
The ship contains the following safety features to improve maneuverability and prevent collisions:

1) bow thruster

2) loran precision position fixing equiprnent

3) bridge control of main engine

4) collision avoidance systeln 
Safety valves on cargo tanks, hold areas, and vapor 1 ine. These protect the storage tanks from overpressure and underpressure. The failure of a safety valve is estimated to have a low probability.

Navigational safety equipment. This equipment (1isted previously) aids ship personnel in avoiding collisions and groundings. The probability of navigational safety equipment failure is estimated to be medium.

Collisions or groundings pose the most significant threat to the cargo storage tanks. Therefore, the ability of the ship to avoid collisions (by special navigational equipment) and the collision resistance of the hulls and the primary barrier are of utmost importance in preventing spills from the cargo storage tanks.

The collision resistance of several LNG vessels has been calculated based on the Minorsky equation. The Minorsky method is a semianalytical approach based on data for 50 actual collisions. With this method, the velocity of a striking ship required for penetration of the cargo tanks of the LNG vessel can be calculated. Appendix $C$ of this study contains further discussion pertaining to the collision resistance of LNG vessels. Included in this discussion is a plot of the critical velocity versus displacement of the striking ship.

\subsection{REPRESENTATIVE RELEASE EVENTS}

Based on the results of the preceding system and component level analyses, a list of potential release events considered to be representative of the marine vessel was developed. These representative release events appear in Table 4.4. Section G.2 of Appendix $G$ includes prel iminary analyses of these events. The representative release events range from relatively frequent but low consequence releases to unlikely but large releases. They form the basis for the quantitative evaluation of the release prevention and control systems in the next phase of analysis.

In performing the overview study, several areas requiring additional information were identified. Some of these are outlined below. 
TABLE 4.4. Representative Release Events for an LNG Marine Vessel

1. Rupture or leak in one of the LNG cargo tanks

2. Cargo tank is overfilled

3. Pressure safety valves relieve to the atmosphere

4. Rupture or leak in the liquid cargo handling system

5. Rupture or leak in the vapor handling system

6. Release of LNG or natural gas from ship due to misoperation of the cargo handling system.

- Collision Probability. Several analytical methods have been applied to Coast Guard collision data to determine the probability of an LNG vessel being involved in a collision. These methods usually include a safety factor for LNG vessels to account for the additional navigation and safety equipment on board and the special navigational procedures used. Additional research and analysis is needed to develop a standard method for calculating these probabilities.

- Effects of a Collision on an LNG Vessel. While the critical velocity for penetration of the storage tanks has been calculated, little attention has been given to the effects of a collision on other portions of the ship such as the cargo handling system and the propulsion system.

- Cargo Handling System. A complete piping and instrument drawing of the cargo handling system is needed.

- Effects of Spill, Fires, and Explosions. The effect of these events on the structural integrity of the ship, on the cargo handling system, and the cargo tanks needs to be determined.

- Failure Rate Data. The overview study of the marine vessel considered release frequency in a qualitative manner. A more detailed study of the marine vessel's release prevention, detection, and control systems must carefully consider the likelihood of the release initiating event and the reliability of the release detection and control systems. Due to the lack of operating experience of LNG facilities, little data is available for LNG equipment failure rates. 
- Operator Interface. Reliability information on operator tasks performed in shipping and cargo handling operations is needed. 


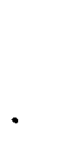




\subsection{ASSESSMENT OF LNG IMPORT TERMINAL}

This section presents the overview study of the reference LNG import terminal.

\subsection{SUMMARY SYSTEM DESCRIPTION}

The reference LNG import terminal consists of a marine terminal for tanker unloading, two 550,000-bbl storage tanks for LNG storage, compressors and sendout pumps, and a vaporization system including both falling-film, open-rack, seawater vaporizers and gas-fired, submerged combustion vaporizers. The major operations performed at the plant are briefly described in the following paragraphs. The plant safety systems are also described. A detailed description is presented in Appendix D.

\subsubsection{Marine Terminal and Unloading System}

The marine terminal for the LNG import facility consists of a dock and a 6,000-ft trestle supporting a roadway and fluid transfer lines. The four major transfer lines include a 42-in. main LNG transfer line from the trestle to the LNG storage facility, a 16-in. vapor return line to maintain adequate pressure in the ship's storage tanks during unloading, a 4-in. LNG recirculation line to keep the LNG unloading lines cold when not unloading a vessel, and a 10-in. Bunker "C" fuel oil line.

Four 16-in.-diameter articulated LNG loading arms are located on the dock at the termina1. The loading arms connect with a 24-in. transfer line. Two sets of four 24-in. lines connect to a 42-in. header which ties into the 42-in. transfer 1 ine.

The marine terminal includes berths to accommodate two vessels, one on each side of the trestle. However, only one ship can unload at a time. A control tower overlooks the ship unloading operations.

\subsubsection{Storage System}

LNG storage at the facility consists of two flat-bottom, double-walled, aboveground LNG storage tanks with a capacity of 550,000 bbl each. The inner 
tank is constructed of $9 \%$ nickel-steel, which possesses excellent low temperature ductility. The outer tank is constructed of carbon steel, which possesse a very poor low temperature ductility. The dimensions of the tank are:

$\begin{array}{lr}\text { inner diameter: } & 215 \mathrm{ft} \\ \text { outer diameter: } & 225 \mathrm{ft} \\ \text { inner shell height: } & 88 \mathrm{ft} \\ \text { outer tank shell height: } & 98 \mathrm{ft} \\ \text { overall tank height: } & 146 \mathrm{ft} .\end{array}$

The high liquid level of LNG in the tank is approximately $87 \mathrm{ft}, 9 \mathrm{in}$.

Expanded perlite, a nonflammable material, insulates the annular space between the inner and outer shells. A resilient fiberglass blanket is wrappec around the outside of the inner shell to alleviate pressures resulting from movement of the inner shell due to thermal cycling. Foamglass blocks, a loadbearing insulation, are used to insulate the tank bottom.

A 4-ft-thick reinforced concrete slab supports each tank. An electrical: heated sandbed is located beneath the tank. This prevents the soil beneath th tank from freezing and causing frostheave. Engineered fill is located direct. beneath the slab.

The tanks are designed to withstand instantaneous wind gusts up to 104 mph, earthquakes up to 7 on the Richter scale, and a maximum horizontal accel. eration of $0.21 \mathrm{~g}$. All piping to the inner tank enters through the roof of the storage tank.

A concrete dike wall surrounds each storage tank. Each dike will hold approximately $133 \%$ of the capacity of one storage tank. The inside of the dike wall is lined with insulating material to reduce the evaporation rate of any spilled LNG.

A weather shield extending from the top of the concrete dike to the oute tank roof keeps precipitation from falling into the annular space.

Normal tank boiloff and vapors from LNG tanker unloading are handled by vent gas compressor system. Storage tank pressure is maintained by returning 
vapors from the vent gas compressor. Excess vapors are compressed by fuel gas and pipeline compressors to be used as fuel or for delivery to the gas transmission pipeline.

\subsubsection{Compressors and Sendout Pumps}

This section of the plant includes all of the equipment operating at high pressure (up to $1300 \mathrm{psig}$ ). There are ten major compressors at the facility: four centrifugal boiloff compressors that take suction on the storage tanks and boost the gas to $10 \mathrm{psig}$; three two-stage, reciprocating fuel gas compressors that take gas from the boiloff compressors and increase the pressure to $150 \mathrm{psig}$; and three two-stage, reciprocating pipeline compressors that compress the gas to $1300 \mathrm{psig.} \mathrm{Only} \mathrm{the} \mathrm{boiloff} \mathrm{compressors} \mathrm{run} \mathrm{cold.} \mathrm{A} \mathrm{fuel} \mathrm{gas} \mathrm{preheater}$ heats the boiloff before it enters the fuel gas compressors.

Each storage tank contains two submerged, primary sendout pumps that boost the LNG to $60 \mathrm{psig.} \mathrm{These} \mathrm{are} \mathrm{followed} \mathrm{by} 10$ secondary pumps. The secondary pumps are submersible, pot-mounted, 15-stage units that raise the LNG pressure up to 1300 psig.

\subsubsection{Vaporization System}

The vaporization system for the import terminal includes two major types of LNG vaporizers: falling-film, open-rack, seawater vaporizers, and gas-fired submerged combustion vaporizers. These vaporizers provide the plant with a total output capacity of 1 billion scfd of gas.

Baseload vaporization occurs in five falling-film, open-rack, seawater vaporizers with a total capacity of 550 MMscfd. LNG is introduced through manifolds at the bottom of banks of vertical panels constructed of special extruded fins. The LNG passes upward inside the panels, where it is heated by the seawater that falls as a film over the outside of the panels. Natural gas emerges at the top, where it is collected in a manifold and routed to the pipeline.

The falling water film used in this design gives extremely high heat transfer coefficients, which reduces the amount of ice formed, thus maintaining high performance. With this open type of system, the limited amount of ice that 
forms does not interfere with the flow of water. The panels of finned tubes and all parts in contact with the LNG are made of aluminum alloy, which maintains its strength at low temperature.

For standby or peaking vaporization, four submerged gas-fired vaporizers having a total capacity of $450 \mathrm{MMscfd}$ are used. The gas-fired vaporizers are used approximately 800 hours per year.

The gas-fired vaporizers are designed so that burners exhaust hot combustion gases downward through a downcomer and into a water bath below the liquid surface. The exhaust forms bubbles in the water, causing turbulence, mixing, and a "lifting" action. This forces the water up at a high velocity through an annular space created by a weir around the downcomer. The water flows over the top of the weir and into the more quiescent tank. A heat exchanger tube coil for the LNG is located in the annular space between the weir and the downcomer, where it is scrubbed by the warm gas-water mixture. This transfers the heat to the LNG and vaporizes it. The vaporizers consume fuel gas equivalent to 1.5 to $2 \%$ of the LNG vaporized.

The inlet piping, all piping inside the vaporizers that comes in contact with the LNG, and the outlet piping to the first flange are all stainless steel construction on both the seawater and the gas-fired vaporizers. An independent containment dike is included in the seawater vaporizer area to contain any LNG release that might occur.

\section{1 .5 Safety Systems}

The plant Emergency Shutdown (ESD) system has three separate circuits: the Master Emergency Shutdown (MES), the Vaporizer Emergency Shutdown (VES), and the Offshore Emergency Shutdown (OES). These systems automatically shut down and isolate portions of the facility or, in the case of the MES, the whole facility. It takes about 30 seconds to shut down the plant, once the ESD is activated. The shutdown systems are activated by detectors located throughout the plant, by limits on certain process control variables, or by the plant operators.

Combustible gas detectors, UV flame detectors, and temperature sensors are located throughout the plant area. These detectors activate alarms that indicate the exact location of a spill or fire on a graphic panel in the control room. 
The fire control system consists of fixed and portable dry chemical extinguishers, high-expansion foam systems, and a fire water system.

\subsection{SYSTEM LEVEL ANALYSIS}

The purpose of the system level analysis is to identify those sections of the import terminal that are most critical with respect to release prevention and control. The evaluation of each system is based largely on two factors: 1) the quantity of a potential release of hazardous material due to either the inventory or the flow rate and 2) an estimate of the relative probability of a release (low, medium, high).

Process operation conditions for a 11 sections of the import terminal, including flow rates, temperatures, pressures, and pipeline sizes, are presented in Table 5.1.

\subsubsection{Marine Terminal and Unloading Syștem}

The primary hazards involved in handling LNG at a marine terminal are the flammability of the gas and the cold temperature of the liquid.

There are two primary methods by which LNG or natural gas can be released from the unloading system:

- leak or rupture in valves, pipes, fittings, loading and transfer arms, etc.

- pressure relief valve discharges from transfer lines.

A containment system is located under the unloading platform to collect al1 spills from the loading arms. Drain valves are included in the transfer line so it can be drained into the containment system under the dock. Any release of LNG between the terminal and shore would fall into the ocean. $A$ containment barrier follows the ship unloading line from shore to the storage tanks. Because of the size of the transfer line and the associated high flow rates, a single leak or break can result in a large spill. The maximum release in the marine terminal area is approximately 960,000 gallons for a large rupture of the 42-in. transfer line. The probability of this release is estimated to be low. 
TABLE 5.1. System Capacities and Flow Rates

\begin{tabular}{|c|c|c|c|c|c|c|}
\hline \multirow[b]{2}{*}{ System } & \multirow[b]{2}{*}{ Component } & \multirow{2}{*}{$\begin{array}{l}\text { Number of } \\
\text { Components }\end{array}$} & \multirow{2}{*}{\multicolumn{2}{|c|}{ Flow Rate }} & \multicolumn{2}{|c|}{ Operating Conditions } \\
\hline & & & & & Pressure (psig) & Temperature $\left({ }^{\circ} \mathrm{F}\right)$ \\
\hline \multirow{3}{*}{$\begin{array}{l}\text { Marine Terminal } \\
\text { and Unloading } \\
\text { System }\end{array}$} & 42-in. LNG Transfer Line & 1 & $53,000 \mathrm{gpm}$ & $53,000 \mathrm{gpm}$ & 100 & -258 \\
\hline & $\begin{array}{l}\text { 4-in. LNG Recirculation } \\
\text { Line }\end{array}$ & 1 & $1,500 \mathrm{gpm}$ & $1,500 \mathrm{gpm}$ & 60 & -258 \\
\hline & 16-in. Vapor Return Line & 1 & $16 \operatorname{MMscfd}(a)$ & $16 \operatorname{MMscfd}^{(a)}$ & 10 & -152 \\
\hline Storage & Storage Tank & 2 & $53,000 \mathrm{gpm}$ & $4,000 \mathrm{gpm}$ & 0.8 & -258 \\
\hline \multirow[t]{4}{*}{ Sendout Pumps } & Primary In-Tank Pumps & 2/Tank & $4,000 \mathrm{gpm}$ & $4,000 \mathrm{gpm}$ & 60 & -258 \\
\hline & 20-in. Tank Outlet Line & $1 /$ Tank & $4,000 \mathrm{gpm}$ & $4,000 \mathrm{gpm}$ & 60 & -258 \\
\hline & Secondary Pumps & 10 & $8,550 \mathrm{gpm}$ & $8,550 \mathrm{gpm}$ & 1,280 & -252 \\
\hline & $\begin{array}{l}\text { 24-in. Secondary Pump } \\
\text { Sendout Line }\end{array}$ & 1 & $8,550 \mathrm{gpm}$ & $8,550 \mathrm{gpm}$ & 1,280 & -252 \\
\hline \multirow{2}{*}{$\begin{array}{l}\text { Vaporization } \\
\text { System }\end{array}$} & Seawater Vaporizers & 5 & $4,700 \mathrm{gpm}$ & $550 \mathrm{MMscfd}$ & 1,300 & -252 to 30 \\
\hline & $\begin{array}{l}\text { Submerged Combustion } \\
\text { Vaporizers }\end{array}$ & 4 & $3,850 \mathrm{gpm}$ & $450 \mathrm{MMscfd}$ & 1,300 & -252 to 30 \\
\hline \multirow[t]{3}{*}{ Compressors } & Boiloff Compressor & 4 & $13-52$ MMscfd $(a)$ & $13-52 \operatorname{MMscfd}(a)$ & 10 & -200 to -150 \\
\hline & Fuel Gas Compressor & 3 & $2-36 \operatorname{MMscfd}^{(a)}$ & 2-36 MMscfd $(a)$ & 150 & 285 \\
\hline & Pipeline Compressor & 3 & $2-36 \operatorname{MMscfd}^{(a)}$ & $2-36 \operatorname{MMscfd}^{(a)}$ & 1,300 & 120 \\
\hline
\end{tabular}

(a) Flow rate during unloading operations. 


\subsubsection{Storage System}

LNG is the only hazardous material stored at the terminal. LNG is hazardous because of the cryogenic storage temperatures and the flammability of the vapor.

There are three primary methods of release in the storage area:

- storage tank failure

- leak or rupture from inlet or outlet piping, flanges, valves, fittings, etc.

- atmospheric discharge from a relief valve.

The inner container of the LNG storage tanks is constructed of $9 \%$ nickel steel, suitable for operating at cryogenic temperatures. The outer tank is constructed of carbon steel and is susceptible to fracture if contacted with any LNG or cold vapors. Thus, failure of the inner tank would probably lead to failure of the outer tank. Each LNG storage tank is surrounded by an insulated concrete dike wall to contain any spills of LNG from the tank.

Each tank has pressure and vacuum relief valves to protect against tank overpressure and underpressure. An auxiliary gas supply system also protects the tanks from underpressure. Activation of the Master Emergency Shutdown (MES) automatically stops all flows into and out of the tanks and isolates them from the rest of the plant. The probability of a gross failure of a storage tank is estimated to be low.

\subsubsection{Compressors and Sendout Pumps}

The hazards involved with operation of this equipment are the cold temperature of LNG, the flammability of the LNG vapor, and the high pressure at which some of the components operate.

There are two general means by which LNG or vapor can be released from these systems:

- failure of piping, valves, fittings, etc.

- failure of the compressors or pumps. 
Either the Master Emergency Shutdown (MES) or the Vapor Emergency Shutdown (VES), when activated, stops the LNG sendout pumps and isolates them from the storage tank and the vaporizers. The MES also shuts down and isolates the compressor system.

The secondary pumps are located in their own diked area which has a dry chemical fire extinguishment system and a high-expansion foam system.

The maximum spill in this area of the plant is approximately 23,000 gallons, assuming the MES is activated promptly and functions as designed. The probabil.. ity of this release is estimated to be low to medium. The spill could be as large as 100,000 gallons if the system has to be shut down manually.

\subsubsection{Vaporization System}

Vaporization occurs in two types of vaporizers: falling-film, open-rack, seawater vaporizers and gas-fired, submerged combustion vaporizers. The gasfired peaking vaporizers operate approximately 30 days/yr.

Primary methods for $L N G$ and vapor release include:

- leak or rupture from inlet and outlet piping, valves, flanges, fittings, etc.

- leaks from vaporizer heat transfer tubing or coils.

A containment dike surrounds the vaporizer area to contain any spills that might occur there. Both the seawater vaporizers and the submerged combustion vaporizers are connected to the Vaporizer Emergency Shutdown (VES) circuit. When activated, this system shuts down the feed pumps to the vaporizers, isolates the vaporizers from the rest of the plant, and vents all gas handling equipment to the vent header. The VES is automatically activated by the loss of seawater flow, by high water temperature, by low outlet gas temperature, and by UV flame detectors in the area. It can also be activated manually from the vaporizer area and the control room. Activation of the MES automatically activates the VES.

The maximum release in this area would probably result from a failure of the 24-in. liquid transfer line from the secondary pumps to the vaporizers. A release of $100,000 \mathrm{gal}$ of $L N G$ is estimated as the maximum spill size that can 
occur from this area. This assumes the VES is not activated or fails to function properly. If the VES operates as designed, the spill would be limited to 23,000 gallons. The probability of this release is estimated to be low to medium. In the event of loss of seawater or fuel gas, failure of the VES can also result in failure of the vaporizer outlet lines. (The cold LNG could contact the carbon steel outlet lines and cause them to crack.)

\subsection{COMPONENT LEVEL ANALYSIS}

The system level analysis indicates that, although the largest potential releases are from the unloading and storage systems, significant releases could come from any of the four systems at the import terminal. As a result, a component level analysis is presented for all four systems.

The component level analys is consists of a preliminary hazards analysis (PHA). The PHAs for the major components in each of the import terminal systems are presented in tabular form in the following subsections. Each PHA includes potential hazards, effects, and existing preventive and control measures.

It is important to note that some of the releases presented in this section require failure of more than one component. For example, a line rupture could occur from a heat leak resulting in a pressure buildup and a relief valve failure.

\subsubsection{Marine Terminal and Unloading System}

The unloading system may be the most critical system at the terminal. Extremely high flow rates, combined with natural forces such as large waves, winds, earthquakes, etc., make this system a major concern. The PHA for the unloading system is given in Table 5.2 .

The following components are judged to be the most important with respect to release prevention and control:

- The 42-in. Main Transfer Line. This line includes various valves, expansion joints, and other fittings. A leak or rupture in this line could result in a large spill. The probability of a transfer line rupture is estimated to be low. 
TABLE 5.2. Preliminary Hazards Analysis for the Marine Terminal and Unloading System

\begin{tabular}{|c|c|c|c|}
\hline Component & $\begin{array}{l}\text { Potential } \\
\text { Hazard Condition }\end{array}$ & Effect & $\begin{array}{l}\text { Existing Preventive } \\
\text { and Control Measures }\end{array}$ \\
\hline \multirow[t]{3}{*}{$\begin{array}{l}\text { 16-in. loading } \\
\text { arm }\end{array}$} & Fissure or break & LNG release & $\begin{array}{l}\text { A spill containment system is } \\
\text { provided under the loading arms }\end{array}$ \\
\hline & & & $\begin{array}{l}\text { Closing of appropriate loading } \\
\text { arm block valve }\end{array}$ \\
\hline & & & LNG remaining in line is drained \\
\hline \multirow[t]{4}{*}{$\begin{array}{l}\text { 24-in. pipe prior } \\
\text { to air-opera- } \\
\text { ted valve }\end{array}$} & LNG surge & $\begin{array}{l}\text { Possible increase in } \\
\text { pressure }\end{array}$ & $\begin{array}{l}\text { Regulation of ship's pumps, } \\
\text { release through pressure relief } \\
\text { valve in } 24-i n . \text { line }\end{array}$ \\
\hline & Fissure or break & LNG release & $\begin{array}{l}\text { A spill containment system is pro- } \\
\text { vided under the loading arms }\end{array}$ \\
\hline & & & $\begin{array}{l}\text { Closing of appropriate loading } \\
\text { arm block valve }\end{array}$ \\
\hline & & & LNG remaining in line is drained \\
\hline $\begin{array}{l}\text { 16-in. loading } \\
\text { arm }\end{array}$ & $\begin{array}{l}\text { Bad flange connection } \\
\text { with ship }\end{array}$ & LNG release into water & Shutdown of pumps \\
\hline $\begin{array}{l}\text { 24-in. pipe } \\
\text { directly after } \\
\text { air-operated } \\
\text { valve }\end{array}$ & Fissure or break & LNG release & $\begin{array}{l}\text { Activation of OES system unless } \\
\text { there are valves in the liquid } \\
\text { header to isolate each } 24 \text {-in. line } \\
\text { from each other }\end{array}$ \\
\hline $\begin{array}{l}\text { 42-in. liquid } \\
\text { header }\end{array}$ & Fissure or break & LNG release & $\begin{array}{l}\text { Drainage of } L N G \text { remaining in the } \\
\text { lines }\end{array}$ \\
\hline \multirow[t]{2}{*}{$\begin{array}{l}\text { Air-operated } \\
\text { valve }\end{array}$} & $\begin{array}{l}\text { Failure to close if break } \\
\text { occurs in the line }\end{array}$ & $\begin{array}{l}\text { LNG release } \\
\text { and unable to isolate } \\
24-\text { in. line and loading } \\
\text { arms }\end{array}$ & $\begin{array}{l}\text { OES system activated } \\
\text { Drainage of LNG remaining in the } \\
\text { lines }\end{array}$ \\
\hline & Rupture & LNG release & Activation of OES system \\
\hline \multirow[t]{3}{*}{ Unloading lines } & $\begin{array}{l}\text { Blockage or restriction } \\
\text { of line }\end{array}$ & $\begin{array}{l}\text { LNG flow is backed up or } \\
\text { stopped }\end{array}$ & $\begin{array}{l}\text { Closing of appropriate valves to } \\
\text { isolate problem if not in ma in } \\
\text { liquid header }\end{array}$ \\
\hline & & & $\begin{array}{l}\text { Pressure buildup released through } \\
\text { pressure safety valve }\end{array}$ \\
\hline & & & Drainage of $L N G$ in line \\
\hline $\begin{array}{l}\text { 42-in. } 1 \text { iquid } \\
\text { transfer } 1 \text { ine }\end{array}$ & Fissure or break & LNG release & $\begin{array}{l}\text { Activation of OES system } \\
\text { Remaining LNG is drained }\end{array}$ \\
\hline \multirow[t]{4}{*}{$\begin{array}{l}\text { 16-in. vapor } \\
\text { return line }\end{array}$} & $\begin{array}{l}\text { Fissure or break during } \\
\text { recycle to cool down } \\
\text { lines }\end{array}$ & LNG release & $\begin{array}{l}\text { OES system is activated, drain } \\
\text { LNG }\end{array}$ \\
\hline & $\begin{array}{l}\text { Fissure or break during } \\
\text { vapor return }\end{array}$ & LNG vapor release & $\begin{array}{l}\text { Isolation of damage by closing } \\
\text { appropriate block valves }\end{array}$ \\
\hline & & & Activate OES system \\
\hline & $\begin{array}{l}\text { Increased vapor return } \\
\text { flow rate }\end{array}$ & Pressure buildup & $\begin{array}{l}\text { Activation of the inline pres- } \\
\text { sure safety valve }\end{array}$ \\
\hline $\begin{array}{l}\text { Vent gas compres- } \\
\text { sor }\end{array}$ & Failure to operate (a11) & No vapor return to ship & Activation of $0 E S$ system \\
\hline \multirow[t]{2}{*}{ LNG tanker } & Any hazardous condition & & $\begin{array}{l}\text { Release of loading arms } \\
\text { from ship }\end{array}$ \\
\hline & & & Activation of OES system \\
\hline Marine trestle & Large winds or earthquake & $\begin{array}{l}\text { Possible collapse of } \\
\text { trestle }\end{array}$ & Activation of MES system \\
\hline
\end{tabular}


TABLE 5.2. (Contd)

\begin{tabular}{|c|c|c|}
\hline Component & $\begin{array}{c}\text { Potential } \\
\text { Hazard Condition }\end{array}$ & Effect \\
\hline $\begin{array}{l}\text { 4-in. recircu- } \\
\text { lation line } \\
\text { during recircu- } \\
\text { lation }\end{array}$ & Fissure or break & LNG release \\
\hline \multirow{3}{*}{$\begin{array}{l}\text { Valves in dock } \\
\text { drain lines }\end{array}$} & Rupture or leak & LNG release to dock drain \\
\hline & Failure to open & Can't drain loading arms \\
\hline & Failure to close & LNG release to dock drain \\
\hline \multirow[t]{2}{*}{$\begin{array}{l}9 \% \text { nickel steel } \\
\text { inner barrier }\end{array}$} & \multirow[t]{2}{*}{ Fissure or break } & $\begin{array}{l}\text { LNG leakage into annular } \\
\text { space }\end{array}$ \\
\hline & & $\begin{array}{l}\text { Possible collapse of } \\
\text { exterior barrier }\end{array}$ \\
\hline Insulation & Excessive heat leak & Pressure buildup \\
\hline \multirow[t]{2}{*}{$\begin{array}{l}\text { Carbon steel } \\
\text { outer barrier. }\end{array}$} & \multirow[t]{2}{*}{ Fissure or break } & $\begin{array}{l}\text { Heat leak could crack } \\
\text { and collapse the tank }\end{array}$ \\
\hline & & $\begin{array}{l}\text { Pressure gradient from } \\
\text { inner tank to annulus } \\
\text { due to vapor release } \\
\text { of annulus }\end{array}$ \\
\hline $\begin{array}{l}\text { Electrical heater } \\
\text { for storage tank }\end{array}$ & Failure to operate & $\begin{array}{l}\text { Possible soil freezing } \\
\text { resulting in frost } \\
\text { heaving, storage tank } \\
\text { collapse, LNG spill, } \\
\text { possible dike collapse }\end{array}$ \\
\hline Vent gas compressor & $\begin{array}{l}\text { Failure to operate } \\
\text { (all of them, no back- } \\
\text { up available) }\end{array}$ & $\begin{array}{l}\text { Unable to return vapor } \\
\text { to the storage tank, } \\
\text { possible underpressuri- } \\
\text { zation }\end{array}$ \\
\hline
\end{tabular}

\author{
Existing Preventive \\ and Control Measures \\ Isolation of damage by clos- \\ ing appropriate valves
}

Shutdown of primary pumps

Drainage of LNG in lines

Activation of OES system

Activation of OES system

Activation of MES system

LNG spill can be contained by an insulated concrete dike capable of holding 133\% of tank capacity

Boiloff compressors handle smaller amounts of pressure buildup

Buildup in boiloff line can be handled by the vent stack header

Pressure relief valves discharge vapor to the atmosphere in the case of an excessive pressure buildup

LNG spill contained by insulated concrete dike

Pressure gradient equilibrated by the vapor return line

Activation of MES system

\section{Activation of MES system}

If the pressure drops below 0.15 psig, a backup gas system supplies natural gas from the transmission pipeline to the storage tank

If the pressure reaches 0.031 psig, three 12-in. vacuum relief valves open to the atmosphere

Activation of MES system

If pressure reaches $1.5 \mathrm{psig}$, three 12-in. presure valves open to the atmosphere

Pressure and vacuum safety valves are frequently checked to ensure operation

Large LNG spił1

( 7 on Richter scale)

Fails to activate upon demand
The unloading system would Operator detects malfunction

not shut down automati- and responds 
- Loading Arms and Ship Coupling Mechanism. The ability of the loading arms to maintain their mobility is a primary concern. Redundant sensing devices on each arm detect excessive motion and automatically activate the offshore Emergency Shutdown (OES) system. The thermal stresses the arms undergo as they are repeatedly warmed and cooled are of major concern. A good arm-to-ship connection is also important. The probability of a loading arm failure is estimated to be low.

- The Offshore Emergency Shutdown (OES) System. When operating properly, this system can limit and control the amount of release that can occur. However, if this system does not operate properly and a manual shutdown is necessary, the amount of LNG released can increase significantly.

\subsubsection{Storage System}

Table 5.3 shows the PHA for the storage system. Components of primary concern, as identified by the PHA, are:

- Pressure Control System. This system includes the boiloff compressors, the pressure/vacuum relief valves, and pressure controllers and indicators on inlet and outlet lines. The probability of failure for these types of components is estimated to be medium.

- LNG Level Indicators and Alarms. These components sound an alarm in the control room and activate the Master Emergency Shutdown system to prevent overfilling the storage tank. The failure of level indicators and alarms is estimated to have a medium probability.

- Outer She11. This carbon steel shell protects the inner shell and insulation from the environment and surroundings. The probability of a failure of the outer shell is estimated to be low.

- Annular Space Insulation. This prevents excessive boiloff of LNG vapors. The insulation also protects the carbon steel outer tank from being exposed to the cryogenic temperature of the LNG. The loss of insulation effectiveness is estimated to have a low probability.

- Inner Shel1. This $9 \%$ nickel-steel is continually exposed to cryogenic temperatures. Thus, any failure of this tank could result in a complete 
TABLE 5.3. Preliminary Hazards Analysis for the Storage System

\begin{tabular}{|c|c|c|c|}
\hline Component & $\begin{array}{l}\text { Potential } \\
\text { Hazard Condition }\end{array}$ & Effect & $\begin{array}{l}\text { Existing Preventive } \\
\text { and Control Measures }\end{array}$ \\
\hline Roof-shell joint & $\begin{array}{l}\text { Failure from overpres- } \\
\text { surization or fatigue }\end{array}$ & Large vapor release & \\
\hline \multirow[t]{3}{*}{$\begin{array}{l}\text { Primary sendout } \\
\text { pump }\end{array}$} & Failure to operate (one) & $\begin{array}{l}\text { Unable to transfer LNG } \\
\text { to vaporizers }\end{array}$ & $\begin{array}{l}\text { Operations are continued at a } \\
\text { slower rate until a second } \\
\text { pump can be activated }\end{array}$ \\
\hline & (two) & $\begin{array}{l}\text { Unable to transfer } L N G \\
\text { to vaporizers }\end{array}$ & A11 loading operations stopped \\
\hline & Leak or rupture & $\begin{array}{l}\text { Decreases the discharge } \\
\text { rate }\end{array}$ & $\begin{array}{l}\text { Shutdown of applicable pump } \\
\text { and activation of standby pump }\end{array}$ \\
\hline $\begin{array}{l}\text { Suction and dis- } \\
\text { charge valves } \\
\text { in primary } \\
\text { pumps }\end{array}$ & Rupture & $\begin{array}{l}\text { Decrease in sendout rate } \\
\text { of LNG }\end{array}$ & Activation of backup pump \\
\hline \multirow[t]{5}{*}{$\begin{array}{l}30 \text {-in. vapor } \\
\text { return line }\end{array}$} & Fissure or break & $\begin{array}{l}\text { Release of return vapor } \\
\text { to storage tank }\end{array}$ & $\begin{array}{l}\text { Isolation of the line by closing } \\
\text { in-line block valves }\end{array}$ \\
\hline & & & Shutdown of vent gas compressor \\
\hline & & & $\begin{array}{l}\text { Shutdown of peaking vaporizers, } \\
\text { if in operation }\end{array}$ \\
\hline & $\begin{array}{l}\text { Regulation failure } \\
\text { of vent gas compressor }\end{array}$ & Pressure buildup & $\begin{array}{l}\text { Excess vapors to vent stack } \\
\text { header }\end{array}$ \\
\hline & & & $\begin{array}{l}\text { Activate standby vent gas com- } \\
\text { pressor }\end{array}$ \\
\hline $\begin{array}{l}36-\text { in. boiloff } \\
\text { line }\end{array}$ & Fissure or break & LNG vapor release & Activation of MES system \\
\hline \multirow{4}{*}{$\begin{array}{l}\text { Outlet line of } \\
\text { storage tank } \\
\text { prior to fail- } \\
\text { safe operated } \\
\text { valve }\end{array}$} & Fissure or break & LNG release & $\begin{array}{l}\text { Isolation of the line by shut- } \\
\text { down of primary pump and closing } \\
\text { of outlet line block valve }\end{array}$ \\
\hline & $\begin{array}{l}\text { Restriction in the line } \\
\text { or heat leak }\end{array}$ & Pressure buildup & Shutdown of LNG pump \\
\hline & & & $\begin{array}{l}\text { Excess vapors or LNG from pres- } \\
\text { sure buildup vented to atmosphere } \\
\text { via pressure relief valve }\end{array}$ \\
\hline & & & $\begin{array}{l}\text { Isolation of the line by closing } \\
\text { fail-safe valve in outlet line }\end{array}$ \\
\hline $\begin{array}{l}\text { Upper outlet line } \\
\text { directly after } \\
\text { fail-safe opera- } \\
\text { ted valves }\end{array}$ & Fissure or break & LNG release & $\begin{array}{l}\text { Isolate line by shutting down } \\
\text { appropriate pump and closing appro- } \\
\text { priate valves }\end{array}$ \\
\hline $\begin{array}{l}\text { Lower outlet line } \\
\text { directly after } \\
\text { fail-safe opera- } \\
\text { ted valves }\end{array}$ & Fissure or break & LNG release & $\begin{array}{l}\text { Isolate line by shutting down } \\
\text { appropriate pump and closing } \\
\text { appropriate valves }\end{array}$ \\
\hline
\end{tabular}


IABLE 5.3 (Contd)

\begin{tabular}{|c|c|c|c|}
\hline Component & $\begin{array}{c}\text { Potential } \\
\text { Hazard Condition } \\
\end{array}$ & Effect & $\begin{array}{l}\text { Existing Preventive } \\
\text { and Control Measures }\end{array}$ \\
\hline \multirow{2}{*}{$\begin{array}{l}\text { Upper or lower } \\
\text { outlet lines } \\
\text { after initial } \\
\text { fail-safe } \\
\text { operated valves }\end{array}$} & $\begin{array}{l}\text { Line restriction or heat } \\
\text { leak }\end{array}$ & Pressure buildup & $\begin{array}{l}\text { Shutdown of appropriate pump } \\
\text { Isolation of line by closing } \\
\text { appropriate valves }\end{array}$ \\
\hline & & & $\begin{array}{l}\text { Excess vapors or LNG to atmos- } \\
\text { phere via pressure rel ief valve }\end{array}$ \\
\hline \multirow[t]{5}{*}{$\begin{array}{l}\text { Storage tank main } \\
\text { outlet line }\end{array}$} & Fissure or break & LNG release & $\begin{array}{l}\text { Isolate line by closing appro- } \\
\text { priate valves }\end{array}$ \\
\hline & & & $\begin{array}{l}\text { Shutdown of primary pumps for } \\
\text { appropriate tank }\end{array}$ \\
\hline & $\begin{array}{l}\text { Restriction or heat } \\
\text { leak }\end{array}$ & Pressure buildup & $\begin{array}{l}\text { Isolate line by closing appro- } \\
\text { priate valves }\end{array}$ \\
\hline & & & $\begin{array}{l}\text { Shutdown of primary pumps for } \\
\text { appropriate tank }\end{array}$ \\
\hline & & & $\begin{array}{l}\text { Excess vapors or LNG to atmos- } \\
\text { phere via pressure relief valve }\end{array}$ \\
\hline \multirow[t]{3}{*}{ 20-in. sendout 1 ine } & Fissure or break & LNG release & Activation of MES system \\
\hline & $\begin{array}{l}\text { LNG restriction or heat } \\
\text { leak }\end{array}$ & Pressure buildup & Activation of MES system \\
\hline & & & $\begin{array}{l}\text { Excess vapors or LNG to atmos- } \\
\text { via pressure relief valve }\end{array}$ \\
\hline \multirow[t]{2}{*}{$\begin{array}{l}\text { 4-in. recirc. line } \\
\text { prior to fail- } \\
\text { safe operated } \\
\text { valve }\end{array}$} & Fissure or break & LNG release & $\begin{array}{l}\text { Activation of MES system } \\
\text { Isolation of damage by closing } \\
\text { appropriate block valves }\end{array}$ \\
\hline & $\begin{array}{l}\text { Line restriction } \\
\text { or heat leak }\end{array}$ & Pressure buildup & $\begin{array}{l}\text { Activation of MES system } \\
\text { Excess vapor or liquid to atmos- } \\
\text { phere }\end{array}$ \\
\hline \multirow[t]{3}{*}{$\begin{array}{l}\text { 4-in. recirc. line } \\
\text { after fail-safe } \\
\text { valve }\end{array}$} & Fissure or break & LNG release & $\begin{array}{l}\text { Isolation of recirculation line } \\
\text { by closing appropriate block } \\
\text { valves }\end{array}$ \\
\hline & $\begin{array}{l}\text { Line restriction or } \\
\text { heat leak }\end{array}$ & Pressure buildup & $\begin{array}{l}\text { Isolation of line by closing appro } \\
\text { priate block valves }\end{array}$ \\
\hline & & & Excess liquid to drain \\
\hline \multirow[t]{3}{*}{$\begin{array}{l}\text { Outlet and send- } \\
\text { out lines fail- } \\
\text { safe control } \\
\text { valves }\end{array}$} & $\begin{array}{l}\text { Failure of valves to opera- } \\
\text { te } \\
\text { Open }\end{array}$ & Unable to pump out LNG & \\
\hline & (one) & Unable to pump out LNG & $\begin{array}{l}\text { Shutdown of appropriate pump, } \\
\text { operations are slowed down until } \\
\text { malfunction is rectified }\end{array}$ \\
\hline & (two) & Unable to pump out LNG & $\begin{array}{l}\text { Shutdown of pumps unless recir- } \\
\text { culating the LNG in the tank or } \\
\text { transferring it to another tank }\end{array}$ \\
\hline
\end{tabular}


TABLE 5.3. (Contd)

\begin{tabular}{|c|c|c|c|}
\hline Component & $\begin{array}{l}\text { Potential } \\
\text { Hazard Condition }\end{array}$ & Effect & $\begin{array}{l}\text { Existing Preventive } \\
\text { and Control Measures }\end{array}$ \\
\hline $\begin{array}{l}\text { Pressure control } \\
\text { valves in vapor } \\
\text { return lines }\end{array}$ & Failure to open & $\begin{array}{l}\text { Unable to return vapor } \\
\text { from the vent gas compres- } \\
\text { sor }\end{array}$ & $\begin{array}{l}\text { Vapor from gas pipeline } \\
\text { returned to storage tank }\end{array}$ \\
\hline $\begin{array}{l}\text { Storage tank } \\
\text { loading valves }\end{array}$ & Failure to open & $\begin{array}{l}\text { Unable to transfer LNG to } \\
\text { the storage tank from } \\
\text { the ship }\end{array}$ & Activation of OES system \\
\hline \multirow{2}{*}{$\begin{array}{l}\text { Loading line } \\
\text { between loading } \\
\text { valves and tank } \\
\text { inlet }\end{array}$} & $\begin{array}{l}\text { Fissure, break, or } \\
\text { heat leak }\end{array}$ & $\begin{array}{l}\text { LNG spill or pressure } \\
\text { buildup }\end{array}$ & $\begin{array}{l}\text { Closing of loading valves } \\
\text { Activation of OES system }\end{array}$ \\
\hline & & & $\begin{array}{l}\text { Excessive pressure buildup } \\
\text { in tank due to heat leak } \\
\text { handled by boiloff or pressure } \\
\text { safety valve }\end{array}$ \\
\hline \multirow[t]{2}{*}{$\begin{array}{l}\text { Pressure or vacuum } \\
\text { safety valves }\end{array}$} & $\begin{array}{l}\text { Failure to open at } \\
\text { appropriate pressures }\end{array}$ & $\begin{array}{l}\text { Pressure buildup or } \\
\text { vacuum }\end{array}$ & \\
\hline & & Possible tank failure & Activates MES system \\
\hline \multirow[t]{3}{*}{$\begin{array}{l}\text { Relief valve vent } \\
\text { nozzle }\end{array}$} & $\begin{array}{l}\text { Failure to open during } \\
\text { purging }\end{array}$ & $\begin{array}{l}\text { Pressure buildup from } \\
\text { inconing } \mathrm{N}_{2} \text { gas }\end{array}$ & $\begin{array}{l}\text { Can be released from boiloff } \\
\text { line }\end{array}$ \\
\hline & & & $\begin{array}{l}\text { Close block valve to vent gas } \\
\text { compressor }\end{array}$ \\
\hline & & & Vent gas to vent stack header \\
\hline \multirow[t]{2}{*}{$\begin{array}{l}\text { 36-in. vapor outlet } \\
\text { line }\end{array}$} & Fissure or break & LNG vapor release & Discontinue flow of heated gas \\
\hline & & & Vent vapor to vent stack header \\
\hline $\begin{array}{l}\text { Trailer unloading } \\
\text { line }\end{array}$ & Fissure or break & $\mathrm{N}_{2}$ purge gas leak & $\begin{array}{l}\text { Isolation of damaged site by } \\
\text { closing appropriate block valves }\end{array}$ \\
\hline $\begin{array}{l}\text { Emergency Shutdown } \\
\text { System }\end{array}$ & $\begin{array}{l}\text { Failure to activate } \\
\text { upon demand }\end{array}$ & $\begin{array}{l}\text { Flows into and out of } \\
\text { the tanks would not be } \\
\text { stopped automatically } \\
\text { in an emergency }\end{array}$ & $\begin{array}{l}\text { Operator detects malfunction } \\
\text { and responds }\end{array}$ \\
\hline
\end{tabular}


storage system failure and the release of large quantities of LNG and natural gas. The probability of such a failure is estimated to be low.

\subsubsection{Compressors and Secondary Pumps}

The results of the preliminary hazards analysis of the pumps and compressors are presented in Table 5.4. Because of the high pressures and large flow rates, a pipe failure in these areas can result in a large release and could spray cold liquid or vapor, resulting in failure of carbon steel components in the area. Components of primary concern with respect to release prevention and control are:

- Emergency Shutdown System. Proper operation of the ESD system can prevent or significantly reduce the size of releases in the vaporizer area.

- Secondary Pumps and 24-in. Sendout Line to Vaporizers. This system not only accommodates a large LNG flow rate, but operates at a very high pressure (1280 psig). A leak could spray LNG and possibly cause failure of some other component. The probability of a rupture of the sendout line is estimated to be low.

- Fuel Gas Preheater. Failure of the fuel gas preheater or temperature controllers could allow cold LNG or vapors to reach carbon-steel components, resulting in the release of LNG or vapor. The probability of a preheater failing is estimated to be medium.

\subsubsection{Vaporization System}

Table 5.5 presents the PHA for the vaporization system. Primary components of concern related to release prevention and control include:

- Temperature Controllers and Alarms. These are probably the most important components related to release prevention and control in this system. The temperature controllers monitor the vaporized LNG temperature and adjust the incoming LNG flow rates, the seawater inlet rate in the seawater vaporizers, and the air/fuel rates and ratios in the gas-fired vaporizers. Any malfunction of these controllers could result in a hazardous situation, possibly causing the release of significant quantities of LNG or LNG vapor. The probability of a temperature controller failing is estimated to be medium. 


\section{TABLE 5.4. Preliminary Hazards Analys is for the Compressors and Secondary Pumps}

\begin{tabular}{|c|c|c|c|}
\hline Component & $\begin{array}{l}\text { Potential } \\
\text { Hazard Condition }\end{array}$ & Effect & $\begin{array}{l}\text { Existing Preventive } \\
\text { and Control Measures }\end{array}$ \\
\hline \multirow[t]{3}{*}{$\begin{array}{l}\text { 36-in. secondary } \\
\text { pump }\end{array}$} & $\begin{array}{l}\text { Fissure, break, or heat } \\
\text { leak }\end{array}$ & $\begin{array}{l}\text { LNG leak or pressure } \\
\text { buildup }\end{array}$ & Activation of VES system \\
\hline & & & $\begin{array}{l}\text { Excessive pressure can be } \\
\text { relieved to the atmosphere } \\
\text { through pressure relief valves }\end{array}$ \\
\hline & & & $\begin{array}{l}\text { Spill contained by concrete } \\
\text { dike }\end{array}$ \\
\hline \multirow[t]{6}{*}{ Secondary pump } & Failure to operate (one) & $\begin{array}{l}\text { Rate of LNG sendout is } \\
\text { decreased }\end{array}$ & Activation of backup pump \\
\hline & More than one & $\begin{array}{l}\text { Rate of LNG sendout is } \\
\text { decreased }\end{array}$ & $\begin{array}{l}\text { Isolate pumps and associated } \\
\text { lines by closing appropriate } \\
\text { valves }\end{array}$ \\
\hline & & & Activation of backup pump \\
\hline & All of them & $\begin{array}{l}\text { LNG sendout is stopped } \\
\text { completely }\end{array}$ & Activation of VES system \\
\hline & Leak or rupture in pump & Reduces LNG flow rate & $\begin{array}{l}\text { Isolation of pump and associ- } \\
\text { ated piping by closing appro- } \\
\text { priate valves }\end{array}$ \\
\hline & & & Activation of standby pump \\
\hline $\begin{array}{l}\text { Suction and dis- } \\
\text { charge valves }\end{array}$ & $\begin{array}{l}\text { Leak, rupture, or fallure } \\
\text { to operate pro- } \\
\text { perly (won't open or } \\
\text { close) }\end{array}$ & $\begin{array}{l}\text { Reduces loading rate } \\
\text { LNG release }\end{array}$ & $\begin{array}{l}\text { Spill contained by concrete dike } \\
\text { Isolation of pump and associ- } \\
\text { ated lines by closing appro- } \\
\text { priate block valves }\end{array}$ \\
\hline \multirow[t]{4}{*}{$\begin{array}{l}\text { Line between } \\
\text { block valve and } \\
\text { pump }\end{array}$} & $\begin{array}{l}\text { Fissure, break, or heat } \\
\text { leak }\end{array}$ & $\begin{array}{l}\text { LNG spill or pressure } \\
\text { buildup due to heat } \\
\text { leak }\end{array}$ & $\begin{array}{l}\text { Isolation of pump by closing } \\
\text { appropriate block valves }\end{array}$ \\
\hline & & & Spill contained by concrete dike \\
\hline & & & Activation of standby pump \\
\hline & & & $\begin{array}{l}\text { Excessive pressure buildup can } \\
\text { be relieved to atmosphere through } \\
\text { a pressure relief valve }\end{array}$ \\
\hline \multirow[t]{2}{*}{$\begin{array}{l}\text { Line between block } \\
\text { valve and } 36-\text { in. } \\
\text { feed line }\end{array}$} & $\begin{array}{l}\text { Fissure, break, or heat } \\
\text { leak }\end{array}$ & $\begin{array}{l}\text { LNG spill or pressure } \\
\text { buildup due to heat leak }\end{array}$ & $\begin{array}{l}\text { Activation of VES system } \\
\text { Excessive pressure buildup can be } \\
\text { relieved to atmosphere via a pres- } \\
\text { sure relief valve }\end{array}$ \\
\hline & & & Spill contained by concrete dike \\
\hline \multirow{5}{*}{$\begin{array}{l}\text { Outlet valve from } \\
\text { pump }\end{array}$} & Fail to open ( 1 of 9 ) & Unable to send out LNG & Activation of sțandby pump \\
\hline & & & $\begin{array}{l}\text { Shutdown of appropriate pump by } \\
\text { closing of block valves to and } \\
\text { from pump }\end{array}$ \\
\hline & (more than one) & $\begin{array}{l}\text { LNG sendout rate is } \\
\text { decreased }\end{array}$ & $\begin{array}{l}\text { Regulate primary pumps from } \\
\text { storage tank }\end{array}$ \\
\hline & & & $\begin{array}{l}\text { Closing of appropriate inlet and } \\
\text { outlet pump block valves }\end{array}$ \\
\hline & & & Activation of standby pump \\
\hline
\end{tabular}




\begin{tabular}{|c|c|c|c|}
\hline Comyonent & $\begin{array}{l}\text { Potential } \\
\text { Hazard Condition }\end{array}$ & Effect & $\begin{array}{l}\text { Existing Preventive } \\
\text { and Control Measures }\end{array}$ \\
\hline & $\begin{array}{l}\text { If all valves fafl to } \\
\text { open }\end{array}$ & $\begin{array}{l}\text { Complete blockage of LNG } \\
\text { flow to vaporizers }\end{array}$ & Activation of VES system \\
\hline & & & $\begin{array}{l}\text { Excessive pressure buildup can } \\
\text { be relleved to atmosphere via } \\
\text { pressure relief valve }\end{array}$ \\
\hline \multirow[t]{3}{*}{$\begin{array}{l}\text { Liquid return } \\
\text { valves from } \\
\text { secondary pumps }\end{array}$} & Fail to open (all valves) & $\begin{array}{l}\text { Unable to return LNG to } \\
\text { storage tanks }\end{array}$ & $\begin{array}{l}\text { Recirculate LNG to tank via out- } \\
\text { let lines from tank or from one } \\
\text { tank to the other if needed }\end{array}$ \\
\hline & (More than one) & $\begin{array}{l}\text { Unable to return LNG to } \\
\text { storage tanks }\end{array}$ & $\begin{array}{l}\text { Activate backup pump and can } \\
\text { recirculate LNG from outlet line } \\
\text { if needed }\end{array}$ \\
\hline & One & $\begin{array}{l}\text { Unable to return LNG to } \\
\text { storage tanks }\end{array}$ & $\begin{array}{l}\text { Shutdown of that pump, activate } \\
\text { backup pump }\end{array}$ \\
\hline \multirow{6}{*}{$\begin{array}{l}\text { Secondary outlet } \\
\text { line } \# 13\end{array}$} & Fissure or break & LNG release & Activation of VES system \\
\hline & & & $\begin{array}{l}\text { Spill contained by concrete } \\
\text { dike }\end{array}$ \\
\hline & LNG pumpout surge & Pressure buildup & $\begin{array}{l}\text { Excessive pressure can be } \\
\text { relieved to atmosphere via pres- } \\
\text { sure relief valve }\end{array}$ \\
\hline & & & $\begin{array}{l}\text { Regulation of liquid return by } \\
\text { PIC valve in LNG sendout line } \\
\text { \#3 to relieve excessive flow } \\
\text { rates }\end{array}$ \\
\hline & Heat leak & Pressure buiidup & Activation of VES system \\
\hline & & & $\begin{array}{l}\text { Excessive pressures can be } \\
\text { relieved via the pressure relief } \\
\text { valve }\end{array}$ \\
\hline $\begin{array}{l}\text { Inlet valve to } \\
\text { secondary } \\
\text { pumps on } 20-i n . \\
\text { sendout line }\end{array}$ & Failure to open & $\begin{array}{l}\text { Unable to pump LNG } \\
\text { through ma in sendout } \\
\text { line }\end{array}$ & $\begin{array}{l}\text { Primary sendout pumps regulated } \\
\text { to maximize flow to the secondary } \\
\text { pumps via the } 4 \text {-in. circulation } \\
\text { line }\end{array}$ \\
\hline $\begin{array}{l}\text { 4-in. circulation } \\
\text { line }\end{array}$ & LNG surge & $\begin{array}{l}\text { LNG recirculation flow } \\
\text { too great }\end{array}$ & $\begin{array}{l}\text { Flow regulator controller adjusts } \\
\text { valve on } 20 \text {-in. sendout line to } \\
\text { increase the fiow in the sendout } \\
\text { line resulting in a decreased flow } \\
\text { in the circulation line }\end{array}$ \\
\hline \multirow[t]{4}{*}{$\begin{array}{l}\text { Liquid return line } \\
\# 2\end{array}$} & $\begin{array}{l}\text { Fissure, break or heat } \\
\text { leak }\end{array}$ & $\begin{array}{l}\text { LNG release or pressure } \\
\text { buildup }\end{array}$ & $\begin{array}{l}\text { Block valves from all pump outlets } \\
\text { to liquid return line are closed }\end{array}$ \\
\hline & & & $\begin{array}{l}\text { Block valves from liquid return } \\
\text { lines to storage tanks are closed }\end{array}$ \\
\hline & & & $\begin{array}{l}\text { LNG can be recirculated from one } \\
\text { tank or the other if need be }\end{array}$ \\
\hline & & & Spill contained by concrete dike \\
\hline
\end{tabular}


TABLE 5.4. (Contd)

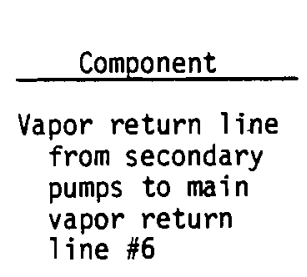

Vapor Line \#8 between vent compressor and pneumatic valve
Vapor line \#8 between pneumatic valve and fuel gas preheater
Fissure or break

Vapor surge

Fissure or break

Vapor surge

Failure to operate

E-201 fuel gas preheater
Potential

Fissure, break, or heat

LNG vapor release, or pressure buildup

LNG release

Pressure buildup

LNG vapor release

Extreme pressure buildup

Slight pressure increase Unable to heat vapor from vent gas compressor

Unable to compress LNG vapors

Unable to compress LNG vapors
Existing Preventive and Control Measures

Closing of block valves from secondary pumps

If a pressure buildup exists, vapor can be vented via the relief vent stack header

Shutdown of cooldown process

Shutdown of vent gas compressor

Closing of pressure control valve in line

Shutdown of all fuel gas compressors and fuel gas preheator closing of vapor return block valves

Isolation of vapor return to storage tank by closing appropriate valves

Shutdown of compressors if extreme pressure buildup and vapors to vent stack header

Excess vapors to vent stack header only, if pressure buildup is not too severe

Isolation of damage by closing pneumatic valve and other appropriate valves

Shutdown of fuel gas compressors and fuel gas preheater

Excess vapors to vent stack header Excess vapors to vent stack header

Excess vapors to vent stack header Shutdown of fuel gas compressors

Isolation of fuel gas compressor system by closing appropriate valves

Vent gas compressor regulation for vapor return only

Activation of backup compressor without loss of flow

Activation of backup compressor

Vent gas compressor is regulated so as not to pass more vapor than the system can handle 
TABLE 5.4. (Contd)

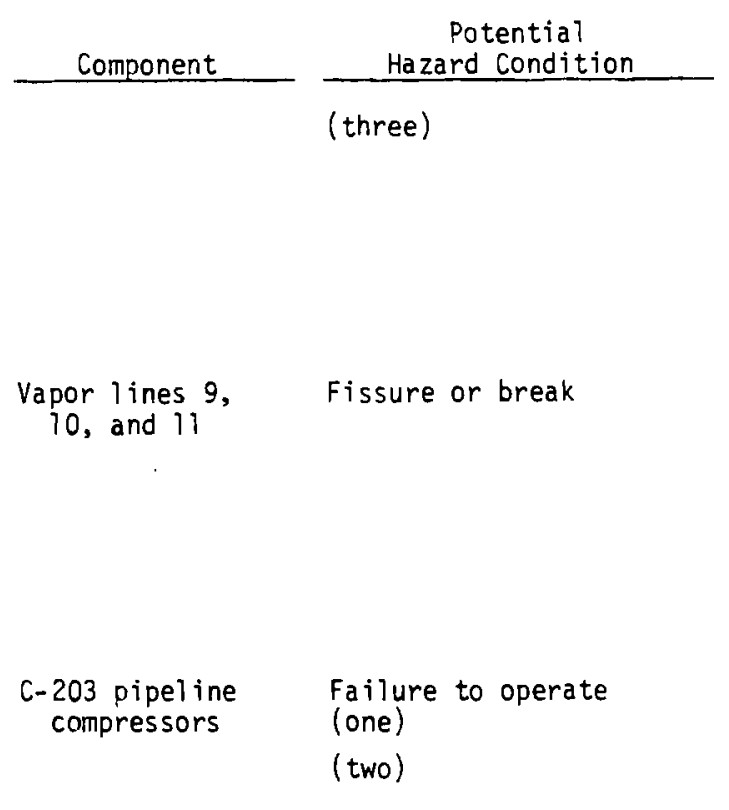

Vapor line $\$ 12 \quad$ Fissure or break

(three)

Effect
$\begin{aligned} & \text { Unable to compress. LNG } \\ & \text { vapors }\end{aligned}$

LNG vapor or release
Existing Preventive and Control Measures

Isolation of fuel gas compressor and pipeline compressor system by closing appropriate valve

Shutdown of pipeline gas compressors and fuel gas preheater Excess vapor exits vent stack header

Isolation of fuel gas and pipeline gas compressors by closing appropriate block valves

Regulation of vent gas compressors to accommodate vapor return header

Excess boiloff to vent stack header

Unable to compress vapors Activation of backup compressor to pipeline pressure wi thout loss of flow

Unable to compress vapors Activation of backup compressor to pipeline pressure

Regulation of valves and vent gas compressor to accommodate for the decrease in flow rate

Excess gas vented via the vent stack header

Unable to compress vapors to pipeline pressure

Isolation of fuel gas to pipeline gas compressor system by closing appropriate valves

Shutdown of fuel gas compressors and preheater

Regulation of valves and vent gas compressor to accommodate for vapor return only

Vent gas to vent stack header

Isolation of fuel gas and pipeline compressor system

Shutdown of fuel gas compressor, pipeline compressor, and fuel gas preheater

Vent gas compressor accommodates vapor return only

Excess gas to vent stack header 
TABLE 5.5. Preliminary Hazards Analysis for the Vaporization System

\begin{tabular}{|c|c|c|}
\hline Component & $\begin{array}{l}\text { Potential } \\
\text { Hazard Condition }\end{array}$ & Effect \\
\hline $\begin{array}{l}\text { LNG } 1 \text { ine } 13 \text { from } \\
\text { secondary pumps }\end{array}$ & Fissure or break & LNG spill \\
\hline \multirow[t]{3}{*}{ Flow control box } & $\begin{array}{l}\text { Fails to regulate LNG } \\
\text { inlet valve }\end{array}$ & $\begin{array}{l}\text { Unable to control inlet } \\
\text { flow of LNG }\end{array}$ \\
\hline & $\begin{array}{l}\text { Fails to register sea- } \\
\text { water inlet flow }\end{array}$ & $\begin{array}{l}\text { Unable to know how much } \\
\text { LNG inlet flowrate is } \\
\text { required }\end{array}$ \\
\hline & Fails to operate & $\begin{array}{l}\text { Unable to control sea- } \\
\text { water and LNG inlet } \\
\text { flow rates }\end{array}$ \\
\hline $\begin{array}{l}\text { Falling film } \\
\text { vaporizer fin }\end{array}$ & Plugs & $\begin{array}{l}\text { Other fins will carry a } \\
\text { faster load }\end{array}$ \\
\hline $\begin{array}{l}\text { Seawater inlet } \\
\text { line }\end{array}$ & Fissure or break & $\begin{array}{l}\text { Water inlet rate slowed } \\
\text { or stopped }\end{array}$ \\
\hline
\end{tabular}

Seawater vaporizer inlet line 13

Fissure or break

LNG release

$\begin{gathered}\text { Existing Preventive } \\ \text { and Control Measures }\end{gathered}$
Activation of MES and VES systems
Automatic regulation of seawater
inlet Shutdown and isolation of appro-
priate vaporizer by closing block valves on inlet and outlet LNG and seawater transfer 1 ines

closing of block valves to prevent $L N G$ and seawater inlet flows to isolate the vaporizer

Slow down LNG flow rate to allow for the plug

Isolation of vaporizer by closing inlet and outlet block valves

If a pressure buildup occurs due to isolation, pressure relief valves are activated to the vent stack header in the exit line from the vaporizers

Shutdown of seawater vaporizer system

Isolation of break by closing appropriate block valves

Activate standby vaporizers if not activated al ready

Flow rate is regulated to accommodate the standby vaporizers

Peaking vaporizer inlet line 13 during peaking operations or any time in use

Fissure or break

LNG release

Shutdown of peaking or standby vaporizer system

Isolation of break by closing appropriate block valves

Flow rate is regulated to accommodate for seawater only

Increased or restricted flow rate

Complete failure to operate

control box on peaking vaporizer

LiNG vapor exit

Fissure or break
Pressure increase

Unable to control flow rates and temperatures

LNG can be released to the atmosphere if excessive pressure occurs

Flow rates are regulated

Isolation of vaporizer

Vapors vented to vent stack header if needed during isolation

Vapor release and temperature readings would drop
Isolation of vaporizer by closing appropriate block valves 
TABLE 5.5. (Contd)

\begin{tabular}{|c|c|c|c|}
\hline Component & $\begin{array}{l}\text { Potential } \\
\text { Hazard Condition }\end{array}$ & Effect & $\begin{array}{l}\text { Existing Preventive } \\
\text { and Control Measures }\end{array}$ \\
\hline $\begin{array}{l}\text { Air flow entrance } \\
\text { line }\end{array}$ & Fissure or break & $\begin{array}{l}\text { Air needed for combustion } \\
\text { would escane }\end{array}$ & $\begin{array}{l}\text { Isolation of vaporizer by clos- } \\
\text { ing appropriate block valves }\end{array}$ \\
\hline \multirow[t]{2}{*}{$\begin{array}{l}\text { Fuel gas entrance } \\
\text { line }\end{array}$} & Fissure or break & $\begin{array}{l}\text { Fuel needed for combustion } \\
\text { would escape }\end{array}$ & $\begin{array}{l}\text { Isolation of vaporizer by clos- } \\
\text { ing appropriate block valves }\end{array}$ \\
\hline & $\begin{array}{l}\text { Fissure or break between } \\
\text { valves }\end{array}$ & $\begin{array}{l}\text { Fuel needed for combustion } \\
\text { would escape }\end{array}$ & $\begin{array}{l}\text { Isolation of damage by closing } \\
\text { appropriate valves and utilizing } \\
\text { bypass line via hand-operated } \\
\text { valves }\end{array}$ \\
\hline Seawater inlet line & Fissure or break & Drop in bath water level & Vaporizer isolation procedures \\
\hline \multirow[t]{2}{*}{$\begin{array}{l}\text { Vapor line prior } \\
\text { to check valve }\end{array}$} & Fissure or break & L.NG vapor discharge & $\begin{array}{l}\text { Isolation of all open rack sea- } \\
\text { water vaporizers by closing appro- } \\
\text { priate block valves }\end{array}$ \\
\hline & & & $\begin{array}{l}\text { Excess vapors vented to vent } \\
\text { stack header }\end{array}$ \\
\hline $\begin{array}{l}\text { 30-in. line after } \\
\text { peaking vapori- } \\
\text { zers }\end{array}$ & Fissure or break & LNG vapor release & Activation of MES and VES systems \\
\hline $\begin{array}{l}\text { Odorant injection } \\
\text { line }\end{array}$ & Fissure or break & $\begin{array}{l}\text { Unable to odorize } \\
\text { vaporized gas }\end{array}$ & Activation of MES and VES systems \\
\hline $\begin{array}{l}\text { Seawater return } \\
\text { line } 16\end{array}$ & Fissure or break & $\begin{array}{l}\text { Temperature gradient in } \\
\text { return seawater }\end{array}$ & $\begin{array}{l}\text { Isolation of vaporizer by closing } \\
\text { inlet and outlet block valves }\end{array}$ \\
\hline $\begin{array}{l}\text { Inlet line to peak- } \\
\text { ing vaporizer } \\
\text { after air-opera- } \\
\text { ted valves }\end{array}$ & Fissure or break & LNG release & Activation of MES and VES systems \\
\hline \multirow{2}{*}{$\begin{array}{l}\text { Inlet line to } \\
\text { peaking vapori- } \\
\text { zer prior to } \\
\text { valves }\end{array}$} & Fissure or break & LNG release & $\begin{array}{l}\text { Isolation of vaporizer by closing } \\
\text { appropriate block values }\end{array}$ \\
\hline & & & Closing of seawater lines \\
\hline Air pump & Faiture to operate & $\begin{array}{l}\text { Unable to obtain the } \\
\text { combustible mixture } \\
\text { of gases needed }\end{array}$ & \\
\hline $\begin{array}{l}\text { TRC in outlet } \\
\text { vapor line }\end{array}$ & Failure to operate & $\begin{array}{l}\text { Unable to control flow } \\
\text { of inlet air and fuel } \\
\text { gas to regulate tempera- } \\
\text { ture of outlet }\end{array}$ & $\begin{array}{l}\text { Regulation of iniet flow by } \\
\text { appropriate valve }\end{array}$ \\
\hline $\begin{array}{l}\text { Temperature recor- } \\
\text { der in vaporizer } \\
\text { outlet line }\end{array}$ & Failure to operate & $\begin{array}{l}\text { Unable to control gas out- } \\
\text { let temperature by sea- } \\
\text { water inlet flowrate }\end{array}$ & $\begin{array}{l}\text { Shutdown of baseload vaporizer } \\
\text { system by closing appropriate } \\
\text { block valves to discontinue inlet } \\
\text { and outlet flow rate of LNG and } \\
\text { seawater }\end{array}$ \\
\hline \multirow{2}{*}{$\begin{array}{l}\text { Water bath pump } \\
\text { in peaking }\end{array}$} & Failure to operate & Unable to cool burner & Shutdown of vaporizer \\
\hline & & & $\begin{array}{l}\text { Isolation of damaged vaporizer } \\
\text { by closing appropriate valves }\end{array}$ \\
\hline
\end{tabular}


- Vaporizer Inlet Lines. A leak or rupture in any vaporizer inlet line, releasing cold LNG, could possibiy cause failure of other components in the system that are not designed to withstand the extreme cold.

\subsubsection{Operator Interface}

Although the plant operators are not traditionally viewed as plant components, they are essential to the proper operation of the plant. The interface between operator actions and plant operations is therefore a critical factor relating to release prevention and control.

Operators perform a number of diverse tasks at the import terminal, most of which relate to release prevention and control either directly or indirectly. During normal plant operations, the operators run the plant within set limits and standards to prevent conditions that may lead to releases. During offstandard conditions, the operators must respond appropriately to alarms, indicators, and other signals to prevent releases from occurring or to limit releases in progress. Plant inspection and maintenance is also important to identify and remedy conditions that may lead to subsequent releases.

Because of the number of operator tasks performed at the facility, the probability of operator error is judged to be medium to high. The probability of LNG or natural gas releases resulting from operator errors varies from a high probability of a small release to a low probability of a maximum release.

\subsection{REPRESENTATIVE RELEASE EVENTS}

Using the results of the analyses presented in Sections 5.2 and 5.3 , a list of potential release events considered to be representative of the import terminal was developed. These representative release events are listed in Table 5.6. Preliminary analyses of these events are presented in Section G.3 of Appendix G. The representative release events range from relatively frequent but low consequence releases to unlikely but large releases. They form the basis for the quantitative evaluation of the release prevention and control systems in the next phase of analysis.

In performing the overview study, several areas requiring additional information were identified. Some of these are outlined below. 
TABLE 5.6. Representative Release Events for an LNG Import Terminal

1. Failure of $9 \%$ nickel-steel inner storage tank.

2. Failure of carbon-steel outer barrier for LNG storage tank.

3. LNG release from 16-in. loading arms.

4. Failure of 42-in. liquid transfer line from unloading dock to shore.

5. Failure of 42-in. liquid transfer line from shore to storage.

6. Failure of 20-in. LNG transfer line from storage to the secondary pumps.

7. Failure of 24-in. LNG transfer line from secondary pumps to vaporizers.

8. Seawater vaporizer failure.

9. Submerged combustion vaporizer failure.

10. Failure of vaporizer exit lines.

11. Failure of fuel gas compressor suction line.

12. Failure of 4-in. LNG recirculation line.

13. Failure of 16-in. vapor return line to ship's tanks.

14. Failure of 30-in. vapor line from pipeline compressors to gas transmission pipeline. 
- Component Stresses from Thermal Cycling. Many components, such as the storage tanks, valves, unloading arms, and transfer lines, undergo a number of thermal cycles. Exactly how many cycles each component is designed to withstand needs to be determined.

- Terminal Piping Network. Details such as diameter, length, wall thickness, and materials of construction are needed for the components that make up the terminal piping.

- Structural Mechanics of the Storage Tank. The effect of hazardous conditions on the structural integrity of the tank is of major importance. Such conditions include overpressure, overfilling, and fire or explosion in the tank or nearby. A more detailed description of the heatup and cooldown procedures is necessary for a complete analys is to be made.

- LNG Vaporizer Process Control. More details on the temperature and flow controllers are needed. Potential hazards and release prevention details relative to these controls are also needed. Additional details on the startup and shutdown procedures are required to complete the analysis in this area.

- Failure Rate Data. The overview study of the import terminal considered release frequency in a qualitative manner. A more detailed study of the import terminal release prevention, detection, and control systems must carefully consider the likelihood of the release initiating event and the reliability of the release detection and control systems. Due to the lack of operating experience at LNG facilities, little data is available for LNG equipment failure rates.

- Operator Interface. Reliability information on operator tasks performed at the facility is needed. 


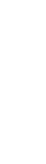




\subsection{ASSESSMENT OF LNG PEAKSHAVING FACILITY}

The overview study of the reference LNG peakshaving facility is presented in this section.

\subsection{SUMMARY SYSTEM DESCRIPTION}

The peakshaving facility overview study is based on a reference facility designed to deliver up to 225 MMscfd of gas to the pipeline during peak-demand periods. The plant consists of a 12.3-MMscfd gas treatment system, a 6.3-MMscfd 1 iquefaction section, a 348,000-bbl storage tank, a 225-MMscfd vaporization system, and a truck terminal capable of shipping or receiving $350 \mathrm{gpm}$ of LNG. The major operations and the safety systems for the plant are briefly described in the following paragraphs. A detailed description is presented in Appendix E.

\subsubsection{Gas Treatment System}

Natural gas from the pipeline first enters a filter separator to remove any free liquids. The 500-psia gas then passes through one of two molecular sieve adsorbers where moisture and $\mathrm{CO}_{2}$ are removed. Each adsorber is capable of handling up to about 12 MMscfd of gas. After passing through the adsorber, the gas is filtered to remove dust. About half the treated gas, $26 \mathrm{MMscfd}$, is routed as feed to the liquefaction unit. The rest of the gas is used to regenerate the off-line adsorber. The regeneration gas is first heated to about $550^{\circ} \mathrm{F}$ in a gas-fired salt bath heater and is then passed through the off-line adsorber. Next, the regeneration gas is filtered to remove dust, cooled in a fan cooler, and passed through a separator to remove free liquids. The gas is then compressed back to 1 ine pressure (about 870 psia), cooled in another fan cooler to under $120^{\circ} \mathrm{F}$, and then reintroduced into the pipeline.

\section{1 .2 Liquefaction System}

After treatment, the natural gas is cooled and liquefied in a mixed refrigerant cycle to provide LNG for storage. The liquefaction unit is comprised of a cold box, refrigerant compressor and coolers, and refrigerant storage. The cold box consists of heat exchangers, separator vessels, and associated piping and instrumentation all enclosed in an insulated shell. All cold box equipment 
is constructed of stainless steel, except for the heat exchanger tubing which is aluminum. The natural gas feed enters the cold box at about 500 psia and passed through a series of six heat exchangers where it is progressively c001, until it is liquefied. The liquefied gas leaves the cold box at about $-260^{\circ} \mathrm{F}$ and about 475 psia. It is expanded to slightly above atmospheric pressure ( 1 psig) as it is introduced into the storage tank.

The mixed refrigerant, which is made up of nitrogen, methane, ethylene, propane, butane, and pentane, is cooled and condensed in stages and then expa ded to provide cooling in the cold-box heat exchangers. The refrigerant is then recompressed by a two-stage compressor with inter and after fan coolers for heat rejection. The boiloff gases from the LNG storage tank also provide cooling for the refrigerant in three cold-box heat exchangers.

\subsubsection{Storage System}

The LNG from the licuefaction system is stored in a flat-bottomed, doubl walled, aboveground storage tank with a capacity of about 350,000 bbl ( 14.6 million gallons). The inner shell of the tank is constructed of an aluminummagnesium alloy that has excellent low temperature ductility. The outer shel of the tank is made of carbon steel. The tank dimensions are:

$$
\begin{aligned}
& \text { inner tank diameter: } 164 \mathrm{ft} \\
& \text { outer tank diameter: } 173 \mathrm{ft} \\
& \text { inner tank height: } \quad 97 \mathrm{ft} \\
& \text { outer tank height: } 134 \mathrm{ft} \text {. }
\end{aligned}
$$

The annular space between the inner and outer tank walls is filled with expanded perlite insulation, with a resilient fiberglass blanket adjacent to the inner wall to protect the perlite from excessive pressure due to expansio and contraction of the inner tank wall. The ceiling of the inner tank is a metal deck suspended from the roof of the outer tank. Perlite insulation is spread evenly over the deck. Open pipe vents are installed in the deck so product vapor can circulate freely in the insulation space to keep the insula dry. The outer tank rests on a concrete ringwall foundation while the inner rests on load-bearing insulation placed on the foundation soil. Electric res tance heating coils prevent the soil underneath the tank from freezing. 
The storage tank is designed to operate at $1.0 \mathrm{psig}$, with a maximum design pressure of $2.0 \mathrm{psig.} \mathrm{The} \mathrm{maximum} \mathrm{external} \mathrm{design} \mathrm{pressure} \mathrm{is} 1$ oz gauge. Tank pressure is controlled by adjusting the boiloff compressor recycle rate. The tank is equipped with two pressure relief valves venting to the atmosphere. In the event of an underpressure, gas from pipeline is brought back into the tank and, if underpressure limits are still exceeded, two vacuum relief valves admit air to the tank. In the event of an emergency, the tank is isolated by internal blockvalves on the inlet and outlet liquid lines. The liquid level in the storage tank is monitored by a servo-powered, displacer-type liquid level device and a differential pressure gauge.

Boiloff gases from the storage tank are heated, compressed to pipeline pressure by one of two compressors, and cooled prior to discharge to the pipeline. Each compressor is capable of handling 1.2 MMscfd of gas. The boiloff gas design rate is about 0.6 MMscfd, with an additional 0.3 MMscfd of flash gas during liquefaction. During liquefaction, the boiloff and flash gases are routed to the coldbox to provide extra cooling, as described previously.

\subsubsection{Vaporization System}

LNG is pumped from the storage tank to the vaporizers by three vertical submerged, pot-mounted pumps. With one pump as a spare, the total rated sendout capacity for two pumps is about 150 MMscfd (1245 gpm) at a discharge pressure of about $900 \mathrm{psia}$. The LNG is vaporized in tube bundles submerged in a heated water bath, after which the vaporized natural gas is reintroduced into the pipeline. The vaporizers, rated at $75 \mathrm{MMscfd}$ each, burn natural gas and bubble the resulting combustion gases through a water bath to heat the tube bundles and thus vaporize the LNG. With three vaporizers in service and one held as a spare, total vaporization capacity of the plant is 225 MMscfd. A11 vaporization equipment normally carrying LNG is constructed of cryogenic materials, to the first flange on the vaporizer outlet.

\subsubsection{Iransportation and Transfer System}

Specially designed truck trailers can be used to transport LNG both to and from peakshaving facilities. Truck transport is mainly used to supply LNG either to satellite facilities without liquefaction capability or to temporarily isolated 
sections of pipeline. A peakshaving facility would likely receive LNG only when its liquefaction unit is inoperative for an extended period of time.

The type of truck trailer used for LNG transport consists of an inner vessel of 5083 aluminum and an outer vessel of carbon steel. The annular space is filled with perlite and maintained at a pressure of 50 microns to insulate the inner vessel. The inner vessel is designed for a maximum working pressure of 70 psig but typically operates at only slightly above atmospheric pressure. The numerous pressure relief valves on the liquid and vapor piping all exhaust to a common elevated vent stack. Remotely operated shutoff valves are installed in the liquid lines. The trailer has a capacity of about 10,500 gallons and weighs about 60,000 lbs when full.

The trucking terminal at the peakshaving plant is diked and trenched for spill retention. Trucks are loaded and unloaded through 3 -inch-diameter flexible metal hoses which connect directly to stainless steel pipes at the terminal. The hoses are drained after each loading/unloading prior to disconnection.

Sma11 LNG sendout pumps are used to load the trailers; pump capacity is $350 \mathrm{gpm}$ yielding a filling time of about 1/2 hour. Boiloff vapors from loading the trailer are returned to the storage tank through a 2-inch vapor return 1 ine. Weight scales and two overflow trycock valves indicate the liquid level in the trailer.

Trucks can be unloaded by pumping but are more often emptied by using the vapor pressure above the liquid. If the vapor pressure is insufficient for good transfer, a small amount of LNG is vaporized in the pressure buildup coil and routed to the top of the tank to provide sufficient pressure.

\section{1 .6 Safety Systems}

Combustible gas detectors, UV flame detectors, and temperature sensors are located throughout the plant area. In the event of off-standard conditions, these detectors activate alarms in the control room. They can also be set to automatically activate the emergency shutdown system or the fire control sys tem. 
The emergency shutdown system has two circuits: the Master Emergency Shutdown (MES) and the Vaporizer Emergency Shutdown (VES). The systems can be activated either automatically by detector alarms or manualiy by the plant operators, and they take about 30 seconds to shut down the plant. Upon activation, the MES:

- de-energizes normal plant electrical circuits, while leaving essential plant electrical equipment energized

- closes valves at the plant boundaries to isolate the plant from the pipeline

- isolates the LNG tank and dike area from the rest of the plant

- sets all control valves in their failsafe positions

- vents gas from all gas-handling equipment and 1 ines via the relief header to the vent stack.

The VES, when activated, shuts down the vaporizers and the LNG sendout pumps, isolates the vaporizers from both the pumps and the pipeline and also isolates the pumps from the LNG storage tank, and vents gas from all equipment and 1 ines to the vent stack. Both the MES and VES are energized by separate "Uninterruptable Power Supplies" which trip the shutdown systems if they fail.

The fire control system consists of fixed and portable dry chemical fire extinguishers, high-expansion foam systems, Halon fire extinguishing systems, and a fire-water system. Automatic venting and isolation systems help to prevent accumulations of flammable gas mixtures in enclosed areas and facilitate extinguishment of any fires.

The LNG storage tank and sendout pumps share a spil1 basin that drains into a diked impoundment basin. The dike walls average $17 \mathrm{ft}$ in height. The impoundment basin is capable of holding about $480,000 \mathrm{bb} 1$, or 1.37 times the capacity of the storage tank. High-expansion foam generation systems installed in the spill basin can be activated either manually or automatically.

The trucking terminal is diked and trenched and is equipped with several dry chemical extinguishers. The spill basin capacity is greater than that of a tank trailer plus the loading/unloading transfer lines. 


\subsection{SYSTEM LEVEL ANALYSIS}

The purpose of the system level analysis is to identify those sections of the peakshaving facility that are the most critical with respect to release prevention and control. The evaluation of each system is based largely on two factors: 1) the quantity of a potential release of hazardous material due to either the inventory or the flow rate and 2) an estimate of the relative probability of a release (low, medium, high).

Process operating conditions, including capacities, flow rates, temperatures, and pressures, are presented in Table 6.1 for major components of the gas treatment, liquefaction, storage, vaporization, and transportation and transfer systems.

\section{TABLE 6.1. System Process Operation Conditions}

\begin{tabular}{|c|c|c|c|c|c|c|c|}
\hline \multirow[b]{2}{*}{ Sys tem } & \multirow{2}{*}{$\begin{array}{c}\text { Major } \\
\text { Components } \\
\end{array}$} & \multirow{2}{*}{$\begin{array}{l}\text { Number of } \\
\text { Components }\end{array}$} & \multirow{2}{*}{$\begin{array}{r}\text { Component } \\
\text { Capacities } \\
\end{array}$} & \multicolumn{2}{|c|}{ Flow Rates } & \multicolumn{2}{|c|}{ Operating Conditions } \\
\hline & & & & In & Qut & Pressure & Temperature \\
\hline Gas Treatment & Adsorbers & 2 & $17,000 \mathrm{scf}$ & $12.3 \mathrm{Mscfd}$ & 12.3 Mscfd & 500 psia & $68^{\circ} \mathrm{F}$ \\
\hline Liquefaction & Cold Box & 1 & -- & $6.3 \mathrm{Mscfd}$ & $\begin{array}{l}6.3 \mathrm{MMscfd} \\
(50 \mathrm{gpm})\end{array}$ & 485 psia & -257 to $106^{\circ} \mathrm{F}$ \\
\hline \multirow[t]{3}{*}{ Storage } & Storage Tank & 1 & $348,000 \mathrm{bbl}$ & $\begin{array}{l}6.3 \mathrm{MMscfd} \\
(50 \mathrm{gpm})\end{array}$ & $\begin{array}{l}200 \mathrm{MMscfd} \\
(1660 \mathrm{gpm})\end{array}$ & $15.8 \mathrm{psia}$ & $-257^{\circ} \mathrm{F}$ \\
\hline & Sendout Pumps & 3 & -- & $\begin{array}{l}150 \text { MMscfd } \\
(1245 \mathrm{gpm})\end{array}$ & $\begin{array}{l}150 \mathrm{MMscfd} \\
(1245 \mathrm{gpm})\end{array}$ & 900 psia & $-257^{\circ} \mathrm{F}$ \\
\hline & Bolloff Compressors & 2 & -- & 0.9 Muscfd & 0.9 Mscfd & 870 psia & $120^{\circ} \mathrm{F}$ \\
\hline Vaporization & $\begin{array}{l}\text { Submerged Combustion } \\
\text { Vaporizers }\end{array}$ & 4 & -- & $\begin{array}{l}225 \text { Miscfd } \\
(1810 \mathrm{gpm})\end{array}$ & $225 \mathrm{MMscfd}$ & 900 psia & -257 to $70^{\circ} \mathrm{F}$ \\
\hline $\begin{array}{l}\text { Transportation } \\
\text { and Transfer }\end{array}$ & Truck Traller & 1 & $10,500 \mathrm{gal}$ & $\begin{array}{l}42 \mathrm{MMscfd} \\
(350 \mathrm{gpm})\end{array}$ & $42 \mathrm{MAsfd}$ & 15 psia & $-257^{\circ} \mathrm{F}$ \\
\hline
\end{tabular}

\subsubsection{Gas Treatment System}

The primary hazard associated with the gas treatment system is the flammability of the natural gas being handled. There are three primary methods of natural gas release from the system:

- adsorber vessel failure

- leak or rupture in inlet or outlet piping, flanges, valves, etc.

- tube failure in the regeneration gas heater.

When activated, the Master Emergency Shutdown (MES) system isolates the gas treatment system from both the pipeline and the rest of the plant (except 
the liquefaction system), after which gas contained in the system is vented via the relief header to the vent stack. However, assuming the MES fails, it could take up to about 10 minutes to isolate the gas treatment system. Normal system flow during this time would result in a release of 85,000 scf of gas. This coupled with a system holdup of about 34,000 scf gives a maximum release of 119,000 scf of natural gas. The probability of this release is estimated to be low to medium.

\subsubsection{Liquefaction System}

The liquefaction system contains both natural gas and LNG. Besides the flammability hazard, there is also the hazard associated with the cryogenic temperature of the LNG. The liquefaction system also contains a mixed refrigerant with hazards similar to those of the LNG.

The primary method by which LNG or natural gas can be released from the system is a leak or rupture in piping, flanges, valves, fittings, etc. The primary methods of refrigerant release are:

- leak or rupture in piping, flanges, valves, fittings, etc.

- failure of separator vessel or refrigerant compressor.

When activated, the MES isolates the liquefaction system from the rest of the plant except the gas treatment system. Thus, the maximum release of natural gas and LNG from the liquefaction system is the same as that from the gas treatment system, 119,000 scf. The probability of this release is estimated to be low to medium. The maximum release of refrigerant in the system is 3,000 gallons, which is the cycle fluid storage capacity in the system. The largest refrigerant storage tank is 10,000 gallons.

\subsubsection{Storage System}

There are three principal methods of release in the storage area:

- storage tank failure

- leak or rupture in inlet or outlet piping, flanges, valves, fittings, pumps, etc.

- atmospheric discharge from a relief valve. 
The inner shell of the LNG storage tank is constructed of an aluminummagnesium alloy that can withstand cryogenic temperatures. The outer tank is constructed of carbon steel and is susceptible to fracture if contacted with any LNG or cold vapors. Thus, failure of the inner tank would probably lead to failure of the outer tank.

Activation of the MES system stops any flows into and out of the tank and isolates the tank from the rest of the facility. The maximum release from the storage system is the total capacity of the tank, which is 348,000 bbl of LNG. A pipe break in a 12-in. outlet 1 ine which leaks for 10 minutes before the block valve is closed would result in a leak of about 23 MMscf $(280,000$ gal). The probability of these releases is estimated to be low.

\subsubsection{Vaporization System}

Vaporization takes place in four gas-fired, submerged combustion vaporizers. The vaporizers have the capacity to empty the storage tank in about 15 days of operation.

Primary methods for LNG or LNG vapor release from the vaporization system are:

- leak or rupture in inlet or outlet piping, flanges, valves, fittings, etc.

- failure of vaporizer heat transfer tubes.

The Vaporizer Emergency Shutdown (VES) system, when activated, shuts down the vaporizers and the LNG sendout pumps, isolates the vaporizers from the rest of the plant, and vents all gas-handling equipment and lines to the vent stack. The maximum release from the vaporization system would occur if the VES failed and the system had to be shut down manualiy, taking up to 10 minutes. Normal flow through the system during this time could result in a release of up to 1.6 MMscf of LNG and LNG vapor. The probability of this release is estimated to be medium. 


\subsubsection{Transportation and Transfer System}

LNG releases in the transportation and transfer system may occur at the truck terminal or during transport on public roads. Primary methods for LNG release at the terminal are:

- leak or rupture in inlet or outlet piping, flanges, valves, fittings, etc.

- failure of the double-shell tank trailer.

A failure of the trailer (due, for instance, to overpressurization) would result in a maximum release of 10,500 gallons of LNG. The probability of such a release is low. The probability of a leak in a transfer line is medium due to the operator interface. Such a leak continuing for ten minutes at the normal loading rate would release 3,500 gal of LNG.

The primary method for release in transport is failure of the trailer due to collision or overturning. Overturning accidents for LNG trailers are relatively frequent because of their high center of gravity. However, the probability of a release is low because of the structural integrity of the doubleshell trailer construction.

\subsubsection{Summary}

The largest release that could occur from the LNG peakshaving facility would result from complete failure of the storage tank. Significant releases could also occur from pipe breaks in the various systems. Postulated releases from pipe breaks, assuming that the leaks continue for 10 minutes before the systems are shut down, are presented in Table 6.2.

Based on this system level analysis, the two systems with the potential for the largest releases are the storage and vaporization systems.

\subsection{COMPONENT LEVEL ANALYSIS}

The purpose of the component level analysis is to identify those components that are most critical with respect to release prevention and control for each of the systems. The system level analysis indicates that a significant release could come from any of the five systems. The largest releases could come from the storage and vaporization systems. 
TABLE 6.2. Postulated Releases from Pipe Breaks in a Peakshaving Facility

\begin{tabular}{|c|c|c|}
\hline Location of Break & $\begin{array}{l}\text { Continuous Leak } \\
\text { Rate (scfm) }\end{array}$ & $\begin{array}{l}\text { Total 10-Minute } \\
\text { Release (scf) }\end{array}$ \\
\hline $\begin{array}{l}\text { Gas Treatment System Outlet } \\
\text { (100\% vapor, } 485 \text { psia) }\end{array}$ & $8.5 \times 10^{3}$ & $1.2 \times 10^{5(\mathrm{a})}$ \\
\hline $\begin{array}{l}\text { Liquefaction System Outlet } \\
\text { (0\% vapor, } 470 \text { psia) }\end{array}$ & $8.5 \times 10^{3}$ & $1.2 \times 10^{5(a)}$ \\
\hline $\begin{array}{l}\text { Liquid Outlet from Tank } \\
\text { (0\% vapor, } 15.8 \text { psia) }\end{array}$ & $2.3 \times 10^{6}$ & $2.3 \times 10^{7}$ \\
\hline $\begin{array}{l}\text { LNG Pump Outlet Header } \\
\text { (0\% vapor, } 900 \text { psia) }\end{array}$ & $1.0 \times 10^{5}$ & $1.3 \times 10^{6(a)}$ \\
\hline $\begin{array}{l}\text { Vaporizer Outlet Header } \\
(100 \% \text { vapor, } 870 \text { psia) }\end{array}$ & $1.6 \times 10^{5}$ & $1.6 \times 10^{6}$ \\
\hline $\begin{array}{l}\text { Trailer Loading Line } \\
\text { (0\% vapor, } 30 \text { psia) }\end{array}$ & $2.9 \times 10^{4}$ & $2.9 \times 10^{5}$ \\
\hline
\end{tabular}

(a) Includes release contribution of holdup in system.

A preliminary hazards analys is (PHA) has been completed for each system. The PHA deals with the major components of each system and the related potential hazard conditions, effects, and existing preventive and control measures. Each PHA is presented in tabular form.

It is important to note that some of the releases presented in this section require failure of more than one component. For example, a line rupture could occur from a heat leak (resulting in a pressure buildup) and a relief valve failure.

\subsubsection{Gas Treatment System}

The gas treatment system is one of the less critical systems in the peakshaving facility with regard to release prevention and control. This is because of the relatively low flow rates and the relatively small holdup in this system as compared to other systems in the facility. The PHA for the gas treatment system is presented in Table 6.3.

The following components of the system are judged to be the most important with respect to release prevention and control: 
TABLE 6.3. Preliminary Hazards Analys is for the Gas Treatment System

Subsystem or Component Potential Hazard Condition Effect

Existing Preventive and Control Measures

Startup-Shutdown Operations

1. Regeneration Gas Improper Valving of Gas to Heater Heater

2. Adsorbers, Filters, Rapid Pressurization on Startup Regeneration Heater

Steady State Operation

1. Gas Feed Valve to Filter Separator

\section{Fails Open}

Fatls Closed

Rupture or Leaks

2. Filter Separator

Ruptures or Leaks

3. Gas Feed Valve After Falls Open Filter Separator

\section{Falls Closed}

Ruptures or Leaks

4. Gas Feed Valves to Fatl Open Adsorbers

Fall Closed

Rupture or Leak

5. Molecular Steve Rupture or Leak Adsorbers

6. Gas Feed Valves After the Adsorbers

Fail Closed

Rupture or Leak

Possible explosion, release of gas, 'fire

Possible vessel failure and release of gas

Possible overpressurization of filter separator

None

Release of natural gas

Release of natural gas and possible release of liquids

Possible overpressurization of downstream components

None

Release of natural gas

Possible overpressurization of adsorbers or release of feed gas to regeneration gas line

\section{None}

Release of natural gas

Release of natural gas (heated or unheated) and possible release of absorbent materia

Possible overpressurization of components or release of unheated gas to the

None

Release of natural gas
- Startup procedures/operator expertise

- Combustible gas and UV fire detectors

- Startup procedures/operator expertise - $P$ instrumentation/operation attention - MES shutoff valves

- Maintenance and inspection

- Maintenance and inspection

- Maintenance and inspection

- P instrumentation/operator attention

- Maintenance and inspection

- MES shutoff valves

--

- Maintenance and inspection

- MES shutoff valves

- Maintenance and inspection

- Maintenance and inspection

- MES shutoff valves

- Maintenance and inspection

- MES shutoff valves

- Maintenance and inspection

- Tinstrumentation/operator attention

--

- Maintenance and inspection

- MES shutoff valves 
TABLE 6.3. (Contd)

Subsys tem or Component Potential Hazard Condition Effect Existing Preventive and Control Measures

Steady State Operation

\section{Gas Feed Valve to} Dust Filter

\section{Fails Open}

Fails Closed

8. Dust F11 ter

Ruptures or Leaks

9. Gas Feed Valve After Dust Filter

Falls open

Fatls Closed

Ruptures or Leaks

10. Gas Feed Valves in Regeneration Gas Line

Fa11 Open

Fail closed

Rupture or Leak

\section{Check Valve Prior} to Regeneration Gas Heater

Fails open

Falls closed

Ruptures or Leaks

12. Regeneration Gas Heater

13. Dust Filter

14. Fan Cooler

15. Regeneration Gas Separator

16. Regeneration Compressor

Ruptures or Leaks

Ruptures or Leaks

Ruptures or Leaks

Ruptures or Leaks
Possible overpressurization of dust filter

None

Releases of natural gas and possible release of dust

Possible overpressurization downstream in system

None

Release of natural gas

Possible overpressurization downstream

No regeneration, excess feed gas to cold box

Release of natural gas

Possible backflow of heated gas

No regeneration, excess feed gas to cold box

Release of natural gas (cool) or heated

Release of natural gas and posstble fire due to burners close at hand
Release of natural gas and possible release of dust

\section{Release of natural gas}

Release of natural gas

Release of natural gas at line pressure
- Maintenance and inspection$$
-
$$

Maintenance and inspection

- P instrumentation/operator attention

- MES shutoff valves

- Malntenance and inspection $--$

- Maintenance and inspection

- MES shutoff valves

- Maintenance and inspection

- P control and flow instrumention/ operation attention

- MES shutoff valves

- Maintenance and inspection

- Maintenance and inspection

- MES shutoff valves

- Maintenance and inspection

- UV flame detector and dry chemical

- MES shutoff valves

- Maintenance and inspection

- P instrumentation/operator

attention

- MES shutoff valves

- Maintenance and inspection

- MES shutoff valves

- Maintenance and inspection

- MES shutoff valves

- Maintenance and inspection

- MES shutoff valves 
Regeneration Gas Heater. This component contains heat exchanger tubes that carry natural gas. If a tube ruptures or leaks, natural gas is released in close proximity to the unit's gas-fired burner, and a subsequent fire or explosion is possible. The probability of such a tube failure is judged to be medium.

Molecular Sieve Adsorbers. These are large vessels (about $20 \mathrm{ft}$ high by $5.5 \mathrm{ft}$ in diameter) that contain gas under pressure (about 500 psia). Thus, the gas holdup in these vessels is significant. If a vessel ruptures or leaks, this holdup gas would be released along with any additional gas flowing into the system before the feed lines are closed. The probability of adsorber vessel failure is judged to be low because of design and maintenance considerations.

Master Emergency Shutdown (MES) System. When operating properly, this system limits the size of a release. However, if the system does not operate properly and a manual shutdown is necessary, the amount of natural gas released can be significantly increased.

\subsubsection{Liquefaction System}

The liquefaction system is another of the less critical systems in the peakshaving facility because of its relatively low flow rates and relatively small holdup. The PHA for the liquefaction system is presented in Table 6.4.

System components of primary concern regarding release prevention and control are as follows:

Temperature and Liquid Level Instrumentation and Controls. These are probably the most important components related to release prevention and control in this system. The temperature controller in the LNG outlet line ensures that the LNG is sufficiently cold before it is sent to the storage tank. If the controller fails and warmer LNG or natural gas is introduced into the storage tank, excessive flashing will occur in the storage tank resulting in increased tank pressure. If this increased pressure cannot be controlled by the boiloff system, the pressure relief valves will open and release LNG vapors. In the refrigerant system, temperature and liquid 


\section{TABLE 6.4. Preliminary Hazards Analys is for the Liquefaction System}

Subsystem or Component Potential Hazard Condition Effect

Existing Preventive and Control Measures

Startup-Shutdown Operations

1. Refrigerant Cycle Too much of low bolling components Inventory Makeup

2. FIC Settings, Sepa- Opened too far rator Liquid Outlets

3. LNG TRC

Set too high

\section{Steady State Operation}

1. Natural Gas Sup- Break or other interruption ply Line

Water in gas supply

3. Boiloff Exchangers Refrigerant tube rupture $\mathrm{E}-211$ to 213

4. Liquefaction Exchangers
$\mathrm{E}-201$ to 206

LNG tube rupture

Refrigerant tube rupture

Shell fallure

5. Vapor Llquid

Rupture

Box, v-20i to 204

\section{Liquid carryover}

Flow stoppage in vapor outlet, plug (ice) or Inadvertent valve closure

Overpressure on shutdown and warmup, rupture of refrigerant containment

Liquid refrigerant floods $V-205$, brittle failure in compressor suction 1 ine, refrig-

Excessive flashing upon letdown to tank pressure, tank bolloff capacity exceeded

Release of pressurized gas

Excess cooling, liquid carryover to $\mathrm{V}-205$, possible carryover of liquid to carbon steel compressor suction

Ice plugs LNG line; See Above

Low $P$ gas release with possible fire, reduced cooling capacity

Pressurization of shell, possible rupture and release to cold box, liquid could fail cold box wall

Pressurization of exchanger shell, shell should hold, unknown upset due to LNG in refrigerant

Possible flashing of large amount of refrigfallure if 1 iquid passes $V-205$

Pressurized gas release to cold box, possible rupture

Release of refrigerant to cold box, possible rupture

Liquid to $\mathrm{V}-205$, brittle failure if liquid passes $V-205$

Relief valve and vent stack

- High P alarm on compressor outlet

- Capacity of V-205

- Limited refrigerant inventory

- Range of controller might be limited

- Relief valves on LNG tank

- $P$ and $T$ instrumentation on tank

- Master emergency shutdown (MES)

- Capacity of V-20

Low T alarm

- High $\mathrm{H}_{2} \mathrm{O}$ analytical alarm

- Combustible gas/uv detectors

- Bypass at tank

- Combustible gas detector

- Limited inventory of refrigerant

- MES valve upstream of gas treatment sys tem

- Capacity of V-205

Low T alarm

- Combustible gas detector

- Relief valve required on cold box

- Combustible gas detector

- Limited inventory of refrigerant/

capacity of separator

- Low L alarm

- Limited inventory of refrigerant

- Capacity of separators

Intitial response might be liquid falling to suction pressure will rise and cooling power will drop off. Process upset, no release. 
TABLE 6.4. (Contd)

Subsys tem or Component

Potential Hazard Condition

Effect

Existing Preventive and Control Measures

Steady State Operation

6. Vapor Liquid Sepa- Rupture rators, Inters tage $\mathrm{V}-2221,222$

Backflow from cold box during startup

7. Vapor Liquid Sepa- Rupture rator Low Pressure Refrigerant

\section{Liquid carryover}

8. Interstage and After Coolers E:221, 222

Fan failure

Rupture

$\frac{i}{G}$

9. Compressor, $C-221$ Motor failure and 222

Rupture

10. Refrigerant Storage Tank rupture Cycle Fluid, Liquid

No Ethylene, Pro

pane, Isobutane,

Pentane

11. Electricity Supply Fallure

12. Air Supply

Failure

13. LNG flow Control

Fails open Valve

14. Compressor Discharge Pressure Control Valve

Fails open

Fails closed
Release of pressurized refrigerant

Brittle fallure, release as above

Release of refrigerant

Brittle failure downstream, release as above

High $T$ in second stage of compressor, lost cooling capacity, sys tem adjusts automatically

Release of pressurized refrigerant, possible fire

Suction pressure rises, rapid loss of cooling capacity, liquefaction stops

Liquefaction stops (see above), release

of pressurized refrigerant vapor

Fire possible, involving other tanks, vapor cloud traveling to other ignition source and larger release

Compressor and cooling fans stop, no apparent consequence except LNG flow stop

Valves to safe position, LNG flow stops

Pressure drives gas to storage tank

Overpressure, possible downs tream ruptures, separators carryover liquid

Compressor "Runs Away," overheats
- Combustible gas detector

- Limited inventory of refrigerant

- Low L alarm

- Check valve required in liquid outlet

- High L alarm

- Conbustible gas detector

- Limited inventory

- Combustible gas detector

- Low L alarm

- Capacity of separator

- High L alarm

- Low T alarm

- High T alarm

- Combustible gas/uV fire detector at cold box, detectors requitred at coolers

- Limited inventory

- Operator attention

- Combustible gas detector

- Limited inventory

- Fire detectors-automatic MES Interlock

- UV flame detector

- Combustible gas detectors required near refrigeration tanks

- Operator attention

- Operator attention

- Venting capacity of tank

- Design of piping to minimize

oversize flow

- MES shutdown of gas feed

High P alarm

- Overdesign of equipment

- Automatic shutoff 
level instrumentation protects against carryover of liquid refrigerant to the carbon steel compressor suction piping. If carryover occurs, brittle failure of the piping accompanied by release of refrigerant is likely. Minor malfunctions of instrumentation and controls are highly probable but, because of design considerations, the probability of malfunctions resulting in the aforementioned releases is judged to be medium.

Heat Exchangers and Vapor-Liquid Separator Vessels. Leaks or ruptures in these vessels would result in the release of refrigerant to the cold box and possibly to the environment. The probability of vessel failure is judged to be low because of design and maintenance considerations.

MES System. When activated, this system limits the size of a release. However, if the system fails and a manual shutdown is required, a much larger release can occur.

\subsubsection{Storage System}

The storage system is probably the most critical in the peakshaving facility with regard to release prevention and control. This is due to the large LNG inventory in this system. Table 6.5 presents the PHA for the storage system.

Storage system components of primary concern with respect to release prevention and control include the following:

Inner Tank She11. Failure of this component would cause the maximum release of LNG or LNG vapor (up to $348,000 \mathrm{bbl}$ of $L N G$ ). The probability of a failure of the inner tank shell is judged to be low because of design considerations.

Annular Space Insulation. This component is important because it prevents excessive boiloff of LNG vapor and protects the carbon steel outer shell from cryogenic temperatures and subsequent failure. The loss of insulation effectiveness is judged to have a low probability due to design and operational factors.

Outer Tank Shell. This carbon steel shell provides a vapor-tight seal and protects the inner shell and annular insulation from the environment. 


\section{TABLE 6.5. Preliminary Hazards Analysis for the Storage System}

Subsystem or Component

Potential Hazard Condition Startup-Shutdown Operations
1. Storage Tank
Inadequa te nitrogen purge
2. Purge Ring
Fails closed during purging process

3. Inner Tank Cooldown monitoring system fails or is inaccurate

4. Downcomer

Disperses LNG unevenly

5. Storage Tank

Heatup with hot natural gas too rapid

6. Combustible Gas Detector System Fails, results in inadequate nitro-
gen purge

Line ruptures or leaks

1. Liquid Discharge Line

2. Sendout Pumps

Pump ruptures or leaks

3. Sendout Pump Vessel

Vessel ruptures or leaks

4. Vapor Return Line from Pumps
Effect

Existing Preventive and Control Measurs
Possible explosive mixture when filling with LNG outer tank, possible flammable gas mixture between shells

Tank fills too fast, resulting in rapid cooldown with possible failure of inner tank and release of LNG

Nonuniform cooldown of inner tank resulting in possible tank failure and release of natural gas or possible stratification and rollover

Overpressurization and possible fallure of tank with release of natural gas

Thermal shock fails inner tank, LNG released to outer tank which subsequently fails and releases LNG

Possible explosive mixture when air admitted to tank

LNG released

Pump leaks to pump vessel, no release

LNG released (severity greatly increased if pump fails in conjunction)
Overpressurization and possible failure of

Startup procedure

Operator expertise

High P alarm on tank

P relief valves

- Startup procedure

Operator expertise

- Cooldown monitoring instrumentation

- Operator attention

- Spill basin

Tank monitoring instrumentation

- Heatup procedure/operator expertise

- Tank monitoring instrumentation

- Heatup procedure/operator expertise

- Spill basin

- Purging procedure

- Maintenance and inspection

- Block valves in line and in tank outlet
MES/VES

- MES/VES

- Maintenance and inspection

- Low discharge $P$ al arms on pumps, MES/VES

- Maintenance and inspection

- Vessel integrity

- Block valves in line and in tank outlet

- Combustible gas detector alarm

- MES/VES

- Spill basin

- Piping integrity

- Combustible gas detector alarm

- MES/VES 
TABLE 6.5. (Contd)

Subsystem or Component Steady State Condition

5. Tank Foundation

Settles nonuniformly

Heating coll system fails

ine ruptures or leaks

Fails, and operator does not notice dangerous condition on liquid level gauge

8. Inner Tank Shell

$\frac{\infty}{\infty}$
Shell fails or leaks

Plane crashes into tank

Sabotage, bomb explodes

Rollover

Inner shell fails

10. Suspended Insulated Fails and falls into tank along Deck

11. Bolloff Heat

Fail

Exchanger

Outer tank fails, inner tank cannot support load and fails, LNG released

Frost heaving fails tank, LNG released

LNG or natural gas released

LNG overflows and leaks to outer tank,

which is failed by cold and releases LNG

LNG leaks to outer tank, which is failed by cold and releases LNG

Forces due to perlite compaction fall tank, LNG released

Loss of insulation, heating of LNG and release of natural gas

Possible rupture of tank with release of LNG and/or natural gas and probable fire Probable rupture of tank with release of LNG and/or natural gas and probable fire

Rapld increase in vaporization and overpressurization, possible failure of tank dome and release of natural gas

LNG leaks to outer tank, which fails due to cold and releases LNG

Extreme cold fails outer tank dome and natural gas is released, debris may foul outlet valves

Cold falls carbon steel lines and natura gas is released
Existing Preventive and Control Measures

- Integrity of foundation

- Maintenance and inspection

- Spill basin

- T ins trumentation/operator attention

- Maintenance and inspection

- Spill basin

- Piping integrity

Maintenance and inspection

- Spill basin

- Combustible gas detector alarm

- Operator expertise/attention

- Temperature instrumentation would

indicate unusual condition

- Spill basin

- Construction standards

- Maintenance and inspection

- Spill basin

- Linear movement indicators

Strain gauges

- Spill basin

- $P$ and $T$ instrumentation on tank

Spill basin

- Fire control systems

- Security measures

- Spill basin

- Fire control systems

- $P$ and $T$ instrumentation

- Tank loading and mixing procedures

- Construction standards

- Maintenance and inspection

- Spill basin

- Structural integrity of deck

Operator attention

- Low T alarm/operator attention

- Combustible gas detector alarm

- Maintenance and inspection 
TABLE 6.5. (Contd)

Subsystem or Component

Potential Hazard Condition

Effect

Existing Preventive and Control Measures

Steady State Condition

12. Boiloff Compressors Compressor ruptures or leaks

Cannot handle boiloff yases fast enough

13. Compressor After- Leaks or ruptures cooler

\section{Fails to adequately cool the compressed boiloff gases}

14. Tank Pressure Falls open Relief Valve

\section{Fails closed}

15. Tank Vacuum Falls open Rellef Valve

Fafls closed

16. Purge Ring

Fafls open

17. Recirculation Line Ruptures or leaks from Pump to Storage

Tank

18. Vapor Return Line Ruptures or leaks from Pump to Storage Tank

19. Tank Outlet Valve Fails open and outlet line

20. MES

falls before secondary valve

Falls on demand
Release of natural gas

Pressure butldup in storage tank, possible rupture of tank and release of natural gas

Release of natural gas

Shutdown of boiloff compressors, leading to pressure buildup in tank and possible rupture

Release of natural gas, possible explosive mixture if air enters tank

Pressure buildup in tank, possible failure of tank dome and release of natural gas

Possible release of natural gas, possible explos ive mixture as air enters tank

Possible outer tank failure due to vacuum, with release of natural gas

Natural gas released through roof deck, per-

lite insulation, and purge ring

\section{Release of LNG}

Release of natural gas

Release of tank contents

Flows not stopped automatically in an emergency
- Block valves either side of compres-

- Combustible gas detector alarm

- Maintenance and inspection

- Adequate compressor design

- Maintenance and inspection

- High P alarm on tank

- P relief valves on tank

- Block valves either side of aftercooler

- Combustrble gas detector alarm

- Maintenance and inspection

- Adequate aftercooler design

- Maintenance and inspection

- High P alarm on tank

- P rel ief valves on tank

- Maintenance and inspection

- Tank $P$ instrumentation/operator attention

- Maintenance and inspection

High $P$ alarm on tank

- Boiloff system can help reduce $P$

- Maintenance and inspection

Tank $P$ instrumentation/operator attention

- Maintenance and inspection

- Tank P instrumentation/operator

attention

- Low P switch/natural gas inlet valve interlock

- Maintenance and inspection

- Piping integrity

- PUmp/MES interlock

- Spill basin

- Combustible gas detector alarm

- Combustible gas detector alarm

- Pump/MES interlock

- Spill basin

- Maintenance and inspection

- Operator attention/manual shutdown 
Failure of the outer tank shell would result in large vapor releases and could possibly result in the failure of the inner shell. The probability of such a failure is judged to be low.

Tank Discharge Line to Pumps. Failure of this line could result in the maximum release for this system if no valves functioned to shut off tank flow. The probability of the line failing is judged to be low because of the types of failure mechanisms considered.

Storage Tank Pump Vessel. If the pump vessel were to fail and the feed valves to the vessel were open, a large $L N G$ release $(14,000 \mathrm{gal})$ could occur. The probability of the pump vessel failing is judged to be low. Pressure Control System. This system includes the boiloff compressor and heat exchangers, the pressure/vacuum relief valves, and pressure controllers and indicators on inlet and outlet lines. Failure of this system could result in over or underpressure in the storage tank which could lead to tank failure and the subsequent release of at least part of the tank contents. Failure of individual components (e.g., relief valves failing open) could result in the uncontrolled release of LNG vapors. Failures of individual components are judged to have low to medium probabilities; the probability of system failure resulting in the failure of the storage tank is low.

\subsubsection{Vaporization System}

Because of the relatively high flow rates through this system, it is one of the more critical systems in the facility with respect to release prevention and control. The PHA for the vaporization system is given in Table 6.6.

The PHA identifies the following system components as being most important in terms of release prevention and control:

Vaporizers. These components contain a number of heat exchanger tubes. If one or more of these tubes fail, LNG is released to the vaporizer and a subsequent fire or explosion is possible. The probability of a heat exchanger tube failure is judged to be medium. 
TABLE 6.6. Preliminary Hazards Analysis for the Vaporization System

Subsystem or Component Potential Hazard Condition

\section{Startup-Shutdown Operations}

1. LNG Pump Discharge High
Pressure Setting

Low

2. Outlet Temperature

Controller Setting

Low

3. Throughput Flow High or turned up too raptdly Setting

4. Block Valve Closing, LNG trapped between valves Various Locations

Steady State Operation

1. LNG Sendout Pumps Break

Suction Line

2. LNG Sendout Pumps

Body fallure from T-shock or external cause

Deadheaded (valve fatlure, clog, or blunder)

3. Transfer Line to Break

Vaporizers

Faflure, complete or partial loss of water
5. Tube Bundle
Failure or leak from thermal shock corrosion or external cause

6. Burner and Downcomers Flameout
Vapor flow control valve throttles, no hazard if piping design adequate for maximum pump pressure

Low flow through vaporizer, outlet temperature increase, burner firing rate goes to min

- Adequate thermal capacity of bath to allow for flow variations

- P instrumentation on pump outlet

LNG not vaporized, possible cryogenic failure downs tream

LNG not vaporized, possible cryogenic faflure downstream Possible tube bundle failure from thermal

Warms to ambient $T$, pipe bursts

Release rate depends on break, driven by hydraulic head in storage tank

Leak forced by head in storage tank, rate depends on crack size

LNG vaporized in pump

Release rate depends on break, driven by pumps

Reduced heat transfer, LNG not vaporized, cryoReduced heat transfer, LNG not vaporized,
genic entrittlement, failure downstream, genic embrittlement, fallure downstream, direct fir

Potential explosive mixture in tank

Potential explosive mixture in tank

LNG not vaporized, potential cryogenic failure downs tream
- Low outlet T/VES interlock

- Low outlet T/VES interlock

Combustible gas detector and/or UV fire detector alarm - Halon fire

- Relief valves between every pair of block

- Low T a larm in spill basin, MES/VES

- Low T alarm in spill basin, MES/VES

- Internal block valve in tank outlet

- Vapor vent line

Low discharge P alarms on pumps, MES/

Liquid level controller - alarm

Low product T/VES interlock

- See tube bundle

- Combustible gas detector alarm, Halon fire extinguisher

- Burner UV flame detector alarm

- Thermal storage in water bath

- Auxiliary electric heater

- Low outlet T/VES interlock 
TABLE 6.6. (Contd)

Subsystem or Component Steady State Operation

7. Burner Jacket Water Pump

8. Burner Gas or Air Supply

9. Electrical Power

10. Water Supply

11. Overflow Drain

Back pressure

12. LNG Flow Control Valve

13. Burner Gas and Air Control valves (Vapor

in Outlet T Controller)

14. Vapor Outlet Line pump stop

Pressure loss

Fails closed

Break
Potential Hazard Condition

Effect

Possible thermal stress failure of burner

See burner and downcomers

Flameout

Failure, blower and burner jacket

Fails open (normally closed)

Fatls open (normally closed)

Loss of heat transfer, LNG not vaporized fallure

Tank overflows, potential tank rupture

Sef tank and weir failure

LNG not completely vaporized

LNG overheated, problem if water supply inadequate

Flameout, LNG not vaporized

Vapor release (small break)
Existing Preventive and Control Measures

- Low discharge $P$ switch on burner

- Jacket pump opens water supply

- Low P alarm on manifold

- Auxiliary power supply

- See burner and downcomers

- Low level alarm

Direct firing of tubes leads to tube bundle

Depressurization causing LNG surge through vaporizer (large break), possible (a) fatlure
- Vapor outlet T/VES interlock

- High T alarm in tank stack

- See tank and weir failure

- Low vapor T/VES interlock closes surrounding valves

- High T alarm in tank stack

- Outlet T/VES interlock

- See burner and downcomers

- MES/VES manually activated

- Low vapor outlet T/VES interlock - LOW discharge P on sendout pumps, 
Natural Gas Discharge Line from Vaporizer. If this carbon steel line fails (possibly from cold LNG or vapors), LNG vapors or LNG will be released. The probability of this line failing is judged to be low considering the temperature control shutdown subsystem.

Vaporizer Water Bath Tank. If the tank fails, the loss of water could result in either heat exchanger tube failure or discharge line failure. The probability of the tank failing is judged to be low.

Temperature Controller on Discharge Line. If this controller fails, the discharge line could fail. The probability of the controller failing is judged to be medium.

\subsubsection{Transportation and Transfer System}

The transportation and transfer system is one of the less critical systems in the peakshaving facility. The PHA, presented in Table 6.7, identifies the following system components judged to be most important with respect to release prevention and control:

Double Shell Truck Tank. Failure of this component causes the maximum release of LNG for this system $(10,500 \mathrm{gal})$. Furthermore, the release may occur on public roads where few or no release control measures are available and numerous sources of ignition are present. The probability of a failure is low because of the ruggedness of the double-shell tank. Truck Pressure Relief Devices. These components are important because their failure in an overpressure situation could lead to failure of the tank. The probability of simultaneous failure of these components is low because of the redundancy of devices.

Valving and Valve Controls. Failure of these devices due to rear-end collision would completely stymie emergency response measures, possibly leading to a slow but total release. The probability of such a failure is low because of judicious valve placement.

\subsubsection{Operator Interface}

Although the plant operators are not traditionally viewed as plant components, they are essential to the proper operation of the plant. The interface. 
TABLE 6.7. Preliminary Hazards Analysis for the Transportation and Transfer System

Subsystem or Component

Normal Transportation

1. Inner Tank Shell

2. Outer Tank Shel1

Defective (corroded)

Fails

3. Main Liquid Line (3") Failure of line

4. Hose Connector (Main liquid line)

Defective (10ose seat)

5. Manual Shut-off Valve Defective (loose seat) (Ma in liquid line)

6. Emergency Shut-off Valve (Main liquid line)

Defective (loose seat)

7. Pressure Build Line Failure of line (2")

8. Manual Shut-off Valve Defective (loose seat)

9. Automatic Shut-off Defective (loose seat) Valve (Pressure build line)
Effect

Existing Preventive and Control Measures

Release of LNG

- Inspection

- Use of appropriate metal

- Two 6" flatplate safety valves

- Outer shell slows release

Release of LNG

- DOT regulations

- Inspection

- Shipper license

- Unique connectors on fill line

- Two 6" flatplate safety valves

- Outer shell slows release

Tank explosion

Release of LNG

- DOT regulations

* Inspection

- Shipper 1 icense

- Unique connectors on fill line

- Two 6" flatplate safety valves

- Outer shell slows release

Rapid increase in vaporization of LNG. Possible failure of

- Relief valves

- Vent system
Lowered failure threshold. - Two 6" flatplate safety valves Potential heat leaks.

Loss of insulation. Increase in vaporization of LNG. Possible fallure of inner tank. Line failure due to loss of structural rigidity.

Release of LNG

Release of LNG

Release of LNG

Release of LNG

Release of LNG

Release of LNG

Release of LNG
- Inspection

- Relief valves

- Vent system 


\section{TABLE 6.7. (Contd)}

\section{Subsystem or Component}

Norma 1 Transportation

10. Automatic Pressure Build Regulator

11. Vent line (3")

12. Main Safety Valve (3" pop-type)

13. Burst Disc Safety Valve and Manual Blowdown valve

14. Shut-off Valve (Gas return $l$ ine)(2")

15. Burst Disc

Fails prematurely
Potential Hazard Condition

Fails open, while isolation valve open

Fails closed, while isolation valve open

Failure of line Fails (70 psig limit), tank overpressured and fails.

Fail, when main safety valve fails, overpressure of tank

Fails
Effect

Pressure increases in tank and overpressures sys tem

Pressure drop in tank not compensated for. LNG heats up. Possible failure of inner tank.

\section{Release of LNG}

Release of LNG

Inner tank fails

Release of LNG

Release of LNG

Release of natural gas or air admitted to trailer

Release of LNG

Overturn in accident, failure of both tanks

Impact fails shell,. loss of insulation.

Puncture fails shell, failure of both tanks.

Fire fails shell

Fire overpressures shell

2. Inner Tank Shell

3. Driver

4. Valve Controls

Impact sufficient to fail
both shells
Outer tank fails by
impact. Loss of insu-
lation, fire fails
inner shell
Outer tank fails by
impact. Loss of insu-
lation.
Untrained (unaware of
high gravity center)
mishandles and over-
turns truck
Rear impact damages valve
controls

LNG heats up, possible failure of inner tank

Release of LNG

LNG heats up, possible failure of inner tank

Release of LNG

Release of LNG

Release of LNG

LNG heats up, overpressures inner tank.

Possible tank failure and release of LNG

Emergency response, measures stymied, possible release of LNG.
Existing Preventive and Control Measures

- Relief valves

- Vent system

- Insulation

- Front pressure gauge

- Inspection procedures

- Burst disc safety valve (3", 105 psig limit)

- Outer tank vent system

- Outer tank shell slows release

- Periodic inspection and replacement

- Double-walled tank resistant to failure

- Relief valves

- Vent system

- Double-walled tank resistant to failure

- Insulation lends great heat resistance

- Relief valves/vent system

- Excellent insulation

- Double-walled tank resistant to failure

- Relief valves/vent system

- On-board fire control system

- Relief valves/vent system

- Training requirements (company and DOT)

- Control box 


\section{TABLE 6.7. (Contd)}

\begin{tabular}{|c|c|c|c|}
\hline $\begin{array}{c}\text { Subsysten or } \\
\text { Component }\end{array}$ & $\begin{array}{c}\text { Potential Hazard } \\
\text { Condition } \\
\end{array}$ & Effect & $\begin{array}{l}\text { Existing Preventive and } \\
\text { Control Measures }\end{array}$ \\
\hline \multicolumn{4}{|l|}{ Truck Loading } \\
\hline $\begin{array}{l}\text { 1. LNG Line from Storage } \\
\text { Tank to Truck Load- } \\
\text { ing Station }\end{array}$ & $\begin{array}{l}\text { Ruptures or leaks while } \\
\text { loading trucks }\end{array}$ & Release of LNG & $\begin{array}{l}\text { - Piping standards/operator } \\
\text { inspectjon } \\
\text { - Dike (a) LAYB, (b) WC, (c) } \\
\text { WM, (d) ESD, (e\} }\end{array}$ \\
\hline $\begin{array}{l}\text { 2. Vapor Return Line to } \\
\text { Storage Tank from } \\
\text { Truck Loading Station }\end{array}$ & $\begin{array}{l}\text { Ruptures or leaks while } \\
\text { loading trucks }\end{array}$ & Release of natural gas & $\begin{array}{l}\text { - Piping standards/operator } \\
\text { inspection } \\
\text { - ESD, vapor return lines }\end{array}$ \\
\hline \multirow[t]{2}{*}{$\begin{array}{l}\text { 3. Truck Loading Station } \\
\text { Fill Valve }\end{array}$} & Ruptures or leaks & Release of LNG & $\begin{array}{l}\text { - Valve maintenance and inspec- } \\
\text { tion/upstream valłf } \\
\text { - ESD, LAVB and C, }\end{array}$ \\
\hline & $\begin{array}{l}\text { Left open after last } \\
\text { load out }\end{array}$ & $\begin{array}{l}\text { Release of LNG } \\
\text { when upstream valve is } \\
\text { opened }\end{array}$ & $\begin{array}{l}\text { - Preloading inspection/up- } \\
\text { stream valve, } \\
\text { - ESD, LAVB and C, WC, WM }\end{array}$ \\
\hline \multirow[t]{2}{*}{$\begin{array}{l}\text { 4. Flexible Loading } \\
\text { Hoses }\end{array}$} & Rupture or leak & $\begin{array}{l}\text { Release of LNG or natural } \\
\text { gas }\end{array}$ & $\begin{array}{l}\text { - High-pressure hose standards } \\
\text { - Preloading inspection/loading } \\
\text { valve } \\
\text { - ESD, LAVB and C, WC, WH }\end{array}$ \\
\hline & $\begin{array}{l}\text { Truck moves with hose } \\
\text { attached }\end{array}$ & $\begin{array}{l}\text { Release of LNG or natu- } \\
\text { ral gas }\end{array}$ & $\begin{array}{l}\text { - Wheels chocked, interlocks, } \\
\text { operator attention } \\
\text { - ESD, LAVB and C, WC, WM }\end{array}$ \\
\hline \multirow[t]{2}{*}{ 5. Ground Cables } & Bad condition & $\begin{array}{l}\text { Possible static spark, } \\
\text { possible explosion and } \\
\text { fire }\end{array}$ & $\begin{array}{l}\text { - Preloading inspection } \\
\text { - WC, WM, EXT }\end{array}$ \\
\hline & Failure to hook up cables & $\begin{array}{l}\text { Possible static spark, } \\
\text { possible explosion and } \\
\text { fire }\end{array}$ & $\begin{array}{l}\text { - Preloading inspection } \\
\text { - WC, WM, EXT }\end{array}$ \\
\hline 6. Tank Atmosphere & Oxygen present & $\begin{array}{l}\text { Possible explosive mix- } \\
\text { ture, possible explosion } \\
\text { and fire }\end{array}$ & $\begin{array}{l}\text { - Preloading inspection } \\
\text { - WC, WM, EXT } \\
\text { - Fittings incompatible with } \\
\text { oxygen service } \\
\text { - Trailer kept above atmos- } \\
\text { pheric pressure }\end{array}$ \\
\hline \multirow[t]{2}{*}{$\begin{array}{l}\text { 7. Trailer Road Safety } \\
\text { Valve }\end{array}$} & $\begin{array}{l}\text { Failure to close before } \\
\text { loading }\end{array}$ & $\begin{array}{l}\text { Possible release of safety } \\
\text { valve and LNG or natural } \\
\text { gas }\end{array}$ & $\begin{array}{l}\text { - Loading procedures/loading } \\
\text { valves } \\
\text { - ESD, LAVB and C, WC, WM }\end{array}$ \\
\hline & $\begin{array}{l}\text { Failure to open before } \\
\text { release of truck after } \\
\text { loading }\end{array}$ & $\begin{array}{l}\text { Possible overpressuriza- } \\
\text { tion of truck tank, pos- } \\
\text { sible rupture or leak }\end{array}$ & $\begin{array}{l}\text { - Postloading procedures } \\
\text { - Pressure gage }\end{array}$ \\
\hline \multirow[t]{2}{*}{ 8. Fill Trycock Valves } & $\begin{array}{l}\text { Failure to open as indi- } \\
\text { cators while loading }\end{array}$ & $\begin{array}{l}\text { Possible overfilling of } \\
\text { tank }\end{array}$ & $\begin{array}{l}\text { - Loading procedures } \\
\text { Scale readings or liquid } \\
\text { level gage }\end{array}$ \\
\hline & $\begin{array}{l}\text { Open empty trycock } \\
\text { instead of } 87 \% \text { or } 90 \% \\
\text { trycock }\end{array}$ & Release of LNG & $\begin{array}{l}\text { - Loading procedures } \\
\text { - Operator attention } \\
\text { - Dike, LAVB and C }\end{array}$ \\
\hline \multirow[t]{2}{*}{$\begin{array}{l}\text { 9. Vapor Return Valve } \\
\text { on Truck }\end{array}$} & Ruptures or leaks & Release of natural gas & $\begin{array}{l}\text { - Valve maintenance and inspec- } \\
\text { tion } \\
\text { - ESD }\end{array}$ \\
\hline & $\begin{array}{l}\text { Left closed during load- } \\
\text { ing }\end{array}$ & $\begin{array}{l}\text { Pressurization of truck } \\
\text { tank, possible leak or } \\
\text { rupture }\end{array}$ & $\begin{array}{l}\text { - Loading procedures } \\
\text { - ESD, LAVB and C, WC, WM }\end{array}$ \\
\hline \multicolumn{4}{|c|}{$\begin{array}{l}\text { (a) Dike - Diked impoundment area } \\
\text { (b) LAVB - Loading Area Vapor Barrier } \\
\text { (c) WC - Water Curtain } \\
\text { (d) WM - Water Monitors }\end{array}$} \\
\hline
\end{tabular}


TABLE 6.7. (Contd)

\begin{tabular}{|c|c|c|c|}
\hline $\begin{array}{c}\text { Subsystem or } \\
\text { Component }\end{array}$ & $\begin{array}{c}\text { Potentia] Hazard } \\
\text { Condition } \\
\end{array}$ & Effect & $\begin{array}{c}\text { Existing Preventive and } \\
\text { Control Measures } \\
\end{array}$ \\
\hline \multicolumn{4}{|l|}{ Truck Loading } \\
\hline \multirow[t]{2}{*}{$\begin{array}{l}\text { 10. Vapor Return Valve } \\
\text { at Loading Station }\end{array}$} & Ruptures or ieaks & Release of natural gas & $\begin{array}{l}\text { - Valve maintenance and } \\
\text { inspection } \\
\text { - ESD }\end{array}$ \\
\hline & $\begin{array}{l}\text { Left closed during } \\
\text { loading }\end{array}$ & $\begin{array}{l}\text { Pressurization of truck } \\
\text { tank, possible leak or } \\
\text { rupture }\end{array}$ & $\begin{array}{l}\text { - Loading procedures } \\
\text { - ESD, LAVB and } C \text {, WC, WM }\end{array}$ \\
\hline \multirow[t]{2}{*}{ 11. Fill Valve on Truck } & Ruptures or leaks & Release of LNG & $\begin{array}{l}\text { - Valve maintenance and } \\
\text { inspection } \\
\text { - Truck loading station fill } \\
\text { valve } \\
\text { - ESD, LAVB and } C, W C \text {, WM }\end{array}$ \\
\hline & Fails to close completely & $\begin{array}{l}\text { Leak of LNG when flexible } \\
\text { hose is removed }\end{array}$ & $\begin{array}{l}\text { - Vaive maintenance and inspec- } \\
\text { tion } \\
\text { - Sump drains } \\
\text { - Dike, LAVB and } C\end{array}$ \\
\hline \multirow[t]{2}{*}{$\begin{array}{l}\text { 12. Orain vaives on } \\
\text { Flexible Hoses }\end{array}$} & Rupture or leak & $\begin{array}{l}\text { Release of LNG or } \\
\text { natural gas }\end{array}$ & $\begin{array}{l}\text { - Valve maintenance and } \\
\text { inspection } \\
\text { - Loading valves } \\
\text { - ESD, LAVB and C, WC, WM }\end{array}$ \\
\hline & $\begin{array}{l}\text { Left open after last } \\
\text { loading }\end{array}$ & $\begin{array}{l}\text { Release of LivG or natural } \\
\text { gas when loading }\end{array}$ & $\begin{array}{l}\text { - Preloading inspection } \\
\text { - Loading valves } \\
\text { - ESO, LAVB and C, WC, WM }\end{array}$ \\
\hline 13. Sump & '-eaks & $\begin{array}{l}\text { Release of } 1 \text { NG or natura } 1 \\
\text { gas }\end{array}$ & $\begin{array}{l}\text { - Maintenance and inspection } \\
\text { - LAVB and } C \text {. WC, WH }\end{array}$ \\
\hline 14. Relief Valves & Fail to relieve pressure & $\begin{array}{l}\text { Overpressurization, pos- } \\
\text { sible rupture or leak }\end{array}$ & $\begin{array}{l}\text { - Inspection and testing } \\
\text { - Loading valves } \\
\text { - Burst disc } \\
\text { - ESO, LAVB and C }\end{array}$ \\
\hline 15. Operator & $\begin{array}{l}\text { Fills warm truck through } \\
\text { bottom fill line }\end{array}$ & $\begin{array}{l}\text { Thermal shock of inner } \\
\text { shell, possible rupture } \\
\text { or leak }\end{array}$ & $\begin{array}{l}\text { - Loading procedures } \\
\text { - Pressure gage } \\
\text { - LAVB and C, ESD, WC, WM }\end{array}$ \\
\hline \multicolumn{4}{|l|}{ Truck Unloading } \\
\hline $\begin{array}{l}\text { 1. Unloading valve on } \\
\text { Truck }\end{array}$ & Rupture or leaks & $\begin{array}{l}\text { Reiease of LNG or natu- } \\
\text { ral gas }\end{array}$ & $\begin{array}{l}\text { - Valve maintenance and inspection } \\
\text { - WM, Dike }\end{array}$ \\
\hline $\begin{array}{l}\text { 2. Flexible Unloading } \\
\text { Hoses }\end{array}$ & Ruptures or leaks & $\begin{array}{l}\text { Release of LNG or natu- } \\
\text { ral gas }\end{array}$ & $\begin{array}{l}\text { - High-pressure hose standards } \\
\text { - Preunioading inspection/ } \\
\text { unloading valve } \\
\text { - WM, Dike }\end{array}$ \\
\hline $\begin{array}{l}\text { 3. Station unloading } \\
\text { Vaive }\end{array}$ & Ruptures or leaks & $\begin{array}{l}\text { Release of LNG or } \\
\text { natural gas }\end{array}$ & $\begin{array}{l}\text { - Valve maintenance and inspec- } \\
\text { tion } \\
\text { - Truck unloading valve } \\
\text { - WM }\end{array}$ \\
\hline \multirow[t]{2}{*}{ 4. Grounding Cables } & Bad condition & $\begin{array}{l}\text { Possible static spark, } \\
\text { possible explosion and } \\
\text { fire }\end{array}$ & $\begin{array}{l}\text { - Preunloading inspection } \\
\text { - EXT, WM, EXT }\end{array}$ \\
\hline & $\begin{array}{l}\text { Failure to hook up } \\
\text { cables }\end{array}$ & $\begin{array}{l}\text { Possible static spark, } \\
\text { possible explosion and } \\
\text { fire }\end{array}$ & $\begin{array}{l}\text { - Preunloading inspection } \\
\text { - EXT, WM, EXT }\end{array}$ \\
\hline
\end{tabular}




\section{TABLE 6.7. (Contd)}

Subsystem or Component

Truck Unloading

5. Pressure Buildup Coil Rupture or leak

6. Relief Valves

7. Trailer Road Safety Valve

8. Drain Valves on Flexible Hoses sure unloading unloading

Rupture or leak
Potential Hazard Condition

Failure to relieve pres-

Failure to close before

Failure to open before release of truck after

Left open after

last unloading

9. LNG Line from Truck Unloading Station to Storage Tank

Ruptures or leaks while unloading trucks
Effect

Existing Preventive and Control Measures

Release of LNG or natural - Pressure buildup system gas

shutoff valve

- Dike

Overpressurization possible rupture or leak

Start storage tank pump

for suction

- Burst disc

Possible release of safety - Preunloading inspection valve and LNG or natural Dike gas

Posstble overpressuriza- Postunloading procedures tion of truck tank. - Pressure gage possible rupture or leak

Release of LNG or natural - Valve maintenance and gas inspection - Unloading valves - Dike

Release of LNG or natural - Preunloading inspection gas when unloading starts Unloading valves

- Dike
- Piping standards

Release of LNG or natural gas
- Operator inspection

- Dike, ESD 
between operator actions and plant operations is therefore a critical factor relating to release prevention and control.

Operators perform a number of diverse tasks at the peakshaving facility, most of which relate to release prevention and control either directly or indirectly. During normal plant operations, the operators run the plant within set limits and standards to prevent conditions that may lead to releases. During off-standard conditions, the operators must respond appropriately to alarms, indicators, and other signals to prevent releases from occurring or to limit releases in progress. Plant inspection and maintenance is also important to identify and remedy conditions that may lead to subsequent releases.

Because of the number of operator tasks performed at the facility, the probability of operator error is judged to be medium to high. The probability of LNG or natural gas releases resulting from operator errors varies from a high probability of a small release to a low probability of a maximum release.

\subsection{REPRESENTATIVE RELEASE EVENTS}

Potential release events considered to be representative of the peakshaving plant were identified based on the system level and the component level analyses. The release events for the main facility operations (gas treatment, liquefaction, storage, and vaporization) are 1isted in Table 6.8, and those for transportation and transfer are listed in Table 6.9. Preliminary analyses of these events are presented in Section G.4 of Appendix G. The representative release events range from relatively frequent but low consequence releases to unlikely but large releases. They form the basis for the quantitative evalaution of the release prevention and control systems in the next phase of analysis.

In performing the overview study, several areas requiring additional information were identified. Some of these are outlined below.

- Component Stresses from Thermal Cycling. Many plant components (including the storage tank, piping, valves, and heat exchanger tubes) undergo therma 7 cycles during operation. These cycles produce stresses that can result in eventual component failure. Information is needed on the number of thermal cycles these various components can withstand prior to failure. 
TABLE 6.8. Representative Release Events for an LNG Peakshaving Facility

1. Gas supply line from pipeline fails.

2. Molecular sieve adsorber vessel fails.

3. Heat exchanger tube in regeneration gas heater fails.

4. LNG piping in cold box fails.

5. Refrigerant compressor suction line fails.

6. Refrigerant storage tank fails.

7. LNG storage tank fails.

8. LNG outlet line from storage tank fails.

9. LNG vapor vented through relief valves after overpressurization of storage tank.

10. Sendout pump vessel fails.

11. LNG supply line to vaporizers fails.

12. Vaporizer heat exchanger tube fails.

13. Natural gas line from vaporizers fails.

TABLE 6.9. Representative Release Events for LNG Transportation and Transfer Operations

1. Liquid line from storage to the truck loading station fails.

2. Flexible loading/unloading hoses fail.

3. Vapor return line from the truck loading station to storage fails.

4. Liquid line from the truck unloading station to the storage tank fails.

5. Truck LNG tank fails.

6. Trailer pressure buildup coil fails.

- Plant and Component Construction Details. Additional information concerning the construction of the plant and its individual components would allow more complete and detailed analysis. Needed details include such things as construction materials, thicknesses, dimensions, valve placement, and equipment configurations.

- Structual Mechanics of the Storage Tank. The effects of hazardous conditions on the structural integrity of the tank are of major importance. 
Such conditions include overpressure, overfilling, and fire or explosion in the tank or nearby. A more detailed description of the heatup and cooldown procedures is necessary for a complete analys is to be accomplished.

- Failure Rate Data. The peakshaving facility overview study considered release frequency in a qualitative manner. A more detailed study of the release prevention and control systems must carefully consider the likelihood of the release initiating event and the reliability of the release detection and control systems. Due to the lack of operating experience at LNG facilities, little data is available for LNG equipment failure rates.

- Operator Interface. Reliability information on operator tasks performed at the facility is needed. 


\subsection{ASSESSMENT OF LNG SATELLITE FACILITY}

This section presents the overview study of the reference LNG satellite facility.

\subsection{SUMMARY SYSTEM DESCRIPTION}

The reference facility for the satellite plant overview study receives LNG by truck from a plant with liquefaction capability, stores it until needed in a 37,000-bbl tank, and vaporizes it at rates of up to 12 MMscfd. The major operations performed at the plant, as well as the plant safety systems, are described briefly in the following paragraphs. A detailed description is presented in Appendix F.

\subsubsection{Transportation and Transfer System}

Specially designed truck trailers are used to transport LNG to the satellite facility from another facility having liquefaction capability. Each truck trailer includes an inner vessel of 5083 aluminum and an outer vessel of carbon steel. The annular space is filled with perlite and a moderate vacuum of 50 microns is established to insulate the inner vessel. The inner vessel is designed for a maximum working pressure of $70 \mathrm{psig}$. Several pressure relief valves are installed in the liquid and vapor piping on the truck trailer and they all exhaust to a common elevated vent stack. Remotely operated shutoff valves are installed in the liquid lines. The trailer has a gross capacity of 11,550 gal and a net capacity of 10,700 gal, and it weighs about 60,000 lb when fully loaded.

The truck trailer is loaded by transferring LNG from a storage tank to the trailer using the LNG sendout pumps. The LNG is pumped through $3-i n$. flexible, high-pressure metal hose to the trailer. Boiloff vapors from loading are returned to the storage tank through a 2-in. vapor return 1 ine. weight scales provide the primary indication of a full trailer load. Two overflow trycock valves serve as backup liquid level indicators. Both the liquid fill and the vapor return hoses are drained prior to disconnection from the trailer. 
The truck trailer is unloaded at the satellite facility through a 3-in. flexible, high-pressure metal hose connecting the trailer to the unloading station. The LNG is forced from the trailer into the satellite storage tank by the vapor pressure above the LNG in the trailer. If the vapor pressure is too low, a little LNG can be vaporized in the pressure buildup coil and routed to the top of the tank to increase the vapor pressure.

\subsubsection{Storage System}

At the satellite facility, LNG is stored in a flat-bottomed, double-wall, aboveground storage tank capable of holding 37,000 bbl. The inner wall of the tank is constructed of aluminum-magnesium alloy AA5083, which has excellent low temperature ductility. The outer wall of the tank is constructed of A131 carbon steel. The dimensions of the tank are:

$$
\begin{array}{ll}
\text { inner wall diameter: } & 69 \mathrm{ft} \\
\text { outer wall diameter: } & 72 \mathrm{ft} \\
\text { inner wall height: } & 63 \mathrm{ft} \\
\text { outer shell height: } & 73 \mathrm{ft} .
\end{array}
$$

A resilient fiberglass blanket is attached to the outside of the inner wal1. The remainder of the annular space between the inner and outer walls is filled with expanded perlite insulation. The fiberglass blanket protects the perlite from excess pressure due to expansion and contraction of the tank walls. The bottom of the outer tank shell sits on a reinforced concrete pile cap that rests on piles in the ground. The pile cap is aboveground, and air passage under the tank bottom eliminates the need for a foundation heating system. Boiloff gases from the storage tank are heated by electric heaters, compressed by one of two reciprocating boiloff compressors, and cooled prior to discharge into the pipeline. Each boiloff compressor is capable of discharging 0.15 MMscfd of gas to the pipeline. The storage tank is designed to operate at 1.0 psig with a maximum design pressure of 2.0 psig. The maximum external design pressure is $1 \mathrm{oz}$. gauge. The tank is equipped with two pressure relief valves that vent to the atmosphere at 2.0 psig and two vacuum relief valves that admit air to the tank at a pressure of $0.031 \mathrm{psig.} \mathrm{The}$ liquid level in the storage tank is monitored by a servo-powered, float-type liquid level device and a differential pressure gauge. 
Two vertical, submerged, pot-mounted pumps serve to recirculate LNG in the storage tank and to pump LNG to the vaporizers. Each pump has a design capacity of 6 MMscfd of gas for a total rated pumping capacity of 12 MMscfd. The pumps operate at a design temperature and pressure of $-260^{\circ} \mathrm{F}$ and $130 \mathrm{psig}$, respectively.

\subsubsection{Vaporization and Sendout System}

Two submerged combustion vaporizers, each rated at 6 MMscfd of gas, are used to vaporize LNG at the satellite facility. The LNG is pumped from the storage tank to the vaporizers at up to the total rated design capacity of $12 \mathrm{MMscfd}$. The vaporizers burn natural gas and bubble the hot combustion gases through a water bath surrounding the LNG heat exchanger tube bundles. The warm gas-water mixture heats the tube bundles and vaporizes the LNG. The vaporized natural gas is then introduced into the pipeline. The inlet piping, a11 piping that comes in contact with the LNG feed stream inside the vaporizers, and outlet piping to the first flange are all stainless steel construction.

\subsubsection{Safety Systems}

Various detectors, alarms, and fire protection equipment are located throughout the satellite facility:

- combustible gas detectors

- low temperature detectors with alarms in control room

- Halon fire extinguishing system

- UV fire detectors that automatically activate the Halon system and/or the Master Emergency Shutdown system

- $20 \#$ dry chemical fire extinguishers

- fire hydrants.

There are two emergency shutdown systems: the Vaporizer Emergency Shutdown (VES) and the Master Emergency Shutdown (MES). The VES, when activated, automatically shuts down the vaporizers and the LNG sendout pumps and isolates the pumps from both the vaporizers and the LNG storage tank. The VES can be activated manually at the vaporizers, the control room, or the exit gates. 
The VES is normally activated automatically by a temperature sensor in the gas outlet line, a UV burner flame monitor, or the water bath level indicator on the vaporizer tank. Upon activation, the MES automatically initiates the following actions:

- Normal plant electrical circuits are de-energized; essential plant electrical equipment remains energized.

- The plant is isolated from the natural gas system.

- The LNG tank and dike area is isolated from the remainder of the plant.

- All control valves go to failsafe positions with loss of instrument air.

- Gas from all gas handling equipment and lines is vented via the relief header to the vent stack.

There is an impoundment area surrounding the LNG storage tank and sendout pumps, with earthen dike walls averaging $10 \mathrm{ft}$ in height. The dike area is capable of holding $44,000 \mathrm{bbl}$, or 1.19 times the capacity of the storage tank. High-expansion foam generation systems are installed in the impoundment area and can be activated either manually or automatically by low temperature detectors or by UV fire detectors located in the impoundment sump.

\subsection{SYSTEM LEVEL ANALYSIS}

The purpose of the system level analysis is to identify those sections of the satellite facility that are the most critical with respect to release prevention and control. The evaluation of each system is based largely on two factors: 1) the quantity of a potential release due to either the inventory or the flow rate and 2) an estimate of the relative probability of a release (low, medium, high).

Process operating conditions, including capacities, flow rates, and pressures, are presented in Table 7.1 for major components of the transport and transfer, storage, and vaporization and sendout systems. 
TABLE 7.1. System Process Operating Conditions

\begin{tabular}{|c|c|c|c|c|c|c|}
\hline System & $\begin{array}{c}\text { Major } \\
\text { Components }\end{array}$ & $\begin{array}{c}\text { No. of } \\
\text { Components }\end{array}$ & $\begin{array}{l}\text { Component } \\
\text { Capacity }\end{array}$ & $\frac{\text { Flow }}{\text { In }}$ & $\begin{array}{r}\text { Rates } \\
\text { Out }\end{array}$ & $\begin{array}{l}\text { Operating } \\
\text { Pressure } \\
\text { (psig) } \\
\end{array}$ \\
\hline $\begin{array}{l}\text { Transportation } \\
\text { and Transfer }\end{array}$ & Truck Trailer & 1 & 11,000 gal & $350 \mathrm{gpm}$ & $350 \mathrm{gpm}$ & $0-25$ \\
\hline \multirow[t]{2}{*}{ Storage } & Storage Tank & 1 & $\begin{array}{l}\left.37,000 \mathrm{bb}^{6} \mathrm{gal}\right) \\
\left(1.55 \times 10^{6} \mathrm{~g}\right.\end{array}$ & $350 \mathrm{gpm}$ & $100 \mathrm{gpm}$ & 1.1 \\
\hline & Pumps & 2 & -- & $100 \mathrm{gpm}$ & $100 \mathrm{gpm}$ & 130 \\
\hline $\begin{array}{l}\text { Vaporization } \\
\text { and Sendout }\end{array}$ & $\begin{array}{l}\text { Submerged } \\
\text { Combustion } \\
\text { Vaporizers }\end{array}$ & 2 & -- & $100 \mathrm{gpm}$ & $12 \mathrm{MMscfd}$ & 120 \\
\hline
\end{tabular}

\subsubsection{Transportation and Transfer System}

The maximum release of LNG or LNG vapor expected in the transportation and transfer system is about 11,000 gal of LNG. This maximum release would result from loss of LNG from a fully loaded truck trailer. The primary causes of a maximum release from a truck trailer are transportation accidents or explosions. The probability of a maximum release is judged to be low. other lesser releases are possible in this system, and the primary causes of a lesser release are overpressurization and operator errors. The probability of lesser releases is judged to be medium because of the operator interface and potential operator errors.

Release control in the transportation and transfer system is dependent on where the release occurs. For example, if the maximum release were to occur in the loading or unloading area, the LHG would be contained onsite by the dikes, channels, and ground contours. However, if the maximum release were to occur during transport between the loading facility and the satellite facility, the release of LNG would most likely not be confined and would spread out according to the contour of the land. The low probability of a maximum release is based on the double-wall construction of the LNG truck trailer and the good accident record of LNG trucks. 


\subsubsection{Storage System}

The maximum release of LNG or LNG vapor expected in the storage system is about $37,000 \mathrm{bbl}\left(1.55 \times 10^{6} \mathrm{gal}\right)$ of LNG. This maximum release could result from either a complete failure of the inner tank shell or a complete break of the outlet line from the tank (assuming failure of internal or upstream valves). The primary causes of inner tank shell failure are internal overpressurization, explosions, or external pressure forces. The primary cause of an outlet line break is internal overpressurization. The probability of a maximum release is judged to be low. Other lesser releases are possible in this system, and the primary cause of a lesser release is internal overpressurization. These lesser releases would most likely be LNG vapor releases. The probability of lesser releases is judged to be medium due to the number of initiating events that could cause overpressurization.

Release control in the storage system consists mainly of a large impoundment area capable of holding the entire contents of the storage tank.

\subsubsection{Vaporization and Sendout System}

The maximum release of LNG or natural gas expected in the vaporization and sendout system is estimated to be 700 to 1,000 gal of LNG. This maximum release could result from either failure of heat exchanger tubes in the vaporizers (700 gal of LNG) or failure of the natural gas discharge line from the vaporizers (about 1,000 gal of LNG or 83,000 scf of natural gas). The primary causes of a failure of the heat exchanger tubes are thermal cyclic stresses or thermal shock. The primary cause of a failure of the natural gas discharge line is the possibility of thermal shock. The probability of a maximum release is judged to be medium. Other lesser releases are possible in this system, and the primary cause of a lesser release is corrosion of heat exchanger tubes.

Release control in the vaporization and sendout system is limited to containment of the LNG release from the heat exchanger tubes within either the vaporizer area or the satellite facility boundaries. 


\subsection{COMPONENT LEVEL ANALYSIS}

The purpose of the component level analysis is to identify those components that are the most critical with respect to release prevention and control. The system level analysis indicates that a significant release could come from any of the three systems at the satellite plant. The largest release could come from the storage system.

A preliminary hazards analysis (PHA) has been completed for each system previously discussed. The PHA for each system deals with the major components of that system and the related potential hazard conditions, effects, and existing preventive and control measures.

Some of the releases in this section require the failure of more than one component. For example, a line failure could occur from internal overpressurization and relief valve failure.

\subsubsection{Transportation and Transfer System}

The PHA for the transportation and transfer system is presented in Section 6.3.5 for the peak shaving plant and is not repeated here. The following components are judged to be the most important with respect to release prevention and control:

Double She11 Truck Tank. This component is important because its failure causes the maximum release of LNG or LNG vapor $(11,000$ gal of LNG) for this system. The probability of both shells completely failing is judged to be low considering the low probability of accident, explosive, or overpressurization causes for a complete failure.

Operator Interface. Although this is not a mechanical component, the probability of operator errors is judged to be medium based on the number of operator tasks performed in this system. The probability of LNG or LNG vapor releases due to operator error varies from a high probability of a smal1 release to a low probability of a maximum release.

Truck Pressure Relief Devices. These components are important because their failure in an overpressure situation could cause a complete failure of the double shel1 truck tank. The probability of these components simultaneous failure is judged to be low because of the redundancy of relief devices. 


\subsubsection{Storage System}

The PHA results for the storage system are presented in Table 7.2. The following components are judged to be the most important with respect to release prevention and control:

Inner Tank She11. Failure of this component would cause the maximum release of LNG or LNG vapor $\left(37,000 \mathrm{bbl}\right.$ or $1.55 \times 10^{6} \mathrm{gal}$ of LNG) for this system. The probability of a failure of the inner tank shell is judged to be low because of design considerations.

Annular Space Insulation. This component is important because it prevents excessive boiloff of the LNG vapor, which could be a major cause of the inner tank shell failure. The insulation also protects the carbon steel outer she 11 from cryogenic temperatures and subsequent failure. The loss of insulation is dependent on the outer tank she 11 failing first.

Outer Tank She11. This carbon steel she11 protects the inner shell and annular insulation from the environment. Failure of the outer tank shell could possibly result in the failure of the inner tank shell. The probability of this failure sequence is judged to be low.

Tank Discharge Line to Pumps. Failure of this line could possibly result in the maximum release for this system if no valves existed or functioned to shut off tank flow to the pumps. In addition, if the failure is between the inner and outer tank shells, the released LNG could fail the outer tank shell. The probability of the discharge line failing is judged to be low because of the types of failure mechanisms considered.

LNG Recirculation Line from Pumps to Tank. The failure of this component would release LNG that could spray on the outer tank shell and fail it. The probability of the line failing is judged to be low, but the probability of a release from the line causing the outer shell to fail is judged to be medium.

Storage Tank Pump Vessel. If the pump vessel were to fail and the feed valves to the vessel were open, a large LNG release $(14,000$ gal) could occur. The probability of the pump vessel failing is judged to be low. 


\section{TABLE 7.2. Preliminary Hazards Analys is for the Storage System}

\section{Subsystem or Component \\ Startup Operations \\ 1. Storage Tank \\ 2. Purge ring \\ 3. Tank inner shell}

4. Downcomer

5. Operator

Shutdown Operations

1. Tank inner she 11

\section{Storage tank}

Steady State Conditions

1. Liquid fill line
Potential Hazard Condition

Inadequate nitrogen purge of tank.

Purge ring fails closed during the purging process.

Storage tank thermocouple monitoring system fails or gives inaccurate readings on cooldown.

Downcomer does not disperse liquid properly.

Lack of operator awareness (e.g. . unconsciousness) during cooldown.
Effect

Possible explosive mixture occurs when the tank is filled with LNG.

Pressure build up in the outer shell with possible fallure of the outer shell.

Tank fills too fast.

Thermal contraction and thermal stress or shock

fail the inner shell with a release of LNG, failure of the outer shell, and release of natural gas and/or LNG.

Inner shell undergoes nonuni form cooldown.

Lack of control over the boiloff treatment system allows pressure to rise.

Uncontrolled cooldown with possible fallure of the inner shell.

Heatup of LNG with hot natural gas is too rapid.

Possible overpressurization with possible fallure of inner tank and release of LNG.

Lack of operator awareness (e.g., unconsciousness) during heatup.

Combustible gas sensor system falls during purging.

Line ruptures or leaks.

Line broken by vehicular damage.

Inner shell may become off-centered and forces due to perlite compaction may fail the inner shell. Then LNG would be released between Inner and outer shells, with the carbon steel outer shell failing due to cold and a release of LNG and natural gas.

Possible explosive mixture when the tank is opened to the air.
Existing Preventive and Control Measures

Startup checklist, operator expertise, combustion gas sensor system.

Maintenance and inspection/ bolloff compressors can lower pressure in the tank. reopen relief valve vent line valve, stop purge.

Maintenance and inspection/ dike.

Storage tank thermocouple monitoring system, operator attention/cessation of cooldown.

Second operator in control room/alarms.

Second operator in control room/a larms.

Heatup procedures, instrumentation of heatup effects/ operator attention, relief valves, dike.

Second operator in control

Purging procedure, operator expertise.

Piping standards/operator inspection, truck unloading station vaive, ESO, (a) dike. Operator and/or driver attention/truck unloading station vaive, ESD, dike.

(a) ESD designates the Emergency Shutdown System, which includes both the Master Emergenc:" Shutdown (MES) and the Vaporizer Emergency Shutdown (VES). 


\section{Subsystem or Component Potential Hazard Condition}

2. High level liquid a larm system

3. Tank inner shell

System fails and operator does not notice dangerous condition on liquid level differential pressure type).

Operator does not hear when alarm sounds due to lack of awareness (e.g., unconsciousness).

Earthquake fails the inner gauges (float type and she 11 .

Plane crashes into tank.

Planted bomb explodes (sabo tage).

Rollover occurs. shell.

Planted bomb explodes (sabotage).
4. Tar.k outer shell Earthquake fails the outer

Existing Preventive and Control Measures

Operator attention, temperature readings would indicate an unusual condition/ dike.

Second operator in the control room/dike. shell. LNG fails the outer shell. Natural gas and/or LNG is

released.

Natural gas and/or LNG is released. If outer shell has not failed due to the earthquake. then it fails due to the cold.

Possible rupture of inner shell with release of natural gas and/or LNG and probable fire.

Probable rupture of outer and inner shelis with release of natural gas and/or LNG and probable fire.

LNG vaporization rapidly increases. Possible failure of inner tank due to overpressurization resulting in release of LNG between inner and outer shells, carbon steel outer shell fails due to cold, and LNG and natural gas are released. Possible failure of the inner shell due to the possibility of the outer shell collapsing with subsequent release of natural gas and/or LNG.

Possible failure of the inner shell due to loss of insulation, increase in vaporization, possible overpressurization with subsequent release of natural gas and/or LNG.

Outer shell fails. Pos- Security measures/dike.

sible failure of inner shell due to the possibility of the outer shell collapsing if the inner shell has not aiready failed from the explosion, with subsequent release of natural gas and/or LNG with probable fire.
Tank shell standards/dike.

Dike.

Security measures/dike.

Bottom loading of tank with adequate mixing, adequately designed boiloff system/

relief valves, vent system.

Tank shell standards/dike.

Tank shell standards, relief valves/dike. 
TABLE 7.2. (contd)

\section{Subsystem or Component Potential Hazard Condition}

5. Boiloff heaters $(E-201, A$ or $B)$

6. Boiloff compressors $(C-201, A$ or $B)$

7. Compressor aftercooler

8. Pressure rellef valve
Both heaters fail due to power outage.

Compressor ruptures or leaks.

Boiloff gases can't be treated fast enough.

Aftercooler fails to adequately cool the compressed boiloff gases.

(1 of 2) valves fail to operate.

Both values fail to operate.
Effect

Dossible failure of the inner shell due to loss of insulation, etc., as for 4 (earthquake), 2nd Effect above.

Outer shell fails. Pos- Dike.

sible fallure of inner shell due to the possibility of the outer shell collapsing if the inner shell has not already failed from the plane crash, with subsequent release of natural gas and/or LNG with probable fire.

Possible failure of the inner shell due to the loss of insulation, etc., as for 4 (earthquake) 2nd Effect above.

Cold boiloff gases fai? the carbon steel lines at the exit of the heaters. Natural gas

is released.

Natural gas released.

Pressure in storage tank rises. Possible overpressurization of the storage tank and subsequent failure of the outer shell, loss of insulation, increase in vaporization of LNG, possible failure of inner tank, and release of LNG.

Hot gases are discharged into the pipeline.

Compressors are shut down and pressure rises in the storage tank because boiloff gases can' $t$ be treated. See 6 , boiloff compressor effect above.

Natural gas is released from the tank.

Same as for 6. Boiloff compressor effect above.
Existing Preventive and Control Measures

Relief valves/dike.

Relief valves/diked.

Emergency power, maintenance and inspection/low temperature indicator controller closes heater out-

let valves should the temperature get too low.

Compressor specifications, preventive maintenance/ operator inspection, block valves on each side of compressor.

Adequate compressor design/ pressure relief valves (2) on tank, dike.

Maintenance and inspection/ compressors are shut down.

Maintenance and inspection/ relief valves on tank.

Annual tests.

Dike. 
TABLE 7.2. (contd)

\section{Subsystem or Component}

9. Vacuum relief valve

10. Liquid discharge line prior to pumps

\section{Potential Hazard Condition}

(1 of 2) valves fail to operate.

Both valves fall to operate.

Line ruptures or leaks between inner and outer shells.

Line ruptures or leaks after the outer shell.

Pump ruptures or leaks. Vessel ruptures or leaks. vessel

13. Vapor return line from pumps

14. Recirculation line from pump to stor age tank

15. Foundation pilings

16. Piling cap

17. Suspended Insulated deck

18. Relief valve line valves

19. Purge ring

Line ruptures or leaks.

Line ruptures or leaks.

pilings don't settle uni formly.

Cap falls.

Deck falls and falls into the inner tank along with insulation.

Line valves are closed when relief valve release.

Purge ring fails open.

\begin{abstract}
Effect
Possible explosive a tmosphere in tank. Possible explosion.

Possible fatlure of outer shell due to high vacuum and subsequent loss of insulation, increase in vaporization of LNG, possible fatlure of inner tank, and release of LNG.

Outer shell fails due to cold and pressure forces, releasing LNG and natural gas. Inner tank may fall due to the possible collapse of the outer shell. releasing more LNG.
\end{abstract} Naturai gas and/or LNG are released.

None (pump is submerged in LNG).

LNG is released to the when pump falls in conjunction).

Natural gas is released.

LNG and/or natural gas is released.

Possible cracking and failure of piling cap.

Possible fallure of inner and/or outer tank shell with subsequent release of natural gas and/or LNG.

Extreme cold falls the carbon steel outer tank roof and natural gas is released.

Pressure falls the tank with possible release of natural gas and/or LNG.

Natural gas is released impoundment area (releases much greater

Existing Preventive and Control Measures

Annual tests/nitrogen purge.

O1ke.

Plping standards/ESD, dike.

Piping standards/operator inspection, ESD, dike, block valves between each of the 2 pumps and the discharge line and between the discharge line and vaporizers.

Malntenance and inspection.

Vessel speciflcation, maintenance and inspection/ESD. dike.

Pipling standards/operator inspection, shutoff valves near the pumps, ESD, dike.

Plping standards/operator inspection, shutoff valves near the pumps, ESD, dike. through the deck, per-

lite, and the purge

ring.
Proper ground testing and preparation, proper installation of pilings.

Proper construction of piling cap/dike.

Foam generation onto surface of LNG.

Pressure can be lowered using boiloff gas compressors.

Maintenance and Inspection. 
Boiloff Heaters. If these fail, cold boiloff gases will either fail the carbon steel exit lines or cause the storage tank pressure relief valves to open. In either case, LNG vapor (about 6,000 scf per hour) will be released until the heaters can be fixed. The probability that both electric heaters could fail (e.g., power outage) is judged to be low to medium.

Storage Tank Pressure Relief Valves. Proper operation of these valves during pressurization of the tank would allow LNG vapor to be released from the top of the tank. Failure of the valves to operate could allow overpressurization to fail the storage tank. The probability of both pressure relief valves failing to operate is judged to be low.

\subsubsection{Vaporization and Sendout System}

The PHA results for the vaporization and sendout system are presented in Table 7.3. The following components are judged to be the most important with respect to release prevention and control:

Vaporizer Heat Exchanger Tubes. If one or more of these tubes fail, LNG is released to the vaporizer and a subsequent fire or explosion is possible. An estimated maximum release from this type of failure is about 700 gal of LNG. The probability of a heat exchanger tube failure is judged to be medium.

Natural Gas Discharge Line from Vaporizer. If this carbon steel line fails (possibly from cold LNG vapors), an estimated release of LNG vapor or LNG of 1,000 gal ( $83,000 \mathrm{scf})$ is possible. The probability of this line failing is judged to be low considering the temperature control shutdown subsystem.

Vaporizer Water Bath Tank. If the tank fails, the loss of water could result in either heat exchanger tube failure or discharge line failure. The probability of the tank failing is judged to be low.

Temperature Controller on the Vaporizer Discharge Line. If this controller fails, the discharge line could fail. The probability of the controller failing is judged to be medium. 


\section{TABLE 7.3. Prel iminary Hazards Analysis for the Vaporization and Sendout System}

Subsystem or Component
$\frac{\text { Startup and Shutcown }}{\text { Operations }}$
1. LNG pump discharge
pressure

2. Tube bundle

3. LNG flow control valve

4. Natural gas line from vaporizers to the pipeline

5. Tank and weir

6. Burner and downcomer
Potential Hazard Condition

Discharge pressure is set too high.

Bath temperature is set too low.

Flow controller setting is too nigh or turned up too rapidly.

Line ruptures or leaks.

Tubes rupture or leak due to either thermal shock, corrosion or excernal cause.

Valve fails open (normally fails closed)

Line mptures or leaks.

Tank and/or weir rupture or leak.

Burner ceases burning.

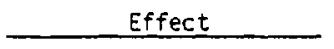

Existing Preventive and Control Measures

and Control Measures

Vapor flow through the

flow control valve is throttled (no hazard if piping design is adequate for the maximur pump pressure).

LNG may not be totaliy vaporized with possibie cryogenic failure of carbon steel piping downstream.

LNG may not be totally vaporized (see 2, Effect).

LNG is released. (The size of release is dependent on whether the pumps are running.)

LNG is released to the vaporizer tank water. Potential explosive gas mixture in the tank with possible fire due to burners.close at hand.

LNG is not compietely vaporized. Probabie thermal shock failure of the carbon steel lines at the outlet of the vaporizer with a subsequent release of LNG and natural gas.

Eso (a) interlocked with the low vapor outlet temperature.

Piping standards/ESD, dike.

Tube design and standards/ LNG inlet shutoff valves,

ESO, comoustibie gas detec-

tion alarm, Halon fire extinguishing sys tern.

Mainzenance and inspection, thermal capacity of water in vaporizer tank/shutorf valve arter the flow control valve, ESD, dike.

Natural gas is released. Piping standards/ESD, dike. If there is a large break, the depressurization may cause LNG to surge through the vaporizer, releasing both LNG and natural gas.

Partial or complete loss of water or lowering of water level which results in reduced heat transfer, LNG not totally vaporized, possible failure of carbon steel pioing downstream due to thermal shock, and possible failure of tubes due to thermal stress or shock.

Porential explosive mixture in downcomer and tank. LNG not totally vaporized with possible cryogenic failure of carbon steel lines downstream.
Tank and weir design/low level alarm and fill system, ESD interlocked to low vapor product temperature, dike.
Adequate gas and air supply, thermal capacity of water in the vaporizer tank/UV flame detector larm, auxiliary electric interlocked to low vapor product temperature. water bath heater, ESD 


\section{TABLE 7.3. (contd)}

\section{Subsystem or Component}

7. Burner jacket water pump

8. Burner gas supply

9. Burner air supply

10. Electrical power

11. Burner gas and air control (vapor outlet temperature controller)

Potential Hazard Condition

Air supply is stopped or

Electrical power fallure. mally fails closed).

Control fails closed.

12. Water supply

13. Drain system
Back pressure existing in drain sys tem.
Pump fails to operate.

Gas supply is stopped or cut off. cut off.

Control fails open (nor-

\section{Effect}

Possible thermal stress failure of burner. Pos sible ignition source if LNG were released to the tank water.

Burner ceases burning (see 6, Effect).

Burner ceases burning (see 6, Effect).

Blower and burner jacket pump stop. Burner ceases burning (see 6, Effect).

LNG is overheated especially if water level is inadequate.

LNG is not totally vaporized with possible cryogenic failure of carbon steel lines downstream.

Water pressure is lost.
Water level may fal slowly or rapidly. depending on other circumstances. Drop in water level will mean possible loss in heat transfer and possibly LNG is not totally vaporized with possible cryogenic failure of carbon steel lines downstream.

Tank may overflow, with possible tank rupture (see 5, Effect).
Existing Preventive and Control Measures

Maintenance and inspection, shutdown of burner.

Pressure and flow indicators on the gas supply line (see 6).

Pressure and flow indicators on the air supply line (see 6),

Auxiliary power supply (see 6).

Maintenance and inspection/ ESD, gas supply valve.

Maintenance and inspection/ auxiliary electric water bath heater, ESD, UV flame detector.

High temperature alarm in tank stack, low leve 1 a larm, ESD interlocked to low vapor product temperature.

(See 5.)

(a) ESD designates the Emergency Shutdown System, which includes both the Master Emergency Shutdown (MES) and the Vaporizer Emergency Shutdown (VES). 


\subsection{REPRESENTATIVE RELEASE EVENTS}

Using the results of the system level and the component level analyses, a list of potential release events considered to be representative of the satellite facility was developed. These representative release events are 1 isted in Table 7.4. Prel iminary analyses for these events are presented in Section G.5 of Appendix G. Release events for transportation and transfer operations are introduced in Table 6.9 of Section 6 and are not included here. The representative release events range from relatively frequent but low consequence releases to unlikely but large releases. They form the basis for the quantitative evaluation of the release prevention and control systems in the next phase of analysis.

TABLE 7.4. Representative Release Events for an LNG Satellite Facility

1. Satellite storage tank fails.

2. Exit gas line from the boiloff heaters fails.

3. Liquid discharge line from the satellite storage tank prior to the sendout pumps fails.

4. Sendout pump vessel fails.

5. Liquid recirculation 1 ine for the sendout pumps fails.

6. Vapor return line from the sendout pumps fails.

7. Liquid line to the vaporizers fails.

8. Vaporizer heat exchanger tubes fail.

9. Naturai gas 1 ine from the vaporizers fails.

In performing the overview study, several areas requiring additional information were identified. Some of these are outlined below.

- Thermal Cycling Stresses. Information is needed on the number of thermal cycles the storage tank and various sizes of pipes or tubing can take prior to failure.

- Operator Interface. Reliability information on operator tasks related to loading, transport, and unloading is needed.

- LNG Line Relief Valves. Reliability information for operation of LNG line relief valves is needed. 
- Boiloff System. Additional information concerning the entire boiloff system, such as construction materials, valve placement, and temperature controllers, is needed.

- Storage Tank. Information concerning discharge valving for the tank is needed.

- Vaporizers. Information concerning the vaporizer internals, such as diameter of tubes, number of tubes, tube configuration, and flowrates, is needed. Information concerned with vaporizer tube corrosion problems is also needed.

- Failure Rate Data. The satellite facility overview study considered release frequency in a qualitative manner. A more detailed study of the release prevention and control systems must carefully consider the likelihood of the release initiating event and the reliability of the release detection and control systems. Due to the lack of operating experience at LNG facilities, little data is available for LNG equipment failure rates. 


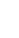




\subsection{CONCLUSIONS AND RECOMMENDATIONS}

This overview study has characterized the basic types of LNG operations, identified information needs relating to LNG release prevention and control and provided an analytical framework for additional detailed analyses. Table 8.1 summarizes the findings of this study. This information provides the basis for ongoing release prevention and control studies at PNL. Table 8.1 is organized in sections to show the units operations, key components, representative release events and information needs of representative LNG facilities.

Gas treatment, liquefaction, storage, vaporization, transfer, and transportation are the basic unit operations encountered in LNG facilities. The storage and transfer operations typically have the potential for the largest LNG releases. The results of this study show that the marine vessel, import terminal, and peakshaving facility contain the basic release prevention and control elements utilized in the LNG industry. More detailed release prevention and control analyses are recommended with emphasis on these facilities. (a) Components such as storage tanks, transfer lines, emergency shutdown, pressure/ vacuum relief valves, liquid level indicators are common to several of the facilities. The reliability of these types of components should be carefully considered in any detailed assessment.

Representative reiease events are summarized in Table 8.1 for each facility. These releases are typically postulated for each unit operation and are based upon the results of the preliminary hazards analysis. These representative release units range from relatively frequent but low consequence releases (e.g., vaporizer failure) to unlikely but high consequence releases (e.g., storage tank failure). These release events are felt to be typical of the range of hazards involved in the LNG facility operations. As seen from the summary table, most of the releases involve storage tank failures, leaks or ruptures in pipes, and process equipment failures. It is recommended that these representative release events be subject to quantitative evaluation during the next phase of analysis.

(a) Marine vessel release prevention and control was considered in a separate portion of the DOE Program (A. D. Little 1980). 
The overview study identified information needs in two basic areas. First those specific to the facility being analyzed and the amount of system description detail available for the more detailed assessment phase. As shown in the summary table, these types of information needs include such areas as emergency shutdown system specifics, piping network design criteria, and LNG vaporizer process control. Secondly, more general information gaps and needs were identified in such areas as the structural integrity of storage tanks when subject to hazardous conditions, the operator interface and its effect on release prevention and control, LNG equipment failure rate data, and the effect of thermal cycling on LNG equipment performance. It is recommended that these areas be considered in the more detailed phase of analysis.

Building upon this study, PNL has initiated more detailed assessments of LNG import terminal and peakshaving facility release prevention and control systems. The objective of the detailed import terminal and peakshaving facilit: assessments is to estimate release frequency and volume for the representative release sequences identified in this assessment. The effect of alternative release prevention and control systems and procedures will be examined and compared on a quantitative basis. Studies have also been initiated on human factors in LNG operations, LNG storage tank operations, and LNG fire and vapor control systems. 
TABLE 8.1. Summary of LNG Facility Scoping Assessment

\begin{tabular}{|c|c|c|}
\hline $\begin{array}{c}\text { Representative } \\
\text { Facility }\end{array}$ & $\begin{array}{c}\text { Unit } \\
\text { Operations }\end{array}$ & $\begin{array}{l}\text { Key Components with } \\
\text { Respect to Relpase } \\
\text { Prevention/Control }\end{array}$ \\
\hline Export Terminal & $\begin{array}{l}\text { - Gas treatment } \\
\text { - Liquefaction } \\
\text { - Storage } \\
\text { - Loading }\end{array}$ & $\begin{array}{l}\text { - Liquefaction process control system } \\
\text { - Refrigerent compressors } \\
\text { - Pressure control system } \\
\text { - Internal shutoff valves } \\
\text { - LNG level indfcators and alarms } \\
\text { - Storage tank insulation } \\
\text { - Outer tank wall } \\
\text { - Inner tank wall } \\
\text { - 36-in. transfer line } \\
\text { - Loading arm and ship coupling } \\
\text { mechanism } \\
\text { - Loading emergency shutdown system } \\
\text { - Operator interface }\end{array}$ \\
\hline
\end{tabular}

Marine Vessel

- Basic ship opera-
ting and propul-
sion sys tems
- Cargo storage
- Cargo hand ling

- Liquid header, crossover line and

- Emergency shutdown system

- Primary barrier

- Cargo tank liquid-level indicators

- Pressure/vacuum relief valves

- Navigation equipment

- Operator interface

Import Terminal

- Marine terminal
and unloading
system
- Storage
- Vaporization

- Main transfer line

- Loading arms and ship coupling mechanism

- Offshore emergency shutdown system

- Pressure control system

- LNG level indicators and alarms

- Storage tank outer shell

- Annular space insulation

- Storage tank tnner shell

- Secondary pumps and sendout line

to vaporizers

- Fuel gas preheater

- Temperature controllers and a larms

- Vaporizer inlet lines

- Operator interface

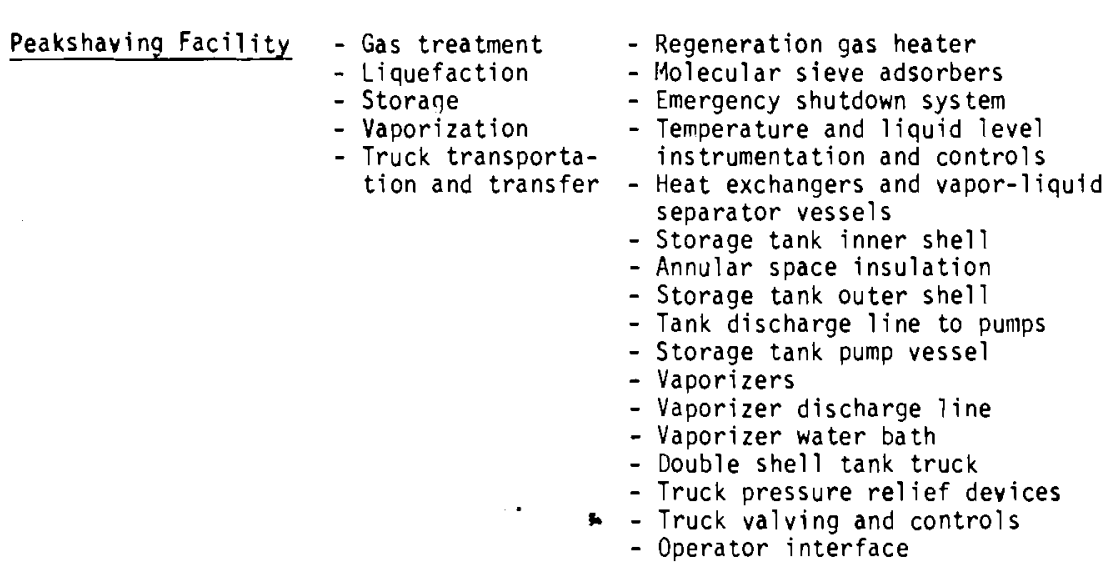

Satellite Facflity - Truck transpor- - Double shell tank truck tation and trans- - Operator interface

fer
- Storage
- Vaporization$$
\text { - Truck pressure relief devices }
$$$$
\text { - Storage tank inner shell }
$$

Representative Release Events

1. Ruptured 36-in. main transfer lin between loading pumps and dock.

2. Ruptured 24-in. liquid outlet 1 ine between storage tank and first block valve.

3. Ruptured 16-in. loading arm

- Storage tank pressure or vacuum rellef valves open.

Inner tank overfilled with L.NG.

6 . Complete fallure of storage tank.

Ruptured $18-1 \mathrm{n}$. gas feed line in liquefaction train.

. Ruptured 20-in. mixed refrigerant liquid piping between high pressure separator

9. Ruptured refrigerant exchanger.

10. Failure of refrigerant compressor. 1. Ruptured 12 -in transfer line from liquefaction area to the storage tanks.

2. Ruptured outlet nozzle or piping on refrigerant storage tanks.

1. Ruptured LNG cargo tank.

2. Overftlled cargo tank.

3. Pressure relief valves release.

4. Rupture or leak in cargo handling. system.

5. Rupture or leak in vapor handling

6. Misoperation of cargo handling
system. system results in LNG/vapor release.

1. Failure of inner storage tank.

2. Failure of storage tank outer barrier.

3. Release of LNG from loading arms.

4. Failure of LNG transfer line from unloading dock to shore.

5. Failure of LNG transfer 1 ine from shore to storage.

6. Failure of LNG transfer line from storage to secondary pump.

7. Failure of LNG transfer line from secondar' pumps to vaporizers.

. Failure of seawater-type vaporizer.

9. Failure of submerged combustion-type vaporizer.

10. Failure of vaporizer exit lines.

11. Failure of fuel gas compressor suction line.

12. Failure of LIVG recirculation line.

3. Failure
tanks.

4. Failure of vapor line from pipeline compressors to gas transmission pipeline.

1. Failure of natural gas supply line.

2. Failure of molecular sieve adsorber vessel

3. Failure of reoeneration gas heater heat exchange tube

4. Failure of LIIG piping in the cold box.

5. Fallure in refrigerant compressor section line.

6. Failure of refrigerant storage tank.

7. Failure of LNG storage tank.

8. Failure of LNG storage tank outlet.

9. Venting of natural gas through pressure relief values.

10. Failure of sendout pump vessel.

11. Failure of LNG supply line to vaporizers.

12. Failure of vaporizer heat exchanger tube.

13. Failure of natural gas line from vaporizers.

14. Failure of transfer line from storage to truck loading.

15. Failure of flexible loading/unloading hoses.

16. Failure of truck loading to storage vapor

return line.

17. Failure of truck LIIG tank.

18. Failure of trailer pressure buildup coil.

4. Failure of sendout pump vessel.

. Failure of the liquid lines to the
Areas Requiring More Information

Emergency shutdown system

Plant piping network Structural mechanics Structural tanks

Liquefaction plant

Lrocess contron plant

process control

Operator interface

with systems and

with systens
- Collision probability Effects of collision

on LNG vesse 1

Cargo handling system

design

Effects of spills,

Failure and explosions

- Operator interface

Component stresses from thermal cycling work design criteria Structural mechanics of the storage tanks - LNG vaporizer process control

Failure rate data

- Component stresses from thermal cycling Plant and component design details - Structural mechanics of storage tanks Failure rate data$$
\text { - Annular space insulation }
$$$$
\text { - Storage tank outer shel }
$$$$
\text { - Storage tank discharge line to }
$$$$
\text { pumps }
$$$$
\text { - LNG recirculation line from }
$$$$
\text { pumps to tank }
$$$$
\text { - Storage tank pump vessel }
$$$$
\text { - Boiloff heaters }
$$$$
\text { izer heat exchanger tubes }
$$$$
\text { - Natural gas discharge line from }
$$$$
\text { vaporizer }
$$

1. Failure of the storage tank.

2. Failure of exit gas line from boiloff heaters.

3. Failure of llquid discharge line from the satellite storage tank prior to the sendout pumps.

5. Failure of liquid recirculation line

6. Failure of vapor return lines from the sendout pumps.

8. Failure of the vaporizer heat exchanger

9. Failure of the natural gas line from the vaporizers.

- Thermal cycling stresses - LNG line relief valves Boiloff system design and construction - Storage tank design and construction Vaporization design and construction - Failure rate data

Temperature controller on vaporizer discharge line 


\subsection{REFERENCES}

Arthur D. Little, Inc. 1980. The Feasibility of Methods and Systems for Reducing LNG Tanker Fire Hazards. DOE/EV/04734-T1, Department of Energy, Washington, D.C.

J.S. Department of Energy. 1979. Liquefied Gaseous Fuels Safety and Environmental Control Assessment Programs: A Status Report. DOE/EV-0036, Department of Energy, Washington, D.C. 


\section{APPENDIX A}

\section{LNG INDUSTRY OVERVIEW}




\section{APPENDIX A}

\section{LNG INDUSTRY OVERVIEW}

To provide for continuing availability of natural gas, particularly to high-priority customers, the natural gas industry has pursued various methods of supplementing its supplies of natural gas both on an annual basis and during periods of peak demand. Liquefied natural gas (LNG) is one source of such supplemental gas supplies. This appendix briefly describes the various types of LNG facilities and the principal operations carried out at these facilities. Vapor dispersion and fire control systems are also discussed briefly. The reference LNG facilities considered in this study are discussed in detail in Appendices $B$ through $F$.

This appendix is based largely on information presented in a U.S. Department of Energy report (1978). Further, more detailed information on LNG facilities and components can be found in two reports by the American Gas Association (1973a and 1973b). Discussions of safety practices and requirements, design criteria, and codes and standards for LNG facilities are also available in the literature (British Cryogenics Council 1970, Allan et al. 1974, Bal1 1973, Bal1 1976).

\section{A. 1 LNG FACILITIES}

LNG facilities extend natural gas supplies to meet two basic types of demand: 1) base-load, year-round demand and 2) seasonal peak-use demand. Briefly, LNG facilities fall into the following categories:

- Export Terminals are large-capacity (185 to 1500 MMscfd liquefaction capacity) facilities that receive, clean, and liquefy natural gas and store the resulting LNG until it is loaded on ocean-going tankers for shipment to base-load import terminals. The reference export terminal for this study is described in detail in Appendix B.

- LNG Marine Vessels (Tankers) are ocean-going ships and barges that transport LNG from export terminals to import terminals. The on-board LNG storage tanks are of either the self-supporting or the membrane design. Basically, a self-supporting tank is structurally independent of the 
ship's hull, whereas a membrane tank's structural support is provided by the ship's hull. Vessels on order or in operation for U.S. trades range in size from 40,000 to $130,000 \mathrm{~m}^{3}$, but vessels of up to $165,000 \mathrm{~m}^{3}$ are under consideration. A detailed description of the reference marine vessel is presented in Appendix $C$ of this study.

- Import Terminals (Base-Load Facilities) are large-capacity (150 to 1000 MMscfd) facilities receiving noncontinental LNG from ocean-going tankers, storing it, and regasifying it to supply base-load demands on the importing company. Storage capacities generally range from 200,000 to $3,000,000 \mathrm{bbl}$ of LNG. Appendix D presents a discussion of the reference import terminal for this study.

- Peakshaving Facilities have gas treatment, liquefaction, and storage units of relatively small capacity coupled with high-capacity vaporizers to supply extra gas when the normal pipeline capacity cannot meet peak demands. Storage capacities range from 45,000 to 630,000 bbl of LNG. During warm weather and other periods of low demand, surplus gas is liquefied and stored for later use. The reference peakshaving facility is discussed in Appendix $E$ of this study.

- Satellite Facilities are small facilities similar to peakshaving plants but without liquefaction capability. LNG is supplied normally by tank trucks (but could also be supplied by barge, pipeline, or rail tankers). The larger satellite plants (over about 5000 bbl of LNG storage capacity) are field erected, whereas smaller units generally use shop-built cryogenic tanks for storage. A detailed description of the reference satellite plant for this study is presented in Appendix F.

- Tank Trucks are over-the-road cryogenic trailers (pulled by tractors) constructed with double-shell tanks insulated in the annular space. The tankers' capacities are on the order of 10,000 gallons. The equipment and operations used for truck transport are discussed in Appendix $E$, together with peakshaving operations. 


\section{A.2 PRINCIPAL OPERATIONS AT LNG FACILITIES}

In the course of LNG production and utilization, four principal unit operations are typically involved:

- gas treatment

- liquefaction

- storage

- vaporization.

As previously discussed, these operations are not all performed at each type of facility. Figure A.l shows which operations relate to each type of facility. Transport between facilities, by either ship or truck, may also be involved.

Each of the major operations are briefly discussed in the following subsections. More detailed discussions are included in the appropriate facility descriptions (Appendices B through F).

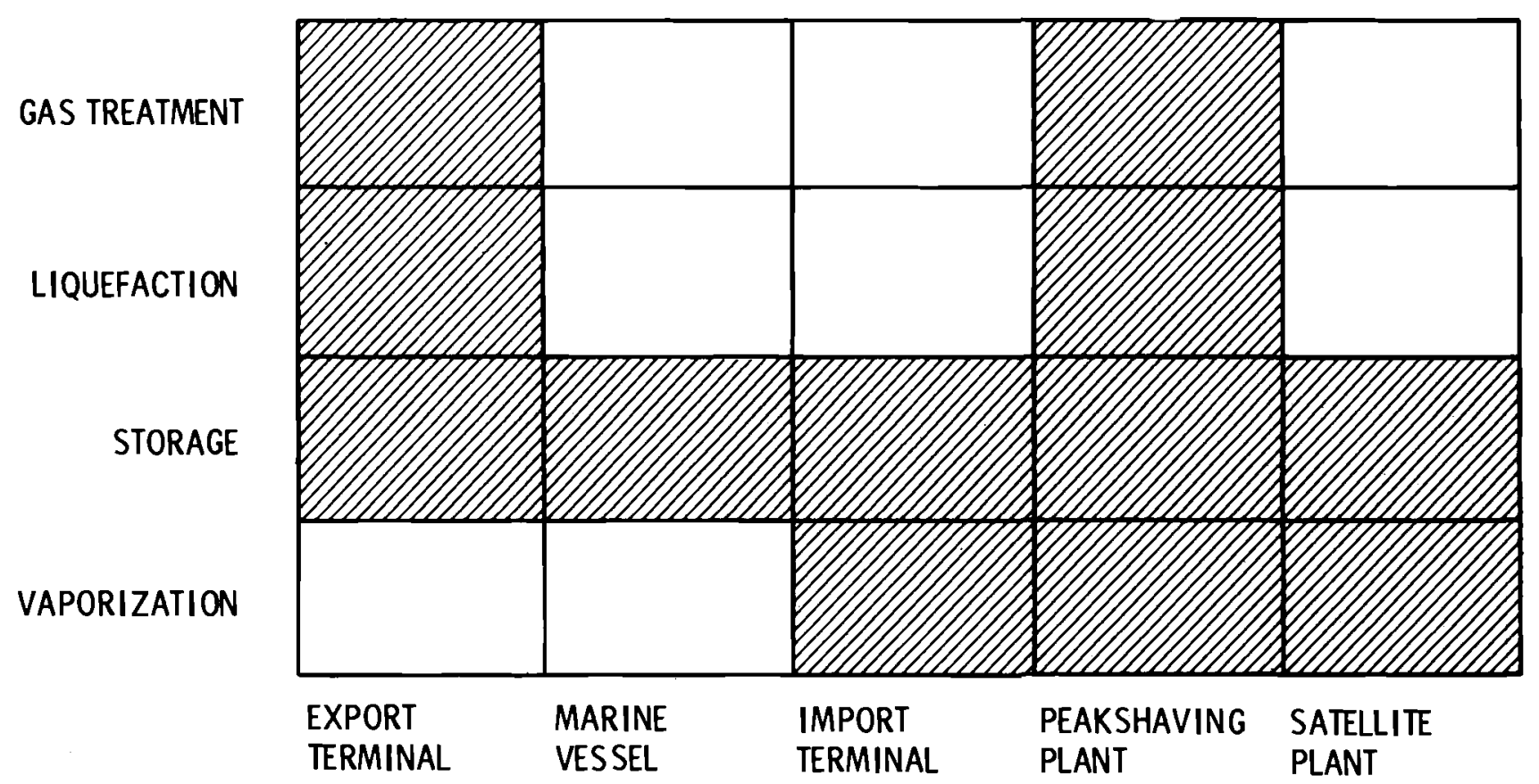

FIGURE A.I. Principal Operations Performed at Various LNG Facilities 


\section{A.2.1 Gas Treatment}

Since 1 iquefaction of natural gas requires temperatures as $10 \mathrm{w}$ as $-260^{\circ} \mathrm{F}$, any constituents in the gas that might solidify at cryogenic temperatures must be removed (or reduced to sufficiently low concentrations) to prevent plugging of piping or valves and fouling of heat exchangers. Two such constituents found in all natural gas feedstock are water and carbon dioxide. In addition, heavy hydrocarbons (e.g., hexane, benzene, lubricating oils), dust, and sulfur compounds used as odorants must be removed. The processes and equipment used are relatively conventional and have been adapted from other gas processing operations.

Water is usually removed using molecular sieves (synthetic zeolite absorbants), though activated alumina, activated bauxite, and silica gel have been used as solid desiccants. Most plants have three drying towers: the first in service for drying the gas, the second being regenerated by counterflowing heated dry gas, and the third cooling. Dehydration using glycol solutions has also been used, but this process alone does not remove enough water and thus is generally utilized as a first-stage dehydration system followed by a final dry desiccant step.

For carbon dioxide and sulfur compound removal, both wet and dry processes are used; the amine process and the molecular sieve process are most widely used.

The amine process involves a chemical reaction between the gas contaminate and the amine solution in a counterflow column. The amine solution is then stripped of the $\mathrm{CO}_{2}$ and $\mathrm{H}_{2} \mathrm{~S}$ gases in a distillation column by the addition of heat which reverses the chemical reaction.

The molecular sieve process for $\mathrm{CO}_{2}$ removal has been used extensively in peakshaving plants in recent years. One advantage to this process is that the molecular sieve may simultaneously remove both water and carbon dioxide in a single unit. Molecular sieves are synthetic zeolite compounds that selectively adsorb gases and liquids from process streams. As in other processes for constituent removal, a regeneration step is necessary in which the sieve is warmed and purged to release the adsorbed contaminates. 
The Rectisol process utilizing an organic solvent, usually methanol, is also used in some instances for removal of $\mathrm{CO}_{2}$ and $\mathrm{H}_{2} \mathrm{O}$.

The type of process and equipment used at a particular plant is determined by the plant designers based on normal engineering and cost factors.

\section{A.2.2 Liquefaction}

The liquefaction section of an LNG plant provides for the removal of sensible and latent heat from the incoming natural gas to convert it to a liquid at atmospheric pressure. Liquefaction plants can be designed in several different ways depending on engineering and cost requirements, so only a brief general discussion of the processes is provided here.

The two basic means of liquefaction are the cascade cycle and the expander cycle. These are both standard refrigeration cycles, details of which are widely available in the literature.

The cascade cycle uses the following major equipment components:

- compressor unit or units

- heat exchangers

- cooling tower

- instrumentation and control system.

The cycle utilizes a series of refrigerants to sequentially obtain a lower temperature in each step. The refrigerants used provide overlap in their condensation and vaporization temperatures without requiring extensive pressures. A modified version of the cascade cycle uses a blend of refrigerants in a single refrigerant circuit and thus requires only a single compressor.

The expander cycle utilizes the Joule-Thomson effect to provide direct cooling as the compressed gas expands isentropically through an engine or turbine, producing work. The amount of refrigeration produced is related directly to both the amount of gas and the ratio of the expander inlet and outlet pressures. In natural gas liquefaction, the expander cycle is utilized primarily where large quantities of gas are available at high pressures (e.g., from high-pressure transmission systems). The major equipment components in the expander cycle include an expansion turbine, heat 
exchanger unit, compressor unit for recompression, and instrumentation and control.

\section{A.2.3 Storage}

Storage systems for LNG involve a basic container for the liquid; an insulation system to control heat transfer to the liquid; piping, valves, pumps, etc., for transfer of liquid into and out of storage; a vapor control system; and various instrumentation for determining the status of the tank and its contents.

Large LNG storage tanks are designed to store the boiling liquid at vapor-space pressures usually in the range 0.5 to 2 psi above atmospheric pressure. At these pressures the liquid is at temperatures near $-260^{\circ} \mathrm{F}$. (Some small tanks, particularly truck tanks, are designed for operation at somewhat higher temperatures and pressures.) Liquid loss rates by boiling are held at low values, typically 0.1 percent per day or less, by means of insulation that limits heat influx to the liquid. The vapor space pressure is maintained above atmospheric pressure in order to preclude leakage of air into the vapor space; there are upper and lower limits for the vapor space pressure for each tank design based on structural integrity considerations. Maintenance of the tank pressure within these limits requires pressure sensors and control of the rate of withdrawal of liquid and vapor, plus pressure and vacuum vents for protection against over-or under-pressure due to unusual circumstances.

Most LNG tanks are cylindrical, with flat bottoms resting on the ground or on a structural platform above the ground. Care must be taken in designing tanks to be built on the ground to consider the effects of heat conduction from the earth into the tank, especially the possibility of frost heave of the soil. Typically, cryogenic storage tanks are built with two walls. The inner tank is constructed of appropriate materials to withstand the cryogenic temperatures associated with the LNG. The outer tank is not designed to hold LNG, but provides both weather protection for the tank insulation and a vapor-tight seal around the inner tank. In most tanks the two walls are both metal, but some tanks have been constructed with a prestressed concrete inner wall to contain the liquid. One tank has been built with a concrete 
outer wal1, the 1 iquid containment consisting of a mylar-aluminum laminate supported against plastic foam insulation by a metal lattice framework. The inner tank in most cases does not have a vapor-tight top; insulation is supported on a light framework over the top of the tank, and vapor diffuses into the whole insulation space. This type of design makes adequate purging of a tank into or out of service somewhat more difficult. Special plumbing is therefore provided to facilitate purging the insulation.

Inlet and outlet piping for LNG penetrates the tank either through the wall near the bottom or directly through the bottom, or enters the tank through the roof. In the latter case, sendout pumps are mounted in the liquid on the floor. Designs in which piping does not penetrate the bottom or the wall below the liquid surface are preferred because of the reduced likelihood of spilling the entire contents of the tank. However, inclusion of an internal valve at the opening in the tank reduces the possibility of such spillage. Inlet piping is designed to avoid stratification of LNG by providing for adequate mixing of new LNG with old LNG. This can be done in part by injecting heavier LNG at the top, and vice versa, and by appropriate design of the nozzles to promote mixing.

Materials for inner tanks, piping, and other components subject to temperatures ranging from ambient to cryogenic must retain strength and ductility throughout that range. A large amount of research has established certain metals, especially 9 percent nickel steel, stainless steels, and certain aluminum alloys, as having appropriate strength and ductility characteristics, in both base metal and welds, for this service. The 9 percent nickel steel and 5083 aluminum alloys are generally used for metal inner tanks of large containers, whereas stainless steels are used for piping, components, and some smaller storage tanks. These materials are recognized in standards, e.g., API 620 (1971), as being suitable cryogenic materials for LNG service. Concrete also is recognized in NFPA 59A (1975) and other codes and standards by reference as an acceptable material for containers subject to LNG temperatures; the standards specify requirements for measuring, mixing, placing, testing, etc., in order to obtain concrete with desirable properties for low temperature service. 
The safety and reliability of LNG storage tanks and associated piping and components depends on many aspects of design, construction, testing, operation, and maintenance, all of which are covered in considerable detail in the applicable codes and standards. A first step in the planning of a facility is the choice of a site, and an important factor in the site selection is the suitability of the soil for a tank foundation. Detailed designs of the tank and accessories will, of course, include complete specifications for all materials to be used, for methods of assembly, for testing and inspection of critical materials, welds, etc., and for proof testing of the vessel when completed. Among the many factors which must be considered during design are: seismic loads, including the possibility of liquid sloshing out of the inner tank into the insulation space; secondary loads including wind, snow, etc.; requirements for purging; requirements for mixing and for instrumentation to minimize possible stratification and its effects; cooldown requirements; and pressure and vacuum control.

A11 above-ground LNG tanks are surrounded with dikes to contain spilled material and to limit the hazards resulting from the spill. Most dikes for large tanks are earthen, and generally are low in profile, i.e., the height is small compared to the horizontal dimensions. A few facilities have high dikes made of concrete; some of these additionally have insulation applied to the floor and lower walls of the impoundment to reduce vapor generation in case of a spil1. In order for a dike to serve the intended purpose, it is necessary that the drainage of surface water be provided for, without at the same time providing a pathway through the dike wall for LNG. The dike should be relatively impervious to $L N G$ and should be resistant to damage by forces such as earthquakes, floods, etc.

Various codes, standards, and guidelines require or suggest the volumes of dikes, the positions of tanks within dikes, distances from dikes to property lines, etc. For example, NFPA 59A (1975) specifies that a dike have a volume equal to that of the full container if there is only one container within the dike or, if more than one, that a spill of one tank will not damage another by exposure to fire or to low temperatures. Some codes provide for dike volumes greater than 100 percent of tank volume. These requirements are 
based on the anticipated need for extra allowance for frothing of spilled LNG, allowance for vapor storage during the early moments of the spill to reduce the dispersion hazard, and to reduce the likelihood of liquid sloshing over the top of the dike. Although in the past most dikes have been built with soil, increasing consideration is being given to materials with more favorable heat transfer characteristics, such as insulating concrete.

To minimize the potential hazards (primarily to plant personnel and to plant equipment) from relatively small spills, the area enclosed by the dike is graded around processing and liquefaction equipment, vaporizers, pumps, piping, etc., so that LNG spilled in these areas will drain away from the equipment into a sump in a remote corner of the impoundment area.

\section{A.2.4 Vaporization}

Vaporization (or regasification) is accomplished using relatively standard and well-proven equipment. The first step of regasification requires the pumping of the LNG to a sufficient pressure so that the natural gas can enter the transportation system, either at distribution or transmission system pressures. Three types of standard pumps are being used at the present time. These are:

- vertical multistaged deep-well turbine pumps

- multistaged submersible pumps

- multistaged horizontal pumps.

The type of pump used is dependent upon engineering factors (such as discharge pressure, volume, and flexibility needed) as well as economics.

The LNG is vaporized by the transfer of heat to a liquid which then heats the LNG to its bubble point, vaporizes it, and superheats the vapor to discharge temperature. Here again, a number of factors, such as whether the facility is baseload or peakshaving, will determine which method of vaporization is feasible. Vaporizers are categorized as:

- integral fired

- remote fired

- ambient heated

- process heated. 
In the integral-heated vaporizers, the tubes through which the LNG flows can be heated by direct impingement of a flame, by radiation, by convection of hot combustion gases, or by a heat-transfer medium such as water between the flame and tubing carrying the LNG. The latter is also called a submerged combustion vaporizer. In remote-heated vaporizers, the primary heat source is remote from the vaporizing exchanger and an intermediate heat-transfer fluid is used. The fluid is heated in a boiler or fired heater and then pumped to the vaporizer where it vaporizes the LNG and warms the natural gas. Ambient heated vaporizers are used in small LNG installations and utilize atmospheric air, sea water, or geothermal waters as their heat source. Process heated vaporizers extract their heat from another thermodynamic or chemical process or operate in such a manner as to utilize the refrigeration effect available from the LNG.

A reliable control system is essential to any of these vaporizers to ensure that gas is available at the outlet at the required pressure, temperature, and flow rate and to provide protection for the facility by limiting pressure and temperature. If the temperature and/or pressure limits are exceeded, the control system must provide for shut-down or other protective response. In addition, normal purge and flame safety controls are employed in the operation of fired vaporizers. Ice formation on vaporizer tubes can also be a problem, and therefore means of detecting and preventing such formation are provided.

\section{A.3 VAPOR DISPERSION AND FIRE CONTROL SYSTEMS}

LNG facilities are designed with features and equipment to limit or control the hazards of vapor dispersion and of fire. Both passive features and active systems are included.

Basic limitation of both the dispersion and the radiation hazard is determined by selection of sites, distances from property lines to the inside surface of the dike, and location of the tank (or tanks) and other equipment within the dike. In addition to these considerations, significant factors in controlling the vapor dispersion hazard include limitation of the boiling rate of spilled LNG by choice of dike-face materials, limitation of total 
vaporization rate by configuration of the dike floor, and design of the dike to have vapor holding capacity, either by oversizing the dike itself or by adding a tight vapor fence on the top of the dike. Other techniques for control of the dispersion hazard have been considered, such as open vapor fences, water sprays, high-expansion foams, blowers to increase mixing with air, etc. Some facilities are equipped with automatic foam equipment actuated by signals from low temperature detectors in the sump floor, so that foam can be produced and delivered in $\sim 15$ seconds (Drake and Wesson 1976).

Fire hazard control begins with careful planning of the facility to limit exposure of parts of the plant to fires in other parts, as suggested above. Passive techniques of fire control also include the use of fire resistant construction, such as concrete and ablative, subliming, and intumescent coatings. Many such materials have been tested under radiation and flame impingement conditions and the results have been summarized (Drake and Wesson 1976). Active protective techniques include systems for spraying water directly on tanks and other structures near fires for temperature control. The designs of such systems are covered in various codes and standards (Drake and Wesson 1976). Water curtains are also used between potential spill areas and vulnerable equipment at some facilities. As indicated above, some facilities have installed foam systems for rapid placement of foam blankets; this serves two purposes, reduction of vapor generation rate and radiation reduction in case of fire. Finally, systems for application of dry chemicals for extinguishment of LNG fires are in general use. 


\section{REFERENCES}

Allan, D. et al. 1974 Technology and Current Practices for Processing, Transferring and Storing Liquefied Natural Gas. A. D. Little, Inc., Report to the Department of Transportation, $\mathrm{PB}-241048$.

American Gas Association. 1973a. LNG Information Book, 1973. LNG Information Task Group of LNG Committee.

American Gas Association. 1973b. Introduction to LNG for Personnel Safety Accident Prevention Committee of the Operating Section.

API Standard 620, Low Pressure Storage Tanks for Liquefied Natural Gas. June 1971.

Ba11, W. L. 1973. "Current Status of National, State, and Local LNG Codes and Standards." Pipeline and Gas Journal, pp. 46, 49, 59, 60, 62, 64.

Ba11, W. L., 1976. "NFPA-59A Storage and Handling of Liquefied Natural Gas-1975, A Review of Recent Changes." Presented at A.G.A. Transmission Conference, Operation Section Proc., T-169 to T-171.

British Cryogenics Council. 1970. Cryogenics Safety Manual, A Guide to Good Practice. Safety Panel, London, S.W. 1, 1970.

Drake, E. M. and H. R. Wesson. 1976. "Review of LNG Spill Vapor Dispersion and Fire Hazard Estimation and Control Methods." Paper presented at A.G.A. Transmission Conference, A.G.A. Operating Section Proc., T-172 to T-188.

NFPA No. 59A-1975, Standard for the Storage and Handling of Liquefied Natural Gas (LNG). National Fire Protection Association, Boston, Massachusetts, (prior editions adopted in 1967, 1971, and 1972).

U.S. Department of Energy. 1978. An Approach to Liquefied Natural Gas (LNG) Safety and Environmental Control Research. DOE/EV-0002, Washington, D.C. 
APPENDIX B

FACILITY DESCRIPTION OF REFERENCE LNG EXPORT TERMINAL 
APPENDIX B

\section{FACILITY DESCRIPTION OF REFERENCE LNG EXPORT TERMINAL}

Export terminals, both planned and operating, are listed in Table B.1 together with pertinent details. Export terminals are located in Algeria, Alaska, Borneo, Abu Dhabi, Indonesia, Chile, Iran, and Libya. Specially designed cryogenic tankers ranging in capacity from 50,000 to $130,000 \mathrm{~m}^{3}$ transport the LNG from the export terminals to the import terminals located in Japan, Europe, and the United States. By 1985, these export facilities are projected to increase the total United States natural gas supply by about 7000 MMscfd, or about $12 \%$ of expected U.S. gas supplies.

Baseload operations in the United States began in 1969 with the AlaskaJapan project that exports 135 MMscfd of gas. Two additional baseload liquefaction facilities are planned for operation in Alaska; one with an expected liquefaction capacity of $400 \mathrm{MMscfd}$ and the other with a liquefaction capacity of 3375 MMscfd.

\section{B. 1 BASIC PROCESS FLOW}

A block flow diagram for an LNG export terminal is shown in Figure B. 1 . The description of the LNG export terminal was developed using information from the sources listed in Section B.5. The major unit operations involved are gas treatment, liquefaction, storage, and marine vessel loading.

Natural gas is supplied to the terminal through about 50 miles of offshore and 240 miles of onshore pipeline with a maximum allowable operating pressure of 1000 psig. A total of about 440 MMscfd of gas is received by the plant. About 40 MMscfd of this is used to meet plant fuel requirements, and the remainder of the gas ( $400 \mathrm{MMscfd}$ ) is liquefied and sent to storage. Allowing for storage tank losses through boiloff, estimated to be about $44 \mathrm{~m}^{3}$ of LNG per day, about 4.8 days are required to fill one of the two 550,000-bbl storage tanks. 


\section{TABLE B.1. International Baseload LNG Liquefaction Facilities}

\begin{tabular}{|c|c|c|c|c|c|c|}
\hline Company and Plant site & $\begin{array}{c}\text { Liquefaction } \\
\text { Plant Capacity } \\
\text { (MMscfd) }\end{array}$ & Type of Cycle & $\frac{\text { Storage }}{\text { (MNscf) }}$ & $\frac{\text { Capacity }}{(M b b 1)}$ & $\begin{array}{c}\text { Type of Storage } \\
\text { Container }\end{array}$ & Year of Operation \\
\hline Camel, Arzew, Algeria & 200.0 & Cascade & 1,840 & $\begin{array}{c}210 \\
(3 \times 70)\end{array}$ & $\begin{array}{l}\text { Aboveground } \\
\text { (2-aluminum } \\
1-9 \% \text { nickel) }\end{array}$ & $\begin{array}{l}1963 \text { et seq LNG } \\
\text { for export to } \\
\text { England, France }\end{array}$ \\
\hline Sonatrach (LNG-1), Arzew, Algeria & 1100.0 & APCI - MCR & 7,000 & $(3 \times 690)$ & $\begin{array}{l}\text { Aboveground } \\
9 \% \text { nickel }\end{array}$ & 1976 \\
\hline Sonatrach (LNG-2), Arzew, Algeria & 1000 & APCI - MCR & 10,500 & 2,880 & Aboveground & 1979 \\
\hline Sonatrach (LNG-3), Arzew, Algeria & 1500 & NA & NA & WA & Aboveground & 1979 \\
\hline Esso Libya, Marsa el Brega, Libya & 385.0 & APCI-MCR & 2,100 & $(2 \times 315)$ & $\begin{array}{l}\text { Aboveground } \\
9 \% \text { nickel }\end{array}$ & 1970 \\
\hline Sonatrach - Phase 1 , Skikda, Algeria & $\begin{array}{l}430.0 \\
\text { (3 trains) }\end{array}$ & TEALARC & 2,500 & $(2 \times 350)$ & $\begin{array}{l}\text { Aboveground } \\
9 \% \text { nickel }\end{array}$ & $\begin{array}{l}1972-\text { Export to } \\
\text { France }\end{array}$ \\
\hline $\begin{array}{l}\text { Sonatrach - Phase II, Skikda, } \\
\text { Algeria }\end{array}$ & $\begin{array}{l}170.0 \\
(1 \text { train) }\end{array}$ & PRICO & 1,250 & 350 & $\begin{array}{l}\text { Aboveground } \\
\text { 9\% nickel }\end{array}$ & 1977 \\
\hline $\begin{array}{l}\text { Sonatrach - Phase III, Skikda, } \\
\text { Algerid }\end{array}$ & $\begin{array}{l}350.0 \\
(2 \text { trains) }\end{array}$ & PRICO & 3,500 & $(2 \times 440)$ & $\begin{array}{l}\text { Aboveground } \\
9 \% \text { nickel }\end{array}$ & 1978 \\
\hline Brunei LNG, Lumut, Brunei, Borneo & 750.0 & APCI - MCR & 4,050 & $(3 \times 377)$ & $\begin{array}{l}\text { Aboveground } \\
9 \% \text { nickel }\end{array}$ & 1973 \\
\hline Phillips-Marathon, Kenai, Alaska & 185.0 & Cascade & 2,300 & $\left(3^{675} \times 225\right)$ & $\begin{array}{l}\text { Aboveground } \\
\text { a luminum }\end{array}$ & 1969 \\
\hline $\begin{array}{l}\text { Abu Dhabi Gas Liquefaction Co. Ltd., } \\
\text { Das Island, Abu Dhabi }\end{array}$ & 350.0 & APCI $M C R$ & 6,600 & $(2 \times 920960)$ & $\begin{array}{l}\text { Aboveground } \\
9 \% \text { nickel }\end{array}$ & $197 ?$ \\
\hline $\begin{array}{l}\text { Pacific Alaska LNG Co., Cook Inlet, } \\
\text { Alaska }\end{array}$ & 400.0 & APCI -MCR & 3,000 & 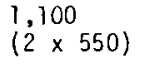 & $\begin{array}{l}\text { Aboveground } \\
9 \% \text { nickel }\end{array}$ & 1978 - Planned \\
\hline $\begin{array}{l}\text { Pertamina/Mobil, Arun. N. Sumatra, } \\
\text { Indonesia }\end{array}$ & 1200 & APCI-MCR & 8,350 & $\begin{array}{l}3,200 \\
(4 \times 800)\end{array}$ & $\begin{array}{l}\text { Aboveground } \\
9 \% \text { nickel }\end{array}$ & 1977 \\
\hline $\begin{array}{l}\text { Pertamina/Huffco, Badak E. Kali- } \\
\text { mantan, Indonesia }\end{array}$ & 550 & APCI-MCR & 6,250 & $(3,800 \times 600)$ & $\begin{array}{l}\text { Aboveground } \\
9 \% \text { nickel }\end{array}$ & 1978 \\
\hline $\begin{array}{l}\text { Empresa Nacional De Petroleo (ENAP), } \\
\text { Cabo Negro, Chde }\end{array}$ & 250 & APCI - MCR & NA & NA & NA & 1980 - Planned \\
\hline $\begin{array}{l}\text { El Paso Alaska, Inc., Point Gra- } \\
\text { vina, Alaska }\end{array}$ & $\begin{array}{l}3375 \\
\text { (8 trains) }\end{array}$ & $\begin{array}{l}\text { "Optimized" } \\
\text { Cascade }\end{array}$ & 6,000 & $\begin{array}{l}2,200 \\
(4 \times 550)\end{array}$ & $\begin{array}{l}\text { Aboveyround } \\
9 \% \text { nickel }\end{array}$ & 1980 - Planned \\
\hline Kangan LNG Co., Iran (on Persian & 1200 & NA & NA & NA & Aboveground & 1983 - Planned \\
\hline
\end{tabular}




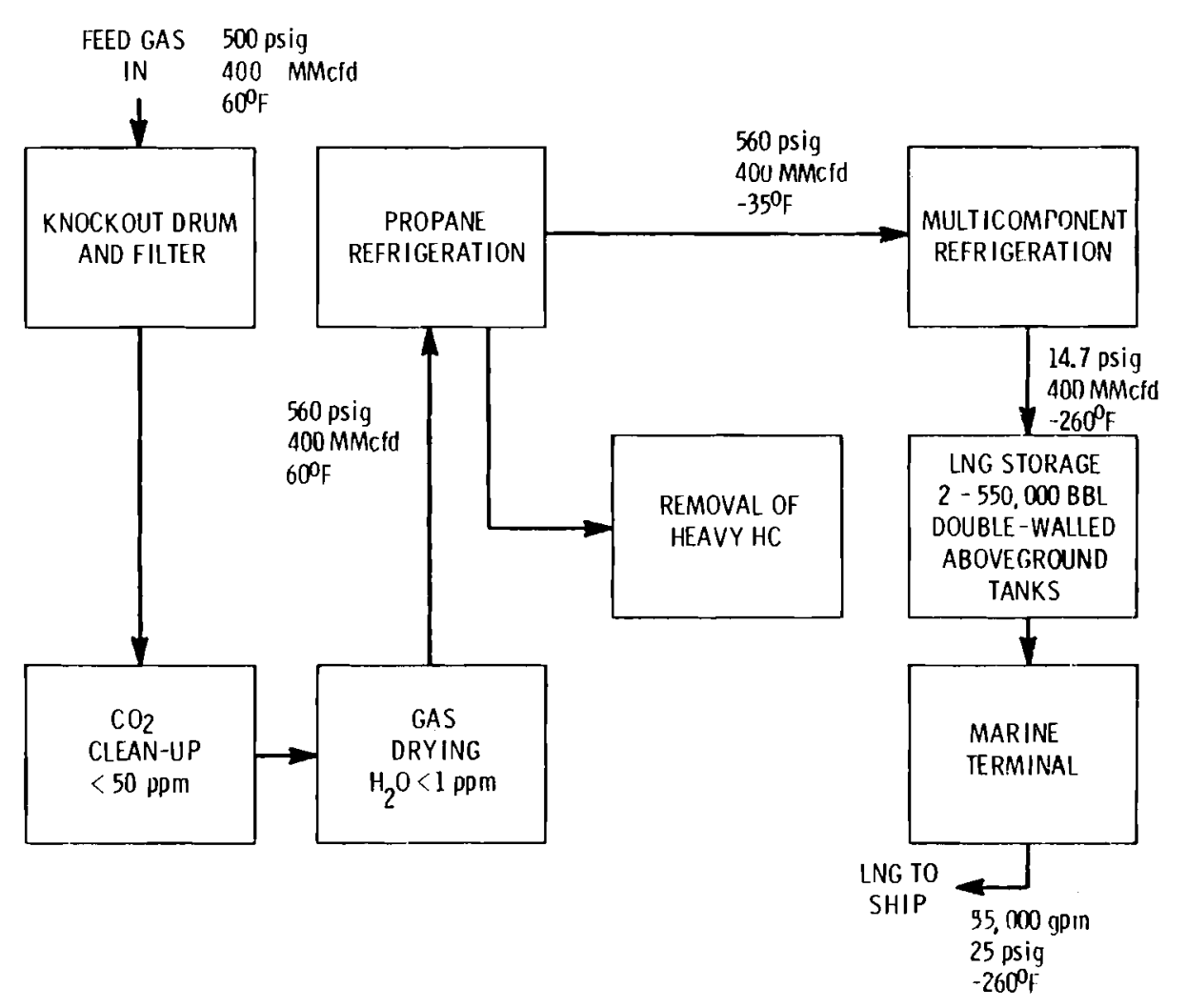

FIGURE B.1. Block Flow Diagram for LNG Export Terminal

Normal gas entering the plant is $99+\%$ methane. The gas enters at approximately $500 \mathrm{psig}$ and $60^{\circ} \mathrm{F}$, and passes through a knockout drum and filter to remove pipeline scale and dirt. From the filter, the gas passes through an MEA scrubber to remove all traces of $\mathrm{CO}_{2}$ and $\mathrm{H}_{2} \mathrm{~S}$ that might be present. The gas is then dried in a molecular sieve desiccant dehydrator to a dew point of about $-100^{\circ} \mathrm{F}$ at 500 psig. Two parallel beds are used in the drying cycle, allowing on-stream operation for twelve hours for each bed while the other bed is being regenerated.

The two-train 1 iquefaction system is rated at 400 MMscfd. The plant operates in the 1 iquefaction mode 345 days per year, with the remaining 20 days allocated for defrosting and maintenance. This plant incorporates a propane precooled multirefrigerant cycle (MCR) for liquefaction of natural gas. The propane-MCR design uses propane and a mixed refrigerant system consisting of nitrogen, methane, ethylene, and propane. Gas being liquefied flows through three stages of propane cooling followed by two stages of mixed refrigerant cooling. The LNG produced exits at approximately $-260^{\circ} \mathrm{F}$ and $15 \mathrm{psig}$, and is pumped to two 
550,000-bbl, double-walled, flat-bottomed, aboveground storage tanks of standard design for LNG. Normal boiloff, which is about $0.05 \%$ of total tank volume per day, is compressed and used to supplement plant fuel requirements.

Three pumps service each storage tank, with two normally used for sendout operations and the third on standby as a spare; however, only one storage tank can be emptied at a time. Loading of an ocean-going LNG tanker requires about 10 to 12 hours at a loading rate of 50,000 to $60,000 \mathrm{gpm}$. During loading, the ship discharges about 20,000 gpm of ballast water into the sea.

\section{B.2 PLANT LAYOUT}

A plot plan for the LNG export terminal is shown in Figure B.2. All major facilities and fire safety components are shown. Key distances to note from this plot plan include:

- minimum distance from storage tank to plant boundary--130 ft

- distance from storage tank to plant area--800 ft

- distance from ship loading dock to shore--2000 ft

- minimum distance from main equipment (1iquefaction trains) to plant boundary--130 ft

- minimum distance from storage tank to main equipment (cold box)--420 ft.

The safety features shown in the figure will be discussed with the various processes to which they are related.

\section{B.3 PROCESS DESCRIPTION}

The basic processes involved in the export terminal are described in detail in the following subsections.

\section{B.3.1 Gas Treatment}

Liquefaction of natural gas requires process temperatures as low as $-260^{\circ} \mathrm{F}$. Any constituents of the inlet gas stream that may become solid at these temperatures must be removed to eliminate fouling or plugging problems in the liquefaction unit. The two constitutents found in all natural gas streams that must 

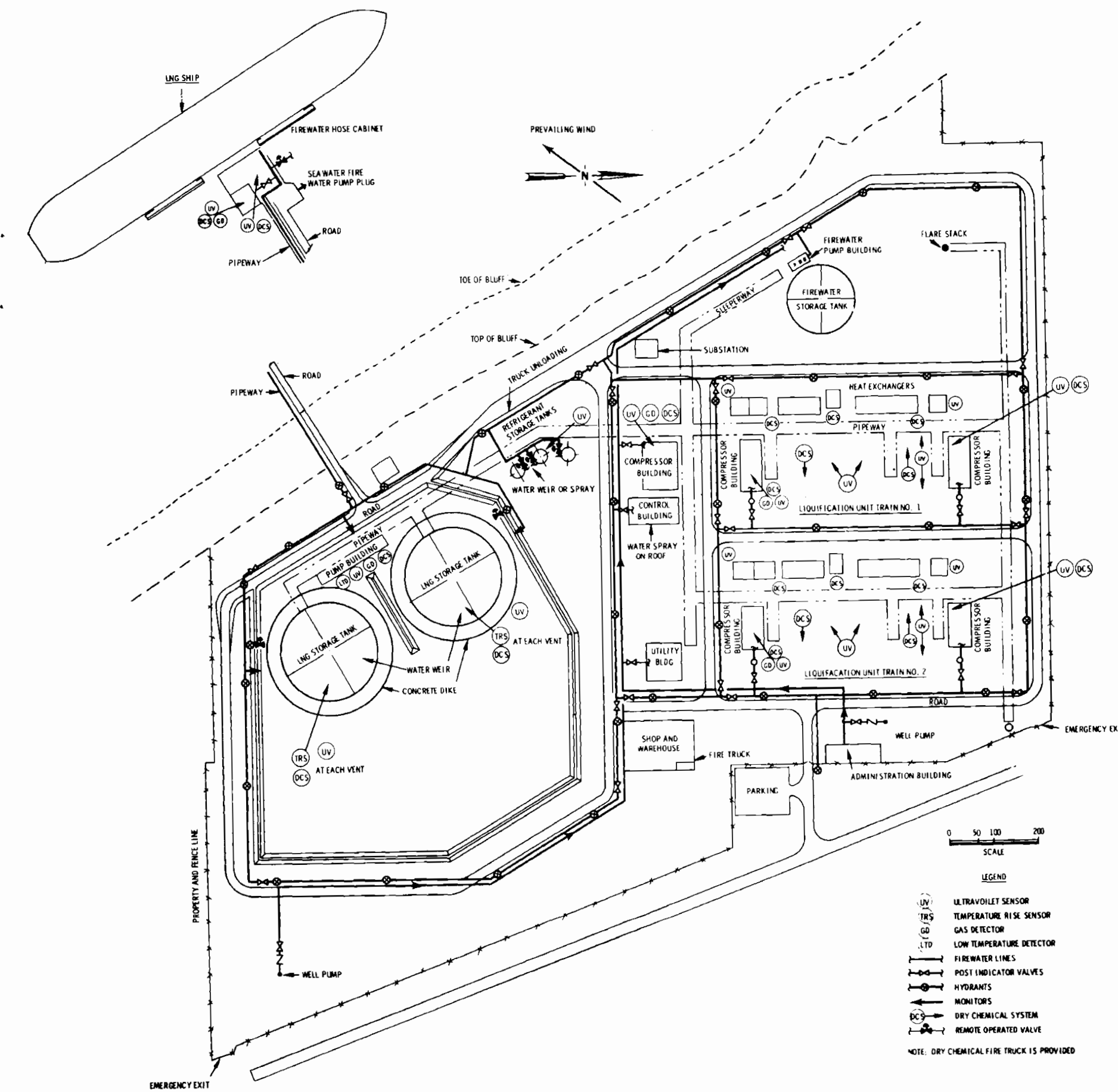

FIGURE B.2. Plot Plan for LNG Export Terminal 


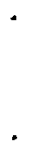


be removed are water $\left(\mathrm{H}_{2} \mathrm{O}\right)$ and carbon dioxide $\left(\mathrm{CO}_{2}\right)$. In addition, heavy straightchain hydrocarbons (such as hexanes), cyclic hydrocarbons (such as benzene), lube oils, dust, hydrogen sulfide $\left(\mathrm{H}_{2} \mathrm{~S}\right)$, and odorant mercaptan sulfur must be removed if present.

The process flow diagram for the gas treatment section is shown in Figure B. 3 . (Flow diagram symbols are defined in Appendix H.) Associated process conditions are given in Table B.2.

TABLE B.2. Gas Treatment Section (one train)

\begin{tabular}{|c|c|c|c|}
\hline Stream Description & $\begin{array}{l}\text { Pressure } \\
\text { (psig) } \\
\end{array}$ & Temp. $\left({ }^{\circ} \mathrm{F}\right)$ & $\begin{array}{c}\text { Flowrate per Train } \\
\text { (MMscfd) }\end{array}$ \\
\hline $\begin{array}{l}\text { Natural Gas Feed From } \\
\text { Pipeline }\end{array}$ & 500 & 60 & 200 \\
\hline $\begin{array}{l}\text { Natural Gas Feed From } \\
\mathrm{CO}_{2} \text { Removal Unit to } \\
\text { High Level Propane } \\
\text { Chiller }\end{array}$ & 560 & 100 & 400 \\
\hline $\begin{array}{l}\text { Natural Gas Feed From } \\
\text { Treatment Section to } \\
\text { Liquefaction Section }\end{array}$ & 560 & 60 & 200 \\
\hline Regeneration Gas & 500 & $\sim 60$ & 200 \\
\hline Fuel Gas Make-up & 500 & 60 & \\
\hline
\end{tabular}

Prior to liquefaction, the incoming natural gas passes through a knockout drum and a series of filters to remove pipeline scale and dirt. The natural gas feed line then passes on to the $\mathrm{CO}_{2}$ and water removal units.

\section{B.3.1.1 $\underline{\mathrm{CO}}_{2}$ Removal}

Carbon dioxide in its free state forms a solid at $-109^{\circ} \mathrm{F}$ and its solubility in LNG is about $250 \mathrm{ppm}$. The carbon dioxide content of the feed gas is approximately $800 \mathrm{ppm}$ at $500 \mathrm{psig}$ and $60^{\circ} \mathrm{F}$ and, thus, must be reduced to prevent plugging in the heat exchangers downstream. The amine process used for $\mathrm{C}_{2}$ removal reduces the carbon dioxide content to about $50 \mathrm{ppm}$. 
The amine process absorbs "acid gases" $\left(\mathrm{CO}_{2}\right.$ and $\mathrm{H}_{2} \mathrm{~S}$ simultaneously) with a lean aqueous organic-amine solution, monoethanolamine (MEA). Feed gas flows counter current to MEA solution in a packed tower. The absorption process is a chemical reaction between the acid gases, water, and amine in which amine carbonates, bicarbonates, and hydrosulfides are formed. The rich amine solution is stripped of the "acid" gases in a distillation column by the addition of heat, as steam, which reverses the chemical reaction and desorbs the "acid" gases from the solution. The "acid" gases are then disposed of.

Carbon dioxide removal rates of 0.12 to 0.20 scf per gallon for each 1 wt\% MEA in solution are common. MEA solution concentrations range from 15 to $25 \mathrm{wt} \%$ in water. Acid-rich amine solutions have an upper safe limit of acid gas content beyond which the solution becomes severely corrosive. A general rule for this upper limit is 0.45 moles $\mathrm{CO}_{2}$ /mole MEA. Inhibitors are added to the MEA solution to reduce corrosion and hydrocarbon foaming.

Steaming requirements for regenerating the $\mathrm{CO}_{2}$-rich MEA solution are 1.0 to 1.4 pounds of steam per gallon of flowing solution. Under-designed equipment may sometimes be operated at higher throughputs, but only at the risk of tower flooding, increased corrosion rates, incomplete stripping, and (most importantly) down-stream freeze-ups.

\section{B.3.1.2 Water Removal}

A little water can cause big problems in cryogenic LNG processing. Temperatures go as low as $-260^{\circ} \mathrm{F}$. The liquefaction heat exchangers have sophisticated networks of small-bore heat-exchange tubing. Frost or "rime" can form on the surfaces of the tubing, adding intolerable resistance to heat transfer and blocking gas flow.

Water removal is accomplished in two steps. Evaporating propane (Section B.3.2.1) cools the gas to $60^{\circ} \mathrm{F}$, and $70 \%$ of the water vapor condenses and is easily separated out. Final dehydration is effected by passing the gas through molecular sieve dessicants, $\mathrm{D}-201$ and $\mathrm{D}-202$, to a dew point of about $-100^{\circ} \mathrm{F}$ at 500 psig. The molecular sieve dryers reduce the water content to less than $1 \mathrm{ppm}$. 
Molecular sieves are synthetic zeolite crystals that can perform precise separation of different molecules. They can separate molecules selectively because of their physical structure: a myriad of tiny, precisely controlled pore openings and interconnected cavities within a crystal matrix.

The crystals are activated for adsorption by removing their water of hydration. Because little or no change in the remaining crystal structure occurs during this dehydration, highly porous adsorbents are formed that have an exceptionally strong selective affinity for water. As a result of this selective action, coadsorption of hydrocarbons is minimized and maximum water adsorption capacity is achieved.

The dehydration system is composed of a dual-bed installation at each of the liquefaction trains, allowing on-stream operation of each bed for twelve hours while the other bed is being regenerated.

When the molecular sieves in the first tower approach saturation, the inlet stream is switched to the second tower. Heated natural gas, flowing in the opposite direction of the stream that was being dried, desorbs the entrapped water from the saturated molecular sieves in the first tower. After leaving the tower, the warm, moisture-laden regeneration gas is cooled and compressed, and the water is condensed, separated, and removed from the stream. The regeneration gas then mixes with wet inlet gas prior to the $\mathrm{CO}_{2}$ removal unit (closed-cycle operation). The strength and integrity of the crystalline structure enables molecular sieves to withstand repeated adsorption-desorption cycles. Once dry, the regenerated tower is cooled by a flow of cool dry gas coming from the first dehydrating tower before being placed back in service. Switching from one tower to the other is accomplished by an operator-initated automatic-control valve system.

\section{B.3.2 Liquefaction}

At the export terminal, natural gas is cooled and liquefied in two stages in a propane precooled mixed refrigerant cycle. A propane refrigerant cycle, similar to the first stage of a cascade liquefaction cycle, provides about $25 \%$ of the feed cooling required. The propane cycle reduces the temperature of the feed gas to $-30^{\circ} \mathrm{F}$ and condenses out the heavy hydrocarbons present. 
The chilled feed gas then flows to the main cryogenic heat exchanger where a mixed refrigerant liquefies the gas and subcools it to $-260^{\circ} \mathrm{F}$. The product LNG is then transferred to the storage tanks.

Table B.3 and Figure B.4 show the details of a liquefaction train. The plant has two identical liquefaction trains, each with a capacity of 200 MMscfd.

\section{TABLE B.3. Liquefaction Section}

\begin{tabular}{|c|c|c|c|}
\hline Stream Description & $\begin{array}{l}\text { Pressure } \\
\text { (psig) } \\
\end{array}$ & $\begin{array}{l}\text { Temp. } \\
\left({ }^{\circ} \mathrm{F}\right)\end{array}$ & $\begin{array}{l}\text { Flowrate } \\
\text { (MMscfd) }\end{array}$ \\
\hline $\begin{array}{l}\text { LNG from Liquefaction } \\
\text { Section to Storage Tank }\end{array}$ & 560 & -260 & 200 \\
\hline $\begin{array}{l}\text { Mixed Refrigerant } \\
\text { from Low-Pressure } \\
\text { Compressor }\end{array}$ & 167 & 120 & 398 \\
\hline $\begin{array}{l}\text { Mixed Refrigerant } \\
\text { from High-Pressure } \\
\text { Compressor }\end{array}$ & 600 & 250 & 398 \\
\hline $\begin{array}{l}\text { Mixed Refrigerant } \\
\text { Vapor to Main Cryogenic } \\
\text { Heat Exchanger }\end{array}$ & 580 & -30 & 195 \\
\hline $\begin{array}{l}\text { Mixed Refrigerant } \\
\text { Liquids to Main Cryo- } \\
\text { genic Heat Exchanger }\end{array}$ & 580 & -30 & 195 \\
\hline $\begin{array}{l}\text { Mixed Refrigerant Vapor } \\
\text { to Low-Pressure Stage } 1 \\
\text { Compressor }\end{array}$ & 50 & -30 & 20 \\
\hline $\begin{array}{l}\text { Mixed Refrigerant } \\
\text { from Main Cryogenic } \\
\text { Heat Exchanger to Low- } \\
\text { Pressure Compressor }\end{array}$ & 50 & -35 & 308 \\
\hline $\begin{array}{l}\text { Propane to First Stage } \\
\text { Compressor }\end{array}$ & 1 & -25 & \\
\hline $\begin{array}{l}\text { Propane to Second Stage } \\
\text { Compressor }\end{array}$ & 25 & 15 & \\
\hline $\begin{array}{l}\text { Propane to Third } \\
\text { Stage Compressor }\end{array}$ & 85 & 70 & \\
\hline
\end{tabular}




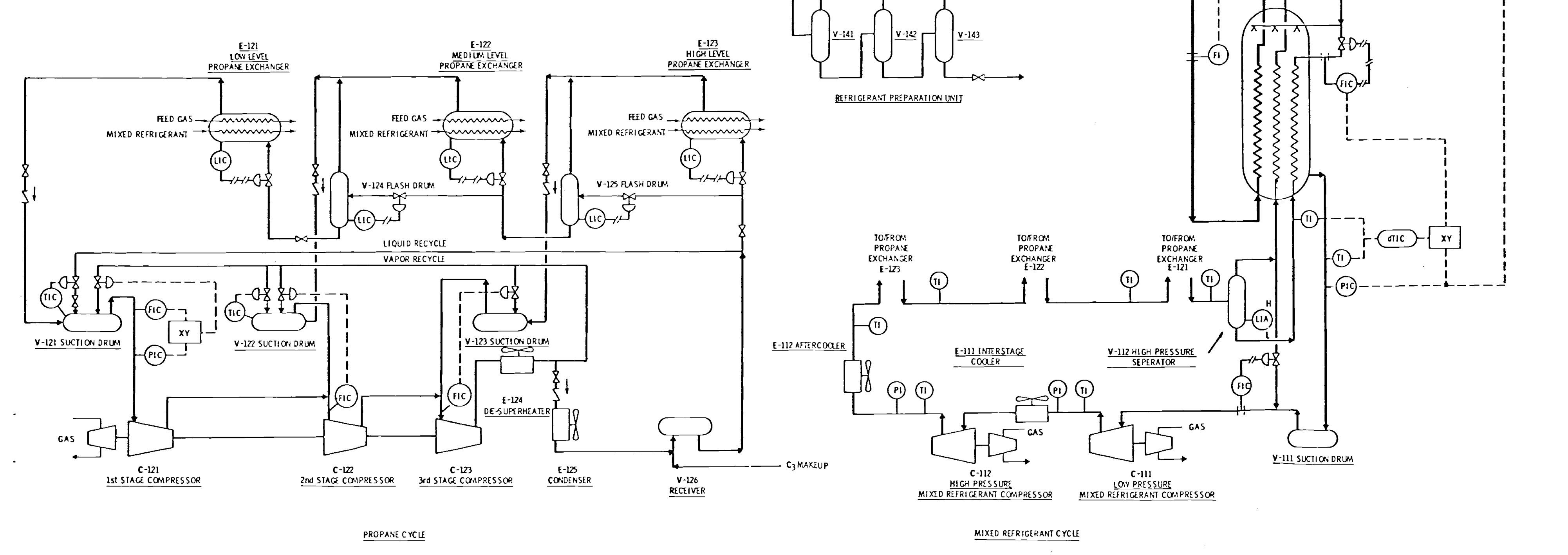

FIGURE B.4. Propane Precooled Multirefrigerant Cycle - Process Flow Diagram 



\section{B.3.2.1 Propane Refrigerant Cycle}

The propane refrigerant cycle cools both the feed gas and the high-pressure mixed refrigerant to $-30^{\circ} \mathrm{F}$. Propane evaporating at three different pressures provides three different levels of cooling.

High-level cooling takes place in E-123. Propane at 100 psia evaporates at around $55^{\circ} \mathrm{F}$ and $\operatorname{cools}$ the feed gas and mixed refrigerant to around $60^{\circ} \mathrm{F}$. After water is removed from the feed gas, both streams enter the medium-level exchanger, E-122. Here, evaporating propane at approximately 40 psia and $5^{\circ} \mathrm{F}$ cools the warm streams to $10^{\circ} \mathrm{F}$.

The heavy hydrocarbons in the natural gas condense at this temperature and are separated in the scrub column $V-102$. Vapors from the scrub column and the mixed refrigerant go to the low level propane exchanger, E-121, where the ir temperature is reduced to $-30^{\circ} \mathrm{F}$. Propane vaporizes at $-35^{\circ} \mathrm{F}$ and $16 \mathrm{psia}$ in E-121.

Propane vapor from E-121, E-122, and E-123 is compressed in a three-stage centrifugal compressor, $\mathrm{C}-121, \mathrm{C}-122$, and $\mathrm{C}-123$, and then cooled and condensed by cooling water. The heat removed from the natural gas is rejected to the cooling water and the liquid propane returns to E-121, E-122, and E-123 to complete the cycle.

Control of the cycle is quite complex. Basically, the propane vapor recycle is used to control the suction pressure of the first stage compressor. Because centrifugal compressors are essentially constant head machines, this also controls the suction pressure of the second and third stage machines. Flow through the compressors is kept constant by adjusting the relative flow rates through the exchangers and through the recycle loop according to the quantity of cooling required. The control system can handle a $60 \%$ step reduction in cooling load without adjusting the compressor speed.

\section{B.3.2.2 Mixed Refrigerant Cycle}

A multicomponent mixed refrigerant cycle liquefies and cools the feed gas to $-260^{\circ} \mathrm{F}$. Nitrogen, methane, ethyl.ene, and propane make up the mixed refrigerant. Pure nitrogen gas comes from an air fractionation $p l a n t$ on site. Methane, 
ethylene, and propane for makeup are separated from the feed gas in the refrigerant preparation unit.

The mixed refrigerant is cooled in the first two propane exchangers, E-123 and $E-122$, and then partia11y condensed in E-121. From E-121, the mixed refrigerant enters $\mathrm{V}-112$ and is separated into liquid and vapor streams. The liquid from $V-112$ is subcooled in the first stage of the main cryogenic heat exchanger, $E-102$, and then expanded into the she 11 side of the first stage of E-102 to provide cooling. Vapor from $\mathrm{V}-112$ is cooled and condensed as it passes through the tube side of both stages of E-102 and then is expanded into the shell side of the second stage to provide cooling.

Low-pressure (30 to $50 \mathrm{psig),} \mathrm{mixed} \mathrm{refrigerant} \mathrm{vapor} \mathrm{leaves} \mathrm{the} \mathrm{first}$ stage of E-102 and is compressed to 600 psig by two centrifugal compressors. The high-pressure vapor is cooled in two cooling-water heat exchangers before going to the propane heat exchangers and completing the cycle.

Primary control of the mixed refrigerant cycle is the two liquid expansion values on E-102. Control of each valve is flow; however, the set point for each controller can be reset automatically. Signals proportional to temperature difference at the warm end of E-102 and C-11 suction pressure can reset the flow controller for the first stage. The flow controller for the second stage can be reset by signals proportional to cold-end temperature difference and $\mathrm{C}-11$ suction pressure. Details of the control system were shown previously in Figure B.4.

The feed gas to be liquefied leaves E-213 in the propane cycle and enters the main cryogenic exchanger E-102. The gas is liquefied and subcooled by heat exchange with the mixed refrigerant. A control valve at the outlet of E-102 lets the gas down to storage tank pressure and controls the amount of LNG produced. The set point for this controller is the preselected LNG flow rate. However, if there is insufficent cooling available to meet this production rate, the set point may be reset automatically at a lower level by signals proportional to the LNG outlet temperature and the mixed refrigerant compressor suction pressure. 


\section{B.3.2.3 Liquefaction Equipment}

The propane refrigerant cycle uses standard horizontal, kettle-type, she11 and tube heat exchangers as shown in Figure B.5. These exchangers are constructed of carbon steel and the tubes have extended surfaces to increase the heat transfer area.

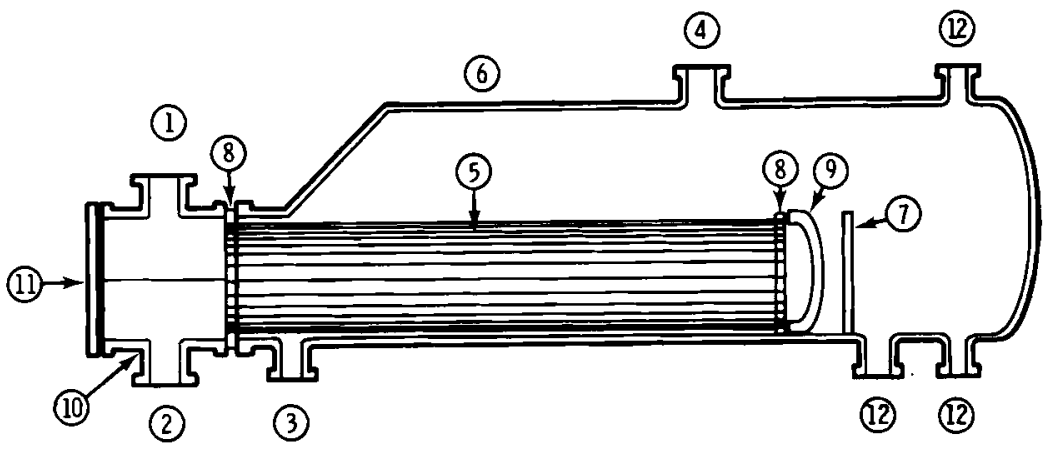

\footnotetext{
1. NATURAL GAS OR MIXED REFRIGERANT INLET NOZZLF

2. NATURAL GAS OR MIXED REFRIGERANT OUTLET NOZZLE

3. LIQUID PROPANE INLET NOZZLE

4. PROPANE VAPOR OUTLET NOZZLE

5. TUBES

6. SHELL

7. WEIR

8. TUBESHEETS

9. FLOATING HEAD

10. STATIONARY HEAD

11. CHANNEL COVER

12. ADDITIONAL NOZZLES
}

\section{FIGURE B.5. Propane Refrigerant Heat Exchanger}

The main cryogenic heat exchanger, E-102, is a spiral wound exchanger. It has thousands of feet of small-bore aluminum tubing arranged in two coil wound bundles, one for the cold (or upper) section of the exchanger and the other for the warm (or lower) section. There are three tube sheets at each end of the lower section for the mixed refrigerant liquid, mixed refrigerant vapor, and for the feed gas. Figure B.6 illustrates how the tubing is wound around a center mandrel and connected to the tube sheets.

Each liquefaction train for the export terminal includes four compressors having a total of 101,260 h.p. The two MCR compressors and the propane compressor are each driven by gas turbines rated at 37,600 h.p. (28 megawatts). The fourth compressor, the feed gas booster compressor, is driven by a smaller gas turbine ( 375 h.p/0.28 megawatts). 


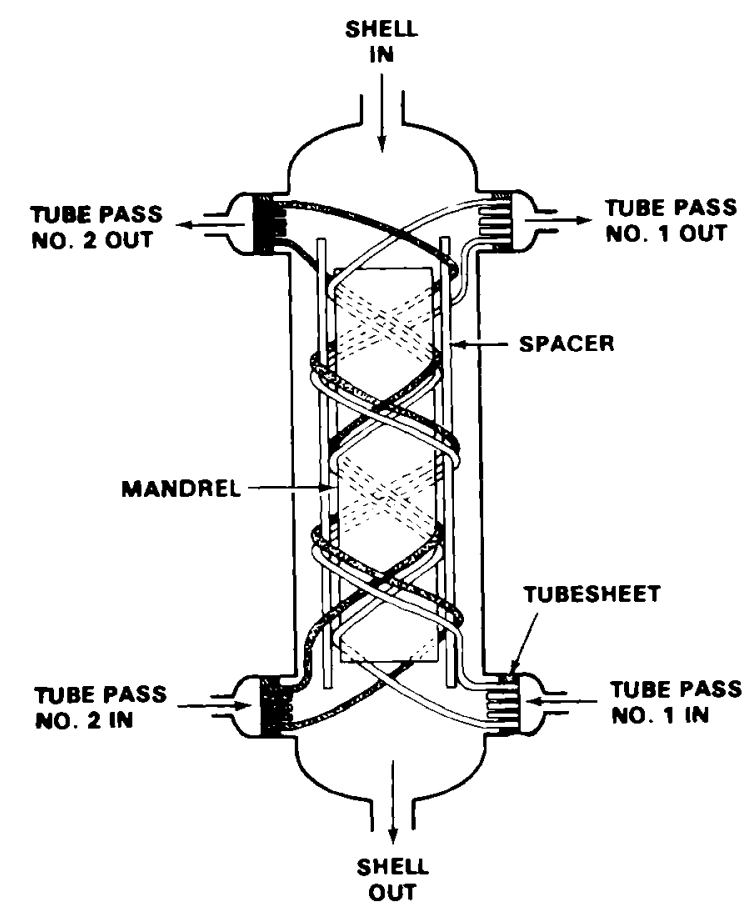

FIGURE B.6. Main Cryogenic Coi1-Wound Heat Exchanger

Materials of construction for the refrigeration compressors are:

- fine-grain carbon steel or $2 \%$ nickel steel case material for the propane refrigeration cycle

- D2M Ni Resist casings and 9\% nickel steel rotors for MCR cycle.

A11 four compressors are located in the compressor building (see Figure B.2). Each compressor has the following alarms and trips:

1. high discharge pressure alarm

2. suction and discharge high temperature alarm and trip

3. various alarms and shutdowns for seal $0 i 1$ and lube oil systems

4. high bearing temperature alarm and trip

5. excess vibration alarm and trip.

\section{B.3.2.4 Procedures}

Startup and Cooldown. To begin the cooldown process, the propane and MCR systems are charged with propane and natural gas respectively. The compressors are operated on total recycle to check out the controls and instrumentation. 
At this point, the feed gas portion of the liquefaction train is pressurized up to the LNG product valve at the outlet of E-102. The pressure control valve in the feed gas line is placed on automatic at the design pressure of around 600 psig. Next, the propane heat exchangers and the main cryogenic exchangers are pressurized with refrigerant gas. Refrigerant flow is then increased to maximum. As additional sections of the liquefaction train are pressurized, makeup refrigerant must be added to the system.

As the refrigerant gas cools and becomes more dense, the expansion valves, operated manualiy, are partially closed. When the LNG temperature before expansion across the LNG product value reaches its design value of $-250^{\circ} \mathrm{F}$, the valve is cracked open to start a small flow of LNG to storage. If the storage tank must also be cooled down, the procedure to be followed at this point is given in Section B.3.3.

Assuming the tank is already cooled down, the next step is addition of the other components: ethylene, propane, and nitrogen. The refrigerants are pumped from their storage tanks and added to the refrigerant at the suction side of the compressor. As the heavier components are added to the cycle gas, the rate of cooling and the power consumption of the compressor increase.

When LNG production reaches approximately $50 \%$ of design rate, the controls and instrumentation have been checked out completely, and refrigerant is at design composition, control of the system is switched to automatic and production is increased to design rate.

Shutdown. To shut down the liquefaction system, the flow of feed gas to the system is stopped and the compressors are either stopped or put on total recycle. If the shutdown is going to be short or is unscheduled, the compressors are usually left on total recycle. If the compressors are stopped and the system heats up, some refrigerant is vented either through vent valves or relief valves.

\section{B.3.2.5 Release Prevention and Control Features}

The following detectors, alarms, and fire protection equipment are located in the liquefaction area: 
- combustible gas detectors with alarms in the control room

- low temperature detectors with alarms in the control room

- UV fire detectors that automatically activate the ESD and alarm in control room

- dry chemical fire extinguishing system

- fire water lines and hydrant.

A dike surrounds each liquefaction train to contain spills of refrigerant or LNG. The surface beneath each liquefaction train is sloped to drain spills away from the equipment and into the corners of the containment area. Drains located at the corners of the impoundment area carry both rainwater runoff and LNG spills to the LNG storage tank containment area. The materials for the drains are selected to withstand cryogenic temperatures.

Compressor buildings include a two-stage ventilation system. The highspeed ventilation rapidly evacuates gas from the building if the gas concentration reaches $25 \%$ of the LFL of methane. A second level alarm, occurring at a higher gas concentration, automatically shuts down the compressor equipment. Gas sensors and flame detectors are located above the compressors and inside the compressor building. Visible and audible alarms are activated if gas concentrations reach $25 \%$ of LFL or if fire is detected. If a fire is detected by a UV detector, it automatically activates the Master Emergency Shutdown system.

\section{B.3.3 LNG Storage}

The LNG produced by the liquefaction system is stored at the facility until it can be loaded on marine vessels for export. The storage system and related equipment are described here.

The process flow diagram for the storage section (and for the marine terminal which is described in Section B.3.4) is shown in Figure B.7. Associated process conditions are listed in Table B.4. 


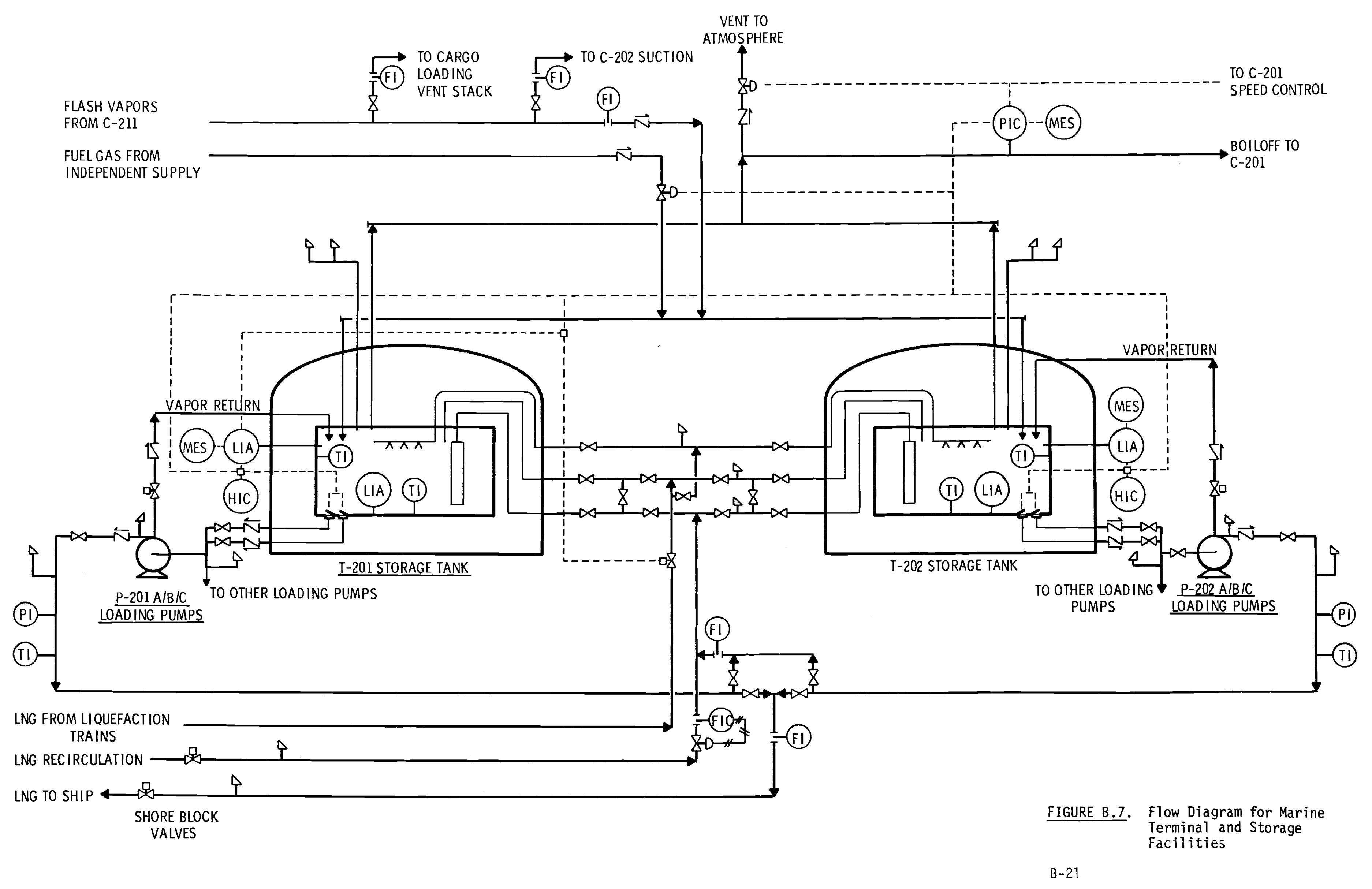



TABLE B.4. Storage and Loading Sections

\begin{tabular}{|c|c|c|c|}
\hline Stream Description & $\begin{array}{l}\text { Pressure } \\
\text { (psig) }\end{array}$ & $\begin{array}{l}\text { Temp. } \\
\left({ }^{\circ} \mathrm{F}\right)\end{array}$ & Flowrate \\
\hline $\begin{array}{l}\text { Independent Fuel Gas } \\
\text { Supply Line }\end{array}$ & - & -- & -- \\
\hline LNG Main Transfer Line & 25 & -258 & $50,000 \mathrm{gpm}$ \\
\hline LNG Recirculation Line & 25 & -258 & $1,500 \mathrm{gpm}$ \\
\hline Vapor Return from Ship & 5 & -220 & 32.1 MMscfd \\
\hline $\begin{array}{l}\text { Normal Boiloff from two } \\
\text { Storage Tanks }\end{array}$ & 1 & -220 & 2.0 MMscfd \\
\hline
\end{tabular}

\section{B.3.3.1 Storage Tanks}

Storage for the plant consists of two flat-bottomed, double-walled, aboveground LNG storage tanks, each with a capacity of 550,000 barrels, as shown in Figure B.8. The inner tank is constructed of $9 \%$ nickel steel, an alloy that retains its strength and ductility throughout the LNG temperature range. The outer she 11 is constructed of A131 carbon steel. The tank has an inner diameter of $215 \mathrm{ft}$ and an outer diamter of $225 \mathrm{ft}$. The she11 height is $98 \mathrm{ft}$, with an overall tank height of $146 \mathrm{ft}$.

The annulus between the inner and outer tank walls is filled with expanded perlite, an inorganic, non-flammable, lightweight insulation produced from special rock. The rock ore is finely ground and then expanded in furnaces at about $2000^{\circ} \mathrm{F}\left(1100^{\circ} \mathrm{C}\right)$. The perlite is expanded on site and placed in the insulation space while hot. A resilient fiberglass blanket is wrapped around the outside of the inner shell to alleviate the problem of perlite compaction that otherwise occurs with thermal cycling and movement of the inner she11 (see Figure B.9). The thermal conductivity of perlite in a methane atmosphere is 0.25 BTU-in. $/ \mathrm{hr} \mathrm{ft}^{2}{ }^{\circ} \mathrm{F}$.

The space between the inner and outer tank floors is insulated with a 25-in. layer of foamglass, a nonflammable load-bearing insulation. The load-bearing insulation rests on a concrete ringwall foundation around the tank perimeter and on a compacted sand foundation in the middle. A 1-ft layer of compacted sand located beneath the outer tank floor contains electrical heating elements 


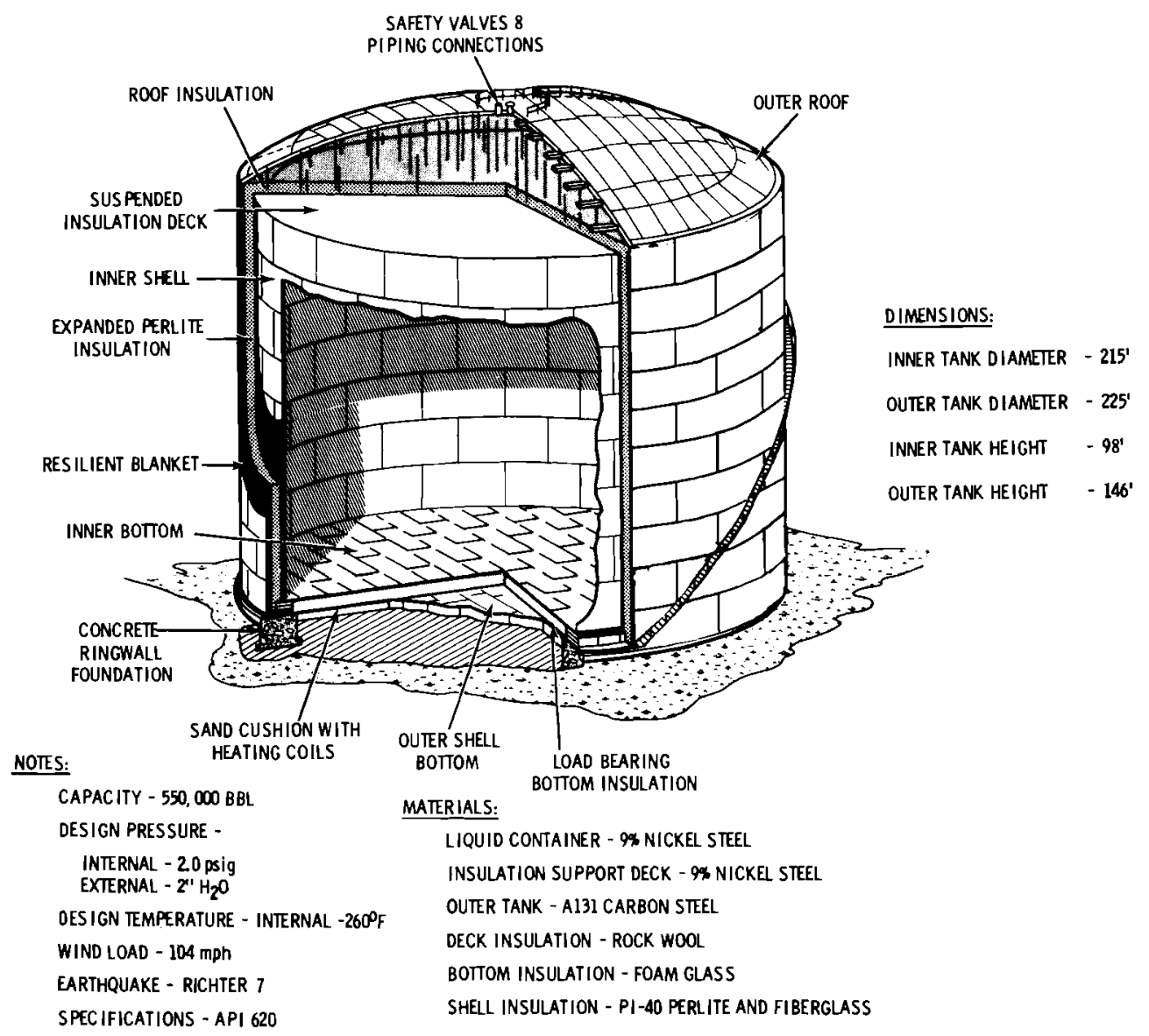

FIGURE B.8. LNG Storage Tank

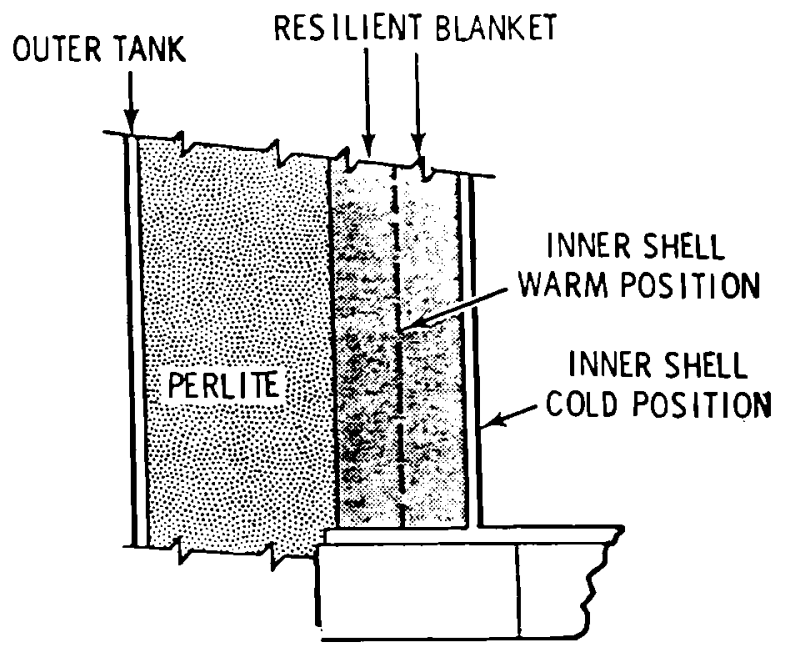

FIGURE B.9. Resilient Blanket in Annular Space Between Walls of LNG Storage Tank 
to prevent freezing of moisture in the subsoil and possible "heaving". Two sets of anchor bolts in the ringwall are connected to the outer tank wall and inner tank wall, respectively. These bolts hold down the tank against lifting forces resulting from internal pressures (see Figures B.10 and B.11).

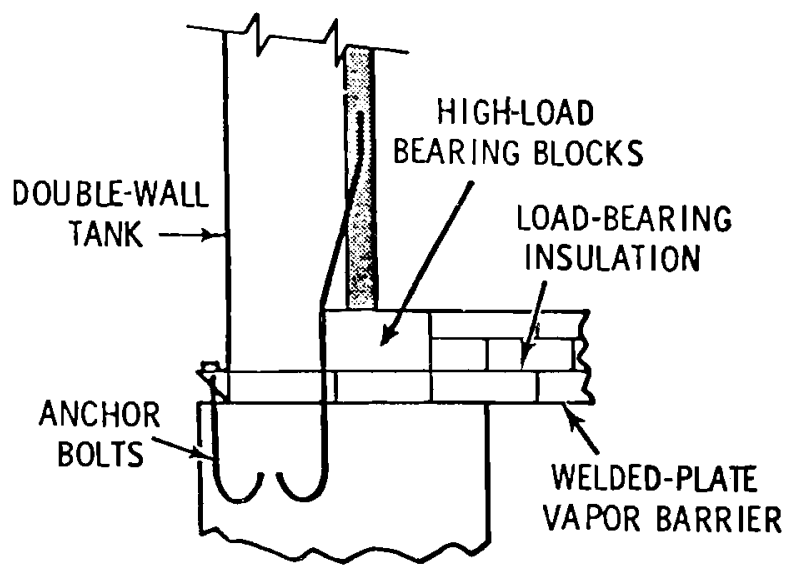

FIGURE B.10. Load-Bearing Insulation and Anchor Bolts

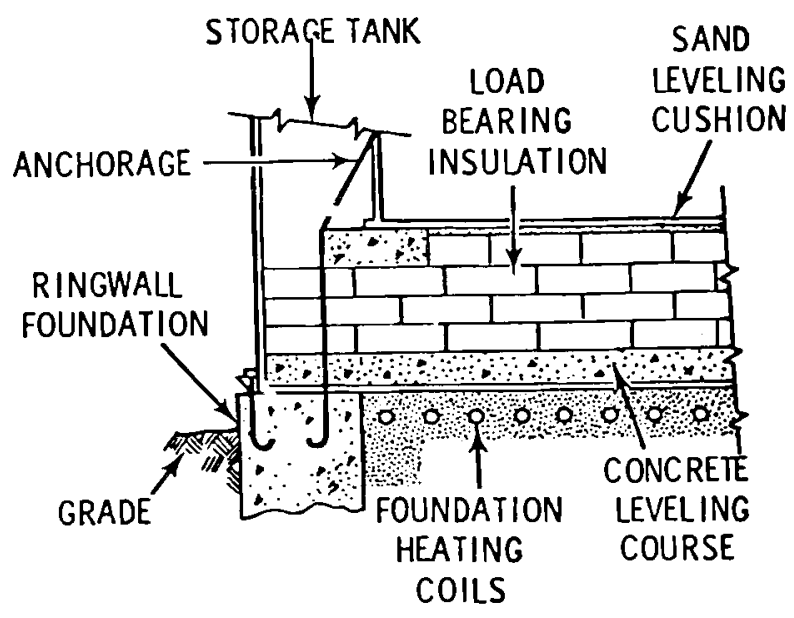

FIGURE B.11. Storage Tank Foundation Details 
The outer tank has a lap-welded, dome-shaped, steel roof. Suspended from the roof framing of the outer tank is a lap-welded metal deck that serves as a ceiling for the inner tank, as shown in Figure B.12. Mineral wool insulation is spread evenly over the deck, and open pipe vents installed in the deck allow product vapor to circulate freely in the insulation space to keep the insulation dry.

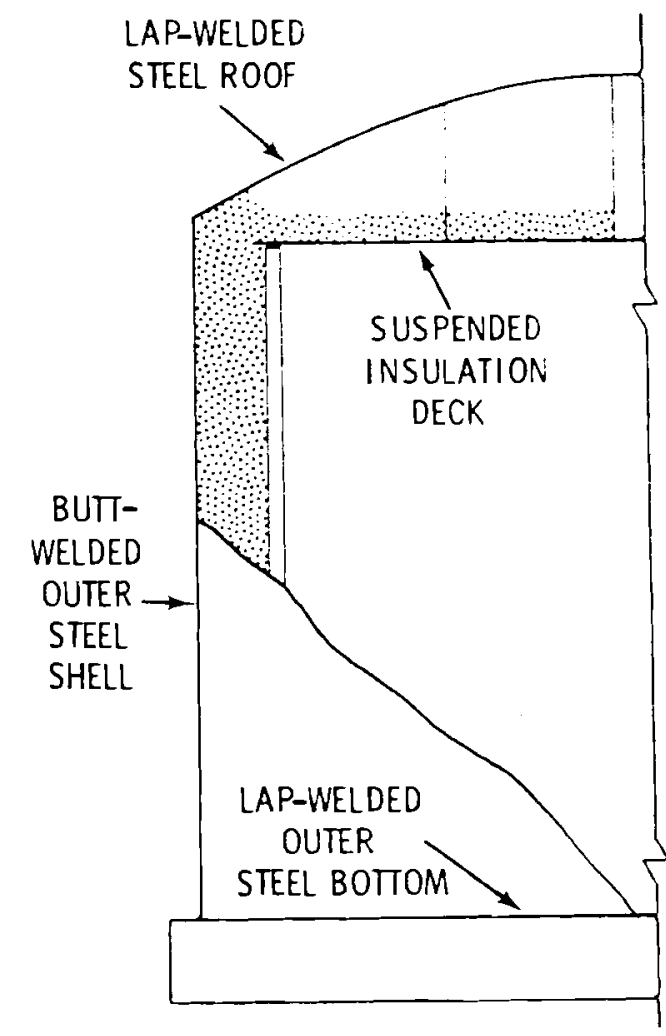

\section{FIGURE B.12. Suspended Insulation Deck}

All piping to the inner tank enters through the roof of the storage tank, with the exception of the unloading lines. LNG is withdrawn from the tank through two 24-in.-diameter outlet nozzles on the inner tank floor. These pipelines pass through the side wall of the outer tank and connect to the suction side of the loading pumps. The valves have pneumatic controls and are normally kept open. The valves close automatically by gravity if the pneumatic controls fai1. Independent structures support all piping external to the tank to prevent the transmission of static and dynamic pipe loads to the storage tank walls. 
Two 20-in.-diameter inlet pipelines enter each tank through the outer tank wall and pass through the suspended deck roof to separate fill nozzles, permitting either top or bottom filling to provide mixing of incoming LNG. One pipe terminates at a nozzle just below the suspended deck to allow top-filling of the tank. The second pipe discharges LNG into the top of a 60-in.-diameter stand pipe extending from above the high liquid level to the bottom of the tank. The stand pipe provides bottom-filling of the tank through evenly spaced perforations near the bottom of the pipe. This arrangement permits LNG to be added to the bottom of the storage tank at the same pressure and temperature as the liquid within the tank. Other major connections are the vapor outlet and pressure relief connections at the top of the inner tank and the relief vent at the top of the outer tank.

The tanks are designed to withstand instantaneous wind gusts up to $104 \mathrm{mph}$, earthquakes up to VIII on the modified Mercalli scale, and a maximum snow load of 60 pounds per square foot. Both storage tanks are tested prior to use. The LNG storage tanks also meet the requirements of the American Petroleum Institute standard 620, Appendix $Q$, which governs materials selection, tank design, construction, and testing procedures. During construction, the welds on all vertical seams are 100 percent $x$-ray inspected. Welds not 100 percent $x$-ray inspected are checked by the liquid penetrant method, as are all attachment welds. Inner tank welds are checked by a combination of x-ray, dye penetrant, vacuum box, and solution film test methods. Hydrostatic and pressure tests subject each tank to $125 \%$ of the maximum product weight and $125 \%$ of the maximum design vapor pressure. The hydrostatic tests utilize 14 to 15 million gallons of well water for each tank. After completion of the tests, the well water is released into the ocean.

\section{B.3.3.2 Pressure Control System}

The storage tank has maximum and minimum design pressures of 2.0 psig and 0 psig, respectively. Gauge pressure control is used and the normal tank operating pressure is $0.9 \mathrm{psig.} \mathrm{Normal} \mathrm{boiloff} \mathrm{gas} \mathrm{from} \mathrm{the} \mathrm{storage} \mathrm{tanks,}$ approximately $0.05 \%$ of two full tank volumes per day, is handled by a twostage compressor system. The first-stage boiloff compressors are centrifugal 
machines, each with a capacity of $1.3 \times 10^{3}$ ICFM/5.0 MMscfd. Storage tank pressure is maintained at 0.9 psig by a pressure controller that adjusts the speed of the first-stage compressor. The second-stage compressors (2) are reciprocating compressors, each with a capacity of 5.0 MMscfd.

If the storage tank pressure rises above the control pressure, the tanks have a vent valve that automatically opens to the vent header to reestablish the normal operating pressure level. If the pressure continues to rise, each tank is equipped with six combination pressure/vacuum relief valves and six pressure-only valves that open and vent a maximum of 792,000 pounds/hr of LNG to the atmosphere.

Gas from an independent supply is injected into the tanks if their pressure falls below the normal operating level. If the pressure continues to fall, the six pressure/vacuum relief valves open to admit air to the tank. Table B.5 shows the various functions of the pressure control system.

TABLE B.5. Functions of the Pressure Control System

\begin{tabular}{cl} 
Pressure (psig) & \multicolumn{1}{c}{ Function } \\
2.0 & $\begin{array}{l}\text { Full relief } \\
\text { High-pressure alarm, vent valve is } \\
\text { opened } \\
\text { Normal operating pressure, maintained } \\
\text { by adjusting the speed of the first- } \\
\text { stage boiloff compressor } \\
0.9\end{array}$ \\
0.2 & $\begin{array}{l}\text { Low-pressure alarm, gas from independent } \\
\text { supply is injected into tanks } \\
\text { vacuum relief }\end{array}$
\end{tabular}

Flash gas from cargo loading operations is returned through the 24-in. vapor return line to the storage tank to maintain pressure or is vented to the atmosphere through a 14-in.-diameter, 75-ft-tall stack at the plant site. Approximately 26 MMscfd is returned to the tank being unloaded, while 6 MMscfd is vented.

The plant boiloff facilities are shown in Figure B.13. 


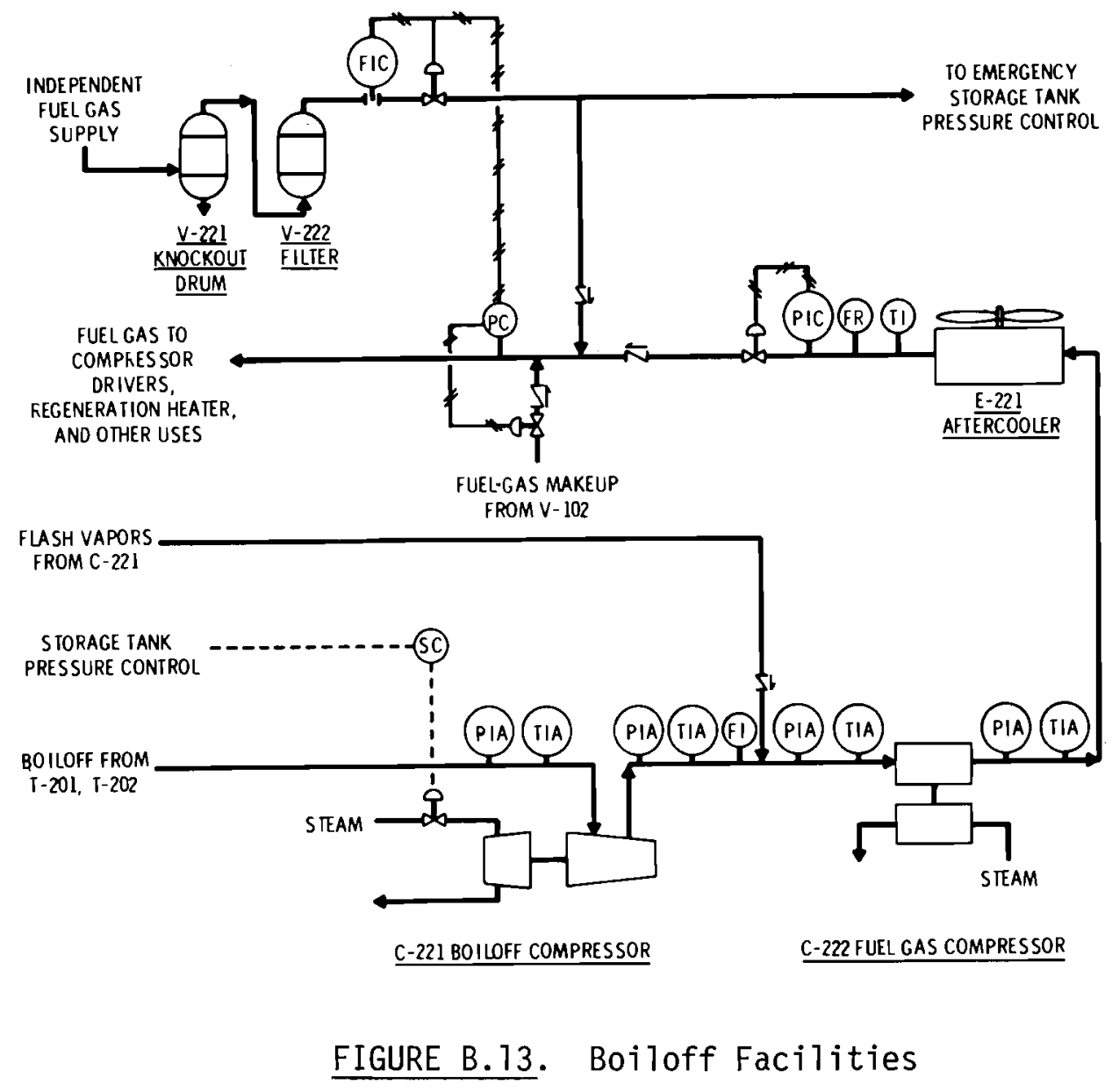

\section{B.3.3.3 Additional Controls and Instrumentation}

Each storage tank contains a movable, vertical temperature probe to monitor the temperature of the LNG at any depth. The probe can also monitor the liquid level in the tank. Temperature differences between any levels would indicate stratification of the LNG. The loading pumps can then circulate to the top fill nozzle and mix the LNG in the tank, reducing the possibility of rollover. Thermocouples are also provided in the floor and inner shell to monitor cooldown. A thermocouple placed in the electrically heated foundation soil monitors and controls the temperature in this area.

The liquid level in the tank is monitored by one displacement float gauge, which can be replaced while the tank is still in service. A liquid level switch sounds an alarm at the high-liquid level, which is $95 \%$ of full capacity. A continued rise of liquid activates the high-high liquid level alarm and closes 
the liquid inlet lines to the LNG storage tank. The storage tank is isolated from other equipment by block valves on the inlet and outlet liquid 1 ines; these valves are activated by the ESD system.

\section{B.3.3.4 Release Prevention and Control Features}

Each storage tank is surrounded by a concrete dike $55 \mathrm{ft}$ high, $1.5 \mathrm{ft}$ thick, and $285 \mathrm{ft}$ in diameter. In the event of a storage tank failure, the dike would hold in excess of 620,000 barrels of LNG $(\sim 113 \%$ of total storage tank capacity). The inner dike walls are insulated to reduce the rate of vapor generation from spilled LNG.

The following detectors, alarms, and fire protection systems are incorporated in the storage and pumpout areas:

- low temperature detectors with alarms in the control room that automatically shut down pumps and loading line valves during loading operations

- ultraviolet flame detectors located at the storage tank relief valves that automatically activate dry chemical extinguishers

- ultraviolet flame detectors that activate the ESD system and alarm in control room

- gas detectors with alarms in the control room

- fire hydrants located at various selected locations in the area

- dry chemical extinguisher at the loading pumps.

The storage tanks have water deluge systems to protect them against radiant heat from fires inside the plant. The system consists of a series of weirs encircling the tank roof at several locations. The system is designed to protect the dome-shaped roof from radiation damage and provide uniform distribution of water on the tank's outer she11. The water is supplied from the main loop at a rate of about $2,600 \mathrm{gpm}$. It is estimated that this flow rate is sufficient to protect one tank, since partial radiation shielding is provided by the 55-ft-high concrete dike wall. 


\section{B.3.3.5 Procedures}

Purging and Cooldown. The first step in cooldown of the storage tank is to purge the tank with nitrogen to prevent an explosive gas mixture from forming. Nitrogen gas for purging requirements and refrigerant makeup is liquefied by an onsite air separation unit and stored in a 240-bbl, insulated, double-walled tank. The inner tank is purged by admitting nitrogen into the bottom of the tank and passing it through the suspended deck vents into the vapor space in the dome.

To purge the liquid container, the nitrogen is exhausted through the relief vent. To purge the dome, the nitrogen is exhausted through the dome vent.

The purging of the annular space is accomplished by opening the purge ring exhaust nozzles at the bottom of the annular space and closing the dome vent and the relief vent.

After the purge, LNG from the liquefaction unit is slowly admitted through the top fill penetration where it is deflected and sprayed over the floor area. The following instruments monitor the effects of cooldown on the tank:

- linear movement indicators that measure relative movement between the inner and outer tank walls

- storage tank thermocouples.

The temperatures in the tank are carefully monitored to ensure that the specified maximum temperature gradients are not exceeded, and to ascertain that the inner vessel is returning to its appropriate position. The LNG flowrate is limited by these temperatures gradients. The cooldown procedures are followed until the tank is sufficiently cooled down and the LNG level in the tank is approximately one foot. At this point, the LNG flowrate from the liquefaction unit is increased to the normal rate. The cooldown with LNG purges the nitrogen atmosphere from the inner vessel. 
Heatup and Entry. Prior to heatup of the tank, the LNG level is lowered until there is approximately one foot of liquid remaining in the tank. The remaining 1 iquid is then removed by injecting heated natural gas, at approximately $275^{\circ} \mathrm{F}$, into the storage tank through the bottom penetration. The natural gas then rises, due to its temperature buoyancy, to the top of the vessel and leaves through the vapor outlet line. The gas is compressed by the boiloff compressor and sent to the fuel line. The tank pressure control system functions as it would during normal operation. The inlet gas flow is maintained at approximately the normal boiloff rate, $1.0 \times 10^{6} \mathrm{scfd}$. At this rate it takes approximately 20 days to warm the tank from $-260^{\circ} \mathrm{F}$ to $+60^{\circ} \mathrm{F}$.

Instrumentation systems monitored to determine the effect of warmup on the tank are:

- linear movement indicators that measure relative movement between the inner and outer tank walls

- storage tank thermocouples

- strain gauges installed around the periphery of the exterior tank to monitor any stresses developed by expansion of the inner vesse 1 and subsequent compaction of the perlite.

The storage tank must be purged to a $98+\%$ nitrogen atmosphere before personnel entry. The off gas is removed from the tank by the boiloff compressor and used as the boiloff gas normally is. As the purging nears completion, however, the nitrogen content of the off gas rises rapidly, and the last portion of the off gas is vented through the vent gas header. Combustible gas detectors are located around the tank to detemine if any combustible gases are descending from the vent. Established weather criteria define acceptable atmospheric conditions for venting.

After the purge, two options exist: 1) personnel can enter the tank using life-support systems or 2) the purging procedure can be repeated using air to displace the nitrogen. 


\section{B.3.4 Marine Terminal and Sendout System}

The LNG stored at the terminal is loaded onto marine vessels for export through the marine terminal and sendout system. The flow diagram for the marine terminal was shown previously in Figure B.7. The loading system is shown in Figure B. 14 .

\section{B.3.4.1 Marine Terminal}

The marine terminal is designed to the same earthquake criteria as the liquefaction and storage facilities, VIII in the Mercalli scale. However, additional features are incorporated into the design of the dock and trestle support structures to withstand the ice and tidal currents of the region. Ice and strong currents could also endanger tankers during docking and loading operations. Therefore, the design of the loading dock and dolphins facilitates rapid undocking of a tanker in an emergency.

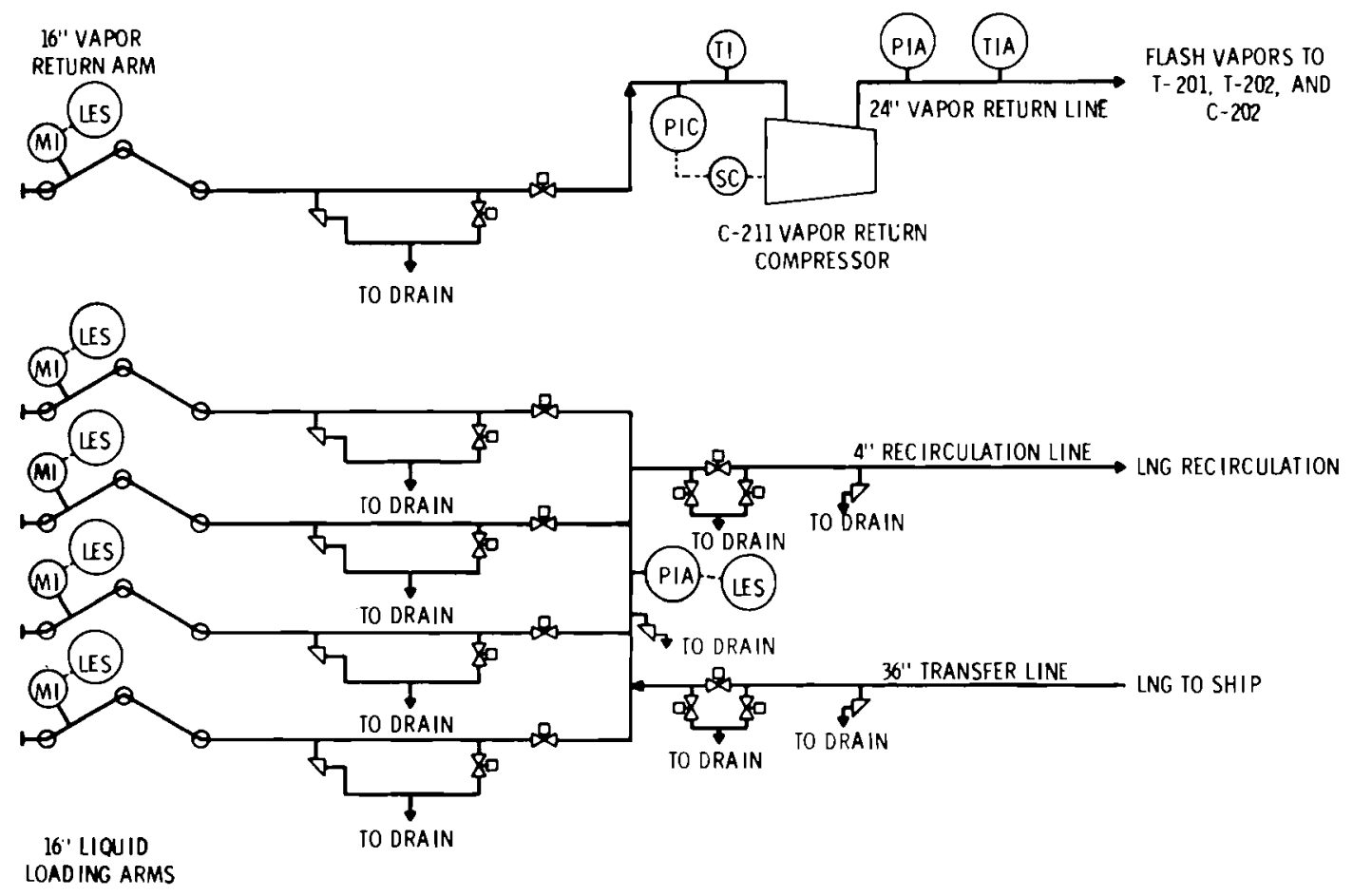

FIGURE B.14. Flow Diagram for Loading System 
The loading platform, the approach trestle, and the berthing and mooring dolphins are supported by piles driven and jetted into the sea bottom. The number of structural members located in the ice zone are minimized to limit the ice forces on the structure. Vertical piles receiving ice forces are tapered to minimize the bending moments from ice. They are also designed to break up the ice sheet as it moves past the pile.

The trestle supports a 36-in.-diameter insulated LNG transfer line, a 24-in.-diameter insulated vapor return line, a 4-in. nitrogen purge and LNG recirculation line, an 8-in. fire-control water line, an insulated and heated sanitary waste discharge 1 ine, and a concrete roadway $12 \mathrm{ft}$ wide. A 100-ft by 130-ft loading platform, located at the end of the $2200-\mathrm{ft}$ trestle, is $50 \mathrm{ft}$ above mean lower line water (MLLW) and is located at a bottom depth of $48 \mathrm{ft}$ below MLLW. The platform supports four 16-in. LNG loading arms, one 16-in. vapor return arm, a nitrogen surge drum, a 48-ft-high control tower, and a compressor building housing two vapor return compressors. The platform is shown in Figure B.15.

The control tower is located in an elevated "pulpit" in order to give the operator an unimpaired view of the ship, as shown in Figure B.16. The pulpits are patterned after the control towers at small airports and are reached by

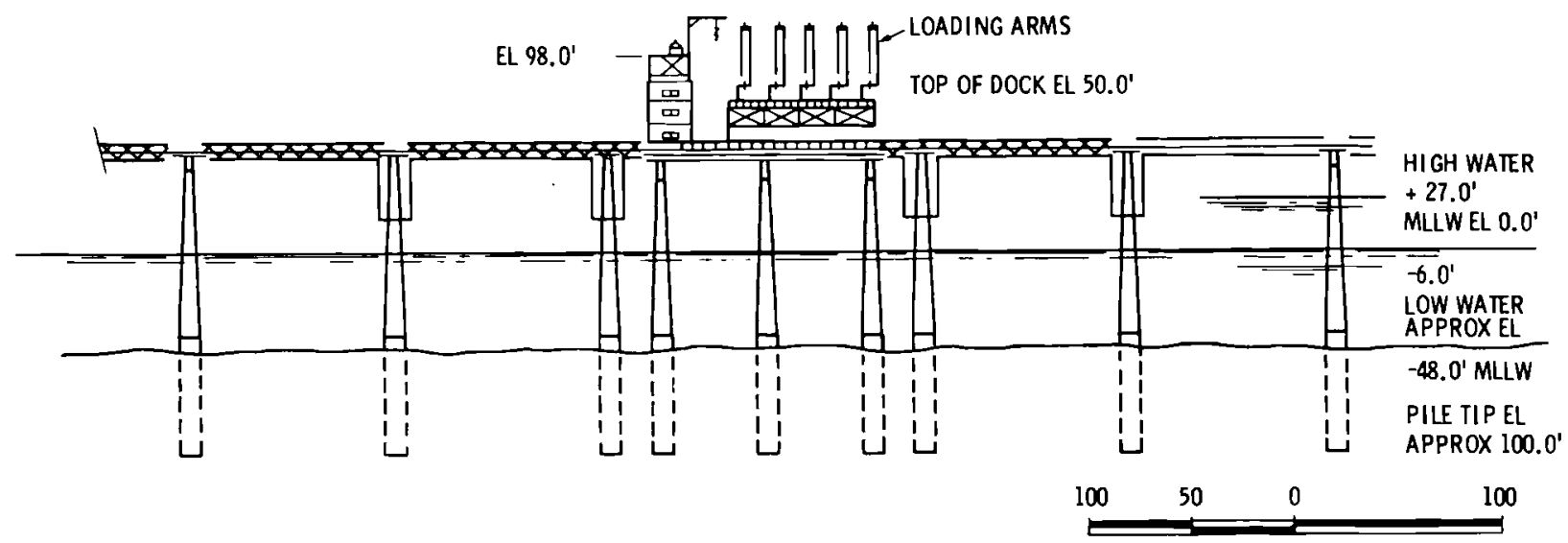

DATUM: MLLW $=0.0^{\prime}$

EL - ELEVATION

MLLW - MEAN LOWER LOW WATER

MD - MOORING DOLPHIN

FIGURE B.15. Export Terminal Loading Platform and Trestle 


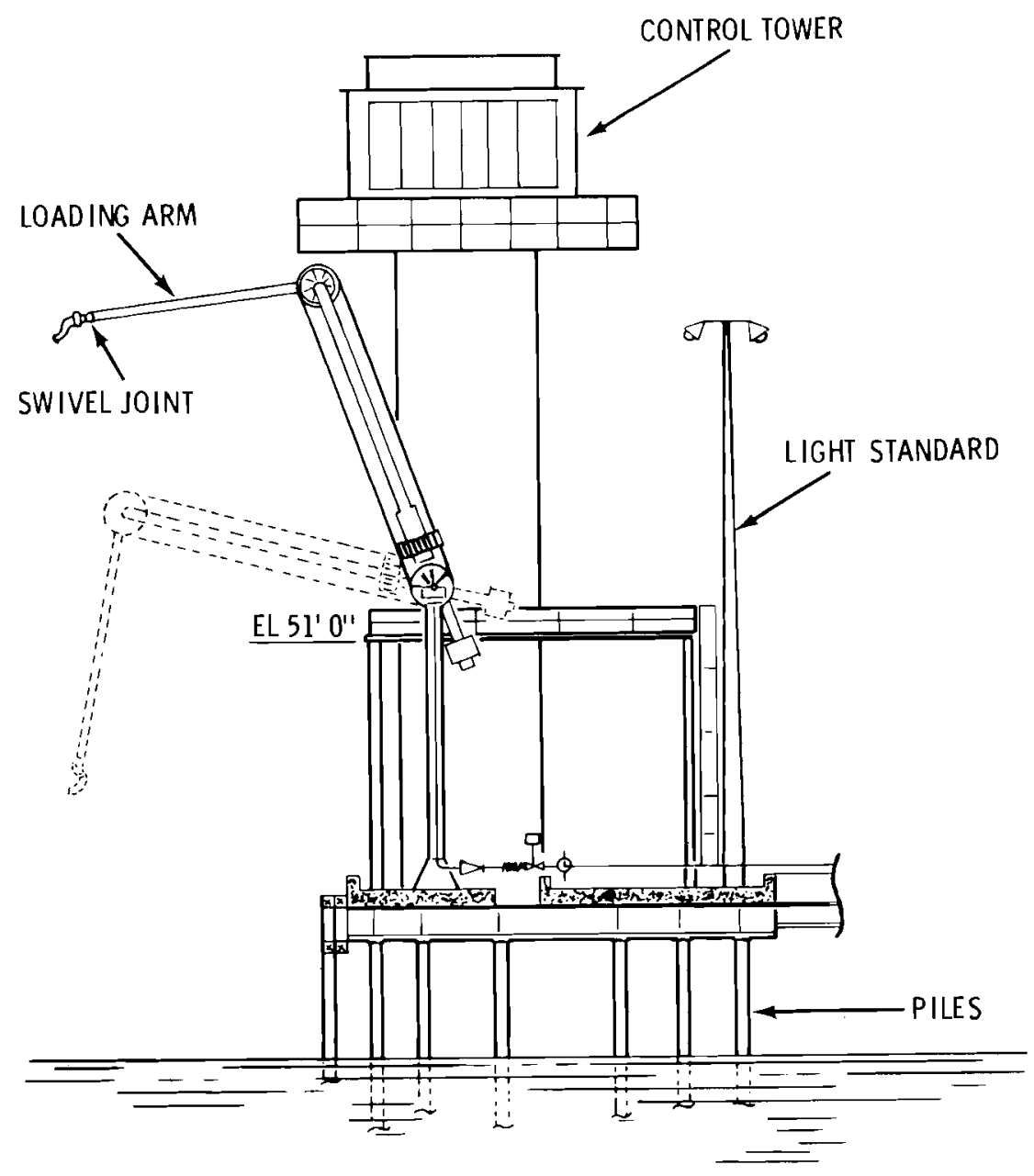

FIGURE B.16. Major Equipment on Loading Deck

spiral stairs inside a 72-in. steel support cylinder. Each pulpit has a waterspray system, and the support cylinders are heavily insulated for fire protection. The entire structure is air-conditioned and heated by a heat pump and is pressurized with a supply of fresh air from a point near the office and service complex.

The pulpit is manned as long as any of the cryogenic arms are connected to a ship, and the pulpit operator has, at his fingertips, the controls for the loading arms, the LNG booster pumps, the vapor return system, the two fire-water pumps, the dual dry chemical fire protection system, and all the offshore valves. For communications, he has a direct line to the ship's cargo control office, a direct line to the terminal main control room, radio, normal telephone, and a 
two-way loudspeaker system. The loading arms extend and rotate to accomodate normal movement of the tanker during loading operations. Each arm is equipped with a shutoff valve designed to prevent $L N G$ spillage during an emergency and a check valve to prevent backflow. The arms, which are not insulated, are constructed of 300-series stainless steel to withstand thermal stresses caused by extreme temperature changes. The loading arms are connected to the tanker by quick-release hydraulic couplers. The couplers are activated by one man from the master control panel in the control tower and can be disconnected in about 1 or 2 minutes. Each arm is equipped with two sets of redundant sensing devices that initiate audible alarms and activate the ESD.

Provisions are also made for emergency shutdown of the transfer systems. This can be accomplished either by isolating specific systems or areas for shutdown or by shutting down the entire operation. The emergency shutdown system is activated at the operator's direction or, in critical areas, by lowtemperature sensors that detect spilled LNG.

Before a tanker can make an emergency departure, the loading arms are first drained, a procedure requiring less than 5 minutes, and then they are disconnected. Six mooring dolphins and four berthing dolphins are equipped with quick-release mooring hooks and powered capstans.

There are currently no plans for shielding to protect the ship from spills at the dock.

\section{B.3.4.2 Shiploading Procedures}

When all preparations are completed on the vessel for loading, terminal personnel extend both the loading and vapor return arms to a position such that persons on the working platform can remove the blinds. After that, and before the blinds are removed, the following steps are followed:

- Terminal personnel open vent valves to depressurize the arms, which have been maintained in a nitrogen atmosphere.

- After venting, they advise the flanging crew that the blinds may be removed and connection made to the ship's manifold.

- When connections have been properly made, the ship's cargo officer advises the terminal that the vessel is ready to receive cargo. Terminal personnel notify other shore facilities. 
The ship's storage tanks are then cooled at a reduced loading rate. When cooling is completed, $L N G$ is introduced into the tanks at a total combined rate of $55,000 \mathrm{gpm}$, which enables a tanker to be loaded in 10-12 hours. As LNG fi11s the tank space, vapors remaining from the ship's cooldown operation are forced toward the top. Vapors are also produced continuously during loading by energy added through the transfer pumps, heat leakage, and latent heat removed from the 1 ines. These vapors must be pumped out at a rate sufficient to prevent pressure from building up in the ships tanks. Therefore, the vapors are continuously pumped back to shore using the ship's boiloff compressors. The vapors are then either returned to the storage tanks to displace the liquid being pumped out, or they are used as a fuel gas or flared.

Cargo transfer is carefully documented. A continuous watch is kept both in the ship's control room and on deck, and a $\log$ is maintained on all operations. Drain pans are placed beneath fittings to collect smal1 leakages of LNG and prevent localized thermal shock to the deck. An option to this is to run seawater over the decks during loading and discharging.

Approximately 40 minutes prior to reaching the fill level of the tanks, or at some predetermined level, the cargo officer notifies terminal personnel to reduce the loading rate. This is done by cutting out all but one shore pump. When the tank reaches proper level, 98\% full, the operator closes the vent valve on top of the tank. Each tank is equipped with an automatic system that senses liquid level and automatically closes a valve at each cargo tank dome if the tank reaches $99 \%$ full. As an added precaution, an Emergency Shutdown System that can be activated manually or automatically is provided on the ship and loading dock. Finally, the cargo officer can manually close the dome valve on the affected tank if both shutdown systems fail.

When the proper level is reached in all of the ship's tanks, the cargo officer notifies the terminal operator to stop loading and orders the ship's compressors shut down. Al1 compressor valves and valves in the compressor line are closed. 
The disconnecting operation requires that the liquid header and loading arm first be drained. They are drained into the ship's tank that was last filled. This involves the following procedures:

- Using the portable console, the ship's personnel close the shore block valves. The terminal operator then closes the vapor manifold valve ashore and notifies the cargo officer to close the vapor manifold valve and stop the compressors. The terminal operator opens a drain line on each loading arm and leaves it open for at least three minutes. The liquid drains into the liquid header aboard the vessel, and the drain valves ashore are then closed.

- The ship's manifold loading valves are closed. The vapor header is then cracked to the crossover 1 ines.

- The terminal operator opens the nitrogen block valve to each arm and pressurizes it.

- At this point, the terminal operator requests the cargo officer to open the ship's liquid and vapor manifold valves slightly for depressurizing into the ship's lines. This operation is repeated at least three times by reclosing and reopening the liquid and vapor manifold valves. The final position of the valves are closed.

- The terminal operator opens wide the atmospheric vent valve on each arm.

- When the arms are depressurized and the flanges are at a temperature that can be handled (salt water may be used to warm up the flanges), the loading arms are disconnected and the blind flanges replaced on manifold and loading arms.

- After the arms are retracted, the terminal operator closes the atmospheric vent valves and repressures the loading arms with nitrogen until the next loading.

When all of the foregoing operations are complete, all valves used for loading are closed. Draining of the ship's lines is facilitated by a slight trim at the stern of the vessel. 


\section{B.3.4.3 Release Prevention and Control Features}

Some of the precautions taken for safety consideration at the terminal are:

- avoidance of any unnecessary flames or fire sources in the terminal area by the prohibition of smoking, open flames, welding, and unsafe electrical equipment

- systems such as lighting and heating installed in accordance with existing safety regulations (National Electric Code NFPA \#70)

- a sufficient safety factor (with regard to pressure and temperature capabilities) designed into the transfer piping, hoses, compressors, pumps, and connections

- periodic and complete inspection of all terminal facilities

- provision of suitable markings on pipes and hoses, when more than one product is handled

- at least one person in constant attendance while loading is taking place, trained in the transfer and emergency procedures and familiar with the equipment layout

- a good system of communication between the cargo officer on board ship and the persons on shore

- a11 gauges checked prior to transfer to ensure against overfill

- provision made for drainage of the transfer lines prior to disconnection

- a sufficient number of fire control units available at strategic locations. The loading platform is equipped with the following fire-fighting systems:

- fixed dry chemical units

- fire hydrant

- equipment cooling capacity

- sprinkler system on the roof of the marine control room

- dry chemical fire extinguishers at the marine control tower and the fire hydrant station 
- a water fire-fighting system consisting of hydrants and water spray monitors to be used primarily for cooling structures during any nearby fire

- water-screen nozzles between the loading arms and the ship to protect the arms from a fire aboard ship

- a fireboat tie-in installed on the fire water level at a point leading to the loading platform.

High-expansion foam systems are not used at the site because it is difficult to store foam concentrate at subfreezing temperatures. Both remote and local manual activation of the fire systems are possible in the marine terminal. The firecontrol water pipeline along the trestle to the dock is kept empty; therefore, heat tracing of insulation is not required.

The following detectors are located at the marine dock:

- Gas Detectors (GD)

- UV Fire Detectors (UV).

Each of these is connected to an alarm in the main control room and the marine control room and is identified by location and type.

A containment system is located under the loading platform to contain all spills from the loading arms. Low temperature detectors in this area indicate when a spill occurs. No containment is provided for the LNG transfer lines, either on the trestle or on shore.

Each transfer arm is equipped with two sets of redundant sensing devices that initiate alarms in both control rooms and automatically activate the marine terminal emergency shutdown system when excessive motion is sensed. Each transfer arm also includes a failsafe-closed-type, air-operated valve that closes automatically when the ESD is activated.

Excessive ship movements are detected by high rotation or extension of the loading arms, activating the first level alarm. Greater ship movement causes the loading operation to stop. Additionally, a cable connecting the tanker to the dock also senses excessive movements and terminates loading operations. 


\section{B.3.4.4 LNG Sendout Pumps}

There are five vertical submerged, pot-mounted LNG pumps for each storage tank, one of which is considered a standby. The pumps and motor drives are hermetically sealed in a vessel and submerged in LNG. This eliminates the extended shaft and the associated seal. The pump and motor surroundings are $100 \%$ rich in LNG and will not support combustion. The pumps are mounted in a suction pot below grade to provide sufficent suction head for operation.

Each pump has a capacity of 15,000 gpm, or approximately 2,000 MMscfd, for a total sendout capacity of $55,000 \mathrm{gpm}$ and a 10 to 12 hour loading time, excluding the spare. The discharge conditions are $-260^{\circ} \mathrm{F}$ and 25 psig.

The LNG to be loaded on the ship is pumped via a 36-in.-diameter insulated LNG transfer line to the loading platform located at the end of a 2,200-ft-long pier and trestle.

\section{B.4 GENERAL PLANT INFORMATION}

General information relating to the plant, particularly to the safety aspects of plant operation, is presented here.

\section{B.4.1 Emergency Shutdown System}

The plant emergency shutdown system consists of two major systems, the Master Emergency Shutdown (MES) and the Loading Emergency Shutdown (LES). When activated, the MES automatically initiates the following actions:

1. Electrical supplies to all normal plant circuits are de-energized; essential plant electrical equipment (e.g., fire pumps, fire and gas detectors, fire system valve operators) remains energized.

2. All compressors are blocked automatically and isolated from the liquefaction unit.

3. A 2,500-kW, engine-driven generator is available for emergency power generation.

4. The natural gas feed line is blocked at the plant boundary to isolate the plant from the natural gas pipeline system. 
5. The LNG tank and dike area is isolated from the remainder of the plant by the following actions:

- valve on liquid inlet line from the liquefaction unit is closed

- LNG pump motors are shut down

- valves on the LNG pump suction and on the liquid withdrawal lines are closed.

The second shutdown system, the LES, allows the rapid shutdown and isolation of all LNG sendout to ships and vapor return from the ships. When activated, the LES initiates the shutdown of LNG and vapor flow to and from the ship by:

1. closing block valves in the loading arms

2. closing cargo crossover valves on the ship

3. closing block valves in the vapor return line.from the ship

4. shutting down the LNG transfer pumps.

The closing sequence and rates of the block valves are programmed to keep fluid hammer within design limits and to prevent any LNG from being trapped between valves.

The MES can be activated manually at the control room and at the two exit gates, or it can be activated automatically by UV flame detectors located in the following areas:

1. compressor building

2. throughout the liquefaction area

3. refrigerant storage

4. LNG storage

5. piping on or adjacent to pipe racks next to the compressor building

6. $\mathrm{CO}_{2}$ removal unit

7. water removal unit

8. loading dock area.

The MES is also activated by the high-high level alarm for either of the storage tanks and by the gas detectors in the compressor building. 
The LES system may be activated manually from several different locations in the loading area, including the main terminal control room, the loading platform control room, and the ship's bridge. The LES can also be activated automatically by:

1. combustible gas detectors on the dock

2. power and air supply failure

3. high or low pressure in the transfer lines

4. excessive flowrates

5. tanker movements outside the established operating conditions

6. low temperature detector in the dock spill basin

7. low temperature detector at the loading pumps

8. low storage tank pressure (0.2 psig)

9. low storage tank leve1.

\section{B.4.2 General Plant Safety Features}

As part of the plant's active defenses, combustible gas detectors, flame detectors, and temperature sensors are located throughout the plant and process equipment. The activation of a sensor sounds an alarm and identifies the exact location of the spill or fire on a graphic panel in the main control room and, in some cases, automatically shuts down the affected equipment. In the event of a fire, the plant's fire protection systems, consisting of a fire-control water system, dry chemical units, and two firetrucks, are then employed.

Gas sensors at the inlets to ventilated buildings activate both visible and audible alarms if the gas concentration reaches $25 \%$ of the LFL for methane. At this time, a high-speed ventilating fan is activated. If the concentration reaches $60 \%$ of LFL, another alarm is sounded and the affected equipment may be shut down automatically.

U1 traviolet sensors are located inside buildings and throughout the plant for fire detection. Each zone is covered by at least two sensors. The activation of flame detectors causes the automatic shutdown of local equipment.

Pressure-relief valves, located throughout the process equipment, are designed to relieve high pressures before the design pressures of the equipment are reached. Gas discharges from these valves enter the flare header system 
and are directed to the flare stack for incineration. The main header, 40 inches in diameter, is sized to handle the maximum discharge rate of the first-stage, multi-component refrigerant compressor. The flare stack, 300 feet high and 50 inches in diameter, contains a fluidic seal to prevent air from entering the relief system. The stack is located at the northwest corner of the plant site so that releases do not pose a hazard to the staff or plant equipment.

Sections of LNG lines that can be isolated are provided with thermal relief valves to protect the lines from overpressure due to thermal expansion. These reliefs are piped back to the storage tanks.

The fire-control water system is designed to provide fire-exposure protection and damage control. It also helps extinguish fires which might originate in the area adjacent to the plant.

The fire-control water system includes a main water loop surrounding the plant, with fire hydrants and water monitor nozzles connected at various intervals. The main loop consists primarily of 8- and 10-in.-diameter pipeline, and is connected to the fire-control water pumps by a segment of 14-in.-diameter pipeline. An 8-in.-diameter pipeline runs along the trestle to water monitors on the dock. Branch lines are also provided to the liquefaction trains and plant buildings.

The main water loop is supplied by a 125,000-gallon freshwater storage tank and is continuously maintained at 75 psig pressure by three circulation pumps. The storage tank is supplied by two onsite wells. A 3,500-gpm seawater pump and 10-in.-diameter pipeline provide a backup for the primary fire-water system.

The environmental conditions of the plant location require precautionary measures to prevent freezing in the fire-control system. The fire-control water loop is buried at a depth of 21 feet below grade in order to be under the frost line. The water lines from the main line to control valves are heat-traced and normally kept dry. The fire-control water pipeline along the trestle to the dock is kept empty; therefore, heat tracing or insulation is not required. The fire-control water storage tank is also not insulated; however, heated water is circulated in the tank to prevent freezeups. 
The dry chemical fire extinguishing systems include fixed systems with permanent nozzles, fixed systems with hoselines, monitor nozzles, and portable extinguishers. The compressor buildings use fixed units with hose lines. The transfer pump area has a fixed system designed to cover the pump area with dry chemical in the event of a fire. The dry chemical systems in the liquefaction trains include hoselines and monitor nozzles. A dry chemical unit at the dock has both monitor nozzles and bicarbonate or potassium carbonate.

Two firetrucks provide backup fire protection for all plant areas and primary fire protection for areas not otherwise covered. The truck contains a dry chemical system with hose 1 ines and a monitor, and it can attach to any of the fixed dry chemical systems for backup. The truck also has water-pumping capability.

\section{B. 5 SOURCES OF INFORMATION}

The description of the LNG export terminal was developed using information from the sources listed below.

1. Federal Energy Regulatory Commission files of applications concerning LNG facilities:

FPC Docket No. CP75-140, Pacific Alaska LNG Associates, October 31, 1978.

2. LNG Equipment Venders:

Chicago Bridge and Iron - Cryogenic Storage, Bulletin No. 8600,

Chicago Bridge and Iron - Cryogenic Systems, Bulletin No. 8650,

Chicago Bridge and Iron - USA Standards for Design and Construction of LNG Installation, Bullietin No. 831,

Pittsburg-Des Moines Steel Company - LNG Storage Tanks, Bulletin No. 303, American Air Liquide - Teal Liquefaction Process Bulletin, Allison Control, Inc. - Fire Detection and Extinguishment Control Systems, (various materials),

American Air Liquide - Turnkey Liquefied Natural Gas Plants Bulletin, Air Products and Chemicals, Inc. - Process Design and Cryogenic Heat Exchangers, Natural Gas Liquefaction, P\&GJ, June 19.75,

Union Carbide Corp. - Linde Molecular Sieves, Gas Dehydration, P\&GJ, Junè 1975. 


\section{Open Literature:}

R. I. Shaheen and M. K. Vora, "Worldwide LNG Survey Cites Existing, Planned Projects." 0i1 and Gas Journal, pp. 59-71, June 20, 1977.

R. F. Stebbing and J. V. O'Brien, "Core Exchangers Update Peak Shaving." 0il and Gas Journal, pp. 46-49, December 22, 1975.

L. Devanna and G. Doulames, "Planning is the Key to LNG Tank Purging, Entry and Inspection." 0il and Gas Journal, pp. 74-82, September 8, 1975.

F. P. Schulz, "Safety at an LNG Peakshaving Facility." Paper presented at the ASME Winter Annual Meeting, New York, NY, November 17-22, 1974.

Hanke, C. C., LaFare, I. V. and Litzinger, L. F., Purging LNG Tanks Into and Out of Service Considerations and Experiences." Paper presented at the AGA Distribution Conference, Minneapolis, Minnesota, May 6-8, 1974.

V. A. Warner, "Liquified Natural Gas Fire Control." Paper presented at the AGA Transmission Conference, Las Vegas, NV, May 3-5, 1976.

N. H. Brock and R. M. Howard, "Upgrading LNG Plant Safety." Paper presented at the AGA Transmission Conference, Bal Harbour, FL, May 19-21, 1975.

H. R. Wesson, "Consideration Relating to Fire Protection Requirements for LNG Plants." Paper presented at the AGA Transmission Conference, Bal Harbour, FL, May 19-21, 1975.

B. M. Vinson, "Basic Safety as Respects Storage, Movement, and Combustion of Gas and 0il Fuels." Proceedings of the American Power Conference, Vol. 34, pp. 591-609, 1972.

R. G. Schlater and C. J. Noel, "Good Axial Compressor Control Aids LNG Plants." 0il and Gas Journal, pp. 52-57, January 15, 1973.

Gas Processing Handbook Issue. Hydrocarbon Processing, pp. 132-138, April 1973.

LNG Information Book, prepared by the LNG Information Book Task Group of the Liquified Natural Gas Committee, American Gas Association, 1973.

D. B. Crawford and G. P. Eschenbrenner, "Heat Transfer Equipment for LNG Projects." Chemical Engineering Progress, pp. 62-70, September 1972.

A. E. Uhl, L. A. Amoroso and R. H. Seiter, "Safety and Reliability of LNG Facilities." Paper presented at the ASME Petroleum Mechanical Engineering and Pressure Vessel and Piping Conference, New Orleans, LA, September 17-21, 1972. 
P. J. Anderson and E. J. Daniels, "The LNG Industry: Past, Present, and Future." Prepared by Institute of Gas Technology for US ERDA under contract No. EE-77-C-02-4234.

I. L. Wissmiller and E. 0. Mattocks, "How to Use LNG Safely." Pipeline and Gas Journal, March 1972.

S. Seroka and R. J. Bolan, "Safety Considerations in the Installation of an LNG Tank." Cryogenics and Industrial Gases, pp. 22-28, September/0ctober 1970.

L. R. Smith, "Submerged Pumps for LNG Sendout." Paper presented at AGA Distribution Conference, 1968.

P. J. Anderson and W. W. Bodle, "Safety Considerations in the Design and Operation of LNG Terminals." Paper presented at the 4th International Conference, Algiers, Algeria, June 24-27, 1974.

A. Eli Nisenfeld, Roger Miyasaki, Tom Liem, J. M. Eskes, "For Easier Compressor Control." Hydrocarbon Processing, pp. 153-156, April 1975.

D. C. Hullock, R. M. Farber and C. E. Davis, "Compressors and Drivers for LNG Plants." Chemical Engineering Progress, pp. 77-82, September 1972.

Jack L. Peterson, "Gas Turbines vs. Steam Turbines as Drivers for Baseload LNG Plants." Pipeline and Gas Journal, pp. 32-38, January 1974.

M. M. Levy, "Cove Point Terminal Near Completion." Pipeline and Gas Journal, pp. 35-40, June 1976.

Philip J. Anderson and William W. Bodle, "Safety Considerations in the Design and Operation of LNG Terminals." Session V, Paper 4, IGT, pp. 1-16.

R. F. Parker and L. L. Phannensteil, "Extensive Indonesian LNG Program Results in Two Large Liquefaction Plants." ASME Paper 74-WA/PID-14, pp. 2-8, for meeting Nov. 17-22, 1974.

Dean, Hale, "Brunei LNG Project Truly An International Undertaking." Pipeline and Gas Journal, pp.29-38, June 1973.

Luino Dell 0sso, Jr., "Algeria II LNG Project Plans Detailed." $0 i l$ and Gas Journal, pp. 65-68, May 29, 1978.

Air Products and Chemicals Inc., "MCR Liquefaction." Hydrocarbon Processing, p. 130, April 1973.

Earl Seaton, "Indonesia's Arun LNG Plant Nears Completion." 0il and Gas Journal, March 13, 1978. 
John L. Kennedy, "Kalimantan's Badak LNG Plant Goes on Stream in Record Time." 0i1 and Gas Journal, pp. 51-56, May 29, 1978.

C. E. Feierabend, "Design Considerations for LNG Production Facilities

in Arctic Regions." AGA Transmission Conference, Montreal Canada, 11 pp. May 8-10, 1978.

World Wide LNG Market, published by Frost \& Sullivan, Inc., New York, NY, June 1977 .

G. E. Thompson, and H. R. Sharp, "Kenai LNG Plant Design." Paper presented at ASME conference in Tulsa, Oklahoma, September 21-25, 1969.

L. Knie1, "Energy Systems for LNG P1ants." Chemical Engineering Progress, pp. 77-84, October 1973.

R. M. Milton and C. F. Gottzman, "High Efficiency Reboilers and Condensers." Chemical Engineering Progress, pp. 56-61, September 1972.

G. E. Kinard and L. S. Gaumer, "Mixed Refrigerant Cascade Cycles for LNG." Chemical Engineering Progress, pp. 56-61, January 1973. 


\section{APPENDIX C}

FACILITY DESCRIPTION OF REFERENCE LNG MARINE VESSEL 


\section{FACILITY DESCRIPTION OF REFERENCE LNG MARINE VESSEL}

The earliest significant development in the marine transportation of liquefied natural gas took place in the United States in 1951. A man named William iNood Prince of the Union Stockyard and Transit Company ("Chicago Stockyards") leveloped the idea that it might be economically feasible to liquify natural gas, then a byproduct disposed of by burning or "flaring," and to transport it by barge to an area, such as Chicago, where it might be sold as a fuel. The idea was further developed, and ultimately a joint venture was agreed upon by the Chicago Stockyards and the Continental $0 i 1$ Company. They formed a new company, Constock Liquid Methane Corporation, and in 1952 made the first serious effort at marine transportation of LNG, from Louisiana up the Mississippi River to Chicago. Their effort resulted in the METHANE, a river barge whose carrying capacity of about $6,000 \mathrm{~m}^{3}$ consisted of five cylindrical, carbon steel tanks 50 feet in diameter and 24 feet deep. The METHANE never developed to the point of being an economic success. However, the interesting and significant aspect of the METHANE was the construction of its tanks, for this provided the sasis for further development in tank construction.

The METHANE's tanks were lined internally with balsa wood, which was to function as an insulator in direct contact with LNG. Balsa wood proved to be an excellent insulator, except that a great deal of surface damage was noted after a series of filling and emptying cycles. Some penetration of the balsa by the LNG was expected; however, upon warmup, trapped LNG volatilized, expanding so rapidly from a liquid to a gaseous state that it caused the balsa lining :o deteriorate at the inner surfaces.

Even though it fell short of commerical success, the METHANE venture showed that marine transportation of LNG was within the capabilities of current engileering technology.

During the middle 1950 's, interest changed from river to ocean transport If LNG. In 1957, the North Thames Gas Board joined Constock in a commerical 
venture to prove the feasibility of large-scale ocean transport of LNG. Their efforts produced the METHANE PIONEER, a converted dry cargo ship with 5,000-m capacity in its rectangular, aluminum alloy (5083-0) storage tank(s). In 195c she carried the first cargo of LNG from Lake Charles, Louisiana, to Canvey Is 1 at the head of the Thames Esturary. Altogether, seven cargoes were successful transported before the experiment was terminated in 1961.

In 1961, Conch International Methane, Ltd., contracted to have two ships of $27,400-\mathrm{m}^{3}$ capacity constructed to deliver LNG from Arzew, Algeria, to Canve Island on a long-term basis. These ships, the METHANE PRINCESS and the METHAR PROGRESS, began their service in 1964 and 1965, respectively. They are currer still in service, as is the METHANE PIONEER, now renamed the ARISTOTLE.

During the time the Constock experiment was underway, Gaz de France begar studying the possibility of transporting natural gas form the Sahara to France This study led to the conversion of a liberty ship to the tanker BEAUVAIS. Tests with the BEAUVAIS began in 1962 and ran for five months, after which it was decided a cylindrical tank system would be the most desirable. As a consequence, a new $25,500-\mathrm{m}^{3}$-capacity vesse1, JULES VERNE, was constructed. It entered into service in March 1965, carrying LNG from Arzew, Algeria, to Le Harve.

With the exception of the barge METHANE, all the vessels used what is described as a free-standing tank, a tank not dependent on the ship's hull for structural integrity. In the early 1960's, the concept of a membrane tank was first considered. This is a tank made of a thin lining of non-load-bearir material fitted into a tank composed of the ship's hull and load bearing insulation. The design was originated by 0ivind Lorentzen \& Company of Norway. ] was later acquired and modified by Technigaz and incorporated in the $630-\mathrm{m}^{3}$ ship PYTHAGORE. This ship has been used by Gazocean primarily as a carrier of ethylene, although it is capable of carrying methane and has done so.

Other membrane designs were developed during the same period by Conch, Worms and Cie, and Gaz de France, the latter two operating as Gaz-Transport. The Gaz-Transprot design was first tested on an LPG ship, the HYPOLITE WORMS; however, the first LNG ships to employ this design were the POLAR ALASKA and ARCTIC TOKYO, built for Marthon and Phillips. The ships were completed in 1969 and entered service between Alaska and Japan. 
Meanwhile, in other parts of the world, other interested parties were attempting to develop their own LNG capabilities. Esso entered the LNG field in the early 1960's by undertaking the development of a natural gas market first in Italy, then in Spain. Their efforts resulted in four $40,000-m^{3}$ ships with free-standing aluminum tanks.

At the beginning of 1978, the world LNG carrier fleet totaled 42 ships. Facilities for liquefaction and regasification coming on stream within the next five years will require an additional 30 vessels to be built.

Anticipated U. S. base-load import projects will require a fleet of 58 ocean-going LNG vessels. To date, only 25 of the vessels required are either in operation or on order. In addition to these vessels, four LNG tankers have made spot deliveries of LNG to the Everett, Massachusetts, import receiving terminal. Pertinent data describing these 29 vessels are listed in Table C.1. Of these 29 vessels, 11 have independent cargo tanks while 18 have membrane cargo containment systems. These vessels range in size from 40,000 to $130,000 \mathrm{~m}^{3}$. However, vessels of up to $165,000 \mathrm{~m}^{3}$ are under consideration for at least one LNG import project. Approximately half of the vessels that will be built to serve United States LNG trades are to be constructed by U.S. shipbuilders.

\section{1 GENERAL DESCRIPTION OF LNG MARINE VESSEL}

The facilities and structure of a typical 125,000- $\mathrm{m}^{3}$ LNG marine vessel are described here. A diagram of the vessel is shown in Figure C.1. The principal characteristics of the tanker are given in Table C.2. The description of the LNG marine vessel was developed using information from the sources listed in Section C.6.

\section{C.1.1 Ship Facilities}

The tanker has an operating time of 345 days/yr, with 20 days allowed for miscellaneous delays and repairs. The approximate cargo deliverability of the vessel is 90 to $92 \%$ of the cargo capacity. The cargo boiloff is approximately $0.25 \mathrm{vol} \% /$ day $\left(317 \mathrm{~m}^{3} /\right.$ day). No boiloff vapors are vented to the atmosphere; 
TABLE C.1. LNG Tankers in U.S. Trades

\begin{tabular}{|c|c|c|c|c|c|c|c|c|c|c|c|c|}
\hline \multirow{2}{*}{$\begin{array}{l}\text { Ship Name and/ } \\
\text { or Hull Number }\end{array}$} & \multicolumn{3}{|c|}{ Dimensions } & \multirow[b]{2}{*}{ №. } & \multirow[b]{2}{*}{$\begin{array}{l}\text { Tanks } \\
\text { Type }\end{array}$} & \multicolumn{3}{|c|}{ Unloading Pumps } & \multicolumn{2}{|c|}{ Propulsion } & \multirow{2}{*}{$\begin{array}{c}\text { Speed } \\
\text { (Nautical } \\
\text { mph) }\end{array}$} & \multirow[b]{2}{*}{$\begin{array}{c}\text { Fuel } \\
\text { (tons/day) }\end{array}$} \\
\hline & LOA & $\begin{array}{l}\text { Extended } \\
\text { Breadth } \\
\end{array}$ & Draft & & & \multirow{2}{*}{$\frac{\text { No. }}{12}$} & \multirow{2}{*}{$\begin{array}{l}\text { Type } \\
\text { Deepwell }\end{array}$} & \multirow{2}{*}{$\begin{array}{l}\text { Capacity } \\
\{1,000 \text { gal } / \mathrm{hr}) \\
1014 \mathrm{at} \\
304 \mathrm{ft}\end{array}$} & \multirow{2}{*}{$\begin{array}{l}\text { - Type } \\
\text { Steam } \\
\text { Turbine } \\
\text { Stal Laval }\end{array}$} & \multirow{2}{*}{$\begin{array}{c}\begin{array}{c}\text { Rating } \\
\text { Shaft Hp }\end{array} \\
17,000\end{array}$} & & \\
\hline Descartes & $721 \mathrm{ft} 10$ in & $104 \mathrm{ft} 6$ in & $27 \mathrm{ft} 7$ in & 6 & $\begin{array}{l}\text { Technigaz } \\
\text { Membrane }\end{array}$ & & & & & & 17 & \multirow[t]{2}{*}{105} \\
\hline Hassi R'Mel & $656 \mathrm{ft}$ & $96 \mathrm{ft} 11$ in & $27 \mathrm{ft} 11 \mathrm{in}$ & 5 & $\begin{array}{l}\text { Gaz Transport } \\
\text { Membrane }\end{array}$ & 12 & Submerged & 88 & $\begin{array}{l}\text { Steam } \\
\text { Turbine }\end{array}$ & 16,250 & 17.6 & \\
\hline $\begin{array}{l}\text { Charles } \\
\text { Tellier }\end{array}$ & $646 \mathrm{ft}$ & $95 \mathrm{ft} 11$ in & $26 \mathrm{ft} 8$ in & 5 & $\begin{array}{l}\text { Technigaz } \\
\text { Membrane }\end{array}$ & 4 & Submerged & $\begin{array}{l}125 \mathrm{at} \\
492 \mathrm{ft}\end{array}$ & $\begin{array}{l}\text { Steam } \\
\text { Turbine }\end{array}$ & 16,800 & 17.5 & \multirow[t]{2}{*}{30} \\
\hline Kenai Multina & $651 \mathrm{ft} 4$ in & $87 \mathrm{ft}$ & $34 \mathrm{ft}$ & 5 & $\begin{array}{l}\text { Gaz Transport } \\
\text { Membrane }\end{array}$ & & & & & 23,000 & 20.2 & \\
\hline $\begin{array}{l}\text { El Paso } \\
\text { Sonatrach }\end{array}$ & $920 \mathrm{ft} 5-1 / 8$ in & $136 \mathrm{ft} 6 \mathrm{fn}$ & $36 \mathrm{ft}$ & $\begin{array}{l}1 \\
5\end{array}$ & $\begin{array}{l}\text { Caz Transport } \\
\text { Membrane }\end{array}$ & 10 & Subinerged & $\begin{array}{l}3045 \text { at } \\
75 \text { psig }\end{array}$ & $\begin{array}{l}\text { Steam } \\
\text { Turbine }\end{array}$ & 44.000 & 20 & 210 \\
\hline $\begin{array}{l}\text { El Paso } \\
\text { Consolidated }\end{array}$ & $920 \mathrm{ft} 5-1 / 8$ in & $136 \mathrm{ft} 6 \mathrm{in}$ & $36 \mathrm{ft}$ & \multirow[t]{2}{*}{$\begin{array}{l}1 \\
5\end{array}$} & $\begin{array}{l}\text { Gaz Transport } \\
\text { Membrane }\end{array}$ & \multirow[t]{2}{*}{10} & \multirow[t]{2}{*}{ Submerged } & \multirow[t]{2}{*}{$\begin{array}{l}3045 \text { at } \\
75 \text { psig }\end{array}$} & $\begin{array}{l}\text { Steam } \\
\text { Turbine }\end{array}$ & 44,000 & 20 & \multirow[t]{2}{*}{210} \\
\hline $\begin{array}{l}\text { Edouard Louis } \\
\text { Dreyfus }\end{array}$ & $872 \mathrm{ft} y$ in & $136 \mathrm{ft} 6 \mathrm{in}$ & $36 \mathrm{ft} 1$ in & & $\begin{array}{l}\text { Gaz Transport } \\
\text { Membrane }\end{array}$ & & & & Turbine & 45,000 & 20.5 & \\
\hline $\begin{array}{l}\text { El Paso } \\
\text { Southern }\end{array}$ & $948 \mathrm{ft} 6$ in & $135 \mathrm{ft}$ & $36 \mathrm{ft}$ & $\begin{array}{l}1 \\
5\end{array}$ & $\begin{array}{l}\text { Prismatic, } \\
\text { Insulated, } \\
\text { stainless Steel }\end{array}$ & 10 & Subnerged & $\begin{array}{l}3552 \text { at } \\
75 \text { psig }\end{array}$ & $\begin{array}{l}\text { Steain } \\
\text { Turbine }\end{array}$ & 40,000 & 20 & 190 \\
\hline $\begin{array}{l}\text { El Paso } \\
\text { Arzew }\end{array}$ & $948 \mathrm{ft} 6 \mathrm{in}$ & $135 \mathrm{ft}$ & $36 \mathrm{ft}$ & $\begin{array}{l}1 \\
5\end{array}$ & $\begin{array}{l}\text { Prlsmatic, } \\
\text { Insulated, } \\
\text { Stainless Steel }\end{array}$ & 10 & Subnerged & $\begin{array}{l}3552 \text { at } \\
75 \text { psig }\end{array}$ & $\begin{array}{l}\text { Steam } \\
\text { Turbine }\end{array}$ & 40,000 & 20 & $? 90$ \\
\hline $\begin{array}{l}\text { El Paso } \\
\text { Howard Boyd }\end{array}$ & $948 \mathrm{ft} 6 \mathrm{in}$ & $135 \mathrm{ft}$ & $36 \mathrm{ft}$ & $\begin{array}{l}1 \\
5\end{array}$ & $\begin{array}{l}\text { Prismatic, } \\
\text { Insulated } \\
\text { Stainless Steel }\end{array}$ & 10 & Submerged & $\begin{array}{l}3552 \text { at } \\
75 \text { psig }\end{array}$ & $\begin{array}{l}\text { Steam } \\
\text { Turbine }\end{array}$ & 40,000 & 20 & 190 \\
\hline $\begin{array}{l}\text { El Paso } \\
\text { Columbia }\end{array}$ & $931 \mathrm{ft} 6$ in & $140 \mathrm{ft} 6 \mathrm{in}$ & $36 \mathrm{ft}$ & 5 & $\begin{array}{l}\text { Rectangular, } \\
\text { Insula ted, } \\
\text { Aluminum }\end{array}$ & 10 & Submerged & $\begin{array}{l}3180 \text { at } \\
75 \text { psig }\end{array}$ & $\begin{array}{l}\text { Steam } \\
\text { Turb ine }\end{array}$ & 41,000 & 20 & 197 \\
\hline $\begin{array}{l}\text { El Paso } \\
\text { Savannah }\end{array}$ & $931 \mathrm{ft} 6$ in & $140 \mathrm{ft} 6$ in & $36 \mathrm{ft}$ & 5 & $\begin{array}{l}\text { Rectangular, } \\
\text { Insulated } \\
\text { Aluminum }\end{array}$ & 10 & Submerged & $\begin{array}{l}3180 \text { at } \\
75 \text { psig }\end{array}$ & $\begin{array}{l}\text { Steam } \\
\text { Turbine }\end{array}$ & 41,000 & 20 & 197 \\
\hline $\begin{array}{l}\text { El Paso } \\
\text { Cove Point }\end{array}$ & $931 \mathrm{ft} 6$ in & $140 \mathrm{ft} 6$ in & $36 \mathrm{ft}$ & 5 & $\begin{array}{l}\text { Rectangular } \\
\text { Insula ted } \\
\text { Alumi num }\end{array}$ & 10 & Submerged & $\begin{array}{l}3180 \text { at } \\
75 \text { psig }\end{array}$ & $\begin{array}{l}\text { Steant } \\
\text { Turbine }\end{array}$ & 41,000 & 20 & 197 \\
\hline $41-289$ & $936 \mathrm{ft}$ & $143 \mathrm{ft} 6 \mathrm{in}$ & $36 \mathrm{ft}$ & 5 & $\begin{array}{l}\text { Spherical, } \\
\text { Insulated } \\
\text { Nickel Steel }\end{array}$ & 10 & Submerged & & $\begin{array}{l}\text { Steam } \\
\text { Turbine }\end{array}$ & 43,000 & 20 & \\
\hline $42-290$ & $936 \mathrm{ft}$ & $143 \mathrm{ft} 6 \mathrm{in}$ & $36 \mathrm{ft}$ & 5 & $\begin{array}{l}\text { Spherical, } \\
\text { Insulated } \\
\text { Nickel Steel }\end{array}$ & 10 & Submerged & & $\begin{array}{l}\text { Steani } \\
\text { Turbine }\end{array}$ & 43,000 & 20 & \\
\hline
\end{tabular}


TABLE C.1. (contd)

\begin{tabular}{|c|c|c|c|c|c|c|c|c|c|c|c|c|}
\hline \multirow{2}{*}{$\begin{array}{l}\text { Ship Name and/ } \\
\text { or Hull Number }\end{array}$} & \multicolumn{3}{|c|}{ Dimensions } & \multirow[b]{2}{*}{ No. } & \multirow[b]{2}{*}{ Tanks } & \multicolumn{3}{|c|}{ Unloading Pumps } & \multicolumn{2}{|c|}{ Propulsion } & \multirow{2}{*}{$\begin{array}{c}\text { Speed } \\
\text { (Nautical } \\
\text { mph) } \\
\end{array}$} & \multirow[b]{2}{*}{$\begin{array}{c}\text { Fuel } \\
\text { (tons/day) }\end{array}$} \\
\hline & LOA & $\begin{array}{l}\text { Extended } \\
\text { Breadth }\end{array}$ & Draft & & & №. & Type & $\begin{array}{c}\text { Capacity } \\
(1,000 \mathrm{gal} / \mathrm{hr})\end{array}$ & Iype & $\begin{array}{l}\text { Rating } \\
\text { Shaft Hp }\end{array}$ & & \\
\hline $46-291$ & $936 \mathrm{ft}$ & $143 \mathrm{ft} 6$ in & $36 \mathrm{ft}$ & 5 & $\begin{array}{l}\text { Spherical, } \\
\text { Insulated, } \\
\text { Nickel Steel }\end{array}$ & 10 & Subnierged & & $\begin{array}{l}\text { Steam } \\
\text { Turbine }\end{array}$ & 43,000 & 20 & \\
\hline $\begin{array}{l}\text { Mostefa Ben } \\
\text { Boulaid }\end{array}$ & $896 \mathrm{ft}$ & $134 \mathrm{ft} 8$ in & $35 \mathrm{ft}$ & 6 & $\begin{array}{l}\text { Jechnigaz } \\
\text { Membrane }\end{array}$ & $\begin{array}{r}10 \\
2\end{array}$ & $\begin{array}{l}\text { Submerged } \\
\text { Submerged }\end{array}$ & $\begin{array}{r}211 \\
92\end{array}$ & $\begin{array}{l}\text { Steam } \\
\text { Turbine }\end{array}$ & 45,000 & 19 & \\
\hline Gastor & $889 \mathrm{ft}$ & $133 \mathrm{ft}$ & $35 \mathrm{ft}$ & & $\begin{array}{l}\text { Gaz Iransport } \\
\text { Membrane }\end{array}$ & & & & $\begin{array}{l}\text { Steam } \\
\text { Turbine }\end{array}$ & 32,000 & 19 & $\begin{array}{l}\text { Fuel } 0 i 1 \\
\text { Natural Gas }\end{array}$ \\
\hline Nestor & $889 \mathrm{ft}$ & $133 \mathrm{ft}$ & $35 \mathrm{ft}$ & 6 & $\begin{array}{l}\text { Gaz Iransport } \\
\text { Membrane }\end{array}$ & & & & $\begin{array}{l}\text { Steam } \\
\text { Turbine } \\
\text { Stal Laval }\end{array}$ & 32,000 & 19 & $\begin{array}{l}\text { Fue } 10 i 1 \\
\text { Natural Gas }\end{array}$ \\
\hline Ben Franklin & $895 \mathrm{ft}$ & $134 \mathrm{ft} 8$ in & $31 \mathrm{ft}$ & 6 & $\begin{array}{l}\text { Technigaz } \\
\text { Membrane }\end{array}$ & $\begin{array}{r}10 \\
2\end{array}$ & $\begin{array}{l}\text { Submerged } \\
\text { Submerged }\end{array}$ & $\begin{array}{r}211 \\
92\end{array}$ & $\begin{array}{l}\text { Steam } \\
\text { Turbine }\end{array}$ & 45,000 & 19 & \\
\hline 671 & $989 \mathrm{ft}$ & & & & $\begin{array}{l}\text { Insulated, } \\
\text { GT-MCD 3D }\end{array}$ & & & & $\begin{array}{l}\text { Steam } \\
\text { Turbine }\end{array}$ & 50,000 & 23 & \\
\hline 672 & $989 \mathrm{ft}$ & & & & $\begin{array}{l}\text { Insulated, } \\
\text { GT-MCD } 30\end{array}$ & & & & $\begin{array}{l}\text { Steam } \\
\text { Turbine }\end{array}$ & 50,000 & 23 & \\
\hline 53 & $936 \mathrm{ft}$ & $143 \mathrm{ft} 6$ in & $36 \mathrm{ft}$ & 5 & $\begin{array}{l}\text { Insulated, } \\
\text { Spherical, } \\
\text { Aluminum }\end{array}$ & 10 & Submerged & & $\begin{array}{l}\text { Steam } \\
\text { Turbine }\end{array}$ & 43,000 & 20 & \\
\hline 54 & $936 \mathrm{ft}$ & $143 \mathrm{ft} 6$ in & $36 \mathrm{ft}$ & 5 & $\begin{array}{l}\text { Insulated, } \\
\text { Spherical, } \\
\text { Aluminum }\end{array}$ & 10 & Submerged & & $\begin{array}{l}\text { Steam } \\
\text { Turbine }\end{array}$ & 43,000 & 20 & \\
\hline Arctic Tokyo & $798 \mathrm{ft} 4 \mathrm{in}$ & $111 \mathrm{ft} 6$ in & $32 \mathrm{ft} 11-1 / 8$ in & 6 & $\begin{array}{l}\text { Gaz Iransport } \\
\text { Membrane }\end{array}$ & 6 & & $\begin{array}{l}1258 \text { at } \\
351 \mathrm{ft}\end{array}$ & $\begin{array}{l}\text { Steam } \\
\text { Turbine }\end{array}$ & 20,000 & 18.25 & $\begin{array}{l}\text { Fuel } 0 i 1 \text { as a } \\
\text { Complement to } \\
\text { Evaporated } \\
\text { Gas }\end{array}$ \\
\hline Polar Alaska & $799 \mathrm{ft}$ & $111 \mathrm{ft} 6$ in & $32 \mathrm{ft} 9$ in & 6 & $\begin{array}{l}\text { Gaz Iransport } \\
\text { Membrane }\end{array}$ & 6 & & $\begin{array}{l}1258 \mathrm{at} \\
351 \mathrm{ft}\end{array}$ & $\begin{array}{l}\text { Steam } \\
\text { Turbine }\end{array}$ & 20,000 & 17 & $\begin{array}{l}\text { Fuel } 0 i l \text { as a } \\
\text { Complement to } \\
\text { Evaporated } \\
\text { Gas }\end{array}$ \\
\hline G26 & $895 \mathrm{ft}$ & $134 \mathrm{ft} 8$ in & $35 \mathrm{ft}$ & & $\begin{array}{l}\text { Gaz Iransport } \\
\text { Membrane }\end{array}$ & & & & $\begin{array}{l}\text { Steam } \\
\text { Turbine }\end{array}$ & 45,000 & 20 & \\
\hline L26 & $895 \mathrm{ft}$ & $134 \mathrm{ft} 8 \mathrm{in}$ & $35 \mathrm{ft}$ & & $\begin{array}{l}\text { Gaz Iransport } \\
\text { Membrane }\end{array}$ & & & & $\begin{array}{l}\text { Steam } \\
\text { Turbine }\end{array}$ & 45,000 & 20 & \\
\hline Chiani Bachis & $924 \mathrm{ft} 3$ in & $136 \mathrm{ft} 6$ in & $37 \mathrm{ft} 3$ in & & $\begin{array}{l}\text { Gaz Iransport } \\
\text { Membrane }\end{array}$ & & & & Steam & 36,000 & 19.4 & \\
\hline
\end{tabular}



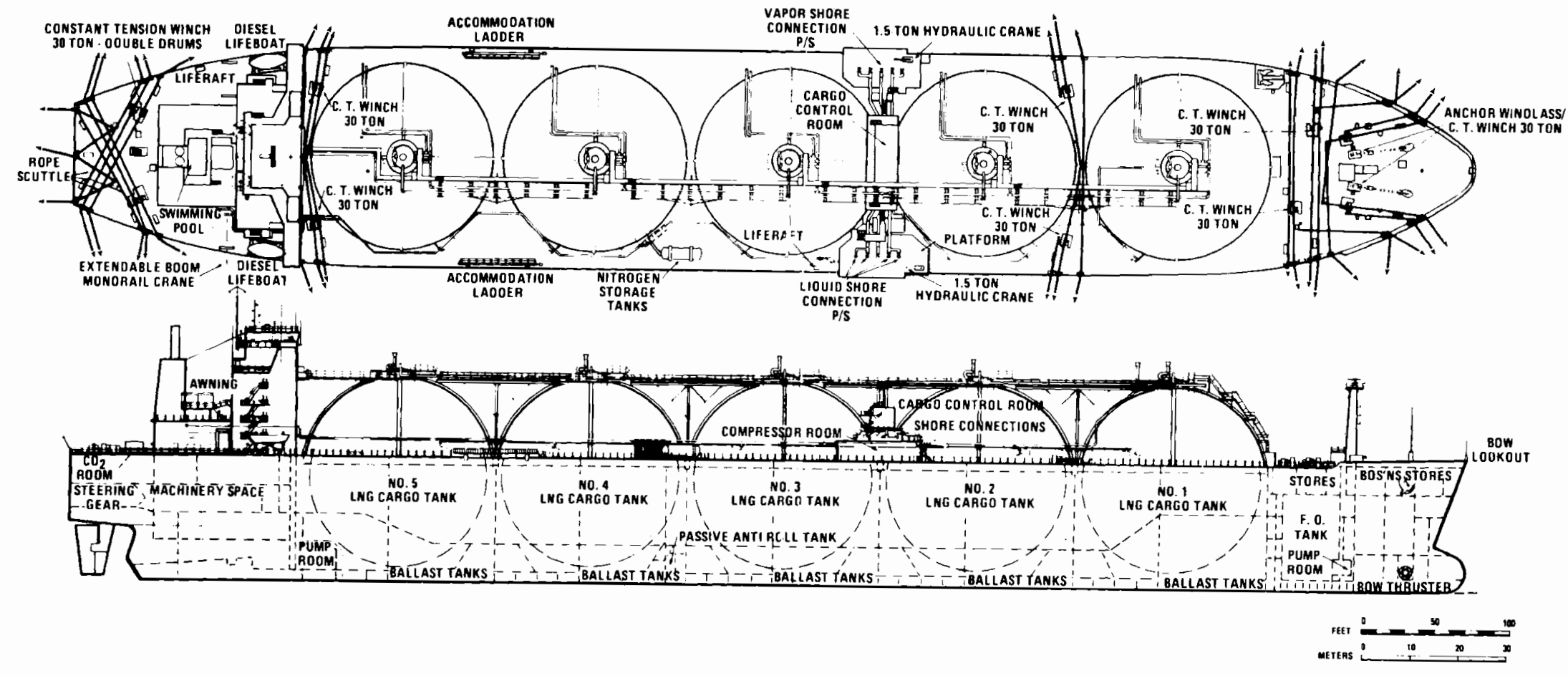

FIGURE C. I. $\quad 125,000-m^{3}$ LNG Transfer Vessel 
TABLE C.2. Principal Characteristics of $125,000-\mathrm{m}^{3}$ LNG Carrier

$\begin{array}{lcc}\text { Length Overal1 } & 926^{\prime} 0^{\prime \prime} & 285.3 \mathrm{~m} \\ \text { Length between Perpendiculars } & 897^{\prime} 0^{\prime \prime} & 273.4 \mathrm{~m} \\ \text { Breadth, Molded } & 143^{\prime} 6^{\prime \prime} & 43.7 \mathrm{~m} \\ \text { Depth, Molded to Upper Deck at Side, Amidships } & 82^{\prime} 0^{\prime \prime} & 25.0 \mathrm{~m} \\ \text { Draft, Design Waterline } & 36^{\prime} 0^{\prime \prime} & 11.0 \mathrm{~m} \\ \text { Total Deadweight } & 63,600 \mathrm{~L} \text {. Tons } & 64,620 \mathrm{M} . \mathrm{T} . \\ \text { Displacement } & 95,088 \mathrm{~L} \text {. Tons } & 96,614 \mathrm{M} . \mathrm{T} . \\ \text { Cruising Radius Burning 0il Only (Approx.) } & 10,500 \mathrm{~N} \text {. Miles } & 19,500 \mathrm{~km} \\ \text { Shaft Horsepower, Max, Continuous } & 43,000 & 43,600 \mathrm{M} . \\ \text { Design Speed, Trail Conditions, Knots } & 20.4 & -- \\ \text { Specific Fuel Consumption Rate (Approx.) } & 0.477 \mathrm{lb} / \mathrm{shp}-\mathrm{hr} & 0.213 \mathrm{~kg} / \mathrm{shp}-\mathrm{hr}\end{array}$

they are removed from the tanks by the boiloff compressors and used to supply approximately $70 \%$ of the ship's fuel during transit.

The ship has a range (oil fuel only) of approximately 10,500 nautical miles. It has a total fuel oil capacity of 6660 long tons, a fresh water capacity of 470 long tons, and a diesel oil capacity of 185 long tons.

The cargo system of the ship includes five spherical aluminum tanks with a total tank volume of $126,750 \mathrm{~m}^{3}$ at $100 \%$ full and $-265^{\circ} \mathrm{F}$. Two unloading pumps, each with a capacity of $1130 \mathrm{~m}^{3} / \mathrm{hr}$, are included in each tank. Spray pumps are also included with each storage tank for the purpose of storage tank cooldown. The total spray pump capacity is $68 \mathrm{~m}^{3} / \mathrm{hr}$. The vessel has a nitrogen system for purging the tanks into and out of service. The nitrogen system includes $25 \mathrm{~m}^{3}$ of liquid storage and a vaporizer. An inert gas generator with a capacity of $184 \mathrm{~m}^{3} / \mathrm{min}$ is also included.

Navigational and electronic equipment for the vessel includes:

- short- and long-range radar systems positioned fore and aft of the vessel

- a depth recorder

- a Loran position fix $A / C$ receiver

- high- and medium-frequency radio communications

- VHF ship-to-ship radio-telephone

- a 50-line automatic-dial telephone system 
- a radio direction finder

- gyro pilot steering-control system

- a gyro compass

- a magnetic compass

- 1000-watt SSB radio-telephone

- an underwater log system

- digital readout depth sounder

- echo depth sounder

- two depth indicators.

Some of this navigational equipment is depicted in Figure C.2. All of the navigational safety equipment is connected to alarms located on the bridge and control room.

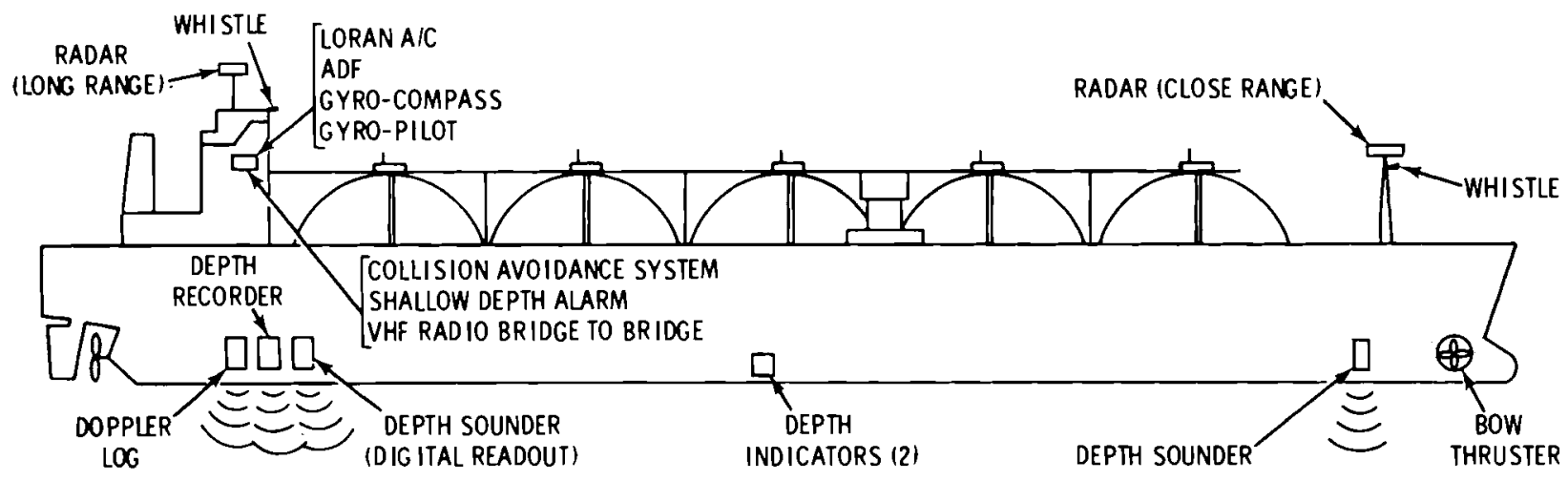

FIGURE C.2. Navigational Equipment for LNG Transfer Vessel

The ship is powered by a heavy-duty marine steam turbine rated at 43,000 shp. Steam for the turbine is generated in two high-pressure $\left(850 \mathrm{psig}, 950^{\circ} \mathrm{F}\right)$ boilers that burn boiloff gas and bunker fuel. Steam is also used to drive the boiloff compressors and generate electricity for the ship.

In addition to the features previously mentioned, the ship includes the following:

- single six-bladed propeller rated at $103 \mathrm{rpm}$

- two turbogenerators for electricity rated at $1250 \mathrm{~kW}$ each

- a 1500-kW standby diesel generator

- a 250-kW diesel emergency electrical plant

- two distilling plants with a total capacity of 16,000 gal/day

- two air-conditioning plants with a total capacity of 60 tons 
- a 2200-hp bow thruster

- two bow anchors at 27,900 1b each

- a 12,000-gal sewage holding tank.

\section{C.1.2 Ship Structure}

The LNG carrier has two principal parts, the basic ship comprising the hull and propulsion plant, and the cryogenic section consisting of containment tanks and cargo handling systems. The cryogenic section is described in detail in later sections of this appendix.

The LNG tanker is designed to meet rigid requirements of both impact and damaged stability. The beam of the ship, along with its large freeboard at full load, is designed to give it exceptional stability. Wing side tanks and a double-hull system throughout the vessel reduce the possibility of damage to the cargo tanks and adjacent inner hull structure in the event of a collision. They also reduce the risk of damage to the storage tanks and tank supports in the event of the ship grounding. The geometry of the LNG tank system and the structural strength of the hull provide excellent resistance to side and botton damage due to collision or grounding.

The hull of the carrier is constructed from a combination of different grades of mild steel, the highest grades being used in the more critical zones. Lloyds Register Grade "A" is generally considered suitable for a minimum temperature of $0^{\circ} \mathrm{C}$, Grade "D" for $-5^{\circ} \mathrm{C}$ or $-10^{\circ} \mathrm{C}$ depending on where used in the ship's structure, and Grade "E" for somewhat lower temperatures. Grades "D" and "E" are impact tested at the minimum temperature for which they are required. The large thermal capacity of the cargo hold structure makes it unlikely that the hull steel will be as cold as the predicted steady-state temperature when exposed to the cold ambient conditions for short periods of time.

The large scantlings; high strength of the deck stringer, sheer strake, and attached longitudinals; and the multitude of structure below the platform supporting the tank provide good resistance to collision penetration. Only over a small portion of the hold length and depth do the spherical boundaries come close to the hu11. At locations other than midtank, the ship can withstand greater penetration and consequently greater impact velocity. 


\section{C.2. CARGO HANDLING}

The systems and procedures used for cargo handling on the LNG vessel are described here. The LNG cargo handling systems are shown in Figure C.3, with corresponding equipment identifications given in Table C.3. (Flow diagram symbols are defined in Appendix H).

TABLE C.3. LNG Cargo Handling Systems

\begin{tabular}{|c|c|}
\hline $\begin{array}{c}\text { Equipment } \\
\text { Identification } \\
\end{array}$ & Description \\
\hline c & Compressor \\
\hline G-101 & Inert Gas Generator \\
\hline $\mathrm{H}-101$ & Boiloff Heaters \\
\hline$H-201$ & Warmup Heater \\
\hline$N-102,103$ & Spray Nozzles \\
\hline$P-102,103, A / B$ & Main Cargo Pumps \\
\hline P-202, 203 & Spray Pumps \\
\hline$T-101,102,103,104,105$ & LNG Storage Tanks \\
\hline$E-100$ & LNG Vaporizer \\
\hline
\end{tabular}

\section{C.2.1 Liquid Cargo System}

The liquid cargo system includes the pipes, fittings, and machinery used to load or discharge LNG from the vessel. The system consists of the following:

- fore and aft pipe main (1 iquid header in Figure C.3)

- manifolds on pipe main for loading or discharging from either side of the vesse 1

- loading lines at each tank dome

- two pump discharge lines, one from port and one from starboard side of each tank

- two submerged, electrically driven pumps in each cargo tank. 


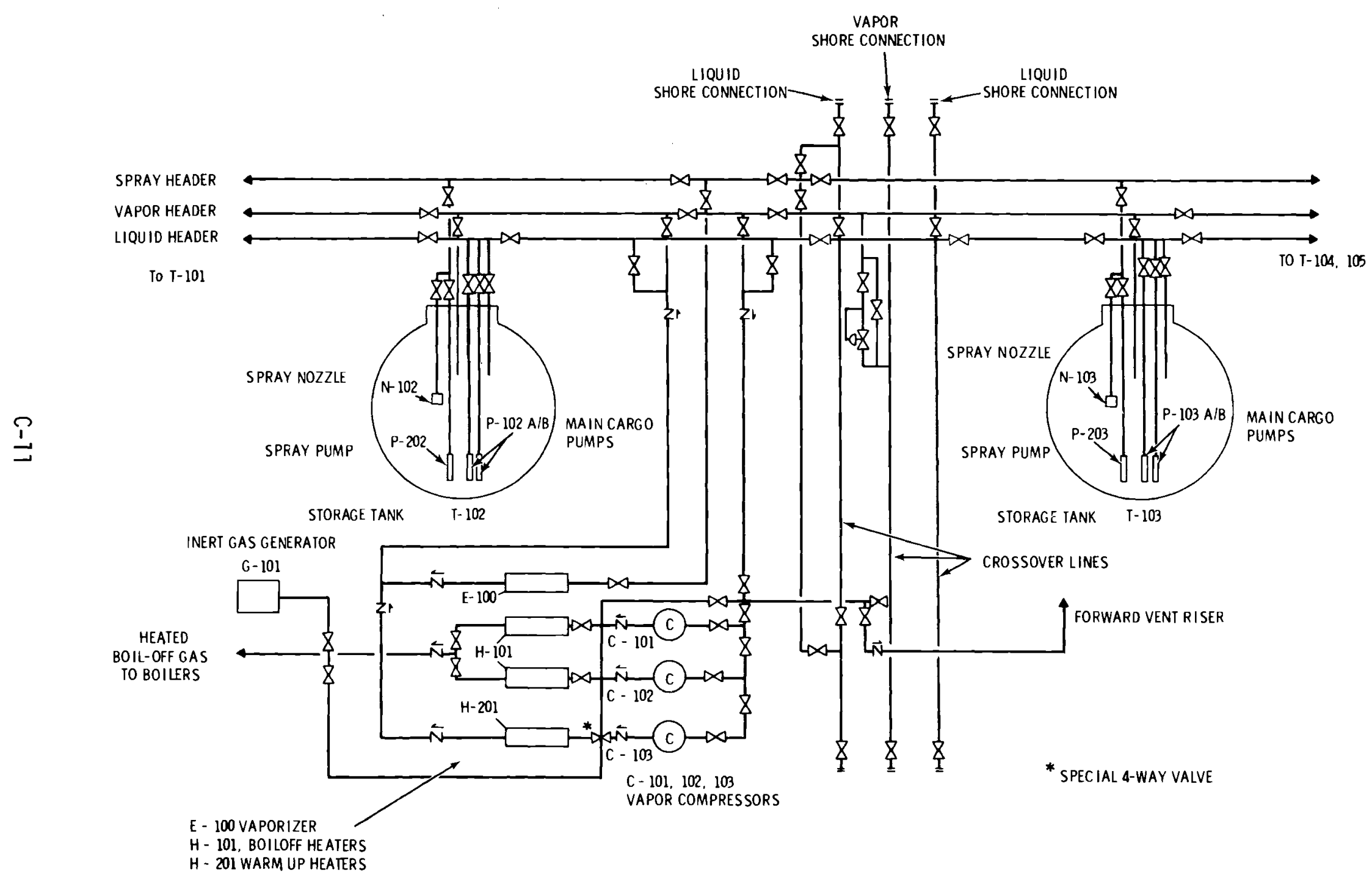

FIGUKE C.3. LNG Cargo Handling Sys tems 
The five cargo tanks in the ship each contain two fully submerged, vertical shaft, electrically-driven cryogenic centrifugal pumps to transfer LNG from the storage tanks of the ship to the terminal storage tanks. Each pump has a capacity of $1130 \mathrm{~m}^{3} / \mathrm{hr}(5,000 \mathrm{gpm})$ with a discharge pressure of $100 \mathrm{psig}$, and this provides for an unloading time for the vessel of approximately 12 hours.

The pumps used in this system offer the following important engineering advantages:

- No mechanical seal or packing gland is required, since the pump is completely exposed to an LNG environment.

- No line shaft or 1 ine shaft bearing is necessary.

- Each pump has a greater horsepower-to-weight ratio, since fewer parts are required.

- Each pump can pump effectively with a very low pressure at its suction side.

Centrifugal pumps pumping liquids near their saturation point often are plagued by cavitation problems due to insufficient NPSH (net positive suction head). By placing the pump inside the tank, the pressure drop normally associated with the transfer piping from the tank to the pumps is eliminated. This provides additional NPSH for the pump and, as a result, reduces cavitation problems.

A further advantage is the LNG surrounding the moving parts of the pumps. The LNG acts as a coolant to these systems. Lubrication to the pump is supplied by the LNG as it flows over the ball bearings and then through the motor casing to the suction side of the pump. In addition, the low temperature environment reduces the electrical resistance of the copper windings and thus increases motor efficiency.

The major drawback of this type of pump 1 ies in the fact that it requires current-carrying wires in a cargo tank.

\section{C.2.2 Liquid Recirculation System}

This system is used to cool down the cargo tanks and to keep them cold during ballast voyages. It consists of a line (spray header in Figure C.3) to 
supply LNG to the tank cooldown system when the ship is at sea, a small spray pump in each tank, and a spray nozzle in each tank.

\section{C.2.3 Gas Main}

The gas main line (vapor header in Figure C.3) serves the following purposes on an LNG vessel:

- to provide a second leg for the closed cargo load/unload cycle

- to supply the gas compressors with boiloff during a voyage

- to supply high-pressure warm methane gas to the warmup system.

In addition, three boiloff compressors draw gas from the gas main to supply the boilers via the gas supply 1 ine.

The boiloff compressors are direct steam-turbine-driven, centrifugal units. These are generally used for all ships larger than 65,000 $\mathrm{m}^{3}$. Since there is sufficient steam on board, superheated steam is. used to drive the steam turbine that is mounted directly on the shaft of the boiloff compressor.

The compressor is from a solid forging; titanium is used for the highduty compressor due to tip-speed considerations and aluminum forgings for the lower tip-speed, low-duty compressor. Each compressor is enclosed in a stainless steel housing with proper flow inlet and discharge volute casing. An insulation system is provided adjacent to the back disc of the compressor impeller. In combination with the seal gas and bearing lube subsystem operation, the insulation achieves essentially room temperature conditions on the bearing housing. The bearing housing contains in-line board positions for the rugged pivoted shoe bearing together with the seal cartridges. These contain a series of controlled air gap, floating carbon ring seals with regulated seal gas feed.

Surge control is provided by measuring the pressure differential across the compressor inlet orifice plate. The differential at which surge occurs is used as the set point on a pneumatic controller. The measured differential is then compared to the set point. The surge control bypass valve is modulated to maintain the compressor outside the surge limits. 
The main control system provides speed control for the compressor by regulating the compressor inlet pressure (tank outlet pressure) to preset values (usually $1.0 \mathrm{psig}$ ) to modulate the steam flow rate. The shaft speed of the compressor is allowed to vary freely up to a specified limit. At this upper limit, the speed controller, being cascaded with the pressure control, controls the steam flow rate as necessary to maintain constant speed, the speed measurement being made by a mechanical-to-pneumatic transducer.

The additional portion of the control system consists principally of compressor startup and stop buttons in both local and remote locations and the series of safety switches that shut the system down by closing a steam shutoff valve immediately upstream of the steam control valve. The safety system is completely independent of the control system and is failsafe in operation. The safety system monitors the pneumatic output signals from the five safety switches, which monitor lube oil pressure, lube oil temperature, compressor speed, speed signal or underspeed, and seal gas pressure. When these switches are in the safe condition, the pneumatic output is approximately 20 psig. When in the unsafe condition, the output falls to 0 psig. Through series arrangements of low pressure selectors, the lowest of these five signals is fed to the steam safety valve. Thus, if any safety switches are in the unsafe condition, the valve receives the lowest of the five signals and therefore closes. The safety valve is prevented from reopening, if the safety switch returns to the safe condition, by a latching circuit.

\section{C.2.4 Blocked Liquid/Gas Relief System}

This is a safety system consisting of relief valves and piping that lead to the gas main. All those sections of piping that are closed off to the vapor are provided with relief valves. If excessive pressure builds up as LNG vaporizes, the relief valves direct excess vapor to the gas main. In addition, there is a relief valve amidship on the gas main to prevent overpressurizing.

\section{C.2.5 Piping and Fittings}

Piping, valves, and other fittings are of the same basic design as those used for cargoes at normal temperatures. The basic difference is in the materials used for their fabrication. Aluminum or aluminum alloy is the most 
desirable material from the point of view of low temperature properties. However, ships are made of steel and are in a sea environment; hence, an aluminumsteel connection forms a galvanic cell (i.e., a wet battery). The result is a rapid corrosion of the aluminum. The possibility of inserting an electrical barrier into the junction has not been considered practical for this service. Therefore, 9\% nickel steel is used for all piping and fittings in cryogenic service. Most of the valving is made of stainless steel. Double piping, one inside the other with the internal pipe carrying the gas, is used for the gas supply lines to the main propulsion machinery.

The control of an LNG facility can be accomplished by controlling flow rates of liquid, gas, or heat. Flow rates are most effectively controlled by valving, although they can sometimes be regulated by adjusting machinery speed, as in the case of the boiloff compressors. Valves can be adjusted manually or automatically. During normal steady operations, automatic control is achieved. For startup and shutdown procedures, manual control is used. Automatic control valves are actuated by air pressure.

\section{C.2.6 Loading}

LNG is loaded onto the vessel by the pumps at the export terminal. The procedures used prior to and during loading are described below.

\section{C.2.6.1 Preparations for Loading}

The following procedures are followed prior to loading:

- The ship is moored with ship and shore manifolds in compatible relative positions.

- The deck area around the cargo tanks is cleared of unnecessary personne 1 and gear.

- The vessel is properly trimmed so the LNG will flow evenly into the liquid header and cargo tanks.

- Upon arrival, cargo tanks are gauged. This involves three people: an officer of the vessel, a terminal representative, and a government authority. (The same procedure is carried out upon completion of loading.) 
- An accurate log of all phases of the loading operation is kept. This log includes gauging information, starts, stops, changes in loading rates, and corresponding times and reasons. The operation of the ship's fill valves, sequence of tank filling, and time of start and stop of loading is the responsibility of the person on deck who represents the ship's master.

Several systems are kept in operation during loading and should be checked for proper operation. These include:

- nitrogen system and alarms

- actuating air supply (for valves, alarms, etc.)

- instrument air supply

- tanks/vapor pressure gauges

- gas analyzer

- tank temperature recorders

- hul1 temperature monitoring system

- motor operated valves

- cargo mimic panel in the cargo control room

- liquid-level measuring systems.

\section{C.2.6.2 Loading Procedures}

Loading LNG into an empty aerated tank is an operation that includes three major steps: purging and drying, cooldown, and loading.

Before LNG is carried through any ship's piping or introduced into the tanks, these areas, together with the space between the cargo tanks and the inner hu11, are purged with an inert gas to exclude oxygen. The ship carries nitrogen for this purpose. The nitrogen is first warmed to slightly above tank temperature and introduced through the vapor piping at the top of the tank. As it moves through the tank, air is purged out through the liquid pipes at the bottom of the tank and exits through the forward vent riser. During the purge, samples of removed gases are tested for their oxygen content. When the oxygen content is reduced to below $6 \%$ by volume, purging may be stopped. One advantage of using nitrogen is that it also effectively dries the tank space and its associated piping during the same process. A visual process description and flowsheet for the purging operation is given in Figure C.4. 


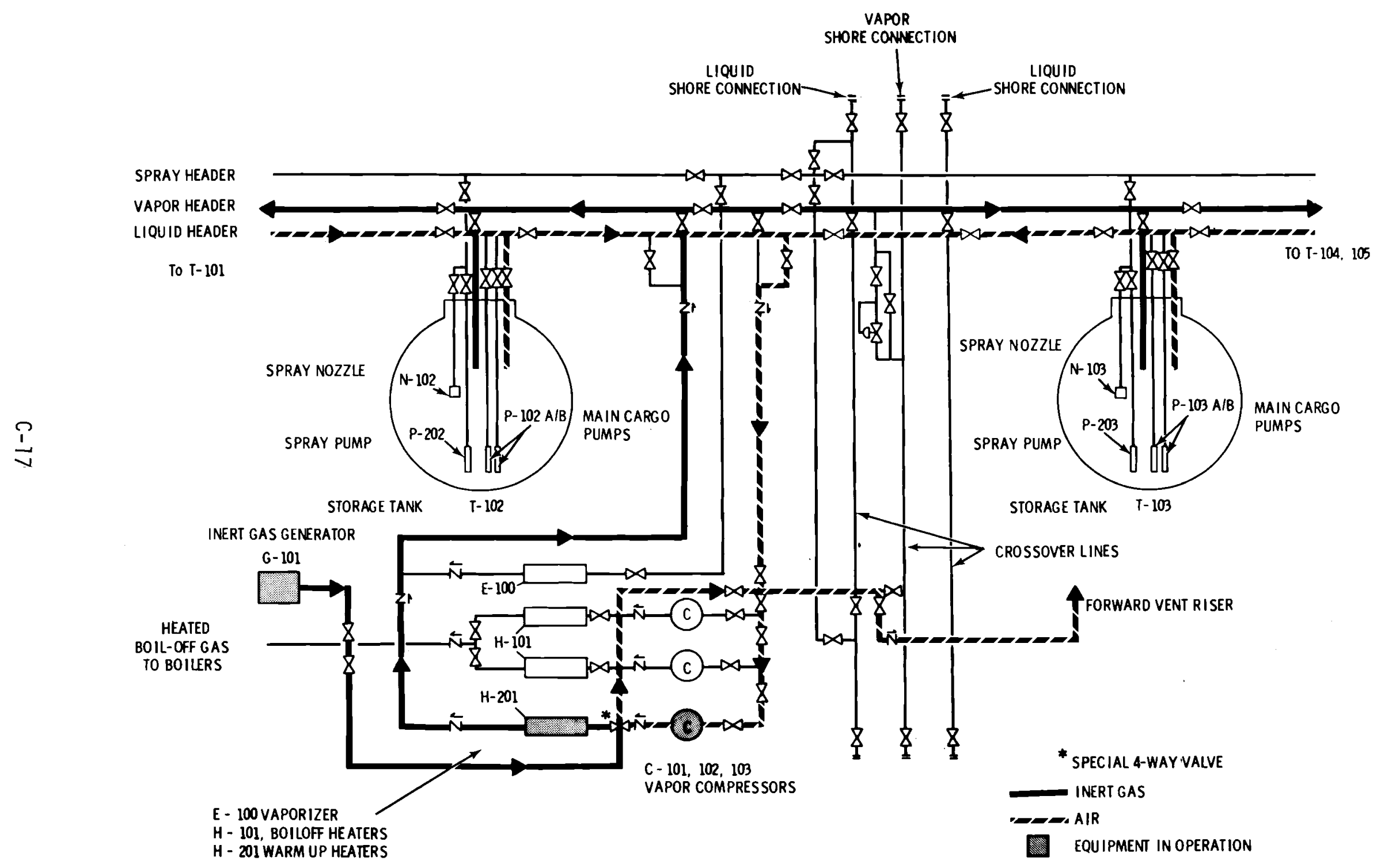

FIGURE C.4. Purging and Drying of Storage Tanks with Inert Gas 
When all preparations for loading are completed on the vesse1, terminal personnel extend both the loading and vapor return arms to a position such that persons on the working platform can remove the blinds. After positioning, and before the blinds are removed, the following steps take place:

- Terminal personnel open vent valves, depressurizing the loading arms, which have been maintained in a nitrogen atmosphere.

- After venting, they advise the flanging crew that the blinds may be removed and connection made to the ship's manifold. These connections are made with hydraulically operated, positive-locking, quick-disconnect couplings.

- When connections have been properly made, the ship's cargo officer advises the terminal that the vessel is ready to receive cargo. Terminal personnel notify other shore facilities.

- Terminal personnel then request readiness of the ship's vapor compressor.

- Terminal personnel slightly open the bypass valves to cool down the loading arm. Cooldown lasts some 30 to 40 minutes, with LNG being circulated through the ship's piping but not into tanks.

- When loading arms cooldown is completed, the loading valve control console is checked and placed on board. Various shore valves are then opened slightly and then closed to ensure that LNG will be directed to the correct ship's tank.

The storage tanks are cooled down, at a relatively slow rate to avoid cracking of the tank walls, to a temperature close to that of LNG. This is done by spraying LNG into the tank. When it hits the tank walls, some of the LNG vaporizes, cooling the tank. The flashed vapors are recycled to the shore plant. The spray cooling process continues until temperature probes indicate that the tank lining and insulation are close to the LNG temperature $\left(-250^{\circ}\right.$ to $-260^{\circ} \mathrm{F}$ ). In this cooldown operation, the tank bottom approaches LNG temperatures first, due to the fact that nonvaporized spray accumulates at the bottom. When the bottom tank temperature is near LNG temperature and the temperature at the top of the tank is not too different, cooldown stops and loading begins. A visual process flow diagram for cooldown is given in Figure C.5. 


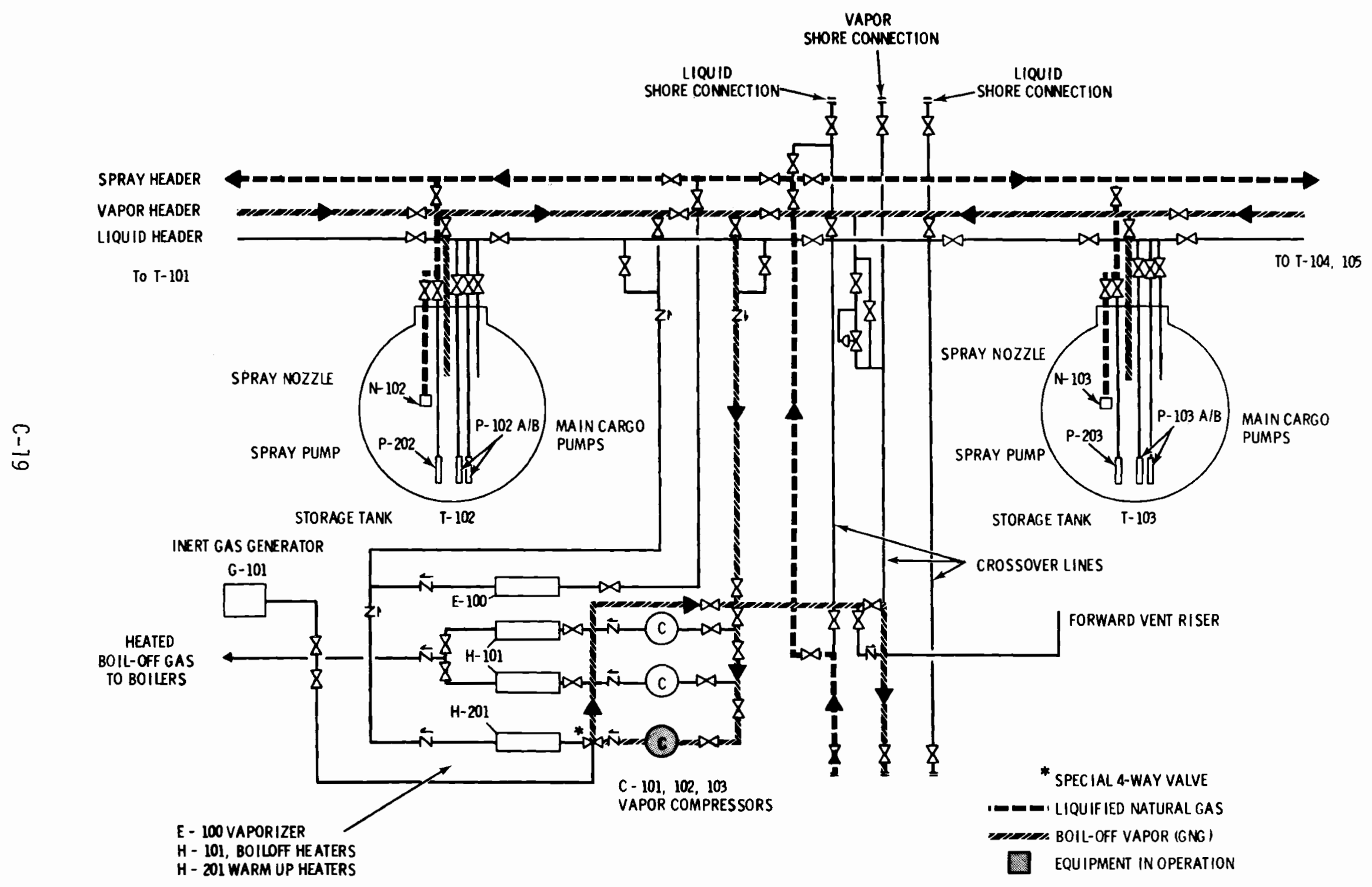

FIGURE C.5. Spray Cooling of Cargo Tanks with LNG 
During normal loading, LNG is introduced into the tanks at a total combined rate of 53,000 gpm. As LNG fills the tank space, vapors remaining from the cooldown operation are forced toward the top. These vapors must be pumped out to prevent pressure from building up in the tanks. Therefore, the vapors are continously being pumped back to shore using the ship's boiloff compressors. A visual process flow diagram for loading operations is shown in Figure C. 6 .

Cargo transfer is carefully documented. Continuous watch is kept both in the control room and on deck, and a log is maintained on all operations. Drain pans are placed beneath fittings to collect LNG leakage and protect the deck from localized thermal shock. An option to this is to run seawater over the decks during loading and discharging.

Approximately 40 minutes prior to reaching the filled level of the tanks, or at some predetermined level, the cargo officer notifies terminal personnel to reduce the loading rate. This is done by cutting out all but one shore pump. When the tank reaches proper 1eve1, 98\% ful1, the operator closes the dome vent vaive on top of the tank. If the tank level reaches $99 \%$, a signal from a second level indicator activates the emergency shutdown system.

When the proper level is reached on all tanks, the cargo officer notifies the terminal operator to stop loading and orders the ship's compressors shut down. Al1 compressor valves and valves in the compressor line are closed. The tank is usually filled to $98 \%$ of its capacity to allow space for the boiloff vapor.

If the ship is to take on LNG cargo when it already has some LNG in its tanks, inerting and cooldown are not necessary. For this reason, after unioading, the ship often retains a small amount of LNG in its tanks (about $5 \%$ by volume) so a new cargo may be directly taken on board. The LNG is usualiy kept in one tank and sprayed into the other four tanks using the spray pumps and spray nozzles. One disadvantage to this method of cooldown is that if LNG of a different composition is loaded, a substantial heat release may result due to physical mixing of the different cargoes. The vapors produced from the released heat must be pumped back to shore at a rate sufficient to prevent pressure buildup in the tank. 


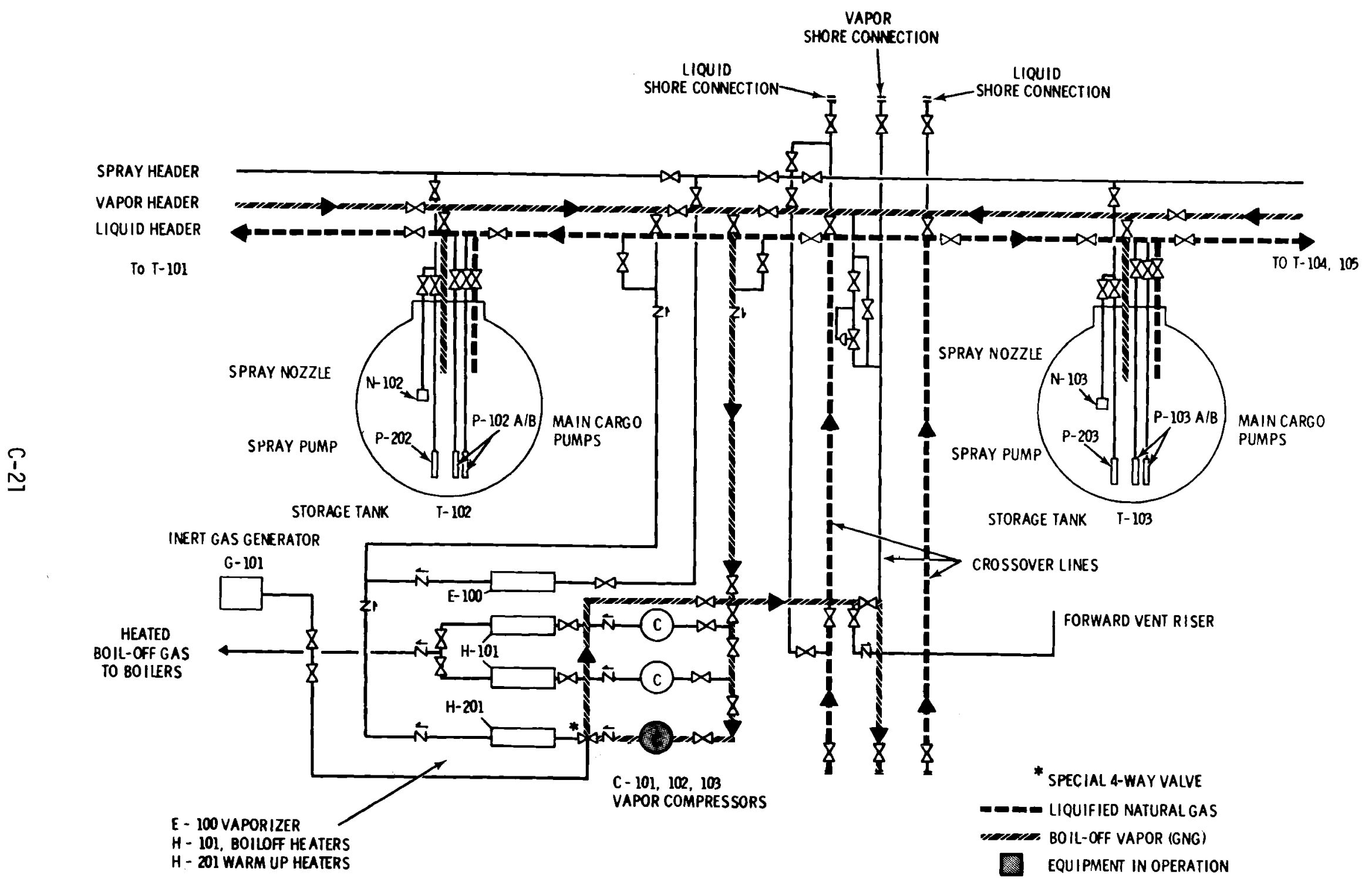

FIGURE C.6. LNG Loading Operations 
The disconnecting operation first requires draining of the liquid header and loading arms. They are drained into the last tank filled. This involves the following:

- Using the portable console, the ship's personnel close the shore block valves. The terminal operator then closes the vapor manifold valve ashore and notifies the cargo officer to close the vapor manifold valve and stop the compressors. The terminal operator opens a drain line on each loading arm and leaves it open for at least three minutes. The liquid drains into the liquid header aboard the vessel. The drain valves ashore are then closed.

- The ship's manifold loading valves are closed. The vapor header is then cracked to the crossover 1 ines.

- The terminal operator opens the nitrogen block valve to each arm and pressurizes it.

- At this point, the terminal operator requests the cargo officer to open the ship's liquid and vapor manifold valves slightly for depressurizing into the ship's lines. This operation is repeated at least three times by reclosing and reopening the liquid and vapor manifold valves. The final position of the valves is closed.

- The terminal operator opens wide the atmospheric vent valve on each arm.

- When the arms are depressurized and the flanges are at a temperature that can be handled (salt water may be used to warm up the flanges), the loading arms are disconnected and the blind flanges replaced on manifold and loading arms.

- After the arms are retracted, the terminal operator closes the atmospheric vent valves and repressurizes the loading arms with nitrogen.

When all of the foregoing operations are complete, all valves used for loading are closed. A slight trim at the stern of the vessel facilitates the draining of onboard lines. 


\section{C.2.7 Un loading}

Unloading procedures are, in many respects, the reverse of loading. There are two submerged pumps per tank on the ship, plus an alternate discharging system. Maximum discharge rate is about the same as that for loading. Shore compressors return vapor displaced from shore tanks to the ship's tanks.

Operations for discharging include:

- cooldown of liquid lines

- draining of liquid lines back into cargo tanks

- gauging of tanks

- connection of ship's manifold to shore liquid and vapor lines

- cooldown of shore liquid and vapor discharge lines

- discharge of cargo

- drainage of 1 ines and disconnection

- gauging tanks and determination of the quantity of cargo discharged.

\section{C.2.7.1 Preparation for Un loading}

In preparing for discharge, one of the first steps is to trim and heel the vessel in accordance with the ship's operating instructions to facilitate drainage operations. Further, the following systems are checked:

- nitrogen system and alarms

- actuating air supply

- instrument air supply

- vapor line pressure switch and alarm

- vapor header pressure gages

- gas analyzer

- data logger

- liquid level alarms and shutdown

- cargo pump emergency stops

- cargo valve actuators

- liquid and vapor manifold valves and emergency closures.

Preliminary procedures include the opening and closing of certain valves and the shutdown of certain equipment. For example: 
- compressors are shut down

- vapor header to compressor valve is closed

- valve from gas to liquid header over the compressor room is closed.

A number of other valves are opened or closed on the cargo dome.

When the vessel is fully prepared for discharge operations, the cargo officer gives notice to ship and terminal crews that the liquid and vapor arms are ready for connection. The terminal operator locates the arms so that blinds can be easily removed. On his end, the terminal operator has to purge the arms of methane vapors with nitrogen gas. Following this, he depressurizes the arms. When finished, he notifies the cargo officer who orders the blinds removed and flanges attached loosely. A second nitrogen purge follows, and then the flanges are tightened. Now cooldown of piping begins.

During cooldown, the ship's cargo pumps are used. LNG used for cooldown is circulated through the liquid header, into the liquid crossover line, and through each loading arm and returned to the ship's cargo tanks via the vapor loading arm, the vapor crossover line, and the vapor header. Cooldown begins by slightly opening vapor and liquid manifold valves. LNG then flows to both loading arms. A small amount of LNG is pumped through the piping system, the purpose being to cool down the connecting lines at a rate somewhat slower than that which occurs with full scale pumping. During this operation, some LNG vaporizes. This is separated from the liquid when it is recirculated back to the top of the cargo tank. As cooldown progresses, a frost line gradually builds up along the discharge arm. When all arms have sufficiently cooled, cargo transfer prodeeds. At this point, ship's personnel receive from the terminal a portable console which can close shore valves and stop motors in the event of an emergency. When all is ready and the recirculation is shut down, unloading operations can begin.

\section{C.2.7.2 Un loading Procedures}

When all connections are made, cooldown completed, and dome liquid and vapor valves opened, the procedure for unloading is as follows: 
- Determine from the terminal that they are ready to receive LNG and that return gas pressure is available.

- One main cargo pump is started so as to put maximum pressure on the ship's system.

- An inspection is made to locate any leaks.

- If leaks are found, the pump is stopped, the liquid is drained, and repair is undertaken.

- If no leaks are found, one of the ship's manifold liquid valves is opened in coordination with shore requirements.

- The other main cargo pumps are then started and the other liquid valves are opened in coordination with shore requirements.

- After a short period of time, the LNG originally filling the main LNG transfer 1 ine to the storage tanks is displaced. During this time no return vapor from the shore is being pumped. Some vaporization of the ship's cargo may have to be carried out so that it can be pumped into the top of the tank as liquid is pumped out through the bottom. When the shore tank pressure increases to the desired level, the terminal advises the cargo officer and arranges to start the vapor return blower. This directs the return vapor via the vapor crossover line through a regulator valve set for about 2 psig. The tanks do not require vapor until their pressure drops below this point. The reason for this operation is that, as liquid is pumped out through the bottom, a suction is created at the top. This could cause a massive evaporation of tank 1 iquid and also require greater work from the pumps. It could also cause pump damage or even sta11. To avoid these problems, vapor is pumped into the tank so that tank pressure is maintained.

- When all compartments are operating properly and the terminal indicates readiness, the cargo officer increases the flow rate by starting one cargo pump at a time. Then, each cargo pump discharge valve is opened wide.

- Cargo operations at this point are then monitored from the cargo control room. 
A visual process flow diagram for unloading cargo is shown in Figure C.7.

Usually, one tank is discharged before the others and so on, so that there is a gradual decrease in cargo discharge rate. This discharge rate is carefully monitored and, about one hour prior to estimated completion, the cargo officer notifies the terminal. Just before stopping the last cargo pump, several events occur in sequence:

- The cargo officer notifies the on-shore control room of his intention.

- The cargo officer cracks open the adjacent filling line for the last tank.

- The terminal operator closes the shore block valve, and cargo circulates back to the tank.

- The pump is then shut down, and the adjacent filling line is closed.

Some LNG is usually left to keep the tanks cool and to provide fuel, from the boiloff, for the return trip.

There is an alternate means for carrying out the discharge of cargo tanks, should the main cargo pumps fail. With the spherical tanks, this is done by pressurizing the tank with an inert gas, such as nitrogen, and "blowing out" the LNG cargo.

\section{C.2.8 Loaded Voyages}

The major concern during a loaded voyage is the vapor pressure in the cargo tanks. If the pressure is too low, boiloff occurs at a higher than normal rate; if it is too high, relief valves may be actuated and boiloff vented. The concern here is the practical means of maintaining the boiloff pressure in the tanks at a maximum of 1 psig. (The 1 psig maximum is a safety figure that helps to ensure that venting does not take place within port limits.)

To obtain the desired boiloff pressure, a series of steps may be taken:

- Keeping in mind any fuel gas must be odorized, start the gas fuel system as soon as possible after leaving the loading port.

- Cargo tank boiloff pressure may be controlled by controlling the gas compressor speed until tank pressure drops to the desired level. 


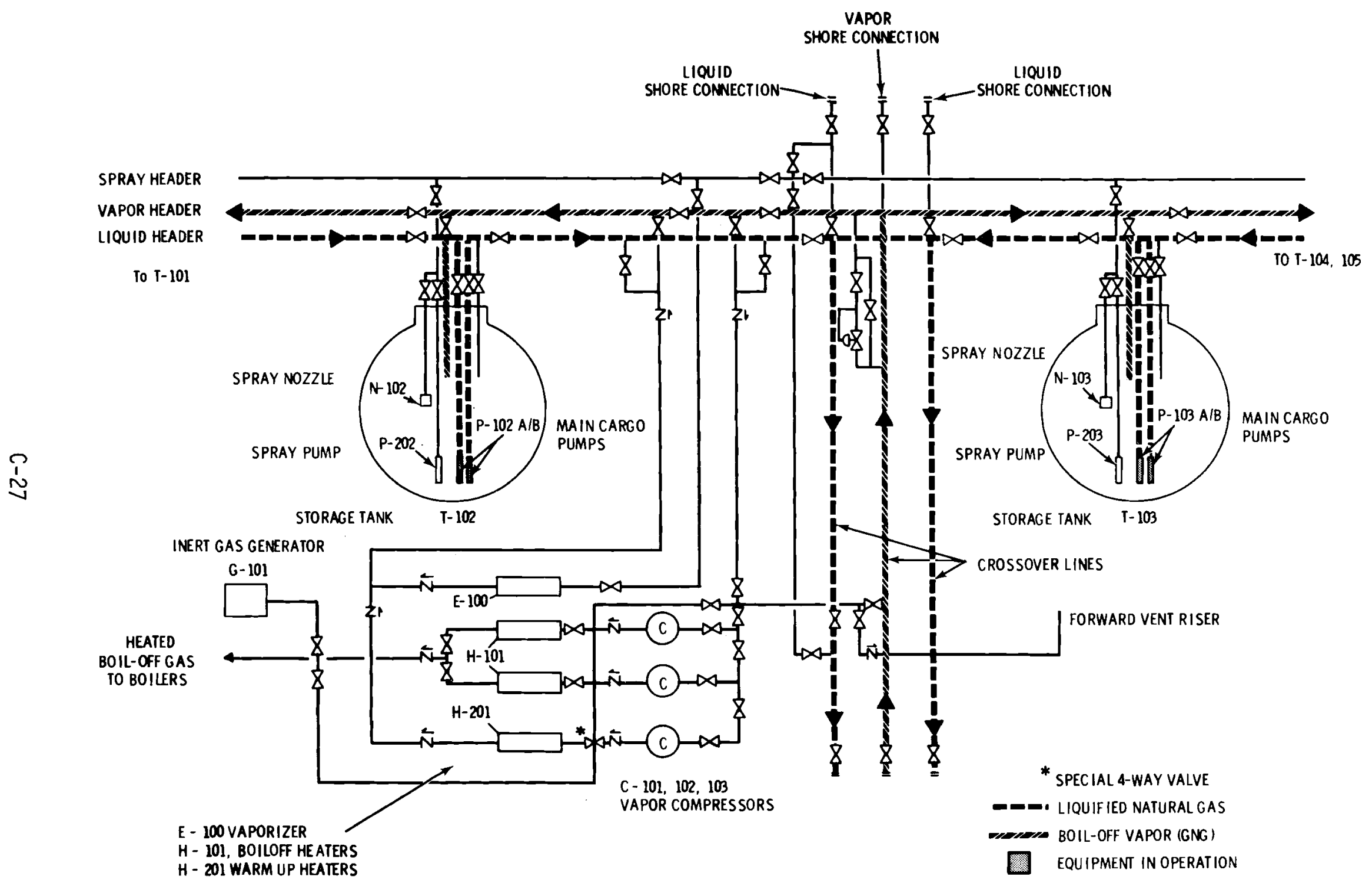

FIGURE C.7. LNG Unloading Operations 
Tank pressure and compressor speed are monitored during steady underway operations. Figure C.8 is a visual process flow description for using boiloff as a fuel.

When the vessel approaches the terminal, the gas compressor is shut down, since maneuvering will be taking place. This causes a slight increase in tank pressure. This pressure drops rapidly as discharge begins.

In the event the LNG berth is occupied and the vessel must anchor, the compressor can be started up again to control tank pressure. This, in turn, causes excess steam to be generated in the boilers. Consequently, a design is incorporated in the ship's power plant to divert excess steam directly to the ship's condensors. When the ship is ordered to proceed to the terminal, the compressor is shut down again.

There are times, however, when the ship must go through some extended period of maneuvering or it finds itself in some situation where venting or dualfuel operation is prohibited. In this case, boiloff pressure can be controlled by pumping liquid from the tank bottoms very slowly and discharging it onto the surface of the liquid. This procedure lowers the temperature at the surface so less boiloff takes place. This method works well when the ship is at rest, since ship motions would ordinarily produce sufficient mixing to disperse the low temperature surface layer.

\section{C.2.9 Preparation for Tank Entry and Inspection}

The first operation that must be carried out before tank entry and inspection is to vaporize the LNG heel remaining in the tank and warm up the tank. This is done by taking boiloff from the tanks out through the liquid header, passing it through the boiloff compressor and boiloff heaters, and then sending it back to the tanks through the vapor header in a continuous recirculation process. The gas is injected into the tanks through spherical perforated headers located at strategic points inside the tanks. As the tanks are warmed, pressure rises, and gas must be periodically vented. When the tank reaches approximately $40^{\circ} \mathrm{F}$, the purging process may be started. The purging procedure is the same as for an air-filled tank, described in Section C.2.6.2, except that the nitrogen is passed through the liquid header and enters the bottom of 


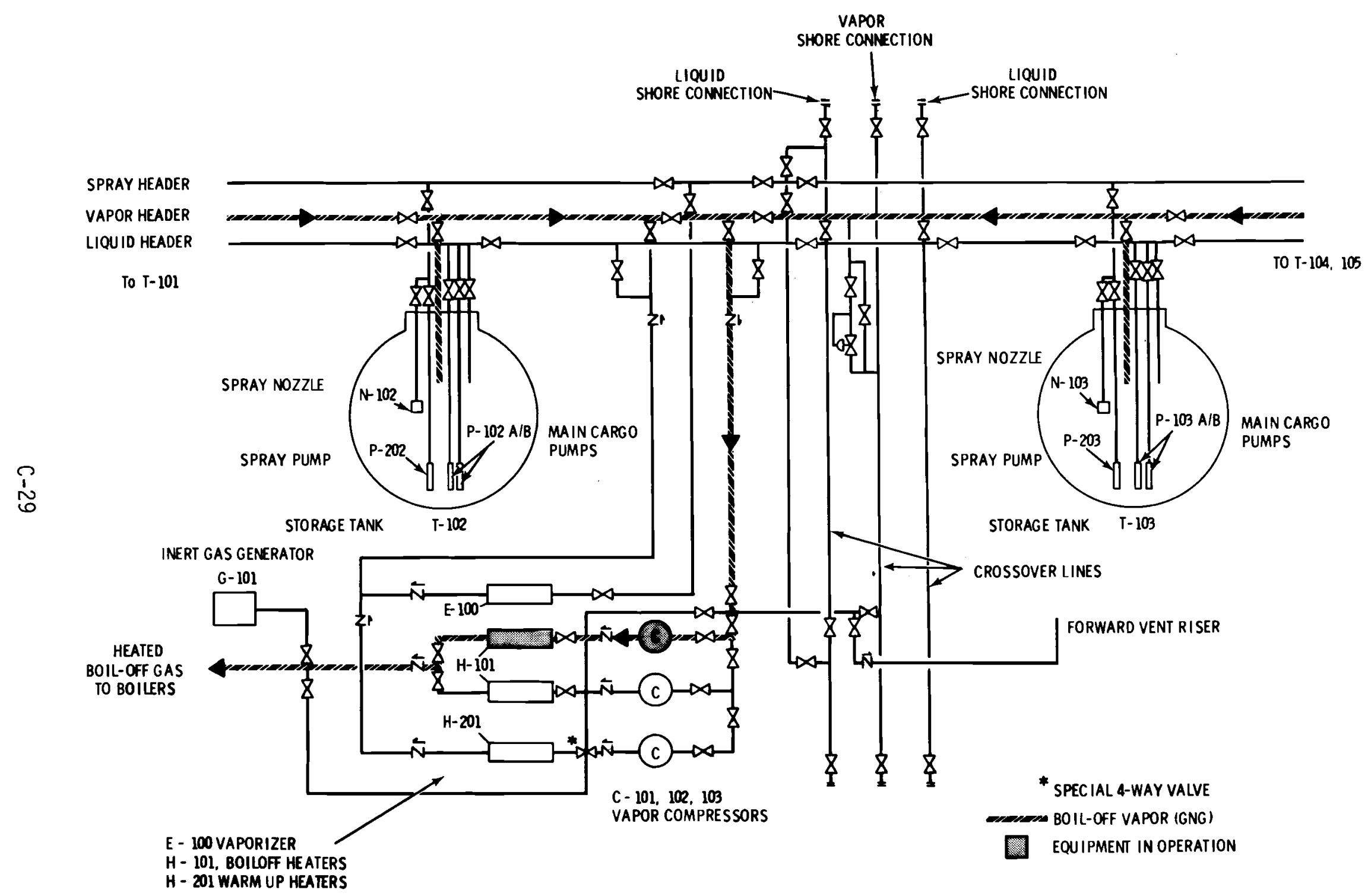

FIGURE C.8. LNG Boiloff for Fuel 
the tank, and the fighter methane gas is drawn off at the top into the vapor header. The methane is compressed in the boiloff compressors and vented out the forward vent riser. To achieve the quickest possible purge, the inerting gas is let in slowly to prevent mixing with the lighter methane gas. Gas drawn off at the top is tested for its methane content. When this is we 11 below combustible limits, purging is stopped and the tanks are then filled with air. The inert gas generator is used to pump air through the warmup heater and into the tank through the vapor header. Nitrogen is drawn out of the bottom of the tank and through the liquid header by the ship's compressors. The gases are vented out the forward vent riser. During this operation, samples of gas are taken from the tank and tested for their oxygen content. When oxygen content is near $21 \%$ by volume, aeration is stopped and the tank may be entered.

\section{3 LNG STORAGE}

The tanks used for LNG storage on the vessel, as well as the instruments and controls for LNG storage, are described here.

\section{C.3.1 LNG Storage Tanks}

Storage for the vessel consists of five Kvaerner-Moss spherical tanks, each with a capacity of $25,000 \mathrm{~m}^{3}$. Some of the advantages and disadvantages of the spherical tanks, as opposed to the other types, are:

- The tanks can be pressurized for emergency discharge of LNG or as an al ternate to pumping.

- They protrude through the deck and cause a visibility problem from the bridge.

- They have a higher boiloff rate due to heat leakage from the tank skirting and support system ( $0.25 \%$ of ful1 tank volume/day).

- They are less susceptible to damage from sloshing.

- They are less likely to rupture during a collision.

- They require less primary-barrier maintenance. 
- They have a longer warmup time (depending on the amount of liquid remaining after discharge).

- Because of their shape, these tanks can be designed according to accepted engineering codes for pressure vessels.

Figure C.9 shows a typical assembly for this type of tank.

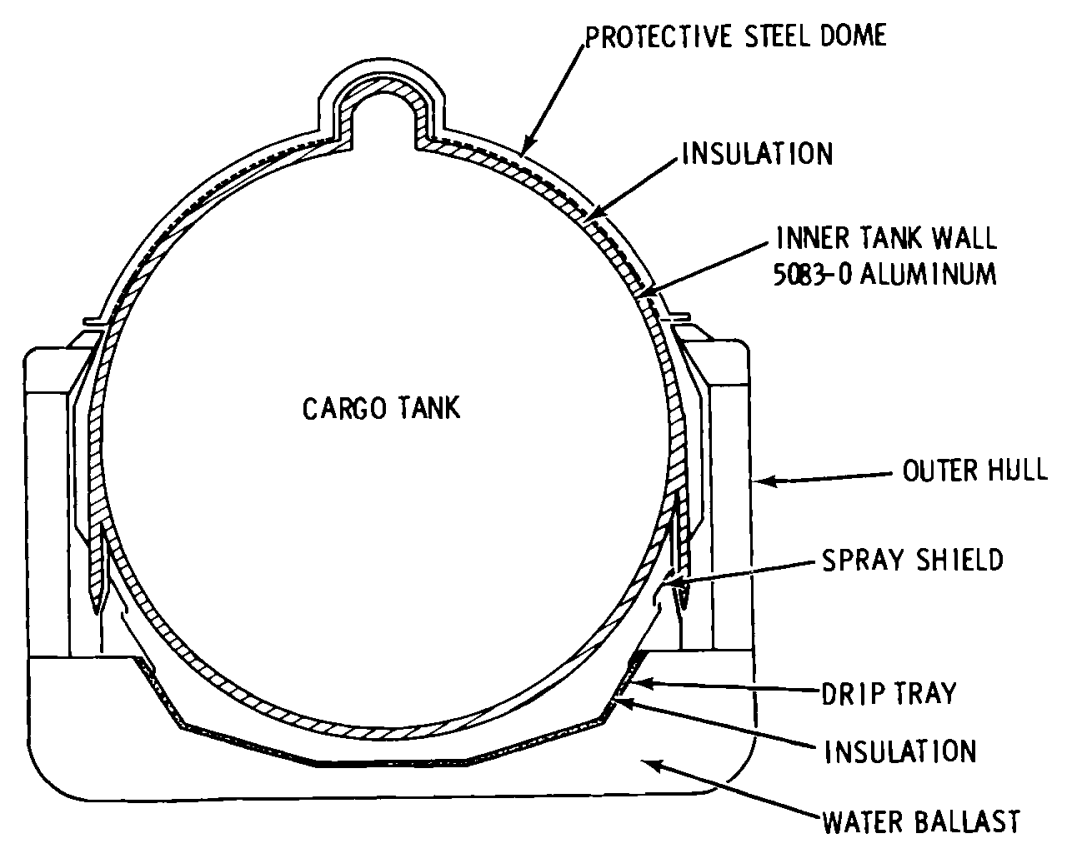

\section{FIGURE C.9. Kvaerner-Moss Spherical Tank Assembly}

The tanks are constructed of 5083-0 aluminum, which possesses excellent low temperature ductility. Each tank has an inside diameter of 120 feet. Each sphere is self-supported, continuously and integrally connected to a vertical cyclinder at its equator, so that the sphers's equator circle and the upper end circle of the cylinder coincide. The bottom end circle of the cylinder is welded integrally into the ship's hull structure. Figure $C .10$ shows how the support skirt and tank plating fit together with forged steel interconnected by welds. All gas boundary welds are butt welds and receive full visual and radiographic inspections. The tanks are hydropneumatically tested to 31 psig.

Insulation for the tank consists of polyurethane foam applied to the entire outer surface of the sphere, and also to a portion of the skirt to 


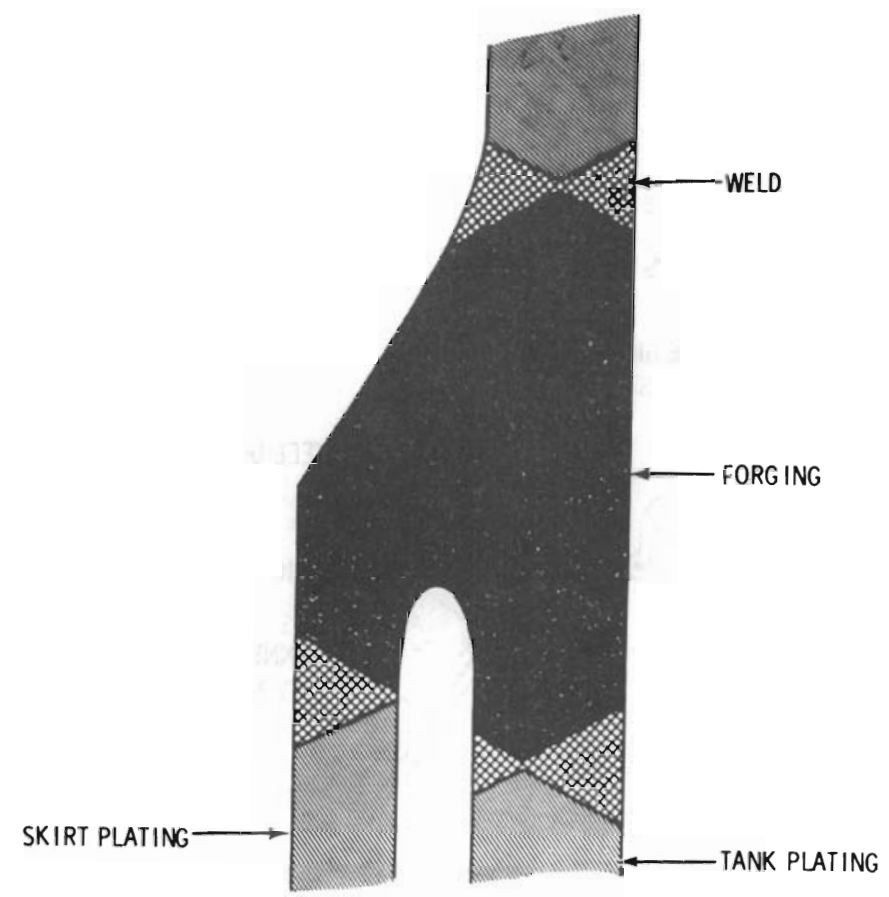

\section{FIGURE C.10. Kvaerner-Moss Spherical Tank-Equator Ring Forging}

control thermal stress and to limit heat leak into the tank through this plating (see Figures C.11 and C.12). Those sections of the ship and the transverse bulkheads that are not covered by insulation are fitted with plywood panels that act as spray shields to protect the hull structural material from excess cooling in the case of a leak in the cargo tank. The cargo tank spaces are fitted with a bilge arrangement capable of handiing both LNG and water. The spaces around the cargo tank are inerted with nitrogen gas. This gas is constantly monitored to detect any buildup of combustible gases from leakage.

Access to the tanks is through a dome at the upper pole through which all piping, cables, and other equipment are led. Above deck, the tanks are protected by a self-supporting structure. Each cargo tank is fitted with two submerged, electrically driven cargo pumps as well as two spray nozzle cooldown systems. One cooldown system is situated in the upper part of the tank to give a general cooldown prior to arrival at the loading port. The second set of nozzles is used to alleviate any unacceptable thermal stress that might arise during loading; these nozzles are situated around the equatorial ring of the tank. 


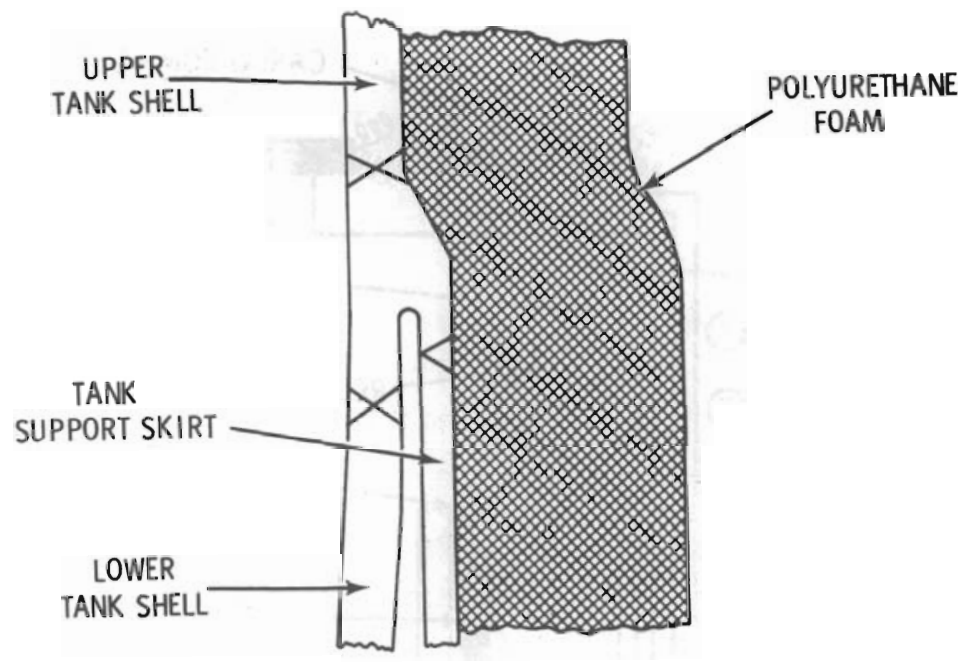

FIGURE C.11. Insulated Skirting

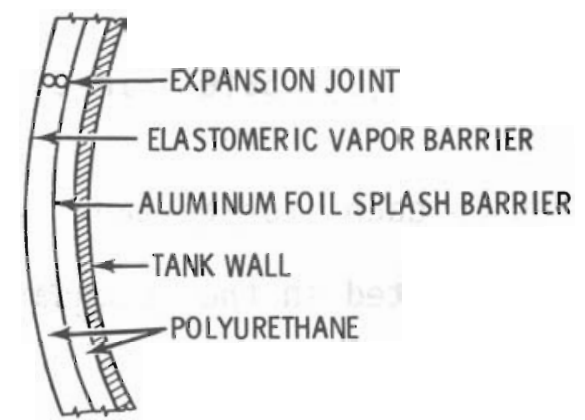

FIGURE C.12. Insulation for KvaernerMoss Spherical Tank

In principle, no secondary barrier or emergency containment system is required. However, a unique feature is the leak protection system external to the tank, consisting of an insulated drip pan with a liquid tight cover situated atop the inner hu11. Several splash shields at the sides are included in this design, shown previously in Figure C.9.

\section{C.3.2 Instruments and Controls}

Instruments and controls for LNG storage are shown in Figure C.13. They include: 


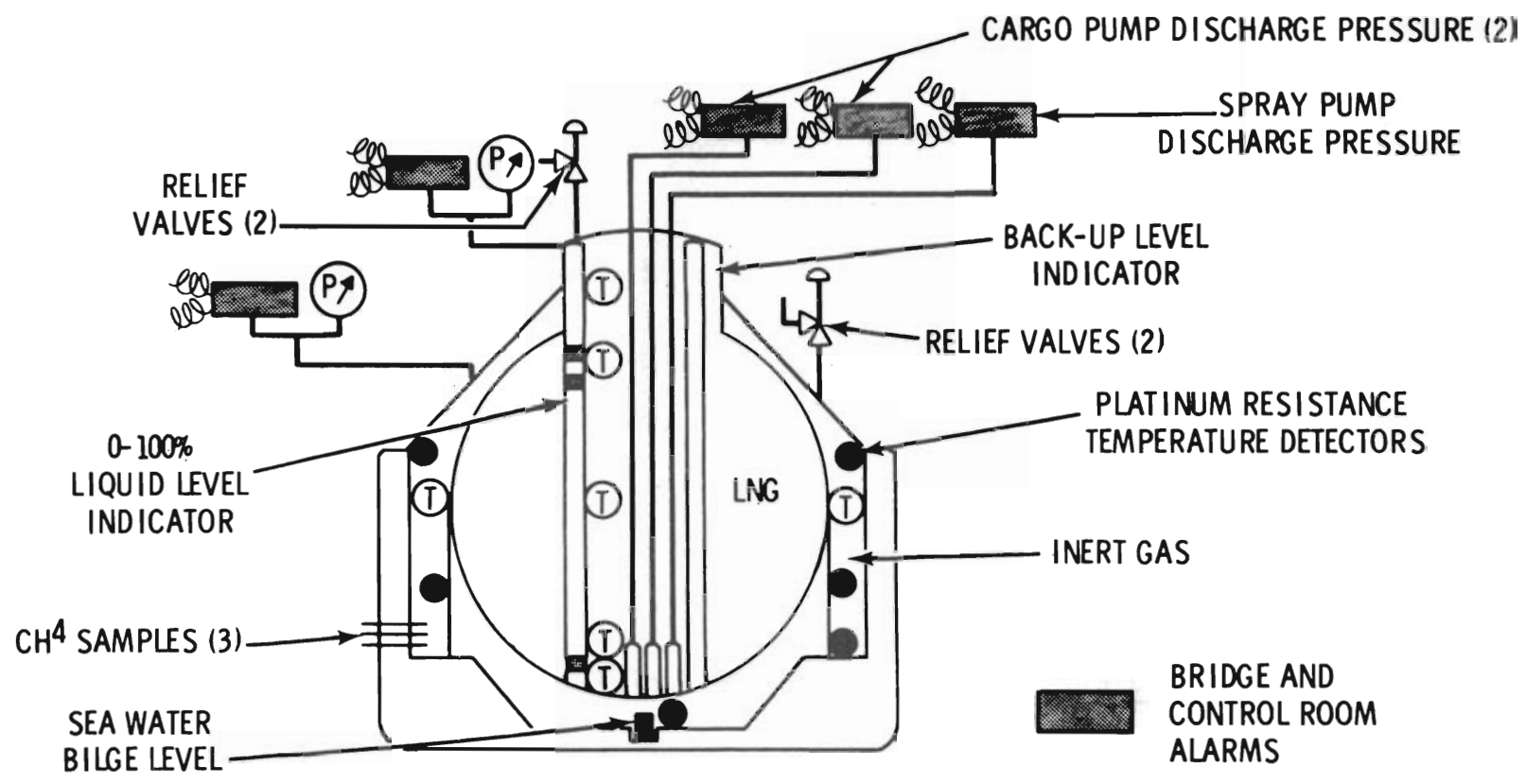

FIGURE C.13. Cargo Tank Safety Instruments

- two pressure relief valves on each storage tank

- two pressure relief valves located in the secondary space between the tank and the inner hull of the ship

- cargo tank vapor pressure controls that can automatically stop pumps and close liquid and shore valves

- monitors on the LNG cargo pump discharge pressures and the spray pump discharge pressures that can automaticaliy shut the pumps down

- a 0-100\% 1iquid 1evel indicator in the storage tank and a backup level indicator to shut down cargo pumps when unloading or cargo system when loading

- platinum resistance temperature sensors attached to the cargo tank structure at various levels to monitor rate of cooldown and warmup

- platinum resistance temperature sensors on the inner hull to detect insulation failure

- liquid temperature sensors installed in four submerged locations 
- specific gravity instrumentation on each tank, displayed on cargo console

- three methane samplers located between the tank and inner hull which supply samples to an automatic infrared analyses system for monitoring the atmosphere around the tank

- a seawater bilge indicator located at the bottom of the inner hull.

\section{4 RELEASE PREVENTION AND CONTROL SYSTEMS}

The release prevention and control systems on the vessel include the fire protection systems, vessel instrumentation, and the Emergency Shutdown (ESD) system.

\subsubsection{Fire Protection Systems}

The LNG cargo vessel is fitted with two types of fire protection systems: detection/alarm systems and extinguishing systems.

\section{C.4.1.1 Detection/Alarm Systems}

Depending on the type of space being protected, various types of sensors are used in the marine vessel for fire detection. Sensors used include combustible gas, ultraviolet (UV) flame, high temperature, and temperature rate-of-rise detectors. Smoke detectors are also used where other sensors are not suitable.

The following portable instruments, with calibration kits and self-contained batteries, are supplied for cargo access, leak testing, and other operations:

- two combustible gas detectors with extended sampling lines

- two oxygen detectors, with extended sampling lines, that can be combined with the combustible gas instruments

- two electronic dew point testers

- a halogen detector, with spare bottle of freon, for testing tightness of the complete gas fuel system in the engine room

- a portable pressure gauge. 
Combustible gas detectors are located in the following areas of the vessel:

- boiler hoods

- gas pipe annutus

- foam discharge areas

- LNG discharge lines and throughout the discharge area.

To monitor the atmosphere surrounding the LNG tankage and in adjacent enclosed spaces where leaked methane might accumulate, an automatic, selfcontained sampling and analysis system is used. The spaces involved include compressor rooms, instrumentation rooms, air ducts surrounding gas piping, areas of the engine room adjacent to the gas piping and burners, the space between the primary barrier and the inner hull of each tank, and the cargo hold area. Location of a sampling point in the boiler uptakes is difficult due to the effect of flue gas on the analyzer. The automatic gas analyzer activates an alarm if it detects a methane concentration greater than a set percentage of the lower explosive limit. This type of analyzer is limited by the need to measure methane concentrations in both air and inert gas. The infra-red type meets this requirement satisfactorily and is reliable in service.

The UV flame detectors, temperature rise sensors, and smoke detectors are located in various areas throughout the ship.

A11 of these detection/alarm systems are tied into visual alarm and point identification panels in the bridge and control room. If the ship's service electrical power fails, the systems are powered from the emergency power circuits. Additional standby and battery power can keep the systems activated for at least 12 hours.

\section{C.4.1.2 Extinguishing Systems}

Fire extinguishing systems are divided into the following types:

- water systems

- $\mathrm{CO}_{2}$ systems

- dry powder systems

- steam-smothering systems

- foam fire system. 
Water is never used to try to put out an LNG fire because it stirs up the LNG and increases the rate of evaporation, causing the fire to become more intense. However, water is used to wash spilled LNG from the decks, to cool down parts of the ship, and to protect personnel who are exposed to the heat of the fire. The water is also used for cooling once a fire is extinguished to keep the fire from reigniting on hot surfaces. The water system is supplied with sea water through two fire pumps located in the ship's engine room and backed up by an emergency fire pump. Pressurized water and portable fire extinguishers are also placed at various locations on the ship.

The LNG carrier has dry powder systems at several locations on the ship so they can reach most of the deck area and the crossover piping where spil1s are most likely to occur. The projectors will put out about 400 ib of a dry powdered chemical in about 40 seconds. Each projector has a range of about 80 yards in a fixed position and 40 yards when sweeping a large area. These projectors can also be used with hoses for putting out small fires. Each hose is capable of discharging about $81 \mathrm{~b}$ of chemical per second. When preparations are being made for loading or unloading LNG, the nearest dry powder projectors are aimed toward the loading connections and locked into place so they can be used immediately on any fires that might start because of leaks at the loading manifold. This type of projector can be operated manually or by remote manual releases. A number of portable dry powder extinguishers are fitted in areas that projectors do not reach and where small fires might occur.

$\mathrm{CO}_{2}$ systems are located around the electrical systems, machinery spaces in store rooms, and in other areas where a general purpose extinguishing agent is useful. These systems are arranged so the $\mathrm{CO}_{2}$ can be automatically released by the fire detection system. In these cases, they are tied to an alarm which gives warning to the crew to evacuate the compartment just before the $\mathrm{CO}_{2}$ is released.

Another fire system on the ship is the steam-smothering system, which is supplied from a deck steam manifold to control or extinguish fires in spaces containing flammable material, such as paint lockers, $0 i 1$ tanks, and storerooms. Release valves are located together on the main deck. 
High expansion foams are used to prevent spread and radiation of fires in these major areas:

- vaporizer area

- all along the discharge lines

- compressor area.

\section{C.4.2 Instrumentation}

The ship's instrumentation can be subdivided into three general categories: 1) the monitoring of pressure, temperature, and any other physical or chemical parameters related to the safe operation of the ship; 2) the collection, transmission, and display of measured information related to operation of ship's equipment and fuel custody transfer; and 3) the instrumentation involved in the remote operation of the ship. These various sytems are extensively connected by interlocks, alarm functions, and control loops.

Instruments used to monitor the gas detectors, thermometers, pressure gauges, and other alarm activation devices use scanning techniques embodying varying degrees of sophistication. In addition to the basic scanning, these instruments include recording of data on tape or by other means.

Alarm panels or consoles for safety monitoring equipment and status displays, which include operational data and cargo measurement readouts, are located in the centralized cargo control room (or gas control room). Signals are transmitted to them for display by pneumatic or intrinsically safe electrical signals. Alarm limits on pressures, temperatures, and liquid levels are built into the transmission circuits and display visually and audibly in the control room. Repeater panels displaying all or parts of the same data are located in the engine room, and a repeater alarm panel is provided on the bridge since the central control room may not be manned at all times while the vessel is at sea.

\section{C.4.2.1 General Instrumentation}

Some of the general instrumentation that is included in this carrier design is as follows: 
- ballasting

- pressure

- temperature instrumentation

- integrated digital cargo instrumentation system.

Ballasting. Instrumentation for readout of all ballast tank levels, and for programmed ballasting and deballasting where applicable, is provided on the cargo console. Fore and aft draft indicators and an inclinometer reading in degrees and minutes are also provided on the console.

Pressure. Several pressure readings are available from the cargo console computer (analog or digital with $1 \%$ accuracy), including:

1. liquid/vapor crossover pressure

2. LNG pump discharge pressures, with low-limit alarm and automatic stopping to prevent running dry

3. cargo-tank vapor-space pressure where tanks are manifolded together, with accuracy of $0.25 \%$ of ful1 scale for custody transfer

4. insulated and void space pressure, with automatic under-and over-pressure control

5. inert gas system pressures with critical overpressure alarm and control

6. compressor discharge pressures

7. atmospheric pressure

8. 1 iquid nitrogen tank pressures

9. compressed-air system pressures

10. heating system pressures.

Temperature Instrumentation. Temperature sensors for cargo and hull services are platinum resistance thermometers with five-digit display on the cargo console. The number and location of these sensors are sufficient to provide adequate coverage of the structure and critical attachments. These include: 
- Cargo tank temperature sensors, with readout accuracy of $1.5^{\circ} \mathrm{C}$, are attached to the tank structure at various levels to monitor rate of cooldown and warmup.

- Inner hu11 temperature sensors are provided, with readout accuracy of $1.5^{\circ} \mathrm{C}$, for detecting insulation failure. Alarms at critical points on steel temperature set limits, including tank keys and key supports, are installed. Logging is also provided.

- Nitrogen system temperatures are measured in each liquid nitrogen tank, with readout accuracy of $1.5^{\circ} \mathrm{C}$.

- Liquid temperature sensors are installed in four submerged locations, for measurement for custody transfer purposes at an accuracy of $0.25^{\circ} \mathrm{C}$. Integrated Digital Cargo Instrumentation System. A programmed system is provided in connection with the cargo control room console. This system serves the following purposes:

1. alarm scanning and annunciation

2. data acquisition, with logging of hull number, date, time pressures, levels, temperatures and other specified variables

3. automatic ballasting and deballasting

4. hull-stress calculations

5. malfunction monitor for alarm on failure of any designated valve or pump to respond to a remote command

6. sequential controls for motor or valve control

7. LNG mass calculations for custody transfer.

\section{C.4.2.2 Alarm System}

The alarm system used on the ship is a 100-point alarm panel that gives a visual and audio signal when selected measurements of operational or functional conditions exceed predetermined values. When an alarm condition is reached on 
any reading, a red light flashes, and a siren sounds in the gas control room where the panel is located and also in the electric motor room. Certain critical alarm points are repeated in the wheelhouse, but the light stays on until these alarm conditions are corrected. Provided on the panel are switches for changing the flashing light to a steady light and for blocking certain alarms used only for special functions (such as loading or unloading operations). Reset buttons on the panel are used to turn off circuits that give an alarm when not actually in an alarm condition. The panel also has a "test" button which is used to test the light and logic circuits of the panel. When the "test" button is pushed, a test is made of all alarm points except those that are temporarily blocked.

The following is a description of some of the alarm points including, in some cases, what they indicate and general corrective measures.

1. Low Differental Pressure Between Tank and Primary Insulated Space An indication that the pressure in the cargo tank and the pressure in the space between the cargo tank and the drip pan have equalized - accompanied by automatic emergency shutdown of the cargo handling system - 6 alarm points.

2. Cargo Pumps Stopped

Indicates that the cargo pumps have stopped - these may be planned stops or due to emergency shutdown, low liquid level, low power, low LNG vapor header pressure, or pump failure - 12 alarm points.

3. Inner-Hu11 Low Temperature

Indicates the inner-hull temperature has dropped below normal. This indication may be caused by either a leak in the primary barrier or water in the insulated spaces. If a leak is detected, steps must be taken to isolate the barrier and tank - 6 alarm points activated from a number of thermocouples and temperature switches. 
4. Water in Insulated Space

An indication of water in the space between the cargo tank and the drip pan results from a leak in the inner hull, and alarm is activated by a water detector. The ballast tanks surrounding the affected cargo tanks are deballasted and a dewatering pump installed - 6 alarm points.

5. Very High Level

Caused by overfill of cargo tank; this occurs when. LNG 1iquid level reaches $99.2 \%$ of tank capacity. Activated by high level probe and accompanied by automatic emergency shutdown of the cargo system -6 alarm points.

High Leve1 - Indicates 1iquid leve1 $98.1 \%$ of tank capacity - 6 alarm points.

6. Desired Remaining Liquid Level

Indicates tank has been pumped out to the volume to be left in the tanks for spraying the other tanks to keep them cool and to provide boiler fuel on the ballast trip - 1 alarm point.

7. Forward Pumproom Bilge Alarm

Excessive accumulation of bilge water in the forward pumproom - requires inspection and pumping out - 1 alarm point.

8. Deck Winches, Hydraulic 0il - Low Level Indicates low oil level in either the forward or aft gravity tanks of the hydraulic deck machinery - 1 alarm point.

9. Ballast Valves, Hydraulic 0il - Low Level

Indicates low level in a sump tank of ballast valve hydraulic qil actuating system.

10. Fire in Electric Motor Room or Gas Compressor Room

Alarm actuation by thermocouples in the electric motor room or the smoke detector system from the gas compressor room. When alarm is activated, a larms sound in affected compartments as well as in gas control room and engine room; the ventilating fans in the midship house automatically stop, and, after a short delay, five bottles of $\mathrm{CO}_{2}$ are automatically released 
into the affected room. Action which ensues includes actuating the emergency shutdown system and the general fire alarm, cutting off electrical power to the gas control switchboard, starting of fire pumps, personnel evacuation of gas control room, isolation of certain LNG vapor valves, activation of the water curtain systems, and the carrying out of general fire fighting instructions.

11. Tank Pressure Below .07 psig

Activated bv a drop in vapor header pressure.

12. High Differential Temperature, Gas Compressor (Figure C.3, C-101 through 103)

13. High Suction Temperature to Compressor

14. Low Suction Temperature to Compressor

15. High Compressor Discharge Temperature

16. Compressor Stopped

17. Gas Pipe Duct Fan or Engine Room Vent Fan Stopped

18. Inert Gas System Failure (Figure C.3, G-101)

19. Methane Exhaust Heater Low Drain Temperature

20. Nitrogen Excess Flow

21. Low Flow Gas Analyzer

22. Vaporizer Starts (Figure C.3, E-100)

23. Vaporizer Outlet High-Low Temperature

24. Nitrogen High-Low Pressure

25. High-Low Level, Nitrogen Tanks

26. $\underline{\mathrm{N}}_{2}$ from Methane Vaporizer, (Figure C.3, E-100) High-Low Temperatures These alarms monitor the temperature of the nitrogen gas from the LNG vaporizer.

27. Fresh Water Pumps Stopped Indication of mechanical or electrical failure in pumps. 
28. High Temperature Methane Heater Outlet

29. Gas Alarm

Actuated by analyzers that monitor the insulated spaces, wtih alarm given when the methane concentration reaches $36 \%$ of LFL (1.8\%). The analyzers, which monitor the various rooms and passageways, sound an alarm at $36 \%$ of LFL. After the alarm sounds, it is necessary to check the gas analyzer panel to determine which sample point gave the alarm.

30. 20 psig Control - Low Air Pressure

31. Venting Methane to Mast

32. Low $\mathrm{N}_{2}$ Header Pressure

33. Atmospheric Nitrogen Heater Outlet Low Temperture (Figure C.3, H-201)

34. Odorizing Pump Stopped

35. Low Temperature Methane Heater Outlet (Figure C.3, H-101 A/B)

36. Fresh Water Pumps, High Suction Temperature

37. Gas Detector Failure Indicates power failure to the gas detector.

38. Impulse Air Low Pressure

39. Emergency Shutdown.

\section{C.4.3 Emergency Shutdown System and Procedures}

The emergency shutdown (ESD) system provides protection for the vessel and crew by automated, fast shutdown during emergency conditions. It also reduces the amount of LNG and natural gas released during emergencies by greatly reducing the time needed to shut down and isolate leaking components. The ESD system and associated procedures are described here.

\section{C.4.3.1 Emergency Shutdown System}

The emergency cargo transfer shutdown system, when activated, automatically initiates the following actions:

- The cargo crossover valves (loading/unloading valves) are closed 
- the vapor and liquid header isolation valves are closed

- the gas supply valve to the boilers is closed

- boiler feed gas heaters are shut down

- the cargo tank valves are closed

- all cargo pumps are shut down

- all vapor compressors are shut down.

The ESD is activated automatically in the event of a fire, excess ship movement at the dock, and overfilling of a cargo tank. The system is manually activated in the event of a spill or other emergency. From the time it is activated, the ESD takes approximately 30 seconds to shut down and isolate the cargo handling system. The ESD shuts down only equipment on the ship; however the captain of the ship has the capability to activate the terminal shutdown system also.

In the event of leakage during LNG loading, the shore loading valves are closed first to permit LNG still in the loading arms to drain back into the ship's tanks, and then the ship's loading valves are closed before the ESD is activated.

As soon as the ESD is activated, the general alarm sounds to alert all crew members and get them to their emergency stations. All ventilation is shut off and weather deck doors are shut.

\section{C.4.3.2 Procedures}

Because pipe leaks in either the liquid nitrogen or liquid LNG system could crack the decks or result in fire hazards, special care is taken to ensure that the possibility of leaks is minimized. All valves in the liquid lines are welded to the piping, and expansion and contraction are taken care of by expansion loops in the piping configuration rather than by using expansion bellows. Expansion bellows are used in gas piping since it does not operate at as high a pressure and because the possibility of deck cracks from gas leaks is small. Drip pans are provided at strategic points to catch possible spills and prevent spilled LNG from contact with the deck or structure.

If a spill occurs, crew members near the spill, using firehoses, immediately start washing the spilled LNG overboard. When the source of leakage 
is isolated and the spilled LNG is washed overboard, there is no further immediate danger of fire.

\section{C.5 GENERAL INFORMATION}

The following subsections provide general information on various aspects of the vessel and its operation.

\section{C.5.1 Venting}

Each cargo storage tank is equipped with two 6-inch relief valves. One valve opens at $3.25 \mathrm{psig}$ and the other opens at $3.5 \mathrm{psig}$. Both vent into the gas main (vapor header). These cargo tank relief valves are sized to handle gas flow from the tank resulting from an extensive fire outside the ship when the tanks are full of LNG.

Each tank has one 6-inch relief valve connected to the space between the primary barrier and the inner hull. This valve opens at $3.5 \mathrm{psig}$ and vents into the gas main. The hold space around each tank also contains a relief valve which opens at 1.0 psig.

All liquid and gas lines in the cargo handling system have pressure relief valves that vent to the gas main. During normal operations, the pressure in the gas main is maintained at 1 psig by controlling the speed of the boiloff compressors. Should the gas main overpressurize, a relief valve (which opens at 3.5 psig) would depressure the main through the vent stack on the mast.

\section{C.5.2 Leak Protection}

Each storage tank has a drip pan beneath it, between the primary barrier and the inner hull. Besides protecting the inner hull and insulation, this drip pan provides early warning of leakage. The space between the primary barrier and the drip pan is filled with nitrogen, and each of the five tanks has a sample inlet for the methane detection system. Suitable drip pans are also placed under areas of possible cargo leakage (e.g., valves, flanged connections) to protect the carbon steel ship structure. Should a spill occur on the deck, it is washed down with water as soon as it is discovered. 


\section{C.5.3 Inert Gas System}

Nitrogen is used on the ship as an inert gas. It is stored in liquid form in two tanks with a total 1 iquid capacity of $25 \mathrm{~m}^{3}$. The inert gas generator (G-101 in Figure C.3) takes liquid nitrogen from the storage tanks, vaporizes and heats it, and then pumps it to various portions of the ship.

Nitrogen is used to prevent underpressure in the cargo storage tanks. If the pressure in a tank falls below 0.1 psig, an on/off control valve opens and nitrogen from the inert gas generator is admitted to the tank until the pressure increases to $0.4 \mathrm{psig}$. The valve then closes.

The cargo hold space is maintained at a slightly positive pressure $(0.6$ to $0.75 \mathrm{psig}$ ) with nitrogen. Nitrogen from the inert gas generator goes through an on/off control valve (which maintains the hold pressure in the desired range) and then to the hold.

Nitrogen is used at various times to purge the cargo storage tanks. (For detailed procedures, see Section C.2.6.) To do this, nitrogen from the inert gas generator flows through the warmup heater, $\mathrm{H}-201$, into the vapor crossover line, and then into either the vapor or liquid header depending on the procedure to be followed.

\section{C.5.4 Collision Resistance}

The LIIG vessel can withstand a certain amount of damage caused by collision with another ship without loss of containment of the LNG cargo. Figure C.14 shows the velocity required for penetration as a function of the displacement of the striking ship. Collision at a right angle to the vessel's axis is assumed. Curves are shown for two collision points: 1) at the center line of a cargo tank and 2) at a tranverse bulkhead midway between two adjacent tanks.

\section{6 SOURCES OF INFORMATION}

The description of the LNG marine vessel was developed using information from the sources listed below.

1. Environmental Impact Statements:

- Pacific-Indonesia, Western LNG Terminal Co., CP75-83-3,

- West Deptford, FPC Bureau of Natural Gas, Dec. 76, CP-76-16. 


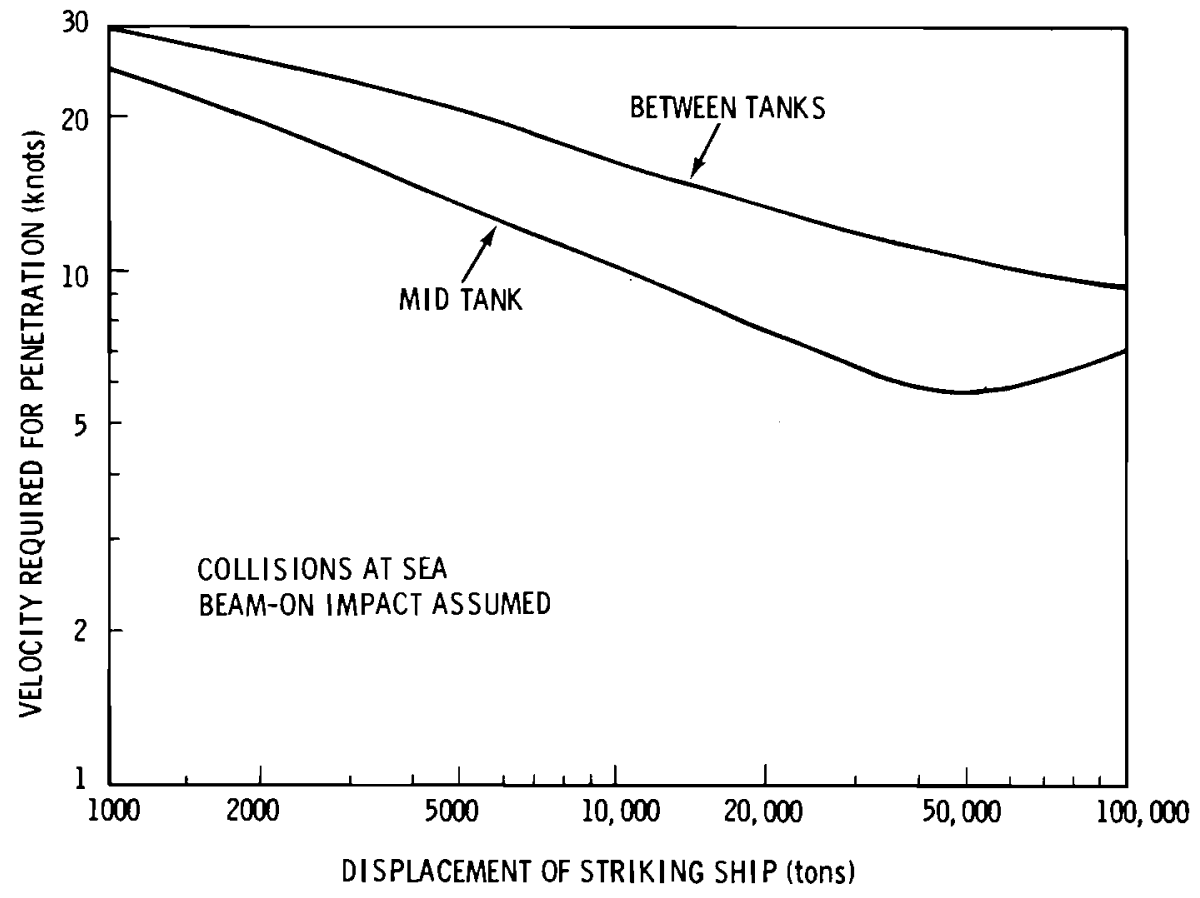

FIGURE C.14. Col1ision Resistance of LNG Vesse1

2. Open Literature:

Anderson, Philip J., Daniels, Edward J., "The LNG Industry: Past, Present and Future," Prepared by Institute of Gas Technology, Project 8988.

Final report prepared for ERDA, Contract \#EE-77-C-02-4234, July 1977, pp. $66-70$.

Bartel, M. R., Geddes, F., Loveday, M., Ruber, P., "Can Offshore Arctic Gas be Produced Economically", Horld Oil, Nov. 1977.

Cashman, Margaret D., "LNG Carriers on Order and Under Construction," Ocean Industry, Oct. 1977.

Curt, Robert P., et al., Marine Transportation of Liquified Natural Gas, National Maritime Research Center, Kings Point, New York, 1973 Dist. by National Technical Information Service, U.S. Dept. of Commerce, PB-249014.

Drake, Elisabeth, Reid, Robert C., "The Importation of Liquified Natural Gas", Scientific American, Vol. 236 No. 4, April 1977.

Fawcett, H. H., et al., Conference Proceedings on LNG (Liquified Natural Gas) Importation and Terminal Safety, Held in Boston, MA, June 13-14 1972 National Academy of Sciences, Prepared for Coast Guard, June 1972.

Frost and Sullivan Inc., Woldwide LNG Market, Vol. 1 and 2, June 1977, No. E209. 
Genera1 Dynamics, LNG Ships (Advertisement).

Geremia, John 0., Marine Transportation of Liquified Natural Gas, 1973.

Gondouin, M., Murat, F., "Transportation and Storage of LNG", American Technigaz Inc., New York, NY.

Linhardt, Hans D., LNG Boiloff-Compressors, Airco Cryogenics, Div. of Airco Inc., Irvine, CA, pp. 6-10.

Smith, L. R., "Submerged Pumps for LNG Sendout", Paper presented AGA Distribution Conference, 1968.

Marine Transportation of LNG, Vol. 1, "History of Development and Design", by Technigaz, Stingmaster and Breyer Inc., Distrigas Corp., Feb. 1971.

Maritime LNG Manual, U.S. Dept. of Commerce, National Technical Information Service, COM-75-10136, Trident Engineering Association, Ju1y 1974.

Wilson, J. J., "Cryogenics", Vol. 14, No. 3, U.S. Naval Academy, March 1974.

Schwendtler, A. H., "LNG Tanker Developments", Pipeline and Gas Journal, pp. 38-40, June 1977.

Smith, J. M. S., lathew, R. C. and Crook, J. A. F., "The Safety of Gas Carriers with Particular Reference to the I.C.S. Tanker Safety Guide (Liquefied Gas)", Paper presented at Gastech 75 LNG and LPG Technology Congress, Paris, September/October 1975. 

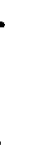


\section{APPENDIX D}

FACILITY DESCRIPTION OF REFERENCE LNG IMPORT TERMINAL 

APPENDIX D

FACILITY DESCRIPTION OF REFERENCE LNG IMPORT TERMINAL

Table D.1 presents details on U.S. and Canadian LNG import terminals both planned and in operation. Five terminals have been built in the U.S. to date, but only three of these are currently importing gas: Columbia LNG Corp. at Cove Point, Maryland and Southern Energy Co. at Elba Island, Georgia receive gas from Sonatrach at Arzew, Algeria; and Distrigas Corporation at Everett, Massachusetts imports gas from Sonatrach at Skikda, Algeria. The other five terminals listed in the table are in various stages of planning.

\section{1 BASIC PROCESS FLOW}

A block flow diagram for an LNG import terminal is shown in Figure D.1. The description of the LNG import terminal was developed using information from the sources 1 isted in Section D.5. The major unit operations involved are marine vessel unloading, storage, and vaporization.

A fleet of nine $125,000-m^{3}$ LNG ships makes a total of approximately 75 deliveries annually to supply the terminal. After a ship is berthed at one of the two berthing facilities, the LNG is pumped, using pumps onboard ship, through four 16-in. marine loading arms that connect to a 42-in. transfer line at the unloading platform. The transfer line carries the LNG along a trestle to shore and then to the storage tanks. Normal transfer rate is $53,000 \mathrm{gpm}$. At this rate, tankers are unloaded in about 12 hours.

The storage tanks are two 550,000-bbl, double-walled, dome-roofed, flatbottomed, aboveground, metal storage tanks of standard design for LNG. Normal boiloff from the storage tanks is compressed either to fuel gas pressure and used to fire the submerged combustion vaporizers during peaking operations or compressed to pipeline pressure and put into the distribution system. Normal boiloff is about $2 \times 10^{6}$ scfd. Boiloff and flash gas rates from the ship untoading vary depending on the transfer rate, the tanker and storage tank 
TABLE D.1. U.S. and Canadian LNG Import Terminals

\begin{tabular}{|c|c|c|c|c|c|c|c|c|}
\hline \multirow[b]{2}{*}{ Company and Plant Site } & \multicolumn{3}{|c|}{ Storage } & \multicolumn{3}{|c|}{ Regasification } & \multirow[b]{2}{*}{ Systems Contractor } & \multirow[b]{2}{*}{ Year of 0peration } \\
\hline & $\begin{array}{l}\text { Capactty } \\
\text { (miscf) (MbbI) }\end{array}$ & $\begin{array}{l}\text { Type of } \\
\text { Contalner }\end{array}$ & Contractor & $\begin{array}{l}\text { Capacity } \\
\text { (MMAcfd) }\end{array}$ & Runs & Type & & \\
\hline $\begin{array}{l}\text { ENERGY TERMINAL SERVICES CO. } \\
\text { Staten Is land, New York }\end{array}$ & $\begin{array}{c}6000 \times \begin{array}{l}1800 \\
(2 \times 900)\end{array}\end{array}$ & $\begin{array}{r}\text { Pressured } \\
\text { concrete }\end{array}$ & $\begin{array}{l}\text { Preload/ } \\
\text { Walsh }\end{array}$ & 360 & 4 at 90 & $\begin{array}{l}\text { Direct } \\
\text { Fired }\end{array}$ & Ralph M. Parsons Co. & $\begin{array}{l}1973-1975 \\
\text { former Distrigas } \\
\text { of N.Y. facility }\end{array}$ \\
\hline $\begin{array}{l}\text { ALGONQUIN LNG INC. } \\
\text { Providence, Rhode Island }\end{array}$ & $\begin{array}{c}6000 \quad 1800 \\
(3 \times 600)\end{array}$ & $\begin{array}{l}\text { Aboveground, } \\
9 \% \text { nickel }\end{array}$ & CBI & $\begin{array}{l}300 \\
375\end{array}$ & $\begin{array}{l}3 \text { at } 100 \\
3 \text { at } 125\end{array}$ & $\begin{array}{l}\text { Direct } \\
\quad \text { Fluid } \\
\text { Seawater }\end{array}$ & CBI & $\begin{array}{l}\text { 1973-1st tank, } \\
1975-2 \text { add } 1 \\
\text { tanks planned }\end{array}$ \\
\hline $\begin{array}{l}\text { COLUMB IA LNG CORP. \& } \\
\text { CONSOLIDATED SYSTEM LNG CO., } \\
\text { Cove Point, Maryland }\end{array}$ & $\begin{array}{c}5000 \quad 1500 \\
(4 \times 375)\end{array}$ & $\begin{array}{l}\text { Aboveground, } \\
\text { aluminum }\end{array}$ & PDM & $\begin{array}{r}1000 \\
200\end{array}$ & $\begin{array}{r}10 \text { at } 100 \\
2 \text { at } 100\end{array}$ & $\begin{array}{l}\text { Submerged, } \\
\text { Intermed. } \\
\text { Fluid }\end{array}$ & $\begin{array}{l}\text { Pullman Kellogg \& } \\
\text { Raymond Technical }\end{array}$ & $\begin{array}{l}\text { 1977-Base Load } \\
\text { Plant }\end{array}$ \\
\hline $\begin{array}{l}\text { DISTRIGAS CORP. } \\
\text { Everett, Massachusetts }(1 \times\end{array}$ & $\begin{array}{r}3250 \\
374+1 \times 600)\end{array}$ & $\begin{array}{l}\text { Aboveground, } \\
9 \% \text { ntckel }\end{array}$ & CBI & 135 & 3 at 45 & Submerged & CBI & 1971 \\
\hline $\begin{array}{l}\text { EL PASO LNG TERMINAL CO. } \\
\text { Port } 0^{\circ} \text { Connor, Texas }\end{array}$ & 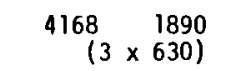 & Aboveground & N.A. & 1050 & 10 at 105 & Seawater & N.A. & 1982-Planned \\
\hline $\begin{array}{l}\text { NATURAL GAS PIPEL INE CO. OF } \\
\text { AMERICA (Peoples Gas) } \\
\text { Ingleside, Texas }\end{array}$ & $\begin{array}{r}5500 \quad 1650 \\
(3 \times 550)\end{array}$ & $\begin{array}{l}\text { Aboveground, } \\
9 \% \text { nickel }\end{array}$ & N.A. & 425 & N.A. & $\begin{array}{l}\text { Seawa ter } \\
\text { Submerged }\end{array}$ & N.A. & 1983-Planned \\
\hline $\begin{array}{l}\text { SOUTHERN ENERGY CO. } \\
\text { Elba Is land, Georgia }\end{array}$ & $\begin{array}{c}4000 \\
(3 \times 400)\end{array}$ & $\begin{array}{l}\text { Aboveground, } \\
\text { a luminum }\end{array}$ & CBI & 540 & 5 at 108 & Submerged & $\begin{array}{l}\text { Bechtel Inc. and } \\
\text { Raymond Technical }\end{array}$ & $\begin{array}{l}\text { 1978-Base } \\
\text { load plant }\end{array}$ \\
\hline $\begin{array}{l}\text { TRUNKLINE LNG CO. } \\
\text { Lake Charles, Louisiana }\end{array}$ & 1800 & $\begin{array}{l}\text { Aboveground, } \\
9 \% \text { nickel }\end{array}$ & PDM & 700 & 7 at 100 & Submerged & $\begin{array}{l}\text { Pullman Kellogg Co. } \\
\text { and Raymond Techni- } \\
\text { cal }\end{array}$ & 1980-Planned \\
\hline $\begin{array}{l}\text { WESTERN LNG TERMINAL CO. } \\
\text { Point Conception, California }\end{array}$ & $\begin{array}{c}5775(3 \times 550 \\
(3 \times 550)\end{array}$ & $\begin{array}{l}\text { Aboveground, } \\
9 \% \text { nickel }\end{array}$ & N.A. & 1600 & 13 at 100 & $\begin{array}{l}\text { Direct } \\
\text { seawater }\end{array}$ & Fluor & $\begin{array}{l}42 \text { nonths after } \\
\text { approval }\end{array}$ \\
\hline $\begin{array}{l}\text { LORNETERM LNG LTD. } \\
\text { St. John, N.B. Canada }\end{array}$ & $\begin{array}{r}8420 \\
(4 \times 600)\end{array}$ & Aboveground & N.A. & 1000 & N.A. & N.A. & N.A. & 1981-Planned \\
\hline
\end{tabular}




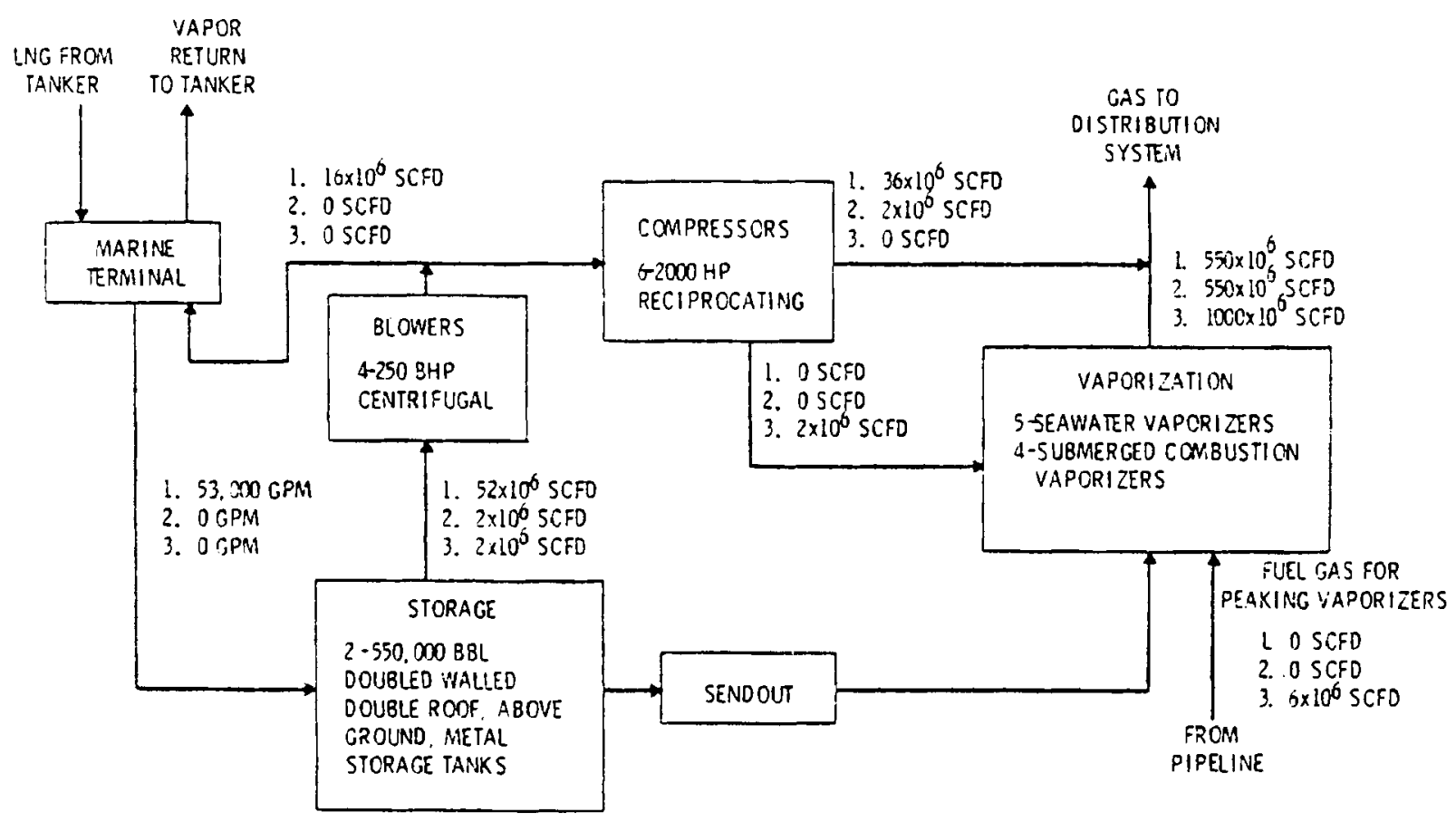

1. TANKER UNLOADING

2. NORMAL OPEPATING CONDITIONS

3. PEAKING OPERATHDNS. NO TANKERS UNLOADING

FIGURE D.1. LNG Import Terminal - Block Flow Diagram

pressures, and the composition of the LNG. A typical rate for the facility is $52 \times 10^{6} \mathrm{scfd}$, of which about $16 \times 10^{6} \mathrm{scfd}$ is returned to the ship's cargo tanks to maintain pressure. The rest of the boiloff and flash gas is handled in the same manner as the normal boiloff.

During peaking operations, submersible in-tank pumps raise the LNG to 60 psig and transfer it to the secondary pumps. The 10 submersible secondary pumps raise the LNG to 1,300 psig and pump it to the vaporizers.

The facility has a total of nine vaporizers. Five of these are seawater heated with a total capacity of $550 \times 10^{6} \mathrm{scfd}$; these are used for normal operations. The other four are submerged combustion vaporizers with a total capacity of $450 \times 10^{6} \mathrm{scfd}$. These are used as spares and for peaking operations. A total of $1,000 \times 10^{6}$ scfd of vaporization capacity is available. Gas leaves the vaporizers and enters the pipeline at 1,250 psig and $50^{\circ} \mathrm{F}$. 


\section{D.2 PLANT LAYOUT}

Figure D.2 shows a plot plan for the LNG import terminal. The locations of major pieces of equipment and the major components of the fire safety system are shown. Some key distances on the figure are:

- ocean to plant boundary

$$
\begin{aligned}
& \sim 500 \mathrm{ft} \\
& \sim 1,400 \mathrm{ft} \\
& \\
& \sim 550 \mathrm{ft} \\
& \sim 200 \mathrm{ft} \\
& \sim 60 \mathrm{ft} \\
& \sim 100 \mathrm{ft} .
\end{aligned}
$$$$
\text { - storage tanks to plant boundary (south) }
$$

- control room to nearest storage tank

- control room to vaporizers

- control room to compressor building

\section{3 PROCESS DESCRIPTION}

The basic processes involved in the import terminal are described in detail in the following subsections.

\section{D.3.1 Marine Terminal}

The marine terminal, discussed here, receives incoming LNG from ocean-going tankers and transfers it to the storage tanks.

\section{D.3.1.1 Marine Terminal Equipment}

The marine terminal for the LNG import facility is shown in Figures 0.3 and D.4. The terminal consists of a dock and a 6,000-ft trestle supporting a roadway and four transfer lines: a 42-in. main transfer 1ine, a 16-in. vapor return line, a 4-in. liquid recirculation line, and a 10-in. Bunker " $C$ " fuel oil line. The structure is $40 \mathrm{ft}$ above the mean lower line water level. A flow diagram for the transfer piping system is shown in Figure D.5. (Flow diagram symbols are defined in Appendix H.)

The trestle is constructed of precast-prestressed concrete girders and supported by cylindrical piles at intervals of about $133 \mathrm{ft}$. The height of the trestle varies with a uniform slope of 1 in. per $100 \mathrm{ft}$. 


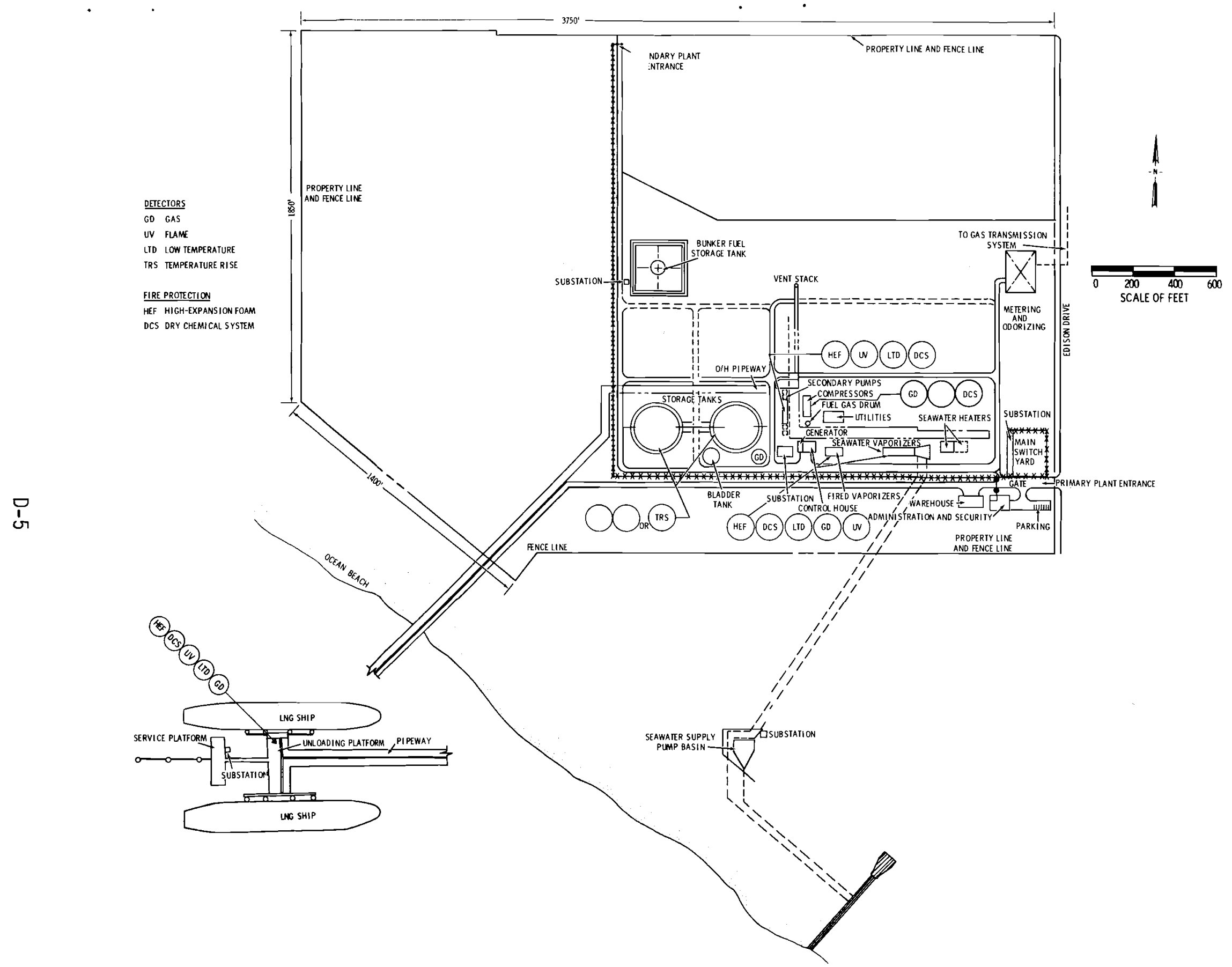

FIGURE D.2. Plot Plan for LNG Import Terminal 


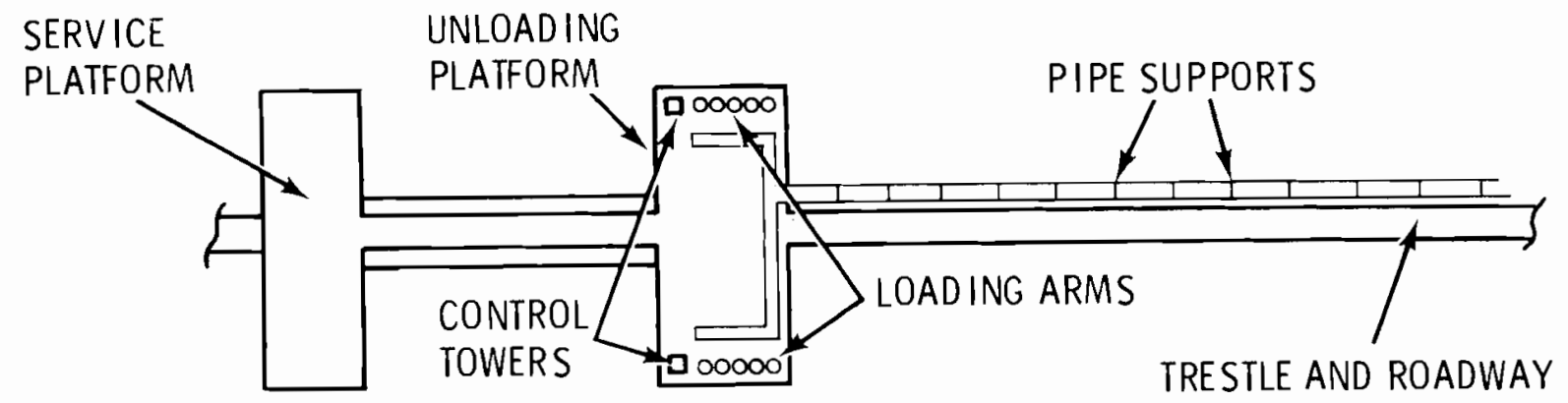

FIGURE D.3. Marine Terminal Overview

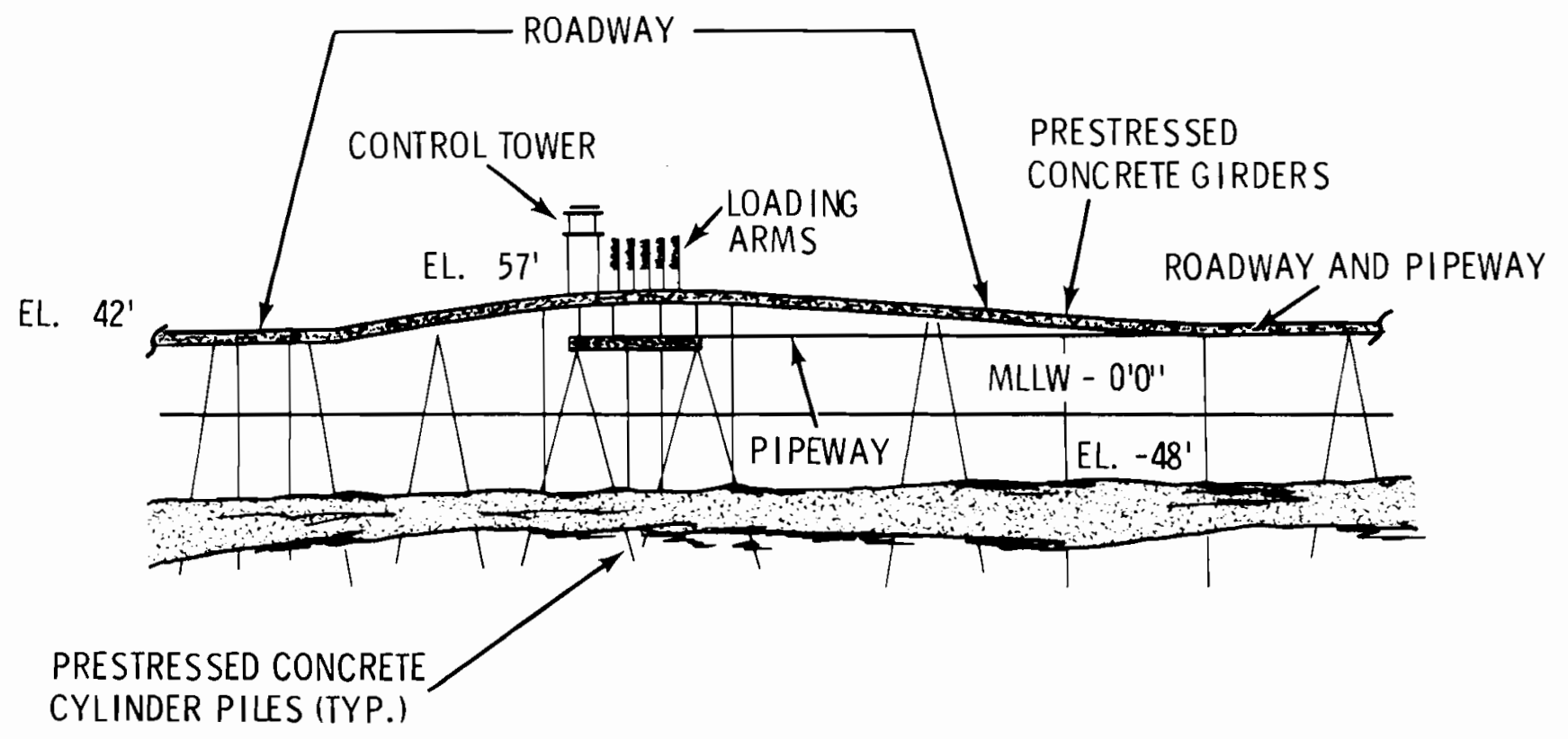

FIGURE D.4. Marine Terminal Elevation 


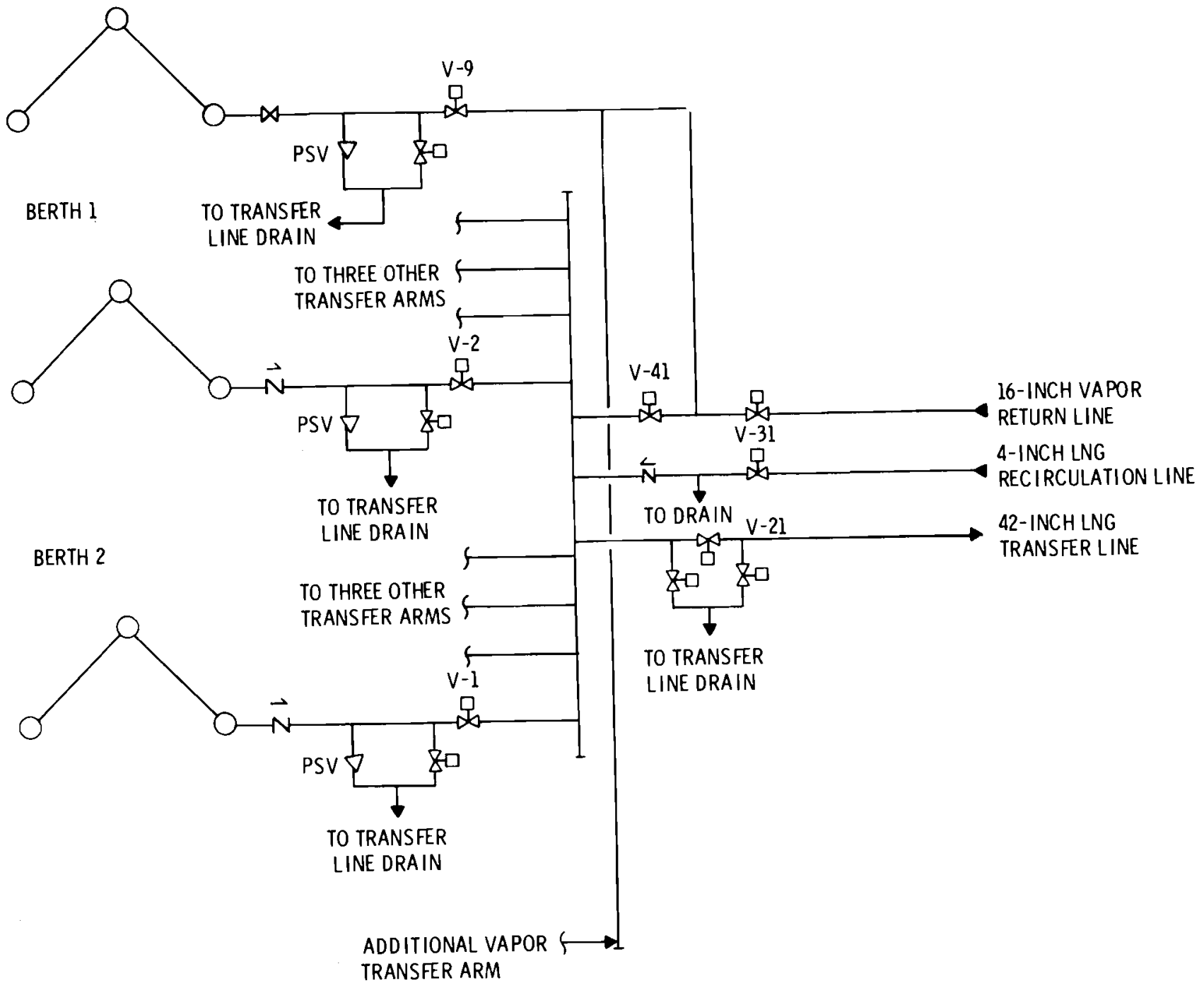

FIGURE 0.5 . Transfer Piping System

There are berths for two ships, one on each side of the trestle. Two ships can be berthed at one time, but only one ship can unload at a time. Each berth is equipped with four main berthing dolphins to absorb the berthing energy of the tanker. Each berthing dolphin is equipped with a powered capstan and quick release hooks. In addition, five mooring dolphins are installed at each 
berth. The mooring dolphins include powered capstans and quick-release hooks similar to the berthing dolphins. The dolphin design allows a tanker to remain at berth during wind gusts of up to 60 knots, depending on sea conditions. Without tankers at berth, the marine trestle and berths can withstand 96-knot wind gusts and 71-knot winds for 1-minute duration. The trestle and berths can handle a 27-ft wave with a 12-second period.

Two platforms extend out from the trestle to each ship. One is the service platform and the other is the main unloading platform. The service platform contains a fixed crane for unloading ship's stores and a gangway for personnel access to the vessel. The main deck of the unloading platform supports the piping, valves, manifolds, equipment, and controls required for the unloading operation. A second deck supports four 16-in.-diameter articulated LNG loading arms, one 16-in.-diameter vapor return arm, and a 10-in.-diameter arm for Bunker "C" fuel oil. A 15-ft-square by 40-ft-high control tower provides an unobstructed view of unloading operations. The unloading platform is shown in Figure D.6.

The control room is manned as long as any of the cryogenic arms are connected to a ship. The operator has controls for the arms, the vapor return system, fire water pumps, the dry chemical fire protection system, and all offshore valves. For communications, he has a direct line to the ship's cargo control officer and another direct line to the terminal main control room, as well as radio, normal telephone, and a two-way loudspeaker system.

The towers are patterned after control towers at small airports and are reached by spiral stairs inside a 72-in. steel support cylinder. Each pulpit has a water-spray system, and the support cylinders are heavily insulated for fire protection. The entire structure is pressurized with a supply of fresh air and is air-conditioned and heated by a heat pump.

The loading arms are equipped with special swivel joints to compensate for ship movement in three directions. The arms and transfer lines are constructed of 300-series stainless steel to withstand thermal stresses caused by extreme temperature changes and are not insulated. The arms are supplied with hydraulic power to control inboard, outboard, and slewing motion. They can be operated by one man from the master control panel in the control tower or 


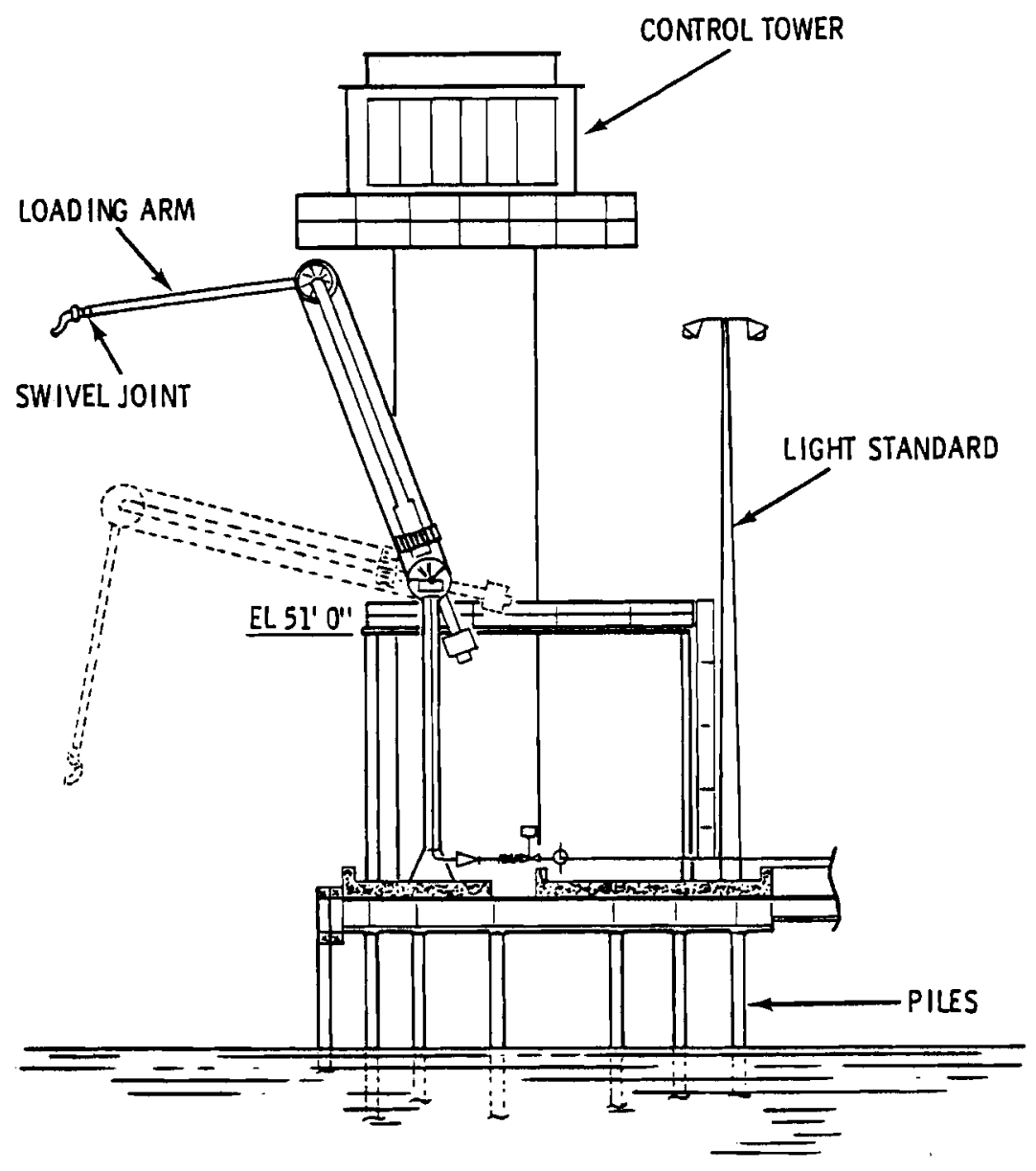

FIGURE D.6. Unloading Platform

by a portable remote-control unit. Each arm is equipped with two sets of redundant sensing devices, which initiate audible alarms and activate the emergency shutdown system whenever excessive motion is sensed.

Each of the four LNG transfer arms connect to a 24-in. pipe containing a failsafe-closed-type valve. The position of the valve can be controlled locally, from the control tower, by the Offshore Emergency Shutdown (OES) system, or by the quick drain system: (See Section D.4.2 for a description of the emergency shutdown systems.) 
Each 24-in. pipe has two connections between a check valve and an airoperated valve. The first connection is for pressure relief, the second is for the drain system. The drain line contains a failsafe-closed valve that can be controlled locally, from the control tower, or by the quick drain system.

The two sets of four 24-in. lines connect to a 42-in. header which ties into the 42-in. transfer 1 ine that runs ashore to the storage tanks. This line contains several corrugated-metal expansion joints to accommodate thermal contraction at cryogenic temperatures. The 42-in. line is insulated with polyurethane, mechanical type insulation.

The 16-in. vapor return 1 ine is connected to a 16-in. pipe containing the same valving as the 24-in. lines. The 16-in. line then runs ashore to the cold blower. All piping and valves in the system are made of 300-series stainless steel. Most piping connections are welded (i.e., a minimum of flanged connections are used). All insulated pipes are free to slide within their insulating cover. Pipe guides support the pipe and allow longitudinal movement while controlling lateral and vertical movement. The major percentage of valves used in this plant are globe valves because they leak less than most other valves in this type of service.

\section{D.3.1.2 Un1oading Procedure}

When the LNG tanker is fully prepared for discharge operations, the cargo officer gives notice to ship and terminal crews that the liquid and vapor arms are ready for connection. The terminal operator locates the arms so that the blinds may be easily removed and then purges the arms with nitrogen gas. Following this, he depressurizes the arms. He then notifies the cargo officer who orders the blinds removed and the flanges attached loosely. A second nitrogen purge follows, and then the flanges are tightened. Cooldown of the loading arms is then begun. For the following discussion, valve numbers correspond to numbers shown previously in Figure D.5. 
Between ship unloadings, the 42-in. transfer line is kept cold by circulating a smal1 stream of LNG out through the 4-in. recirculation line and back through the 42-in. line to shore. To start the unloading, the recirculation is stopped by closing $V-31$ and $V-21$. Next, valves $V-1, V-2$, etc. on each LNG loading arm are opened and the ship's recirculating pumps are started to circulate a small flow of LNG through each arm into the main liquid header, through a jumper $(V-41)$ to the 16 -in. vapor return line, and then back to the ship. When all arms are sufficiently cool, the recirculating pump and valves are shut down and unloading can proceed.

The following step-by-step procedure is used for unloading:

- Determine from terminal that they are ready to receive LNG and that the vapor return blower is operable.

- With ship's liquid and gas manifold valves closed, start one main cargo pump to put maximum pressure on the ship's system.

- Inspect for leaks; if any are found, stop pump, drain liquid, and make necessary repairs.

- If no leaks are found, open one of the ship's manifold liquid valves and gas manifold valves and commence discharge. (Loading arm valves $\mathrm{V}-1$, $V-2$, etc., should already be open from recirculation procedure.)

- Start other main cargo pumps and open other liquid valves in coordination with shore requirements.

- After about 20 minutes, the LNG originally filling the 42-in. transfer line is displaced. During this initial period, no return vapor is being pumped. When shore tank pressure has increased to the desired level, the terminal advises the cargo officer and starts the vapor return blower. The vapor is routed through the vapor loading arm ( $V-9)$ and through the ship's manifold valve, which directs the vapor through a regulator valve set for 2 psig. The ship's tanks do not require vapor until their pressure has dropped to this point. 
- When a11 compartments are operating properly and the terminal officer indicates readiness, the cargo officer increases the flow rate by starting one cargo pump at a time. Then each cargo pump discharge valve is opened wide.

Each ship has some prescribed tank level at which cargo pumps are secured. In most a11 cases, one tank will complete discharge before the others and so on, so that there will be a gradual decrease in cargo discharge rate. This rate is carefully monitored, and about 1 hour prior to estimated completion the cargo officer notifies the terminal. Just before stopping the last cargo pump, several events occur in sequence:

- The cargo officer notifies the shore control room of his intention.

- The cargo officer then cracks the adjacent filling line for the last tank.

- The terminal operator then closes the shore block valve (V-21) and cargo circulates back to the ship's tank. The cargo pump is shut down and the adjacent filling line closed.

- The terminal operator then drains all the loading arms and closes the loading arm valves $V-1, V-2$, etc., including the vapor return arm V-9.

- Valves $V-31$ and $V-21$ are then opened and circulation through the 42-in. transfer 1 ine is resumed.

\section{D.3.1.3 Release Prevention and Control Features}

As shown previously in Figure 0.2 , the following detectors are located at the marine dock:

- gas detectors

- low temperature detectors

- UV fire detectors.

Each of these are connected to an alarm and identified by location and type in both the main control room and the marine control room. 
The fire extinguishment system at the marine terminal consists of the following:

- high-expansion foam system

- fixed dry chemical units

- one fire hydrant

- four dry chemical fire extinguishers, two each at the marine control tower and the fire hydrant station

- sprinkling system on the roof of the marine control room.

None of the fire extinguishing equipment at the marine terminal is activated automatically. It can be activated manually either locally or remotely from the marine control tower or the main control room.

A containment system is located under the platform area to hold all spills from the loading arms. The low temperature detectors are located in this spill area to indicate when a spill occurs. Containment for LNG transfer lines at the beach and plant area is included. The transfer system includes welded pipe connections rather than flanges to reduce the likelihood of leaks.

Each transfer arm is equipped with two sets of redundant sensing devices that initiate alarms in both control rooms and automatically activate the Offshore Emergency Shutdown (OES) system when excessive motion is sensed (see Section D.4.2). Each transfer arm also has a failsafe-closed-type, air-operated valve. This valve closes automatically when the emergency shutdown system is activated.

\section{D.3.2 LNG Storage}

The LNG is stored at the facility until it is regasified and sent out to the pipeline. The storage system and related equipment and procedures are described in detail below.

The process flow diagram for the LNG transfer and storage systems is shown in Figure D.7. Associated process conditions and equipment identifications are given in Table D.2. 


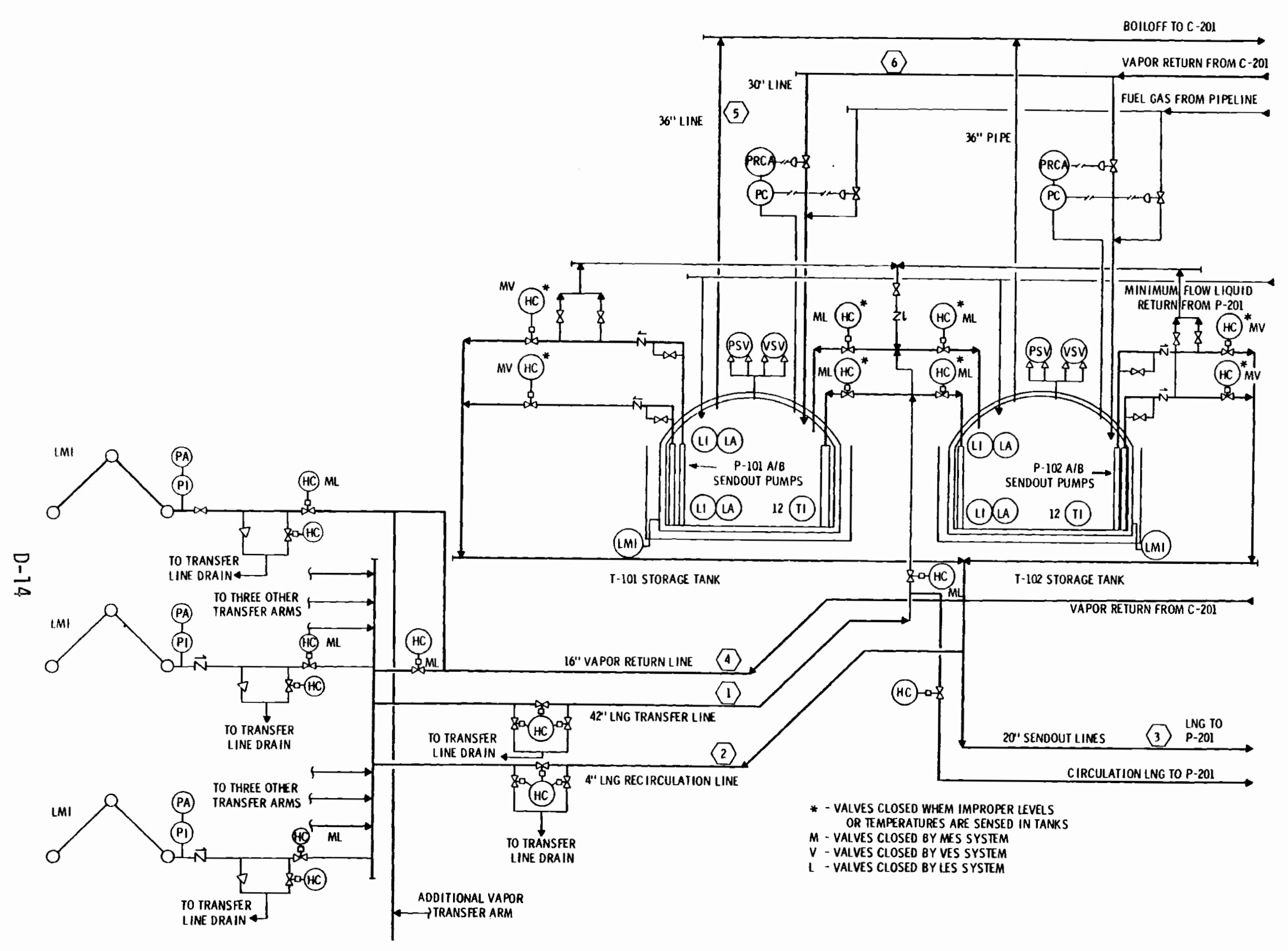

FIGURE D.7. Piping and Instrumentation for LNG Transfer and Storage 
TABLE D.2. LNG Transfer and Storage Systems

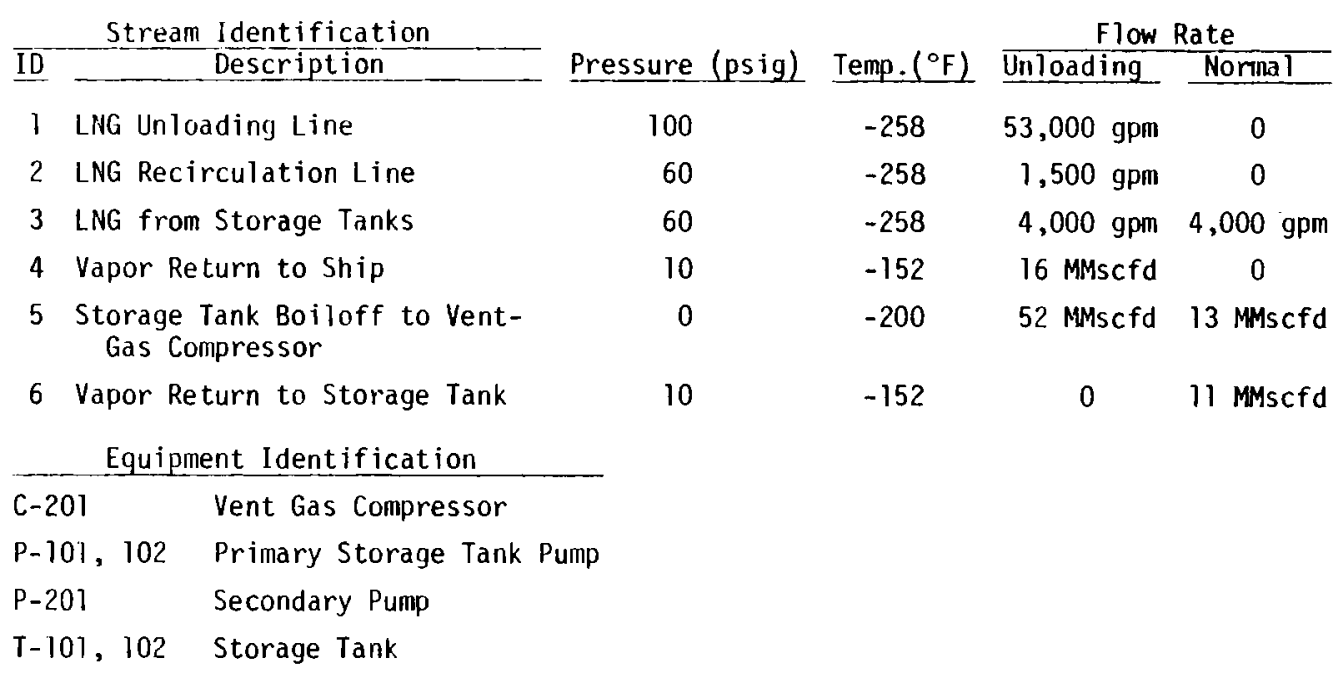

\section{D.3.2.1 Storage Tank}

Storage for the facility consists of two flat-bottom, double-walled, aboveground LNG storage tanks, each with a capacity of 550,000 bbl. The tank is shown in Figure D.8. The inner tank is constructed of $9 \%$ nickel steel, an alloy that retains its strength and ductility throughout the LNG temperature range. The outer shell is constructed of A131 carbon steel. The diameters of the inner and outer tanks are $215 \mathrm{ft}$ and $225 \mathrm{ft}$, respectively. The height of the outer shell is $98 \mathrm{ft}$, while total height to the top of the tank dome is $146 \mathrm{ft}$.

The annulus between the inner and outer tank walls is filled with expanded perlite, an inorganic, non-flammable, lightweight insulation produced from special rock. The rock or ore is finely ground and then expanded in furnaces at about $2000^{\circ} \mathrm{F}\left(1100^{\circ} \mathrm{C}\right)$. The perlite is expanded onsite and placed in the insulation space while hot. The thermal conductivity of perlite in a methane atmosphere is $0.25 \mathrm{Btu}-\mathrm{in} . / \mathrm{hr} \mathrm{ft}^{2}{ }^{\circ} \mathrm{F}$. A resilient fiberglass blanket is wrapped around the outside of the inner shell to protect the perlite from excess pressure due to thermal cycling and movement of the inner shell (see Figure D.9). The space between the inner and outer tank floors is insulated with a 25-in. layer of foamglass, a nonflammable load-bearing insulation. The load-bearing insulation 


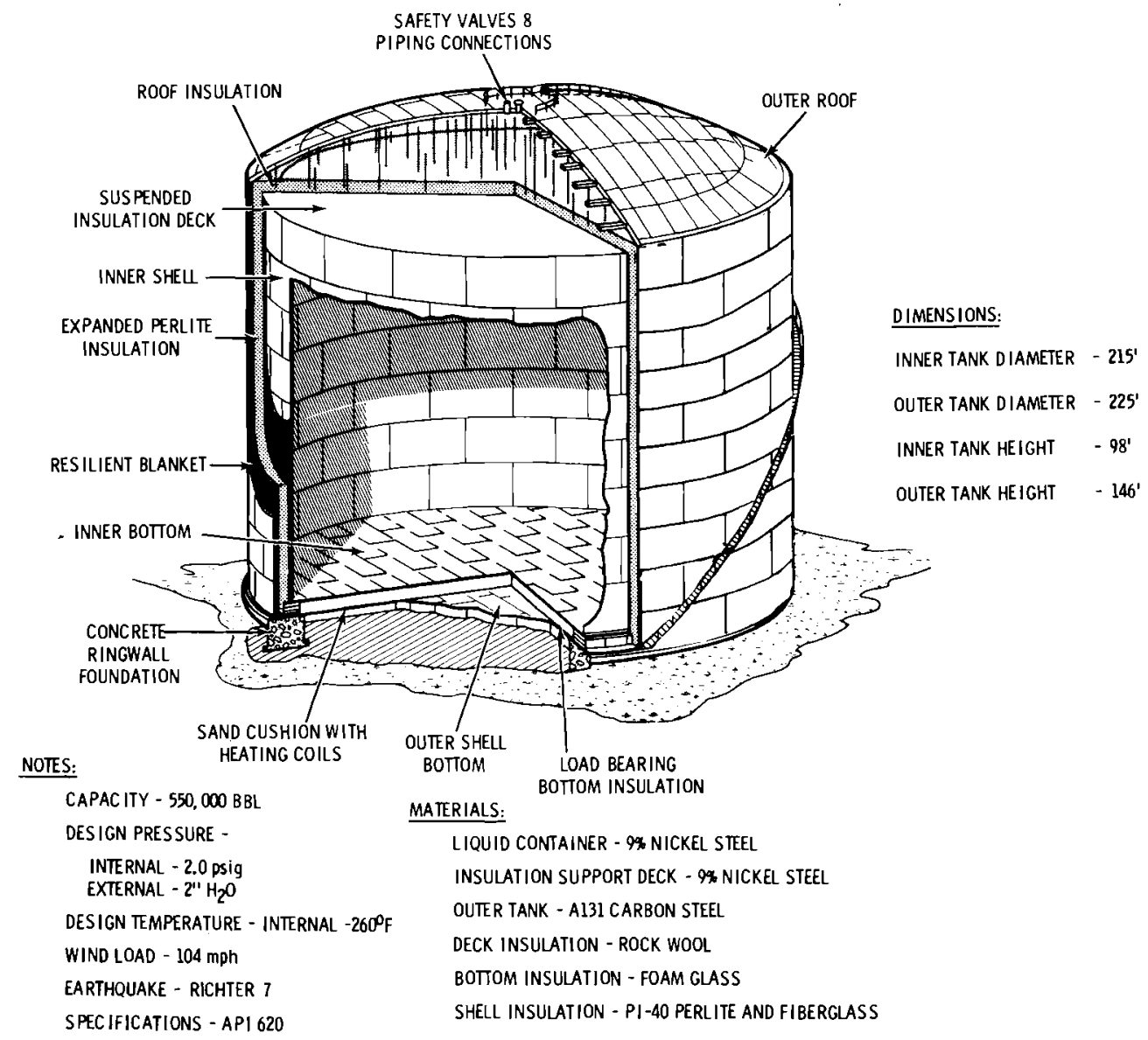

FIGURE D.8. LNG Storage Tank Details

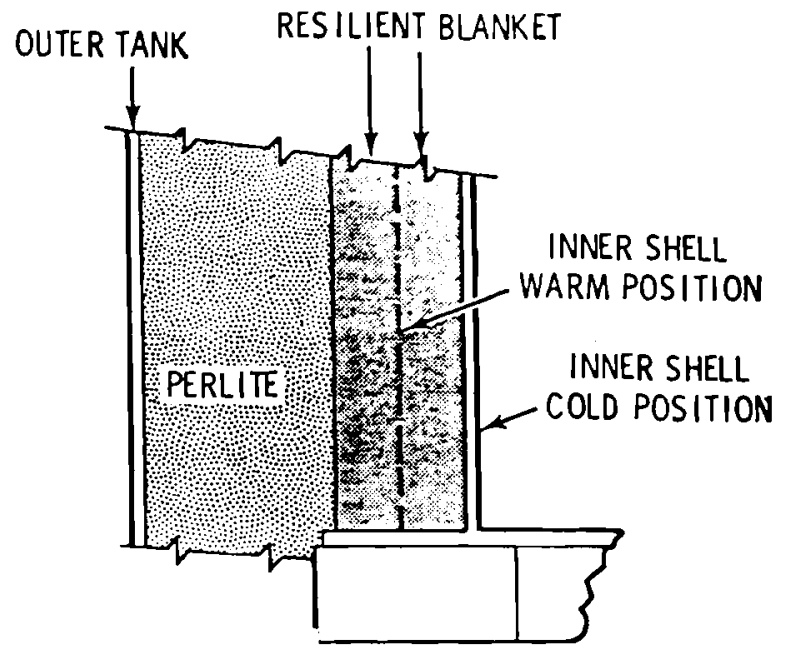

FIGURE D.9. Resilient Blanket in Annular Space Between Walls of LNG Storage Tank 
rests on a concrete ringwall foundation around the perimeter and on a compacted sand foundation in the middle. A 1-ft layer of compacted sand is located beneath the outer tank floor and contains electrical heating elements to prevent freezing of moisture in the subsoil and the "heaving" that can result. There are two sets of anchor bolts in the ringwall, one connected to the outer tank wall and the other connected to the inner tank wall. These bolts hold down the tank against lifting forces resulting from internal pressure. (See Figure D.10.)

The outer tank has a lap-welded, dome-shaped, steel roof. Suspended from the roof framing of the outer tank is a lap-welded metal deck that serves as a ceiling for the inner tank. Mineral wool insulation is spread evenly over the deck. Open pipe vents are installed in the deck to allow product vapor to circulate freely in the insulation space to keep the insulation dry.

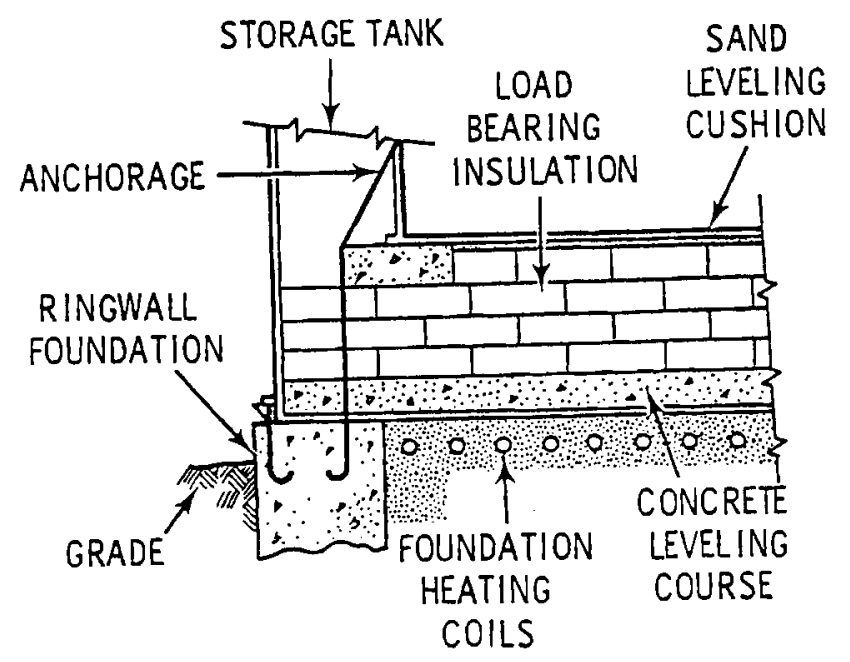

\section{FIGURE D.10. Storage Tank Foundation Details}

The tanks are designed to withstand instantaneous wind gusts up to $104 \mathrm{mph}$, earthquakes of up to 7 on the Richter scale, and a maximum horizontal acceleration of $0.21 \mathrm{~g}$.

Both storage tanks are tested prior to use. They also meet the requirements of the American Petroleum Institute standard 620, Appendix $Q$, which governs 
materials selection, tank design, construction and testing procedures. During construction, the welds on all vertical seams are $100 \% \mathrm{x}$-ray inspected. Welds not $100 \% x$-ray inspected are checked by the liquid penetrant method, as are a11 attachment welds. Inner tank welds are checked by a combination of x-ray, dye penetrant, vacuum box, and solution film test methods. Hydrostatic and pressure tests subject each tank to $125 \%$ of the maximum product weight and $125 \%$ of the maximum design vapor pressure.

A11 piping to the inner tank enters through the roof of the storage tank. Independent structures support all piping external to the tank and prevent the transmission of static and dynamic pipe loads to the storage tank walls.

Two separate fill nozzles permit either top or bottom filling. Incoming LNG heavier than the tank heel is introduced through the top fill line. This procedure permits the tank contents to mix by natural convection and should eliminate the possibility of stratification.

The inlet and outlet lines of the tank are valved so that LNG can be pumped from the bottom of the tank to the top, pumped from one tank to another, pumped out the 4-in. recirculation arm through the transfer arms and back to the tanks, or pumped out the 20-in. sendout line to the secondary pumps.

The tank inlet valves are failsafe-closed valves that can be controlled locally, from the main control room, or by the emergency shutdown system. The tank outlet valves are also failsafe-closed valves that can be controlled locally or from the main control room.

\section{D.3.2.2 Pressure Control System}

The storage tanks have an operating pressure of 0.8 psig ( 15.5 psia) and a maximum and minimum design pressure of 1.5 psig and 0 psig respectively. Normal tank boiloff and vapors from LNG tanker unloading are handled by a vent gas compressor system. The compressors and the secondary LNG pumps are shown in Figure D.11. Associated process conditions and equipment identifications are shown in Table D.3. 


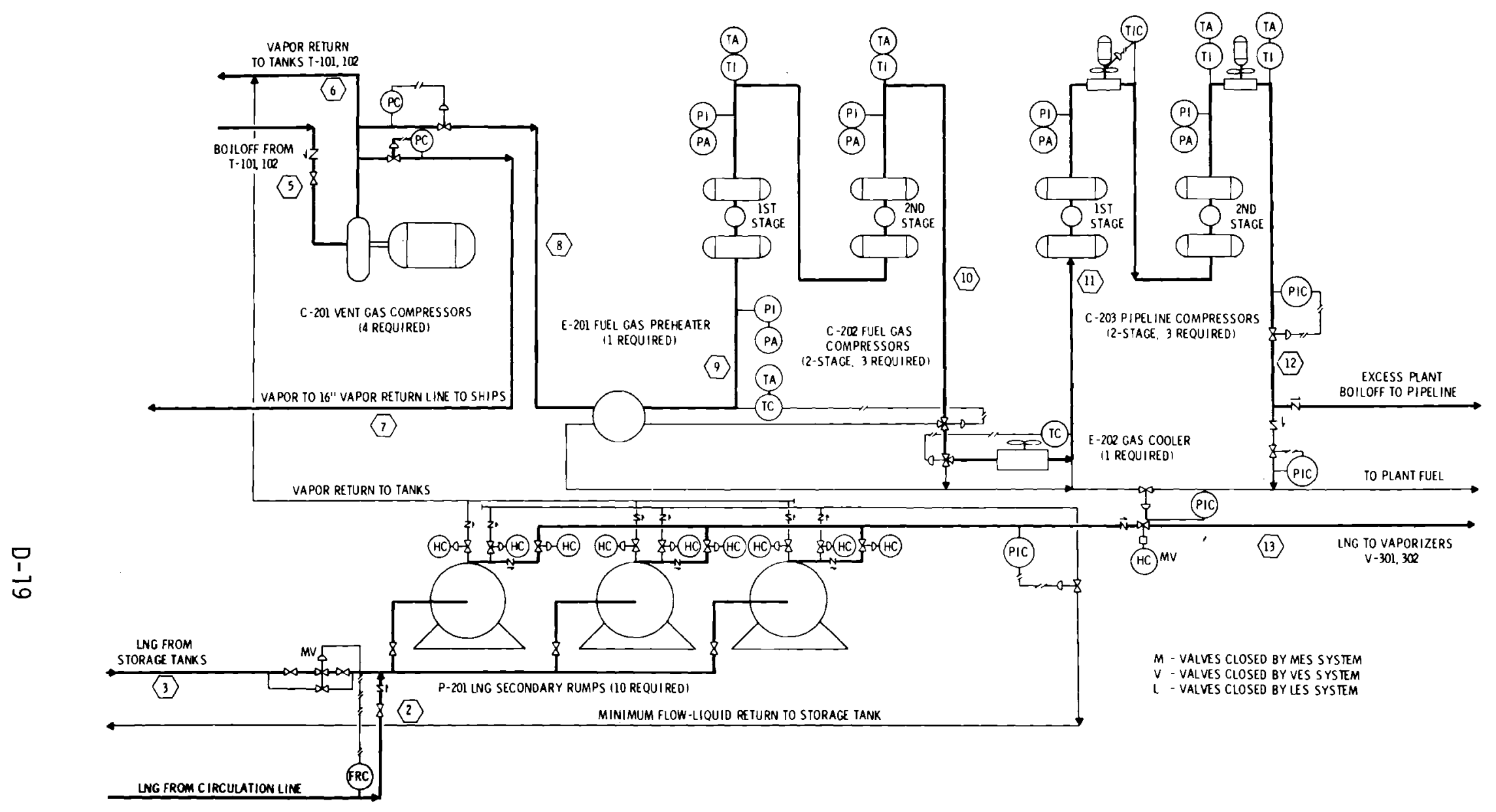

FIGURE D.11. Compressors and Secondary Pumps 
TABLE D.3. Compressors and Secondary Pumps

\begin{tabular}{|c|c|c|c|c|c|}
\hline \multirow{2}{*}{\multicolumn{2}{|c|}{$\frac{\text { Stream Identification }}{\text { Description }}$}} & \multirow[b]{2}{*}{ Pressure (psig) } & \multirow[b]{2}{*}{ Temp. $\left({ }^{\circ} \mathrm{F}\right)$} & \multicolumn{2}{|c|}{ Flowrate } \\
\hline & & & & Unl oading & Norma l \\
\hline 2 & LNG Recirculation Line & 60 & -258 & $1,500 \mathrm{gpm}$ & 0 \\
\hline 3 & LNG from Storage Tanks & 60 & -258 & $4,000 \mathrm{gpm}$ & $4,000 \mathrm{gpm}$ \\
\hline 5 & $\begin{array}{l}\text { Storage Tank Boiloff to Vent } \\
\text { Gas Compressor }\end{array}$ & 0 & -200 & 52 MMscfd & $13 \mathrm{MMscfd}$ \\
\hline 6 & Vapor Return to Storage Tank & 10 & -152 & 0 & 11 MMscfd \\
\hline 7 & Vapor Return to Ship & 10 & -152 & 16 MMscfd & 0 \\
\hline 8 & $\begin{array}{l}\text { Vapor from Vent Gas Compressor } \\
\text { to Fuel Gas Preheater }\end{array}$ & 10 & -750 & 36 MMscfd & 2 MMscfd \\
\hline 9 & $\begin{array}{l}\text { Vapor from Fuel Gas Preheater to } \\
\text { Fuel Gas Compressor }\end{array}$ & 10 & -40 & 36 MMscfd & $2 \mathrm{Mscfd}$ \\
\hline 10 & Vapor from Fuel Gas Compressor & 150 & 285 & 36 MMscfd & 2 MMscfd \\
\hline 11 & $\begin{array}{l}\text { Vapor from Gas Cooler to Pipeline } \\
\text { Compressor }\end{array}$ & 145 & -- & 36 MMscfd & 2 MMScfd \\
\hline 12 & Vapor from Pipeline Compressor & 1,300 & 120 & 36 MMscfd & 2 MHiscfd \\
\hline 13 & $\begin{array}{l}\text { LNG from Secondary Pumps to } \\
\text { Vaporizers }\end{array}$ & 1,280 & -252 & $8,550 \mathrm{gpm}$ & $8,550 \mathrm{gpm}$ \\
\hline
\end{tabular}

Equipment Identification

$\begin{array}{ll}C-201 & \text { Vent Gas Compressor } \\ C-202 & \text { Fuel Gas Compressor } \\ C-203 & \text { Pipeline Compressor } \\ E-201 & \text { Fuel Gas Preheater } \\ E-202 & \text { Gas Cooler } \\ P-201 & \text { Secondary Pump } \\ T-101,102 & \text { Storage Tanks } \\ V-301 & \text { Baseload Seawater Vaporizers } \\ V-302 & \text { Standby and Peaking Gas-rirec Vaporizers }\end{array}$

Storage tank pressure is maintained at $0.8 \mathrm{psig}$ by returning vapor from the vent gas compressors through pressure control valves at the 30 -in. inlet vapor 1 ines to the tanks. Excess vapors are further compressed to be used as fuel gas or for delivery to the gas transmission pipeline. If the pressure control system fails and the pressure in the tank reaches $1.5 \mathrm{psig}$, each storage tank is also equipped with a 20 -in. vent valve and three 12-in. pressure valves that open to the atmosphere. If the pressure in the tank falls below 0.15 psig, a backup gas system supplies vaporized LNG from the gas transmission pipeline to maintain appropriate pressure in each storage tank. If the pressure continues to fall and reaches $0.031 \mathrm{psig}$, three $12-\mathrm{in}$. vacuum relief valves open to the atmosphere. Pressure control settings are summarized in Table D.4. 
TABLE D.4. Pressure Control Settings

Pressure (psig) Function

1.5

Full Relief (vent valve and relief valves)

1.3

High Pressure Alarm

0.8 (15.5 psia)

Control Pressure

0.15

Vapor Injection from Fuel Gas System

0.031

Vacuum Relief

The compression facilities for the boiloff vent gas consist of four 250-bhp, electric-motor-driven, single-stage centrifugal units, each with a capacity of approximately $13 \times 10^{6} \mathrm{scfd}$ discharging at $10 \mathrm{psig}$ and $-150^{\circ} \mathrm{F}$. Two of the four compressors serve as backups. During tanker unloading, the design gas rate (boiloff and flash) is $50 \times 10^{6} \mathrm{scfd}$. Each storage tank has a normal boiloff rate $\left(0.05 \%\right.$ of full tank capacity per day) of $1 \times 10^{6} \mathrm{scfd}$. A total design boiloff and flash gas rates from 2 storage tanks and tanker unloading is $52 \times 10^{6}$ scfd. At the outlet side of the vent gas compressors are pressure control valves for maintaining appropriate pressures in the 36-in. piping system leading to the fuel gas compressors and the piping system returning to the ship. From the vent gas compressors, the vapor is taken to three 2,000-bhp, gas-driven, reciprocating compressor units, each having a capacity of $17 \times 10^{6} \mathrm{scfd}$ at a discharge temperature and pressure of $285^{\circ} \mathrm{F}$ and $150 \mathrm{psig}$, respectively. These serve as the fuel gas compressors, with two compressors on line and the third being a backup. An additional three pipeline compressors are included in the system. These are similar to the fuel gas compressors in design and capacity, and they pump the gas to the gas transmission 1 ine at $120^{\circ} \mathrm{F}$ and 1,300 psig.

\section{D.3.2.3 Additional Control and Instrumentation}

Instrumentation in each LNG storage tank includes a vertical temperature probe supporting thermocouples at 10-ft intervals for the purpose of detecting the onset and buildup of thermal stratification in the stored LNG. A total of 
12 temperature sensors on the floor and lower shell of each tank monitor LNG storage cooldown. A thermocouple placed in the electrically heated soil foundation monitors and controls the temperature there.

Each tank is equipped with two float-type liquid level indicators and one ultrasonic liquid level indicator. In the event of high-high level, the ultrasonic indicator sounds an alarm in the main control room and automatically stops al1 liquid flows into the tank. The float-type level indicators are each set to indicate high, high-high, low, and low-low liquid levels. Alarms are activated in the control room for each of these conditions.

Instrumentation is also included to indicate relative movement between the inner and outer shells of the storage tanks. This instrumentation is located in a quadrant at or near the floor of the inner shell, and can be of either the direct reading or the electronic (1 inear-motion transducer) type.

\section{D.3.2.4 Procedures}

Cooldown. The first step in the cooldown of the storage tank is to purge the tank with nitrogen. This prevents an explosive gas mixture from forming and also dries out the tank. The nitrogen used must be dry to avoid depositing water in the cold perlite insulation, thus reducing the insulation's effectiveness. The inner tank is purged by admitting the nitrogen gas into the bottom of the tank and venting the mixture of air and inert gas through the vents in the suspended ceiling and out the dome and relief valve vents. The annular space is purged by closing the dome vent and the relief valve vent, allowing the nitrogen to flow down through the insulated annulus and out the perlite fill nozzles at the bottom of the tank.

After the purge, LNG brought to the facility by truck is slowly admitted to the tank through the cooldown nozzle where it is deflected and sprayed over the floor area. Instruments that monitor the effects of cooldown on the tank are:

- linear movement indicators that measure relative movement between the inner and outer tank walls

- storage tank thermocouples. 
The LNG flow rate is limited to avoid exceeding specified maximum temperature gradients between the tank thermocouples. When the liquid level in the tank reaches $1 \mathrm{ft}$ or more and the tank is sufficiently cooled, LNG can be fed through the normal liquid fill 1 ine and the input rate can be increased to the maximum.

The cooldown purges the nitrogen from the tank and the off gas is vented through the vent gas header. When the methane level in the off gas reaches a specified level, the off gas is compressed and sent to the pipeline.

Heatup, Purging, and Entry. Prior to the heatup of the tank, the LNG level is lowered until the sendout pumps lose suction. This leaves approximately $1 \mathrm{ft}$ of LNG in the tank. Heatup is then begun by injecting natural gas, heated to $275^{\circ} \mathrm{F}$, into the storage tank through the bottom penetration. The natural gas rises, due to its temperature buoyancy, to the top of the vessel and leaves via the 36-in. vapor outlet line. The tank pressure control system functions as it would during normal operation. The inlet gas flow is maintained at approximately the normal boiloff rate, $1.0 \times 10^{6} \mathrm{scfd}$. At this rate, it takes approximately 20 days to warm the tank from $-250^{\circ} \mathrm{F}$ to $+60^{\circ} \mathrm{F}$.

The following instrumentation systems monitor the effects of warmup on the tank:

- linear movement indicators that measure relative movement between the inner and outer tank walls

- storage tank thermocouples

- strain gauges installed around the periphery of the exterior tank to monitor any stresses due to expansion of the inner vessel and resulting compaction of the perlite.

The storage tank must be purged to a $98 \%+$ nitrogen atmosphere before personnel entry. Liquid nitrogen is brought in by cryogenic trailer, vaporized, and admitted to the tank through the bottom penetration inlet. The purging is done in the same manner as described before. As the purging nears completion, however, the nitrogen content of the off gas rises rapidly. Because there is 
a limit on the nitrogen concentration in gas that is sent to the pipeline, the last portion of the off gas is vented through the vent gas header. Combustible gas detectors are located around the tank to detect any off gas descending from the vent. Established weather criteria define acceptable atmospheric conditions for venting.

Storage Tank Isolation. The objective of the storage tank isolation is to eliminate the possibility of an uncontrolled source of gas contaminating the nitrogen atmosphere.

In isolating the storage tank, care must be taken to ensure that the inner vessel will not be subjected to an excessive positive or negative pressure condition.

The storage tank isolation is performed by a physical separation of all nonessential piping connections at the storage tank flanges. Where valves are removed, the two remaining flanges are blanked off and a minimum 4-in. air space established between blanks. The only piping penetration that remains connected to the storage tank is the trailer unloading line through which the vaporized nitrogen purge gas enters the storage tank. On this particular line, all connections to other piping systems are physically isolated, including reversing all safeties to prevent discharge into the plant-vent system.

Manometers are installed to monitor inner vessel and annular space pressures. In addition to the normal purging nitrogen, a full load of nitrogen is maintained at the site at all times. This provides a sufficient reserve that can be vaporized into the tank in the event of a rapid barometric pressure change.

\section{D.3.2.5 Release Prevention and Control Features}

Each LNG storage tank is surrounded by a concrete dike wall with a capacity of about $737,500 \mathrm{bbl}$, or 1.34 times the capacity of the tank. The dike wall is approximately $81 \mathrm{ft} 4 \mathrm{in}$. high, $1 \mathrm{ft} 6 \mathrm{in}$. thick, and $259 \mathrm{ft}$ inside diameter. The inside of the dike wall is lined with a 2 1/2-in.-thick insulating material to reduce the evaporation rate of $L N G$ in the event of a tank failure. A 10-ft space separates the dike from the outer shell of the storage tank. The dike wall rests on the same 4-ft-thick, reinforced concrete mat that supports the 
storage tank. However, the dike wall is not structurally tied into the foundation, in order to allow the concrete wall to contract freely in the event of a large LNG spil1.

A weather shield extends from the top of the concrete dike to the outer tank roof to keep precipitation from falling into the annular space. An air circulation system is installed to circulate ambient temperature air throughout the annular space. Withdrawal of cold air by this system prevents excessive moisture buildup, condensation, and ice formation in the annular space. A water pump designed for a flow of $44 \mathrm{gpm}$ is installed at the bottom of the annular space to remove any water that might collect there. High-expansion foam generation systems in this area can be activated either manualiy or automatically from lowtemperature detectors located in the pumpout area. A1so, UV fire detectors located in the pumpout area near the spill basin and at each pressure/vacuum relief valve on top of the tank can activate dry chemical and high-expansion foam systems and shut down pumps and associated equipment. Combustible gas detectors located in the pump area sound alarms at $25 \%$ of lower flammable limit. At $65 \%$ of lower flammable limit, another alarm sounds and the sendout pumps are shut down, either automatically or manually. (For a list of detectors that activate the shutdown system, see Section D.4.2.)

Each of the main storage tanks is also protected by a fixed water deluge system. Water from this system is applied only to the roof of the tank because the walls of the main containment extend to the top of the outer shell of the tank. The excess water runoff from the water deluge system is carried across the annular space between the tank and the concrete containment and discharged down the outside of the containment wall. The deluge system is designed to deliver sufficient water to maintain the tank roof at safe operating temperature during the maximum fire that could be expected at the receiving terminal. Deluge water is provided by electrical pumps in addition to the city water pressure. A UV fire detector located near the tank relief valves automatically activates a dry chemical extinguisher aimed at the relief vaives. Also, each storage tank area contains a manual fire alarm and two portable dry chemical fire extinguishers, each with a 30-1b capacity. 
A fire truck containing a dry chemical system is used as a backup. Additional hoses and a small water-pumping capability are also provided on the truck.

\section{D.3.3 LNG Sendout Pumps}

Each storage tank contains two removable, submerged, cryogenic, primary pumps (with an additional pump well for installation of a third pump as required) to transfer LNG from the storage tanks to the suction of the secondary pumps located external to the tanks. The primary pumps are also used to recirculate LNG to the ship's unloading lines to keep the lines cooled down. Each primary pump has a capacity of $2,000 \mathrm{gpm}$ with a discharge pressure of $60 \mathrm{psig}$.

There are $10^{\prime}$ secondary pumps, with nine operating and one as backup. Each pump is a 15-stage, 950-gpm, 1,200-hp, 3,600-rpm, submerged-motor pump designed with a discharge pipeline pressure of 1,280 psig. The secondary pumps and their motor drives are hermetically sealed in a vessel and submerged in LNG. This design eliminates the extended pump shaft and associated seal. The pump and motor surroundings are $100 \%$ rich in LNG and will not support combustion.

There are two outlet lines from each tank. Each line contains a check valve, a line that connects to the tank inlet 1 ines for recirculation, and a failsafe-closed control valve that can be operated locally, from the control room, by the emergency shutdown system, or by a signal from temperature or level sensors in the tank.

The outlet lines join to form the 20-in. sendout line. This line is interrupted by a failsafe-closed, air-operated control valve and then joins with the 4-in. LNG circulation line to become the $36-$ in. feed line to the secondary pumps.

The secondary pump outlets are divided into two 1ines. The 24-in. main 7 lines, which contain a check valve and a failsafe-closed, air-operated valve that can be activated locally or from the main control room, join together to become the main feed line to the vaporizers. The minimum flow lines, which contain the same valves as the main lines, join together and return to the storage tanks. Each pump also has a vapor vent line with the same valving as the liquid lines. The vapor vent lines combine and return to the tanks via 
the 30-in. vapor return line. Piping and instrumentation for the sendout pumps were shown previously in Figure D.11.

An independent dike surrounding the pumpout area helps contain any spills that might occur in this area.

\section{D.3.4 Vaporization}

LNG sent out from storage is vaporized and injected into the pipeline. Vaporization equipment and procedures are described here. The process flow diagram for the vaporization system is shown in Figure D.12. Corresponding process conditions and equipment identifications are given in Table $\mathbf{D . 5}$.

\section{D.3.4.1 Vaporizers}

Baseload vaporization occurs in five falling-film, open-rack, seawater vaporizers with a total capacity of 550 MMscfd. One such vaporizer is shown in Figure D.13. LNG is introduced through manifolds at the bottom of banks of vertical panels constructed of special extruded fins. The LNG passes upward inside the tubes where it is heated by the seawater which falls as a film over the outside of the panels. Vaporized LNG emerges at the top and is routed to a 24-in. outlet line.

The falling water film used in this design gives extremely high heat transfer coefficients, which reduces the amount of ice formed, thus maintaining high performance. With this open type of system, the small amount of ice that is formed does not interfere with the flow of water. The panels of finned tubes and all parts in contact with the LNG are made of aluminum alloy, which maintains its strength at low temperature. The surface of the panels in contact with the seawater are protected by a sacrificial zinc cladding.

The seawater is pumped to the vaporizers at rates that result in approximately a $5^{\circ} \mathrm{F}$ temperature drop between incoming and outgoing seawater. About $170,000 \mathrm{gpm}$ is required for the $550 \mathrm{MMscfd}$ vaporization capacity. The seawater supply system to the LNG plant consists of an 830-ft-long, 14-ft-diameter, carbon-steel pipeline from a neighboring power plant's condensers to a pump supply basin and a 1,650-ft-long, 9-ft-diameter, carbon-steel pipeline from the basin to the LNG vaporizers. The temperature of the water is about $90^{\circ} \mathrm{F}$. 


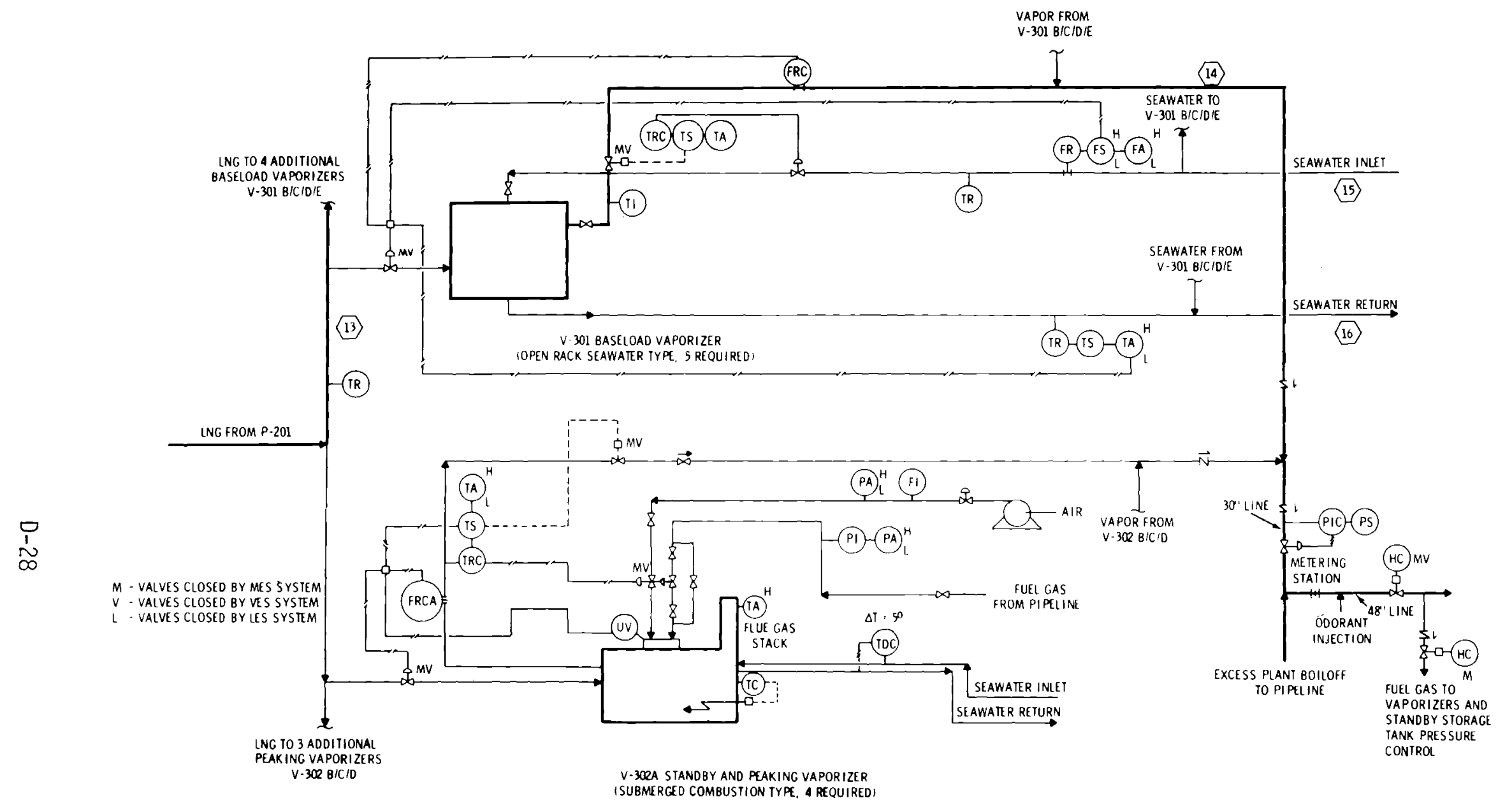

FIGURE D.12. Flow Diagram of Vaporization System 


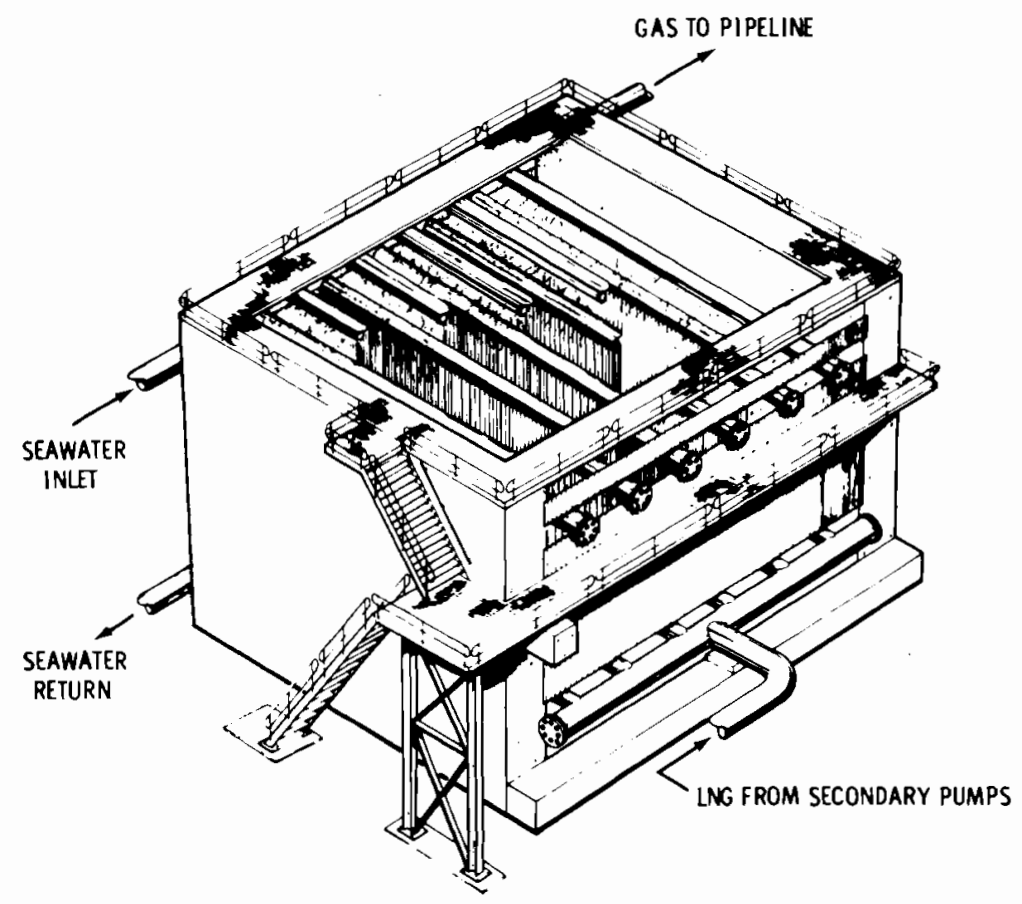

FIGURE D.13. Falling Film Open-Rack Seawater Vaporizers

TABLE D.5. Vaporization System

\begin{tabular}{|c|c|c|c|}
\hline \multicolumn{2}{|r|}{ Stream Identification } & \multirow[b]{2}{*}{ Pressure (psig) } & \multirow[b]{2}{*}{ Temp. } \\
\hline$\overline{\mathrm{ID}}$ & Description & & \\
\hline 13 & LNG to Baseload Vaporizers & 1,280 & \\
\hline 14 & Vapor from Baseload Vaporizers & 1,300 & \\
\hline 15 & Seawater Inlet & 20 & \\
\hline 16 & Seawater Return & 20 & \\
\hline 17 & LNG to Peaking Vaporizers & 1,280 & -252 \\
\hline 18 & Vapor from Peaking Vaporizers & 1,300 & \\
\hline \multicolumn{4}{|c|}{ Equipment Identification } \\
\hline$P-2$ & Secondary Pump & & \\
\hline & Baseload Seawate & laporizers & \\
\hline$V-3$ & Backup and Peaki & ig Gas-fired Va & zers \\
\hline
\end{tabular}


A parallel 2,500-ft-long, 9-ft-diameter, carbon-steel pipeline returns the seawater from the vaporizers to the power plant at a temperature $5^{\circ} \mathrm{F}$ cooler than the supply water from the power plant's condensers (about $85^{\circ} \mathrm{F}$ ).

For standby or peaking vaporization, four submerged combustion, gas-fired vaporizers having a total capacity of 450 MMscfd are used. Vaporized LNG exits each unit via a 12-in. 1ine. This brings the total plant output capacity to 1 billion scfd of gas during peak conditions. The gas-fired vaporizers are used approximately 800 hours per year.

The gas-fired vaporizers are designed such that the burners exhaust hot combustion gases downward through a downcomer and into a water bath below the liquid surface. The exhaust bubbles into the water causing turbulence, mixing, and a "lifting" action. This lifting action forces the water up through an annulair space created by a weir around the downcomer. The water flows over the top of the weir and into the more quiescent outer tank. Bath temperature ranges from $90^{\circ} \mathrm{F}$ to $130^{\circ} \mathrm{F}$. A heat exchanger tube coil for the LNG is located in the annular space between the weir and the downcomer where it is scrubbed by the warm gas-water mixture, thus transferring heat to the LNG and vaporizing it. The submerged combustion technique results in a very high thermal efficiency of 94-96\% because: 1) al1 the water in the combustion products condenses and the high heating value of the fuel can be used, and 2) the violent turbulence and mixing of the gas and water result in a high rate of heat transfer to the tubes. The vaporizers consume gas equivalent to $1.5 \%$ to $2.0 \%$ of the LNG vaporized.

The LNG inlet piping, tube bundle, and outlet piping to the first flange are all stainless steel construction. The rest of the outlet piping is carbon stee 1, as are the tank, weir, and downcomer. The section of each downcomer above the water bath is surrounded by a water jacket with continuous circulation of cooling water. The burner, fuel gas piping, air inlet piping, and blower are al1 carbon stee1. The air blower drive is a 250-hp electric motor. The overall dimensions of each vaporizer are approximately $12 \mathrm{ft} \times 27 \mathrm{ft}$ with a height of $10 \mathrm{ft}$. The vaporizer is surrounded by a fiberglass building for weather protection. 
The main line from the secondary pumps divides into two lines, one of which goes to the seawater vaporizers and the other to the submerged combustion vaporizers. The inlet lines to each of the vaporizers are interrupted by failsafeclosed, air-operated, control valves. These valves are used to control the LNG flow to the vaporizers but can also be closed locally, from the main control room, by the emergency shutdown systems (see Section D.4.2), and if desired, by several sensors located in the vaporizer system (see Section D.3.4.4).

The outlet lines from the vaporizers each contain a valve that can be closed locally, from the control room, by the emergency shutdown system, or by a low temperature sensor in the gas outlet line. The outlet lines join together in a 30-in. line that contains a check valve, a fail-safe-closed airoperated valve (normally used for pressure control), and a pressure sensing device.

The 30-in. line expands to a 48-in. line that contains a metering station, the odorant injection line, a failsafe-closed valve (closed locally, from the control room, or by the emergency shutdown system), and the fuel gas supply line for the terminal.

\section{D.3.4.2 Control System and Instrumentation}

Two major controls associated with the vaporizers (both seawater and gasfired types) are:

- LNG flow control

- gas outlet temperature control.

LNG throughput is automatically maintained at a preselected flowrate by a control valve in each vaporizer inlet line. Each LNG control valve is tied into a gas-outlet flow recorder controller. The control valve in the seawater inlet line is tied into a temperature recorder controller in the gas outlet line and regulates the outlet gas temperature by adjusting the seawater flow rate. The gas outlet temperature from the submerged combustion vaporizer is controlled by automatic adjustment of the air-operated control valves in the fuel gas and air supply lines.

Water level in the tank (of each submerged combustion vaporizer) is controlled by several means. An overflow nozzle is located at the normal water depth 
to prevent high levels. A small pump sits at the surface of the water in the bath and pumps water to the cooling jackets on the burners. If the water level is low, the pump loses suction and the discharge pressure falls. A low pressure switch then opens a control valve to admit more water. A low water level alarm is also included.

Vaporizer outlet pressure is controlled by a pressure control valve in the 30-in. line beyond where the outlet lines come together. Other controls include a pneumatic fuel pressure control valve and a pilot line with a pressure regulator for the burners.

\section{D.3.4.3 Procedures}

To start up the vaporizers, the first step is the cooldown of the secondary LNG pumps. The block valves on the outlet lines to the vaporizers are closed and the primary intank pumps are started. The sendout pumps then operate on total recycle until they and their associated piping are sufficiently cool. The vapor produced by cooling the pumps is vented through the vapor vent line on each pump. These vent lines combine and return to the tank via the 30-in. vapor return line, as described previously.

Seawater flow to the open rack vaporizers is brought up to the anticipated normal flow rate and then the discharge valves on the secondary pumps are opened to the vaporizers. LNG flow to the vaporizers is increased slowly to provide gradual cooldown of the heat exchanger tubes. Once the desired LNG flow is reached, operation of the vaporizers is automatically controlled as described previously in Section D.3.4.2. To shut down the seawater vaporizers, the LNG flow is gradually reduced and then stopped. Seawater flow continues until no more vapor flows out of the vaporizers. During emergency shutdown of the vaporizers, the LNG is stopped immediately and the seawater flow is continued until the vapor flow ceases.

To start up the submerged combustion vaporizers, the burners are fired and the water bath heated to the proper operating temperature (95 to $130^{\circ} \mathrm{F}$ ). At this point, the discharge valves on the secondary pumps are opened to the 
vaporizers and a small flow of LNG starts. The rest of the startup of these vaporizers is semi-automatic, with the burner firing rate and the LNG flow rate both gradually increased until the desired flow rate is reached.

Shutdown of these vaporizers is also semi-automatic, with the LNG flow and burner firing rate gradually reduced. The large heat-storage capacity of the water bath permits fairly rapid startup and shutdown of the vaporizers with little variation in the process outlet temperature.

Emergency shutdown procedures for the vaporizers are described in Section D.4.2.

\section{D.3.4.4 Release Prevention and Control Features}

The seawater vaporizer area and submerged combustion vaporizer area are continuously monitored by multiple combustible gas detectors, ultraviolet flame detectors, and low temperature detectors. Each detector is hooked to an alarm in the main control room and is identified by type and location.

High-expansion foam units are located at the vaporizers and are activated either manually or automatically by low temperature detectors (grade level) that also activate an alarm and automatically shut down the vaporizers. The UV fire detectors have very fast, adjustable ( 0 to 30 seconds) response times. These detectors sound an alarm and activate the dry chemical units for approximately 30 seconds, expending the supply, after which the high-expansion foam units are activated to cover any LNG spills and limit the amount of vapor generation. Gas detectors in the area activate alarms at $25 \%$ of the 1 ower flammable 1imit. At $65 \%$ of the lower flammable limit, another alarm sounds; automatic or manual shutdown of the vaporizer follows.

Fire hydrants with spray monitors are located at the vaporizers. Manual fire alarm switches, as well as two 30-1b chemical extinguishers, are also located in the area.

A fire truck is available to back up the dry chemical, water, and highexpansion foam systems. This truck contains a dry chemical unit which connects to the vaporization system. Additional hoses and a small water pumping capability are also provided on the truck. 
Pressure relief valves set below critical levels for the equipment are located at the outlet and inlet portions of the vaporizers. Gas discharge from the pressure relief valves enters a nitrogen-purged collector system where it is routed to the vent stack. An independent dike system surrounds the vaporizers to contain any spills that might occur.

All vaporizers are equipped with an automatic vaporizer emergency shutdown (VES) that, upon activation, automatically shuts down the vaporizers and the LNG sendout pumps and isolates the pumps from both the vaporizers and the LNG tank. The VES can be activated manually at the vaporizers or the control room. The VES can also be activated automatically, if desired, by a temperature sensor in the gas outlet line, temperature and flow sensors in the water lines, UV burner flame monitors, water bath level indicators, or the pressure sensor in the 30-in. outlet line. Normally, the VES is not automatically activated.

\section{D.4 GENERAL PLANT INFORMATION}

The following subsections provide general information on various aspects of the LNG import terminal and its operation.

\section{D.4.1 Venting}

The import terminal is designed to be operated without venting. Even in a case where the pipeline facilities are shut down, it is possible to pack normal terminal boiloff gas into the end of the pipeline. Provided the first 10 miles are available, this allows a complete terminal shutdown for at least 2-1/2 days before any venting is required.

All gas lines and gas handling equipment can be vented to the vent stack through a nitrogen-purged vent header (collector) system. The header is sized to accommodate the load caused by any single failure or relieving situation. Gas is not normally vented except in the case of an emergency shutdown, when the Master Emergency Shutdown (MES) system automatically vents all gas lines and gas handling equipment. The LNG sendout pumps are vented back to the storage tank via the $30-i n$. vapor return 1 ine. 
The storage tank has three 12-in. pressure/vacuum relief valves which vent to the atmosphere. Normal off gas from the storage tank is handled by the boiloff compressor. The relief valves open only when needed to protect the tank from over or underpressurization.

A11 vessels or sections of LNG lines that can be isolated with LNG in them and allowed to warm are protected by relief valves venting to the atmosphere.

\section{D.4.2 Emergency Shutdown System}

The operation and activation of the emergency shutdown system for the import terminal are described here.

\section{D.4.2.1 Operation of Emergency Shutdown}

The plant emergency shutdown (ESD) system consists of three major systems: 1) the Master Emergency Shutdown (MES), 2) the Vaporizer Emergency Shutdown (VES), and 3) the Offshore Emergency Shutdown (OES). It takes approximately 30 seconds after activation for any of these systems to complete shutdown.

The MES allows the rapid shutdown of the import terminal and isolation of the various plant systems. When activated, the MES automatically initiates the following actions:

1. Electrical supplies to all normal plant circuits are de-energized; essential plant electrical equipment (e.g., fire pumps, fire and gas detectors, fire system valve operators) remain energized.

2. Natural gas valves at plant boundaries are closed to isolate the plant from the natural gas pipeline. These valves include:

- gas from vaporizers

- boiloff gas from storage tanks and ships

- fuel gas to vaporizers.

3. The LNG tank and dike area is isolated from the remainder of the plant by the following:

- valves at the LNG pump suction and valves on the liquid withdrawal lines are closed

- block valves on the tank inlet lines are closed 
- LNG pump motors are shut down

- block valves between the LNG pumps and the vaporizers are closed

- loading arm block valves are closed.

4. A telemetric signal "MES Tripped" is transmitted to the company's head office.

5. With loss of instrument air, all control valves go to their failsafe positions.

6. Gas from all gas handling equipment and lines is vented through the relief header to the vent stack.

The second shutdown system, the VES, allows the rapid shutdown and isolation of LNG sendout systems outside the dock area. When activated, the VES automatically initiates the following actions:

1. The following natural gas valves at plant boundaries are closed:

- gas from vaporizers

- boiloff from storage tanks and ships

- fuel gas to vaporizers.

2. LNG pump motors are shut down.

3. Block valves between the pumps and the vaporizers are closed.

4. Pump suction valves and the valves on the liquid withdrawal lines are closed.

5. Gas from all gas handling equipment and lines is vented through the relief header to the vent stack.

The third shutdown system, the OES, allows the rapid shutdown and isolation of all LNG sendout from the ships and vapor return to the ships. When activated, the OES automatically initiates the following actions:

1. Block valves in the unloading arms are closed.

2. Block valves in the vapor bypass lines are locked into position to prevent operation. 
3. Block valves in the vapor return line are closed.

4. LNG transfer pump motors on the ship are shut down.

The closing rates of the block valves and the sequence of shutdown events are programmed to limit fluid hammer and to keep any LNG from being trapped between valves.

In the event of a total power failure, the MES, VES, and OES circuits are energized with a battery power supply. After approximately 10 seconds, a 600-kW diesel-driven emergency generator is automatically started to provide the power to these systems. Fire water is provided during emergency shutdown through the use of diese1-driven pumps and/or city water pressure.

\section{D.4.2.2 Activation of Emergency Shutdown System}

Both the MES and VES can be activated manually at the two exit gates. The MES can also be activated automatically by the ultraviolet (UV) fire detectors that monitor the following areas:

- compressor building

- vaporizers

- LNG pumps

- piping on or adjacent to pipe racks next to compressor area

- unloading dock area.

The VES may be automatically activated, if desired, by a temperature sensor in the vaporizer gas outlet line (low temperature), temperature and flow sensors in the seawater lines of the open rack vaporizers, by the UV flame monitors on the submerged combustion vaporizer burners (burner flameout) and throughout the vaporizer area (fire), by gas detectors in the area, or by the water bath level indicator (low level) on the submerged combustion vaporizers.

The OES may be activated by UV fire detectors on the dock, low temperature detectors, combustible gas detectors, power and air supply failure, high or low pressure in the transfer lines, excess flowrate, and tanker movements outside the established operating conditions. In addition to automatic shutdown of the OES system, manual shutdown may be initiated from several locations in the unloading area, including the main terminal control room, the loading platform control room, and the ship's bridge. 


\section{D.4.3 Construction, Inspection, and Testing}

The procedures used during construction, inspection, and testing of an import terminal are discussed below.

\section{D.4.3.1 Codes and Standards}

Various codes and standards apply to the construction, testing, and operation of LNG facilities. These codes and standards are discussed in Section E.4.2.1 of Appendix $E$ and will not be covered further here.

\section{D.4.3.2 Procedures}

A11 welding on the LNG storage tanks is performed in strict accordance with API 620 Appendix Q. All inner tank butt welds are visually inspected and 100\% radiographed. All outer tank butt welds are visually inspected and 100\% dye penetrant tested. In addition, the tank is inspected by an independent outside agency in accordance with API 620.

Strength and leak test procedures for the completed tanks are carefully conducted and include the following major steps:

1. Bottom seams of both the inner and outer tanks are leak tested by vacuum box.

2. Inner tank she11-to-bottom fillet welds are leak tested by air pressure and soap suds.

3. Outer tank shell-to-bottom fillet welds are tested by either air pressure and soap suds or by penetrating oil.

4. The inner tank is filled with water to the equivalent pressure of the full head of LNG. Appendix $Q$ allows this head to be increased by $25 \%$ if considered desirable, but limits tank shell stresses to a maximum of $80 \%$ of the specified minimum yield strength of the material or $50 \%$ of the specified minimum tensile strength.

5. The inner tank is then pressurized in several stages to a maximum of $150 \%$ of design pressure. 
6. The pressure is then reduced to the design pressure, and shell and roof seams above the liquid level are tested with soap suds. Opening pressure of the pressure vent is checked at this time.

7. While the inner tank is being emptied, the opening pressure of the vacuum vent is checked.

8. With the tank empty, the inner tank is again pressurized to design pressure and the anchor system is rechecked.

9. The outer tank is then pressurized to its design pressure and is tested for leaks with soap suds. As an al ternate to this, the outer tank shell seams can be checked by penetrating oil. Also, outer tank roof seams can be checked by vacuum box.

10. Operation of outer tank pressure vents is checked during this test, and the vacuum vent is checked by applying the design vacuum.

The tanker unloading system and the cold piping to the sendout system are insulated with a combination of fiberglass, urethane, and a vapor barrier. The fiberglass is applied on the pipe wall, and urethane of required thickness is added and sealed with fiberglass-reinforced-plastic vapor barrier. For fittings and components, the urethane is applied to the pipe wall.

The pipeline is strung along the right-of-way and bent as required to conform with the plant contours. Pipe sections are welded and inspected in compliance with the Department of Transportation minimum Federal Safety Standards, Section 192.243. All piping welds at water crossings, in environmentally sensitive areas, and in encased sections are 100\% radiographically inspected.

\section{5 SOURCES OF INFORMATION}

The description of the LNG import terminal was developed using information from the sources listed below. 
1. Federal Energy Regulatory Commission Docket Files:

Environmental Impact Statements

Pacific-Indoriesia Project, Western LNG Terminal Co., CP 75-83-3

Cook Inlet Project, Western LNG Terminal Co., CP 75-83-1

Western Deptford CP76-16

National Bureau of Standards - Cryogenic Reviews

Western LNG Co., Oxnard Storage Facility, CP 75-83-3

Southern Energy Co., Elba Island Terminal, CP 73-272

Distrigas, Everett Marine Terminal, CP 73-132

Distrigas, New York Terminal, CP 73-132

Transco Terminal Co., Gloucester County Terminal, CP 73-268

Algonquin LNG Inc., Providence Facilities, CP 73-139

Trunkline LNG Co., Lake Charges Terminal, CP 73-138

2. LNG Terminal Risk Assessment Study for Oxnard, California

Prepared for Western LNG Terminal Company by Science

Applications, Inc., La Jolla, California, December 22, 1975

LNG Terminal Risk Assessment Study for Point Conception, California

Prepared for Western LNG Terminal Company by Science

Applications, Inc., La Jolla, California, January 23, 1976

3. Environmental Impact Report for the Proposed Oxnard LNG Facilities

Prepared by Socio-Economic Systems, Inc., Los Angeles, California

4. LNG Equipment Vendor Literature:

Chicago Bridge and Iron Co. - Cryogenic Storage, Bulletin No. 8600,

Chicago Bridge and Iron Co. - Cryogenic Systems, Bulletin No. 8650,

Chicago Bridge and Iron Co. - USA Standards for Design and Construction of LNG Installations, Bulletin No. 831,

Pittsburg-Des Moines Steel - LNG Storage Tanks, Bulletin No. 303, Company

FMC Fluid Control Equipment - Chiksan Loading Systems,

Ryan Industries - Sub-X Vaporizer, Bulletin LNG-200,

Sumitomo Precision Products - LNG Open Rack Vaporizers,

Alison Control Inc. - Fire Detection - Extinguishment Control System. 
5. Open Literature:

Alexander, Jean B., and N. Thomas Williams, "Elba Island LNG Facility on Schedule." Pipeline and Gas Journal, pp. 26-31, June 1976.

Anderson, P. J., and W. W. Bodle, "Safety Considerations in the Design and Operation of LNG Terminals." Paper presented at the 4th International LNG Conference, Algiers, Algeria, January 24-27, 1974.

Bolan, R. J., "Safety and Design Priorities for LNG Import Terminals." Pipeline and Gas Journal, pp. 46-56, June 1974.

Brock, N. H., and R. M. Howard, "Upgrading LNG Plant Safety." Paper presented at the AGA Transmission Conference, Bal Harbour, Florida, May 19-21, 1975.

Crawford, D. B., and R. A. Bergman, "Innovations Will Mark LNG Receiving Terminal." Oil and Gas Journal, August 5, 1974.

Crawford, D. B., and G. P. Eschenbrenner, "Heat Transfer Equipment for LNG Projects." Chemical Engineering Progress, pp. 62-70, September 1972.

DeVanna, L., and G. Doulames, "Planning is the Key to LNG Tank Purging, Entry and Inspection." $0 i 1$ and Gas Journal, pp. 74-82, September 8, 1975.

Duckman, H. E., "LNG Import Terminal Design Considerations." Cryogenics and Industrial Gases, pp. 41-48, September/0ctober, 1972.

Durr, C. A., "Progress Techniques and Hardware Uses Outlined for LNG Regasification." 0il and Gas Journal, May 13, 1974.

Durr, C. A., and D. B. Crawford, "LNG Terminal Design." Hydrocarbon Processing, November 1973.

Dzubak, Edward, "Cove Point: Nation's Largest LNG Receiving Terminal." Pipeline Industry, pp. 41-45, February 1976.

Hale, Dean, "LNG Scorecard." Pipeline and Gas Journal, pp. 19-21, June 1968.

Hanke, C. C., I. V., LaFare and Litzinger, L. F., "Purging LNG Tanks Into and Out of Service Considerations and Experiences." Paper presented at the AGA Distribution Conference, Minneapolis, Minnesota, May 6-8, 1974.

Levy, M. M., "Cove Point Terminal Near Completion." Pipeline and Gas Journal, pp. 35-40, June 1976.

Levy, M. M., "LNG Terminal Will Ease Gas Shortage." 0il and Gas Journal, pp. 133-136, June 21, 1976. 
LNG Information Book, Prepared by the LNG Information Book Task Group of the Liquefied Natural Gas Committee, American Gas Association, 1973.

Napoli, R. N. D., "Design Needs for Base-Load LNG Storage, Regasification." 0il and Gas Journal, pp. 67-70, October 22, 1973.

Schuller, M. R., and J. C. Murphy, "LNG Storage Tanks for Metropolitan Areas." Paper presented at the 4th International LNG Conference, Algiers, Algeria, January 24-27, 1974.

Seroka, S., and R. J., Bolan, "Safety Considerations in the Installation of an LNG Tank." Cryogenics and Industrial Gases, pp. 22-28, September/0ctober 1970.

Shaheen, E. I., and M. K. Vora, "Worldwide LNG Survey Cites Existing Planned Projects." 0i1 and Gas Journal, pp. 59-71, June 20, 1977.

Smith, L. R., "Submerged Pumps for LNG Sendout." Paper presented at AGA Distribution Conference, 1968.

Uhl, A. E., L. A. Amoroso and R. H. Seiter, "Safety and Reliability of LNG Facilities." Paper presented at the ASME Petroleum Mechanical Engineering and Pressure Vessel and Piping Conference, New Orleans, Louisiana, September 17-21, 1972.

Warner, V. A., "Liquified Natural Gas Fire Control." Paper presented at the AGA Transmission Conference, Las Vegas, Nevada, May 3-5, 1976.

Wesson, H. R. "Consideration Relating to Fire Protection Requirements for LNG Plants." Paper presented at the AGA Transmission Conference, Bal Harbour, Florida, liay 19-21, 1975.

Wissmiller, I. L., and E. O. Mattocks, "How to Use LNG Safely." Pipeline and Gas Journal, March 1972.

World Wide LNG Market, published by Frost \& Sullivan, Inc., New York, New York, June 1977. 


\section{APPENDIX E}

FACILITY DESCRIPTION OF REFERENCE

LNG PEAKSHAVING PLANT 


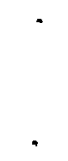


APPENDIX E

FACILITY DESCRIPTION OF REFERENCE

LNG PEAKSHAVING PLANT

Liquefied Natural Gas (LNG) peakshaving plants are one of several means by which gas distribution companies handle variations in demand. Minimum transmission costs result when the pipelines are operated at or near capacity every day of the year. Demand for gas, however, is subject to hourly, daily, and seasonal variations. To reconcile these differences, natural gas is liquefied during the off season and stored until peak-demand periods when it is revaporized and delivered to customers. LNG facilities referred to as peakshaving plants have a liquefaction unit, storage facilities, and vaporizers. Facilities used for peakshaving purposes that have only storage and vaporization capabilities are referred to as satellites; they receive LNG, usually by truck, from a facility with a liquefaction unit (see Appendix F).

LNG peakshaving operations are usually based on a 240-day/year 1iquefaction cycle and a 120-day/year vaporization cycle. Liquefaction units are sized to fill the storage tanks over a period of 200-240 days. Vaporizers have the capacity to empty the storage tanks in 5 to 25 days of continuous operation. Normal operation involves filling and emptying the storage tanks once per year. Thus a peakshaving plant operates in three modes: liquefaction, vaporization, and storage. In the latter mode, neither liquefaction nor vaporization takes place (except for boiloff gases).

In the liquefaction mode, gas is taken from the pipeline and treated to remove water and $\mathrm{CO}_{2}$. This is typically done by passing the gas through molecular sieves, although amine and other scrubbing processes are used for $\mathrm{CO}_{2}$ removal. After treatment, the gas is liquefied by cooling it to about $-260^{\circ} \mathrm{F}$. Any of several liquefaction cycles can be used depending on the rate of liquefaction, feed gas conditions (composition, pressure, temperature), plant location, and economic factors.

The cascade cycle was the first liquefaction cycle. In this cycle, a series of refrigerants (usually propane, ethylene, and methane) are used to cool the 
the gas stepwise by heat exchange. The use of a series of refrigerants requires many separate pieces of equipment such as compressors and heat exchangers. As a result, initial investment costs and maintenance costs for the cascade cycle are the highest of any liquefaction cycle. Consequently, the cascade cycle has not been used for new peakshaving facilities in several years.

Expander cycles apply the well known Joule-Thompson or self-refrigeration effect by expanding a compressed gas isentropically through a turbine or engine to extract work and simultaneously lower the temperature of the gas. The expansion cycle is usually employed where considerable quantities of gas are being let down from transmission to distribution pressure. This energy can be used by expanding the gas through a turbine and using the low-temperature gas to cool and liquefy a separate gas stream.

The mixed refrigerant cycle, a fully developed and proven concept, is considered the most economical and practical for a wide range of liquefaction requirements. The process uses a single mixed refrigerant containing various light hydrocarbons and nitrogen. The use of a single compressor and fewer heat exchangers is less costly than the conventional cascade process.

The basic components of the cascade and mixed refrigerant cycles are:

- compressor(s) to provide the work required to transfer heat from a lower temperature to a higher temperature

- heat rejection system (cooling tower or air coolers)

- heat exchanger(s) to transfer heat from the natural gas to the refrigerant fluid.

In the expander cycle, the turbine replaces the compressors and the heat rejection equipment.

The LNG, at about $-260^{\circ} \mathrm{F}$ and slightly above atmospheric pressure ( $\sim 1 \mathrm{psig}$ ), is stored in a double-walled cryogenic storage tank. The inner wall is constructed of a cryogenic material, usually $9 \%$ nickel steel or an aluminum magnesium alloy. The outer tank is typically made of carbon steel. The space 
between the two walls is filled with perlite, a granular insulation material. Surrounding the storage tank is a containment area, usually formed by an earthen dike. This area is large enough to contain all the LNG in the storage tank in the event of failure.

A small quantity of boiloff gases results from heat leakage into the tank. These gases are compressed and either sent out to the pipeline or reliquefied.

During periods of peak demand, the LNG is pumped out of the tank and up to pipeline pressure and is then fed to vaporizers to be heated and reconverted to gas before entering the pipeline. Vaporizers for peakshaving plants fall into four major categories:

- direct fired

- submerged combustion

- intermediate fluid (indirect fired)

- ambient air type.

Direct fired units use flue gases from a burner to heat a product coil. Submerged combustion vaporizers bubble the flue gases through a water bath containing the product coils. Intermediate fluid systems use a fired heater to heat a fluid that is pumped through separate heat exchangers to vaporize the LNG. Ambient air vaporizers (large product coils exposed to ambient conditions) are the simplest type but are significantly more expensive.

Most peakshaving facilities also have the capability of shipping and receiving LNG in specially designed cryogenic trailers. The trailers are designed to transport LNG at $-260^{\circ} \mathrm{F}$ and slightly above atmospheric pressure. The tank consists of an inner vessel of 5083 aluminum and an outer vessel of carbon steel. The annulus is filled with perlite and is maintained at a pressure of 50 microns to insulate the inner vessel. A small (350 gpm) sendout pump is used for filling operations. During unloading, LNG is forced from the truck by the pressure of the vapor above the liquid. The trucks have a capacity of 10,500 gal and weigh 60,000 1bs when ful1.

There are currently over 50 peakshaving facilities in operation in the United States, about $90 \%$ of which are located in the eastern half of the country. 
Storage capacities of these facilities range from 45,000 to $630,000 \mathrm{bbl}$. A typical facility has 1 iquefaction capacity of $6.0 \times 10^{6} \mathrm{scfd}$, storage capacity of $400,000 \mathrm{bbl}\left(1400 \times 10^{6} \mathrm{scf}\right)$, and vaporization capacity of $135 \times 10^{6} \mathrm{scfd}$. Table E.l shows the percentages of various types of liquefaction cycles, storage tanks, and vaporization units used by U.S. peakshaving plants.

\section{TABLE E.1. U.S. LNG Peakshaving Plants}

\begin{tabular}{|c|c|c|c|c|c|}
\hline \multicolumn{2}{|c|}{ Liquefaction } & \multicolumn{2}{|c|}{ Storage } & \multicolumn{2}{|c|}{ Vaporization } \\
\hline Cascade & $15 \%$ & $9 \%$ Nickel & $50 \%$ & Direct Firec & $35 \%$ \\
\hline Expander & $40 \%$ & Aluminum & $48 \%$ & $\begin{array}{l}\text { Submerged } \\
\text { Combustior }\end{array}$ & $46 \%$ \\
\hline $\begin{array}{l}\text { Mixed } \\
\text { Refrigerant }\end{array}$ & $45 \%$ & Other & $2 \%$ & $\begin{array}{l}\text { Indirect } \\
\text { Fired }\end{array}$ & $16 \%$ \\
\hline & & & & -Other & $3 \%$ \\
\hline & $100 \%$ & & $100 \%$ & & $100 \%$ \\
\hline
\end{tabular}

\section{E.1 BASIC PROCESS FLOW}

The basic process flow for an LNG peakshaving facility is described in the following subsections. The description of the LNG peakshaving facility was developed using information from the sources listed in Section E.5.

\section{E.1.1 Unit Operations}

A block flow diagram of an LNG peakshaving facility is shown in Figure E.1. The major unit operations involved are gas treatment, liquefaction, storage, vaporization, and transportation and transfer.

The gas treatment system consists of two molecular sieve adsorbers and associated regeneration facilities. The adsorbers alternate operation, with one adsorber on line at all times while the other adsorber regenerates. The molecular sieves remove water, $\mathrm{CO}_{2}$, and sulfur compounds from the incoming natural gas.

An integrated cascade refrigeration (ICR) process is used for the 1 iquefaction cycle. A single mixed refrigerant consisting of methane, ethylene, propane, isobutane, pentane, and nitrogen is used to liquefy the natural gas. 


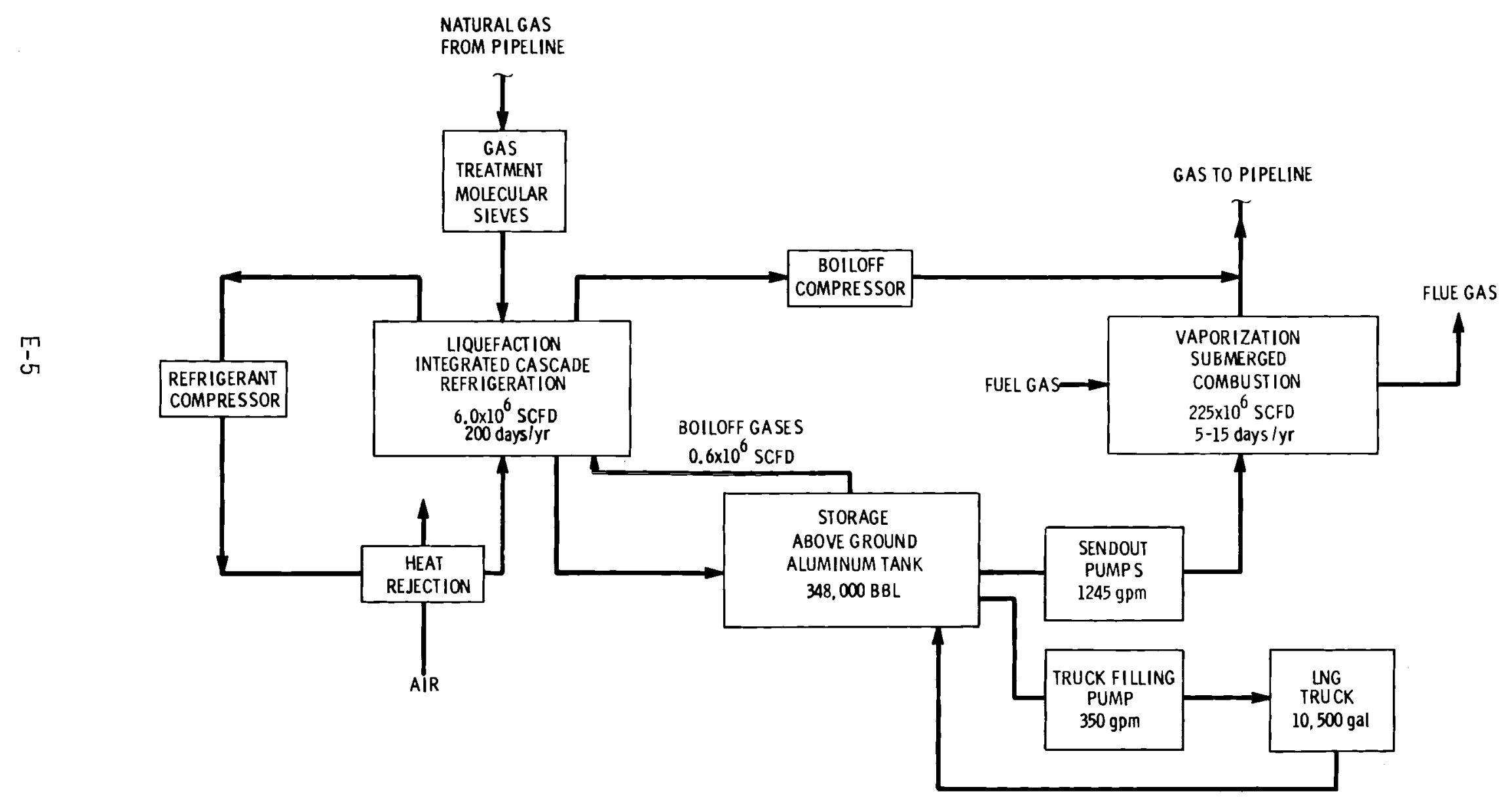

FIGURE E.1. LNG Peakshaving Plant - Block Flow Diagram 
After liquefaction, the $L N G$ is stored in an aboveground, double-walled storage tank. The inner tank is aluminum and the outer tank is carbon steel. Perlite insulation between the walls reduces in-leakage of heat and limits production of boiloff gases. Boiloff gases are warmed either in the liquefaction unit or in their own heat exchangers, compressed to pipeline pressure, and returned to the pipeline.

Submersible LNG pumps draw on the storage tank, pump the LNG to pipeline pressure, and send it to the vaporizers.

The vaporizers are submerged combustion units. A gas burner heats a water bath which in turn heats and vaporizes the LNG passing through the exchanger tubing. The gas from the vaporizers is then fed into the pipeline.

Truck loading and unloading is performed on an as-needed basis. The truck trailers are double-walled, insulated, cryogenic tankers with a design operating pressure of $70 \mathrm{psig}$. Because of the excellent insulation, trips up to 4 weeks long with no loss of product are possible.

\section{E.1.2 Flow Rates and Operating Conditions}

The ICR liquefaction unit has a capacity of $6.0 \times 10^{6}$ scfd or 1710 bbl/day. The plant operates in the liquefaction mode at or near this capacity for 200 to 240 days/year from spring through fall. The natural gas enters the molecular sieve adsorbers at 500 psia and ambient temperature. After treatment, it is cooled and liquefied in the cryogenic heat exchangers to $-260^{\circ} \mathrm{F}$ and then let down to 1 psig as it enters the storage tank. The storage tank operates at about 1 psig and $-260^{\circ} \mathrm{F}$. Boiloff gases average $0.05 \%$ of full tank volume: $0.6 \times 10^{6} \mathrm{scfd}$ or $170 \mathrm{bbl} /$ day. Flash gas produced when the LNG is let down to storage tank pressure is $0.3 \times 10^{6} \mathrm{scfd}$, thus the total offgas production during 1iquefaction is approximately $0.9 \times 10^{6} \mathrm{scfd}$. The cold boiloff gases pass through a series of heat exchangers to cool the refrigerant for liquefaction and to warm the boiloff gases; if the liquefaction unit is not working, the boiloff gases are warmed by their own heat exchangers. The boiloff is then compressed to pipeline pressure, cooled, and sent out to the pipeline. 
During the winter season the plant operates in a holding mode until a period of peak demand. At this time the LNG is pumped from the tanks to pipe1 ine pressure $(870 \mathrm{psig})$ at rates up to $1245 \mathrm{gpm}(43,000 \mathrm{bb} / /$ day $)$ depending on demand. The LNG goes to the vaporizers where it is vaporized and warmed to approximately $60^{\circ} \mathrm{F}$ before entering the pipeline. The four vaporizers have a total capacity of $300 \times 10^{6} \mathrm{scfd}(86,000 \mathrm{bbl} /$ day $)$; however, one vaporizer is a spare so the capacity of the plant is considered to be $225 \times 10^{6} \mathrm{scfd}$ $(65,000 \mathrm{bbl} / \mathrm{day})$. The vaporizers require fuel equivalent to $1.5 \%$ to $2.0 \%$ of the LNG vaporized. The plant operates in the vaporization mode for up to 20 days/year, with 10 to 12 days being average.

Trucking activity varies greatly from plant to plant. Some facilities truck LNG rarely, if ever; others ship or receive LNG on a fairly regular basis, usually in the spring and summer. Gross truck capacities range from 10,500 to 12,800 gallons. The normal rate for filling and emptying is $350 \mathrm{gpm}$.

\section{E.2 PLANT LAYOUT}

A plot plan for the facility is shown in Figure E.2. All the major pieces of equipment and the various safety features are shown. Key items to note from this plot plan include:

- storage tank impoundment area-- 110,000 $\mathrm{ft}^{2}$

- average dike height-- $17 \mathrm{ft}$

- minimum distance from storage tank to plant boundary-- $350 \mathrm{ft}$

- minimum distance from major equipment (vaporizers) to plant boundary-- $100 \mathrm{ft}$

- minimum distance from storage tank to major equipment (cold box)-- $325 \mathrm{ft}$.

The safety features shown in the figure will be discussed in later sections with the various processes to which they are related.

\section{E. 3 PROCESS DESCRIPTION}

The basic processes involved in the peakshaving facility are described in detail in the following subsections. 


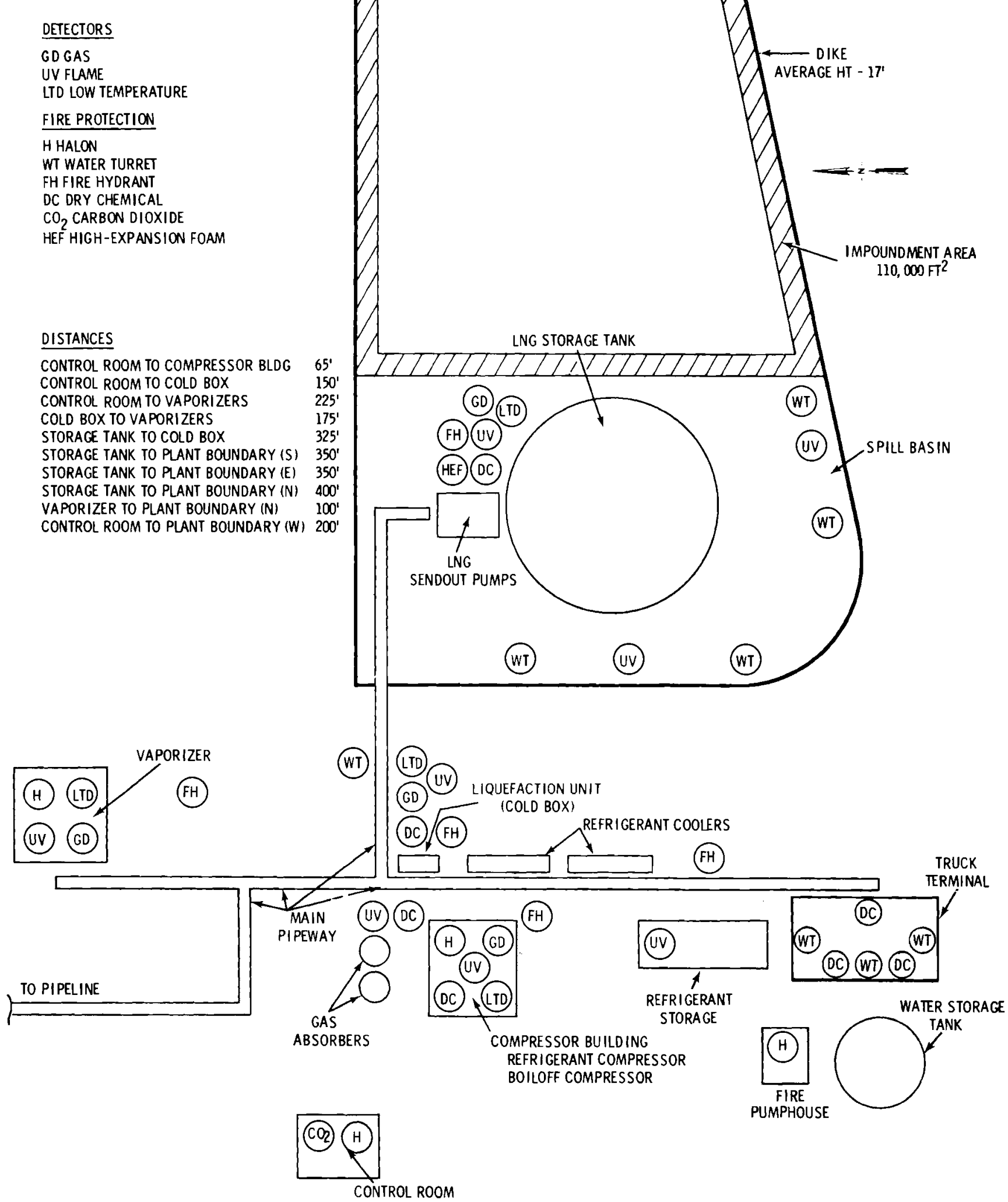

FIGURE E.2. LNG Peakshaving Plant - Plot Plan 


\section{E.3.1 Gas Treatment}

The gas treatment system, described in detail here, prepares incoming natural gas from the pipeline for liquefaction by removing impurities such as water and $\mathrm{CO}_{2}$.

\section{E.3.1.1 Equipment for Gas Treatment}

The gas treatment system consists of an inlet separator, a moisture and $\mathrm{CO}_{2}$ removal unit (molecular sieves), and a regeneration gas system (heater, coolers, and compressor). A flow diagram for the gas treatment system is shown in Figure E.3. (Flow diagram symbols are defined in Appendix H.) Associated process conditions and equipment identifications are given in Table E.2.

Gas from the pipeline first enters a filter separator, $\mathrm{V}-101$, that removes any free liquids present. The gas then goes to the molecular sieve adsorbers. There are two adsorbers, $V-102 A$ and $B$, each capable of handling $12.3 \times 10^{6} \mathrm{scfd}$ of gas. One adsorber is on line while the other is regenerating. The adsorber vessels are designed to the latest ASME pressure vessel code for an operating pressure of 870 psia. They are packed with molecular sieve type 4A. From the adsorbers, part of the gas goes to the liquefaction unit and the rest is used for regeneration. The regeneration gas heater, E-101, is a gas-fired, salt bath unit capable of heating the regeneration gas to $550^{\circ} \mathrm{F}$. The regeneration gas compressor, C-101, compresses the gas back to pipeline pressure, and two fin-fan coolers, E-102 and 103, cool the gas before it is returned to the pipeline.

\section{E.3.1.2 Regeneration Procedure}

To regenerate an adsorber, clean gas from the adsorber that is on 1 ine is heated to $550^{\circ} \mathrm{F}$ in E-101 and then passed through the adsorber being regenerated. Total gas flow to the adsorber on line is 212.3 MMscfd. Of this, $6.3 \mathrm{MMscfd}$ goes to the liquefaction unit and $\sim 6.0 \mathrm{MMscfd}$ is used for regeneration. The hot gas removes the impurities collected in the adsorber and then is filtered in V-104 and cooled in E-102, with the resulting liquids separated in $V-105$. The gas is then compressed by $C-101$, cooled in E-103, and sent to the pipeline. The regeneration cycle, one hour on line and one hour regenerating, is automatically controlled by timers and switches in a locally mounted panel. 


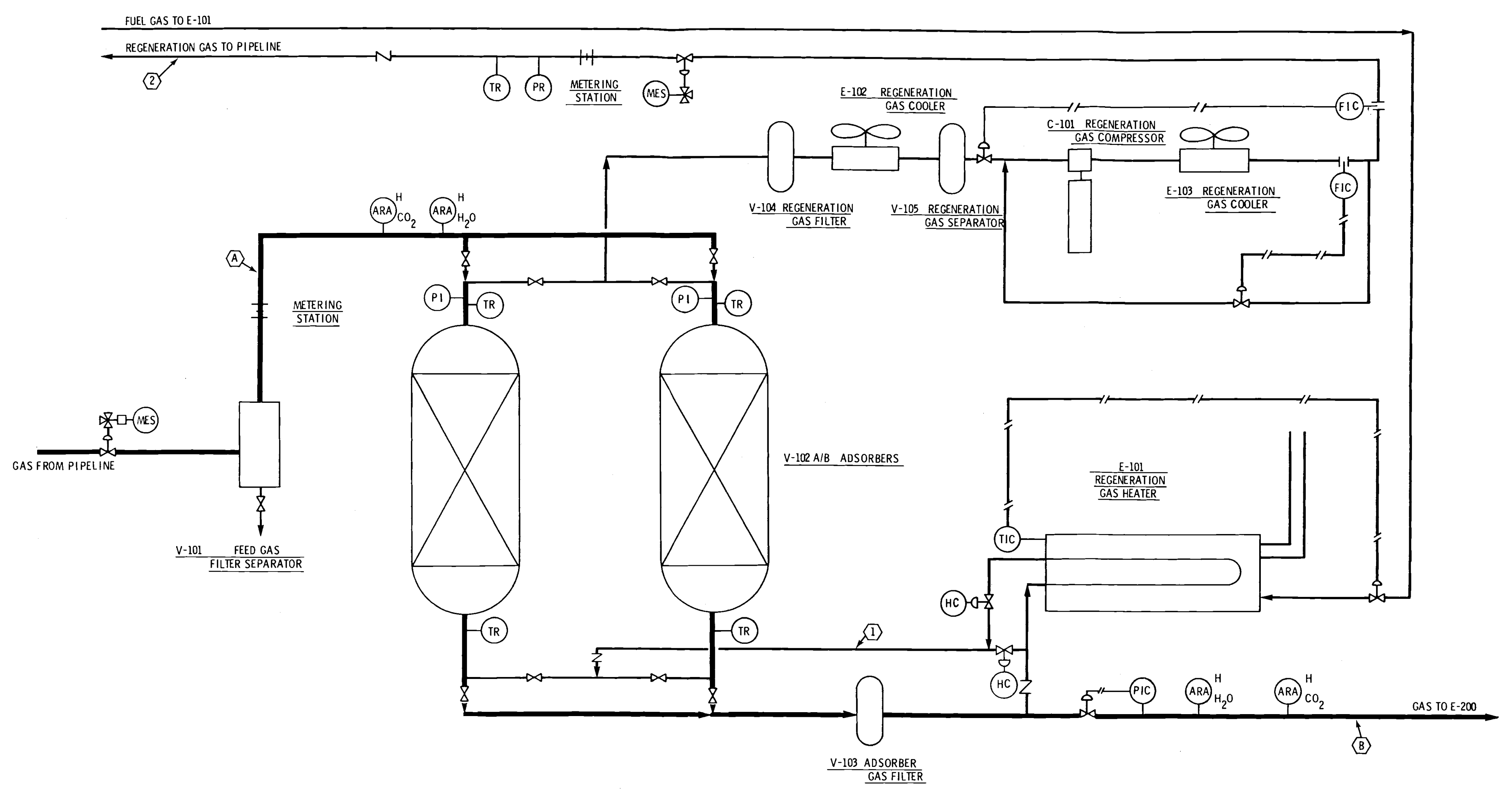

FIGURE E.3. Gas Treatment Section 

TABLE E.2. Gas Treatment Section

\begin{tabular}{|c|c|c|c|c|c|}
\hline \multicolumn{2}{|r|}{ Stream Identification } & Pressure (psia) & Temperature $\left({ }^{\circ} \mathrm{F}\right)$ & Phase $(\% \mathrm{~L}$ or $\mathrm{V})$ & Flow Rate (MMscfd) \\
\hline ID & Description & & & & \\
\hline A & Feed Gas from Pipeline & 500 & 68 & $\begin{array}{l}100 \% \mathrm{~V}: 94.0 \% \\
\mathrm{CH}_{4} ; 2.0 \% \mathrm{~N}_{2} ; \\
2.0 \% \mathrm{C}_{2} \mathrm{H}_{6} ; 1.0 \% \\
\mathrm{CO}_{2} ; 1.0 \% \mathrm{C}_{3} \mathrm{H}_{8}\end{array}$ & 12.3 \\
\hline B & Feed Gas to Liquefaction & 485 & 68 & $100 \% \mathrm{~V}$ & 6.3 \\
\hline 1 & Regeneration Gas to Adsorber & 485 & 550 & $100 \% \mathrm{~V}$ & 6.0 \\
\hline 2 & Regeneration Gas to Pipeline & 870 & 120 & $\begin{array}{l}100 \% \quad \mathrm{~V}: \\
93 \% \mathrm{CH}_{4} ; 2 \% \mathrm{~N}_{2} ; \\
2 \% \mathrm{C}_{2} \mathrm{H}_{6} ; 2 \% \mathrm{CO}_{2} ; \\
1 \% \mathrm{C}_{3} \mathrm{H}_{8}\end{array}$ & 6.0 \\
\hline & & Equipm & dentification & & \\
\hline
\end{tabular}

\begin{tabular}{ll}
\hline C-101 & Regeneration Gas Compressor \\
E-101 & Regeneration Gas Heater \\
E-102 & Regeneration Gas Cooler \\
E-103 & Regeneration Gas Cooler \\
V-101 & Feed Gas Filter Separator \\
V-102 & A/B Adsorbers \\
V-103 Adsorber Gas Filter \\
V-104 Regeneration Gas Filter \\
V-105 Regeneration Gas Separator
\end{tabular}

\section{E.3.2 Liquefaction}

The liquefaction system, which cools and condenses the natural gas for storage, is described here.

\section{E.3.2.1 Liquefaction Cycle}

Refrigeration for the liquefaction unit is provided by an integrated cascade refrigeration (ICR) mixed refrigerant cycle. The essential function of this cycle is to provide progressive gas cooling (i.e., gas condensation by successive cooling stages) using a multiple-component refrigerant. The condensation pressure is essentially the same for all stages ( 490 psia) as is the vaporization pressure ( $\sim 47$ psia). Partial condensation of the refrigerant takes place at each stage. The resulting liquid is then revaporized at the lower pressure, thus lowering the temperature. 
The composition of the refrigerant is adjusted so that the successive partial condensations exactly correspond to the amount of cold required by the next stage downstream. Thus, the refrigerant's vaporization curve closely follows the liquefaction curve of the ratural gas. The design composition of the refrigerant is $4.3 \% \mathrm{~N}_{2}, 26.3 \% \mathrm{CH}_{4}, 40.8 \% \mathrm{C}_{2} \mathrm{H}_{4}, 8.0 \% \mathrm{C}_{3} \mathrm{H}_{8}, 7.1 \% \mathrm{iC}_{4} \mathrm{H}_{10}$, and

\section{$13.5 \% \mathrm{nC}_{5} \mathrm{H}_{12} \cdot$}

The process flow diagram for the liquefaction unit is shown in Figure E.4. Table E.3 lists the major streams shown in the figure, giving the design flow rate, the phase (1iquid or vapor), and the operating temperature and pressure of each stream. The treated natural gas from the adsorbers is progressively

\section{TABLE E.3. Liquefaction Section}

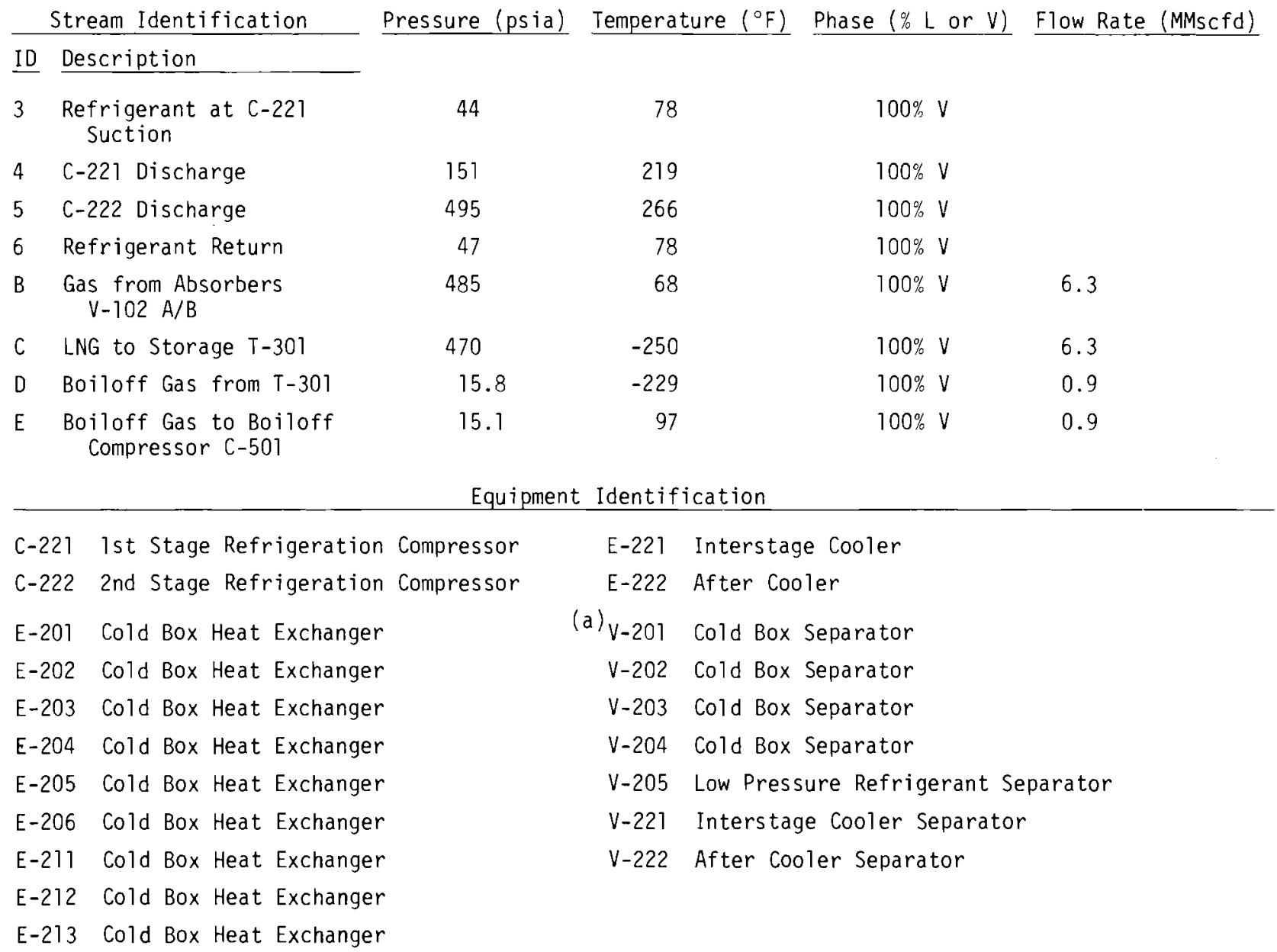

(a)E-201,202,203,204,205,206,211,212, 213 and V-201,202, 203, 204, are collectively referred to as E-200, Cold Box. 


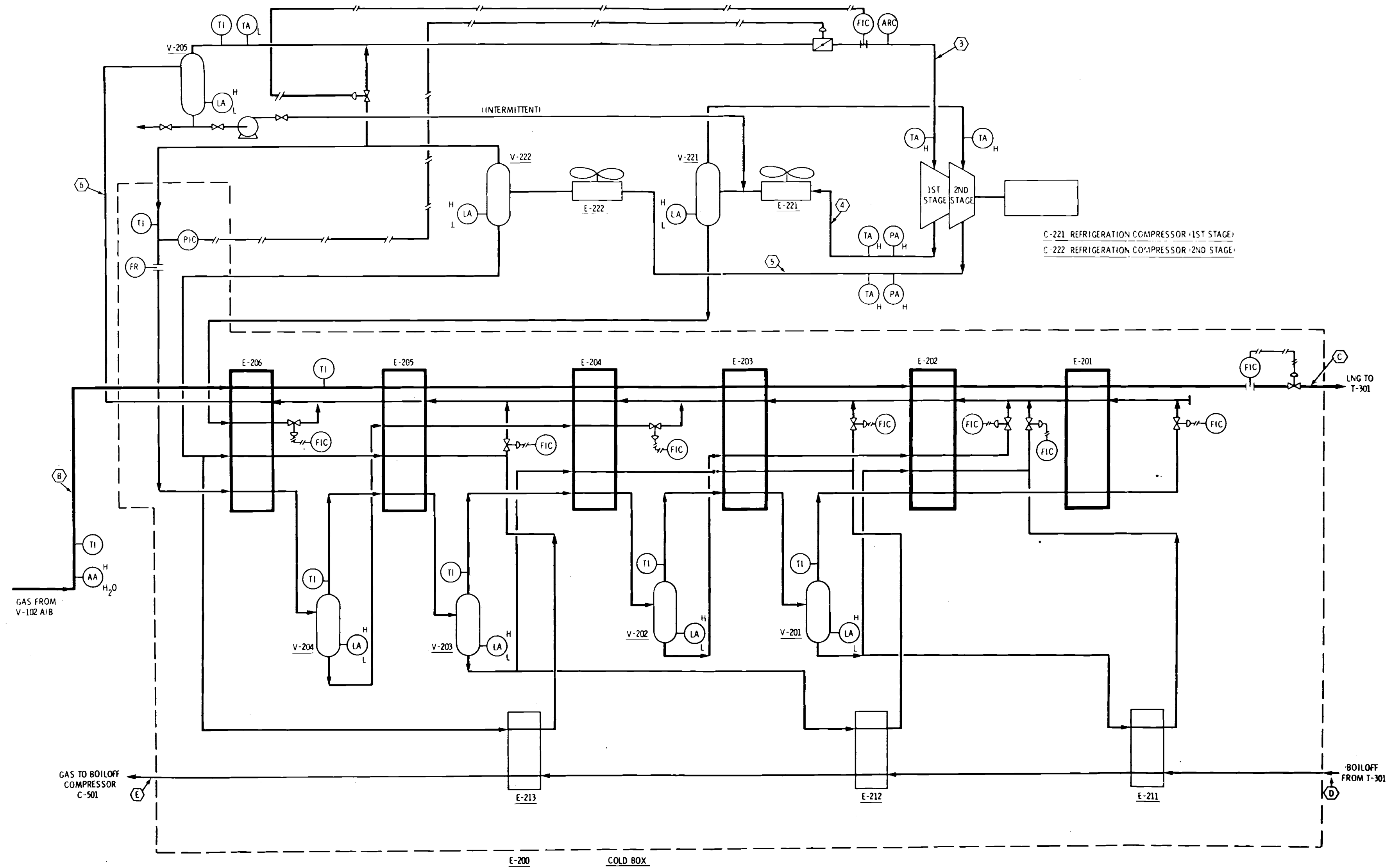

FIGURE E.4. Liquefaction Section - 

cooled in exchangers E-206, E-205, and E-204; liquefied in exchanger E-203; and subcooled in exchangers E-202 and E-201. The resulting LNG is then sent to the storage tank. The subcooling minimizes flash gas when the LNG is let down to storage pressure.

The mixed refrigerant is compressed, cooled, and partially condensed in a two-stage compression cycle. The vapor phase is cooled and partially condensed in each of the exchangers E-201 through E-206. The liquid phase, which is separated from the vapor after each partial condensation, is subcooled in exchangers E-201 through E-206 and also in exchangers E-211 through E-213, after which it is expanded into the shel1 side of an exchanger (E-201 through E-206) to provide refrigeration to cool the incoming, tube-side streams. Cold boiloff gases from the storage tank provide the cooling in exchangers E-211 through E-213.

Each exchanger E-202 through E-206 has 5 streams passing through it (see Section E.3.2.2 for a description of the exchangers). On the tube side there are four streams: the natural gas (vapor or 1iquid), two streams of refrigerant 1 iquids from separators or other exchangers, and refrigerant vapor from a separator. The tube side of the exchanger operates at higher pressures (400500 psia). On the shell side, which operates at lower pressure (40-50 psia), refrigerant liquid is expanded to a gas to provide cooling. The final exchanger, E-201, has only two streams on the tube side, the liquefied natural gas to be subcooled and the vapor from the last separator, V-201. The vapor from V-201 is cooled and condensed in E-202 and E-201 and then expanded into the shell side of $E-201$. The 1 iquefied natural gas from $E-201$ goes to the storage tank (T-301) where it is let down to storage pressure (1 psig).

\section{E.3.2.2 Liquefaction Equipment}

The liquefaction unit is comprised of a cold box, refrigerant compressor and coolers, and refrigerant storage. Major cold box equipment includes nine heat exchangers, E-201 through E-206 and E-211 through E-213, four vessels, V-201 through V-204, and associated piping and instrumentation all surrounded by perlite insulation and enclosed in a steel shell. The dotted line on Figure E.4 indicates the boundaries of the cold box. 
The heat exchangers are the spiral-wound type, with aluminum tubing wound on a center mandrel as shown in Figure E.5. The tubes are attached to tubesheets at each end. The number of tubesheets depends on the number of process streams handled on the tube side of the exchanger. The tubesheets and the shell surrounding the winding are made of stainless steel, as are all the interconnecting piping and valves in the cold box. All the separator vessels are also stainless steel. The heat exchangers and vessels are surrounded by gaseous-nitrogen-purged perlite insulation (see Section E.3.3.1 for a description of perlite insulation). The cold-box she11, made of carbon steel, has approximate dimensions of $13^{\prime} \times 12^{\prime} \times 60^{\prime}$.

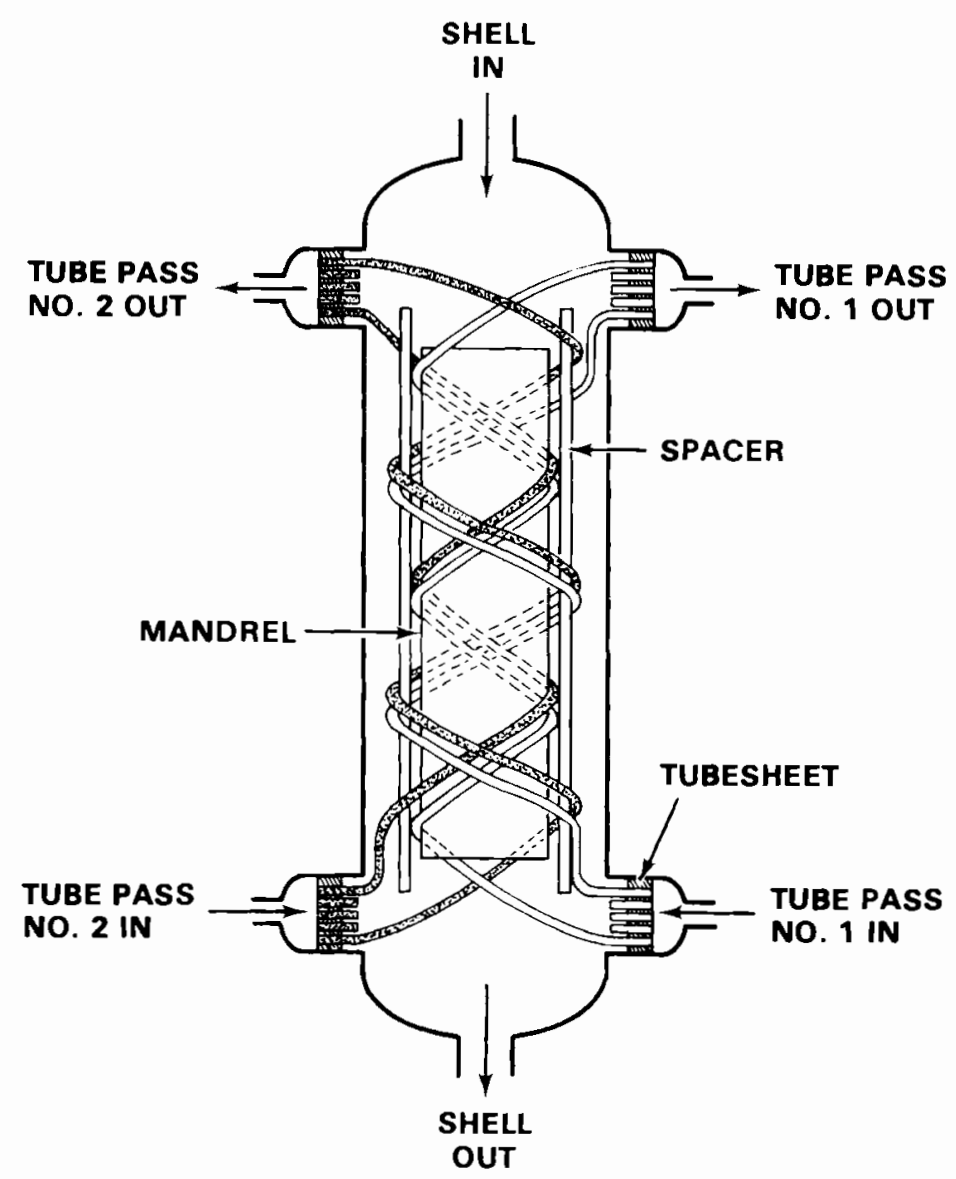

FIGURE E.5. Spiral-Wound Heat Exchanger 
The refrigerant recycle compressor is a two-stage, electric-motor-driven, centrifugal compressor with 4500 brake horsepower. The compressor, geardrive, motor, and oil coolers are mounted on a common baseplate and located in the compressor building. To minimize leakage, the compressor is equipped with a special seal that also provides positive shutoff during shutdown conditions.

Two fin-fan heat exchangers provide interstage and after-cooling for the refrigerant compressor. These exchangers consist of a carbon steel, finned tube bundle through which the refrigerant flows and an electric-motor-driven, two-speed, induced-draft fan that draws air over the bundles to cool the refrigerant.

Refrigerant storage capacities for the plant are:

- liquid nitrogen storage -- 0.6 MMscf equivalent gas capacity

- pentane make-up storage -- 3500 gallon capacity

- isobutane make-up storage -- 1500 gallon capacity

- propane make-up storage -- 2500 gallon capacity

- ethylene make-up storage -- 10,000 gallon capacity

- cycle fluid storage -- 3000 gallon capacity.

\section{E.3.2.3 Control System}

An interlocking system of controls regulates the liquefaction system and determines the LNG product temperature. The liquefaction unit normally operates at full capacity, but if the flow of LNG is reduced, the unit controllers adjust the system parameters to maintain the desired outlet temperature. The rate of LNG production varies depending on the ambient temperature and the corresponding amount of heat leakage into the system.

\section{E.3.2.4 Procedures}

Initial Startup and Cooldown. To begin the cooldown process, the liquefaction system is charged with refrigerant and the refrigerant compressor is operated on total recycle to check out the controls and instrumentation. A small refrigerant flow is then started to the cold box. As the cold box cools down, progressively more refrigerant is allowed to circulate through the system. When the cold box is sufficiently cool, natural gas flow is started. 
If the storage tank is not already cooled down, the initial liquefaction rate is limited to ensure proper cooling of the tank (see Section E.3.3.5). If the tank is already cool, the cold box can be cooled down and maximum 7 iquefaction rates reached in 4 to 8 hours.

Shutdown. Shutdown of the liquefaction unit is instantaneous after pushing the compressor stop button. Refrigerant flow stops and natural gas and LNG flow are stopped almost immediately by the outlet temperature control. The suction side of the compressor, including the suction pot $V-205$, is designed to handle the refrigerant inventory at ambient temperature without venting. Settle-out pressure is approximately 170 psia. Startup of the refrigerant loop from the settle-out condition is virtually instantaneous. LNG production can reach full capacity anywhere from $1 / 2$ to 4 hours after startup, depending upon how long the unit was shut down (i.e., how much cooldown is required).

The liquefaction unit is connected to the emergency shutdown system, which is described in Section E.4.1.

\section{E.3.2.5 Release Prevention and Control Systems}

As shown previously in Figure E.2, the following detectors, alarms, and fire protection equipment are located in the liquefaction area:

- combustible gas detectors (see Section E.3.4.4 for detector operation)

- low temperature detectors with alarms in control room

- UV fire detectors which automatically activate the Master Emergency Shutdown system (Section E.4.1) and alarm in control room

- $20 \#$ dry chemical fire extinguisher

- fire hydrant.

The refrigerant compressor is located in the compressor building (along with the boiloff compressor and regeneration gas compressor) next to the cold box. This building has the following detectors, alarms, and fire protection equipment:

- combustible gas detectors in each corner of the building

- low temperature detectors with alarms in control building 
- Halon fire extinguishing system (see Section E.3.4.4 for description)

- UV fire detectors which automatically activate the Halon system and the Master Emergency Shutdown system (Section E.4.1).

- \#20 dry chemical fire extinguisher

- fire hydrant adjacent to the building.

When the combustible gas concentration in the building reaches $25 \%$ of the lower flammability limit (LFL), an alarm in the control room is activated (see Section E.3.4.4 for further detaiis). High-rate ventilating fans turn on automatically to reduce the gas concentration. If the gas concentration reaches $60 \%$ of LFL, another alarm in the control room is activated, the fans are shut down, building openings (louvered windows) are closed, and the Halon system is discharged, all automatically. The Halon floods the building and inerts the atmosphere.

\section{E.3.3 LNG Storage}

The LNG is stored at the facility until needed. The storage system and related equipment are described in detail below.

The process flow diagram for the storage section is shown in Figure E.6. Associated process conditions and equipment identifications are given in Table E.4.

\section{E.3.3.1 Storage Tank}

Storage for the facility is a standard flat-bottom, double-walled, aboveground LNG storage tank with a capacity of 348,000 bbl as shown in Figure E.7. The inner tank is constructed of aluminum-magnesium alloy AA5083. Aluminummagnesium alloys, 9\% nickel steel, and 300-series stainless steels all possess excellent low temperature ductility and can be used for the inner tank. Carbon steel, which has a very poor low temperature ductility, is used for the outer tank. The diameters of the inner and outer tanks are $164 \mathrm{ft}$ and $173 \mathrm{ft}$, respectively. The space between the tank walls is filled with expanded perlite, an inorganic, nonflammable, lightweight insulation produced from special rock. The rock or ore is finely ground and then expanded in furnaces at about $2000^{\circ} \mathrm{F}$ $\left(1100^{\circ} \mathrm{C}\right)$. The perlite is expanded onsite and placed in the insulation space 


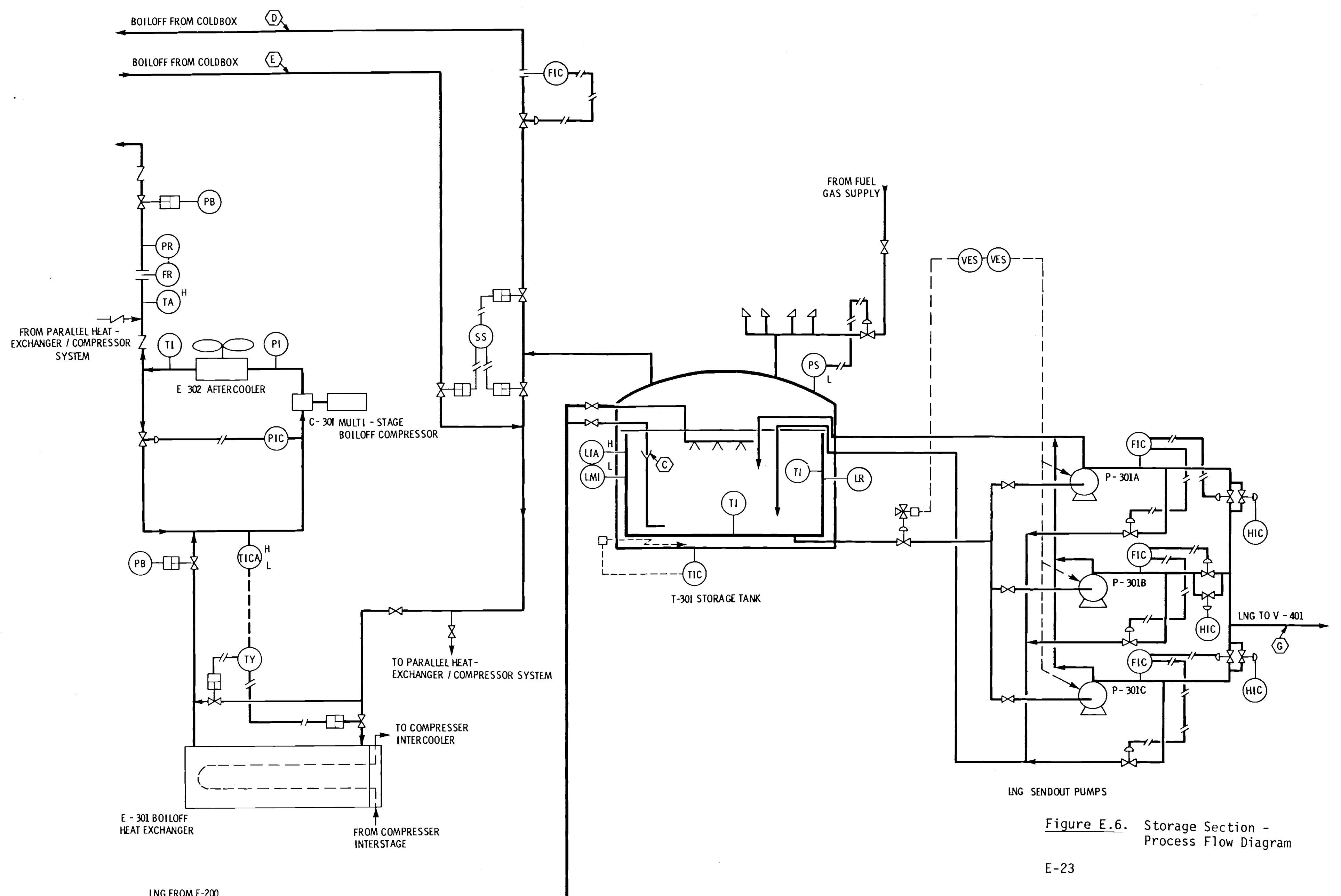





\section{TABLE E.4. Storage Section}

\begin{tabular}{|c|c|c|c|c|c|}
\hline \multicolumn{2}{|r|}{ Stream Identification } & \multirow[t]{2}{*}{ Pressure (psia) } & Temperature $\left({ }^{\circ} \mathrm{F}\right)$ & Phase $(\% \mathrm{~L}$ or $\mathrm{V})$ & \multirow[t]{2}{*}{ Flow Rate (MMscfd) } \\
\hline$\underline{10}$ & Description & & & & \\
\hline C & LNG from $E-200$ & 15.8 & -257 & $\begin{array}{r}95.7 \% \mathrm{~L} \\
4.3 \% \mathrm{~V}\end{array}$ & $\begin{array}{l}6.0 \\
0.3\end{array}$ \\
\hline D & Boiloff Gas from $T-301$ & 15.8 & -229 & $100 \% \mathrm{~V}$ & 0.9 \\
\hline E & Boiloff Gas from E-200 & 15.1 & 97 & $100 \% \mathrm{~V}$ & 0.9 \\
\hline$F$ & Boiloff Gas to Pipeline & 870 & 120 & $100 \% \mathrm{~V}$ & 0.9 \\
\hline G & Liv to $V-401$ & 900 & -257 & $100 \% \mathrm{~L}$ & 150 (or $1245 \mathrm{gpm}$ ) \\
\hline \multicolumn{6}{|c|}{ Equipment Identification } \\
\hline \multirow{3}{*}{\multicolumn{3}{|c|}{$\begin{array}{ll}C-301 \mathrm{~A} / \mathrm{B} & \text { Boiloff Compressors - } 2 \\
E-301 \mathrm{~A} / \mathrm{B} & \text { Boiloff Heat Exchangers } \\
E-302 & \text { Aftercooler }\end{array}$}} & \multicolumn{3}{|c|}{ PRCA-301 Storage Tank Pressure Controller } \\
\hline & & & \multirow{2}{*}{\multicolumn{3}{|c|}{ ITC-301 A/B Boiloff Gas Temperature Controllers }} \\
\hline & & & & & \\
\hline \multicolumn{3}{|c|}{ P-301A/B/C Livg Sendout Pumps } & \multicolumn{2}{|c|}{ PIC-302 A/B/C LNG Pump Disch } & Pressure Controll \\
\hline & LNG Storage Tank & & & & \\
\hline
\end{tabular}

while hot. A resilient fiberglass blanket 12 inches thick is attached to the outside of the inner tank wall to protect the perlite from excess pressure due to expansion and contraction of the tank walls (see Figure E.8). The thermal conductivity of perlite in a methane atmosphere is $0.25 \mathrm{Btu}-\mathrm{in} . / \mathrm{hr} \mathrm{ft}^{2}{ }^{\circ} \mathrm{F}$.

The outer tank has a 1ap-welded, dome-shaped, steel roof. Total tank height to the top of the dome is $134 \mathrm{ft}$. Suspended from the roof framing of the outer tank is a lap-welded metal deck that serves as a ceiling for the inner tank, as shown in Figure E.9. The height of the inner tank is $97 \mathrm{ft}$. Perlite insulation is spread evenly over the deck. Open pipe vents are installed in the deck to allow product vapor to circulate freely in the insulation space to keep the insulation dry. Superheated vapors remain stratified in the upper space, while colder, saturated vapors are below the deck. The butt-welded outer steel shell and lap-welded steel roof provide permanent weather protection for the tank insulation as well as an air-tight seal.

The inner tank sits on load-bearing insulation that carries the weight of the contents to the foundation (see Figures E.10 and E.11). The bottom of the tank is a thin section of aluminum alloy AA5083 that serves only as a seal and is not subject to significant stress. The load-bearing insulation rests on 


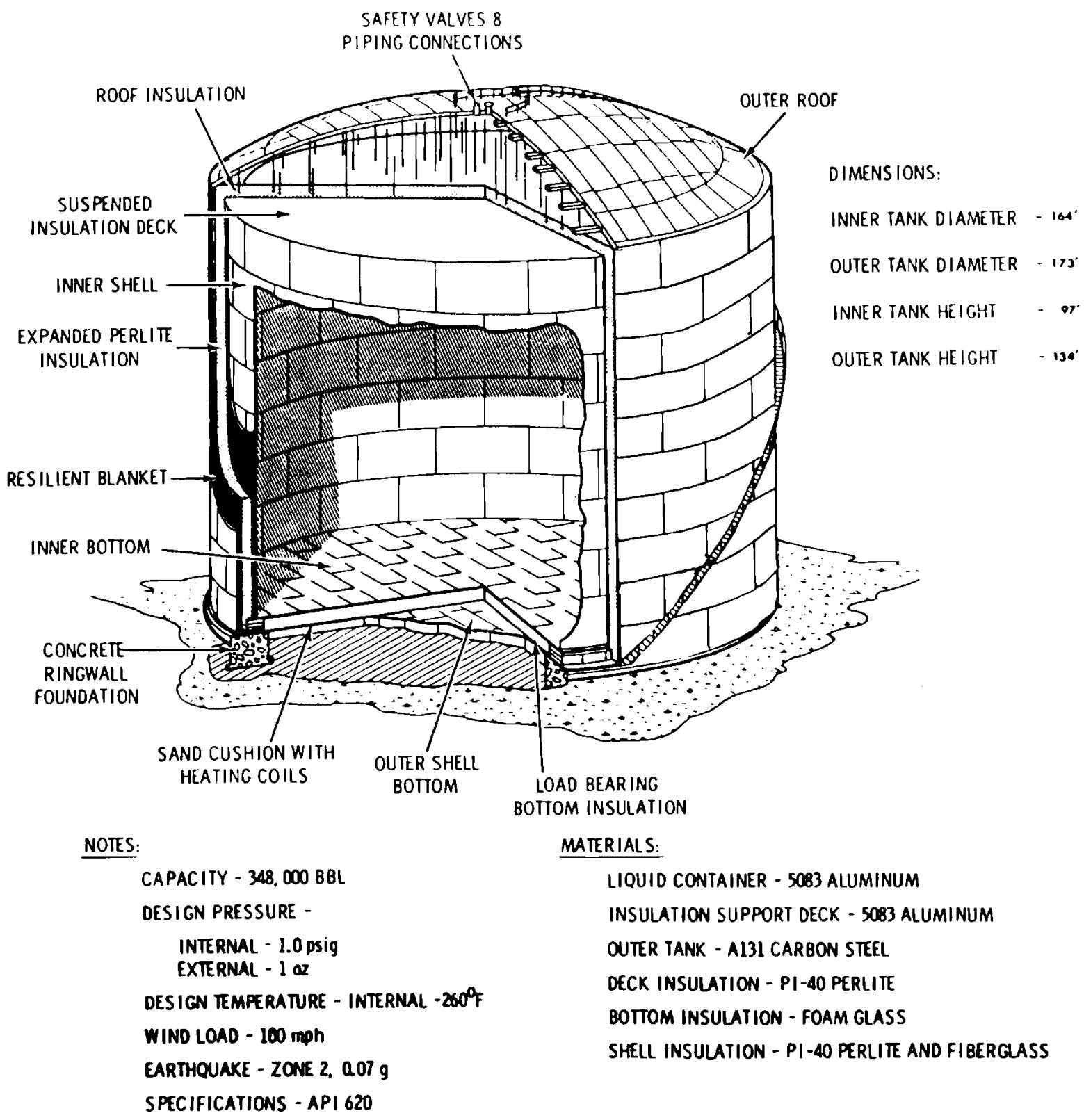

FIGURE E.7. LNG Storage Tank Details 


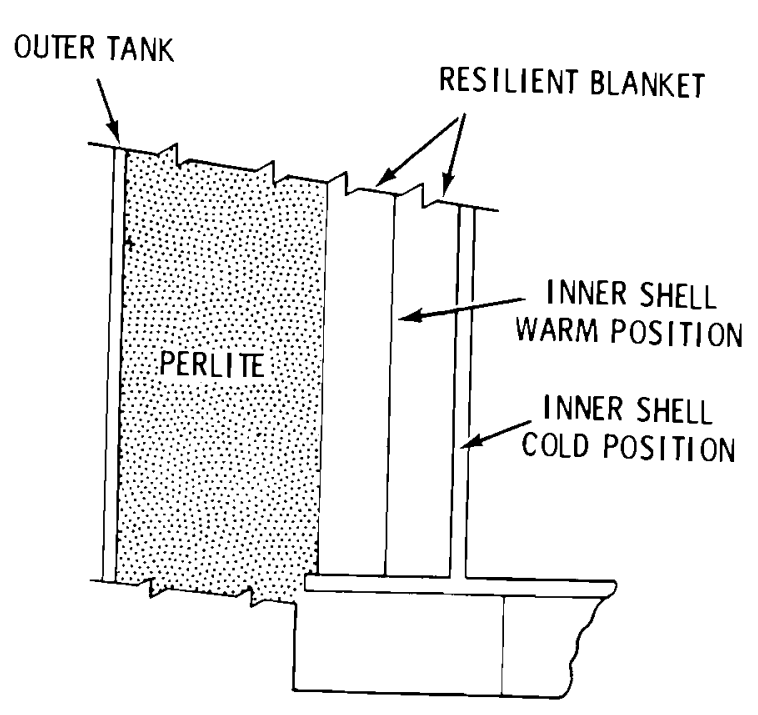

FIGURE E.8. Resilient Blanket in Annular Space Between Walis of LNG Storage Tank

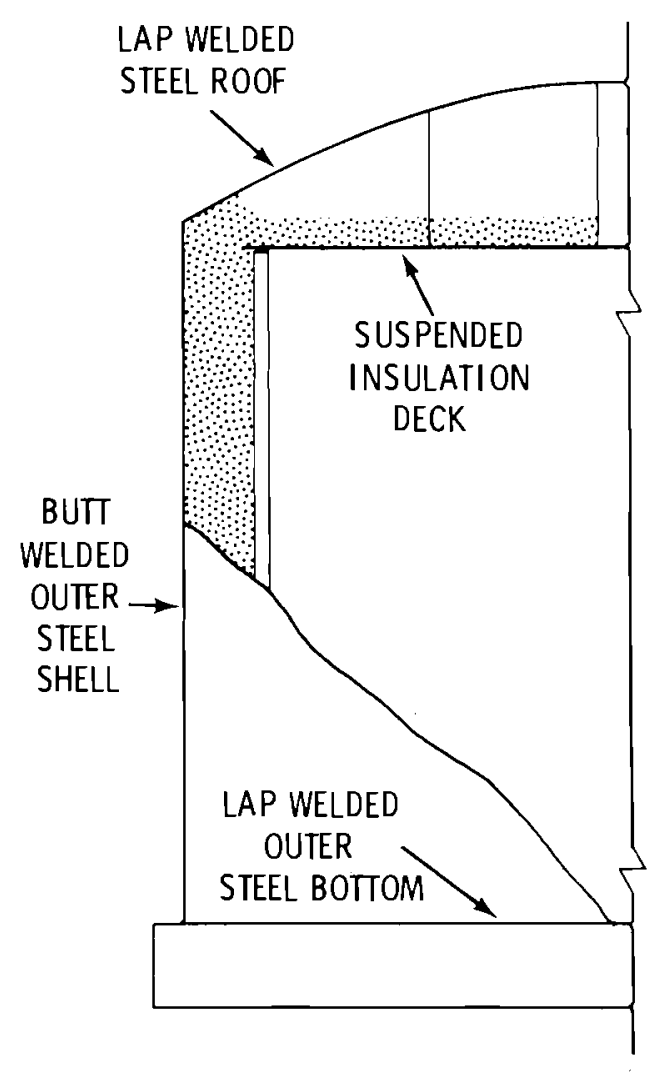

FIGURE E.9. LNG Storage Tank Suspended Insulation Deck

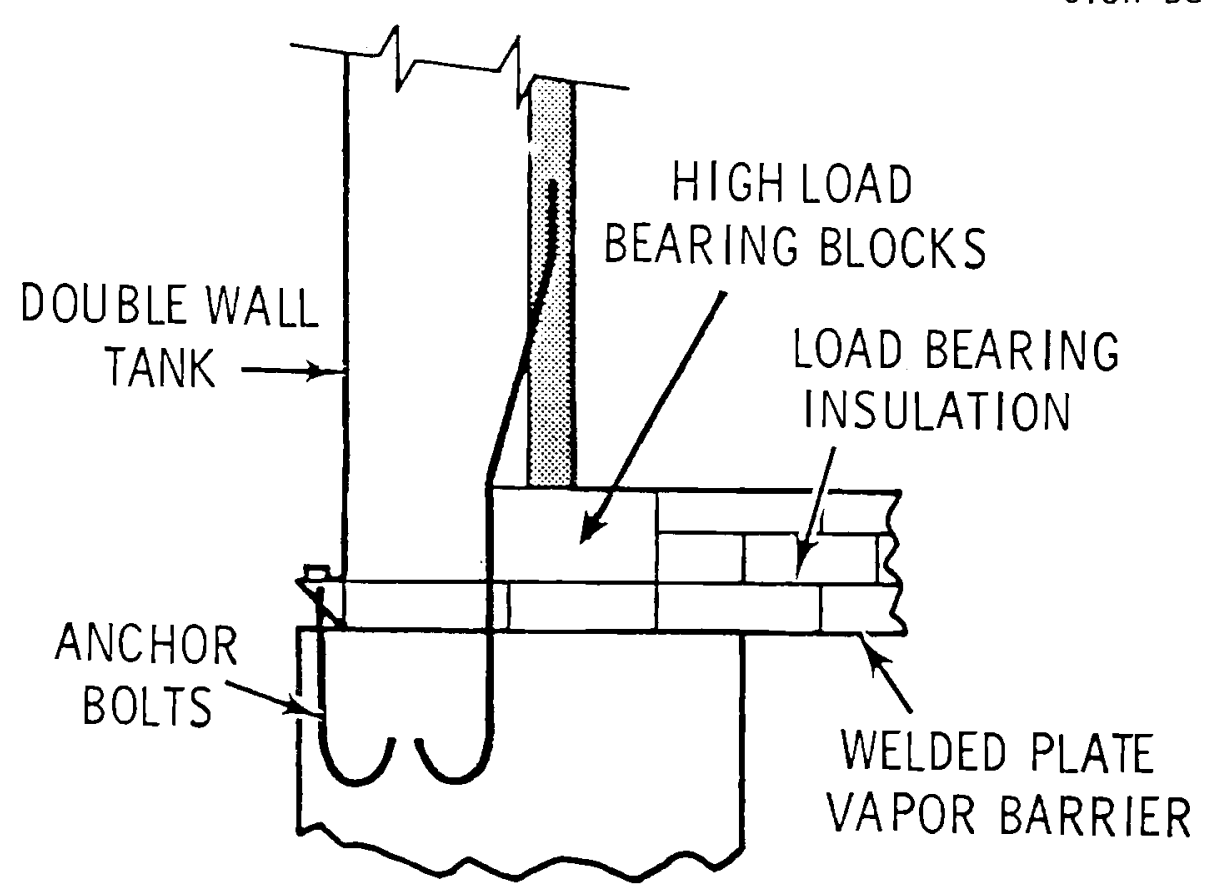

FIGURE E.10. Load Bearing Insulation and Anchor Bolts 


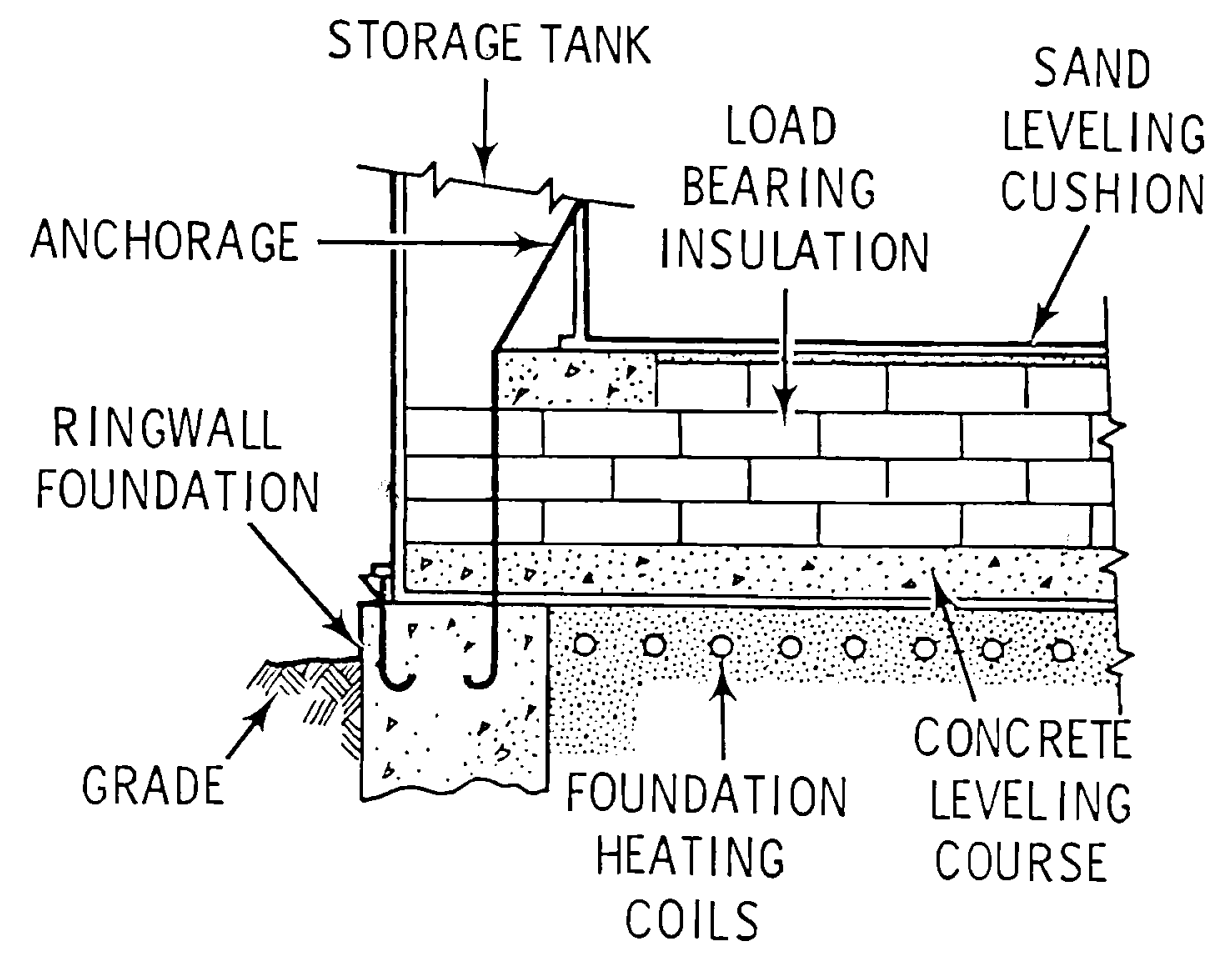

FIGURE E.11. Storage Tank Foundation Details

a concrete ringwall foundation around the perimeter and on a compacted soil foundation in the middle. Electrical resistance heating coils are embedded in the foundation soil to prevent freezing of moisture and possible "heaving".

There are two sets of anchor bolts in the ring wall, one set connected to the outer tank wall and the other connected to the inner tank wall. These bolts hold down the tank against lifting forces resulting from internal pressure, but permit the vessel to move readily in response to thermal displacements.

Table E.5 shows the inlet and outlet connections and fittings for the tank. The major connections are the inlet and outlet liquid lines at the bottom of the inner tank, the vapor outlet at the top of the inner tank, and the relief vents at the top of the outer tank. All fittings which carry cold gases or liquids and pass through the outer carbon steel tank are provided with "distance pieces." These protect the outer shell from brittle fracture by dissipating cold before it reaches the carbon steel. 
TABLE E.5. Storage Tank Connections and Fittings

\begin{tabular}{|c|c|c|c|}
\hline Item & Description & Location & Size and Fittings \\
\hline 1 & Vapor Outlet & Top inner tank & $8 \mathrm{in.}$ \\
\hline 2 & $\begin{array}{l}\text { Liquid Level Float } \\
\text { Gage }\end{array}$ & Top inner tank & -- \\
\hline 3 & Overfill Indicator & Top inner tank & --- \\
\hline 4 & Liquid Fill Line & Bottom inner tank & $\begin{array}{l}3 \text {-in., spills into } \\
4 \text {-in. downcomer/ } \\
\text { standpipe }\end{array}$ \\
\hline 5 & Liquid Outlet Lines & $\begin{array}{l}\text { Bottom inner tank } \\
\text { (with vortex breakers) }\end{array}$ & $\begin{array}{l}\text { 12-in. line with } \\
12-i n . \text { internal valve }\end{array}$ \\
\hline 6 & Access Manhole & Top outer tank & \\
\hline 7 & Relief Vent & Top outer tank & $\begin{array}{l}\text { Two 12-in. pressure } \\
\text { relief valves }\end{array}$ \\
\hline 8 & $\begin{array}{l}\text { Pressure Vacuum } \\
\text { Breather Vent }\end{array}$ & Top outer tank & $\begin{array}{l}\text { Two } 12 \text {-in. vacuum } \\
\text { relief valves }\end{array}$ \\
\hline 9 & Insulation Fill Holes & Top outer tank & --- \\
\hline 10 & $\begin{array}{l}\text { Pump Liquid Recir- } \\
\text { culation Line }\end{array}$ & Bottom inner tank & $4-i n$. \\
\hline 11 & Vapor Return Line & Top inner tank & --- \\
\hline 12 & $\begin{array}{l}\text { Liquid Level (Dis- } \\
\text { placer Type) }\end{array}$ & Top inner tank & --- \\
\hline 13 & $\begin{array}{l}\text { Liquid Level (D.P. } \\
\text { Gage) }\end{array}$ & Top inner tank & --- \\
\hline 14 & Thermocouple & Top inner tank & --- \\
\hline 15 & High Level Alarm & Top inner tank & --- \\
\hline 16 & Purge Ring & Bottom outer tank & -- \\
\hline
\end{tabular}

\section{E.3.3.2 Pressure Control System}

The storage tank has a design operating pressure of 1 psig and a design maximum pressure of 2 psig. The maximum external pressure is 1 oz gauge. The pressure in the tank is controlled by adjusting the boiloff compressor recycle rate. 
The boiloff compressors are multi-stage, horizontal reciprocating compressors for continuous compression of boiloff and flash gases. Each compressor has a capacity of $1.2 \times 10^{6} \mathrm{scfd}$ and discharges into the pipeline at approximately 870 psig. There are two compressors, with one being a spare. During liquefaction, the design gas rate (boiloff and flash gas) is $0.9 \times 10^{6} \mathrm{scfd}$. In the holding or vaporization mode, the design boiloff gas rate is $0.6 \times 10^{6} \mathrm{scfd}(0.05 \%$ of full tank capacity). The boiloff compressor has high and low suction pressure alarms, a high discharge pressure alarm, a low temperature alarm on the inlet, and a high temperature alarm on the outlet. It is also equipped with the standard compressor alarms and trips for high vibration, low lube-oil level or pressure, and high bearing temperature.

In the 1 iquefaction mode, the boiloff and flash gases go through the cold box $(E-211,212,213)$ to cool the refrigerant and warm the boiloff. During holding or vaporization, the boiloff is warmed by waste heat from the compressor. Piping and valves to the outlet of E-200 and the boiloff heat exchangers (E-301 A/B) are stainless steel; all other piping and equipment are carbon steel.

The storage tank is equipped with two 12-inch pressure relief valves that vent to the atmosphere. In the event of an underpressure, gas from the pipeline is brought back into the tank. If this is insufficient to prevent underpressure damage, two 12-inch vacuum relief valves admit air to the tank.

\section{E.3.3.3 Additional Control and Instrumentation}

In order to monitor liquid level, the tank is equipped with a servo-powered, displacer-type liquid level device, a differential pressure gauge, and a 2-inch trapped liquid overflow line with a temperature sensor and wave baffle. A high liquid-level alarm is activated at $95 \%$ of full capacity.

The tank has thermocouples in the inner tank shell and floor to monitor cooldown. Thermocouples embedded in the foundation control the electric heating coils under the tank to prevent frost heave.

In the event of an emergency, the storage tank is isolated from other equipment by block valves on the inlet and outlet lines which are activated by either the Master Emergency Shutdown or the Vaporizer Emergency Shutdown system. 


\section{E.3.3.4 LNG Sendout Pumps}

The three $L N G$ sendout pumps ( $P-301 A, B, C)$ are vertical submerged, potmounted LNG pump systems. The pumps and the motor drives are hermetically sealed in a vessel and submerged in LNG. This design eliminates the extended pump shaft and the associated seal. The pump and motor surroundings are $100 \%$ rich with LNG and will not support combustion. The pumps are mounted in a suction pot below grade to provide sufficient suction head for operation.

Each pump has a capacity of 75 MMscfd or $625 \mathrm{gpm}$ for a total rated sendout capacity of 150 MMscfd with one pump as a spare. The operating temperature is $-260^{\circ} \mathrm{F}$ and the discharge pressure is 945 psia.

Each pump has two Tiquid discharge rines. The main lines join and go to the vaporizers, $V-401$. The secondary 1 ines join and return to the storage tank. Sendout flowrate is controlled by the amount of LNG returned to the tank. This liquid return line is also used to recirculate the tank contents if necessary. Each pump also has a vapor return line to the tank to vent vapors during startup and shutdown.

\section{E.3.3.5 Procedures}

Cooldown. The first step in cooldown of the storage tank is to purge the tank with nitrogen. This prevents an explosive gas mixture from forming and also dries out the tank. The nitrogen purge is carried out from top to bottom with the nitrogen entering the 8-in. vapor outlet and leaving through the 4-in. downcomer on the 3-in. liquid fill line. Nitrogen also enters at the top of the dome through the relief vent and exits through the purge ring at the bottom of the outer tank, thus purging the annular space between the inner and outer walls. If the tank has been taken out of operation and is filled with nitrogen, no purge is required.

After the purge, LNG from the liquefaction unit is slowly admitted to the top of the tank via the 2-inch cool down 1 ine. The LNG is deflected and sprayed over the floor. The following instruments monitor the effects of cooldown on the tank:

1. linear movement indicators that measure relative movement between the inner and outer tank walls

2. storage tank thermocouples. 
The LNG flow rate is limited to avoid exceeding specified maximum temperature gradients between the storage tank thermocouples. When the liquid level in the tank reaches 1 foot or more and the tank is sufficiently cooled, LNG can be fed through the normal liquid fill line and the liquefaction unit can be adjusted to maximum LNG production.

The cooldown purges the nitrogen from the tank and the off gas is vented through the vent gas header. When the methane level in the off gas reaches a specified level, the off gas is compressed and sent to the pipeline.

Heatup, Purging, and Entry. Prior to the heatup of the tank, the LNG level is lowered until the sendout pumps lose suction. This leaves approximately $1 \mathrm{ft}$ of LNG in the tank. Heatup is then begun by admitting warm natural gas into the 12-inch liquid withdrawal line in the bottom of the tank. The gas rises and disperses through the tank and leaves via the 8-in. vapor outlet line. The gas is compressed by the boiloff compressor and sent to the pipeline. The tank pressure control system functions as it would during normal operation. The inlet gas flow is maintained at approximately the normal boiloff plus flash rate, $0.9 \times 10^{6} \mathrm{scfd}$. At this rate, it takes approximately 20 days to warm the tank from $-257^{\circ} \mathrm{F}$ to $+60^{\circ} \mathrm{F}$.

The following instrumentation systems monitor the effects of heatup on the tank:

1. linear movement indicators that measure relative movement between the inner and outer tank walls

2. storage tank thermocouples

3. strain gauges installed around the periphery of the exterior tank to monitor any stresses due to expansion of the inner vessel and subsequent compaction of the perlite.

The storage tank must be purged to a $98 \%^{+}$nitrogen atmosphere before personnel entry. Liquid nitrogen is brought in by cryogenic trailer, vaporized, and admitted to the tank through the 12-inch liquid withdrawal line. The nitrogen is maintained at the lowest temperature possible $\left(\sim 20^{\circ} \mathrm{F}\right)$ to ensure a large difference between the densities of the nitrogen and of the gas in the 
tank. This minimizes mixing and results in a piston effect. The gas exits through the vapor outlet, after which it is compressed in the boiloff compressor and sent to the pipeline. During most of the purging, the off gas is mainly methane. As the purge nears completion, however, the nitrogen content of the off gas rises rapidly. Because there is a limit on the nitrogen concentration in gas sent to the pipeline, the last portion of the off gas is vented through the vent gas header. Combustible gas detectors are located around the tank to detect any combustible gases descending from the vent. Established weather criteria define acceptable atmospheric conditions for venting.

When the inner tank purge is complete, the vapor outlet is blocked and the insulation fill holes and the relief vent in the dome are opened so the dome can be purged. After the dome is purged, the insulation fill holes and the relief vent are closed and the purge ring in the bottom of the outer tank is opened. Nitrogen then flows down through the insulation space and out the purge ring, thus furging the annular space between the inner and outer walls of the tank.

\section{E.3.3.6 Release Prevention and Control Features}

The LNG storage tank and sendout pumps share a common spill basin, as shown previously in Figure E.2. High-expansion foam qeneration systems installed in this area can be activated either manually or automatically by low-temperature detectors or UV fire detectors located in the pumpout area.

The spill basin drains into a trapezoidal diked area located to the east of the storage tank. The area of this impoundment basin is $110,000 \mathrm{ft}^{2}$ and the dike walls average $17 \mathrm{ft}$ in height. The basin can hold about 480,000 bbl of LNG, or $137 \%$ of the capacity of the tank. All structural steel in the diked area is coated with an insulating, fire-retarding concrete.

The following detectors, alarms, and fire protection equipment are located in the LNG pump area:

- combustible gas detectors (see Section E.3.4.4 for detector operation)

- low temperature detectors with alarms in control room 
- Halon fire extinguishing system (see Section E.3.4.4 for description)

- UV fire detectors that automatically activate the Halon system and the Master Emergency Shutdown system (Section E.4.1)

- $20 \#$ dry chemical fire extinguisher

- fire hydrant.

A UV fire detector and dry chemical extinguisher are located on top of the tank near the relief valves. The extinguisher, directed at the relief valves, is activated by the UV detector.

\section{E.3.4 Vaporization and Sendout}

When extra gas is needed to meet a peak demand, LNG is withdrawn from the storage tank, vaporized, and sent out to the pipeline. Vaporization and sendout are described here.

\section{E.3.4.1 Vaporizers}

The process flow diagram for the vaporization section is shown in Figure E.12. Corresponding process conditions and equipment identifications are given in Table E.6. The vaporizers for the plant are four submerged combustion units each rated at $75 \times 10^{6}$ scfd capacity. With one vaporizer considered a spare, the total vaporization capacity of the plant is $225 \times 10^{6}$ scfd.

The vaporizers are designed such that the burners exhaust hot combustion gases directly downward through a downcomer arid into a water bath, as shown in Figure E.13. The exhaust bubbles into the water causing turbulence, mixing, and a "lifting" action. This lifting ection forces the water up through an annular space created by a weir around the downcomer. The water flows over the top of the veir and into the more cuiescent outer tank. Bath temperature ranges from $90^{\circ} \mathrm{F}$ to $130^{\circ} \mathrm{F}$. A heat exchanger tube coil for the LNG is located in the annular space between the weir and the downcomer where it is scrubbed by the warm gas-water mixture, thus transferring heat to the LNG and vaporizing it. The submerged combustion technique results in a very high thermal efficiency of 94 to $96 \%$ because: 1) a 11 the water in the combustion products condenses and the high heating value (HHV) of the fuel can be used, and 


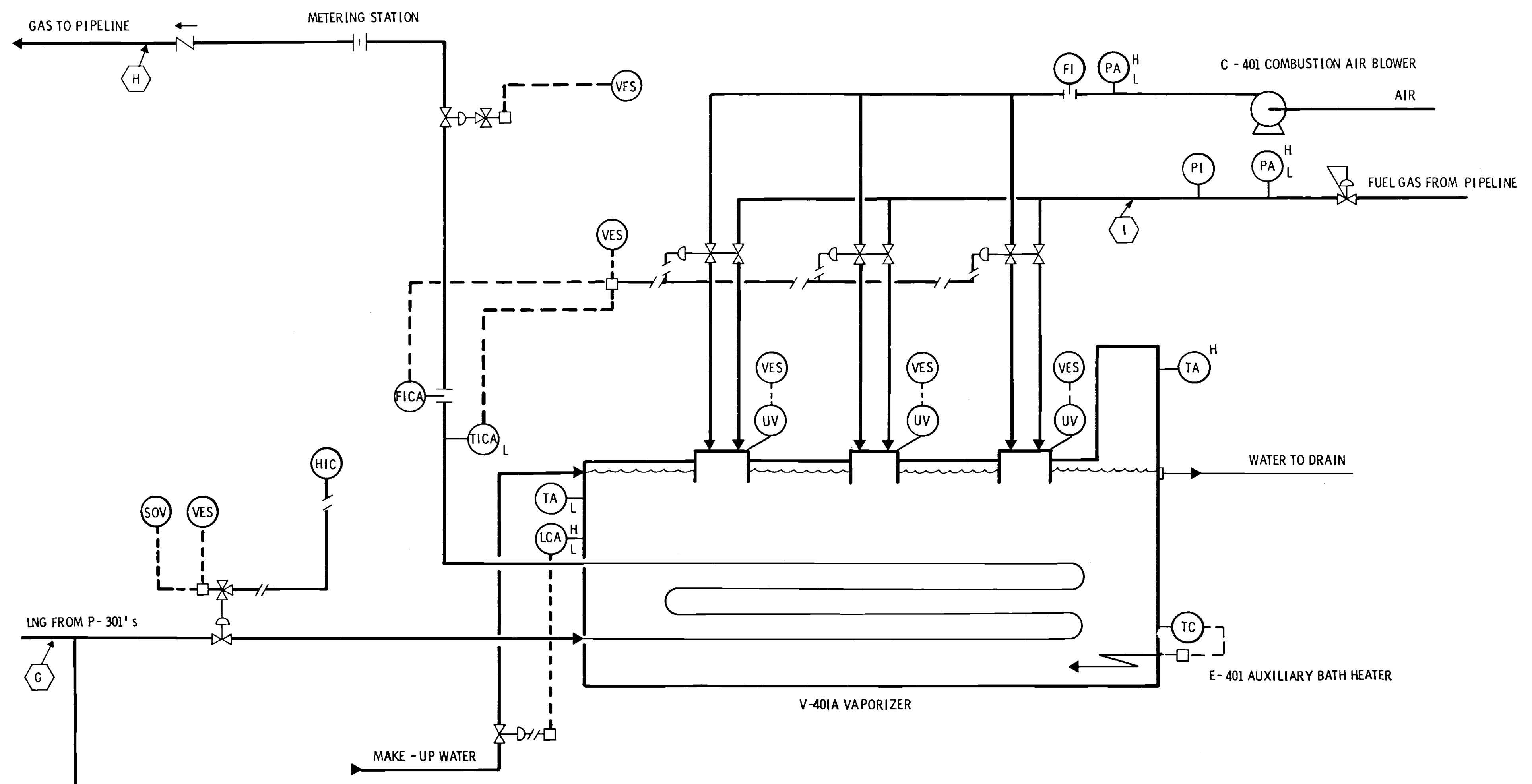

TO THREE ADDITIONAL VAPORIZERS V - 401 B/CID 

TABLE E.6. Vaporization Section

\begin{tabular}{|c|c|c|c|c|c|c|}
\hline \multicolumn{3}{|c|}{ Stream Identification } & Pressure (psia) & Temperature $\left({ }^{\circ} \mathrm{F}\right)$ & Phase $(\%$ or $V)$ & Flow Rate (MMscfd) \\
\hline \multicolumn{7}{|c|}{ ID Description } \\
\hline G & \multicolumn{2}{|c|}{ LNG from $P-301$ 's } & 900 & -257 & $100 \%\llcorner$ & 225 (or $1870 \mathrm{gpm}$ ) \\
\hline H & \multicolumn{2}{|c|}{ Gas to Pipline } & 870 & 70 & $100 \% \mathrm{~V}$ & 150 \\
\hline \multirow[t]{2}{*}{ I } & Fuel Gas to & Vaporizers & 20 & 70 & $100 \% \mathrm{~V}$ & 3.5 \\
\hline & \multicolumn{6}{|c|}{ Equipment Identification } \\
\hline & & Combustion & Blower & & & \\
\hline & & Auxiliary & Heater & & & \\
\hline & $A / B / C / D$ & Vaporizers & & & & \\
\hline
\end{tabular}

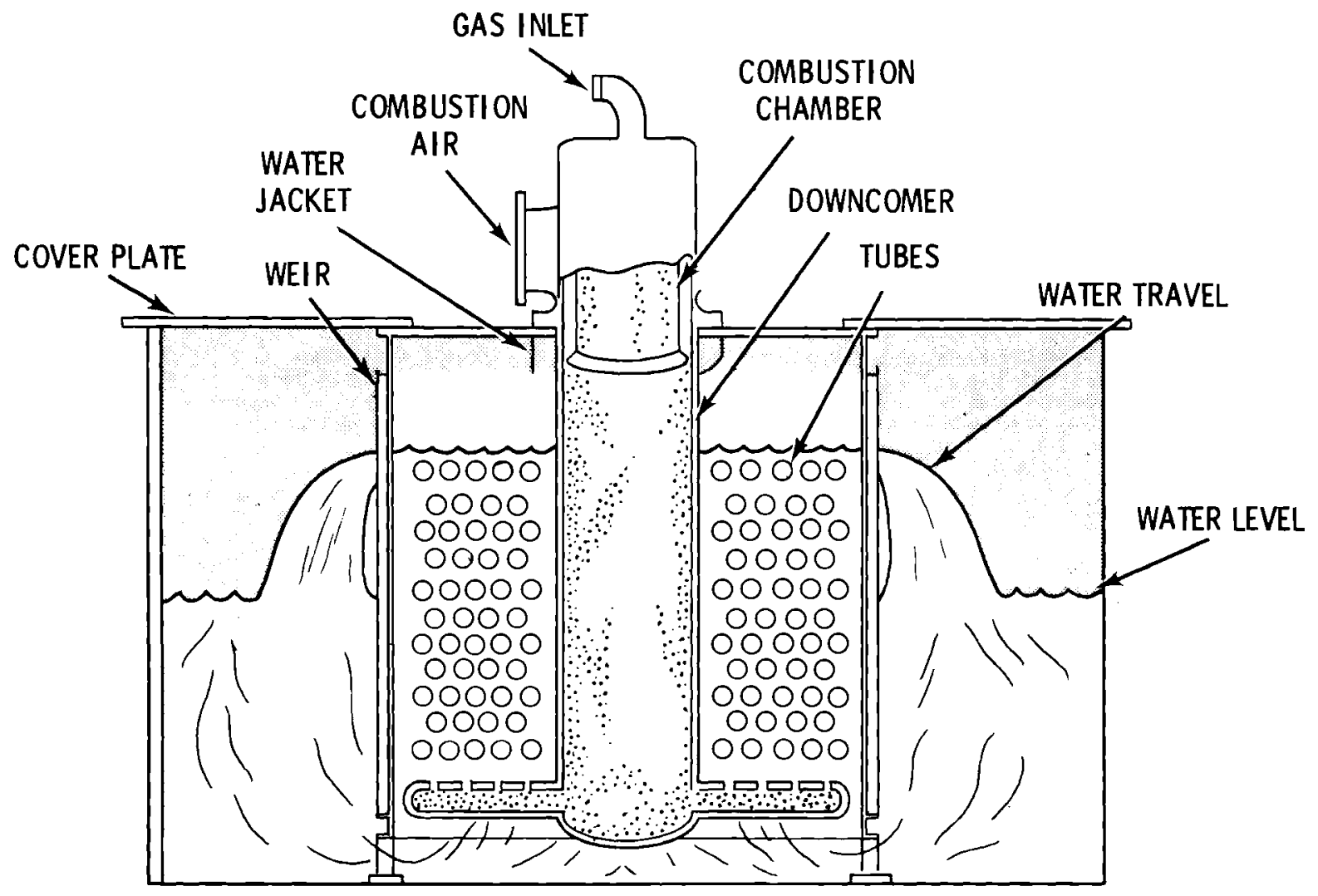

FIGURE E.13. Cutaway View of Submerged Combustion Vaporizer 
2) the violent turbulence and mixing of the gas and water result in a high rate of heat transfer to the tubes. The vaporizers consume gas equivalent to $1.5 \%$ to $2.0 \%$ of the LNG vaporized.

Figure E.14 shows the major components of the vaporizers. The LNG inlet piping, tube bundle, and outlet piping to the first flange are all stainless steel construction. The rest of the outlet piping is carbon steel, as are the tank, weir, and downcomer. The section of each downcomer above the water bath is surrounded by a water jacket with continuous circulation of cooling water. The burner, fuel gas piping, air inlet piping, and blower are all carbon steel. The air blower drive is a 150-hp electric motor. The overall dimensions of the vaporizer are approximately $12 \mathrm{ft} \times 20 \mathrm{ft}$ with a height of $10 \mathrm{ft}$. The vaporizer is surrounded by a fiberglass building for weather protection.

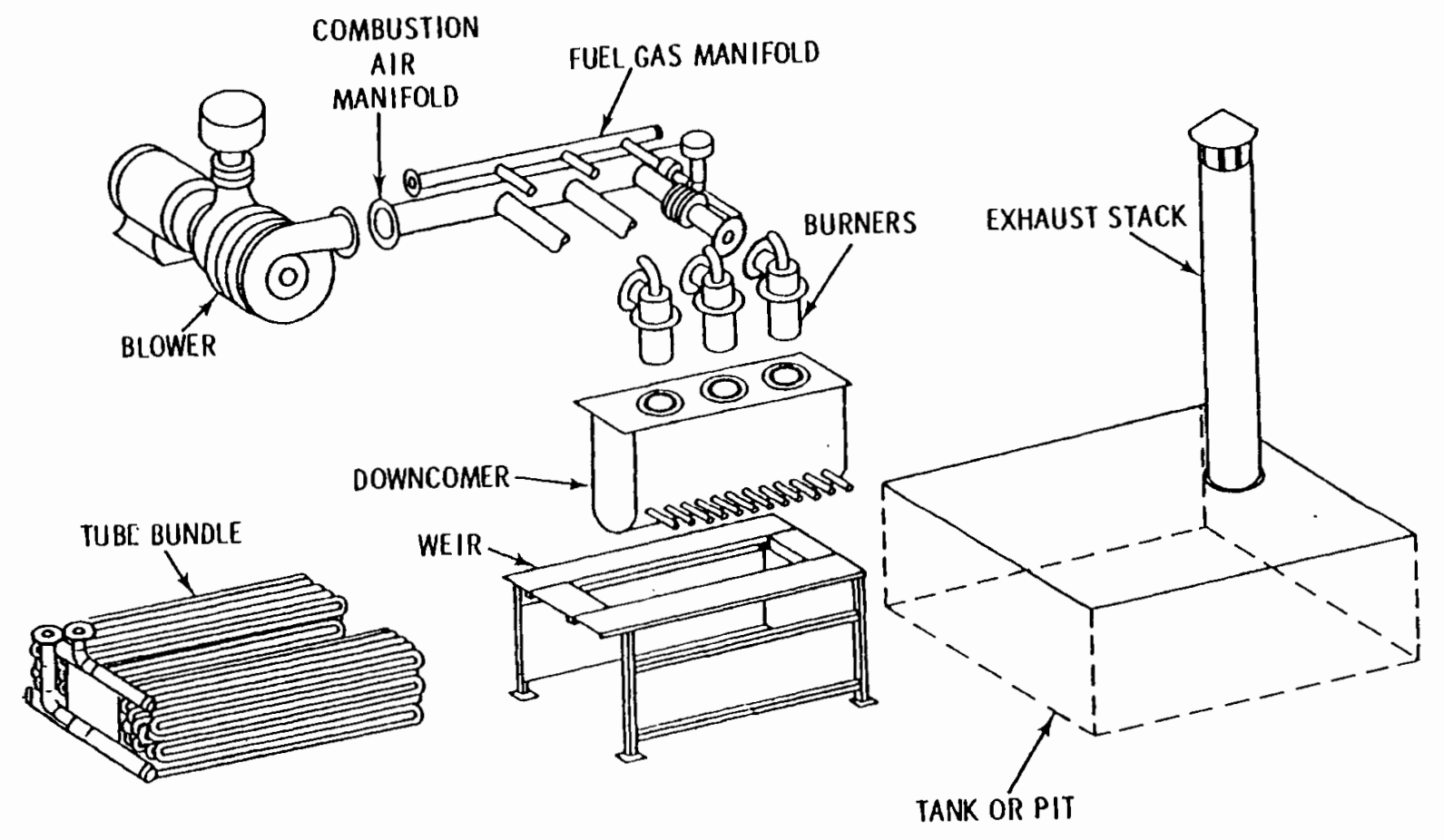

FIGURE E.14. Components of Submerged Combustion Vaporizers 


\section{E.3.4.2 Control System and Instrumentation}

Two major controls are associated with the vaporizers:

- LNG flow control

- gas outlet temperature control.

LNG throughput is automatically controlled by a pneumatically operated control valve in the line from the sendout pumps. The gas outlet temperature from the vaporizer is controlled by automatic adjustment of the air-operated control valves in the fuel gas and air supply lines.

Water level in the tank is controlled by several means. An overflow nozzle is located at the normal water depth to prevent high levels. A small pump sits at the surface of the water in the bath and pumps water to the cooling jackets on the burners. If the water level is low, the pump loses suction and the discharge pressure falls. A low pressure switch then opens a control valve to admit more water. A low water level alarm is also included.

Other vaporizer controls include a pneumatic fuel-pressure control valve and a pilot line with pressure regulator for the burner. (The instrumentation was shown previously in Figure E.12.)

The vaporizer is equipped w'ith an automatic Vaporizer Emergency Shutdown (VES) system which, on activation, automaticaliy shuts down the vaporizers and the LNG sendout pumps and isolates the pumps from both the vaporizers and the LNG storage tank. The VES can be activated manually at the vaporizers or in the control room. The VES can also be activated automatically by a temperature sensor in the gas outlet line, a UV burner flame monitor (see Section E.4.4), or the water bath level indicator. Normally, the VES is not automatically activated.

\section{E.3.4.3 Procedures}

To start up the LNG pumps, the discharge valve to the vaporizers is closed and the pumps are operated on total recycle until they cool down. The vapor produced by cooling the pumps is vented to the storage tank through the 4-inch vapor return line. The burners on the vaporizers are fired and the water bath heated to proper operating temperature $\left(95-130^{\circ} \mathrm{F}\right)$. At this 
point the discharge valve to the vaporizers is opened and a small flow of LNG starts. The rest of the startup is semi-automatic, with the burner firing rate and LNG flow rate both gradually increased until the desired flow rate is reached.

Shutdown of the vaporizers is also semi-automatic, with the LNG flow and burner firing rate gradually decreased. The large heat-storage capacity of the water bath permits fairly rapid startup or shutdown of the vaporizers with little variation in the process outlet temperature.

The vaporizers can also be shut down by the MES and VES systems (see Section E.4.1).

\section{E.3.4.4 Release Prevention and Control Features}

Each vaporizer building has four combustible gas detectors, one in each corner. A detector is also located near the air blower outside the building. Each detector has four indicating lights located on the control panel which denote:

1. "Safe" condition

2. "Warning" condition, which signifies a gas concentration of approximately $25 \%$ of the LFL of methane

3. "Danger" condition, which indicates a gas concentration of approximately $60 \%$ or greater of LFL (this condition also sounds an alarm)

4. "Trouble," which indicates a malfunction of the gas detection system.

The warning condition automatically activates a high-rate ventilation fan to reduce the gas concentration in the vaporizer building. If the danger condition still results, the fan is turned off and the building openings are closed automatically. The Halon fire extinguisher system then discharges automatically.

The fire extinguisher system in the vaporizer building is a Halon (halogenated hydrocarbons 1301 and 1212) inerting and fire extinguishment, total flooding system. This system can be used not only to extinguish natural gas fires but also to inert an enclosure and prevent an explosion. The Halon system is activated by a UV detector sensitive to the ultraviolet radiation from flames. It can also be activated by the combustible gas detection system. 
The UV fire detectors have very fast, adjustable ( 0 to 30 seconds) response times. They detect very small fires in any wind condition. However, the UV sensors tend to give false alarms from such things as reflected welding arcs, and they use $A C$ power and thus are sensitive to induced currents and power fluctuations. The detectors are often turned off when construction or maintenance requires welding in the area. Activation of the Halon or other fire fighting systems requires simultaneous signals from two UV detectors located in the same area.

The first flange on the vaporizer outlet piping marks the change from cryogenic materials for LNG ( $9 \%$ nicke1, aluminum alloy, or stainless stee1) to carbon steel construction for natural gas. As a result, the vaporizer contains several safeguards to ensure that cold LNG does not reach the carbon steel piping where it could cause failure due to embrittlement. All burners are equipped with UV flame detectors that alarm in the control room in the event of flame-out. The UV detector can also be tied in to the VES (see Section E.4.4) to shut down the vaporizer in case of a burner flameout. The water bath contains a significant amount of thermal storage that prevents immediate carryover of LNG to the outlet piping after burner flameout. The outlet line also has a temperature sensor that is tied to the burner controls and to the VES. The water bath is equipped with an electric heater to help prevent freezeup of the bath during abnormal operating conditions, particilarly shutdown.

\section{E.3.5 Transportation and Transfer}

The equipment and procedures used for transportation and transfer of LNG are described in the following subsections.

\section{E.3.5.1 LNG Truck Trailers}

The trailers used to transport LNG to and from the peakshaving facility are specially designed for LNG use. Figure E.15 shows a cutaway view of one of the trailers. The tankers are designed and constructed under CGA 341, a Compressed Gas Association specification for insulated tank trucks intended primarily for the transportation of cold liquefied gases. Transportation of LNG is also governed by the hazardous liquid regulations of the Department of Transportation (DOT), part 170 through 179 of Title 49 of the Code of Federal Regulations, and by DOT Special Permit Number 6113. 


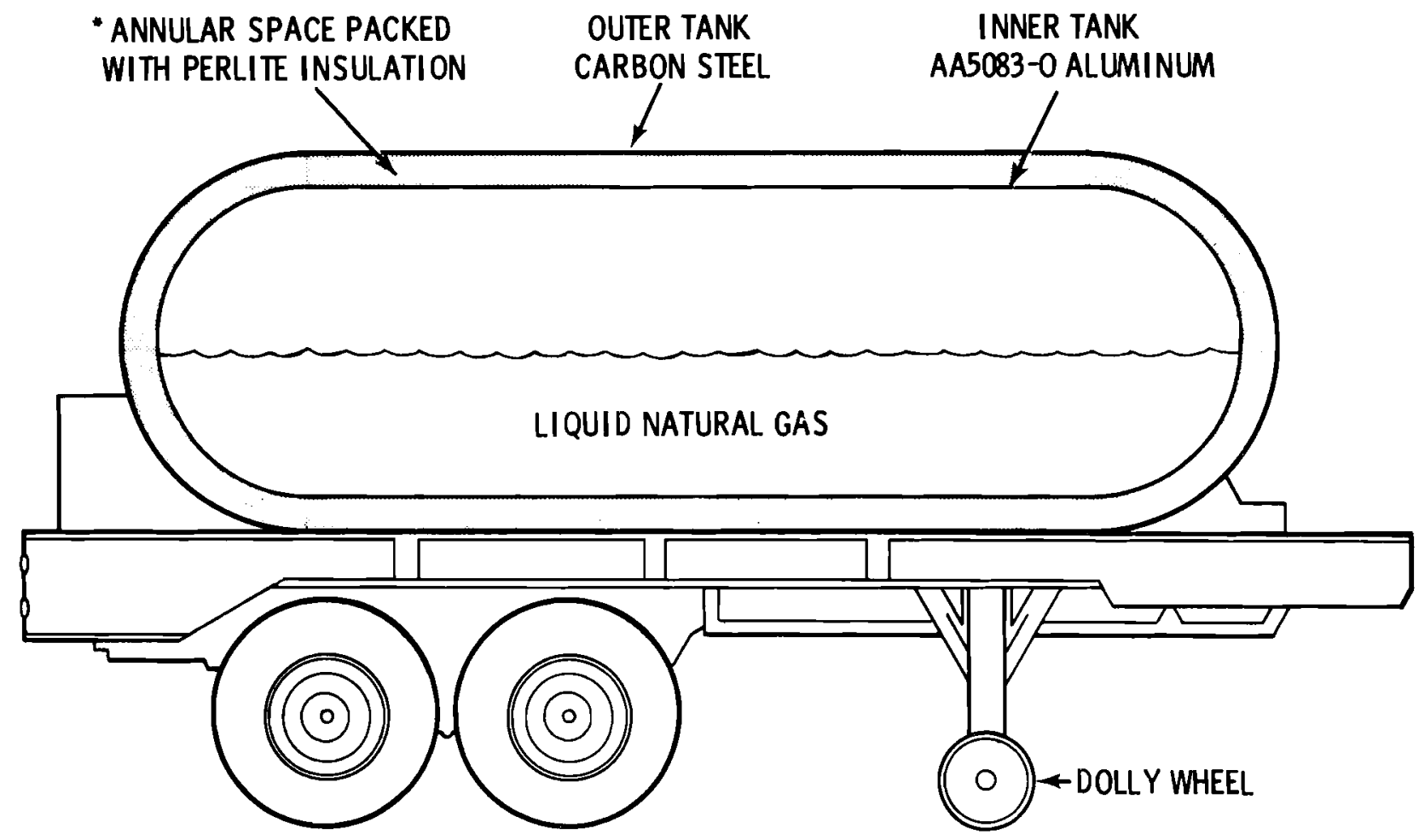

- 50 MICRON VACUUM IN ANNULAR SPACE

FIGURE E.15. Cross Section of LNG Trailer

The inner vessel is constructed of 5083 aluminum and the outer vessel of carbon steel. The annular space is filled with perlite and a vacuum of 50 microns is established to insulate the inner vessel. The inner shell is supported by low-heat-leak rods within the outer shell. Three flow baffles prevent excessive sloshing of the cargo during shipment. The outer shell acts as a structural member of the semi-trailer and is attached to the fifth wheel and tandem assemblies. The inner vessel is designed to conform to the ASME pressure vessel code, with a maximum working pressure of $70 \mathrm{psig.} \mathrm{The} \mathrm{outer} \mathrm{vesse} 1$ is designed for vacuum service. The trailer has a 10,500 gallon capacity and a length of 40 feet, and it weighs $21,500 \mathrm{lb}$ empty and 60,000 1b fully loaded.

Because of the relatively low density of LNG, the tank diameter is rather large (I.D. $=7$ feet 4 inches, O.D. $=8$ feet). The large diameter results in a high center of gravity, about nine inches higher than that of an LPG trailer. This results in an increased susceptibility to overturning accidents during collisions and high-speed turns. 
Figure E.16 shows the piping, valving, and instrumentation for the LNG trailer and the loading/unloading terminal. The trailer's main fill and drain line is a 3-inch line passing through the lower half of the shell. The line is equipped with a manual throttling valve, a remotely operated shutoff valve, and a line safety valve. A gas return line at the top of the trailer allows vapors to return to the storage tank during normal filling operations. A pressure buildup coil is provided to vaporize liquid during unloading and thus maintain adequate trailer pressure. Three manual trycock valves also assist in loading and unloading. The trailer is equipped with numerous pressure relief devices, all of which vent to a common elevated stack.

\section{E.3.5.2 Transfer System}

The transfer system consists of a graded and diked transport terminal and stainless steel liquid and vapor lines connecting the terminal to the peakshaving facility's LNG storage tank. A 350-gpm transfer pump loads the LNG. The 3-inch truck loading line has a hand-operated shutoff valve and a remotely operated emergency valve. The vapor return line is 2 inches in diameter and has a manual valve only. The 3 -inch liquid unloading line has a manual valve and no pump since trailer pressure is used to transport the LNG to the storage tank.

The terminal is equipped with weight scales to indicate the trailer liquid level. The trailer is connected to the appropriate lines with flexible 3 -inch metal hose. The terminal area is diked and graded so that spills flow away from the trailer and into a sump.

\section{E.3.5.3 Control System}

The transport terminal control system consists simply of the pump on/off control, manual valves on all three transfer lines, and a remotely operated shutoff valve in the truck loading line. The loading pump is sized to provide the correct flow rate for filling a truck under normal conditions. If throttling is required (for filling a warm truck, for instance), the manual valve is used. The level to which the truck is filled is determined by the scales and by opening the $87 \%$ full and $90 \%$ full trycocks while filling 


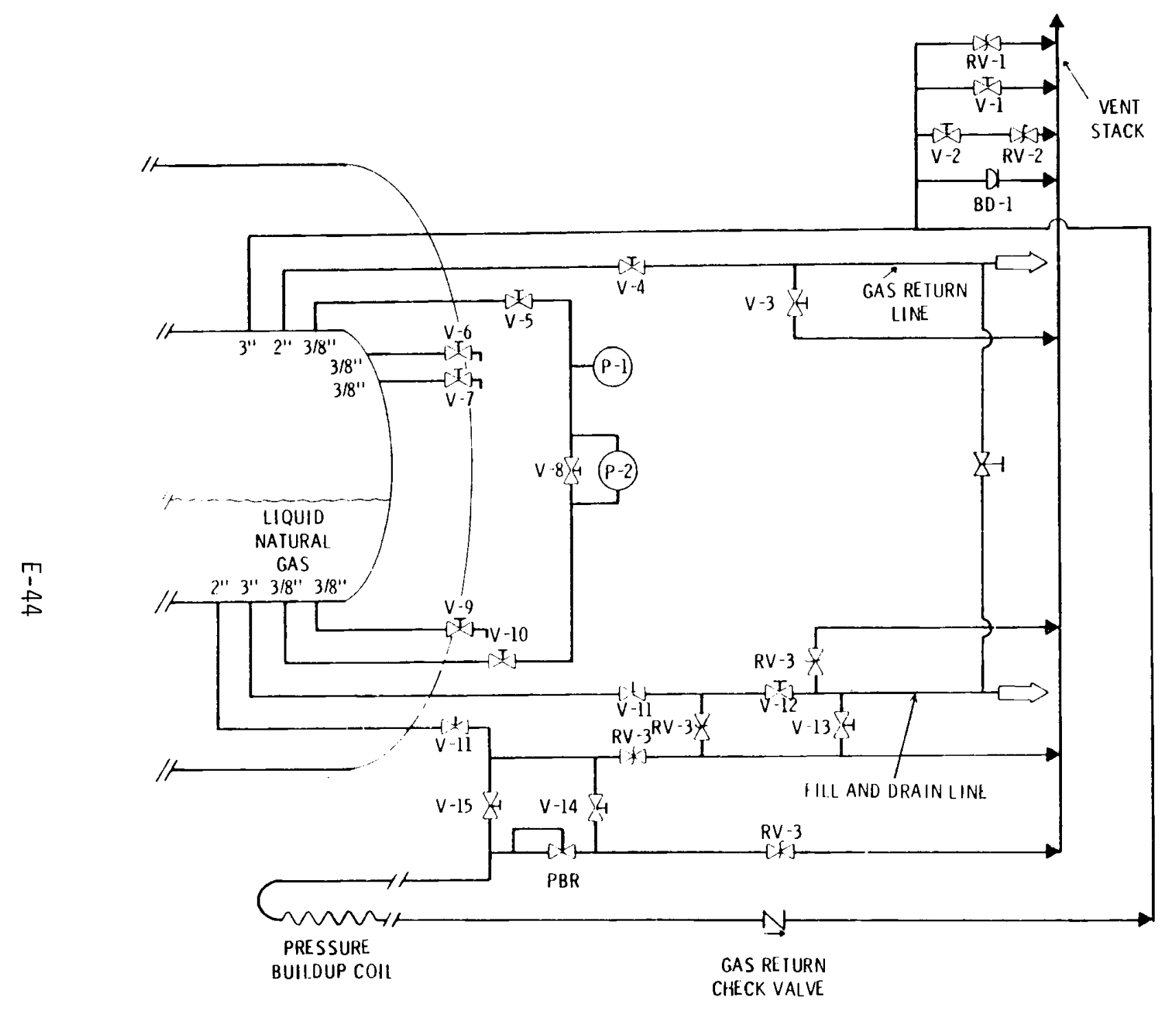

\begin{tabular}{|c|c|}
\hline EY: & \\
\hline 正 & HAND OPERATED VALVE \\
\hline 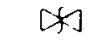 & REL IEE VALVE \\
\hline 计 & REMOIE OPERAIED VALVE \\
\hline$v-1$ & VENT - 3"' \\
\hline$v-2$ & ROAD RELICF SHUTOFF - 1/2" \\
\hline$v-3$ & HOSE DRAIN - 1/2" \\
\hline$v-4$ & GAS RE IURN - $\boldsymbol{\gamma}^{\prime}$ \\
\hline$v-5$ & CAS GAGE LINE - $1 / 4^{\prime \prime}$ \\
\hline$v-6$ & $90 \%$ FULL TRYCOCK - 1/4" \\
\hline$\vee-7$ & $87 \%$ FULL TRYCOCK - I/4' \\
\hline$v-8$ & GAGE BY-PASS - 1/4" \\
\hline$\vee-9$ & EMPTY IRYCOCK - $1 / 4^{\prime \prime}$ \\
\hline$V-10$ & LIQUID GAGE LINE - I/4" \\
\hline V-11 & REMOTE CONIROL SHUTOFF \\
\hline$v-12$ & FIIL ANO DRAIN - 3" \\
\hline$v-13$ & HOSE DRAIN - 1/2" \\
\hline$v-14$ & PRE SSURE BUHIOUP \\
\hline & RECULATOR SHUTOFF \\
\hline$\checkmark-15$ & PRESSURE BUILDUP - Z \\
\hline$R V-1$ & INNER IANK RELIEF - 3'" \\
\hline$R V-2$ & ROAD SAFETY - $1 / 2^{\prime \prime}$ \\
\hline$R V-3$ & LINE SAFETY - 1/4" \\
\hline$B D-1$ & BURST DISK - 3" \\
\hline$P-1$ & TANK PRESSURE GAGE \\
\hline$P-2$ & LIQUID IEVEL GAGE \\
\hline PBR & PRESSURE BUHLDUP REGUI \\
\hline
\end{tabular}

FIGURE E.16. Flow Diagram for Trailer Loading and Unloading 
(Figure E.16). The rate at which a truck is unloaded is controlled by either the manual valve in the unloading line or the throttling valve on the pressure buildup coil.

The LNG trailer requires only passive pressure control devices, including relief valves and burst discs, since it is designed to operate for up to 28 days without loss of cargo. As mentioned previously, a pressure buildup coil is provided to increase trailer pressure for unloading.

\section{E.3.5.4 Procedures}

Truck Filling. At most facilities, trailers are filled by plant employees rather than the truckers themselves. Trailers are inspected for general roadworthiness and other requirements: (1) evidence of a good annulus vacuum;

(2) a serviceable fire extinguisher; (3) valves and gauges in good condition; (4) positive trailer pressure not more than $25 \mathrm{psig}$; and (5) no oxygen gas present inside the trailer. If acceptable, the trailer is then weighed, chocked, and grounded. The 1 iquid fill line and vapor return line are cooled with LNG and then connected to the trailer with 3-inch flexible metal hose. If the trailer is warm, the top fill line is used at a reduced flow rate to minimize thermal shock. Cold trailers are filled through the bottom fill line at about $350 \mathrm{gpm}$. A cold trailer requires on1y $1 / 2$ hour to fill, while a warm one can take up to 4 hours. Weight scales provide the primary indication of a fu11 1oad. The $87 \%$ and $90 \%$ full trycocks provide a backup indication. When the truck is full, drain valves on the fill and vapor return 1 ines are opened and the trapped LNG flows into a heated sump, where it is vaporized and returned to storage. The flexible lines are disconnected, and together the operator and driver verify the truck weight and the final valve positioning. The chocks and grounding cable are then removed and the truck leaves the terminal.

Truck Unloading. Unloading is carried out in much the same way as fi11ing. The truck is inspected and then chocked and grounded. The trailer is connected to the terminal with a 3 -inch flexible metal hose. The LNG is forced from the truck to the storage tank by the vapor pressure in the trailer. If the pressure is too low, a small amount of liquid is routed through the pressure buildup coil where it is vaporized by the ambient air. The vapor is 
routed to the top of the tank to provide the desired pressure increase. Unloading proceeds at a rate of about $350 \mathrm{gpm}$ and requires about $1 / 2$ hour.

\section{E.3.5.5 Release Prevention and Control Features}

LNG trailers have proven to be safe and reliable for transporting LNG. As of October 1978, LNG trailers had travelled roughly 26 million miles with only 12 accidents in transit. However, 9 of these accidents resulted in rollovers of the LNG trailers, due at least in part to their high center of gravity. Three accidents, one a rollover, resulted in LNG spills, the worst releasing $20 \%$ of the cargo. None of the accidents involved a fire of the natural gas.

The primary reason for this good safety record is the durability of the double-walled tank design. The outer shell and perlite insulation protect and cushion the inner shell and its contents. In the event of a fire, the carbon-steel outer shell retains its structural integrity and the insulation keeps the cargo cool for several hours.

LNG trailers are equipped with numerous pressure relief valves and a burst disc to prevent overpressurization (see Figure E.16). Remotely operated shutoff valves are installed in all liquid lines. A fusible link is included with the remote controls so the valves will close in the event of a fire. The trucks are inspected on a regular basis, and drivers are given a formal training program that includes instruction on the characteristics and safe handling of $L N G$.

Three separate dry chemical fire extinguishers and three water turrets with multi-position nozzles are available in the transport terminal area. A closed-circuit television camera scans the terminal whenever a trailer is present and an operator watches for liquid or vapor leaks. The spill retention system has the capacity to contain the cargo of a full trailer plus the holdup in the loading lines. The area is graded so that spills flow away from the trailers. Five events resulting in three automatic and two manual sequences will stop LNG flow within 10 seconds of emergency:

- fire

- loss of electrical power

- loss of air pressure

- LNG line rupture

- emergency shutdown. 


\section{E.4 GENERAL PLANT INFORMATION}

The following subsections provide general information on various aspects of the LNG peakshaving facility and its operation.

\section{E.4.1 Emergency Shutdown System}

The operation and activation of the emergency shutdown system for the peakshaving facility are described here.

\section{E.4.1.1 Operation of Emergency Shutdown System}

The plant emergency shutdown system consists of two separate systems, the Master Emergency Shutdown (MES) and the Vaporizer Emergency Shutdown (VES).

The MES allows the rapid shutdown of the plant and isolation of the various plant systems. When activated, the MES automatically initiates the following actions:

1. Electrical supplies to all normal plant circuits are de-energized; essential plant electrical equipment (e.g., fire pumps, fire and gas detectors, fire system valve operators) remains energized.

2. Natural gas valves at plant boundaries are closed to isolate the plant from the natural gas pipeline. These valves include:

- natural gas feed to plant

- gas from vaporizers

- boiloff gas from storage tank

- fuel gas to vaporizers.

3. The LNG tank and dike area is isolated from the remainder of the plant by the following:

- valves at the LNG pump suction and the interior tank outlet valves are closed

- valve on the liquid inlet line from the liquefaction unit is closed

- LNG pump motors are shut down

- block valves between the LNG pumps and the vaporizers are closed. 
4. A telemetric signal "MES Tripped" is transmitted to the company's head office.

5. With loss of instrument air, all control valves go to their failsafe positions.

6. Gas from all gas handling equipment and lines is vented through the relief header to the vent stack.

The second shutdown system, the VES, allows the rapid shutdown and isolation of a 11 LNG sendout systems. When activated, the VES automatically initiates the following actions:

1. The following natural gas valves at the plant boundaries are closed:

- gas from vaporizers

- fuel gas to vaporizers.

2. LNG pump motors are shut down.

3. Block valves between the pumps and the vaporizers are closed.

4. Pump suction valves and the interior valves on the liquid withdrawal lines are closed.

5. Gas from all gas handling equipment and lines is vented through the relief header to the vent stack.

The MES and VES circuits are energized with 120 VAC power from a separate "Uninterruptable Power Supply" (UPS) unit that maintains these systems energized and ready for operation. When these circuits are de-energized (failsafe), the emergency shutdown actions described above are initiated.

\section{E.4.1.2 Activation of Emergency Shutdown System}

Both the MES and VES can be activated manually at the control room and at the two plant exit gates. The MES can also be activated automatically by the ultraviolet (UV) fire detectors that monitor the following areas:

1. compressor building

2. vaporizers

3. refrigerant storage 
4. LNG pumps

5. piping on or adjacent to pipe racks next to compressor building

6. cold box

7. adsorbers

8. regeneration heater.

The VES may be automatically activated, if desired, by a temperature sensor in the vaporizer gas outlet 1 ine (10w temperature), by the UV flame monitors on the vaporizer burners (burner flameout), or by the water bath level indicator (low leve1).

\section{E.4.2 Construction, Inspection, and Testing}

The procedures used during construction, inspection, and testing of a peakshaving facility, as well as the codes and standards governing these activities, are discussed here.

\section{E.4.2.1 Codes and Standards}

The important difference between a code and a standard is a question of law. In the United States, codes officially adopted by federal or state governments become legal documents with the force of law. Standards are not generally binding by law, but are often included as part of a code or used to form parts of contractual specifications.

A facility operated by an interstate natural gas pipeline company is under the jurisdiction of the Department of Transportation (DOT) Office of Pipeline Safety Operations. The DOT federal safety standards included in the Code of Federal Regulations, Title 49, Parts 191 and 192 cover interstate LNG facilities. The code incorporates the National Fire Protection Association Standard 59A for Liquefied Natural Gas Facilities. Intrastate gas companies are regulated by state codes that also quite frequently refer to NFPA59A.

The American Petroleum Institute has issued two standards that are often used for LNG facilities: 1) API Standard 2510A - Design and Construction of LNG Installations at Petroleum Terminals, Natural Gas Processing Plants, Refineries and Other Industrial Plants; and 2) API Standard 620 - Recommended Rules for Design and Construction of Large, Welded, Low Pressure Storage Tanks. Appendix $Q$ is directed specifically to aboveground, metal LNG storage tanks. 
Various sections (VIII and IX) of the ASME Boiler and Pressure Vessel Code are applicable to specific components of an LNG facility such as boilers, unfired pressure vessels, and heat exchangers. This code has been adopted in 31 states where it is binding by law.

The American Society of Testing and Materials issues standards for materials. All of the U.S. codes and standards use these as bases for material specification requirements. For example, ASTM A-353-64 and -65 cover requirements for $9 \%$ nickel steel, which is widely used in LNG plant construction.

\section{E.4.2.2 Procedures}

Cold Box. A11 welding in the cold box was performed in strict accordance with ANSI B31.3 and ASME Section VIII, and al1 welders were aualified in accordance with ANSI B31.3 and ASME Section IX. A11 welds in the cold box were visually examined and met the requirements of ANSI B31.3 and ASME Section VIII for visual inspection. All pipe butt welds and some other cold box welds were $100 \%$ radiographed in accordance with the 100\% radiography inspection requirements of ANSI B31.3. A11 welds not 100\% radiographed were $100 \%$ dye penetrant tested in accordance with ASME Section VIII.

Storage Tank. All welding on the tank was performed in strict accordance with API 620 Appendix Q. A11 inner tank butt welds were visually inspected and $100 \%$ radiographed. All outer tank butt welds were visually inspected and $100 \%$ dye penetrant tested. In addition, the tank was inspected by an independent outside agency in accordance with API 620.

Following construction, the tank was subjected to a series of overload tests to further ensure $i$ ts integrity, leaktightness, and readiness for LNG service. Prior to this final proof-testing, the inner and outer tank bottoms were vacuum-box tested with soap solution to ensure that there were no leaks or defects in these parts of the tanks.

For hydrostatic loading, the inner tank was filled with water to a level $(\sim 1 / 2 \mathrm{ful1})$ that stressed the lower portion of the tank to $125 \%$ of the stress produced when the tank is completely filled with the lighter LNG. Pneumatic pressure was then applied to the upper portion of the tank to 1.25 times 
the design pressure. For the portions of the tank above the liquid level, a soap solution was applied to detect leakage. This method was also used to test the roof and outer tank shell. After the hydrostatic test, a pneumatic overpressure test was carried out for the purpose of overloading the anchor bolts and for testing the pressure venting system. A vacuum test was carried out to test the vacuum relief system.

\section{E.4.3 Venting}

A11 gas lines and gas handling equipment can be vented to the vent stack through the vent gas header. Gas is not normally vented except in the case of an emergency shutdown, when the MES automatically vents all gas lines and gas handling equipment. The LNG sendout pumps are vented back to the storage tank via the 4-inch vapor return line.

The storage tank has two 12-inch pressure relief valves that vent to the atmosphere. Normal off gas from the storage tank is handled by the boiloff system. The relief valves open only when needed to protect the tank from overpressure.

A11 vessels or sections of LNG lines that can be isolated with LNG in them and allowed to warm are protected by relief valves venting to the atmosphere.

\section{E.4.4 Plant Operation}

The control system for the peakshaving plant is designed for unattended operation in the liquefaction, vaporization, and holding modes. One operator is on duty each shift to monitor the plant and to adjust plant production or output rates as dictated by the central office. Al1 critical operating equipment and process variables are monitored so that if there is an equipment malfunction or process upset, the entire plant or section of the plant affected will automatically shut down in a safe manner. When the emergency shutdown system is activated, a telemetric signal "MES tripped" is transmitted to the company's head office. 
For scheduled startups, two operators are on shift; however, the plant is designed so one trained operator can restart any portion of the plant after a shutdown, providing that all equipment is in proper working order. Visual and audio alarms indicate the nature of the problem that caused shutdown of the system.

Major tasks such as heatup and cooldown of the storage tank and initial filling and startup of the liquefaction system require a significant number of additional operating and supervisory personnel. These operations are not automated (see Sections E.3.2.4 and E.3.3.5) and require close, continuous monitoring for safe operation.

The fire extinguishment systems for the vaporizer building, compressor building, LNG pumpout area, and storage tank relief valves are all activated automatically by UV fire detectors or by combustible gas detectors. The highexpansion foam system in the storage tank spill basin can be activated automatically by low temperature detectors or UV detectors or can be operated manua11y. A11 other equipment for fires and for control of vapor generation and dispersion must be operated manually.

\section{E.5 SOURCES OF INFORMATION}

The LNG peakshaving plant description was developed using information from the sources listed below.

1. Federal Energy Regulatory Commission files of application concerning LNG facilities:

FPC Docket No. CP74-46, Northwest Pipeline Corp., September 20, 1973, FPC Docket No. CP76-106, Northwest Pipeline Corp., September 29, 1975.

2. LNG Equipment Vendors:

Chicago Bridge and Iron - Cryogenic Storage, Bulletin No. 8600, Chicago Bridge and Iron - Cryogenic Systems, Bulletin No. 8650, Chicago Bridge and Iron - USA Standards for Design and Construction of LNG Installation, Bulletin No. 831 ,

Ryan Industries - Sub-X Vaporizer, Product Bulletin LNG-200, 
Pittsburg-Des Moines Steel Company - LNG Storage Tanks, Bulletin No. 303, American Air Liquide - Teal Liquefaction Process Bulletin, J.F. Pritchard and Company - Prico ${ }^{\mathrm{TM}}$ Process Brochure, Allison Control, Inc - Fire Detection and Extinguishment Control Systems, (various materials),

American Air Liquide - Turnkey Liquefied Natural Gas Plants Bulletin.

3. Open Literature:

E. I. Shaheen and M. K. Vora, "Worldwide LNG Survey Cites Existing, Planned Projects." $0 i 1$ and Gas Journal, pp. 59-71, June 20, 1977.

R. F. Stebbing and J. V. O'Brien, "Core Exchangers Update Peak Shaving." $0 i 1$ and Gas Journal, pp. 46-49, December 22, 1975.

L. DeVanna and G. Doulames, "Planning is the Key to LNG Tank Purging, Entry and Inspection." 0il and Gas Journal, pp. 74-82, September 8, 1975.

Arthur D. Little, Inc., "Assessment of Risks and Risks Control Options Associated with Liquefied Natural Gas Trucking Operations from the Distrigas Terminal, Everett, Massachusetts, "(preliminary draft for comment), ADL Ref 82280, December 1978.

F.P. Schulz, "Safety at an LNG Peakshaving Facility." Paper presented at the ASME Winter Annual Meeting, New York, NY, November 17-22, 1974.

Hanke, C.C., LaFare, I. V., and Litzinger, L. F., "Purging LNG Tanks Into and Out of Service Considerations and Experiences." Paper presented at the AGA Distribution Conference, Minneapolis, Minnesota, May 6-8, 1974.

V. A. Warner, "Liquefied Natural Gas Fire Contro1." Paper presented at the AGA Transmission Conference, Las Vegas, NV, May 3-5, 1976.

N.H. Brock and R. M. Howard, "Upgrading LNG Plant Safety." Paper presented at the AGA Transmission Conference, Bal Harbour, FL, May 19-21, 1975.

H.R. Wesson, "Consideration Relating to Fire Protection Requirements for LNG Plants." Paper presented at the AGA Transmission Conference, Bal Harbour, FL, May 19-21, 1975.

R.G. Schlater and C.J. Noel, "Good Axial Compressor Control Aids LNG Plants." 0il and Gas Journal, pp. 52-57, January 15, 1973.

Gas Processing Handbook Issue. Hydrocarbon Processing, pp. 132-138, Apri1, 1973.

LNG Information Book, prepared by the LNG Information Book Task Group of the Liquefied Natural Gas Committee, American Gas Association, 1973. 
D. B. Crawford and G. P. Eschenbrenner, "Heat Transfer Equipment for LNG Projects." Chemical Engineering Progress, pp. 62-70, September, 1972.

A. E. UhT, L. A. Amoroso and R. H. Seiter, "Safety and Reliability of LNG Facilities." Paper presented at the ASME Petroleum Mechanical Engineering and Pressure Vessel and Piping Conference, New Orleans, LA, September 17-21, 1972.

P.J. Anderson and E. J. Daniels, "The LNG Industry: Past, Present, and Future." Prepared by Institute of Gas Technology for US ERDA under contract No. EE-77-C-02-4234.

I. L. Wissmiller and E. 0. Mattocks, "How to Use LNG Safely." Pipeline and Gas Journal, March, 1972.

S. Seroka and R. J. Bolan, "Safety Considerations in the Installation of an LNG Tank." Cryogenics and Industrial Gases, pp. 22-28, September/ October, 1970.

I. C. Stanfill, "Startup Experiences and Special Features at Memphis LNG Plant." Paper presented at the First LNG International Conference, Chicago, IL, Apri1 7-12, 1968.

Smith, L. R. "Submerged Pumps for LNG Sendout." Paper presented at AGA Distribution Conference, 1968.

4. Tour of Northwest Pipelines Peakshaving Plant at Plymouth, Washington, Apri1 11, 1978.

5. World Wide LNG Market, published ky Frost \& Sullivan, Inc., New York, NY, June 1977. 
APPENDIX $F$

FACILITY DESCRIPTION OF REFERENCE

LNG SATELLITE PLANT 
. 
APPENDIX F

\section{FACILITY DESCRIPTION OF REFERENCE}

\section{LNG SATELLITE PLANT}

LNG peakshaving operations are one means by which gas distribution companies handle seasonal variations in demand for natural gas. Most peakshaving facilities liquefy natural gas during the off-season, store it until winter peak-demand periods, and then vaporize it and put it back into the pipeline for customer use (see Appendix E). In some cases, however, it is more economical to build a peakshaving plant consisting only of storage and vaporization facilities and to truck the LNG in from another facility with a liquefaction unit or from an import terminal. Peakshaving plants with only storage and vaporization facilities are referred to as satellite plants.

There are two basic types of LNG truck-trailers that serve LNG satellite plants. The first and most common type is a perlite-filled, vacuum-insulated trailer with a typical capacity of 10,000 to 12,500 gal. This type of trailer has an inner shell of cryogenic metal, usually aluminum; an annular space filled with perlite and under a moderate vacuum of 50 microns; and an outer carbon-steel shell integral to the trailer. The second type of trailer uses urethane foam insulation. It consists of an inner cryogenic she11, usually aluminum; a 5-1/2 in. layer of urethane foam insulation; and an outer skin of 20 gauge stainless stee 1 sheet.

Although some of the satellite facility owners have their own LNG tankers, most arrange transportation with trucking companies. Because the requirements for LNG vary depending on winter weather, transportation contracts generally take the form of term contracts for a specified number of deliveries during the season and spot deliveries as required to fill storage capacity.

At the satellite facility, the $L N G$ is stored in a double-walled, cryogenic storage tank at $-260^{\circ} \mathrm{F}$ and slightly above atmospheric pressure ( $\sim \mathrm{psig}$ ). The tank is surrounded by a containment area, usually an earthen dike, that is large enough to hold the entire contents of the tank. Boiloff gases, resulting from heat leakage into the tank, are compressed and sent to the pipeline. 
During periods of peak demand, the LNG is pumped out of the tank and up to pipeline pressure. It is then fed to the vaporizers where it is heated and converted back to a gas before being fed to the pipeline. Vaporizers for satellite plants fall into four major categories:

- direct fired

- submerged combustion

- intermediate fluid (indirect fired)

- ambient air type.

Direct fired units use flue gases from a burner to heat a product coil. Submerged combustion units bubble flue gases through a water bath containing the product coils. Intermediate fluid systems use a fired heater to heat a fluid that is pumped through separate heat exchangers to vaporize the LNG. Ambient air vaporizers, the simplest type, consist of large product coils exposed to ambient conditions.

There are about 20 LNG satellite facilities currently operating in the U.S.; all located in the eastern half of the country. These facilities range in size from 5000 to 450,000 bbl of storage capacity with a median capacity of about 55,000 bbl. All but three of the storage tanks are aboveground metal tanks, of which $84 \%$ have aluminum inner tanks and the rest have $9 \%$ nickel steel inner tanks. Of the three remaining tanks, one is a partial in-ground aluminum tank, and two are aboveground concrete tanks.

To deliver LNG to these satellite facilities, there are approximately 130 LNG truck-trailers, of which $90 \%$ are the perlite-filled, vacuum-insulated type. Capacities for these tankers generally are 10,000 to 12,500 gal.

\section{F.1 BASIC PROCESS FLOW}

The basic process flow for an LNG satellite facility is described in the following subsections. 


\section{F.1.1 Unit Operations}

A block flow diagram for an LNG satellite plant is shown in Figure F.T. The major unit operations involved are transportation and transfer, storage, vaporization and sendout.

LNG is transported to the satellite facility in specially designed, cryogenic truck-trailers. These trailers are loaded at an LNG facility with liquefaction capability. The LNG is unloaded into an aboveground, double-walled, metal storage tank. The inner cryogenic barrier is constructed of an aluminum alloy and the outer tank is constructed of carbon steel. The annular space between the walls is filled with perlite insulation to reduce heat leakage into the tank and reduce the amount of boiloff. The boiloff gases are compressed to distribution pressure and sent out.

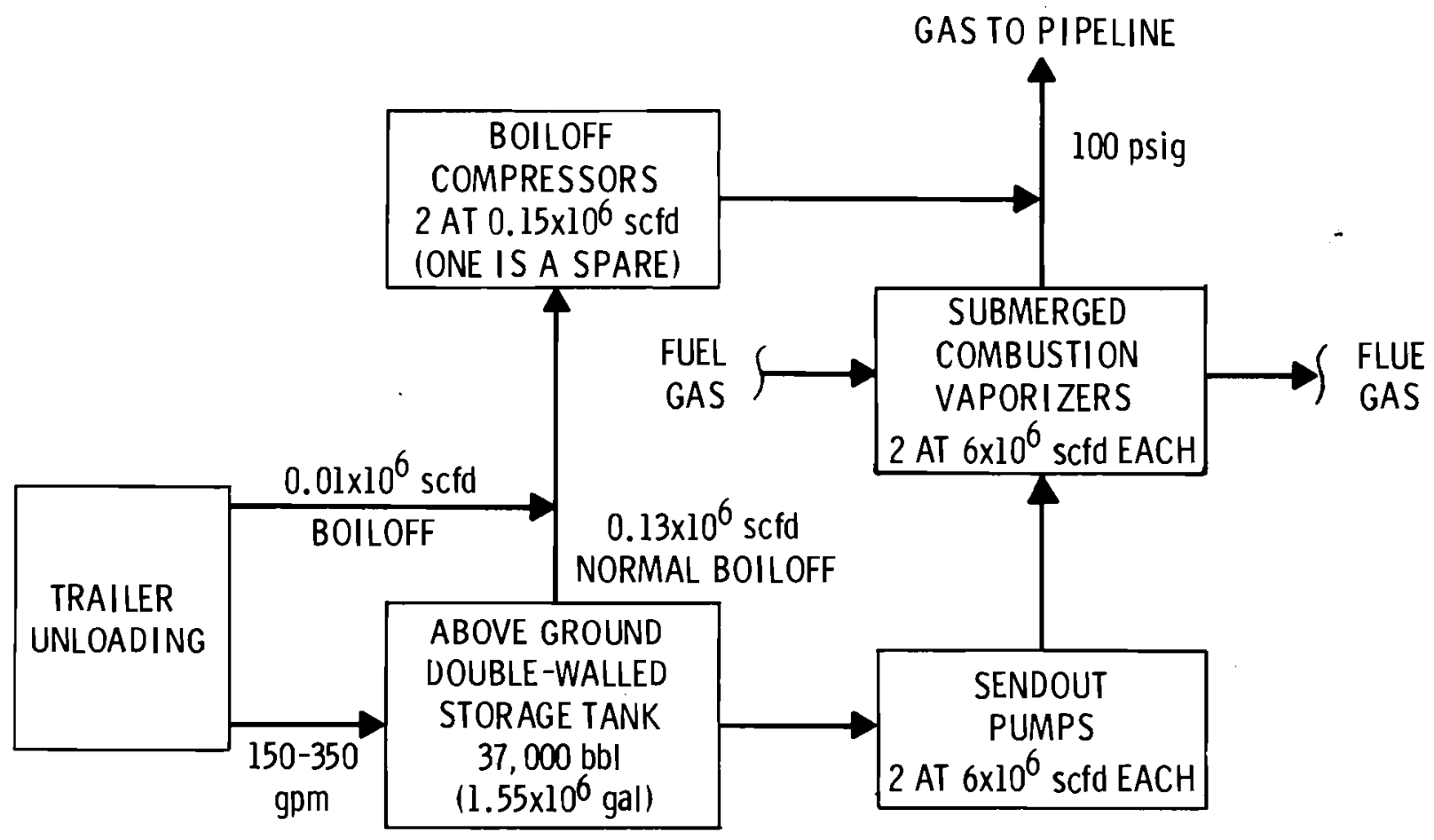

FIGURE F.1. LNG Satellite Plant - Block Flow Diagram 
Two submersible LNG pumps take suction on the storage tank, pump the LNG to pipeline pressure, and send it to the two submerged combustion vaporizers. These vaporizers exhaust hot combustion gases from a burner into a water bath containing LNG product coils. From the vaporizer, the gas is metered and odorized and then fed to the distribution main.

\section{F.1.2 Flow Rates and Operating Conditions}

LNG is unloaded from the truck-trailers to the storage tank at rates varying from 150 to $350 \mathrm{gpm}$. At these rates, the time required to unload a trailer is about 30 to $60 \mathrm{~min}$. The vapors produced during unloading are vented to the storage tank boiloff line. Vapor production from unloading is approximately 10 Mscfd. Normal tank boiloff is about 130 Mscfd.

The maximum sendout rate with both pumps and both vaporizers operating is $100 \mathrm{gpm}$ or $12 \mathrm{MMscfd}$. The boiloff compressors, sendout pumps, and vaporizers are all paired. The sendout pumps and vaporizers each furnish $50 \%$ of the plant's maximum capacity. Each of the boiloff compressors is capable of handling $100 \%$ of the plant boiloff, with the other compressor held as a spare.

\section{F.2 PLANT LAYOUT}

A plot plan for the satellite facility is shown in Figure F.2. The site is graded so that it provides a diked impoundment area located immediately below the storage tank and plant equipment to the south. Any spillage from the tank or process equipment will flow away from the tank and plant into the impoundment area. The average height of the dike in the impoundment area is $10 \mathrm{ft}$, and the area is sized to hold the entire contents of the storage tank.

The safety features shown in the figure will be discussed in later sections with the various processes to which they are related.

\section{F.3 PROCESS DESCRIPTIO:I}

The basic processes involved in the satellite facility are discussed in the following subsections. The description of the LNG satellite facility was developed using information from the sources listed in Section F.5. 


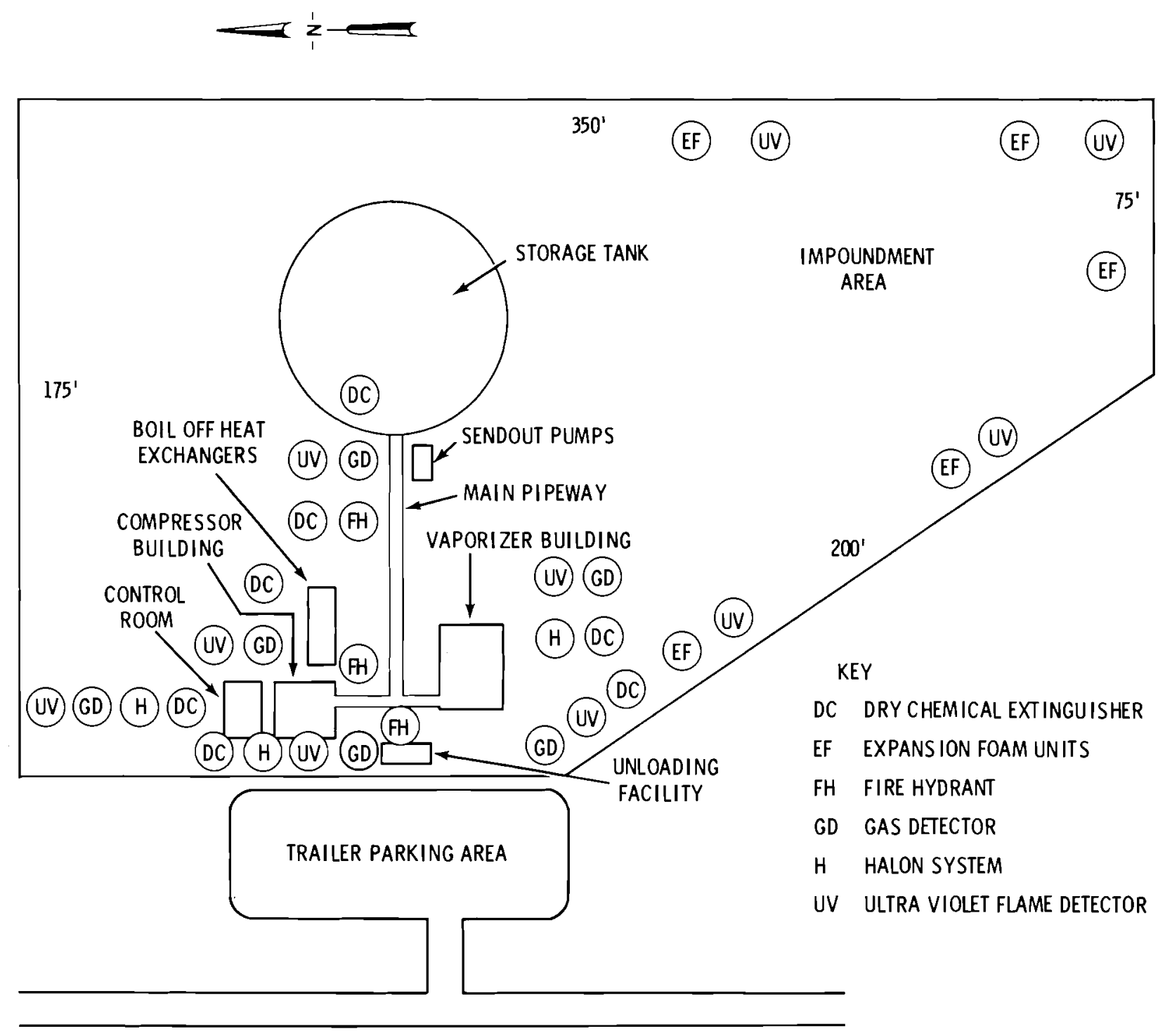

FIGURE F.2. Plot Plan for LNG Satellite Facility

\section{F.3.1 Transportation and Transfer}

The equipment and procedures used for LNG transportation and transfer at the satellite plant are essentially the same as those described in Section E.3.5 of Appendix $E$ for the peakshaving plant; thus, transportation and transfer are not discussed in detail here. Because of the lack of liquefaction capability at the satellite plant, LNG is only received there, never shipped out. 


\section{F.3.2 LNG Storage}

The LNG trucked in to the facility is stored onsite until needed. The storage system and related equipment are described in detail here.

The process flow diagram for the storage section is shown in Figure F.3. (Flow diagram symbols are defined in Appendix H.) Associated process stream identifications are given in Table F.1.

TABLE F.1. Storage System

\begin{tabular}{|c|c|c|c|}
\hline$\frac{\text { Stre }}{\mathrm{ID}}$ & $\frac{\text { Identification }}{\text { Description }}$ & Size (in.) & Flowrate \\
\hline A & $\begin{array}{l}\text { LNG from Truck } \\
\text { Unloading to } \\
\text { Storage Tank }\end{array}$ & 3 & $150-350 \mathrm{gpm}$ \\
\hline B & $\begin{array}{l}\text { Vapor from Truck } \\
\text { Unloading to } \\
\text { Storage Tank }\end{array}$ & 2 & $0.01 \mathrm{MMscfd}$ \\
\hline c & $\begin{array}{l}\text { Normal Tank } \\
\text { Boiloff to } \\
\text { Compressors }\end{array}$ & 2 & $0.13 \mathrm{MMscfd}$ \\
\hline D & $\begin{array}{l}\text { Normal Boiloff } \\
\text { Gas from Boiloff } \\
\text { Compressors to } \\
\text { Pipeline }\end{array}$ & 2 & $0.13 \mathrm{MMscfd}$ \\
\hline $\mathrm{E}$ & $\begin{array}{l}\text { LNG from Storage } \\
\text { Tank to Vapor- } \\
\text { izors }\end{array}$ & -- & 12 MMscfd \\
\hline 1 & $\begin{array}{l}\text { LNG Return from } \\
\text { Sendout Pumps } \\
\text { to Storage Tank }\end{array}$ & 1 & - \\
\hline 2 & $\begin{array}{l}\text { Vapor Return from } \\
\text { Sendout Pumps to } \\
\text { Storage Tank }\end{array}$ & n & -- \\
\hline
\end{tabular}




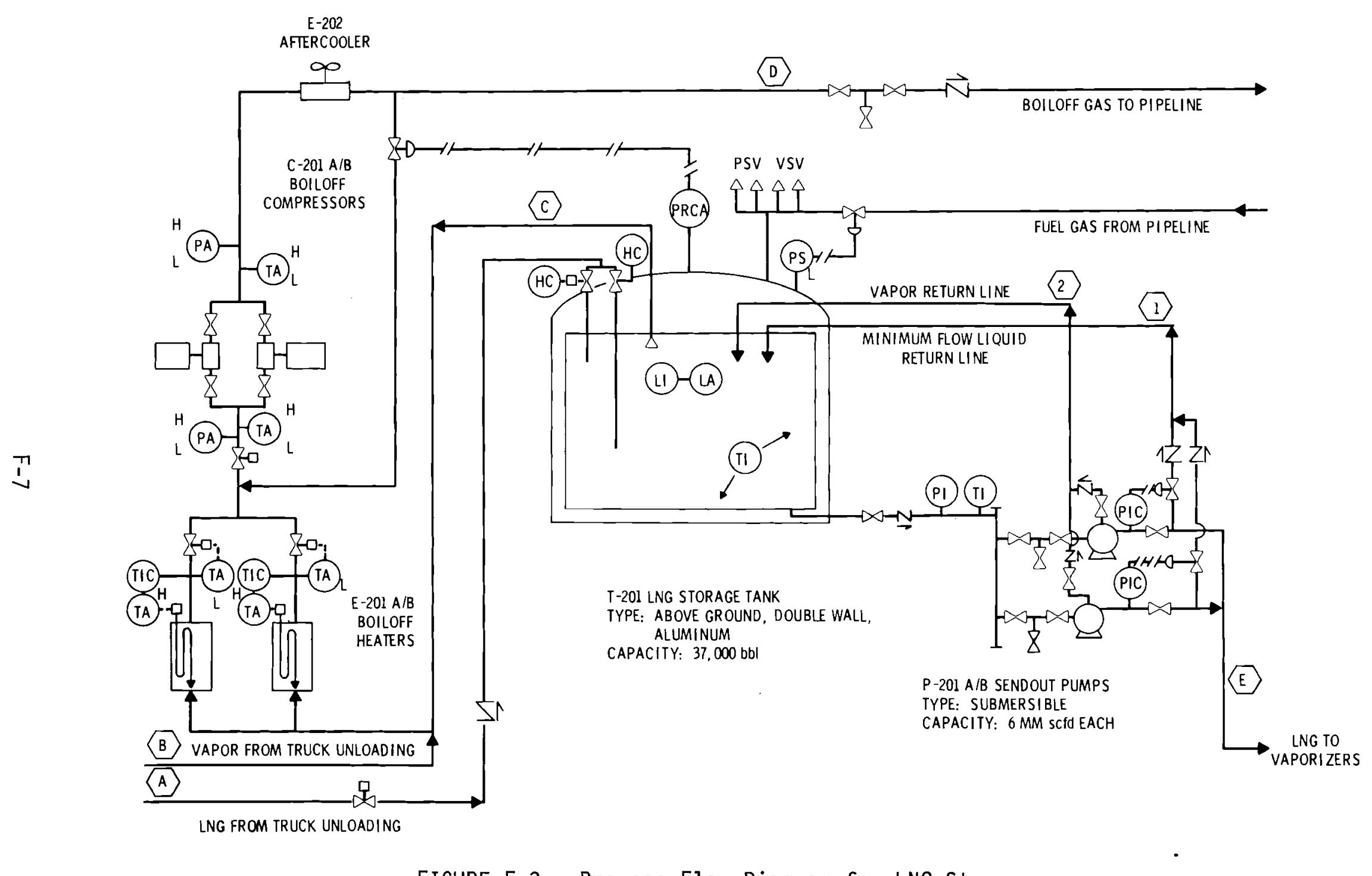

FIGURE F.3. Process Flow Diagram for LNG Storage 


\section{F.3.2.1 Storage Tank}

Storage for the facility is a flat-bottomed, double-walled, aboveground LNG storage tank with a 37,000-bbl capacity as shown in Figure F.4. The inner tank is constructed of aluminum-magnesium alloy AA5083 and the outer tank is constructed of A131 carbon steel. The diameters of the inner and outer tanks are $69 \mathrm{ft}$ and $72 \mathrm{ft}$, respectively. The annular space between the tank walls

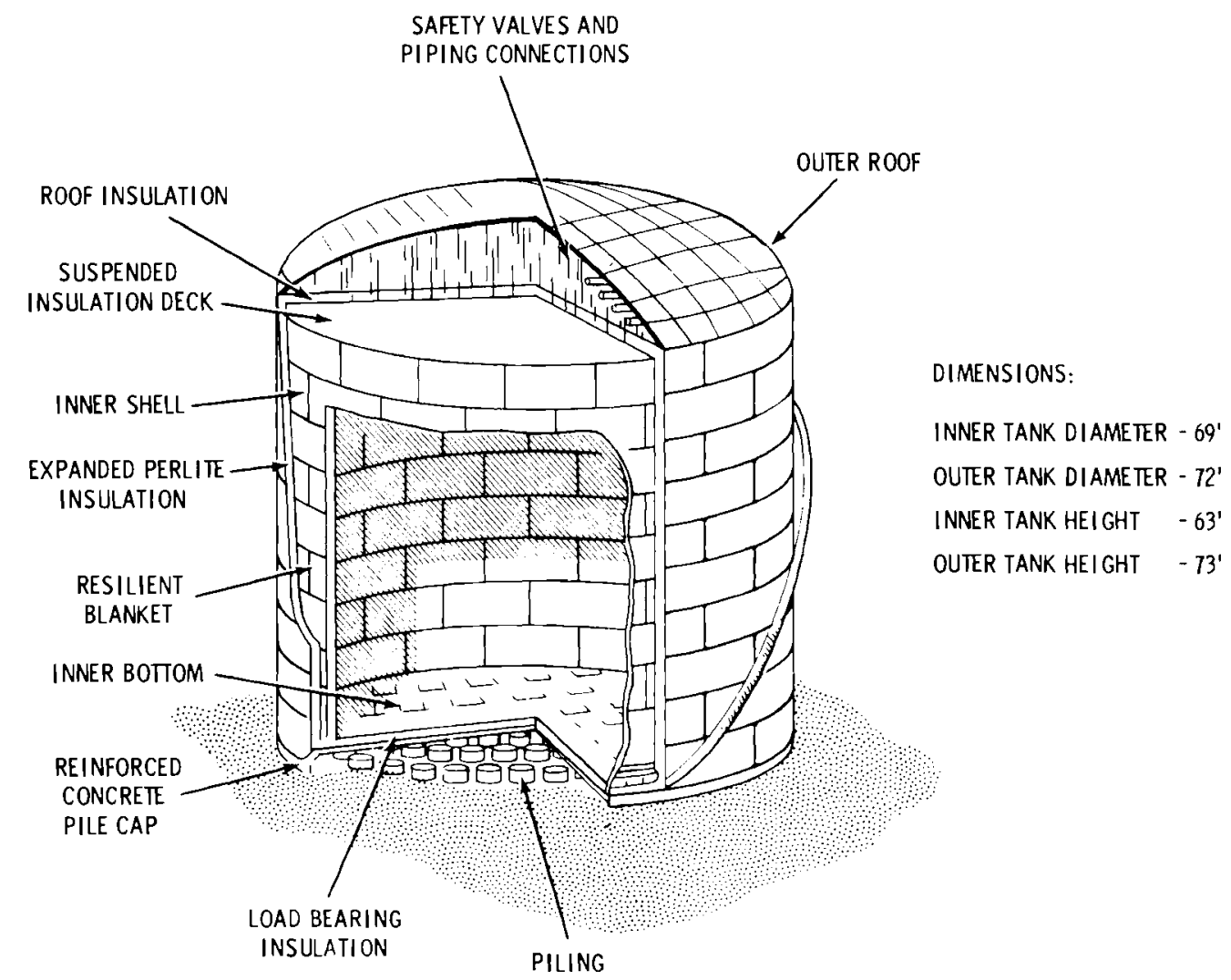

NOTES:

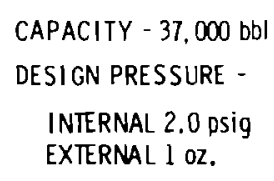

MATERIALS:

LIQUID CONTAINER - AI-MG ALLOY AA 5083
INSULATION SUPPORT DECK - AI - MI ALLOY AA 5083
OUTER TANK - AI3I CARBON STEEL
DECK INSULATION - ROCK WOOL
BOTTOM INSULATION - FOAM GLASS
SHELL INSULATION - PI-4O PERLITE AND FI BERGLASS

FIGURE F.4. LNG Storage Tank 
is filled with expanded perlite, an inorganic, nonflammable, lightweight insulation produced from special rock. The rock or ore is finely ground and then thermally expanded onsite and placed in the insulation space while hot. A resilient fiberglass blanket is attached to the outside of the inner tank wall to protect the perlite from excess pressure, due to expansion and contraction of the tank walls (see Figure F.5).

The outer tank has a lap-welded, dome-shaped steel roof. Total tank height to the top of the dome is $73 \mathrm{ft}$. Suspended from the roof framing of the outer tank is a lap-welded, metal deck that serves as a ceiling for the inner tank, as shown in Figure F.6. The height of the inner tank is $63 \mathrm{ft}$. Rock wool insulation is spread evenly over the deck. Open pipe vents are installed in the deck to allow product vapor to circulate freely in the insulation space to keep the insulation dry. Superheated vapors remain stratified in the upper space, while colder, saturated vapors are below the deck. The butt-welded outer steel shell and lap-welded steel roof provide permanent weather protection for the tank insulation as well as an air-tight seal.

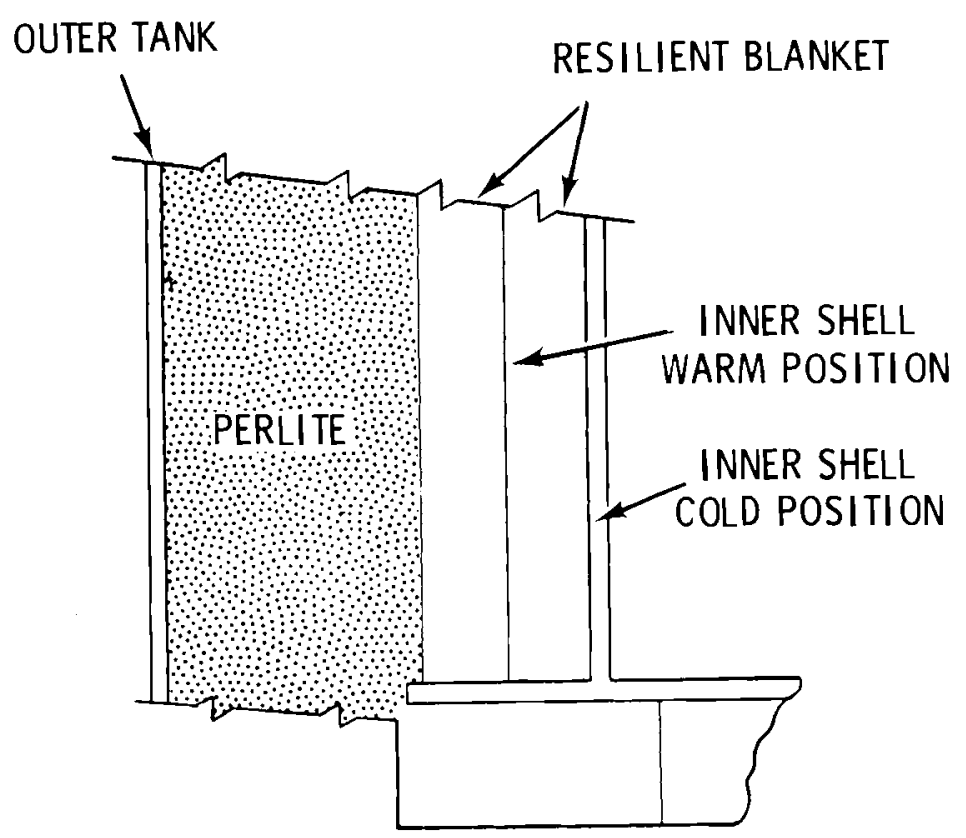

FIGURE F.5. Resilient Blanket in Annular Space Between Walls of LNG Storage Tank 


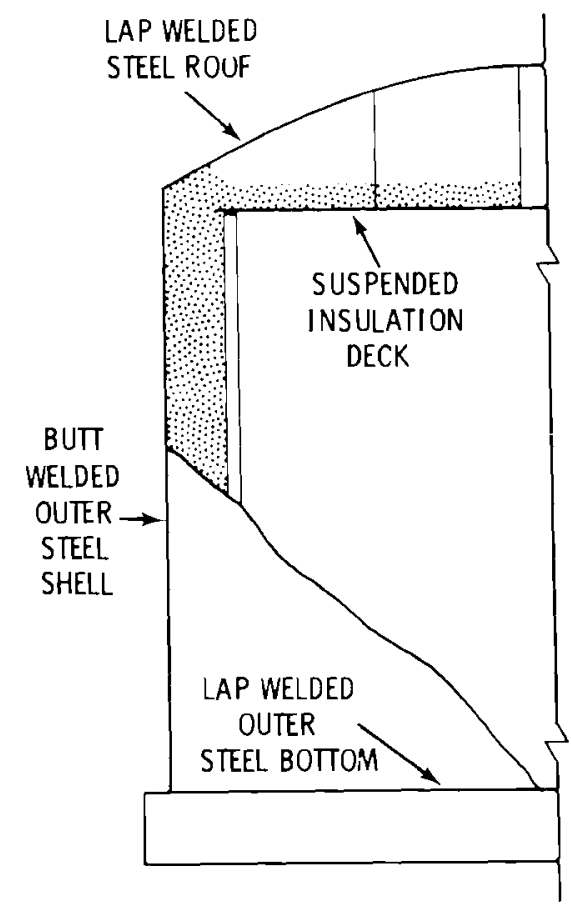

FIGURE F.6. Suspended Insulation Deck

The inner tank sits on load bearing insulation that carries the weight of the inner tank and its contents to the foundation (see Figure F.7). The bottom of the tank is a thin section of aluminum alloy AA5083 that serves only as a seal and is not subject to significant stress. The load bearing insulation rests on a level concrete pad which sits on the bottom of the outer tank. The outer tank sits on a reinforced concrete pile cap which rests on piles in the ground. Air passage under the tank bottom eliminates the need for a foundation heating system such as that used for tanks resting directly on the ground, as described in Section E.3.3 of Appendix E.

There are two sets of anchor bolts in the pile cap, one set connected to the outer tank wall and the other connected to the inner tank wall. These bolts hold down the tank against lifting forces resulting from internal pressure, but permit the vessel to move readily in response to thermal displacement.

The major connections are the inlet and outlet liquid lines in the bottom of the inner tank, the vapor outlet and pressure relief connections in the top 


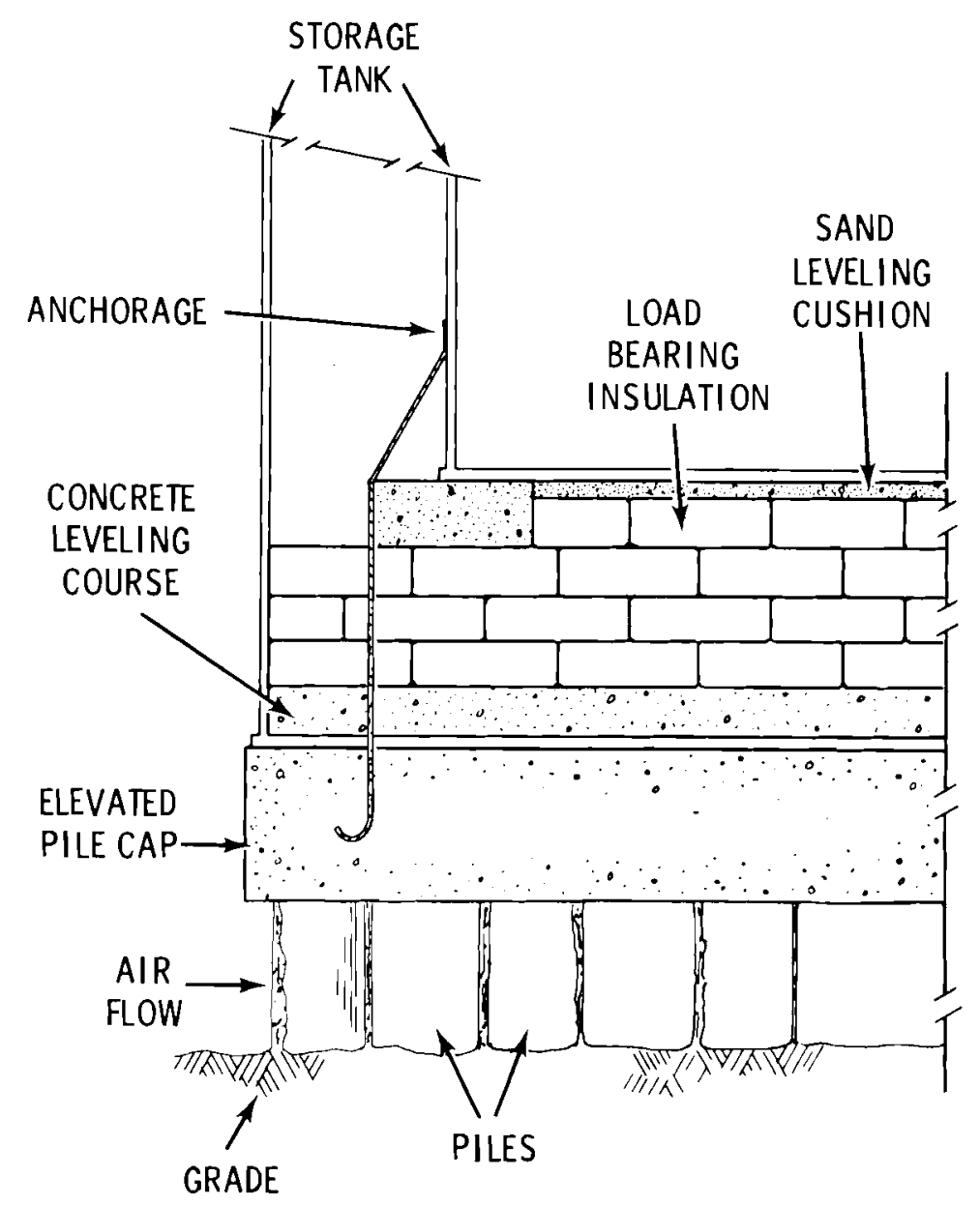

FIGURE F.7. Foundation for LNG Storage Tank

of the inner tank, and the relief vent in the top of the outer tank. All fittings which carry cold gases or liquids and pass through the outer carbon steel tank are provided with "distance pieces." These protect the outer shell from brittle fracture by dissipating cold before it reaches the carbon steel, and they also allow for thermal expansion and contraction without damage to fittings or the tank.

A11 materials of the inner tank, manholes, nozzle connections, and other appurtenances which come in contact with the liquefied natural gas, or which operate at or near the temperature of LNG, are made of AA5083 aluminum. 


\section{F.3.2.2 Pressure Control System}

The storage tank has a design operating pressure of 1 psig and a design maximum pressure of 2 psig. The maximum external pressure is 1 oz gauge. The pressure in the tank is controlled by adjusting the boiloff compressor recycle rate.

The boiloff compressors are heavy-duty industrial, slow-speed, reciprocating machines for continuous compression of the tank boiloff gases and vent gases from trailer unloading operations. Boiloff rate for the storage tank is $0.13 \times 10^{6}$ scfd $(0.1 \%$ of full tank capacity). The boiloff compressors have a total capacity of $0.15 \times 10^{6}$ scfd each, giving reserve capacity to handle intermittent truck unloading. Each compressor has high and low suction pressure alarms, a high discharge pressure alarm, a low temperature alarm on the inlet, and a high temperature alarm on the outlet. It is also equipped with the standard compressor alarms and trips for high vibration, low lube oil level or pressure, and high bearing temperature. The boiloff gases are heated by two electric heaters before being compressed. Piping and valves to the outlet of the heaters are all stainless steel; all other piping and equipment, including the compressor, are carbon steel.

The storage tank is equipped with two pressure relief valves that vent to the atmosphere at 2.0 psig. If tank pressure falls to 0.15 psig, gas from the pipeline is automatically brought back into the tank. If this is insufficient to prevent underpressure damage, two vacuum relief valves admit air to the tank when the pressure reaches 0.031 psig.

\section{F.3.2.3 Additional Instrumentation and Control Systems}

To monitor liquid level, the tank is equipped with a float-type liquid level device and a differential pressure gauge. A high-level alarm is activated at $95 \%$ of full capacity. Thermocouples in the inner tank shell and floor monitor cooldown.

In the event of an emergency, the storage tank is isolated from other equipment by block valves on the inlet and outlet lines. These valves are closed by the Emergency Shutdown (ESD) system. 


\section{F.3.2.4 Procedures}

Cooldown. The first step in the cooldown of the storage tank is to purge the tank with nitrogen. This prevents an explosive mixture from forming and also dries out the tank. The nitrogen purge is carried out from top to bottom with the nitrogen entering the 2-in. vapor outlet and leaving via the 4-in. downcomer on the 3-in. liquid fill line. Nitrogen also enters at the top of the dome through the relief vent and exits through the purge ring at the bottom of the outer tank, thus purging the annular space between tanks. If the tank has been taken out of operation and is filled with nitrogen, no purge is required.

After the purge, LNG is slowly admitted to the top of the tank via the 1-in. liquid return line. The LNG is deflected and sprayed over the floor. All storage tank thermocouples are continuously monitored to determine the effect of cooldown on the tank. The temperatures in the tank are carefully analyzed to make sure the maximum temperature gradients are not exceeded. The LNG flow rate is limited by these temperature gradients. When the liquid level in the tank reaches $1 \mathrm{ft}$ or more and the tank is sufficiently cooled, LNG can be fed through the normal liquid fill line.

The cooldown purges the nitrogen from the tank and the off gas is vented to the atmosphere. When methane reaches a specified concentration in the off gas, it is compressed and sent to the pipeline.

Heatup, Purging, and Entry. Prior to the heatup of the tank, the LNG level is lowered until the sendout pumps lose suction. This leaves approximately $1 \mathrm{ft}$ of LNG in the tank. Heatup is then begun by admitting natural gas, heated to $275^{\circ} \mathrm{F}$, into the $3-\mathrm{in}$. liquid withdrawal line in the bottom of the tank. The gas rises and disperses through the tank and leaves via the 2-in. vapor outlet line. The gas is compressed by the boiloff compressor and sent to the pipeline. The tank pressure is controlled the same as during normal operation. The inlet gas flow is maintained at approximately the normal boiloff rate, $0.13 \times 10^{6}$ scfd. At this rate, it takes approximately 20 days to warm the tank from $-260^{\circ} \mathrm{F}$ to $+60^{\circ} \mathrm{F}$. All storage tank temperatures are constantly monitored and analyzed to make sure the maximum temperature gradients are not exceeded. 
The storage tank must be purged to a $98 \%+$ nitrogen atmosphere before personnel entry. Liquid nitrogen is brought in by cryogenic trailer, vaporized, and admitted to the tank through the 3-in. 1iquid withdrawal 1 ine. The nitrogen is maintained at the lowest temperature possible $\left(\sim 20^{\circ} \mathrm{F}\right)$ to ensure a large difference between the densities of the gas in the tank and the nitrogen. This minimizes mixing and results in a piston effect. The gas exits through the vapor outlet, after which it is compressed in the boiloff compressor and sent to the pipeline. During most of the purging, the off gas is mostly methane. As the purge nears completion, however, the nitrogen content of the off gas rises rapidly. Because there is a limit on the nitrogen concentration in gas sent to the pipeline, the last portion of the off gas may have to be vented through the vent gas header to the atmosphere. Combustible gas detectors are located around the tank to detect any combustible gases descending from the vent. Established weather criteria define acceptable atmospheric conditions for venting.

When the inner tank is purged, the vapor outlet is blocked and the insulation fill holes and the relief vent in the tank dome are opened so the dome can be purged. After the dome is purged, the insulation fill holes and the relief vent are closed and the purge ring in the bottom of the outer tank is opened. Nitrogen then flows down through the insulation space and out of the purge ring, thus purging the annular space between the inner and outer tank walls. The tank can then be purged with air, as desired, using the same procedures.

\section{F.3.2.5 Release Prevention and Control Features}

The storage tank at the facility is surrounded by an earthen dike averaging $10 \mathrm{ft}$ in height and capable of holding approximately 44,000 bbl of LNG, as shown previously in Figure F.2. Site grading in the impoundment area ensures that any LNG spillage drains away from the tank. A high-expansion foam generation system installed in this area can be activated either manually or automatically by low-temperature detectors or UV fire detectors located in the pumpout area.

The following detectors, alarms, and fire protection equipment are located in the pump and storage areas: 
- combustible gas detectors

- low temperature detectors with alarms in control room

- Halon fire extinguishing system

- UV fire detectors which automatically activate the Halon system and the Master Emergency Shutdown (MES) system

- 20 lb dry chemical fire extinguisher

- fire hydrant.

A UV fire detector and dry chemical extinguisher are located on top of the storage tank near the relief valves. The extinguisher, directed at the relief valves, is activated by the UV detector. A fixed water deluge system is also included to direct water on the roof of the storage tank to keep it at a safe operating temperature during the maximum fire that could be expected at the terminal.

\section{F.3.2.6 Sendout Pumps}

The two LNG sendout pumps ( $\mathrm{P}-201 \mathrm{~A}, \mathrm{~B}$ ) are vertical submerged, pot-mounted LNG pump systems. The pumps and motor drives are hermetically sealed in a vessel and submerged in LNG. This design eliminates the extended shaft and associated seal. The pump and motor surroundings are 100\% rich with LNG and will not support combustion. The pumps are mounted in a suction pot below grade to provide sufficient suction head for operation.

Each pump has a capacity of 6 MMscfd or $50 \mathrm{gpm}$ for a total rated sendout capacity of $12 \mathrm{MMscfd}$. The operating temperature is $-260^{\circ} \mathrm{F}$ and the discharge pressure is 130 psig.

Each pump has two liquid discharge lines. The main lines join and go to the vaporizers. The secondary $l$ ines join and return to the storage tank. This liquid return line can be used to recirculate the tank contents if necessary. Each pump also has a vapor return line to the tank to vent vapors during startup and shutdown. 


\section{F.3.3 Vaporization and Sendout}

When there is a demand for gas from the satellite facility, LNG is drawn from the storage tank, vaporized, and sent out to the pipeline. Vaporization and sendout are described here.

The process flow diagram for the vaporization section is shown in Figure F.8. Associated process stream identifications are given in Table F.2.

TABLE F.2. Vaporization and Sendout System

$\frac{\text { Stream Identification }}{\text { ID Dlowrate (MMscfd) }}$

E LNG from Storage 12

Tank to Vaporizers

F Vaporized LNG to $\quad 12$

Pipeline

G Fuel Gas from Pipe- $\quad 0.02$

line to LNG Vaporizer

\section{F.3.3.1 Vaporizers}

The vaporizers for the plant are two submerged combustion units, each rated at $6 \times 10^{6} \mathrm{scfd}$ capacity. These units are designed such that the burners exhaust hot combustion gases directly downward through a downcomer and into a water bath below the liquid surface, as shown in Figure F.9. The exhaust bubbles into the water causing turbulence, mixing, and a "lifting" action. This lifting action forces the water up through an annular space created by a weir around the downcomer. The water flows over the top of the weir and into the more quiescent tank. Bath temperatures range from $90^{\circ} \mathrm{F}$ to $130^{\circ} \mathrm{F}$. A heat exchanger tube coil for the LNG is located in the annular space between the weir and the downcomer where it is scrubbed by the warm gas-water mixture, thus transferring heat to the LNG and vaporizing it. The submerged combustion technique results in a very high thermal efficiency of 94 to $96 \%$ because 1) all the water in the combustion products condenses and the high heating value (HHV) of the fuel can be 


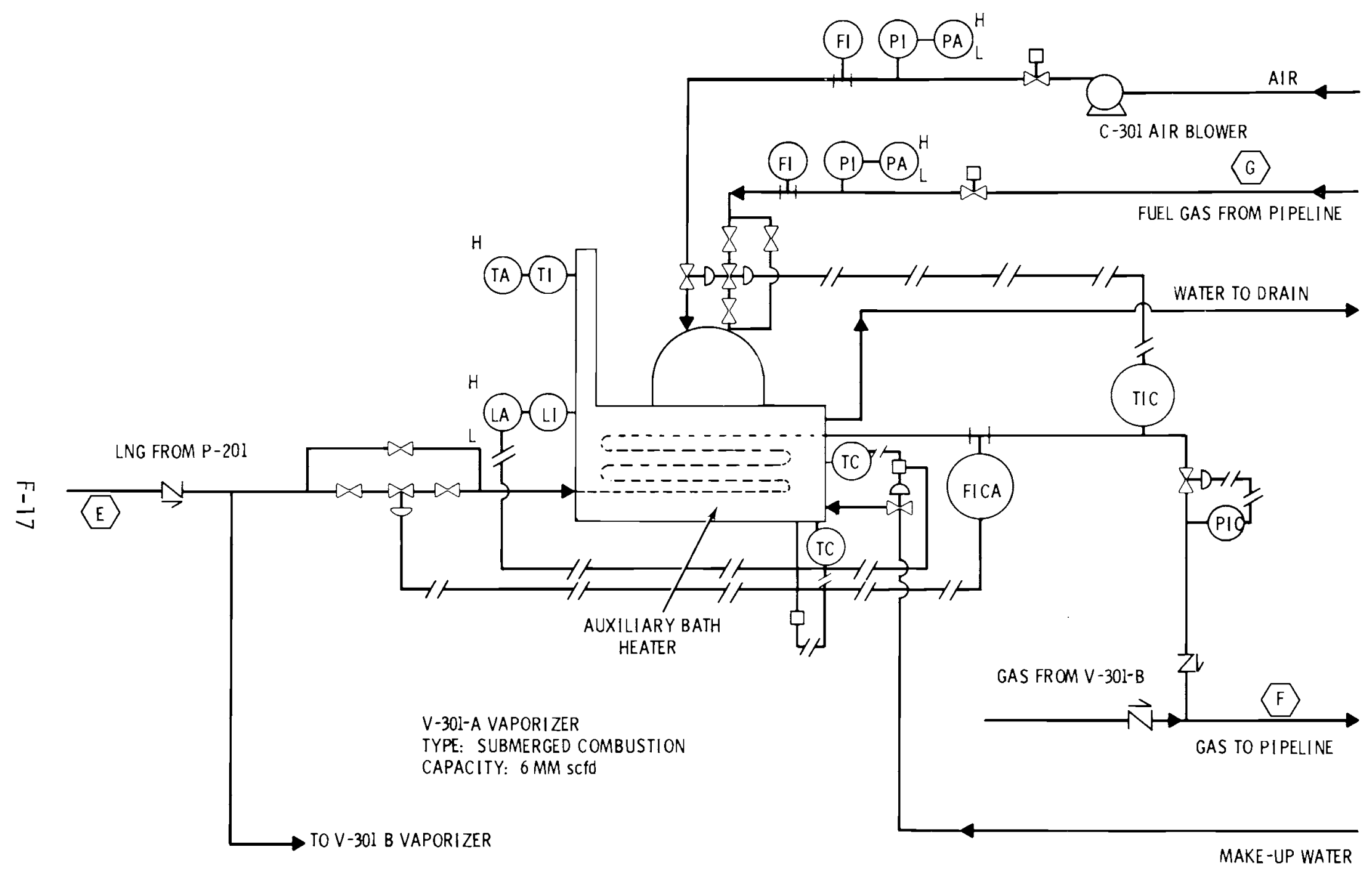

FIGURE F.8. Process Flow Diagram for LNG Vaporization and Sendout 


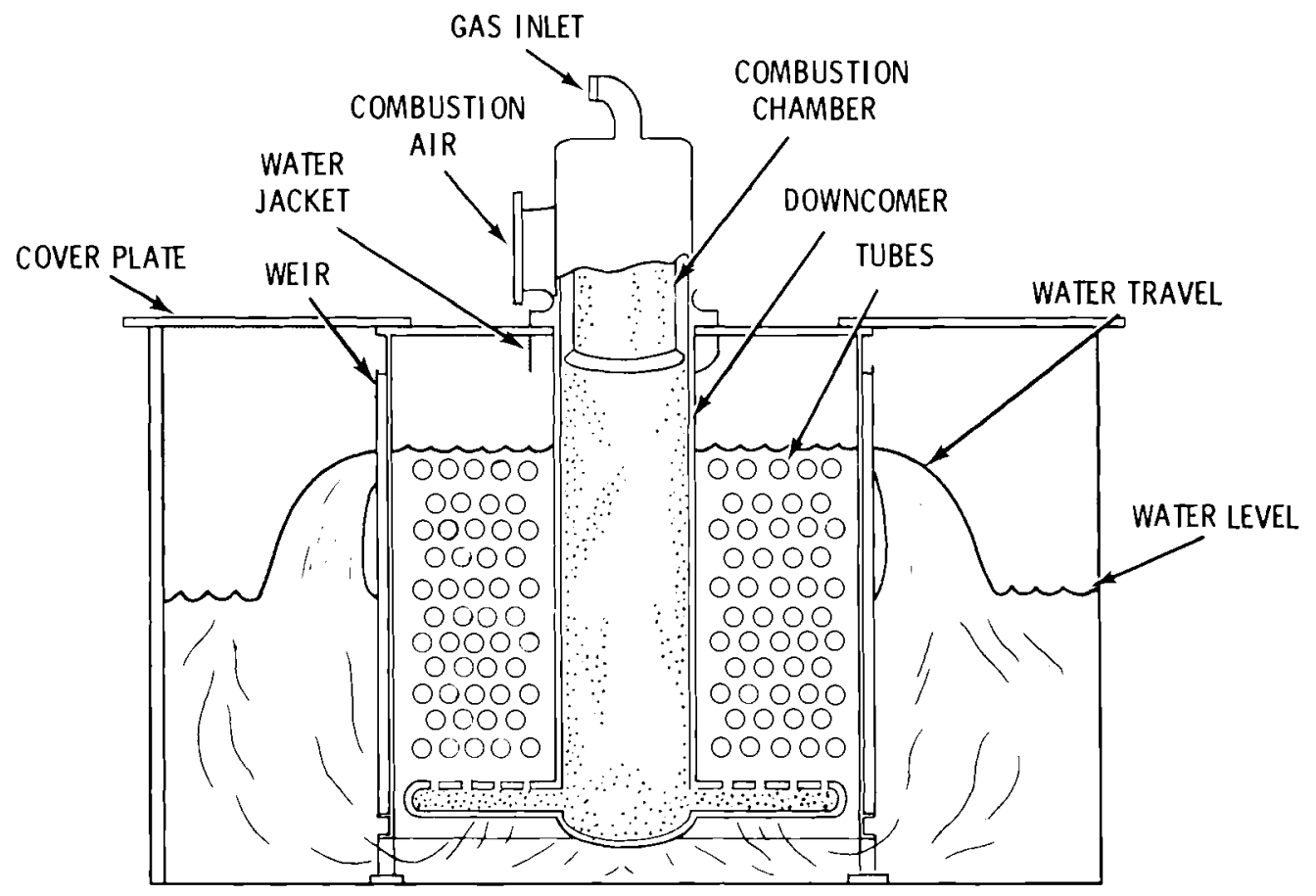

FIGURE F.9. Cutaway View of Submerged Combustion Vaporizer

used, and 2) the violent turbulence and mixing of the gas and water result in a high rate of heat transfer to the tubes. The vaporizers consume gas equivalent to 1.5 to $2.0 \%$ of the LNG vaporized.

Figure F.10 shows the major components of the vaporizers. The LNG inlet piping, tube bundle, and outlet piping to the first flange are all stainless steel construction. The rest of the outlet piping is carbon steel, as are the tank, weir, and downcomer. The section of each downcomer above the water bath is surrounded by a water jacket with continuously circulating water to cool the downcomer. A small pump sits at the surface of the water in the bath and pumps water to the water jacket on the burner. The burner, fuel gas piping, air inlet piping, and blower are all carbon steel. The overall dimensions of the vaporizer are approximate $1 y 10 \times 12 \mathrm{ft}$, with a height of $9 \mathrm{ft}$. The vaporizer is surrounded by a fiberglass building for weather protection. 


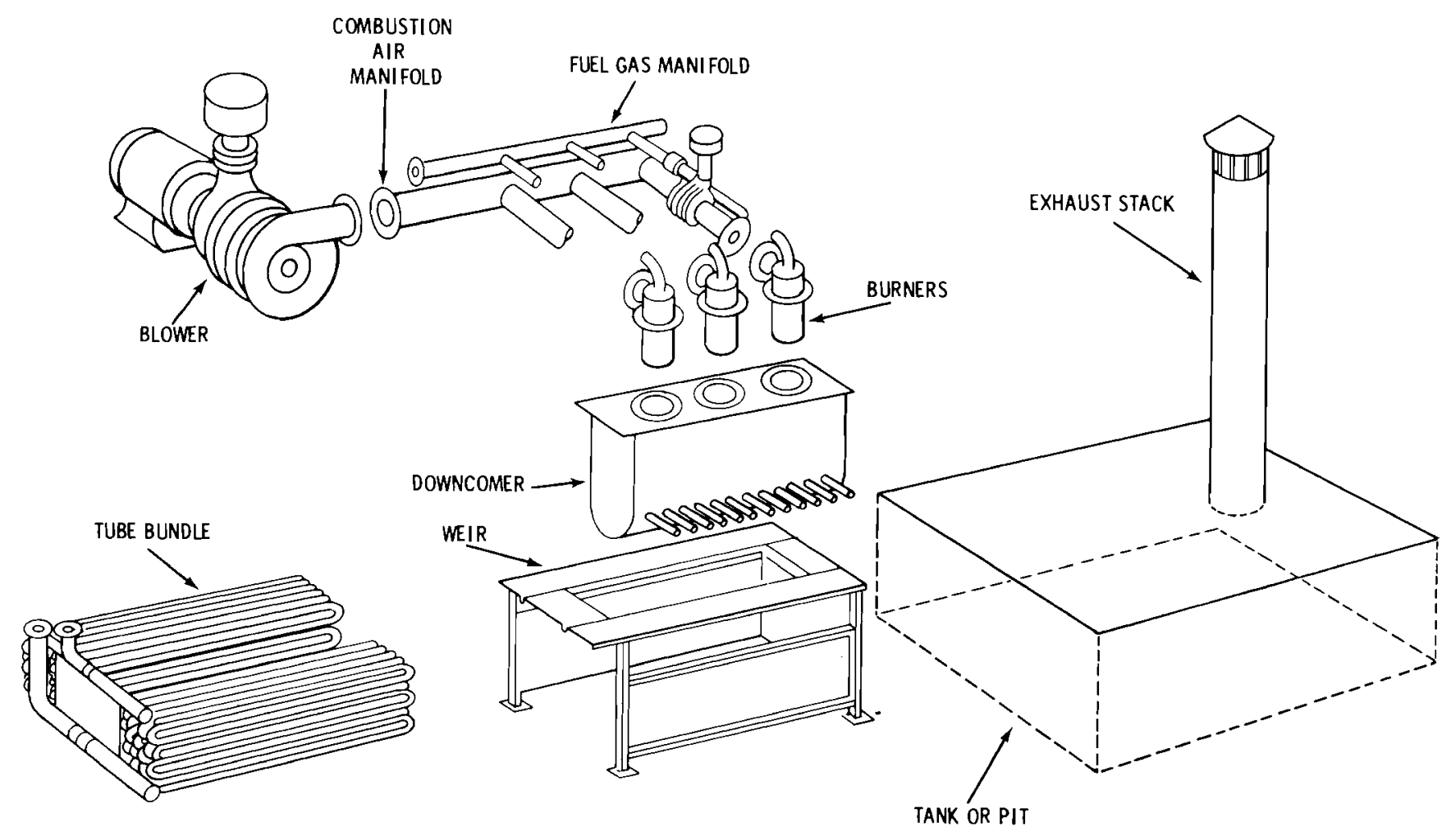

FIGURE F.10. Components of Submerged Combustion Vaporizers

\section{F.3.3.2 Control System and Instrumentation}

Two major controls are associated with the vaporizers:

- LNG flow control

- gas outlet temperature control.

LNG throughput is automatical1y controlled by a pneumatically operated control valve in the discharge line from the sendout pumps. The gas outlet temperature from the vaporizer is controlled by automatic adjustment of the air-operated control valves in the fuel gas and air supply lines.

Water level in the tank is controlled by several means. An overflow nozzle is located at the normal water depth to prevent high levels. Water flow into the bath is controlled to keep the temperature in the bath in the proper range. A low-level alarm and switch will override this temperature control and admit additional water if the water level falls too low. 
Other controls include a pneumatic fuel-pressure control valve and a pilot 1 ine with pressure regulator for the burner. (The instrumentation was shown previousiy in Figure F.8.)

The vaporization system is equipped with an automatic Vaporizer Emergency Shutdown (VES) system which, on activation, automatically shuts down the vaporizers and the LNG sendout pumps and isolates the pumps from both the vaporizers and the LNG storage tank. The VES can be activated manually at the vaporizers or the control room. The VES can also be activated automatically by a temperature sensor in the gas outlet line, a UV burner flame monitor, or the water bath level indicator. Normally the VES is automatically activated.

\section{F.3.3.3 Procedures}

To start the LNG pumps, the discharge valve to the vaporizers is closed and the pumps are operated on total recycle until they cool down. The vapor produced by cooling the pumps is vented back to the storage tank through the 1-in. vapor return line. The burners on the vaporizers are fired and the water bath heated to the proper operating temperature $\left(95\right.$ to $\left.130^{\circ} \mathrm{F}\right)$. At this point, the discharge valve on the pumps is opened to the vaporizers and a small flow of LiNG starts. The rest of the startup is semi-automatic, with the burner firing rate and the LNG flow rate both gradually increased until the desired flow rate is reached.

Shutdown of the vaporizers is also semi-automatic, with the LNG flow and burner firing rate gradually decreased. The large heat-storage capacity of the water bath permits fairly rapid startup or shutdown of the vaporizer with little variation in the process outlet temperature.

The vaporizers can also be shut down by the MES and VES systems (see Section F.4.1).

\section{F.3.3.4 Release Prevention and Control Features}

Each vaporizer building has two combustible gas detectors. An additional detector is located near the air blower outside the building. Each detector has four indicating lights located on the control panel to denote: 
1. "Safe" condition

2. "Warning" condition, which signifies a gas concentration of approximately $25 \%$ of the Lower Flammable Limit (LFL) of methane.

3. "Danger" condition, which indicates a gas concentration of approximately $60 \%$ or greater of LFL (this condition also sounds an alarm).

4. "Trouble," which indicates a malfunction of the gas detection system.

The warning condition automatically activates a high-rate ventilating fan to reduce the gas concentration in the vaporizer building. If the danger condition still results, the fan is turned off and the building openings closed automatically. The Halon fire extinguisher system is then discharged automatically.

The fire extinguishment system in the vaporizer building is a Halon (halogenated hydrocarbons 1301 and 1212) inerting and fire extinguishment, total flooding system. This system can be used not only to extinguish natural gas fires but also to inert an enclosure and prevent an explosion. The Halon system is activated by a UV detector sensitive to the ultraviolet radiation from flames. It can also be activated by the combustible gas detection system.

The UV fire detectors have very fast, adjustable ( 0 to 30 seconds) response times. They detect very small fires in any wind condition. However, the UV sensors tend to give false alarms from such things as reflected welding arcs, and they use $A C$ power and thus are sensitive to induced currents and power fluctuations. The detectors are often turned off when construction or maintenance requires welding in the area. Activation of the Halon or other fire fighting systems requires simultaneous signals from two UV detectors located in the same area.

The first flange on the vaporizer outlet piping marks the change from cryogenic materials for $L N G$ (aluminum alloy) to carbon steel construction for natural gas. As a result, the vaporizer contains several safeguards to ensure that cold LNG does not reach the carbon steel piping where it could cause a failure due to embrittlement. A11 burners are equipped with UV flame detectors that alarm in the control room in the event of flameout. The UV detector can also be tied in to the VES to shut down the vaporizer in case of a burner flameout. The water bath contains a significant amount of thermal storage, thus preventing immediate carryover of LNG to the outlet piping after burner flameout. 
The outlet line also has two temperature sensors that are independently tied to alarms in the control room and to the VES. The water bath is equipped with an electric heater to help prevent freeze-up of the bath during abnormal operating conditions, particularly shutdown.

\section{F.4 GENERAL PLANT INFORMATION}

The following subsections provide general information on various aspects of the LNG satellite facility and its operation.

\section{F.4.1 Emergency Shutdown System}

The operation and activation of the Emergency Shutdown (ESD) system for the satellite facility are described here.

\section{F.4.1.1 Operation of Emergency Shutdown System}

The plant emergency shutdown system consists of two separate systems, the Master Emergency Shutdown (MES) and the Vaporizer Emergency Shutdown (VES).

The MES allows the rapid shutdown of the plant and isolation of the various plant systems. When activated, the MES automatically initiates the following actions:

1. Electrical supplies to all normal plant circuits are de-energized; essential plant electrical equipment (e.g., fire pumps, fire and gas detectors, fire system valve operators) remains energized.

2. Natural gas valves at plant boundaries are closed to isolate the plant from the natural gas pipeline. These valves include:

- gas from vaporizers

- boiloff gas from storage tank

- fuel gas to vaporizers.

3. The LNG tank and dike area is isolated from the remainder of the plant by the following:

- valves at the LNG pump suction are closed

- LNG pump motors are shut down

- block valves between the LNG pumps and the vaporizers are closed. 
4. A telemetric signal "MES Tripped" is transmitted to company's head office.

5. With loss of instrument air, all control valves go to their fail-safe positions.

6. Gas from all gas handling equipment and lines is vented through the relief header to the vent stack.

The second shutdown system, the VES, allows the rapid shutdown and isolation of a 11 LNG sendout systems. When activated, the VES automatically initiates the following actions:

1. The following natural gas valves at the plant boundaries are closed:

- gas from vaporizers

- fuel gas to vaporizers.

2. LNG pump motors are shut down.

3. Block valves between the pumps and the vaporizers are closed.

4. Pump suction valves on the liquid withdrawal lines are closed.

5. Gas from all gas handling equpiment and lines is vented through the relief header to the vent stack.

The MES and VES circuits are energized with a $525-\mathrm{kW}$, gas-engine-driven generator, with a second unit for $100 \%$ standby, that maintains these systems energized and ready for operation. When these circuits are de-energized (failsafe), the emergency shutdown actions described above are initiated.

\section{F.4.1.2 Activation of Emergency Shutdown System}

Both the MES and VES can be activated manually at the control room and at the two plant exit gates. The MES can also be operated automatically by the ultraviolet (UV) fire detectors that monitor the following areas:

1. compressor building

2. vaporizers

3. LNG pumps

4. piping on or adjacent to pipe racks next to compressor building. 
The VES is normally activated automatically by a temperature sensor in the vaporizer gas outlet line (low temperature), by the UV flame monitors on the vaporizer burners (burner flameout), or by the water bath level indicator (low level).

\section{F.4.2 Plant Fire Protection}

A combination of dry chemical, high-expansion foam, and water systems has been installed at the plant for fire protection.

Water from a 750,000 gal storage tank is provided to a 10-in. ductile-iron, fire-water loop by an engine-driven fire pump. A second engine-driven pump provides a $100 \%$ standby. Fire plugs with hose, nozzles, and hose cabinets are located throughout the plant. Nozzles are a combination stream and fog type with shutoff.

Monitor nozzles are strategically located to provide cooling water for major plant components. Monitor nozzles are handwheel operated for elevation, with lockable bal1-bearing swivel bases for full $360^{\circ}$ horizontal rotation. Elevation is by wheel-operated worm gear, which locks positively unless the wheel is turned. Each nozzle, discharging $350 \mathrm{gpm}$, is adjustable for straight stream, narrow fog, or wide fog water pattern.

Localized impoundment wells made of insulated concrete are provided for truck unloading stations, vaporizers, and sendout pumps. Manual dry chemical systems with hose lines are provided to make dry chemical available to plant equipment.

High-expansion foam is produced by water-motor-driven fans supplied with a mixture of foam concentrate (biodegradable detergent) and water at fire main pressure of $125 \mathrm{psig}$. These units produce foam having an expansion ratio of 500:1 in sufficient quantity to maintain a 3-ft-thick blanket of foam over a 11 impounding areas. This blanket serves to warm the vapors produced by a spill, providing control of the vapor cloud by reducing the distance of travel to reach a temperature of positive buoyancy. It also serves, in case of ignition, to reduce both the effect of radiant energy from a fire and the rate of pool evaporation, reducing the heat release to $5 \%$ of the amount with no foam blanket. 
In the event of a spil1, high-expansion foam generators are activated automaticaliy by a temperature sensor in the impoundment sump, and both high-expansion foam and dry chemical units are activated by UV detectors if ignition takes place.

\section{F.4.3 Venting}

A11 gas 1 ines and gas handling equipment, including those in the loading area, can be vented to the vent stack through the vent gas header. Gas is not normally vented except in the case of an emergency shutdown, when the MES automatically vents all gas 1 ines and gas handling equipment. The LNG sendout pumps are vented back to the storage tank via the 1-in. vapor return line.

The storage tank has two pressure relief valves that vent to the atmosphere. Normal off gas from the storage tank is handled by the boiloff compressor. The relief valves open only when needed to protect the tank from overpressure.

A11 vessels or sections of LNG lines that can be isolated with LNG in them and allowed to warm are protected by relief valves venting to the atmosphere.

\section{F.5 SOURCES OF INFORMATION}

The LNG satellite plant description was developed using information from the sources listed below.

1. LNG Equipment Vendors:

Chicago Bridge and Iron - Cryogenic Storage, Bulletin No. 8600,

Chicago Bridge and Iron - Cryogenic Systems, Bulletin No. 8650,

Chicago Bridge and Iron - USA Standards for Design and Construction of LNG Installation, Bulletin No. 831,

Ryan Industries - Sub-X Vaporizer, Product Bulletin No. LNG-200, Ryan Industries - Satellite and Transport Systems for Liquefied Natural Gas, Bulletin LNG-100,

Pittsburgh-Des Moines Steel Company - LNG Storage Tanks, Bulletin No. 303. 
2. Open Literature:

Devanna, L. and G. Doulames, "Planning is the Key to LNG Tank Purging, Entry and Inspection." 0il and Gas Journal, pp. 74-82, September 8, 1975.

Hanke, C. C., I. V. LaFare, and L. F. Litzinger, "Purging LNG Tanks Into and Out of Service, Considerations and Experiences." Paper presented at the AGA Distribution Conference, Minneapolis, MN, May 6-8, 1974.

Gas Processing Handbook Issue. Hydrocarbon Processing, pp. 132-138, Apri1 1973.

LNG Information Book, prepared by the LNG Information Book Task Group of the Liquefied Natural Gas Committee, American Gas Association 1973.

Crawford, D. B. and G. P. Eschenbrenner, "Heat Transfer Equipment for LNG Projects." Chemical Engineering Progress, pp. 62-70, September 1972.

Anderson, P. J. and E. J. Daniels, "The LNG Industry: Past, Present, and Future." Prepared by Institute of Gas Technology for U.S. ERDA Under Contract No. EE-77-C-02-4234.

Seroka, S. and R. J. Bolan, "Safety Considerations in the Installation of an LNG Tank." Cryogenics and Industrial Gases, pp. 22-28, September/0ctober 1970.

LNG Economics and Technology (ed. by Dean Hale) Library of Congress Catalog Card No. 74-79766, copvright 1974 by Energy Communications, Inc., Petroleum Engineer Publishing Co.

Bennett, W. F., Algerian LNG Plays Dual Peakshaving Role in Georgia." Pipel ine and Gas Journa 1, pp. 54-58, November 1978.

De1 Tatto, D. L., "LNG - Satellite Peakshaving." Presented at the American Gas Association Distribution Conference, Houston, TX, May 6-9, 1968, $12 \mathrm{pp}$.

Wakefield, B. D., "Plant Launches LNG Sate11ite." Iron Age, pp. 78-79, November 13, 1969.

Stevens, J. L., Sr., "LNG - From Wellhead to User by Highway Tanker Transport." Pipeline and Gas Journal, pp. 32-34, May 1975.

Fowler, D. B., J. M. Burns, "Trucking Gas: A New Way to Market Isolated Reserves." World 0i1, pp. 71-75, November 1977.

Parker, M. L. "Automated Truck Load-Out System." Chemical Engineering Progress, Vo1. 65, №. 4, pp. 58-60, Apri1 1969. 
Warner, V. A., "Liquefied Natural Gas Fire Control." Paper presented at the AGA Transmission Conference, Las Vaga, NV, May 3-5, 1976.

Brock, N. H. and R. M. Howard, "Upgrading LNG Plant Safety." Paper presented at the AGA Transmission Conference, Bal Harbour, FL, May 19$21,1975$.

Wesson, H. R., "Consideration Relating to Fire Protection Requirements for LNG Plants." Paper presented at the AGA Transmission Conference, Bal Harbour, FL, May 19-21, 1975.

Wissmiller, I. L. and E. 0. Mattocks, "How to Use LNG Safely." Pipeline and Gas Journal, March 1972.

Schulz, F. P., "Safety at an LNG Peakshaving Facility." Paper presented at the ASME Winter Annual Meeting, New York, NY, November 17-22, 1974.

Smith, L. R., "Submerged Pumps for LNG Sendout." Paper presented at AGA Distribution Conference, 1968.

Anderson, P. J. and W. W. Bidle, "Safety Considerations in the Design and Operation of LNG Terminals." Paper presented at the 4th International LNG Conference, Algiers, Algeria, June 24-27, 1974.

Durr, C. A., "Process Techniques and Hardware Uses Outlined for LNG Regasification." 0il and Gas Journal, May 13, 1974.

Durr, C. A. and D. B. Crawford, "LNG Terminal Design." Hydrocarbon Processing, November 1973.

Hale, D., Ed., "Peakshaving Supplies Reach A11-Time High for 1978-1979 Winter." Pipeline and Gas Journal, November 1978.

Sarkes, L. A., et a1., "LNG: Current Status Confirms its Technical Maturity." Pipeline and Gas Journal, November 1978. 
APPENDIX G

ANALYSES OF REPRESENTATIVE RELEASE EVENTS 

APPENDIX G

\section{ANALYSES OF REPRESENTATIVE RELEASE EVENTS}

Representative release events for the LNG facilities considered in this study are developed in Sections 3 through 7 . These representative release events are analyzed in this appendix. Included in the analysis of each release event are:

- possible initiating events leading to the potential release

- results and effects of release prevention and control systems (includes magnitude of release)

- additional information required for more accurate or complete analysis of the event

- potential design and operational changes that could prevent or reduce the consequences of the release.

The arialyses presented here are only preliminary. Fore detailed technical and cost evaluations are needed before any specific design modifications can be recommended.

In most cases, the release quantities calculated in this appendix are miaximums, based on plant throughput capacities and component inventories given in the facility descriptions (Appendices B through F). Several simplifying assumptions are made to facilitate the analyses:

1. Shutdown times are chosen to be realistic and representative of actual times for the event in question. In most cases, two shutdown times are considered: 1 minute for automatic or manual shutdown with the emergency shutdown (ESD) system and 10 minutes for manual shutdown without the ESD (e.g., ESD fails to operate).

2. Leak rates are assumed to be step functions, with the flow continuing at a constant level for the specified time and then ceasing instantaneously. It is recognized that this is somewhat inaccurate in that, as shutoff valves close, the flow will gradually be reduced. However, because of a 
lack of good data and the preliminary nature of these analyses, the approach used is judged to be sufficiently accurate.

3. Due to a lack of good data, no speed-up of pumps (or compressors) is assumed to result from breaks in the lines pressurized by the pumps (or compressors), even though the drop in back pressure is likely to allow a certain amount of speed-up to occur.

4. Holdup of LNG and natural gas in lines and equipment drained by a leak is calculated to be realistic (i.e., representative of actual conditions at the facility).

Any other assumptions used are described in the specific analyses to which they apply.

\section{G. 1 REPRESENTATIVE RELEASE EVENTS FOR THE LNG EXPORT TERMINAL}

The potential release events chosen to be representative of the reference LNG export terminal are 1 isted in Table G.1. (The facility description of the reference export terminal appears in Appendix B.) The analyses of the individual events are presented below.

TABLE G.1. Representative Release Events for an LNG Export Terminal

1. Rupture of the $36-$ in. main transfer 7 ine between the loading pumps and the dock.

2. Rupture of the $24-i n$. liquid outlet 1 ine between the storage tank and the first block valve.

3. Rupture of a 16-in. loading arm.

4. Storage tank pressure relief valves open.

5. Storage tank vacuum relief valves open.

6. Inner tank is overfilled with LNG.

7. Complete failure of storage tank.

8. Rupture of 18-in. feed gas line in liquefaction train.

9. Rupture of $20-i n$. mixed refrigerant liquid piping between high pressure separator and main cryogenic heat exchanger.

10. Rupture of 10-in. nozzle to propane/mixed refrigerant exchanger.

11. Failure of a refrigerant compressor (propane or mixed refrigerant).

12. Rupture of $12-i n$, transfer line from 1 iquefaction area to the starage tanks.

13. Rupture of outlet nozzle or piping on refrigerant storage tanks (propane, e thylene). 
G.1.1 Rupture of the 36-in. Main Transfer Line Between the Loading Pumps and the Dock

Possible Initiating Events

- Failure of valve closure control mechanism causes valve to close too fast and the resulting fluid hammer overpressures the line. (low probability)

- The line is blocked and filled with LNG and the drain system is not activated. The line heats up and the relief valves do not function properly, causing the line to overpressure. (low probability)

- Fatigue failure from thermal cycling and pressure cycling. (The transfer line is normally kept at operating temperature and pressure by circulating LNG.) (low probability)

- Failure of valve body or pipe fittings. (low probability)

- Failure at the expansion joint. (medium probability)

- Stresses to trestle support from large waves, winds, or earthquakes. (low probability)

Results and Effects of Release Prevention and Control Systems

- ESD shuts off the loading pumps within 1 minute of spill, limiting release to contents of the 1 ine, 170,000 gallons.

- ESD is not activated or fails to respond. It takes operator 10 minutes to shut down system. The maximum release is 670,000 gallons.

- If the spill occurs at the dock, it will drain into a containment area. If the spill occurs in the middle of the trestle, it will drain into the ocean. If the spill occurs near the loading pumps, it will drain into the diked area.

Additional Information Required

- What are the details of the ESD, i.e., how fast it would be activated and how fast it isolates the system?

- What are the details of drain system--if a break occurs, how fast and how much of the line can be drained into a containment area? 
- What is the failure frequency of long, large cryogenic pipes and fittings?

Potential Design and Operational Changes

- Install a double-pipe transfer line or some type of enclosure around transfer line to contain a spill.

- Two smaller lines (e.g., 24 in.) could be used instead of the large 36-in. line. The smaller valves, expansion joints, and other fittings may be more reliable, thus reducing the probability of failure. 


\section{G.1.2 Rupture of the 24-in. Liquid Outlet Line Between the Storage Tank and}

the First Block Valve

Possible Initiating Events

- Fatigue failure from pressure and thermal cycling. (low probability)

- Failure of block valve or pipe fitting. (low probability)

- Failure of expansion joint. (medium probability)

- Fluid hammer. (low probability)

Results and Effects of Release Prevention and Control Systems

- Gas detector warns operator who closes the internal block valve. Elapsed time - one minute, maximum spill volume - 110,000 gallons.

- Gas detectors fail or operator ignores warning and internal valve is not closed for 10 minutes. Maximum spill- $1.1 \times 10^{6}$ gallons.

- Internal valve fails and cannot be closed. Entire tank contents are spilled. Maximum spill is $23 \times 10^{6}$ gallons.

- Spills will be contained by diked area around the storage tanks.

Additional Information Required

- What is the failure frequency of large cryogenic pipes and fittings?

- What are the details on operation of the internal valve and possibility of failure?

Potential Design and Operational Changes

- Internal block valve could be activated by the Master Emergency Shutdown system. 


\section{G.1.3 Leak or Rupture of a 16-in. Loading Arm}

Possible Initiating Events

- Bad make-up of the flange connection with the ship. (medium probability)

- Loading-arm swivel joint fails from excessive motion or lack of inspection and maintenance. (medium probability)

- Fatigue failure from thermal and pressure cycling. (low probability)

- The loading arm is blocked in and not drained. The line heats up and the relief valves do not function properly, causing the line to fail from overpressure. (low probability)

- Failure of hydraulic power unit prevents arm from moving freely, resulting in rupture of arm. (low probability)

- Emergency uncoupling prior to shutting down system. (low probability)

- Failure of motion indicator to activate ESD system in the event of excessive ship motion causes rupture of loading arm. (low probability)

- Another vessel collides with LNG tanker while it is docked. (low probability)

\section{Results and Effects of Release Prevention and Control Systems}

- The ESD shuts off loading pumps and closes block valves within 1 minute after spil1. Maximum spill volume would be 14,000 gallons.

- The ESD is not activated or fails to respond, and it takes 10 minutes for operator to shut down system. Maximum release is 140,000 gallons.

- Spills will drain into the containment area under loading arms, except for spills at flange connection which could spill on to ship and into the water.

- Leaks from swivel joints and other failures could spray all over dock area.

Additional Information Required

- What are the details of operation of the ESD, i.e., how fast a spill is detected and how soon the ESD shuts down the system?

- What is the failure frequency of cryogenic, marine loading arms? 


\section{G.1.4 Storage Tank Pressure Safety Valves Relieve.}

If these valves fail on demand or their capacity $(792,000 \mathrm{lb} / \mathrm{hr})$ is exceeded, the storage tank could fail from overpressure.

\section{Possible Initiating Events}

- Refrigerant systems shut down but natural gas flow is not stopped either by temperature override of flow control valve or manually by the operator. Tank reaches vent pressure in two minutes and vent rate is $350,000 \mathrm{lb} / \mathrm{hr}$. (9.4 $\times 10^{4}$ equivalent gallons liquid) (medium probability)

- LNG leaving liquefaction train is not sufficiently cooled because of failure of the liquefaction process control equipment or because controller setpoints are wrong. If temperature is within $14^{\circ} \mathrm{F}$ of tank saturation temperature, boiloff compressor will handle vapor produced. If temperature is $17^{\circ} \mathrm{F}$ above saturation, the tank will reach relief pressure in 20 to 60 minutes and the vent rate would be 8,000 to $26,000 \mathrm{lb} / \mathrm{hr}$. (2.2. $\times 10^{3}$ to $7.0 \times 10^{3}$ equivalent gallons liquid) (medium probability)

- Rollover - the amount of vapor vented depends on excess thermal energy of feed and on filling rate. (low probability)

- Boiloff compressor or pressure controller fails and no vapor is removed from the tank (e.g., power failure). At normal boiloff rates, it would take 4 to 5 days to reach vent pressure. Vent rate $2000 \mathrm{lb} / \mathrm{hr}$. (5.4 $\times 10^{2}$ equivalent gallons 1iquid) (medium probability)

- Insulation failure - this is not likely to cause overpressure, as total failure would only increase boiloff to $5000 \mathrm{lb} / \mathrm{hr}$, which can be handled by one compressor. $\left(1.3 \times 10^{3}\right.$ equivalent gallons liquid) (low probability)

Results and Effects of Release Prevention and Control Systems

- Vapor released by relief valves will be denser than the air and will tend to drift downward. 
- If the relief valves fail, the tank could overpressure and split. Split would most likely occur at roof-wall seam and only vapor would be released.

- Failure at roof joint could possibly cause failure of entire tank.

- There is little chance of rollover occurring if feed composition is constant and liquefaction operation is normal.

- Tank contains top and bottom fill nozzles. The bottom fill nozzle empties into a 60-in. stilling well and flashes at tank conditions. The liquid is dispersed out holes at the bottom of the well.

- If light feed is bottom filled and heavy feed top filled, chances of stratification are less.

- If the tank became stratified and rollover occurred, the resulting vapor produced would be reduced by the fact that all feed is flashed at tank conditions. The resulting vapor produced would be equal to the heat leak into the bottom layer.

\section{Additional Information Required}

- What is the frequency of relief valve failure and the effect of inspection and testing on frequency of failure?

- What are the frequencies of liquefaction plant upsets and product control valve failures? Combination could lead to overpressure of tank.

- If tank overpressures and relief valves fail or are not large enough, where will tank fail and what is likelihood of the whole tank collapsing?

Potential Design and Operational Changes

- Design tank to withstand higher pressures.

- Design tank to split at roof/wall seam, leaving bottom container intact in the event of overpressure. (This is normally the case for LNG tanks.) 


\section{G.1.5 Storage Tank Underpressures and Vacuum Relief Valves Open.}

If these valves fail or are not large enough, storage tank could collapse. Possible Initiating Events

- The following events can cause the pressure in the storage tank to fall:

- Pressure control system fails or is inoperable and both boiloff compressors are run at full speed. Will take 36 minutes to reach vacuum relief pressure. (medium probability)

- No vapor is returned to tank during ship loading. The tank will reach 0.03 psig in 12 minutes. (medium probability)

Results and Effects of Release Prevention and Control Systems

In each of these cases, the emergency gas supply system would be automatically activated before the relief valves would open. For the relief valves to open, the emergency gas supply system would have to fail to operate or not have a large enough capacity.

\section{Additional Information Required}

- Capacity of emergency gas supply system and frequency of failure of control valve and controller.

- Frequency of relief valve failure and effect of inspection and testing on frequency of failure.

Potential Design and Operational Changes

- Design tank to withstand higher vacuum. 


\section{G.1.6 The Storage Tank is Overfilled with LNG.}

The LNG covers the suspended ceiling and flows down the annular space between the tank walls.

Possible Initiating Events

- Two levels of failure are required:

- High level alarm fails, or level indicator gives improper reading, or operator ignores high level alarm.

- The high-high level signal fails to activate shutdown system or level indicator gives improper reading and does not activate alarm. (low probability)

- Liquid sloshes over inner wall due to horizontal acceleration of the tank from earthquake. (low probability)

Results and Effects of Release Prevention and Control Systems

- The consequences of overfill are hard to determine. The insulating properties of the perlite in the annular space would be reduced, increasing heat leakage to 2-1/2 times normal. The outer carbon steel shell could fail and the roof fall, causing the inner tank to fail.

- The inner tank has $13 \mathrm{ft}$ of freeboard (distance from maximum liquid level to top of tank) to prevent liquid from sloshing over.

Additional Information Required

- What effect would overflow have on the following parts of the tank?

- Suspended ceiling

- Insulation

- Outer tank

- Details on level indicator and likelihood of it giving an incorrect reading.

Potential Design and Operational Changes

- Construct outside tank of materials suitable for cryogenic service. 
- Provide the tank with an overflow line to prevent spilling into the annular space between the inner and outer tanks. 


\section{G.1.7 Storage Tank Fails.}

Size of spill could be up to 550,000 bbls $\left(2.3 \times 10^{7}\right.$ gallons $)$ for a total failure.

\section{Possible Initiating Events}

- Overpressure or underpressure of outer tank (see other release events)

- Sabotage (low probability)

- Large earthquake (low probability)

- Airplane crash (low probability)

- Fire and explosion in other sections of the plant (low probability)

- Stress from thermal and pressure cycling (low probability)

- Stress corrosion (low probability)

- Failure of shell-to-roof welds, nozzle welds, or shell-to-bottom welds (low probability)

- Differential settling of foundation or frostheave resulting from heater failure (low probability)

Results and Effects of Release Prevention and Control Systems

- Overpressure or underpressure do not necessarily cause complete failure.

- The high, small-diameter dike surrounding the tank holds $133 \%$ of full tank contents.

\section{Additional Information Required}

- What is the effect of fire or explosions in other sections of the plant on the storage tank?

- What effect will collapse of the tank have on the structural integrity of the dike?

- What design factors are included to account for cycling stresses?

Potential Design and Operational Changes

- Build the tank underground. 


\section{G.1.8 Rupture of 18-in. Feed Gas Line in Liquefaction Train.}

Possible Initiating Events

- A leak from cold line contacts carbon steel line and causes it to fail. (medium probability)

- Fatigue from static and cyclic stresses. (1ow probability)

- Failure of valve body or pipe fitting. (low probability)

Results and Effects of Release Prevention and Control Systems

There are no gas detectors in area, so operator would have to notice spill - low pressure in pipeline would be an indication of a break. Depending on how long it takes to isolate the system, the maximum releases would be:

$$
\begin{array}{ll}
1 \text { minute } & \begin{array}{l}
1.7 \times 10^{5} \mathrm{scf}\left(2.1 \times 10^{3}\right. \text { equivalent } \\
\text { gailons } 1 \text { iquid })
\end{array} \\
10 \text { minutes } & 1.4 \times 10^{6} \mathrm{scf}\left(\begin{array}{c}
\left(1.7 \times 10^{4}\right. \text { equilvalent } \\
\text { gailons } 1 \text { iquid })
\end{array}\right.
\end{array}
$$

\section{Additional Information Required}

- Does pressure indicator in the line alarm in the control room? Is there other instrumentation that would indicate a pipe break?

- How long would it take operator to isolate the system?

Potential Design and Operational Changes

- Put combustible gas detectors in liquefaction area.

- Pressure indicator in feed gas 7 ine could activate the MES in the event of low or high pressure.

- The MES could include isolation valves in the liquefaction system. 
G.1.9 Rupture of 20-in. Mixed Refrigerant Liquid Piping Between High Pressure Separator and Main Cryogenic Heat Exchanger.

Possible Initiating Events

- Fatigue from thermal cycling. (low probability)

- Fatigue from pressure cycling. (low probability)

- Failure of expansion joint to operate properly. (medium probability)

- Failure of valve body or pipe fitting. (low probability)

- Fluid hammer from fast valve closure. (low probability)

Results and Effects of Release Prevention and Control Systems

LNG product valve would reduce or stop the feed gas flow because of lack of cooling. Refrigerant cycles would go to total recycle. Operator would have to recognize spill and isolate system. Entire inventory of 4000 gallons would be lost in 1 minute.

Additional Information Required

- A large portion of the refrigerant inventory would be exhausted before the operator could isolate the system. The size of the spill would depend on the following:

- inventory in the system

- portion of the inventory that could escape through the break.

- Frequency of failure of piping, fittings, and vessels in refrigerant systems.

Possible Design and Operational Changes

- See modifications listed in Section G.1.8. 
G.1.10 Rupture of 10-in. Inlet Nozzle to Propane/Mixed Refrigerant Exchanger.

Possible Initiating Events

- Fatigue failure from thermal cycling. (low probability)

- Fatigue failure from pressure cycling. (low probability)

- Failure of valve body or pipe fitting. (low probability)

Results and Effects of Release Prevention and Control Systems

LNG product valve would reduce or stop the feed gas flow because of lack of cooling. Refrigerant cycles would go to total recycle. Operator would have to recognize spill and isolate system. Entire inventory of 10,000 gallons could be lost in 3 minutes.

Additional Information Required

- A large portion of the refrigerant inventory would be exhausted before the operator could isolate the system. The size of the spill would depend on the following:

- inventory in the system

- portion of the inventory that could escape through the break.

- Frequency of failure of piping, fittings, and vessels in refrigerant systems.

Potential Design and Operational Changes

- See modifications listed in Section G.1.8. 
G.1.11 Leak or Rupture in a Refrigerant Compressor (including inlet and outlet nozzles and piping).

Possible Initiating Events

- Low flow rate causes surging that could result in failure. Control scheme includes antisurge control. (medium probability)

- Controller failure or improper control point allows liquid carryover from the flash drums or separators to the compressor suction. (medium probability)

- Failure of air coolers causes compressor to overheat. (medium (probability)

- Low oil pressure causes compressor to overheat. (medium probability)

Results and Effects of Release Prevention and Control Systems

- Initial release would be limited to the vapor in the system. As the system heats up the liquid would eventually boil out.

- The compressors trip out automatically for the following conditions:

- high vibration

- high or low suction or discharge pressure

- high oil temperature

- high bearing temperature

- low oil pressure

- Master Emergency Shutdown is activated

- gas detector in compressor building reaches second level alarm.

Additional Information Required

- Inventory in the refrigerant systems and the quantity that would escape from a leak at the compressors.

- Rate of compressor failure from surging, overheating, and liquid in the suction line.

- Frequency of failure of controllers and control valves.

Possible Design and Operational Changes

- Combustible gas detectors could be located in the area.

- Each refrigerant storage tank with a bottom outlet line could be equipped with an internal block valve. 
G.1.12 Rupture of 12-in. Transfer Line from Liquefaction Area to the Storage Tanks.

Possible Initiating Events

- Fatigue failure from thermal cycling. (low probability)

- Failure of valve body or pipe fittings. (low probability)

Results and Effects of Release Prevention and Control Systems

- Spi11 is detected by gas sensor and operator shuts down system in one minute. Spill is 10,000 gallons.

- Spill goes undetected for 10 minutes - total spill volume is 40,000 galions.

Additional Information Required

- Frequency of failure of large cyrogenic pipes and fittings. 
G.1.13 Rupture of Outlet Nozzle or Piping on Refrigerant Storage Tanks

(propane, ethylene).

Possible Initiating Events

- Fatigue failure from thermal cycling. (low probability)

- Failure of valve body or pipe fitting. (low probability)

- Section of outlet piping blocked in and filled with liquid refrigerant. Relief valves fail to handle thermal pressure buildup. (low probability)

Results and Effects of Release Prevention and Control Systems

- No gas detector in area, must depend on operator observance. If ruptures occur after 1st block valve, operator can block in tank and limit spill. If not, the entire contents of the tank will spill 100,000 gallons from ethylene tank or 170,000 gallons from either of the propane tanks.

Additional Information Required

- Several incidents of this type have been reported in the literature. The consequences of this type of incident could affect the main LNG storage tanks $120 \mathrm{ft}$ away. Failure frequency for these types of tanks should be determined. 


\section{G.2 REPRESENTATIVE RELEASE EVENTS FOR THE LNG MARINE VESSEL}

The potential releases chosen as representative release events for the LNG marine vessel are listed in Table G.2. (The reference marine vessel was described previously in Appendix C.) The analyses of the individual release events appear below.

TABLE G.2. Representative Release Events for an LNG Marine Vesse1

1. Rupture or leak in one of the LNG cargo tanks.

2. Cargo tank is overfilled.

3. Pressure safety valves relieve to the atmosphere.

4. Rupture or leak in the liquid cargo handling system.

5. Rupture or leak in the vapor handling system.

6. Release of LNG or natural gas from ship due to misoperation of the cargo handling system. 


\section{G.2.1 Rupture or Leak in One of the LNG Cargo Tanks.}

\section{Possible Initiating Events}

- Collision with another ship. (low probability)

- Grounding. (low probability)

- Fatigue failure from dynamic loads imposed by wave-induced forces. (low probability)

- Fatigue failure from thermal cycling (the cargo tanks may be kept cool during ballast voyages using the spray system). (low probability)

- Overpressure (see Section G.2.4). (low probability)

- Fire or explosion in another part of the ship. (low probability)

- Sabotage. (low probability)

- Failure of storage tank support skirt due to bending and compressive load stresses and deformations due to hull bending and torsion. (low probability)

Results and Effects of Release Prevention and Control Systems

- Loss of one cargo storage tank could release up to $25,000 \mathrm{~m}^{3}$ (160,000 bbl) of LNG.

Additional Information Required

- Probability of $L N G$ vessel being involved in a collision.

- Effect of loss of one cargo tank on the integrity of the ship and the other cargo tanks.

\section{Potential Design and Operational Changes}

- Design tanks to withstand higher pressures.

- Provide secondary containment system. 


\section{G.2.2 Cargo Tank is Overfilled.}

Possible Initiating Events

- Level indicators in tank give false readings. (medium probability)

- Crewman does not close inlet valve and ESD fails. (medium probability)

Results and Effects of Release Prevention and Control Systems

- Liquid will enter the vapor header at a rate of 11,000 gpm until the flow to the tank is stopped.

- Liquid would leave the tank through the vapor line to the compressors and could cause compressor failure. Liquid would eventually have to be drained from vapor line.

Additional Information Required

- Type of level indicators used and the likelihood of their failing or giving an incorrect reading.

- Effect of LNG on vapor header and compressors. How is liquid removed from the vapor handling system?

Potential Design and Operational Changes

- Provide overflow line to other tanks to prevent overflow into vapor header. 


\section{G.2.3 Pressure Safety Valves Relieve to the Atmosphere.}

Failure of these safety valves could eventually result in failure of a cargo $\operatorname{tank}(s)$ from overpressure.

Possible Initiating Events

- Loss of boiloff compressor. (medium probability)

- Failure of pressure controller (compressor speed control) or pressure indicating device. (medium probability)

- Failure of tank insulation. (10w probability)

- Rollover (loading). (low probability)

- Addicion of "warm" LNG to cargo tanks (loading). (medium probability)

- Failure of pressure regulator on vapor return line (unloading). (medium probability)

- Ship in port and not allowed to unload or vent boiloff. (medium probability)

Results and Effects of Release Prevention and Control Systems

- Under normal conditions, the tank would take 2 to 3 days to reach relief valve pressure ( 3.5 psig) if no vapor is removed from the tank.

- The tanks have a maximum design pressure of 31 psig in port. Under normal circumstances, the tank will reach this pressure in 10 to 40 days if no vapor is removed from the tank.

- The tanks have a maximum design pressure of 10 psig at sea. Under normal conditions, the tank will reach this pressure in 5 to 12 days if no vapor is removed.

- Relief valve capacity is 24,000 scfm per valve at 4.7 psig.

Additional Information Required

- Probability of failure of pressure controller, pressure regulator, and boiloff compressor.

- Does ship have capability to vent steam when it is in port?

Potential Design and Operational Changes

- Design tank for higher pressure. 


\section{G.2.4 Rupture or Leak in the Liquid Cargo Handling System.}

\section{Possible Initiating Events}

- Fluid hammer from fast valve closure. (low probability)

- Fatigue failure from thermal and pressure cycling. (low probability)

- Failure of valves or pipe fittings. (medium probability)

- Failure of expansion joint. (medium probability)

- Line is blocked and filled with LNG. The line is allowed to heat up and the thermal relief valves do not open, allowing the line to overpressure. (low probability)

- Collision or grounding. (low probability)

- Fire or explosion in another part of the ship. (low probability)

\section{Results and Effects of Release Prevention and Control Systems}

- A gas detector alarm or a crewman activates the ESD and the system is isolated in 1 minute. Spill size would range from 0 to 67,000 gallons depending on size of the rupture or leak.

- Rupture or leak goes undetected or emergency shutdown system fails to isolate leak--release continues for 10 minutes--release ranges from 0 to 520,000 gallons.

Additional Information Required

- How long does it take to detect a leak or rupture?

- Complete description of liquid handling system--number and type of valves and fittings, size and materials of construction for pipes, and number of expansion joints or loops.

Potential Design and Operational Changes

- Provide some type of secondary containment system, e.g., a pipe within a pipe or a diked area beneath the liquid header. 


\section{G.2.4 Rupture or Leak in the Vapor Handling System.}

Possible Initiating Events

- Failure of valves or pipe fittings from manufacturing defects. (medium probability)

- Fatigue failure from thermal and pressure cycling. (low probability)

- Failure of expansion joint. (medium probability)

- Line filled with LNG is blocked in and allowed to heat up. Thermal relief valves do not open, allowing the line to overpressure. (low probability)

- Collision or grounding. (low probability)

- Fire or explosion in another part of the ship. (1ow probability)

Results and Effects of Release Prevention and Control Systems

- A gas detector or a crewman activates the ESD and the system is isolated in 1 minute--spill size would range from 0 to $18,000 \mathrm{scf}$ depending on the size of the rupture or leak.

- Rupture or leak goes undetected or ESD fails to isolate leak and release continues for 10 minutes--release ranges from 0 to 155,000 scf.

\section{Additional Information Required}

- How long does it take to detect a leak or rupture?

- Complete description of the vapor handling system--number and type of valves and fittings, size and materials of construction for piping, and number of expansion joints or loops.

- Probability of failure of the components of the piping network.

Potential Design and Operational Changes

- Make the vapor header a pipe within a pipe to provide for containment of a release. 
G.2.6 Release of LNG or Natural Gas from Ship due to Misoperation of Cargo Handling System.

Possible Initiating Events

- Operator disconnects loading arms while loading/unloading is taking place. (medium probability)

- Loading (crossover) valves are left open and blinds are off or improperly connected on the side of the ship opposite from where loading/unloading is taking place. (medium probability)

- Valve to vent stack or riser is left open during loading/unloading operations. (medium probability)

Results and Effects of Release Prevention and Control System

- Spill size would range from 0 to 67,000 gallons, assuming the situation is rectified in one minute.

- Spills out the vent riser could crack deck plates.

- Coast Guard inspection of the vessel prior to offloading should reduce errors of this type.

Additional Information Required

- Complete piping and instrument drawings (P\&ID) of cargo handling system are needed to determine all possible means of misoperation of the system.

- Details on which valves and equipment are inspected by the Coast Guard prior to unloading/loading.

Potential Design and Operational Changes

- Provide an interlock system which would automatically open and close valves as required for loading and unloading, i.e., all valves that must be closed during loading would be closed automatically by activation of one switch. 


\section{G.3 REPRESENTATIVE RELEASE EVENTS FOR THE LNG IMPORT TERMINAL}

The potential release events chosen as representative of the LNG import terminal are given in Table G.3. (A discussion of the reference import terminal was presented previously in Appendix D.) The individual release events are analyzed here.

TABLE G.3. Representative Release Events for an LNG Import Terminal

1. Failure of $9 \%$ nickel-steel inner storage tank.

2. Failure of carbon-steel outer barrier for LNG storage tank.

3. LNG release from 16-in. loading arms.

4. Failure of 42-in. liquid transfer line from unloading dock to shore.

5. Failure of 42-in. liquid transfer line from shore to storage.

6. Failure of 20-in. LNG transfer line from storage to the secondary pumps.

7. Failure of 24-in. LNG transfer line from secondary pumps to vaporizers.

8. Seawater vaporizer failure.

9. Submerged combustion vaporizer failure.

10. Failure of vaporizer exit lines.

11. Failure of fuel gas compressor suction line.

12. Failure of 4-in. LNG recirculation line.

13. Failure of 16-in. vapor return line to ship's tanks.

14. Failure of 30-in. vapor line from pipeline compressors to gas transmission pipeline. 


\section{G.3.1 Failure of 9\% Nickel-Steel Inner Storage Tank.}

\section{Possible Initiating Events}

- Overpressure or underpressure of tank (medium probability)

- Sabotage (low probability)

- Large earthquake (low probability)

- Airplane crash (low probability)

- Fire and explosion in other sections of the plant (low probability)

- Failure of shell-to-roof or shell-to-bottom welds and nozzle welds (low probability)

- Differential foundation settling, or frostheave from foundation heating coil failure (low probability)

- Corrosion stress (1ow probability)

- Outer tank collapse. (low probability)

Results and Effects of Release Prevention and Control Systems

The maximum amount of LNG release from each of the two tanks is 550,000 bbl. $\left(2.3 \times 10^{7}\right.$ gallons $)$

Additional Information Required

Are the she11-to-roof and she11-to-bottom joints weak in case of overpressure to prevent a complete tank failure?

Potential Design and Operational Changes

- Build tank underground and surrounding earth could be used as containment dike.

- Design tank to withstand higher pressures and a higher vacuum. 


\section{G.3.2 Failure of Carbon-Steel Outer Barrier for LNG Storage Tank.}

Possible Initiating Events

- Leaks from the inner tank (1ow probability)

- Insulation failure resulting in frost spots on the outer shell and possible fracture due to compression and expansion cycling of the insulation (low probability)

- Cyclic thermal pressure and static load stresses (low probability)

- Differential settling of the foundation or frostheave due to foundation heater failures (low probability)

- Flaws in the corner welds, nozzle welds, and roof-shell joints (low probability)

- If inner tank pressure relief valves were activated, cold vapor could settle on the outer tank and fracture it (low probability)

- Leakage of air into the $\mathrm{N}_{2}$ purge 1 ine into the annular space, moisture could form and frost spots could form on the exterior shell and could fracture it (low probability)

- Sabotage (low probability)

- Large earthquake (low probability)

- Airplane crash (low probability)

- Fire or explosion in other facilities nearby. (low probability)

Results and Effects of Release Prevention and Control Systems

A complete failure of the outer shell could collapse the inner she11, resulting in a maximum release of 550,000 bbl of LNG from each tank.

A concrete dike designed to contain 1.3 times the maximum storage tank capacity surrounds each tank.

Discussion and Additional Information Required

- What is the effect on the concrete dike in the event of a storage tank collapse? 
- What is the effect on the storage tank of a fire or explosion in adjacent areas?

- What design factors are included for the cyclic stresses the storage tank undergoes?

\section{Potential Design and Operational Changes}

- Utilize stainless steel or other cryogenic material for outer shell.

- Incorporate an overflow 1 ine to prevent any overflow of LNG from making contact with the outer shell. 
G.3.3 LNG Release from 16-in. Loading Arms.

Possible Initiating Events

- Bad connection of the flanges with the arms and the ship (medium probability)

- Emergency uncoupling due to extreme motion of the ship (medium probability)

- Fissure or break due to extreme motion stresses and failure of the high rotational sensing devices (low probability)

- Hydraulic power failure would fail to keep the arms moving freely and a rupture could result (low probability)

- Fatigue failure from thermal and pressure cycling (low probability)

- The loading arm is blocked in and not drained. The line heats up and if the relief valves failed, the line could rupture from overpressure (low probability)

- Thermal and pressure cyclic stresses. (low probability)

Results and Effects of Release Prevention and Control Systems

- The ESD shuts off loading pumps and closes block valves within 1 minute after spil1. LNG release volume would be 15,000 gallons.

- If the ESD failed to respond and a norma? shutdown was required, a maximum of ten minutes to shutdown would result in a 134,000-gallon LNG release for a break.

- A containment system could hold spills from the loading arms.

- Leaks from swivel joints and other components could spray all over the dock.

Additional Information Required

- How fast can the ESD system actually detect the hazard and shut down the process?

- What is the failure frequency for the loading arms? 
Potential Design and Operational Changes

- Provide a movable trough under the arms to catch spills and drain into the containment facilities under the dock. 
G.3.4 Failure of 42-in. Liquid Transfer Line from Unloading Dock to Shore.

Possible Initiating Events

- Stresses to the trestle support and piping from large waves, high winds, earthquakes, lightning, etc. (low probability)

- Malfunction of a valve causing it to close too rapidly could result in extreme fluid hammer and rupture the line. (low probability)

- The drain system is either not activated or faits to activate when the line is blocked, leaving the line filled with LNG. The relief valves fail when the line heats up and pressurization results. (low probability)

- Thermal, static, and pressure cycling stresses; however, the line is normaliy maintained at operating conditions by recirculating LNG. (low probability)

- Failure of valve bodies or welding flaws at the pipe fittings. (low probability)

- Failure of expansion joint. (medium probability)

Results and Effects of Release Prevention and Control Systems

- Spilis enroute would fall into the ocean.

- ESD shuts down the system in 1 minute. If ESD fails to operate, it takes 10 min to shut down the system.

Break $\frac{1 \text {-min Shutdown }}{485,000 \mathrm{gal}} \quad \frac{10-\mathrm{min} \text { Shutdown }}{962,000 \mathrm{gal}}$

Additional Information Required

- How fast can the ESD system actualiy detect the hazard and shut down the system?

- What is the frequency of failure of this line?

- A more detailed description of the drain system is required. 
Potential Design and Operational Changes

- Employ a pipe-within-a-pipe system offshore to contain any LNG release.

- Use two smaller transfer lines rather than the 42-in. 1ine. The smaller components should be more reliable. 


\section{G.3.5 Failure of 42-in. Liquid Transfer Line from Shore to Storage.}

\section{Possible Initiating Events}

- Malfunction of a valve causing it to close too rapidly could result in extreme fluid hammer and could rupture the line. (low probability)

- Thermal, static, and pressure cyclic stresses; however, these are unlikely because recirculating LNG maintains the line at operating conditions. (low probability)

- Valve body failures or flaws at welded pipe fittings. (low probability)

- Expansion joint malfunction. (medium probability)

Results and Effects of Release Prevention and Control Systems

- ESD system shuts down the operations in 1 minute. If ESD fails to operate, it could take up to 10 min to shut down.

Break

$$
\frac{1 \text {-min Shutdown }}{485,000 \mathrm{gal}} \frac{\frac{\text { Amount }}{10-\text { min }} \text { Shutdown }}{962,000 \mathrm{ga} 1}
$$

- A containment dike is located on shore to contain any spills of LNG.

\section{Additional Information Required}

- What type of components are included to activate the ESD system?

- How long does the ESD system actually take to detect, activate, and shut down the system?

- What is the frequency of failure of this system? 


\section{G.3.6 Failure of 20-in. LNG Transfer Line from Storage to the Secondary Pumps.}

\section{Possible Initiating Events}

- Static, cyclic, and thermal stresses. However, these lines operate 345 days/yr. Therefore, the operating conditions at these lines seldom change. (low probability)

- Fluid hammer stresses due to a valve malfunction and rapid closure of the valve during operation. (low probability)

- Leaky valves, flanges, couplings, or flaws contained within. (medium probability)

- Expansion joint malfunction. (medium probability)

Results and Effects of Release Prevention and Control Systems

- The ESD system shuts down the pumps and closes the valves in 1 minute. If the ESD system fails, it takes 10 minutes for shutdown to occur.

- An independent dike system encloses the secondary pumps to contain any spill there.

Break

$$
\frac{1-\text { min Shutdown }}{16,000 \mathrm{gal}} \quad \frac{\text { Release }}{52,000 \mathrm{gal}}
$$

Additional Information Required

- What is the frequency of failure for this system? 


\section{G.3.7 Failure of 24-in. LNG Transfer Line from Secondary Pumps to Vaporizers.}

Possible Initiating Events

- Static, cyclic, and thermal stresses. However, these systems operate 345 days/yr and operating conditions very seldom change. (low probability)

- If the line is blocked off and relief valves fail to operate when it heats up, a rupture could occur. (low probability)

- Leaky valves, or fittings or flaws for crack propagation therein. (medium probability)

- Welding flaws in fittings or pipe couplings. (low probability)

- Fluid hammer from rapid closing of a malfunctioning valve. (low probability)

Results and Effects of Release Prevention and Control Systems

The ESD system stops operations in 1 minute. If the ESD system fails, it takes 10 minutes to manually close valves.

Break

$$
\frac{1 \text {-min Shutdown }}{23,000 \text { ga } 1} \frac{\frac{\text { Amount of Release }}{10-\text { min }} \text { Shutdown }}{100,000 \mathrm{gal}}
$$

\section{Additional Information Required}

- If the pressure control system malfunctions, can the system overpressure due to a continued pumping increase and relief valve failure?

- What is the frequency of failure for this system?

Potential Design and Operational Changes

- Incorporate a spray shield to cover transfer line. 


\section{G.3.8 Seawater Vaporizer Failure.}

Possible Initiating Events

- Vaporizer leaks from tube vibrations causes failure by local fretting. (medium probability)

- Icing on the exterior fins would result in poor heat transfer capabilities, which could allow cold vapors to reach carbon-steel components if the temperature outlet indicator fails. (1ow probability)

- Temperature controller fails and allows cold vapors to reach carbonsteel components. (medium probability)

Results and Effects of Release Prevention and Control Systems

- The ESD system should shut down the pumps and valves in 1 minute. If the ESD system fails, it would take approximately 10 minutes to manually shut down the system.

- Any spill from the seawater vaporization system is controlled by a dike surrounding the immediate vicinity.

Break $\frac{1 \text {-min Shutdown }}{1,700 \mathrm{gal}} \quad \frac{\frac{\text { Amount }}{10-\mathrm{min}}}{17,000 \mathrm{gal}}$

Additional Information Required

- What is the frequency of failure for the seawater vaporizers?

- What would be the effect on the vaporizer in the event of a tube failure? 


\section{G.3.9 Submerged Combustion Vaporizer Failure.}

\section{Possible Initiating Events}

- Clogging of a nozzle can result in a hot spot on the downcomer which can eventually burn through, thus allowing hot gases access to the tube chamber above the water line. If the water level should be low and any of the top tubes exposed due to controller failure, this would in turn expose the tube to the hot gases. (medium probability)

- Temperature controller and flow controller failure could allow cold vapors to reach carbon-steel components. (medium probability)

\section{Results and Effects of Release Prevention and Control Systems}

The vaporization ESD system would shut down appropriate pumps and valves automatically within 1 minute. If the ESD system fails, the system can be manually shut down in approximately 10 minutes. LNG would be released into the water bath and vapor would exit through the exhaust gas stack.

Additional Information Required

- Is there a containment dike located in the area to contain any spills?

- What is the maximum LNG flow capacity for these vaporizers?

Potential Design and Operational Changes

- Backup controls to ensure the downcomer stays cool and the LNG coils are never exposed. 


\section{G.3.10 Failure of Vaporizer Exit Lines.}

Possible Initiating Events

- Malfunction of temperature controller allowing cold vapors to reach carbon-steel components by not supplying enough water to the vaporizer or allowing the LNG to flow too rapidly. (medium probability)

- Control valve malfunction allowing an increased flow rate and colder outlet product. (medium probability)

- Loss of seawater flow and failure of flow sensor to activate ESD system. (low probability)

\section{Results and Effects of Release Prevention and Control Systems}

The vaporizer ESD shuts down the system automatically in 1 minute. If the ESD system fails, the system can be shut down in 10 minutes manually.

Break

\begin{tabular}{|c|c|}
\hline $\begin{array}{l}\text { Amount of } \\
\text { 1-min Shutdown }\end{array}$ & $\frac{10 a s e}{10}$-min Shutdown \\
\hline $\begin{array}{l}84,000 \text { scf } \\
\text { ( } 1000 \text { equivalent } \\
\text { gallons) }\end{array}$ & $\begin{array}{l}770,000 \text { scf } \\
\text { ( } 9300 \text { equivalent } \\
\text { gallons) }\end{array}$ \\
\hline
\end{tabular}

Additional Information Required

How close are the inlet and carbon-steel outlet lines? A small leak in the vaporizer inlet line could possibly spray LNG on the outlet line and crack it.

Potential Design and Operational Changes

- Incorporate stainless steel exit lines for a longer distance to handle any cold vapors.

- Incorporate a spray shield around the exit lines to protect adjacent components from cold vapors. 


\section{G.3.11 Failure of Fuel Gas Compressor Suction Line.}

Possible Initiating Events

- Fuel-gas preheater failure allowing cold vapors to reach carbon-steel components. (medium probability)

- Failure of valves, fittings, or welds. (10w probability)

Results and Effects of Release Prevention and Control Systems

The VES system closes appropriate valves and shuts down pumps in 1 minute. If the VES system fails, the system can be shut down manually in 10 minutes.

\begin{tabular}{|c|c|c|}
\hline & \multicolumn{2}{|c|}{ Amount of Release } \\
\hline & 1-min shutdown & 10-min Shutdown \\
\hline Break* & $\begin{array}{l}11,000 \text { scf } \\
\text { ( } 140 \text { equivalent } \\
\text { gal1ons) }\end{array}$ & $\begin{array}{l}24,000 \text { scf } \\
\text { ( } 290 \text { equivalent } \\
\text { gallons) }\end{array}$ \\
\hline Break** & $\begin{array}{l}35,000 \text { scf } \\
\text { ( } 420 \text { equivalent } \\
\text { gallons) }\end{array}$ & $\begin{array}{l}260,000 \text { scf } \\
\text { ( } 3100 \text { equivalent } \\
\text { gallons) }\end{array}$ \\
\hline
\end{tabular}

*Normal Operations

**Unloading Operations

Additional Information Required

- Exactly where is it in the compressors that the stainless steel components change to carbon-steel?

- What is the frequency of failure for this system?

Potential Design and Operational Changes

- Include stainless steel lines up to fuel gas compressors.

- Temperature sensor in suction line should activate ESD system in the event of low temperature. 


\section{G.3.12 Failure of 4-in. LNG Recirculation Line.}

Possible Initiating Events

- Static and corrosion stresses (low probability)

- Welding flaws in pipefittings or valves (low probability)

- If a section of pipe is blocked and the drain valves fail to open, the LNG could heat up, overpressure, and rupture the line if the relief valve failed. (low probability)

- Fluid hammer stresses possibly due to a malfunction in a valve resulting in a rapid closing of the valve. (low probability)

- Stresses from large waves, high winds, earthquakes, lightning, etc. (low probability)

Results and Effects of Release Prevention and Control Systems

- The ESD system would automatically shut down the recirculation line in 1 minute. If the ESD system failed, it would take 10 minutes to shut down the system.

Break

$\frac{1-\text { min Shutdown }}{5,400 \mathrm{gal}} \frac{\frac{\text { Amount of Release }}{10-\mathrm{min}} \text { Shutdown }}{19,000 \mathrm{ga} 1}$

- A containment dike is located on shore and at the unloading site to contain any spills.

\section{Additional Information Required}

- How fast can the ESD system actualiy detect the hazard and shut down the system?

- What is the frequency of failure for this system?

- A more detailed description of the drain system is required. 


\section{G.3.13 Failure of 16-in. Vapor Return Line to Ship's Tanks.}

\section{Possible Initiating Events}

- Flange, coupling, or fitting failure (low probability)

- Static, cyclic, and thermal stresses (low probability)

- Valve failure (low probability)

- Stresses from large waves, earthquakes, lightning, etc. (low probability)

Results and Effects of Release Prevention and Control Systems

- The ESD system would automatically shut down the line within 1 minute. If the ESD system fails, it takes 10 minutes to shut down.

Amount of Release

Break

$\begin{array}{ll}\frac{1 \text { 1-min Shutdown }}{35,000 \text { scf }} & \frac{10-\text { min }}{135,000 \text { scf }} \\ \begin{array}{l}\text { (420 equivalent } \\ \text { gallons) }\end{array} & \begin{array}{l}\text { (1600 equivalent } \\ \text { gallons) }\end{array}\end{array}$

Additional Information Required

- How fast would the ESD system be activated?

- What is the frequency of failure for this system? 
G.3.14 Failure of 30-in. Vapor Line from Pipeline Compressors to Gas Transmission Pipeline.

\section{Possible Initiating Events}

- Pressure control valve and relief valve malfunction could overpressure the system. (low probability)

- Failure of the cooling fans could allow the temperature to increase and stress the system, causing failure. (low probability)

- Fatigue from static and corrosion stresses and welding flaws. (low probability)

Results and Effects of Release Prevention and Control Systems

The ESD system would isolate the line and shut down compressors in 1 minute. If the ESD system failed, it would take 10 minutes to manually shut down the sytem.

\begin{tabular}{|c|c|c|}
\hline & Amo & se \\
\hline & 1-min Shutdown & 10 -min Shutdown \\
\hline Break & $\begin{array}{l}420,000 \text { scf } \\
(5,100 \text { equivalent } \\
\text { gallons) }\end{array}$ & $\begin{array}{l}640,000 \text { scf } \\
\text { ( } 7,800 \text { equivalent } \\
\text { gallons) }\end{array}$ \\
\hline
\end{tabular}

\section{Additional Information Required}

What is the frequency of failure for this system?

Potential Design and Operational Changes

- Design piping to withstand higher pressures and temperatures. 


\section{G.4 REPRESENTATIVE RELEASE EVENTS FOR THE LNG PEAKSHAVING PLANT}

The potential release events chosen as representative of normal operations at a peakshaving plant are listed in Table G.4. The release events for transportation and transfer are shown separately in Table G.5. (The reference peakshaving plant was described previously in Appendix E.) The analyses of the individual release events are presented below.

\section{TABLE G.4. Representative Release Events for an LNG Peakshaving} Facility

1. Gas supply line from pipeline fails.

2. Molecular sieve adsorber vessel fails.

3. Heat exchanger tube in regeneration gas heater fails.

4. LNG piping in cold box fails.

5. Refrigerant compressor suction line fails.

6. Refrigerant storage tank fails.

7. LNG storage tank fails

8. LNG outlet line from storage tank fails

9. LNG vapor vented through relief valves after overpressurization of storage tank.

10. Sendout pump vessel fails.

11. LiV supply 1 ine to vaporizers fails.

12. Vaporizer heat exchanger tube fails.

13. Natural gas 1 ine from vaporizers fails.

TABLE G.5. Representative Release Events for Transportation and Transfer Operations

1. Liquid line from storage to the truck loading station fails.

2. Flexible loading/unloading hoses fail.

3. Vapor return line from truck loading station to storage fails.

4. Liquid line from the truck unloading station to the storage tank fails.

5. Truck LNG tank fails.

6. Trailer pressure buildup coil fails. 


\section{G.4.1 Gas Supply Line from Pipeline Fails.}

Possible Initiating Events

- Fatigue resulting from pressure cycling or static stress (low probability)

- Flaws in pipe, valves, flanges, couplings, or welds (low probability)

- External forces such as vehicular crash or earthquake (low probability)

Results and Effects of Release Prevention and Control Systems

The estimated maximum natural gas release from a guillotine break, based on times for emergency or normal shutdown, are given below:

$$
\text { Guillotine Break } \quad \frac{1-\text { min Shutdown }}{42,000 \mathrm{scf}} \quad \frac{\frac{\text { Amount }}{10-\text { min }}}{120,000 \mathrm{scf}}
$$

These releases include natural gas holdup in the system. The gas treatment system can be shut down either manually or by the Master Emergency Shutdown (MIES).

\section{Additional Information Required}

- What design factors are included for pressure cycling and static stresses?

- What quality assurance (QA) procedures are used to eliminate flaws in components and connections, and what is the reliability of these procedures?

- What provisions are made for protection against and alleviation of stresses caused by external forces?

Potential Design or Operational Changes

- Conduct periodic non-destructive tests to identify component degradation and allow replacement before failure occurs.

- Install checkvalve at molecular sieve adsorbers to prevent backflow and leakage of adsorber holdup gas. 


\section{G.4.2 Molecular Sieve Adsorber Vessel Fails.}

Possible Initiating Events

- Fatigue resulting from thermal cycling or static stress (low probability)

- Flaws in construction materials or welds (low probability)

- Stresses caused by uneven settling of vessel foundation or shifting of vessel contents (low probability)

- Corrosion (low probability)

- Penetration by flying projectile (low probability)

- Excessive pressure in vessel (low probability)

- Fire or explosion in plant (medium probability)

Results and Effects of Release Prevention and Control Systems

The estimated maximum natural gas releases from a guillotine break, based on times for emergency or normal shutdown, are given below:

Guillotine Break $\frac{1 \text {-min Shutdown }}{42,000 \text { scf }} \frac{10 \text {-min Shutdown }}{120,000 \text { scf }}$

The releases include natural gas holdup in the system. The gas treatment system can be shut down either manually or by the MES.

\section{Additional Information Required}

- What design factors are included for thermal cycling and static stresses?

- What QA procedures are used to eliminate flaws in materials and welds, and what is the reliability of these procedures?

- What precautions are taken to ensure an adequate base for vessel foundations? 
- What procedures are used during vessel filling with molecular sieve material to prevent against both abnormal vessel stresses during loading and material shifting during operation?

- What plant design features protect the adsorbers in the event of fire or explosion in the plant?

- What is the reliability of the pressure control system?

\section{Potential Design or Operational Changes}

- Conduct periodic non-destructive tests to identify vessel degradation and allow repair before failure occurs.

- Design vessels and foundations to withstand greater stresses.

- Incorporate features (e.g., shielding bulkheads) into plant design to protect vessels in the event of fire or explosion in the plant. 


\section{G.4.3 Heat Exchanger Tube in Regeneration Gas Heater Fails.}

\section{Possible Initiating Events}

- Therma 1 shock or thermal cycling stresses (low probability)

- Corrosion (low probability)

- Flaws in materials or welds (low probability)

- Burner explosion (low probability)

Results and Effects of Release Prevention and Control Systems

The estimated maximum natural gas releases from a guillotine break, based on times for emergency or manual shutdown, are given below:

Guillotine Break

$$
\frac{\text { 1-min Shutdown }}{42,000 \mathrm{scf}} \frac{10-\text { min Shutdown }}{120,000 \mathrm{scf}}
$$

These releases include natural gas holdup in the gas treatment system. Because of the proximity of the release to the regeneration heater burner, there is a high probability that a fire or explosion may occur. The gas treatment system can be shut down either manualiy or by the MES.

Additional Information Required

- What are the details on diameters, thicknesses, configuration, and flow rates through the tubes in the regeneration gas heater?

- How is flowrate controlled through the regeneration gas heater?

- What are the corrosion problems involved?

- What design factors are included for thermal stress effects?

- What QA procedures are employed to eliminate flaws, and what is their reliability?

Potential Design and Operational Changes

- Conduct periodic non-destructive testing of tubes to identify degradation and allow repair or replacement before failure occurs.

- Use indirect-fired or other type of heater to reduce potential for fire or explosion as a result of a leak. 


\section{G.4.4 LNG Piping in Cold Box Fails.}

\section{Possible Initiating Events}

- Thermal shock or thermal cycling stresses (medium probability)

- Flaws in materials or welds (low probability)

\section{Results and Effects of Release Prevention and Control Systems}

When the piping fails, LNG is released to the cold box, resulting in possible failure of the cold box. The estimated maximum releases of LNG and natural gas, based on times for emergency or manual shutdown, are given below:

Guillotine Break $\quad \frac{1 \text {-min Shutdown }}{42,000 \mathrm{scf}} \frac{\frac{10-m i n ~ S h u t d o w n}{120,000 \mathrm{scf}}}{12000}$

These releases include system gas holdup. The liquefaction system can be shut down either manualiy or by the MES.

Additional Information Required

- What are the details on materials and fabrication techniques used in the cold box?

- Are there any automatic valves to shut down the gas supply 7 ine to the cold box?

ح What design factors are included for thermal stress effects?

- What QA procedures are employed and what is their reliability?

Potential Design and Operational Changes

- Conduct periodic non-destructive tests to identify piping degradation and allow replacement or repair before failure occurs.

- Incorporate spray shields and sump or drain system in cold box to prevent spilled LNG from contacting sides of cold box and causing failure. 


\section{G.4.5 Refrigerant Compressor Suction Line Fails.}

Possible Initiating Events

- Carryover of liquid refrigerant or cold vapor from compressor suction trap (medium probability)

- Flaws in materials or welds (low probability)

- Fatigue resulting from pressure cycling, vibrational, or static stress (low probability)

Results and Effects of Release Prevention and Control Systems

The maximum release of refrigerant is 3000 gallons, which is the cycle fluid storage capacity in the system. Based on a normal system flowrate of about $190 \mathrm{gal} / \mathrm{min}$ and times for emergency or normal shutdown, more likely release quantities are given below:

Guillotine Break $\frac{1 \text {-min Shutdown }}{190 \mathrm{gal}} \frac{\frac{\text { Amount of Release }}{10 \text {-min Shutdown }}}{1,900 \mathrm{gal}}$

The 1 iquefaction system can be shut down either manually or by the MES. Additional Information Required

- What is the reliability and response time of the temperature and liquid level instrumentation designed to protect against carryover?

- What QA procedures are employed and what is their reliability?

- What design factors are included for suction line stresses?

Potential Design and Operational Changes

- Instal1 secondary suction trap or other device to minimize chances of carryover.

- Conduct periodic non-destructive tests to identify and rectify problems before failure occurs.

- High liquid level alarm on suction trap should be tied to liquid recycle pump to automatically maintain liquid level. 
- High liquid level alarm should be tied in to vapor flow control valve to shut off flow in case of imminent carryover.

- Insta11 a low temperature alarm on suction line tied in to vapor flow control valve. 


\section{G.4.6 Refrigerant Storage Tank Fails.}

\section{Possible Initiating Events}

- Fatigue resulting from vibration or static stress (low probability)

- Flaws in construction materials or welds (low probability)

- External forces such as vehicular crash, earthquake, or flying projectile (low probability)

- Fire or explosion in plant (medium probability)

Results and Effects of Release Prevention and Control Systems

The largest refrigerant storage tank has a 10,000 gallon capacity. Thus, the maximum release from failure of a single tank is 10,000 gallons. UV flame detectors in the refrigerant storage area would alarm in the event that the leaking refrigerant caught fire.

Additional Information Required

- What design factors are included for vibration and static stresses?

- What QA procedures are employed and what is their reliability?

- What provisions are made for protection against external forces?

- What plant features protect the storage tanks in the event of fire or explosion in the plant?

Potential Design and Operational Changes

- Install combustible gas detectors in refrigerant storage area.

- Conduct periodic non-destructive tests to identify and rectify problems before failure occurs.

- Design storage tanks to withstand greater stresses and external forces.

- Incorporate features into plant design to protect storage tanks from external forces and from the effects of fire or explosion in the plant. 


\section{G.4.7 LNG Storage Tank Fails.}

Possible Initiating Events

- Overpressure or underpressure due to failure of relief systems plus any of the following:

- Rollover of LNG in tank (medium probability)

- Sudden change in barometric pressure (medium probability)

- Fire (medium probability)

- Heatup or cooldown of tank too fast (medium probability)

- Boiloff treatment system not properly controlled (low probability)

- Failure of boiloff compressors (low probability)

- Loss of tank insulation effectiveness (low probability)

- Explosion due to explosive gas mixture in tank resulting from:

- Inadequate purge (medium probability)

- Vacuum relief allowing air into the tank (low probability)

- Inner shell off-centered with resulting pressure forces failing the tank (medium probability)

- Thermal stress from too rapid or nonuniform cooldown or heatup (low probability)

- Differential foundation settling, or frostheave from foundation heating coil failure (low probability)

- Earthquake or tornado (low probability)

- Aircraft crash (low probability)

- Sabotage (low probability)

- Structural failure due to flaws in materials or welds (low probability)

- Fire or explosion in other sections of plant (low probability)

Results and Effects of Release Prevention and Control Systems

The maximum LNG release from a failed tank is 348,000 bbl. The spil1 basin surrounding the storage tank would route the LNG to the diked impoundment 
area, which has the capacity to contain the entire leak. Fire-fighting systems are available to control possible fires.

\section{Additional Information Required}

- What is the reliability and adequacy of the pressure and vacuum relief systems (including boiloff system and natural gas addition)?

- What QA procedures are employed in tank construction and what is their reliability?

- What provisions are made for protection against and alleviation of stresses caused by external forces?

- What precautions are taken to ensure an adequate base for the tank foundation?

- What is the reliability and response time of the temperature and liquid level instrumentation on the tank?

- What is the reliability of the electric foundation heaters?

Potential Design and Operational Changes

- Conduct periodic non-destructive tests on the storage tank.

- Completely automate the cooldown and heatup procedures.

- Design tank to withstand greater stresses.

- Build tank underground so surrounding earth provides containment of leaks, additional support, and added thermal insulation.

- Develop and install instrumentation to detect conditions likely to result in rollover. 


\section{G.4.8 LNG Outlet Line from Storage Tank Fails.}

Possible Initiating Events

- Fatigue resulting from pressure or thermal cycling or static stress (low probability)

- Overpressurization due to LNG trapped in line and vaporized, coupled with failure of relief valve (medium probability)

- Fluid hammer stresses caused by too rapid closure of valve during operation (low probability)

- Flaws in pipe, valves, flanges, couplings, or weld (low probability)

- Failure of expansion joint due to excessive flexing (medium probability)

- External forces such as vehicular crash or earthquake (low probability)

Results and Effects of Release Prevention and Control Systems

If the leak is prior to block valves in the line and the internal block valve in the tank fails to operate, the total contents of the tank might leak to the spill basin. Thus, the maximum release of LNG is 348,000 bbl. Estimated releases from guillotine leaks beyond line valves, based on times for emergency or manual shutdown, are given below:

Suillotine Break $\quad \frac{\text { Amount of Release }}{\frac{1 \text { 1-min Shutdown }}{28,000 \mathrm{gal}}} \frac{\frac{10-\text { min Shutdown }}{280,000 \mathrm{gal}}}{\frac{28}{2}}$

If the break is between the inner and outer shells of the tank, it would probably lead to failure of the tank due to contact of the outer tank shell with the cold LNG. (See also Section G.4.7.)

Additional Information Required

- What design factors are included for cyclic and static stresses?

- What is the reliability of the pressure relief valve? 
- What precautions and design provisions are used to avoid fluid hammer?

- What provisions are made for protection against and alleviation of stresses caused by external forces?

- Can space between tank shells be drained of leaking LNG? Also, are there any temperature or liquid level sensors in annular space to detect such a leak?

- What is the reliability of expansion joints in this sort of service?

Potential Design and Operational Changes

- Conduct periodic non-destructive tests on the pipe and associated valves.

- Put at least two parallel relief valves in each isolatable section of pipe.

- Design pipe and connections to withstand greater stresses.

- Incorporate provisions for draining annular space in tank. 


\section{G.4.9 LNG Vapors Vented through Relief Valves after Overpressurization of Stor- age Tank.}

\section{Possible Initiating Events}

- Rollover of LNG in tank (medium probability)

- Sudden drop in barometric pressure (low probability)

- Fire (medium probability)

- Heatup of LNG in storage tank too fast (medium probability)

- Boiloff treatment system not properly controlled (low probability)

- Failure of boiloff compressors (low probability)

- Loss, of tank insulation effectiveness (low probability)

\section{Results and Effects of Release Prevention and Control Systems}

The estimated LNG vapor releases depend on the length of time the tank is overpressurized. The values given below are based on the maximum venting rate of 74,000 scfm and assumed venting times for minor and major overpressurization events.

Two 12-in. Relief Valves $\frac{10 \text {-min Venting Period }}{740,000 \mathrm{scf}} \frac{2-\mathrm{Amr} \text { Venting Period }}{8,900,000 \mathrm{scf}}$

The released vapors may also catch fire or explode. A UV fire detector and dry chemical extinguisher are located on top of the tank near the relief valves; the extinguisher, directed at the valves, is actuated by the detector.

Additional Information Required

- What precautions are taken to ensure against rollover?

- What is the reliability of the boiloff treatment system?

- What is the reliability and response time of the temperature and liquid level instrumentation on the tank?

Potential Design and Operational Changes

- Completely automate the heatup procedure.

- Develop and install instrumentation to detect conditions likely to result in rollover. 


\section{G.4.10 Sendout Pump Vessel Fails.}

Possible Initiating Events

- Fatigue resulting from cyclic thermal stresses (low probability)

- Flaws in materials or welds (low probability)

- External forces such as earthquake (low probability)

Results and Effects of Release Prevention and Control Systems

If the block valves in the tank and the outlet line fail to operate, the maximum release would be the total contents of the tank, or 348,000 bbl. If the valves operate properly, the maximum releases would be based on times for emergency or normal shutdown, as given below:

\begin{tabular}{|c|c|c|}
\hline & $1-\min \frac{\text { Amount of }}{\text { Shutdown }}$ & $\frac{\text { Release }}{10-\text { min Shutdown }}$ \\
\hline Total Vessel Failure & 28,000 gal & 280,000 gas \\
\hline
\end{tabular}

These releases include the LNG holdup in the pump vessel as well as the flow through the system. Both the MES and the Vaporizer Emergency Shutdown (VES) can be used to stop the flow of LNG to the pump vessel. The area around the pump vessel is monitored by both UV fire detectors and combustible gas detectors, and high-expansion foam and other fire-fighting systems are available to control any resulting fire. The leak would be confined to the spill basin.

\section{Additional Information Required}

- What design factors are included for cyclic thermal stresses?

- What provisions are made for protection against and alleviation of stresses caused by external forces?

Potential Design and Operational Changes

- Conduct periodic non-destructive tests on the pump vessels.

- Design vessels to withstand greater stresses. 


\section{G.4.11 LNG Supply Line to Vaporizers Fails.}

\section{Possible Initiating Events}

- Fatigue resulting from thermal or pressure cycling or static stress (low probability)

- Flaws in pipe, valves, flanges, couplings, or welds (low probability)

- Externar forces such as vehicular crash or earthquake (low probability)

- Overpressurization due to LNG trapped in Tine and vaporized, coupled with failure of relief valve (medium probability)

- Fluid hammer stresses caused by too rapid closure of valve during operation (low probability)

Results and Effects of Release Prevention and Control Systems

The estimated maximum LNG releases from a guiliotine break, based on times for emergency or norma 7 shutdown, are:

\begin{tabular}{|c|c|c|}
\hline & \multicolumn{2}{|c|}{ Amount of Release } \\
\hline & 1-min Shutdown & 10-min Shutdown \\
\hline Guillotine Break & $4,700 \mathrm{gal}$ & 20,000 gal \\
\hline
\end{tabular}

These releases include LNG holdup in the line. Even without sendout pumps operating, the 3000-galion line holdup (assuming $500 \mathrm{ft}$ of 12-in. Tine) would be leaked. The sendout system can be shut down manually or by using either the MES or the VES. Fire-fighting systems are available to control any resulting fire.

\section{Additional Information Required}

- What design factors are included for cyclic and static stresses?

- What provisions are made for protection against and alleviation of stresses caused by external forces?

- What is the reliability of the pressure relief valve?

- What precautions and design provisions are used to avoid fluid hammer? 
Potential Design and Operational Changes

- Conduct periodic non-destructive tests on pipe and associated valves.

- Put at least two relief valves in each section of pipe that can be isolated.

- Design pipe and connections to withstand greater stresses. 


\section{G.4.12 Vaporizer Heat Exchanger Tube Fails.}

Possible Initiating Event

- Thermal shock or thermal cycling stresses (medium probability)

- Corrosion (1ow probability)

- Flaws in materials or welds (low probability)

- Birner explosion (low probability)

Results and Effects of Release Prevention and Control Systems

The estimated maximum reieases of LNG and LNG vapor from a guillotine break, based on time for emergency or manual shutdown, are given below:

Guillotine Break $\frac{1 \text {-min Shutdown }}{100,000 \mathrm{scf}} \frac{\frac{\text { Amount of Release }}{10 \text {-min Shutdown }}}{1,000,000 \mathrm{scf}}$

The released vapor may explode or catch fire due to the burner nearby. The vaporizers can be shut down by either the MES or the VES. The VES wi11 also close off the fuel gas and air lines to the burners. Combustible gas detectors will close the vents and release Halon into the vaporizer building if gas concentrations exceed set limits.

Additional Information Required

- What are the details on diameters, thickness, configuration, and flow rates through the tubes in the vaporizers?

- What are the corrosion problems involved?

- What design factors are included for thermal siress effects?

- How reliable are the various vaporizer components?

Potential Design and Operational Changes

- Conduct periodic non-destructive tests on tubes.

- Use indirect-fired or other type of heater to reduce the potential for fire or explosion resulting from a leak. 


\section{G.4.13 Natural Gas Line from Vaporizers Fails.}

\section{Possible Initiating Events}

- Carryover of LNG or cold vapor from vaporizers (medium probability)

- Fatigue resulting from pressure cycling or static stress (low probability)

- Flaws in pipe, valves, flanges, couplings or welds (low probability)

- External forces such as vehicular crash or earthquake (low probability).

\section{Results and Effects of Release Prevention and Control Systems}

Assuming three vaporizers are operating and based on times for emergency or normal shutdown, the estimated maximum natural gas releases from a guillotine break are as follows:

Guillotine Break $\frac{1-\min \frac{\text { Amount of Release }}{100,000 \mathrm{scf}}}{1,000,000 \mathrm{scf}}$

The 1 ine can be isolated manually or by using the VES.

Additional Information Required

- What design factors are included for pressure cycling and static stresses?

- What provisions are made for protection aginst and alleviation of stresses caused by external forces?

- What is the reliability and response time of the vaporizer outlet temperature instrumentation?

Potential Design and Operational Changes

- Conduct periodic non-destructive tests on line to identify problems before failure occurs.

- Install vapor-liquid separator vessel after each vaporizer to prevent LNG carryover to carbon steel line. 


\section{G.4.14 Liquid Line from Storage to the Truck Loading Station Fails.}

\section{Possible Initiating Events}

- Overpressurization due to LNG trapped in the line and heated up and failure of the relief valve to function (medium probability)

- Thermal cyclic stresses (low probability)

- Vehicular damage (low probability)

- Earthquake (low probability)

Results and Effects of Release Prevention and Control Systems

The estimated maximum LNG releases from a guillotine break are given below, based on the assumption of a time for an emergency or a normal shutdown:

Guillotine Break $\frac{1-\text { min }}{460 \mathrm{gal}} \frac{\frac{\text { Amount of }}{\text { Shutdown }}}{3,600 \mathrm{gal} \text { gal }}$

The tank loading pumps can be shut down by the Emergency Shutdown (ESD) system. The LNG reieased from a break will be contained within the impoundment area if the release is inside the dike walls.

Additional Information Required

- What is the reliability of the relief valves on the line?

- How many thermal cycles can stainless steel pipe take prior to failure?

Possible Design and Operational Changes

- If economically feasible, put at least two relief valves in each section of pipe that can be isolated with LNG in it.

- Periodically check welds with non-destructive techniques. 


\section{G.4.15 Flexible Loading/Unloading Hoses Fail.}

\section{Possible Initiating Events}

- Wearing of the hose braid by rubbing on the ground or on other sharp or abrasive surfaces (medium probability)

- Vehicular damage (medium probability)

- Thermal cyclic stresses (low probability)

- Hose coupling doesn't seal properly (low probability)

\section{Results and Effects of Release Prevention and Control Systems}

The estimated maximum LNG releases from a guillotine break are given below, based on the assumption of a time for an emergency shutdown or a normal shutdown:

\begin{tabular}{llrl} 
& & \multicolumn{2}{c}{ Amount of Release } \\
\cline { 2 - 3 } Guillotine Break: loading & $470 \mathrm{gal}$ & $3,600 \mathrm{gal}$ \\
\cline { 2 - 3 } & unloading & $1,600 \mathrm{gal}$ & $10,500 \mathrm{gal}$
\end{tabular}

The LNG from a break will flow away from the truck and either vaporize or be contained by dikes and trenches. During loading, shutdown of the loading pump will limit the release to the holdup in the lines. The loading station valves can also be closed to stop the flow.

During unloading, the remote liquid flow shutoff valves on the truck can be closed to stop the flow. The flow of LNG to the pressure buildup coil must also be shut off to prevent overpressurization.

\section{Additional Information Required}

- What is the life expectancy and wear resistance of the flexible hose?

- What is the reliability of the hose connectors?

\section{Possible Design and Operational Changes}

- Possibly remote controls from the unloading station could operate the truck's remote shutoff valves. 


\section{G.4.16 Vapor Return Line from the Truck Loading Station to Storage Fails.}

\section{Possible Initiating Events}

- Thermal cyclic stresses (low probability)

- Vehicular damage (low probability)

- Earthquake (low probability)

Results and Effects of Release Prevention and Control Systems

The estimated maximum natural gas vapor releases from a guillotine break are given below, based on the assumption of a time for an emergency shutdown or a normal shutdown:

\begin{tabular}{|c|c|c|}
\hline & \multicolumn{2}{|c|}{ Amount of Release } \\
\hline & 1-min Shutdown & 10-min Shutdowr \\
\hline uillotine $B$ & 1,10 & 11,000 \\
\hline
\end{tabular}

Shutdown of the sendout pump may decrease the vapor release, depending on how much LNG has been pumped into the truck prior to the vapor return line failure. The pump can be shut down by the ESD. The vapor return valve on the truck or at the loading station can be shut to stop flow through the vapor return line. However, this may cause overpressurization of the truck tank and subsequent release through one of the safety valves. All natural gas vapor releases will most likely rise into the atmosphere and dissipate.

Additional Information Required

- How many thermal cycles can stainless steel pipe withstand prior to failure?

Possible Design and Operational Changes

- Periodically check welds with non-destructive techniques. 


\section{G.4.17 Liquid Line from the Truck Unloading Station to the Storage Tank Fails.}

\section{Possible Initiating Events}

- Overpressurization due to LNG trapped in the line and heated up, coupled with failure of the relief valve (medium probability)

- Thermal cyclic stresses (low probability)

- Vehicular damage (low probability)

- Earthquake (low probability)

Results and Effects of Release Prevention and Control Systems

The estimated maximum LNG releases from a guillotine break are given below, based on the assumption of a time for an emergency shutdown or a normal shutdown:

Guillotine Break

$$
\begin{aligned}
& \text { Amount of Release } \\
& \frac{1-m i n \text { Shutdown }}{870 \text { gal }} \frac{10-\min \text { Shutdown }}{8,200 \mathrm{gal}}
\end{aligned}
$$

The station unloading valve or the truck unloading valve can be closed or the remote liquid flow shutoff valves on the truck may be operated to stop the flow of LNG from the truck. The flow of LNG to the pressure buildup coil must also be shut off or overpressurization of the truck tank may occur. The LNG released from a break will be contained within the impoundment area if the release is inside the dike walls.

\section{Additional Information Required}

- How many cycles can stainless steel pipe withstand prior to failure?

- What is the reliability of the relief valves on the line?

Possible Design and Operational Changes

- If economically feasible, put at least two relief valves in each section of pipe that can be isolated with LNG in it.

- Periodically check welds with non-destructive techniques. 


\section{G.4.18 Truck LNG Tank Fails.}

\section{Possible Initiating Events}

- Overpressurization due to any one of the following plus failure of the relief systems:

- Trailer road safety valve is not opened after truck loading or unloading (medium probability)

- Fire (medium probability)

- Loss of insulation and subsequent heatup of inner shell (medium probability)

- Vapor return valves are left closed during truck tank loading (medium probability)

- Rollover of LNG in the truck tank (low probability)

- Automatic pressure buildup regulator fails open when feed valve is open (low probability)

- Explosion caused by:

- Static spark due to grounding cables in bad condition or failure to hook up cables (medium probability)

- Explosive mixture of air and natural gas due to improper purging (medium probability)

- Explosive mixture due to use of tank for commodity incompatible with LNG (low probability)

- Accidents causing failure of both shells:

- Puncture of both shells by collision with other objects (medium probability)

- Overturn of truck (medium probability)

- Thermal stresses resulting in a cracked inner tank with subsequent outer tank failure and release of LNG (low probability)

- Fire fails both shells of truck tank (low probability) 
Results and Effects of Release Prevention and Control Systems

A complete rupture of the trück tank while full would result in the release of about 10,500 gal of $L N G$, either as a liquid or vapor. Explosions or fires might result from the release.

Additional Information Required

- What is the reliability of the various operator tasks related to loading, transport, and unloading of LNG trucks?

Possible Design and Operational Changes

- More interlocks could possibly be incorporated to prevent errors in performing checklist procedures. 


\section{G.4.19 Trailer Pressure Buildup Coil Fails.}

\section{Possible Initiating Events}

- Thermal cyclic stresses (low to medium probability)

- Accident (low probability)

Results and Effects of Release Prevention and Control Systems

An estimated maximum of 100 gal of LNG or natural gas could be released from a guillotine break of the pressure buildup coil, assuming 30 seconds to shut off LNG flow to the coil. Flow to the coil can be shut off by either a manual flow control valve or a remote liquid flow shutoff valve.

Additional Information Required

- How many thermal cycles can the buildup coils withstand prior to failure?

- What is the accident record regarding the pressure buildup coil? 


\section{G.5 REPRESENTATIVE RELEASE EVENTS FOR THE LNG SATELLITE PLANT}

The potential release events chosen to be analyzed for the reference LNG satellite plant are given in Table G.6. (The facility description for the satellite plant was presented previously in Appendix F.) The analyses of the individual events appear below. Release events for transportation and transfer operations are covered in Section G.4 and are not included here.

\section{TABLE G-6. Representative Release Events for an LNG Satellite Facility}

1. Satellite storage tank fails

2. Exit gas line from the boiloff heaters fails.

3. Liquid discharge line from the satellite storage tank prior to the sendout pumps fails.

4. Sendout pump vessel fails.

5. Liquid recirculation line from the sendout pumps fails.

6. Vapor return line from the sendout pump fails.

7. Liquid line to the vaporizers fails.

8. Vaporizer heat exchanger tubes fail.

9. Natural gas line from the vaporizers fails. 


\section{G.5.1 Satellite Storage Tank Fails.}

Possible Initiating Events

- Overpressurization due to any of the following plus failure or relief systems:

- Rollover of LNG in tank (medium probability)

- Sudden drop in barometric pressure (medium probability)

- Fire (medium probability)

- Heatup of LNG too fast during tank heatup (medium probability)

- Boiloff treatment system not properly controlled (low probability)

- Failure of boiloff compressors (low probability)

- Explosion due to explosive gas mixture from:

- Inadequate purge (medium probability)

- Vacuum relief allowing air into the tank (low probability)

- Inner shell off-centered with resulting pressure forces failing the tank (medium probability)

- Too rapid or nonuniform cooldown (low probability)

- High external pressure and failure of both vacuum relief valves (low probability)

- Piling cap failure (low probability)

- Earthquake (low probability)

- Airplane crash (low probability)

- Sabotage (low probability)

Results and Effects of Release Prevention and Control Systems

The maximum release of LNG from a completely failed tank would be 37,000 bbl, which would be contained in the impoundment area surrounding the tank. Foam generation, dry chemical fire extinguishers, and a water supply system are available to combat fire and its effects. 


\section{Additional Information Required}

- What is the reliability of the pressure and vacuum relief system?

- What design factors are included for the cyclic stresses the storage tank undergoes?

\section{Possible Design and Operational Changes}

- Connect the vacuum relief to a nitrogen supply.

- Completely automate the cooldown procedure.

- If economically feasible, non-destructively test the total tank (e.g., acoustic emission). 


\section{G.5.2 Exit Gas Line from the Boiloff Heaters Fails.}

Possible Initiating Events

- Heaters fail due to one of the following, which results in cold gases failing the carbon steel lines:

- power outage (medium probability)

- mechanical failure (medium probability)

- Rapid boiloff not adequately handled by the heaters, resulting in cold gases failing the carbon steel lines (medium probability)

- Earthquake (low probability)

Results and Effects of Release Prevention and Control Systems

If the gas line fails completely prior to the heater exit valve, then an estimated 6250 scf per hour would be released to the atmosphere. If the gas line fails completely after the heater exit valve, then the exit valve can be closed, but an estimated 6250 scf per hour would be vented to the atmosphere from the storage tank. When low temperatures are detected in the exit line from the heaters, the exit valves are automatically closed.

Additional Information Required

- Are the heater exit lines and exit valves made of stainless steel?

- Additional details concerning the entire boiloff system are required. Possible Design and Operational Changes

- An auxiliary, gas-fired, hot water bath heater could be on hand for emergencies. 


\section{G.5.3 Liquid Discharge Line from the Satellite Storage Tank prior to the}

Sendout Pumps Fails.

Possible Initiating Events

- Overpressurization due to LNG trapped in the line and heated up coupled with failure of the relief valve to function (medium probability)

- Thermal cyclic stresses (low probability)

- Earthquake (low probability)

Results and Effects of Release Prevention and Control Systems

A complete break of the line could possibly release the total contents of the tank (as much as 37,000 bbl) to the diked impoundment area. If the break is between the inner and outer shells, the outer shel1 will fail and with its failure possibly the inner shell will fail.

Additional Information Required

- What internal valves, if any, are in the tank?

Possible Design and Operational Changes

- If economically feasible, put at least two relief valves in the pipe between the storage tank and the pumps or between valves in that section of pipe.

- Install internal tank valves if they are not already present. 


\section{G.5.4 Sendout Pump Vessel Fails.}

Possible Initiating Events

- Thermal cyclic stresses (low probability)

- Vehicular damage (low probability)

Results and Effects of Release Prevention and Control Systems

A complete rupture of the pump vessel would release the volume of LNG in the vessel to the impoundment area, unless the feed valves to the pump are open simultaneously. Then the release would be about 14,500 gal plus the volume of the pump vesse1, assuming it takes 10 minutes to close the feed valves to the pump. Either the MES or VES could be activated to stop the LNG flow to the pump vessel.

Additional Information Required

- What is the volume of the pump vessel?

- Is any of the pump vessel in the ground?

Possible Design and Operational Changes

- If economically or practically feasible, put a barrier around the pump vessels. 


\section{G.5.5 Liquid Recirculation Line from the Sendout Pumps Fails.}

Possible Initiating Events

- Thermal cyclic stress (low probability)

- Vibrational stresses (low probability)

Results and Effects of Release Prevention and Control Systems

The estimated maximum LNG releases from a guillotine break are given below, based on the assumption of a time for an emergency shutdown or a norma? shutdown:

Guillotine break $\frac{\text { Amount of Release }}{\frac{1-\text { min Shutdown }}{10-\text { min Shutdown }}}$

Shutdown of the pumps will decrease the LNG release from a break. The storage tank pumps can be shut down by either a MES or VES. The LNG released from a break will be contained within the impoundment area. If the LNG released from the break hits the outer shell of the tank, the outer shell may crack or fail.

\section{Additional Information Required}

- How many thermal cycles can the stainless steel pipe take prior to failure?

- How much vibration can the pipe take prior to failure?

Possible Design and Operational Changes

- Put a shield along portions of the recirculation line that runs close to the outer shell of the storage tank. 
G.5.6 Vapor Return Line from the Sendout Pump Fails.

Possible Initiating Events

- Thermal cyclic stress (10w probability)

- Vibrational stresses (low probability)

Results and Effects of Release Prevention and Control Systems

A break in the vapor return line while the pumps are cooling down would release cold natural gas to the atmosphere.

Additional Information Required

- How much LNG is vaporized when one of the pumps is cooled down?

- How many thermal cycles can the vapor return line take prior to failure?

- How much vibration can the pipe take prior to failure? 


\section{G.5.7 Liquid Line to the Vaporizers Fails.}

Possible Initiating Events

- Overpressurization due to LNG trapped in the line and heated up coupled with failure of the relief valves (low probability)

- Vehicular damage (low probability)

- Earthquake (low probability)

Results and Effects of Release Prevention and Control Systems

The estimated maximum LNG releases from a guillotine break are given below, based on the assumption of a time for an emergency shutdown or a normal shutdown:

Guillotine break $\frac{1 \text {-min Shutdown }}{120 \mathrm{gal}} \frac{\frac{\text { Amount of Release }}{10-\mathrm{min} \text { Shutdown }}}{1,000 \mathrm{gal}}$

These releases are based on the assumption that both pumps are operating at the time of the break. Shutdown of the pumps will decrease the LNG release from a break. The storage tank pumps can be shut down by either the MES or VES. The LNG released from a break should drain into and be contained by the impoundment area.

\section{Additional Information Required}

- What diameter is the line to the vaporizers?

- How many thermal cycles can the line take prior to failure?

Possible Design and Operational Changes

- If economically feasible, put at least two relief valves in each section of pipe that can be isolated with LNG in it. 


\section{G.5.8 Vaporizer Heat Exchanger Tubes Fail.}

Possible Initiating Events

- Thermal cyclic stresses (medium probability)

- Thermal shock (medium probability)

- Corrosion (low probability)

- Explosion (low probability)

Results and Effects of Release Prevention and Control Systems

At a maximum, about 500 gàl of LNG could be released to the water bath, assuming one pump is running at $50 \mathrm{gal} / \mathrm{min}$ for 10 minutes prior to shutdown. The LNG might explode or catch fire due to the burners nearby. Shutdown of the pumps or the feed valves to the vaporizer wil1 decrease the LNG release from a break. The pumps and the feed valves can be shut down by either the MES or VES. The MES will also shut off the fuel to the vaporizer burners.

Additional Information Required

- What are the details on diameters, configuration, and flow rates through the tubes in the vaporizers?

- What are the corrosion problems?

Possible Design and Operational Changes

- If economically feasible, hot-water heat exchangers should be used. 
G.5.9 Natural Gas Line from the Vaporizers Fails.

Possible Initiating Events

- Cold gases or LNG coming from vaporizers (medium probability)

- Vehicular damage (low probability)

- Earthquake (low probability)

Results and Effects of Release Prevention and Control Systems

A maximum of about 83,000 scf of natural gas could be released to the atmosphere, assuming both vaporizers operating at a total of about $8,300 \mathrm{scfm}$ for 10 minutes prior to shutdown of the vaporizers and vaporizer exit valves. The vaporizers and vaporizer exit valves can be shut down by either the MES or VES.

Additional Information Required

- What is the response time of the vaporizer outlet temperature controller? 
APPENDIX H

PROCESS FLOW DIAGRAM SYMBOLS 


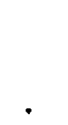


PROCESS FLOW DIAGRAM SYMBOLS

The symbols used in the process flow diagrams throughout this study are defined in this appendix. The appendix is divided into two parts: the first deals with instrumentation and controls, and the second covers valves, iines, and equipment. All of the items presented here do not necessarily appiy to each individual facility considered in this study.

\section{H.1 INSTRUMENTATION AND CONTROLS}

A 11 instrumentation and controls are indicated in the various process flow diagrams by small circles. The letters inside the circles, defined below, identify the functions of the various items. No distinction is made between boardmounted and locariy mounted equipment.

- Pressure Instrumentation and Controllers - P

I Indicator

R Recorder

C Controlier

A Alarm ( $H$ or L outside circle indicates high or low)

S Switch

- Flow Instrumentation and Controllers - F

I Indicator

R Recorder

C Controlier

A Alarm ( $H$ or L outside circle indicates high or low)

- Anatyzer Instrumentation - A

R Recorder

A Alarm ( $H$ or L outside circle indicates high or low) 
- Level Instrumentation - $\mathrm{L}$

I Indicator

R Recorder

A Alarm ( $H$ or L outside circle indicates high or low)

- Temperature Instrumentation and Controllers - T

I Indicator

R Recorder

C Controlier

A Alarm ( $H$ or L outside circle indicates high or low)

S Shutdown

- Hand Actuated Controllers - H

I Indicators

c Controllers

- Emergency Shutdown Systems

LES - Loading Emergency Shuidown

MES - Master Emergency Shutdown

OES - Offshore Emergency Shutdown

VES - Vaporizer Emergency Shutdown

H.2 VALVES, LINES, AND EOUIPMENT

The major valves, lines, and equipment associated with the various LNG facilities are shown in the appropriate process flow diagrams. The identification systems used for these components are explained below.

Vaives

Ail valves shown in the process flow diagrams are identified by graphic symbols, as shown here:
T Control valve, pneumatic operator
$\$$ Control valve, solenoid or motor operator
Hand operated process valve
$\vec{N}$ Check valve
个 or Telief valve. 
Lines

The various 1 ines in the process flow diagrams, are shown graphically as follows:

Process lines

_-11- Pneumatic instrument leads

Equipment

A single letter is used to identify each type of major plant components:

C Compressor

$E$ or $A$ Heat exchanger

P Pump

$\checkmark \quad$ Vessel or Vaporizer

T Tank.

Numbers are used with each letter to indicate the specific piece of equipment:

$\mathrm{P}-301 \mathrm{~A} / \mathrm{B} / \mathrm{C}$

C-221

$T-101$. 


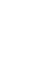


No. of

Copies

10 J. M. Cece (EP-323)

Office of Environmental

Protection, Safety and

Emergency Preparedness

U.S. Department of Energy

Washington, D.C. 20545

10 H. F. Walter (EP-35)

Office of Environmental

Protection, Safety and

Emergency Preparedness

U.S. Department of Energy

Washington, D.C. 20545

27 DOE Technical Information Center

A. A. Allen

Alaskan Beaufort Sea

0ilspill Response Body

6700 Arctic Spur Road

Anchorage, AK 99502

P. J. Anderson

Institute of Gas Technology

3424 South State Street

Chicago, IL 60616

S. Atallah

Gas Research Institute

8600 West Bryn Mawr Avenue

Chicago, IL 60631

S. M. Bark in

Committee on Hazardous

Materials

National Research Council

2101 Constitution Avenue

Washington, D.C. 20418

A. C. Barre 11

Major Hazards Assessment Unit

Health and Safety Executive

25 Chape 1 Street

London, NW1 50T, UK
No. of

Copies

C. Batty

British Petroleum North

American, Inc.

620 Fifth Avenue

New York, NY 10020

L. E. Bell

Western LNG Terminal Associates

700 South Flower Street

Suite 3300

Los Angeles, CA 90017

W. M. Benkert

American Institute of

Merchant Shipping

$1625 \mathrm{~K}$ Street, N.W.

Washington, D.C. 20006

G. F. Bennett

Professor of Biochemical

Engineering

University of Toledo

2801 Bancroft Street

Toledo, $\mathrm{OH} 43606$

K. Blower

Standard 0 il of Ohio

1748 Guildhall Building

Cleveland, $\mathrm{OH} \quad 44115$

F. Bodurtha

DuPont Company

Louviers Building 1351

Wilmington, DE 19898

A. Bon i

Science Applications Inc.

1200 Prospect Street

La Jolla, CA 92037

W. J. Bradford

01 in Corporation

120 Long Ridge Road

Stamford, CT 06904 
No. of

Copies

W. C. Brasie

Dow Chemical USA

633 Building

Midland, MI 48640

F. E. Brinker

Trunk line LNG Company

P.0. Box 1642

Houston, TX 77001

W. Brobst

The Transport Environment

285 01d Squaw Drive

Kitty Hawk, NC 27949

S. J. Broussard, P.E.

Manager, Occidental Chemical Company

P.0. Box 1185

Houston, TX 77001

C. P. Buck ley

Boston Gas Company

One Beacon Street

Boston, MA 02108

D. J. Campbe 11

Trunk 1 ine LNG Company

P.0. Box 1642

Houston, TX 77001

T. Carlisle

Senior Mechanical Safety Engineer

Santa Fe Pipeline Company

1200 Thompson Building

Tulsa, OK 74103

A. M. Clarke

Algonquin Gas Transmission Company

1284 Soldiers Field Road

Boston, MA 02135

John J. Closner

Preload Technology

839 Stewart Street

Garden City, NY 11530
No. of

Copies

W. E. Coe, Jr.

Southern Energy Company

P.0. Box 1367

Savannah, GA 31402

R. I. Cole

American Gas Association

1515 Wilson Bou levard

Arlington, VA 22209

S. Colgate

Los Alamos National Laboratory

Los Alamos, NM 87545

G. Colonna

U.S. Coast Guard (G-DMT-1)

2100 Second Street, S.W.

Washington, D.C. 20593

Committee on Commerce, Science and Transportation

U.S. Senate

Washington, D.C. 20510

C. Corbett

Commandant (G-WEP)

U.S. Coast Guard

2100 Second Street, S.W.

Washington, D.C. 20593

P. Cubbage

British Gas Corporation

Research and Development Station

Midlands Research Station

Whaft Lane, Solihull,

West Midlands B9K $2 \mathrm{JW}$

ENGLAND

R. Danielson

Bay State Gas Company

120 Roya 11 Street

Canton, MA 02021

R. E. Dehart, II

Union Carbide Corporation

P. 0. Box 8361

South Charleston, WV 25303 
No. of

Copies

W. Denn is

Office of Pipeline Safety

Regulations

4007 th Street, S.W.

Washington, D.C. 20590

L. C. Doe 1p

Corporate Engineering

Air Products and Chemicals

Allentown, PA 18105

E. Drake

Arthur D. Little, Inc.

Acorn Park

Cambridge, MA 02140

F. Edeskuty

Los Alamos Scientific Laboratory

P.0. Box 1663

Los Alamos, NM 87545

J. Edge 11

Bulk Plant Operations

Columbia Hydrocarbon

Corporation

1600 Dublin Road

Columbus, $\mathrm{OH} 43215$

T. Eichler

IIT Research Institute

10 West 35th Stre $t$

Chicago, IL 6061u

W. G. England

Energy Resources Company, Inc. 3344 North Torrey Pines Court

La Jolla, CA 92037

H. K. Fauske

Fauske and Associates, Inc. 16070 West 83rd Street

Burridge, IL 60521
No. of

Copies

\author{
J. A. Fay \\ Department of Mechanica 1 \\ Engineering \\ Massachusetts Institute of \\ Techno logy \\ Cambridge, MA 02139
}

J. P. Frazier

Natural Gas Pipeline Company of America

122 South Michigan Avenue

Chicago, IL 60603

S. Fujinami

Tankage Designing Section

Kawasaki Heavy Industries, LTD

118 , Futatsuzuka, Noda-shi,

Chiba 278, JAPAN

M. Futana

No. 3 Group Chemical Plant and Machinery Department $B$

Mitsubishi Heavy Industries, LTD

118, Ichigaya Tomihisa-Cho, Sh injuku-ku

Tok yo 162, JAPAN

W. Geiger

Battelle-Institute e.v.

Am Roemerhof 35

6000 Frankfurt am Ma in 90

FEDERAL REPUBLIC OF GERMANY

R. D. Gerges

Manager, Process Hazard Ana lys is

Rohm and Haas Company

Engineering Division

Box 584

Bristo 1, PA 19007

D. Gideon

Battelle Columbus Laboratories

505 King Avenue

Columbus, $\mathrm{OH} 43201$ 
No. of

Copies

E. B. Graham

British Gas Corporation

326 High Holborn

London WC17PT, ENGLAND

K. Hagiwara

No. 1 Sales Department

J.G.C. Corporation

2-1, Otemach i 2-chome, Chiyoda-ku

Tokyo 100, JAPAN

H. C. Hardee

Supervisor, Fluid Mechanics and Heat Transfer

Sandia Laboratories

Albuquerque, NM 87115

J. Havens

College of Engineering

University of Arkansas

227 Engineering Building

Fayetteville, AR 72701

T. Hellman

Director, ENRL Services

Allied Corporation

P.0. Box 2120

Houston, TX 77001

E. W. Hofer

Process Engineer ing Manager

Allied Corporation

P.0. Box 2105R

Morristown, NJ 07960

10 W. J. Hogan

Lawrence Livermore Laboratory

P.0. Box 808

Livermore, CA 94550

R. Holden

Pacific Gas and Electric Company

77 Beale Street, Room 2971

San Francisco, CA 94106
No. of

Copies

C. C. Hong

Columbia Gas System Service

Corporation

1600 Dublin Road

Columbus, $\mathrm{OH} 43215$

W. B. Howard

Manager, Process Safety

Monsanto

800 North Lindbergh Boulevard

St. Louis, MO 63166

P. E. Hyam

Directorate Staff

Imperial Chemical Industries

Box 1

Billingham Cleveland

TS23 1LB ENGLAND

D. Igo

Transportation Research

Department of Transportation

400 7th Street, S.W.

Washington, D.C. 20590

K. Ishida

Technical Department

Measuring Instrumentation

Division

Fuji Electric Company, LTD

No. 1, Fuji-mach $i$, Hino-shi,

Tokyo 191, JAPAN

F. Jeglic

National Energy Board

473 Albert Street

Ottawa, Ontario K1A OE5

CANADA

D. W. Johnson

Applied Technology Corporation

P.0. Box FF

Norman, OK 73070 
No. of

Copies

W. H. Johnson

National L. P. Gas Association

1301 West 22nd Street

0ak Brook, IL 60521

L. J. S. Kaplan

Dangerous Commodities Review Committee officer

Railway Transport Committee

Ottawa, K1A 0N9, CANADA

J. W. Kime

U.S. Coast Guard (G-W)

2100 Second Street

Washington, D.C. 20593

W. C. Kohfeldt

Exxon Chemical Company

P.0. Box 271

Florham Park, NJ 07932

H. J. Kolodner

Director, Corporate Safety

Celanese Corporation

P.0. Box 32414

Char lotte, NC 28232

J. K. Lathrop

National Fire Protection

Association

470 At lantic Avenue

Boston, MA 02210

P. E. Laurie

Acres Consulting Services Limited

5259 Dorchester Road

P.0. Box 1001

Niagara Fa11s, CANADA L2E 6W1

J. A. Lawrence

Vice President and Manager of

Nitrogen Operations

CF Industries, Inc.

Salem Lake Drive

Long Grove, IL 60047
No. of

Copies

L. Lemon

Energy and Minerals Research Company

P.0. Box 389

Exton, PA 19341

D. J. Lewis

Imperial Chemical Industries, LTD

Mond Division, Research and

Deve lopment Department

P.0. Box 7 Winnington

Northwich Cheshire, CW8 4DJ, UK

J. P. Lewis

Project Technical Liaison

Associates, Inc.

4201 FM 1960 West, Suite 240

Houston, TX 77060

C. D. Lind

Code 3262

U.S. Naval Weapons Center

China Lake, CA 93555

G. Logan

Phillips Chemical Company

Seneca Building

Bartlesville, OK 74004

P. Lunnie

Asst. VP, Industrial Relations

Director, OSH

National Association of

Manufacturers

1776 F Street, N.W.

Washington, D.C. 20006

L. Ma11on

Committee on Merchant Marine and Navy

House of Representatives

Washington, D.C. 20515 
No. of

$\underline{\text { Copies }}$

J. Manney

American Petroleum Institute

2101 L Street, N.W.

Washington, D.C. 20037

Commanding officer

Marine Safety office

U.S. Coast Guard

Baltimore, MD 21202

D. H. Markste in

Factory Mutual Research Corporation

1151 Boston - Providence

Turnpike

Norwood MA 02062

J. Martin

She 11 International Gas

She 11 Centre

London, SE1 7NA, UK

W. E. Martinsen

Energy Analysts Inc.

2001 Priest ley Avenue

P.0. Box 1508

Norman, OK 73070

Y. Matsui

Systems Department

Toyo Engineering Corporation

12-10, Higashi-funabashi 6-chome

Funabashi-shi, Chiba 273, JAPAN

H. Mayo

COOP Farm Chemical Association

P.0. Box 308

Lawrence, KS 66044

R. N. Meroney

Fluid Mechanics and Wind

Engineering Program

Department of Civil

Engineering

Colorado State University

Fort Collins, c0 80523
No. of

Copies

R. Morrison

Boston Gas Company

One Beacon Street

Boston, MA 02108

N. Neafus

EDECO Engineering Company

1601 South Main Street

P.0. Box 589

Tulsa, OK 74101

J. A. Nicholls

Department of Aerospace

Engineering

University of Michigan

Ann Arbor, MI 48109

R. Norton

Distrigas, Inc.

125 High Street

Boston, MA 02110

0. Okawa

Chiyoda Chemical Engineering Company

P.0. Box 10

Tsurumi, Yokohama 230, JAPAN

A. K. Oppenheim

Department of Mechanical

Engineering

University of California

Berkeley, CA 94720

J. C. Pace, Jr. Long Is land Lighting Company

175 East 01d Country Road

Hicksville, NY 11801

M. C. Parnarousk is

U.S. Coast Guard (G-OMT-1)

2100 2nd Street, S.W.

Washington, D.C. 20593 
No. of

Copies

H. Pasman

Prins Maurits Laboratory TNO Technological Research

P.0. Box 45

2280 AA Rijswikj, NETHERLANDS

E. Pearlman

JRB Associates

8400 Westpark Drive

McLean, VA 22102

J. Peebles

Commandant (G-WPE)

U.S. Coast Guard

2100 Second Street, S.W.

Washington, D.C. 20593

W. H. Penn

Tennessee Gas Pipeline Company

P. 0. Box 2511

Houston, TX 77001

A. W. Perry

Trumk line LNG Company

Highway 384 and Lincoln Road

P.0. Box 6327

Lake Charles, LA 70606

H. W. Peter

Brooklyn Union Gas Company

195 Montague Street

Brooklyn, NY 11201

C. Peterson

SRI Washington

1611 North Kent Street

Rosslyn Plaza

Arlington, VA 22209

R. E. Petsinger

CNG Services, Inc.

2000 0xford Drive

Bethel Park, PA 15102

C. N. Petterson

Northwest Natural Gas Company

123 Northwest Flanders Street

Portland, OR 97209
No. of

Copies

W. B. Porter

Process Engineer

W. R. Grace Company

100 North Ma in Street

Memph is, TN 38101

T. Raines

Alabama Gas Corporation

P.0. Box 721

Pinson, AL 35126

P. Raj

Technology and Management

Systems, Inc.

102 Drake Road

Burlington, MA 01803

R. C. Reid

Department of Chemical Engineering

Massachusetts Institute of Technology

Cambridge, MA 02139

A. Roberts

Office of Hazardous Materials

Regulations

Department of Transportation

Transpoint Building

2100 Second Street, S.W.

Washington, D.C. 20590

\section{A. Rosenbaum}

National Tank Truck Carriers, Inc. 1616 P Street, N.W.

Washington, D.C. 20036

M. I. Rudnicki

Aerojet Energy Conversion Company

P.0. Box 13222

Sacramento, CA 95813 
No. of

Copies

A. Salvadori

Gaz de France

Direction des Etudes et Techniques Nouve lles

Department des Etudes Cryogenics, Industrielles et Metallurgiques 23, rue Philibert-Delorme

Paris-17, FRANCE

L. Santman

Materials Transportation Bureau

U.S. Department of Transportation 4007 th Street, S.W.

Washington, D.C. 20590

L. Sarkes

American Gas Association

1515 Wilson Boulevard

Arlington, VA 22209

L. C. Schaller

E. I. du Pont de Nemours and Co.

12430 Nemours Building

Wilmington, DE 19898

H. P. Schorr

Brook lyn Union Gas Company

195 Montague Street

Brook Iyn, NY 11201

S. Schreiber

Allied Corporation

P.0. Box 2332R

Morristown, NH 07960

P. Schreurs

Katholieke Universite it Leuven

CIT

De Croylaan 2

B.3030 Leuven

THE NETHERLANDS

R. J. Schuttler

Manager

Hooker Chemicals

P.0. Box 728

Niagara Falls, NY 14302
No. of

Copies

R. F. Schwab

Manager, Process Safety and

Loss Prevention

Allied Corporation

P.0. Box 2332R

Morr istown, NJ 07960

P. Seay

Technical Division

Office of Hazardous Materials

Regulations

Materials Transportation Bureau

400 Seventh Street, S.W.

Washington, D.C. 20590

J. Seelinger

Office of Commercial Development

U.S. Maritime Administration

U.S. Department of Commerce

Washington, D.C. 20230

S. M. Sett Te

Associate Director, OSH

NAM

1776 F Street, N.W.

Washington, D.C. 20006

J. D. Shefford

British Gas Corporation

59 Bryanston Street

Marble Arch

London W1A2AZ, ENGLAND

R. B. Smith

Battelle Columbus Laboratories

505 King Avenue

Co lumbus, $\mathrm{OH} 43201$

J. K. Speckhals

Columbia LNG Corporation

20 Montchan in Road

Wi lmington, DE 19807

Spill Techno logy News letter

Environmental Protection Service

Ottawa, Ontario KIA 1C8 CANADA 
A. N. Stewart

San Diego Gas and Electric Company P.0. Box 1831

San Diego, CA 92112

R. A. Stehlow

105 Transportation Building

University of 111 ino is

Urbana, IL 61801

H. Stevens

Northwet Pipeline Corporation

P.0. Box 30

Umatilla, OR 97882

J. D. Swanburg

Supt. of Process Engineering

Union Chemical Division

Union 0il Company of California

P.0. Box 1280

Brea, CA 92621

B. Sweedler

National Transportation Safety Board

800 Independence Avenue

Washington, D.C. 20591

T. Tanaka

System Engineering Department

J. G. C. Corporation

14-1, Bessho-cho 1-chome, Minami-ku

Yokohama-shi, Kanagawa 232 JAPAN

J. Tatematsu

Technology Transfer Institute Kyodo Building

3-1, Ak asaka 4-chome, Minato-ku

Tokyo 105, JAPAN

R. Tatge

CV International, Incorporated

2741 Toledo Street, Suite 208

Torrance, CA 90503

M. J. Turner

Health and Safety Executive

25 Chapel Street

London NW1 5DT, ENGLAND
T. Uozumi

Assistant to the Manager

EDP Education Department

Fujitsu LTD

17-25, Shinkamata 1-chome, Ohta-ku

Tokyo 144, JAPAN

W. Walls

National Fire Protection Association

470 Atlantic Avenue

Boston, MA 02210

S. K. Wakamiya

Product Engineering Division

National Bureau of Standards

Department of Commerce

Wash ington, D.C. 20234

D. J. Watters

Union Carbide Corporation

P.0. Box 8361

South Charleston, WV 25303

S. J. Wiersma

Gas Research Institute

8600 West Bryn Mawr Avenue

Chicago, IL 60631

J. R. Welker

Applied Technology Corporation

P.0. Box FF

Norman, OK 73070

M. M. Williams

U.S. Coast Guard

Technical Advisor (G-MHM/83)

400 Seventh Street, S.W.

Washington, D.C. 20590

W. Wilson

San Diego Gas and Electric Company

P.0. Box 1831

San Diego, CA 92112

RADM K. E. Wiman

U.S. Coast Guard (G-D)

2100 Second Street, S.W.

Washington, D.C. 20593 
No. of

Copies

B. Witcofski

NASA-Langley

Hampton, VA 23665

R. E. Witter

Monsanto Company

800 North Lindbergh Boulevard

St. Louis, MO 63166

J. L. Woodward

Exxon Research and Engineering

P.0. Box 101

Florham Park, NJ 07932

R. Zalosh

Factory Mutual Research

1151 Boston-Providence Turnpike Norwood, MA 02062
No. of

Copies

60 Pacific Northwest Laboratory

W. J. Bair

E. G. Baker

H. J. Bomelburg

C. A. Counts

W. E. Davis

J. G. DeSteese (40)

G. M. Holter

P. J. Pelto

T. B. Powers

W. L. Rank in (HARC)

R. E. Rhoads

A. M. Schreiber

R. Shikiar (HARC)

L. D. Williams

Library (5)

Publishing Coordination (2)

\section{ONSITE}

DOE Rich land Operations

H. E. Ransom 


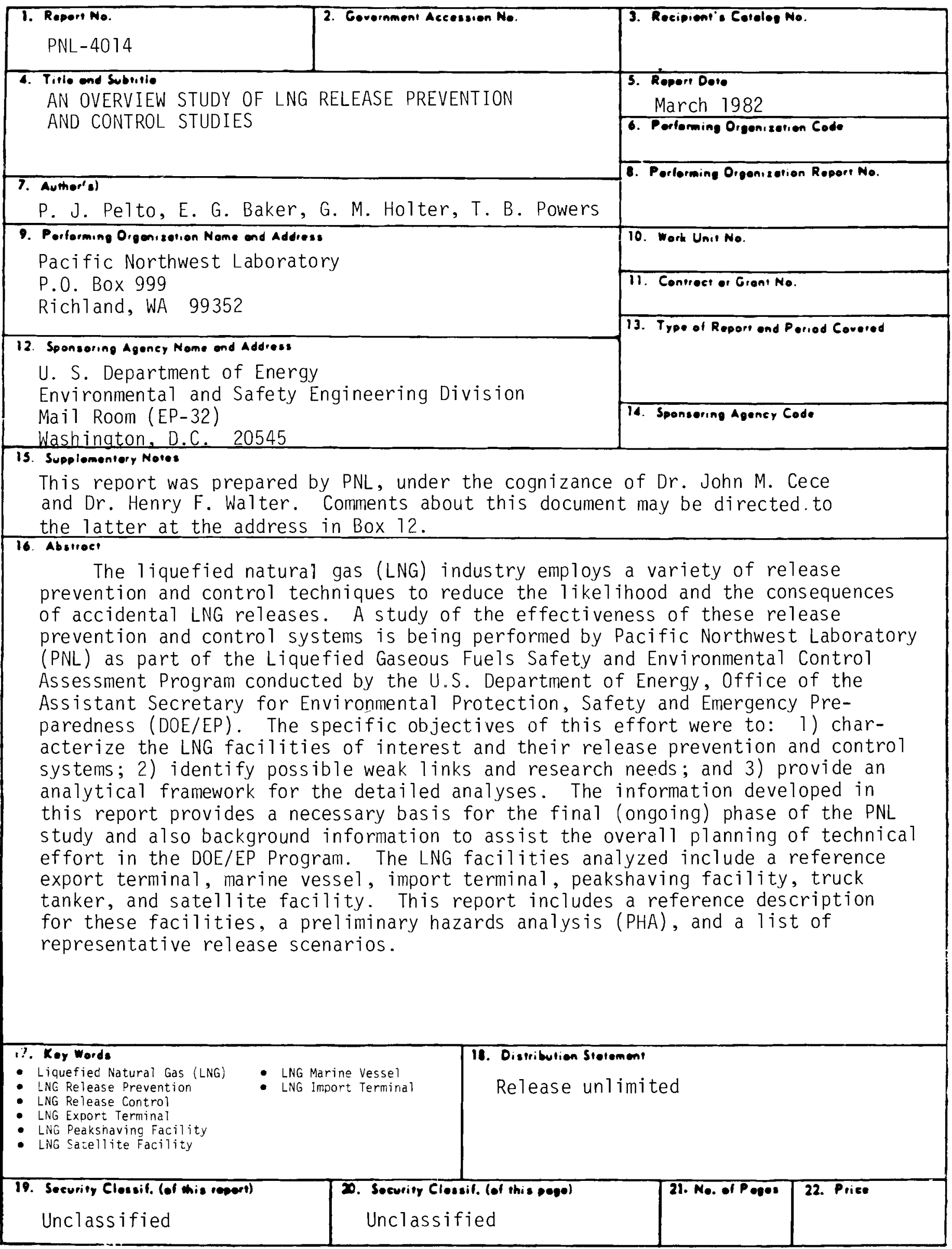



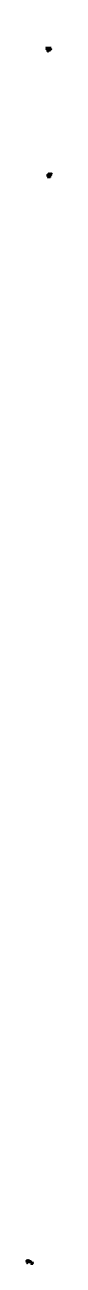